Érica Cristina Cunha

\title{
Placas Recicladas de Embalagens Longa Vida: caracterização, design e propostas projetuais.
}

Tese apresentada ao Programa de Pós-graduação em Arquitetura e Urbanismo da Escola de Engenharia de São Carlos - Universidade de São Paulo, para obtenção do título de Doutor em Arquitetura e Urbanismo.

Área de concentração:

Tecnologia do ambiente construído.

Orientador:

Prof. Titular Eduvaldo Paulo Sichieri 
AUTORIZO A REPRODUÇÃO E DIVULGAÇÃO TOTAL OU PARCIAL DESTE TRABALHO, POR QUALQUER MEIO CONVENCIONAL OU ELETRÔNICO, PARA FINS DE ESTUDO E PESQUISA, DESDE QUE CITADA A FONTE.

Ficha catalográfica preparada pela Seção de Tratamento da Informação do Serviço de Biblioteca - EESC/USP

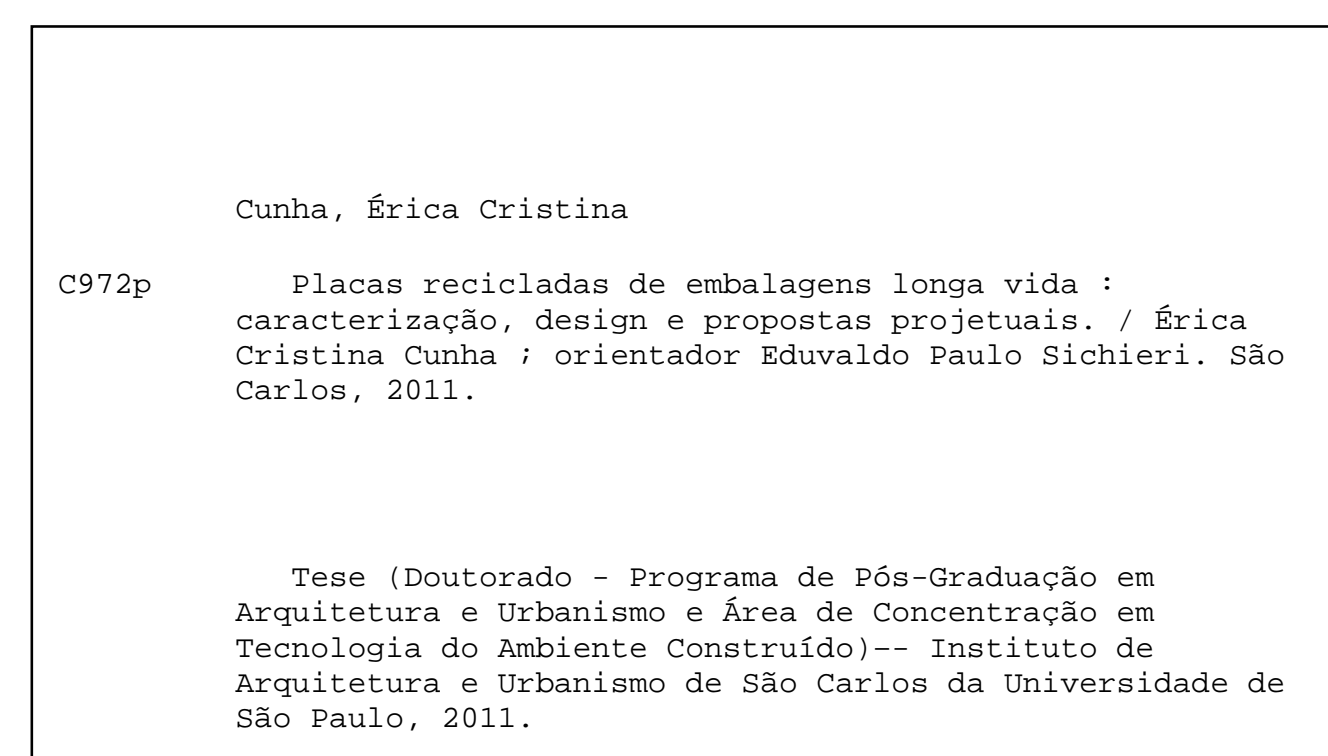




\section{FOLHA DE JULGAMENTO}

Candidato: Arquiteto Urbanista ÉRICA CRISTINA CUNHA

Título da tese: Placas recicladas de embalagens longa vida: caracterização, design e propostas projetuais.

Data da defesa: $30 / 09 / 2011$

Comissão Julgadora:

Prof. Titular Eduvaldo Paulo Sichieri (Orientador)

(Instituto de Arquitetura e Urbanismo/USP)

Prof. Associado João Adriano Rossignolo

(Faculdade de Zootecnia e Engenharia de Alimentos/USP)

Prof D. Ruth Cristina Montanheiro Paulino

(Universidade de Franca)

Prof. Dr. Celso Carlos Novaes

(Universidade Federal de São Carlos/UFSCar)

Prof. Dr. Tomas Queiroz Ferreira Barata

(Universidade Estadual Paulista "Julio de Mesquita Filho"/UNESP/Campus de Bauru)

$\triangle P R O V D D A$ $\underline{\text { Resultado: }}$
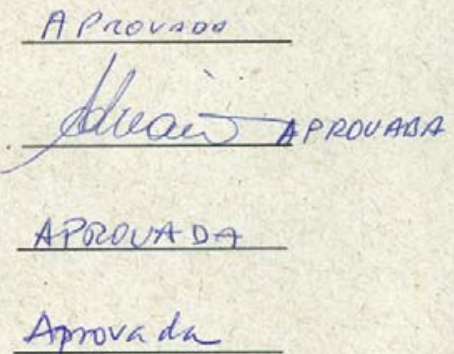

Coordenador do Programa de Pós-Graduação em Arquitetura e Urbanismo:

Prof. Titular Renato Luiz Sobral Anelli

Presidente da Comissão de Pós-Graduação:

Prof. Associado Paulo Cesar Lima Segantine 

Dedico este trabalho à minha família querida, especialmente aos meus pais Renê e Teresinha e ao meu amor e companheiro Silvio. 



\section{AGRADECIMENTOS}

Ao meu orientador, Prof. Titular Eduvaldo Paulo Sichieri por todos os anos de apoio, direcionamento e credibilidade em minhas idéias.

À Universidade de São Paulo (USP) - EESC, pela estrutura oferecida para desenvolvimento dessa pesquisa.

Ao Senhor Eduardo Gomes da Empresa IBAPLAC pelo fornecimento das placas recicladas e receptividade na visita técnica. Aos funcionários da TETRA PAK, especialmente à Luana Pinheiro, pela receptividade e orientações.

Aos Professores e Técnico que acompanharam os ensaios: Kelen Dorneles, Wilson Nunes dos Santos (UFSC), Salvador Claro Neto e Sergio Trevelin.

Aos professores Rosana Caran, Karin Chvatal, Catalano (Departamento de aeronáutica) e Márcia Branciforti (Dep.Engenharia de materiais), por ajudarem a solucionar muitas dúvidas.

Aos funcionários e técnicos, sempre prestativos, do Departamento de Arquitetura e Urbanismo: Paulo Pratavieira, Tico e Sérgio Trevelin; Paulo Ceneviva; aos secretários Marcelo Celestini, Sérgio Celestini, Geraldo Pereira e Caio; Odinei Canevarollo e José Renato Dibo.

Ao Prof. Dr. José Roberto Geraldine Júnior, coordenador do curso de Arquitetura e Urbanismo do Centro Universitário Barão de Mauá, e todos os professores e amigos de trabalho. Obrigada pela força.

Aos professores amigos, exemplos profissionais e incentivadores: Simone Barbosa Villa, Fernando Garrefa, Flávio Cesar Mirabelli Marchesoni; Rose Borges, Ana Ferraz e Rita Paschoalato.

Às amigas Gerusa de Cássia Salado, Anna Gagliano, Masumi Wakasugui, Maria Elvira Robazzi, Aline Frossard, Carolina Frossard, Samantha, Andreza Cardoso e D.Tereza, por me acompanharem nesta etapa, cada uma a sua maneira.

À Maria Élide de Conti Travain, por me mostrar os caminhos mais leves.

À D. Juliana Carvalho e Mário Carvalho por serem sempre flexíveis com meus horários e, assim, colaborarem com minha formação.

Ao meu amor, cheio de bom humor, Silvio Luiz de Flório, por sempre saber "o momento certo" e me incentivar e acompanhar em todas as etapas.

À minha família, por ser minha fonte de amor e confiança, o que me dá força para Realizar! 

"O que você fizer será insignificante, mas é muito importante que você o faça." Mahatma Gandhi 



\section{RESUMO}

CUNHA, E.C. Placas Recicladas de Embalagens Longa Vida: Caracterização, design e propostas projetuais. 2011. 120 folhas. Tese (doutorado) - Escola de Engenharia de São Carlos - EESC, Universidade de São Paulo - USP, São Carlos, 2011.

Esta tese apresenta o estudo das placas recicladas provenientes de Embalagens Longa Vida. São compostas principalmente por polietileno de baixa densidade, alumínio e resíduos de papel. Embora as placas recicladas sejam tratadas como sustentáveis e aplicadas nas edificações com resultados positivos, são poucos os dados publicados que apresentam sua caracterização geral. Outros problemas foram identificados, como a necessidade de melhoria na tecnologia para produção, dificuldade na aceitação estética e pouco design incorporado aos produtos e objetos resultantes. Apesar dos problemas, a observação do uso crescente dessas placas resultou no traçado da hipótese desta pesquisa: as placas podem ser mais eficientes e atrativas para especificação, se utilizadas com design incorporado aos componentes arquitetônicos. A partir disso, o trabalho busca dois objetivos essenciais: traçar um perfil de caracterização técnica e de design relacionados ao material e, a partir desse repertório, apresentar propostas projetuais alternativas para uso na arquitetura. Para tanto, foram estudadas as conceituações sobre materialidade, as abordagens técnicas, estéticas e culturais e a reciclagem e produção das placas, além de ensaios térmicos de condutividade térmica e calor específico, absortância, envelhecimento acelerado em câmera de UV e o ensaio complementar de transição vítrea. A caracterização estética gerou dados sistematizados sobre textura, tamanho, espessura e estudos compositivos com outros materiais. Por fim, foram criadas três propostas projetuais como indicativos de novas possibilidades de uso das placas. Este estudo concluiu que as placas de polietileno-alumínio podem ser utilizadas em várias superfícies arquitetônicas, desde que cuidadosamente incorporadas aos sistemas, prezando-se a qualidade da produção, projeto, design e acabamento.

Palavras chave: materiais reciclados, design, materiais sustentáveis. placas recicladas de embalagens longa vida. 
Placas recicladas de embalagens longa vida: caracterização, design e propostas projetuais. 


\section{ABSTRACT}

CUNHA, E.C. Recycled Plates from Cartoon Packaging: characterization, design and project proposals. 2011. Thesis (Ph.D) - Engineering School of São Carlos - EESC, University of São Paulo - USP, São Carlos, 2011.

This thesis presents the study of plates from recycled cartoon packaging. They are composed mainly of low density polyethylene, aluminum and paper waste. Although the plates are treated as recycled and sustainable, applied in building with positive results, there are few published data to show their general characterization.

Other problems were identified: need for improvement of production technology, difficulty in accepting some design aesthetics and few design incorporated to the products and the resulting objects. Despite the problems, the observation of the growing use of these plates resulted in the design of the hypothesis of this research: the plates can be more efficient and attractive to specification if used with design incorporated into the architectural components. Based on this, the work seeks two essential goals: a profile of technical characterization and design-related material, and from this repertoire, present proposals about design alternatives for use in architecture. To this end, were studied the concepts of materiality, in technical, aesthetics and cultural approaches and the recycling and production of plates, besides the thermal tests of thermal conductivity and specific heat, absorptance, accelerated aging and UV camera and additional test of glass transition. The aesthetic characterizations generated systematic data on texture, size, thickness and compositional studies with other materials. Finally, were created three project proposals as indicative of new possibilities to use the plates. Through this study it can be concluded that the polyethylene-aluminum plates can be used in various architectural surfaces, as long as they are carefully incorporated into the systems, maintaining the quality the quality of production, design and finish.

Keywords: recycled materials, design, sustainable materials, recycled plates, cartoon packaging. 
Placas recicladas de embalagens longa vida: caracterização, design e propostas projetuais. 


\section{LISTAS}

\section{Lista de Siglas e Abreviaturas}

ABNT - Associação Brasileira de Normas Técnicas

NBR - Norma Brasileira

ArqTema - Arquitetura Tecnologia e Materiais - Grupo de Pesquisa da EESC-USP

EESC - Escola de Engenharia de São Carlos

USP - Universidade de São Paulo

IPT - Instituto de Pesquisas Tecnológicas

LaMEM - Laboratório de Madeiras e Estruturas de Madeira

DMA - Análise Dinâmico Mecânica

$\mathrm{Tg}$ - Transição vítrea

IP - Índice de propagação de chamas

$\mathrm{m}$ - metro

$\mathrm{m}^{2}$ - metro quadrado

$\mathrm{m}^{3}$ - metro cúbico

cm - centímetro

$\mathrm{cm}^{2}$ - centímetro quadrado

$\mathrm{mm}$ - milímetro

$\mu \mathrm{m}$ - micrometro

$\mathrm{nm}$ - nanometro

$\mathrm{Kg}$ - quilograma - unidade de medida de massa

$\mathrm{h}$ - hora

$\min -$ minuto

$\mathrm{s}$ - segundo

Mpa - Mega pascal - unidade de pressão e tensão

$\mathrm{K}$ - Kelvin - unidade de base do Sistema Internacional para temperatura.

${ }^{\circ} \mathrm{C}$ - grau Celsius - unidade de temperatura

W - Watt - unidade de potência do Sistema Internacional

$\mathrm{J}$ - Joule - unidade de energia e trabalho

$\mathrm{Hz}$ - hertz - unidade de frequência

A - ampere - unidade de intensidade de corrente elétrica do Sistema Internacional

UV - Ultra violeta

IV - Infra vermelho

VIS - Visível 


\section{Lista de figuras}

Figura.2.1: Cadeira produzida com plástico reciclado Design de Bär \& Knell .................... 11

Figura 2.2: Luminárias produzidas a partir de plástico reciclado. Design de Bär+Knell. ...... 11

Figura 2.3: Espreguiçadeira de plástico reciclado. Design de Bär+Knell ............................. 11

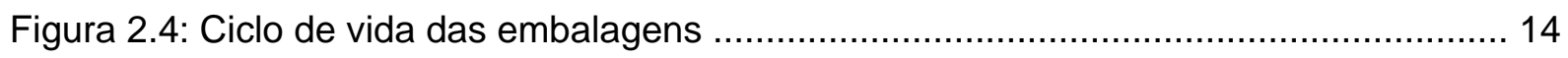

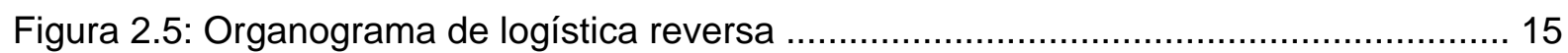

Figura 2.6: Edifício Arquivo nacional EDF - França - LAN Arquitetura ............................ 32

Figura 2.7: Edifício Arquivo nacional EDF - Detalhe da fachada ...................................... 33

Figura 2.8: Edifício Arquivo nacional EDF - Fabricação dos painéis texturizados ............... 33

Figura 3.1: Logística Reversa para embalagens Longa Vida. ....................................... 42

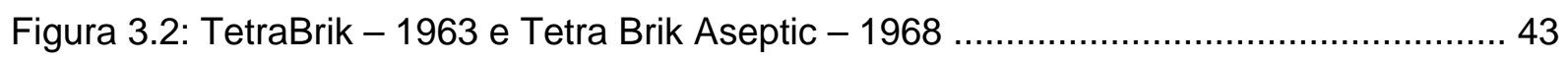

Figura 3.3: Multi-camadas da embalagem longa vida. ................................................... 44

Figura 3.4: Teste caseiro para separação das camadas da embalagem Longa Vida. ........ 48

Figura 3.5: Início do processo de reciclagem - Hidrapulper ........................................... 49

Figura 3.6: Vassoura e lixeira recicladas a partir de embalagens longa vida. ..................... 50

Figura 3.7: Parafina e lingote de alumínio - reciclagem por plasma térmico. ...................... 51

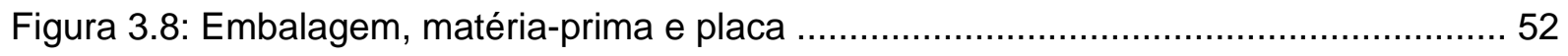

Figura 3.9: Película de poliéster sobre placa reciclada .................................................. 55

Figura 3.10: Placas empilhadas - Instabilidade dimensional ........................................... 55

Figura 3.11: Telha reciclada usada como tapume na EESC-USP .................................... 56

Figura 3.12: Casinhas de cachorro de placas recicladas de embalagem longa vida. .......... 57

Figura 3.13: Lixeira de material reciclado de embalagem longa vida. ................................ 57

Figura 3.14: Galpão com uso de placas curvadas, configurando um pequeno beiral .......... 58

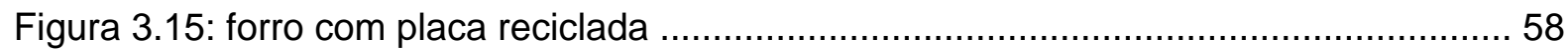

Figura 3.16 - Telhas e cumeeiras recicladas em embalagens Longa Vida ........................ 58

Figura 3.17:Telhas recicladas de embalagem longa vida ............................................ 59

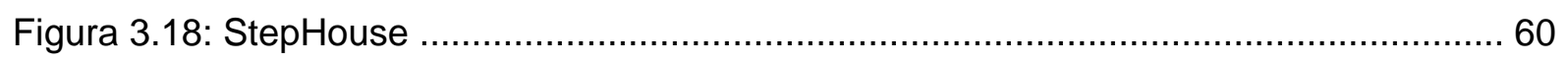

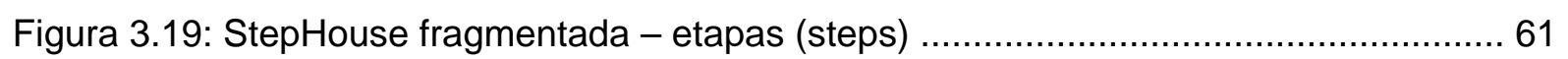

Figura 3.20: Paleta de materiais propostos para a Step House ........................................ 61

Figura 3.21: Maquete Eletrônica da Casa AQUA - sobrado versão 2009 ............................. 62

Figura 3.22: Protótipo da constução da Casa Aqua - Térrea - versão 2010 ....................... 63

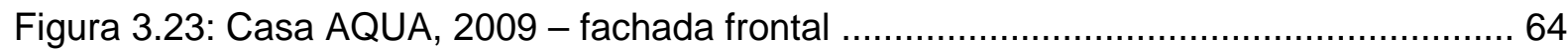

Figura 3.24: Casa AQUA, 2009: peitoril metálico com argila expandida ..............................65

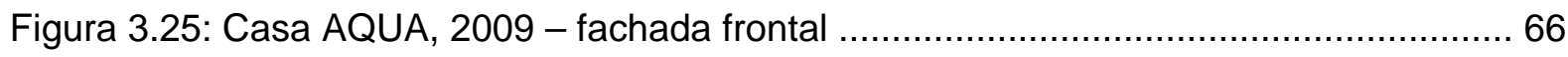

Figura 3.26: Casa AQUA, 2009 - detalhe dos painéis de fechamento externo. .................. 67 
Figura 3.27: Casa AQUA, 2009 -placas recicladas com tijolo de solo-cimento.

Figura 4.1: Corpo de prova marcado em três pontos para ensaio de Refletância................ 72

Figura 4.2: Espectrofotômetro: Equipamento para ensaio de Refletância............................ 72

Figura 4.3: diagrama esquemático dos equipamentos e técnica do fio quente..................... 77

Figura 4.4: Diagrama esquemático do arranjo experimental dos corpos de prova............... 78

Figura 4.5: Organização e movimentação das placas diariamente dentro do aparelho........ 83

Figura 4.6: Registro de retirada das placas ao longo do ensaio de Intemperismo............... 84

Figura 4.7: Corpos de prova para ensaio de Análise Dinâmico Mecânica - Transição

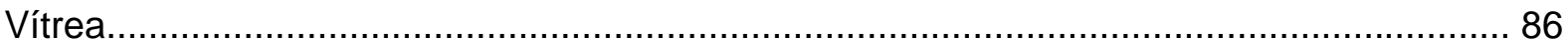

Figura 4.8: Detalhe de Corpo de prova encaixado pronto para ensaio de DMA.................. 88

Figura 4.9: Vista microscópica comparativa de estrutura interna das placas recicladas...... 90

Figura 5.1: Texturas e cores das placas recicladas de embalagem longa vida................... 99

Figura 5.2: Detalhes da mescla de materiais................................................................. 100

Figura 5.3: Placa reciclada revestida com filme plástico colorido................................... 100

Figura 5.4: Detalhe da Matéria-prima com sujeira....................................................... 101

Figura 5.5: Estudos de vista das placas a diferentes distâncias...................................... 102

Figura 5.6: Texturas argamassadas e concreto em composição com placa reciclada....... 104

Figura 5.7: Texturas argamassadas coloridas em composição com placa reciclada.......... 105

Figura 5.8: Texturas de madeiras em composição com placa reciclada............................ 106

Figura 5.9: Texturas de metais em composição com placa reciclada................................. 107

Figura 5.10: Texturas de pedras em composição com placa reciclada............................... 108

Figura 5.11: Texturas de vidros em composição com placa reciclada............................... 109

Figura 5.12: Texturas de plásticos e borrachas em composição com placa reciclada........ 110

Figura 5.13: Texturas comparadas - granitos e placas recicladas de polietileno alumínio. 112

Figura 5.14 : Placa reciclada sendo curvada em Calandra.......................................... 114

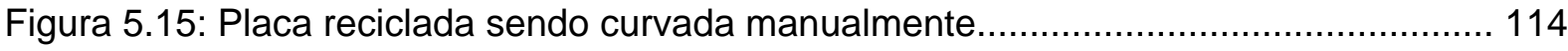

Figura 5.16 : Protótipo final e detalhe da fixação com parafusos inoxidáveis..................... 120

Figura 5.17: Possibilidades de design: Prateleira e Cômoda de plástico reciclado............. 121

Figura 5.18: Wohnwagen - veículo com material reciclado........................................... 121

Figura 5.19: Kubus - Instalação com painéis de placas recicladas de embalagens plásticas -

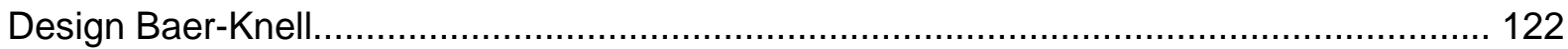

Figura 5.20: Rotunde - Instalação com painéis de placas recicladas de embalagens plásticas

Figura 5.21: Ambiente com painéis de placas recicladas proveniente de embalagens plásticas. 


\section{Lista de tabelas}

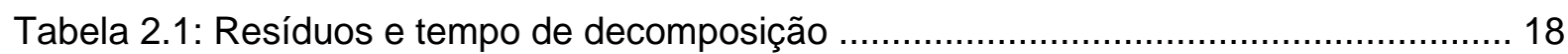

Tabela 2.2: Proporção de material reciclado em atividades industriais selecionadas .......... 19

Tabela 2.3: Preço do material reciclável (preço da tonelada, em Real) .............................. 20

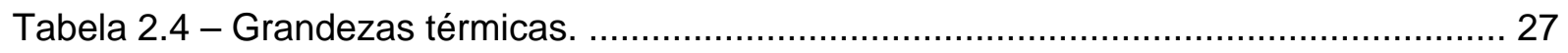

Tabela 3.1: Recicladoras de embalagens Longa Vida no Brasil e produtos produzidos....... 51

Tabela 4.1: Compilação de dados técnicos: Placas Recicladas de Emb. Longa Vida.......... 70

Tabela 4.2 : Resultados de Refletância e Absortância nos três pontos marcados na placa $(\%)$ 74

Tabela 4.3: Refletância e Absortância total das Placas Recicladas de Emb. Longa Vida.... 75 Tabela 4.4: Porcentagem de Refletância e Absortância das Placas Recicladas de Emb. Longa Vida, por comprimento de onda (UV, VIS e IV)................................................... 75

Tabela 4.5: Condutividade térmica $(\mathrm{k})$ de alguns materiais de construção........................... 80

Tabela 4.6: Classificação das Placas Recicladas de Embalagem Longa Vida.................... 91

Tabela 4.7: Características dimensionais das Placas Recicladas de Polietileno-Alumínio....

Tabela 4.8: Propriedades gerais das Placas Recicladas de Polietileno-Alumínio................. 92

Tabela 4.9: Resumo dos Resultados térmicos com símbolos e unidades.......................... 93

Tabela 4.10: Transmitância térmica de paredes externas - Valores máximos admissíveis...

Tabela 5.1: Classificação quanto aos elementos visuais............................................. 124

Tabela 5.2: Indicativo de relações estéticas.............................................................. 125

Tabela 6.1: Aspectos técnicos e estéticos.do design: material, componente, superfície e edifício. 


\section{Lista de quadros}

Quadro 3.1 -Processo de fabricação das Placas Recicladas de Embalagem Longa Vida... 54

Quadro 4.1: Etapas ensaio de Refletância / Absortância .73

Quadro 4.2: Etapas de ensaio de condutividade térmica pelo método do fio quente. 79

Quadro 4.3: Equipamento para ensaio de envelhecimento acelerado UV e Umidade. 82

Quadro 4.4: Equipamento para ensaio de DMA Tg 87

Quadro 5.1: Comparativo placas recicladas semelhantes.

Quadro 5.2: Trabalhabilidade das Placas Recicladas de Embalagens Longa Vida.

Quadro 5.3: Módulos - aproveitamento de corte das placas recicladas.

Quadro 5.4: Estudos de composição com placas quadradas curvadas.

Quadro 5.5 : Estudos de possibilidade construtiva com uso das placas recicladas.

Quadro 6.1: Sistemas construtivos de referência para projeto

Quadro 6.2 - Possibilidades projetuais com Placas Recicladas de Embalagens Longa Vida.

\section{Lista de gráficos}

Gráfico 2.1: Distribuição dos municípios com coleta seletiva no Brasil.

Gráfico 2.2: Composição de materiais da coleta seletiva no Brasil, em peso. 19

Gráfico 3.1: Taxa de reciclagem de embalagens longa vida no Brasil ( em \%)

Gráfico 4.1 - Refletância em três pontos da Placa Reciclada de Embalagem Longa Vida......

Gráfico 4.2 - Módulo de armazenamento por Temperatura. 88

Gráfico 4.3 - Tan Delta por Temperatura 89

\section{Lista de Desenhos e Projetos}

Desenho 6.1 : Painel com tabuado de Reciclado Longa Vida - Paginação Horizontal...... 133

Desenho 6.2 : Detalhe de Painel com tabuado de Reciclado Longa Vida........................ 133

Desenho 6.3: Painel com tabuado de Reciclado Longa Vida - Paginação alternada........ 134

Desenho 6.4 : Detalhe da paginação tabuada alternada............................................... 134

Desenho 6.5: Estudo de aplicação da peça em sistema Steel Frame. ............................... 135

Desenho 6.6: Brise com aletas verticais, baseado em modelos existentes...................... 135 
Desenho 6.7: Painel interno ou externo com quadriculado de reciclado Longa Vida e vidro...

Desenho 6.8: Painel interno: mosaico iluminado 136

Desenho 6.9: Objeto luminoso para parede - arandela............................................... 137

Desenho 6.10: Objeto luminoso para teto - Luminária orgânica de reciclado e vidro........ 137

Desenho 6.11: Objeto luminoso para teto - Luminária ondulada com "sanduíche" de placas

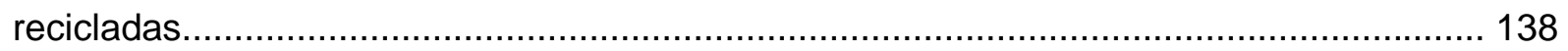

Desenho 6.12: Banco curvo com reciclado Longa Vida em suporte metálico..................... 138

Desenho 6.13 :Mesa de reciclado Longa Vida com cobertura/acabamento de vidro......... 138

Desenho 6.14: Portas com reciclado Longa Vida e vidro (direita).................................. 139

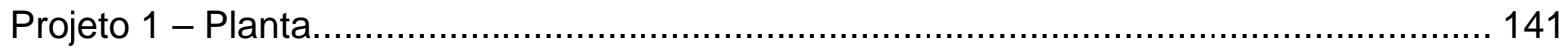

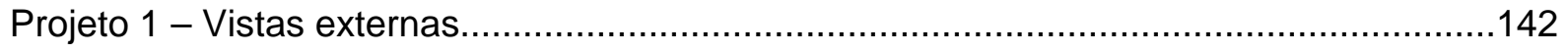

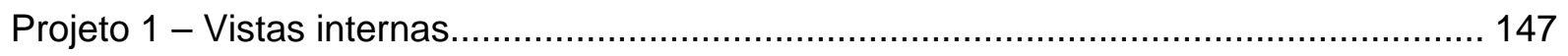

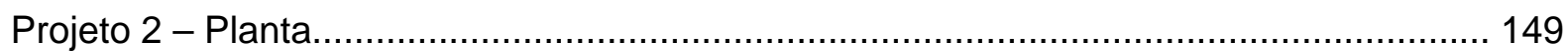

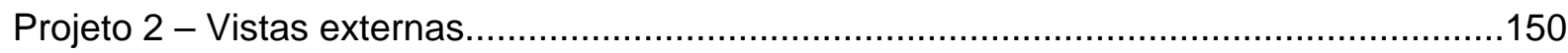

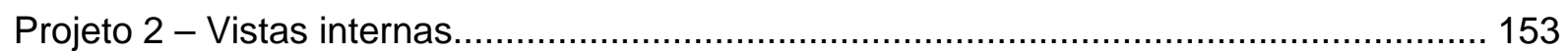

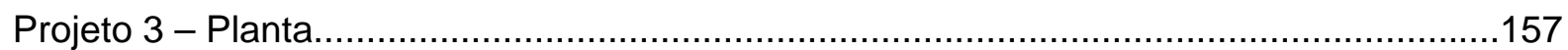

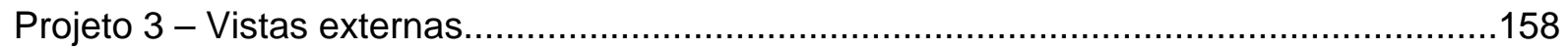

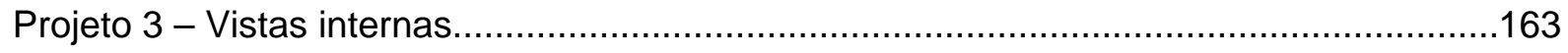




\section{SUMÁRIO}

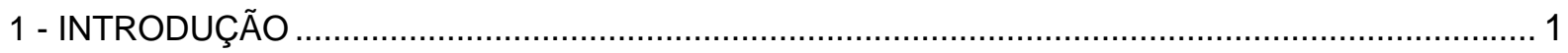

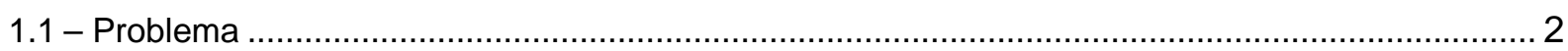

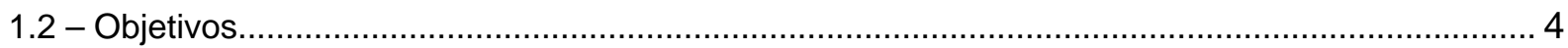

1.3 - Justificativa

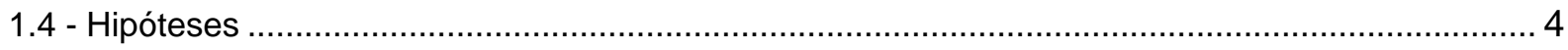

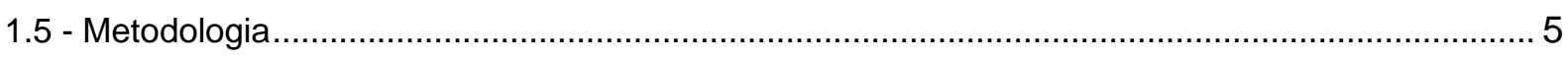

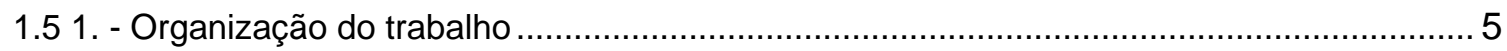

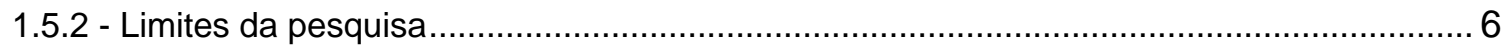

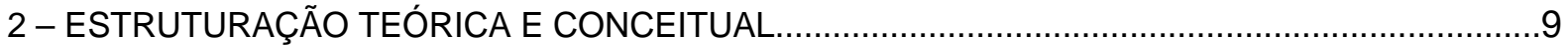

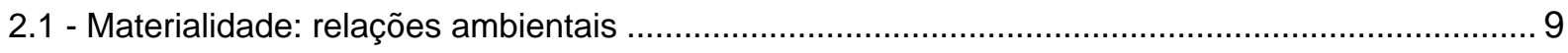

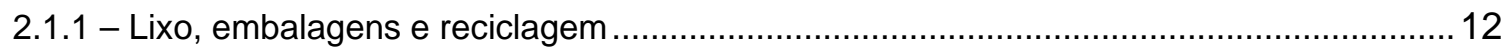

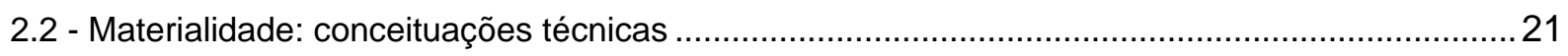

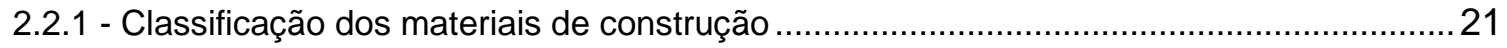

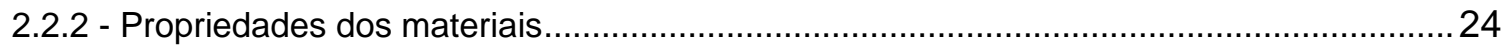

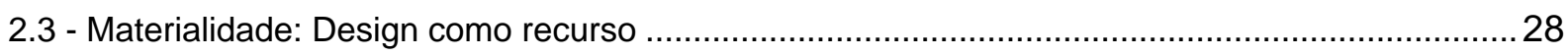

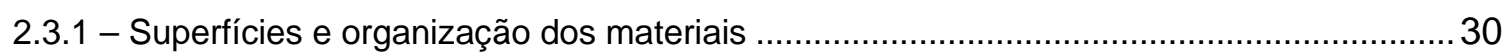

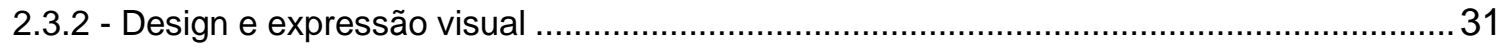

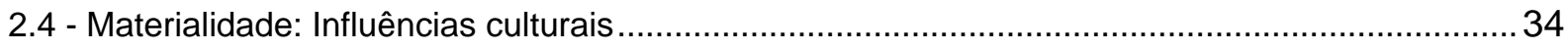

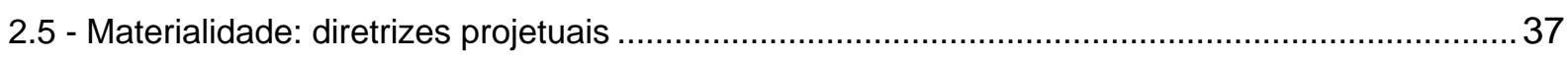

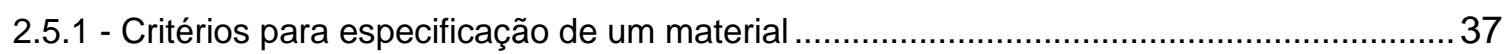

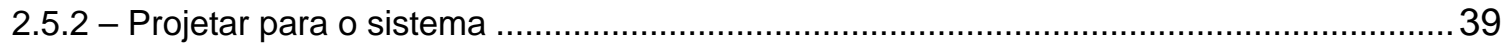




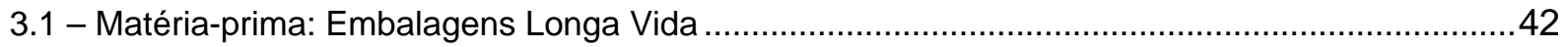

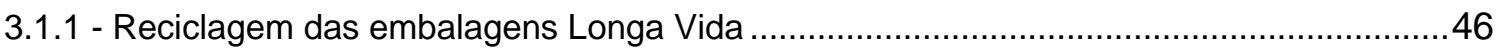

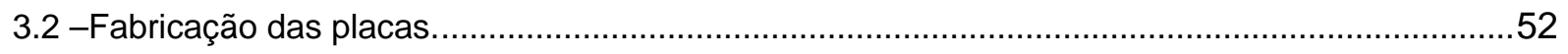

3.3 - Estado da Arte do design com Placas Recicladas de Embalagens Longa Vida.........................56

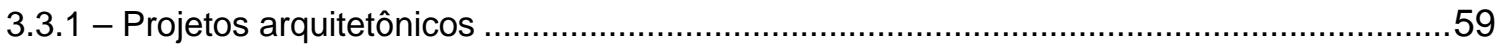

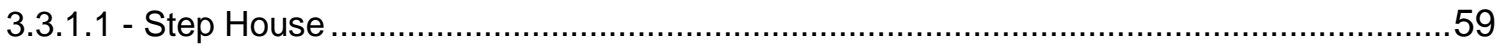

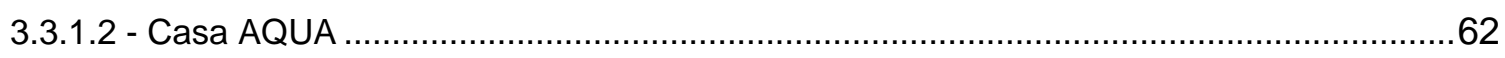

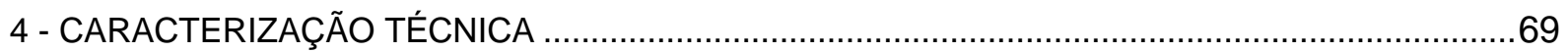

4.1 - Ensaio para determinação de Refletância e Absortância à radiação solar ...................................71

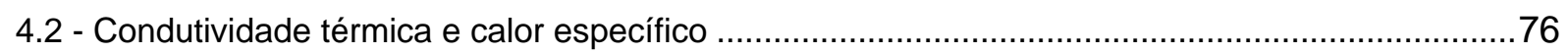

4.3 - Envelhecimento acelerado: Exposição das placas aos raios UV e intemperismo artificial ..........81

4.4 - Análise Dinâmico-mecânica - Transição vítrea (DMA Tg) ……….............................................. 85

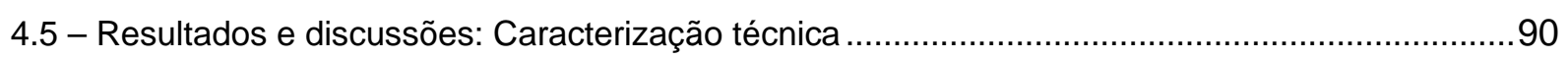

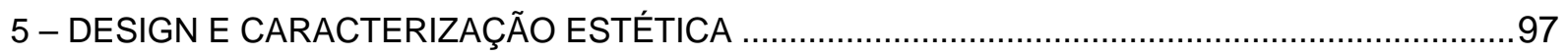

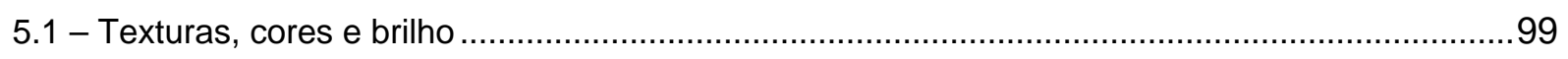

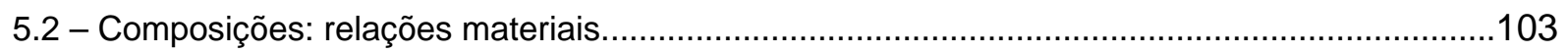

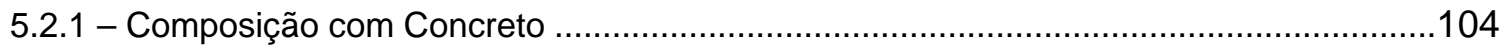

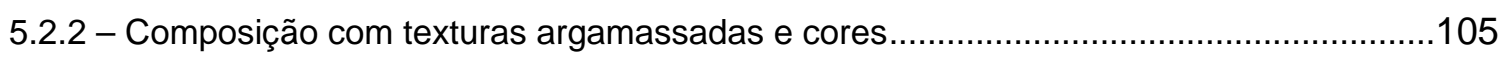

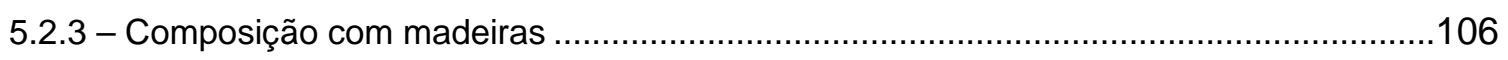

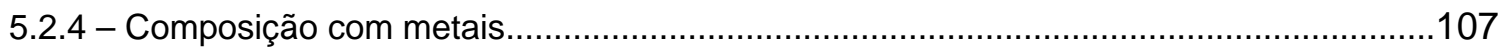

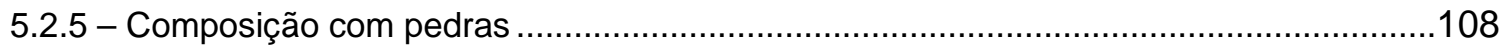

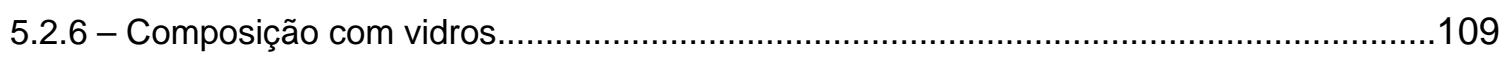


5.2.7 - Composição com plásticos e borrachas

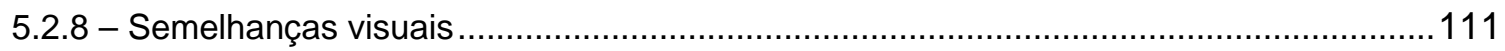

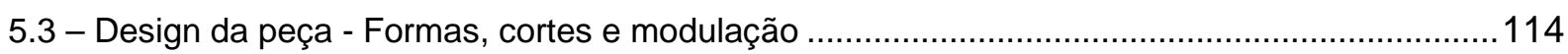

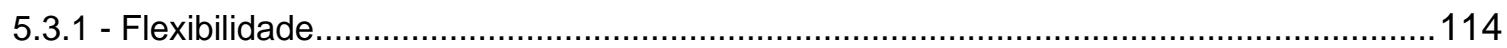

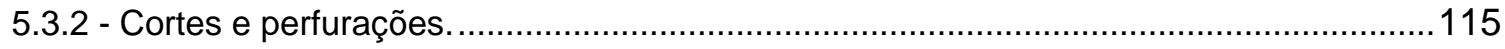

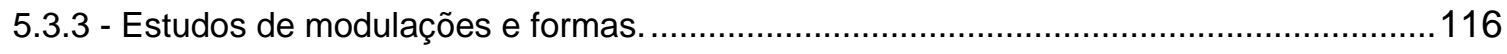

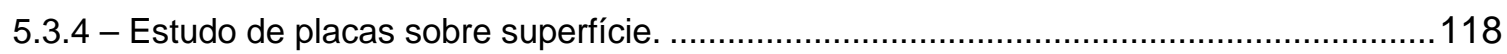

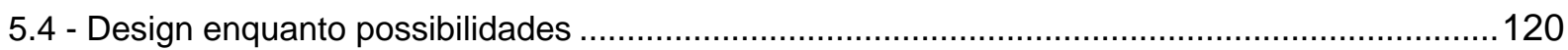

5.5 - Resultados e discussões - caracterização estética ……......................................................... 123

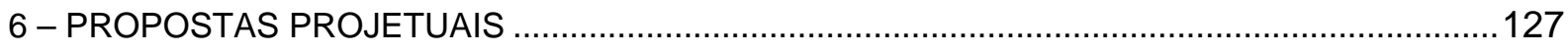

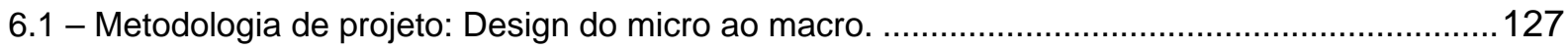

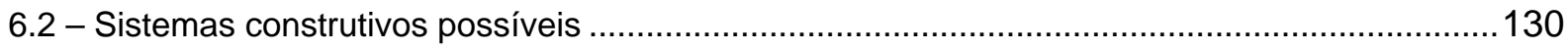

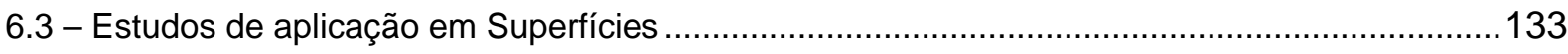

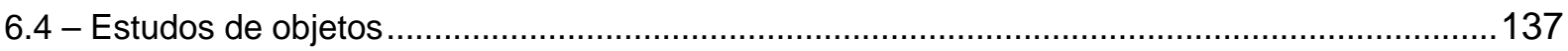

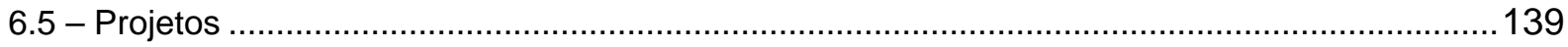

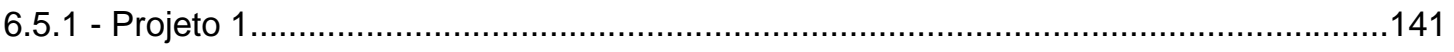

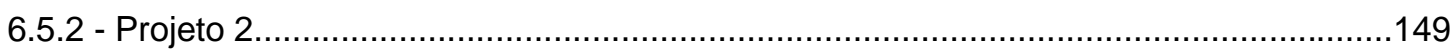

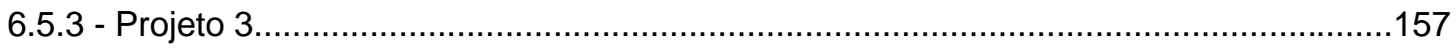

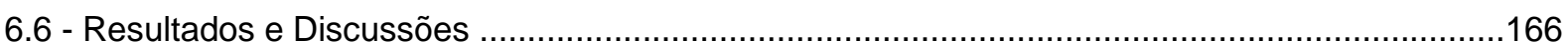

7 - DISCUSSÕES

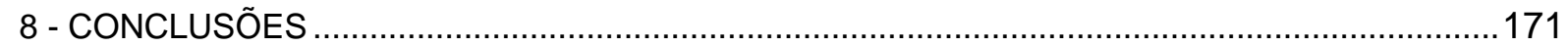

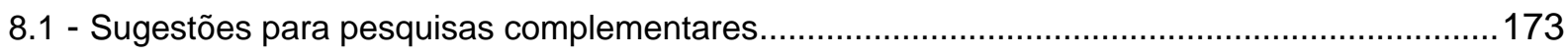

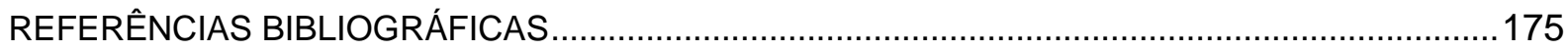

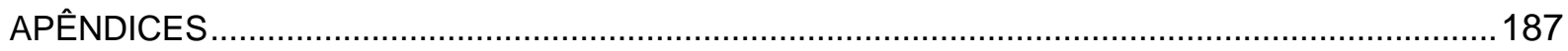

ANEXOS 



\section{1 - INTRODUÇÃO}

$\mathrm{Na}$ história do desenvolvimento tecnológico dos materiais, percebe-se uma quantidade de opções praticamente imensurável, por ser extraordinariamente vasta, que gerou uma cultura com fortes preferências pelos materiais naturais utilizados há séculos, como as rochas ornamentais e os cerâmicos, assim como os materiais com alta tecnologia incorporada, como os perfis metálicos, os vidros, policarbonatos, entre vários outros. Essa variedade de materiais, quando compõe uma superfície, proporciona, igualmente, uma variedade de identidades arquitetônicas, já que os materiais se associam às formas e aos volumes do edifício, gerando diferentes resultados de design, com expressões culturais e tecnológicas que marcam a arquitetura de uma determinada região, em uma determinada época. $\mathrm{Na}$ arquitetura modernista, por exemplo, houve o interesse pela expressão da "verdade dos materiais", referindo-se ao uso, naquela época, dos materiais em sua forma pura e aparente, como, por exemplo, o concreto e o vidro. No entanto, à medida em que há consciência de que o uso excessivo dos materiais demanda extração agressiva do meio ambiente e de que realmente pode causar danos ambientais irreversíveis, tem-se buscado considerar o impacto ambiental das decisões para especificação. Assim, atualmente, a "verdade dos materiais" parece estar mais embasada nas questões ambientais. O novo material apresenta-se com uma nova matéria-prima, completamente diferente do que era referência e proveniente do acúmulo diário de resíduos, daquilo que menos se desejava até então: do lixo. O que tem surgido como resultado desse processo é também um novo "catálogo de opções" de materiais: os compostos, os reconstituídos e os reciclados, que, na maioria das vezes, não possuem um traçado de seu perfil material estruturado para conhecimento de suas propriedades e características. Assimilar essa materialidade requer mudanças de comportamento, pesquisas, desenvolvimento tecnológico, aceitação do novo e escolhas materiais diferentes das tradicionais. Com base nesse pequeno panorama, o que se percebe é um momento de transição, com a reavaliação dos critérios para concepção projetual, da produção industrial dos materiais reciclados, do design e do surgimento de novas pesquisas nesta área. 
Esta tese apresenta o estudo de um desses novos materiais: o reciclado proveniente das Embalagens Longa Vida. As Embalagens Longa Vida estão presentes no cotidiano das pessoas, acondicionando leite, sucos e molhos, entre outros, e são descartadas em enorme quantidade, diariamente, e pouca parte do descarte é reciclada. No entanto, com a pequena parcela que se recicla anualmente, vários objetos são produzidos. A tecnologia desenvolveu-se de tal forma que, atualmente, nada se perde das três camadas que compõem as caixinhas (o polietileno, o alumínio e o papel). Dois dos produtos da reciclagem dessas embalagens, as placas e telhas, estão sendo utilizados na construção há mais de dez anos e têm-se mostrado boas soluções para coberturas, tapumes e também na confecção de objetos variados, como lixeiras, partes de cadeiras e casas para animais.

A identificação, por meio da observação e de publicações técnicas e científicas, do comportamento das Placas Recicladas de Embalagem Longa Vida, com boas respostas em relação à impermeabilização e também à boa eficiência na proteção térmica, foi o ponto de partida para se traçarem os objetivos e hipóteses desta pesquisa. Acredita-se que a potencialidade do material possa ir além dos usos propostos atualmente, podendo se estender para as superfícies externas e internas das edificações, adaptando-se aos sistemas construtivos existentes. O que, a princípio, pode causar certa resistência devido ao aspecto visual das placas, em um contato constante, em composições com design elaborado, pode se transformar em um material mais atrativo com a originalidade $\mathrm{e}$ personalidade de uma era que, gradativamente, assume-se reciclada. Acredita-se que a natureza do material da era sustentável expresse-se por meio de novas texturas e mescla de cores e, desta forma, propõe-se aqui o uso das Placas Recicladas de Embalagens Longa Vida em sua forma pura, demonstrando suas potencialidades de forma a colaborar com o processo de especificação e incentivando seu uso nas diversas superfícies arquitetônicas.

\section{1 - Problema}

Vários são os problemas identificados em relação às Placas Recicladas de Embalagem Longa Vida. Um dos problemas de base está relacionado à coleta seletiva. Além do problema geral da coleta de recicláveis no Brasil, especificamente em relação às embalagens longa vida, enfrenta-se o fato de que o preço dessas embalagens no mercado da reciclagem é muito mais baixo do que o preço de outros materiais, como o alumínio, o PET e outros plásticos, o que, obviamente, não incentiva a coleta desse material por parte dos catadores. 
Outro problema básico é o desenvolvimento tecnológico para as etapas da reciclagem e produção das placas. Apesar da busca constante por melhoria no processo de produção, as tecnologias industriais instaladas até o momento são adaptadas e, além de produzirem uma matéria-prima que varia em composição (com maior ou menor quantidade de papel na mistura, por exemplo), também, durante a fabricação, uma pequena variedade de placas é produzida. Além disso, o maquinário e processo como um todo não favorecem o acabamento das peças.

Tecnicamente, o problema apresenta-se devido à necessidade de complementação de dados aos existentes e também à falta de normas relacionadas à produção das placas e procedimentos de aplicação. Esse é um problema que envolve os materiais reciclados de forma geral.

No que se refere às questões estéticas, percebe-se que o aspecto visual das placas não agrada muito ao olhar do observador. Também não foram encontrados trabalhos que abordem o tema pelo enfoque estético e de design. Em conseqüência ao desinteresse estético, percebe-se a dificuldade em encontrar esse material aplicado em sistemas construtivos mais complexos e com design agregado. As placas são principalmente usadas em produtos muito simples ou subprodutos.

O enfoque desta pesquisa são os problemas relacionados à falta de sistematização de dados técnicos e estéticos e ao uso restrito das placas nos projetos de arquitetura. Este trabalho busca responder às seguintes perguntas:

- Por que as Placas Recicladas de Embalagem Longa Vida são utilizadas, essencialmente, como telhas e tapumes?

- Como criar soluções que colaborem para ampliação de seu uso?

- Como traçar um perfil de caracterização do material?

- Quais são as possibilidades de design com as placas para uso nas superfícies arquitetônicas?

A partir desta problemática, foram traçados os objetivos da pesquisa que, com o olhar científico, buscou identificar as várias potencialidades que as Embalagens Longa Vida podem oferecer. 


\section{2 - Objetivos}

Os objetivos gerais desta pesquisa são sistematizar dados sobre as Placas Recicladas de Embalagens Longa Vida, por meio de uma abordagem holística de suas características e possibilidades de uso na arquitetura e estudar as placas em sua forma e textura originais, como meio de valorizar a identidade dos materiais reciclados e suas implicações sustentáveis.

Os objetivos específicos são traçar um quadro de caracterização técnica e estética como referencial para identificação do perfil do material e apresentar propostas de design como alternativas para aplicação das placas em superfícies arquitetônicas.

\section{3 - Justificativa}

Identificar as qualidades técnicas e estéticas de um material relativamente novo no mercado e apontar possibilidades de uso em ambientes arquitetônicos são formas de criar um ponto de referência que gere interesse e confiança para a especificação desse material. Com a valorização e comprovação de suas propriedades, pode-se instigar o desenvolvimento de design mais arrojado e o desenvolvimento tecnológico para aumento da produção das placas recicladas, com maior qualidade e competitividade no mercado de materiais e componentes para construção.

Em relação às questões ambientais, o uso de Embalagens Longa Vida na construção é uma forma de incentivar a coleta, reciclagem e uso dos componentes reciclados, já que, dada a quantidade de embalagens longa vida que é descartada no meio ambiente, todos os anos, seria possível uma produção praticamente triplicada de placas e telhas.

\section{4 - Hipóteses}

- Placas recicladas de embalagens longa vida podem, de forma eficiente, ter variados usos arquitetônicos e de design, além daqueles usualmente especificados.

- O design de componentes e sistemas construtivos pode agregar valor estético às placas e aumentar o interesse pela sua especificação. 


\section{5 - Metodologia}

Considerando-se que a metodologia de uma pesquisa apresenta as perguntas "Como comprovar as hipóteses?" e "Como atingir os objetivos?" três métodos foram traçados para buscar respostas.

O primeiro método consistiu na observação, coleta e descrição das placas recicladas, como parte de uma materialidade maior, que sofre influências das questões ambientais, técnicas, de design, de origem de sua matéria-prima, assim como das influências culturais. Essa análise foi considerada valiosa como embasamento e estrutura conceituais para a defesa do material estudado. Essa etapa foi essencialmente realizada através de pesquisa bibliográfica e pesquisa de campo, com visitas técnicas e contato com empresa fabricante de embalagens longa vida e recicladora produtora de placas e telhas.

O segundo método foi a sistematização de uma caracterização para identificação das potencialidades técnicas e de design das placas recicladas, com uma avaliação criteriosa dos elementos visuais, de técnicas comparativas entre materiais e de ensaios laboratoriais. A caracterização técnica do material foi baseada na literatura clássica sobre materiais de construção. Esses dados foram importantes para verificar se a primeira hipótese desta pesquisa se confirma e para traçar indicativos de possibilidades para projeto. Para essa etapa, foram realizados principalmente os ensaios laboratoriais e análises visuais comparativas.

O terceiro método foi a criação e a demonstração de possibilidades projetuais por meio de modelos eletrônicos, com os quais foi possível visualizar usos alternativos das placas recicladas, tanto em design de objetos, quanto em design de superfícies arquitetônicas. Os projetos apresentados indicaram algumas soluções para comprovar a segunda hipótese traçada por esta pesquisa.

\subsection{1. - Organização do trabalho}

O conteúdo da pesquisa está organizado da seguinte maneira:

- No Capítulo 2, são apresentadas várias análises relacionadas às placas recicladas, tanto no que se refere ao meio ambiente, sustentabilidade, lixo e reciclagem, assim como no que se refere ao design, à cultura material e as classificações e propriedades dos materiais de construção. 
- O Capítulo 3 trata das Placas Recicladas de Embalagens Longa Vida, desde sua matéria-prima (as embalagens), seu ciclo de vida, os processos de reciclagem e o resultado do design dos produtos derivados.

- No Capítulo 4, são apresentados os ensaios realizados e a proposta para caracterização técnica das placas, considerando os dados existentes e os novos dados ensaiados para esta pesquisa.

- O Capítulo 5 trata das características estéticas das placas recicladas, como textura, cor e tamanho, e seu potencial de design por meio de analogias com alguns materiais e estudos de composições visuais.

- No Capítulo 6 são apresentadas as propostas projetuais criadas com uso das placas recicladas.

- $\quad$ No Capítulo 7 são feitas as discussões sobre os resultados obtidos na pesquisa.

- O Capítulo 8 apresenta as conclusões do trabalho e indica temas para continuidade e complementação desta pesquisa

Em seguida são apresentadas as Referências Bibliográficas os Apêndices e Anexos com complemento textual sobre sustentabilidade, lixo e reciclagem; relatório de ensaios técnicos, modelo de questionários, entre outros dados complementares à pesquisa.

\subsection{2 - Limites da pesquisa}

Por ser uma pesquisa que trata das Placas Recicladas de Embalagens Longa Vida em seus vários aspectos para o uso na arquitetura, cada um dos tópicos foi abordado de maneira equilibrada, tanto na quantidade de informações, como no aprofundamento de cada tema relacionado (técnico, estético e design/projetual).

Esta pesquisa não apresenta o projeto de um novo produto "placa" ou soluções de revestimento e acabamento para a superfície da própria placa. Este trabalho também não contempla apresentar soluções de pintura, adesivagem, entre outras que pudessem visar esconder a textura original do material. A idéia é observar a utilização das placas com o aspecto e acabamento originais, pelas razões apresentadas no tópico dos objetivos gerais.

Os ensaios ficaram limitados àqueles considerados mais importantes para comprovar o que se observa na prática do uso das placas recicladas: a proteção térmica. O uso desses 
dados também ficou limitado à tabulação e descrição dos mesmos. Usar os dados ensaiados para cálculos térmicos e conseqüentes discussões sobre eles, estenderia consideravelmente a abordagem técnica em relação aos objetivos da pesquisa.

As alternativas projetuais apresentadas incluem soluções de aplicação das placas recicladas para superfícies verticais e horizontais, internas e externas, com exceção dos pisos.

Em função da amplitude da pesquisa, não é objetivo a criação de soluções de sistemas construtivos ou detalhamento gráfico/construtivo dos projetos; sendo assim, as propostas projetuais são limitadas à apresentação na forma de maquetes eletrônicas renderizadas, consideradas mais eficientes para tratar dos aspectos visuais.

Finalmente, por se tratar de uma pesquisa realizada sem recursos provenientes de agências fomentadoras de pesquisa ou de outras fontes, o fator financeiro foi determinante para não executar modelos construtivos ou protótipos das soluções projetuais apresentadas. 


\section{2 - ESTRUTURAÇÃO TEÓRICA E CONCEITUAL}

Este capítulo tem como objetivo estruturar conceitualmente algumas relações que a materialidade tem com as questões ambientais, técnicas, culturais, projetuais e de design. Essas abordagens demonstram cada uma das várias faces de influência dos materiais no conjunto arquitetônico. Objetiva-se organizar um raciocínio e sistematização teóricos para defender o uso dos materiais reciclados, especificamente o uso das Placas Recicladas de Embalagem Longa Vida como componente arquitetônico.

\section{1 - Materialidade: relações ambientais}

Historicamente, a preocupação com as questões ambientais está associada aos grandes eventos mundiais, que ocorreram, principalmente, a partir do começo da década de 1970, como expressão da preocupação dos Estados com temas como o meio ambiente e o destino e qualidade da vida da população mundial.

Ao longo da estruturação das ideias sobre o meio ambiente, surgiram muitos "Ecoconceitos": 3R's (Reduzir, Reutilizar e Reciclar o lixo produzido) e vários outros "R's" (Refletir, Recusar, Reaproveitar, Redesenhar, Retrofit), sustentabilidade, eco design, arquitetura ecológica, produção mais limpa, pegada ecológica, entre outros (ver apêndice). Os termos são muitos, o que gera certa confusão, porque são termos técnicos, ou são associados ao marketing e propaganda e perdem sua essência, banalizando o que realmente deve ser considerado em relação ao meio ambiente. Segundo Bahamón e Sanjinés (2008), simplesmente o tema está na moda e é a desculpa ideal para captar a atenção de um público potencial, ficando, então, muito difícil distinguir quais iniciativas comportam um compromisso real com o meio ambiente. Outro aspecto salientado pelos mesmos autores é de que o manejo inteligente do que se descarta, apesar de ser uma medida urgente na atualidade, foi e é, em outras sociedades em desenvolvimento, parte integrante da sociedade; não como uma iniciativa para o meio ambiente, mas como medida alternativa para remediar situações de necessidade. Para as culturas que não lidam com 
isso de forma natural e incorporada, a relação com os materiais deve ser reconstruída, visando projetar buscando resultados positivos para o meio ambiente.

Sabe-se que o setor da construção civil é um grande gerador de resíduos materiais. A reutilização e reciclagem para fins construtivos arquitetônicos têm sido recursos para manipular e administrar o desperdício e criar componentes e resultados construídos que se adaptem às novas necessidades de sustentação e preservação do meio ambiente.

A sustentabilidade tem sido base para tecnologias inovadoras e abordagens de design, representando um novo paradigma para a equidade social, proporcionando nova forma estética e cultural à paisagem, além de uma nova perspectiva por meio da qual as empresas poderão projetar seus futuros. (EDWARDS, 2008, p.11)

Fuad-Luke (2002), diz que um material ecológico caracteriza-se por um impacto ambiental mínimo e um rendimento máximo para a tarefa requerida pelo desenho, ou projeto, e por ser fácil de ser reintroduzido nos ciclos naturais. Os materiais da biosfera reciclam-se na natureza e os materiais da tecnosfera reciclam-se em processos elaborados pelo homem.

Com relação à materialidade, a sustentabilidade visa estabelecer meios de utilizar menos os materiais naturais e energia para sua produção, projetar para o ciclo de vida, para a menor geração de resíduos, prezando a "Iongevidade do produto", e gerir o reuso, reaproveitamento e reciclagem no processo construtivo, explorando os resíduos como potenciais fontes de energia e matéria-prima para usos diversos, como no design de mobiliário e na produção de novos componentes para a construção. E, terminada a vida útil do objeto, que ele possa ser reciclado ou reutilizado em outra configuração formal, seja compondo um novo objeto (figuras 2.1, 2.2 e 2.3), seja remanejando e requalificando espacialmente suas funções para que adie ou evite ao máximo o descarte no meio ambiente. Esse parece ser um desafio enorme para uma sociedade acostumada ao consumo e às facilidades que os objetos proporcionam. 


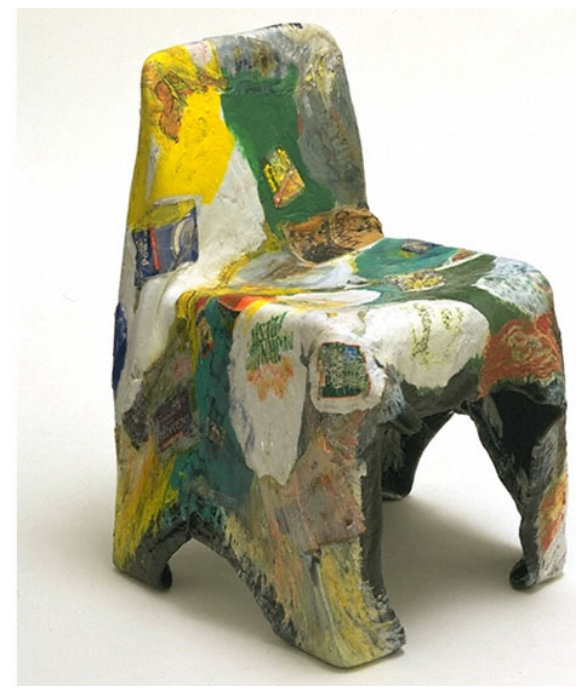

Figura.2.1: Cadeira produzida com plástico reciclado Design de Bär \& Knell, Alemanha, 1996. Fonte:VICTORIA \& ALBERT MUSEUM (2010)

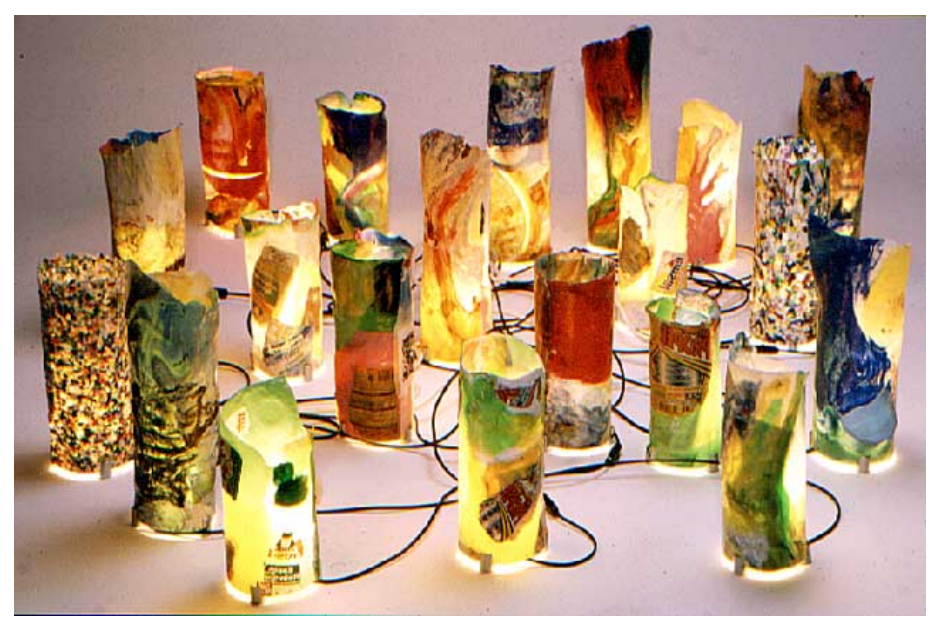

Figura 2.2: Luminárias produzidas a partir de plástico reciclado. Design de Bär+Knell Fonte: BAER-KNELL (2010)

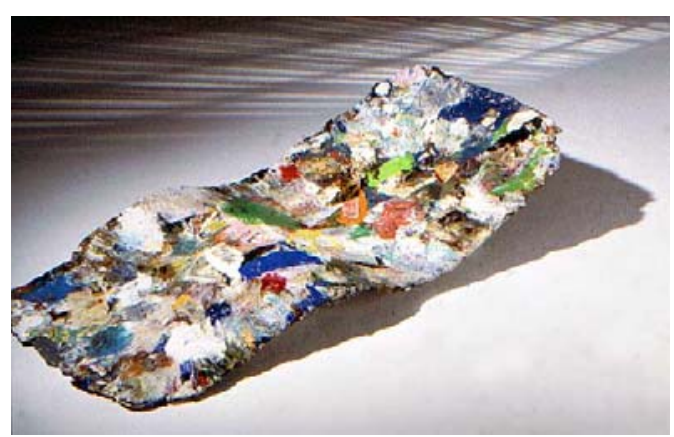

Figura 2.3: Espreguiçadeira de plástico reciclado. Design de Bär+Knell Fonte: BAER-KNELL (2010) 


\subsection{1 - Lixo, embalagens e reciclagem}

$\mathrm{O}$ ato de embalar alimentos, líquidos, objetos e outros itens da vida cotidiana desenvolveu-se clara e paralelamente ao crescimento tecnológico da humanidade, o que obviamente demandou longos processos de adaptação no comportamento das pessoas em relação às embalagens, evidenciado com o surgimento das embalagens descartáveis.

No século XIX, surgiram as latinhas metálicas como opção para conservar os alimentos. Assim como o metal, outros materiais foram descobertos e aperfeiçoados ao longo das décadas, como as embalagens de madeira, papelão, e mesmo o plástico, que, segundo Peltier e Saporta (2009), surgem a partir de 1927, com a industrialização do PVC e invenção das principais matérias plásticas de origem petrolíferas, como o poliestireno, em 1930; o polietileno de baixa densidade, em 1933; o polietileno de alta densidade em, 1953, e o polipropileno, em 1954. Ainda, segundo esses autores, quando, em 1968, foi lançada a primeira garrafa plástica de água, pela Vittel, começa definitivamente a era da embalagem descartável.

Com o aumento do volume do lixo doméstico ao longo de todo esse processo, o consumidor encontrou-se diante do montante da sobra do pós-consumo: a embalagem vazia. Esta deveria, então, ser descartada em algum lugar. Os resíduos, inevitáveis, trouxeram a necessidade da utilização de recipientes coletores em cada residência: a lata de lixo doméstica. Uma solução encontrada em 1884 pelo francês Eugène Poubelle, que, nas palavras de Peltier e Saporta (2009, p.13) "obriga os proprietários dos imóveis a deixarem à disposição dos inquilinos recipientes coletivos, munidos de uma tampa, para que depositem os lixos domésticos." As pessoas foram então, ao longo da história, organizandose para acomodar e destinar seus lixos. Esse hábito e o da coleta municipal ficam mais organizados após a Segunda Guerra Mundial.

Desde então, o acúmulo imenso de materiais começou a incomodar por seu volume e permanência no meio ambiente. Assim, com a necessidade de coleta mais eficiente e a preocupação com a reciclagem, as lixeiras passaram a permear ainda mais os espaços: separadas por cores, em diversos recipientes, ou simplesmente dois recipientes dividindo os "recicláveis" dos "não recicláveis", ou separando o "lixo orgânico" do lixo "seco". Também começam iniciativas dos próprios produtores de embalagens, para dar destino a seus produtos pós-uso e aumentar o ciclo de vida desses materiais. Começou, então, a iniciativa pela retirada do "lixo" do meio urbano e sua transformação em nova matéria-prima para novos produtos. Isso vem acontecendo com o PET, com o vidro, com as latinhas de 
alumínio e, menos intensamente, mas crescentemente, com as Embalagens Longa Vida. Mais uma vez, percebe-se a constante adaptação da sociedade em relação aos diversos resíduos, seus tipos, recipientes, formas de coletar e conhecimento de seus destinos e possibilidades de uso.

\subsubsection{1 - Embalagens e o impacto ambiental}

O desenvolvimento tecnológico que na década de 60 do século $X X$, propiciou a criação e permanência das Embalagens Longa Vida no mercado de alimentos, não deixou de causar um impacto ecológico ao longo de todos esses anos. Assim como todas as embalagens, é impossível não associar a produção à exploração dos recursos naturais e matérias-primas. Três materiais envolvidos em multicamadas apareceram como uma excelente solução para acondicionamento, porém tornou-se um desafio para o pósconsumo, no que se refere ao destino dado para essas embalagens.

Impossível isolar as etapas de produção da embalagem e do acondicionamento dos outros setores de atividade. A exploração dos recursos e das matérias-primas integra-se num ecossistema industrial. Destinadas a medir os impactos das diferentes atividades no meio ambiente, as análises do ciclo de vida (ACV) permitiram orientar as diretrizes do progresso para cada solução de embalagem, graças à identificação dos principais impactos, sejam eles no nível da gestão dos recursos da energia, do ar, da água, dos gases de efeito estufa (GEE), ou ainda dos resíduos sólidos e líquidos. (PELTIER e SAPORTA, 2009, p. 32)

Peltier e Saporta (2009) comentam que, já na década de 70 do século $X X$, os resíduos de embalagens haviam assumido uma importância considerável nas latas de lixo domésticas e que, com o aceleramento da produção, as embalagens começam, então, a ser estigmatizadas pelos ecologistas como o símbolo do desperdício da sociedade de consumo e uma das culpadas pela poluição do planeta.

Limitar a proliferação dos resíduos vai tornar-se um imperativo para toda a Europa. Em 15 de julho de 1975, o artigo 3 da diretiva 75/442/CEE, relativa aos resíduos, estipula: 'Os Estados membros tomam medidas apropriadas para promover a prevenção [...] dos resíduos [...]. Informam à Comissão qualquer projeto referente à diminuição das quantidades de certos resíduos'. Vinte anos depois, os resultados são muito decepcionantes, até mesmo catastróficos. Dentre os 15 países-membros da União Européia, apenas a Inglaterra chegou a estabilizar a quantidade de seus resíduos. 
Durante esse período, o volume dos resíduos de embalagens foi multiplicado por 5 , ou até por 50, para certos materiais como o plástico. Os resíduos de embalagens assumiram uma amplitude tal, que os poderes públicos nacionais europeus passam a adotar um conjunto de medidas que visam a reduzi-los e geri-los melhor. (PELTIER e SAPORTA, 2009, p. 18)

Seguindo a mesma idéia, Pinatti (1999) diz que as embalagens cartonadas sempre foram criticadas pelos ambientalistas como agressoras do meio ambiente e também pelo difícil processo de separação dos materiais constituintes da embalagem para a reciclagem.

As indústrias recicladoras, no entanto, vêm buscando maneiras de aperfeiçoar e aprimorar os processos, tanto de produção, quanto de reciclagem das embalagens.

A imagem a seguir mostra o ciclo completo pelo qual passa um produto, especialmente uma embalagem.

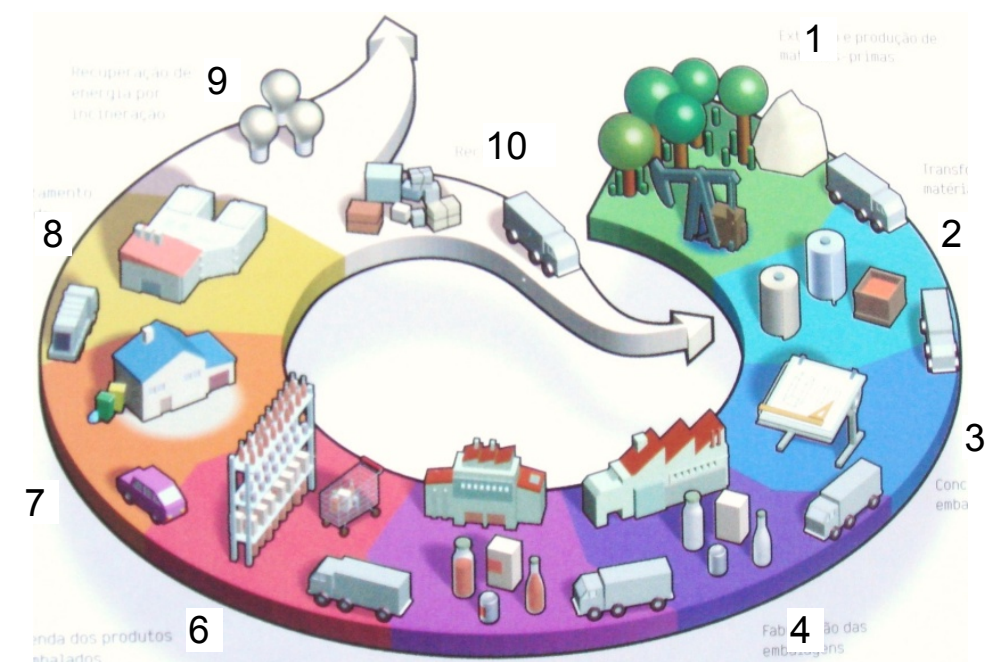

5

Figura 2.4: Ciclo de vida das embalagens Fonte: (PELTIER E SAPORTA, 2009, p.5) 
1. Extração e produção das matérias-primas

2. Transformação das matérias-primas

3. Concepção das embalagens

4. Fabricação das embalagens

5. Preenchimento das embalagens - envase

6. Venda dos produtos embalados

7. Consumo e descarte dos produtos embalados

8. Recuperação dos resíduos de embalagens - coleta seletiva

9. Incineração ou descarte

10. Nova matéria prima para novo processo de produção reciclagem.

O organograma de logística reversa é outra forma de visualizar o caminho percorrido pelos materiais, ou de forma mais abrangente, pelas matérias-primas. Fluir no sentido reverso busca o resgate dos materiais descartados, seja na reutilização, seja na reciclagem, administrando de forma organizada e eficiente esses materiais pós-consumo, sua reciclagem e redirecionamento para o mercado. Abaixo, um organograma organizado por Paulo Roberto Leite.

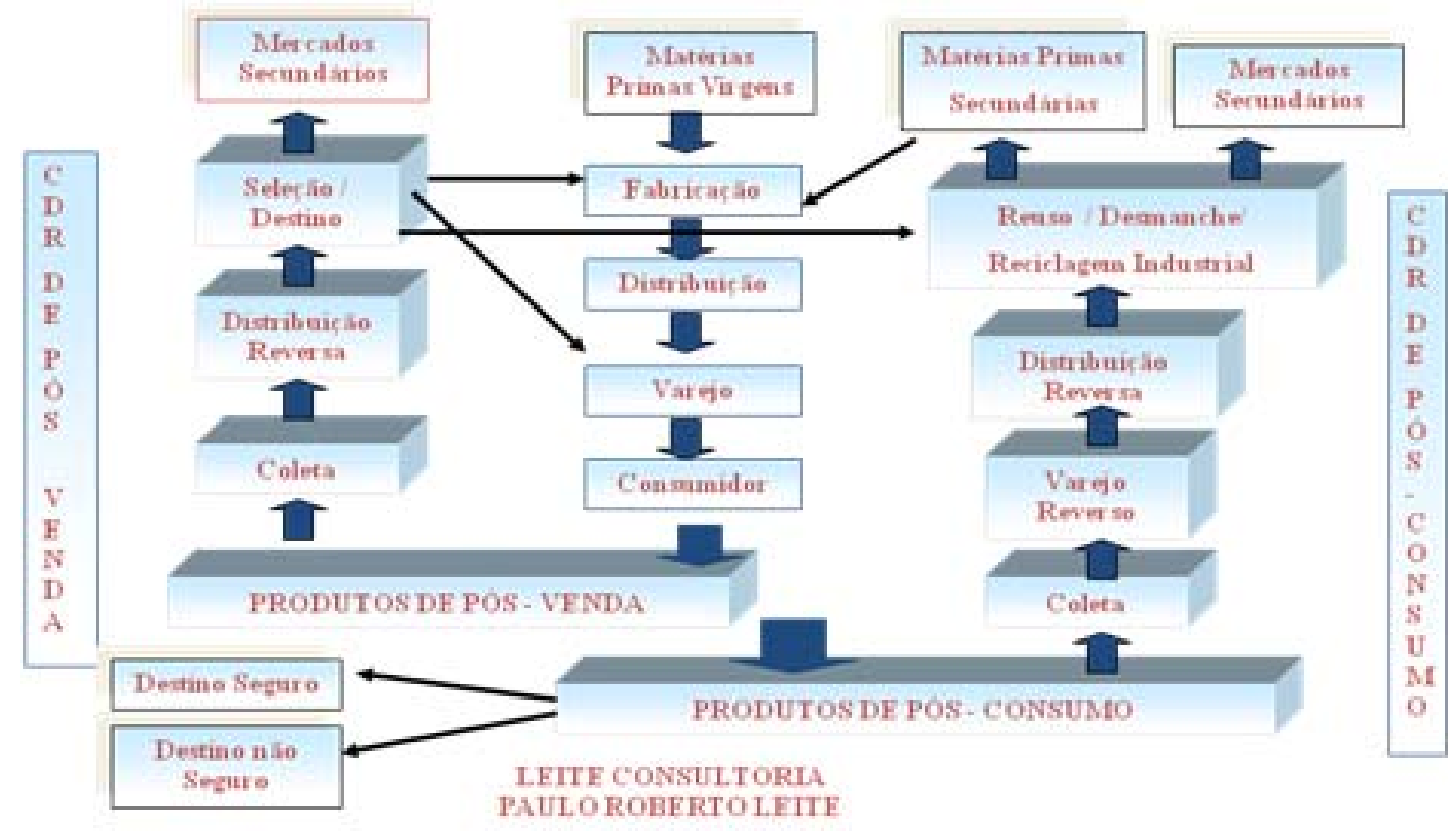

Figura 2.5: Organograma de logística reversa Fonte: LEITE (2003) 
Entender todo o processo, o ciclo de vida e a logística que envolve a produção de um material, dos objetos e sua reciclagem faz parte do processo projetual que preza pela sustentabilidade.

\subsubsection{2 - Lixo e Classificação}

Popularmente, lixo é "aquilo que ninguém mais quer", o que é velho, sujo, são restos, sobras, o que é inútil ou que está quebrado ou estragado. Essas são algumas denominações de lixo que Muhringer e Shayer (2007) colocam.

Tecnicamente, lixo é definido como Resíduo Sólido e a NBR 10004:2004 descreve o seguinte:

Resíduos nos estados sólido e semissólido, que resultam de atividades de origem industrial, doméstica, hospitalar, comercial, agrícola, de serviços e de varrição. Ficam incluídos nessa definição os lodos provenientes de sistemas de tratamento de água, aqueles gerados em equipamentos e instalações de controle de poluição, bem como determinados líquidos cujas particularidades tornem inviável o seu lançamento na rede pública de esgotos ou corpos de água, ou exijam para isso soluções técnica e economicamente inviável em face à melhor tecnologia disponível. (NBR 10004:2004 p.1)

A NBR 10004:2004 classifica os resíduos sólidos em Perigosos e Não Perigosos:

- Resíduos classe I - Perigosos: que apresentam inflamabilidade, corrosividade, reatividade, toxicidade e patogenicidade.

- Resíduos classe II - Não perigosos:

o - resíduos classe II A - Não inertes: Aqueles que não se enquadram nas classificações de resíduos classe I - Perigosos ou de resíduos classe II B- Inertes. Podem ter propriedades, tais como: biodegradabilidade, combustibilidade ou solubilidade em água.

o - - resíduos classe II B - Inertes

\subsubsection{3 - O lixo como matéria-prima}

Para entender o processo de evolução do "lixo como refugo" para o "lixo como matéria-prima" para novos usos, primeiramente é preciso entender o lixo como um material não totalmente descartável, como sendo de possível transformação. Com relação a isso 
Barbosa (2002) diz que, para agir sobre o lixo, para refletir criticamente sobre ele, é preciso que a categoria "lixo" seja destruída.

Além do termo "lixo útil", já consolidado na sociedade, o lixo começa a ser entendido, ainda que de forma lenta, como uma segunda matéria-prima que, com o respaldo do design e da tecnologia, pode gerar produtos "de primeira".

A preocupação com a produção de objetos novos a partir de objetos usados é uma iniciativa presente em todas as civilizações, ao longo da história da humanidade, mas ao mesmo tempo, de caráter contraditório em relação aos valores atribuídos ao resultado final desses objetos. Muhringer e Shayer (2007) consideram que a relação que se faz com os objetos está relacionada aos princípios e valores que se atribui para cada um desses objetos: coisas que são consideradas lixo para uns podem ser consideradas elementos úteis para outros, tanto para reaproveitamento, como para reciclagem.

[...] o feito de manipular desperdícios e utilizar processos para convertê-los em algo útil e belo resulta muito inovador, e quase atrevido, segundo certas convenções sociais. O lixo, na nossa sociedade atual, é considerado um produto de caráter imundo, degenerado e inútil, que só queremos perder de vista. Aqueles que trabalham com lixo, os que estão na primeira fase da coleta e da reciclagem, são considerados pessoas em contato com material contaminante, de um nível social baixo e aos quais se respeita muito pouco. Temos criado um sistema em que produzimos milhões de toneladas de resíduos sólidos que são incinerados ou enterrados diariamente, só uma mínima porcentagem é reciclada hoje em dia, com as graves consequências ambientais que isto acarreta. (BAHAMÓN e SANJINÉS, 2008, p.7)

\subsubsection{4 - Coleta seletiva e reciclagem}

Com o aumento gradativo dos processos de reciclagem, coletar embalagens tornouse um negócio para centenas de pessoas, tanto para catadores de rua, quanto para intermediários nas usinas de triagem e para as recicladoras, que utilizam essa nova matériaprima para produzir novos objetos. As usinas de triagem são os locais para onde os lixos recicláveis vão após a coleta e serão separados por tipologia, organizados em fardos, pesados e vendidos para as recicladoras de cada tipo de material. O primeiro destino das Embalagens Longa Vida é a usina papeleira, que faz a trituração para retirada do papel e, 
então, conforme o produto final que se pretende produzir com o polietileno e alumínio restante, o destino pode ser variado.

A tabela 2.1 demonstra o impacto ambiental, através do tempo de permanência dos vários materiais, quando deixados no meio ambiente. A linha marcada destaca o tempo de decomposição de 100 anos atribuído às Embalagens Longa Vida, principalmente devido ao alumínio e ao plástico, pois o papel degrada-se mais rapidamente. Em seguida à tabela, o gráfico 2.1 demonstra o potencial de reciclagem de cada região do Brasil.

Tabela 2.1: Resíduos e tempo de decomposição

\begin{tabular}{|l|l|}
\hline \multicolumn{2}{|c|}{ TEMPO DE DECOMPOSIÇÃO DE RESÍDUOS } \\
\hline Materiais e Objetos & Tempo de decomposição* \\
\hline Aço & Mais de 100 anos \\
\hline Alumínio & 200 a 500 anos \\
\hline Cerâmica & Indeterminado \\
\hline Chicletes & 5 anos \\
\hline Cordas de náilon & 30 anos \\
\hline Embalagens Longa Vida & Até 100 anos (alumínio) \\
\hline Embalagens PET & Mais de 100 anos \\
\hline Esponjas & Indeterminado \\
\hline Filtros de cigarro & 5 anos \\
\hline Isopor & Indeterminado \\
\hline Luvas de borracha & Indeterminado \\
\hline Metais (componentes de equipamentos) & Cerca de 450 anos \\
\hline Papel e papelão & Cerca de 6 meses \\
\hline Plásticos (embalagens e equipamentos) & Até 450 anos \\
\hline Pneus & Indeterminado \\
\hline Sacos e sacolas plásticas & Mais de 100 anos \\
\hline Vidros & Indeterminado \\
\hline & \\
\hline
\end{tabular}

Fonte: SECRETARIA (2010)

* O tempo de decomposição varia de acordo com certas condições, tais como umidade e temperatura.

Gráfico 2.1: Distribuição dos municípios com coleta seletiva no Brasil.

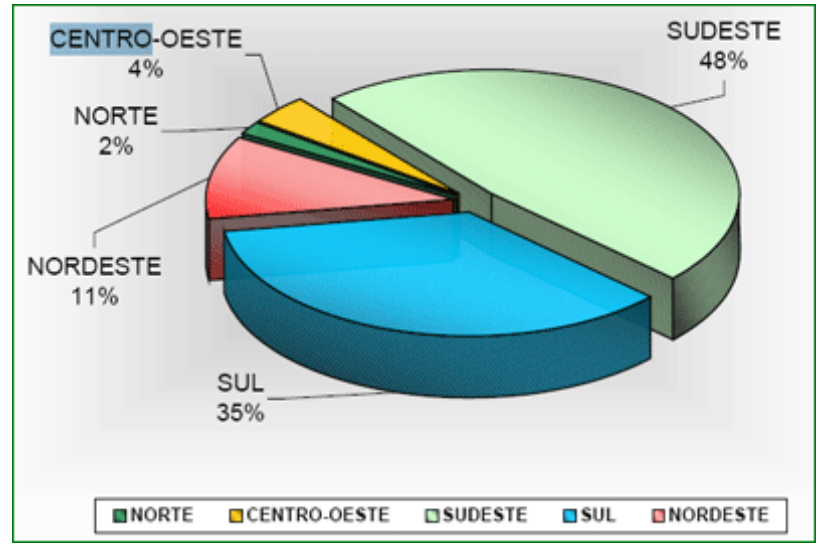

Fonte: CEMPRE (2008) 
As Embalagens Longa Vida representam 3\% na composição da coleta seletiva total no Brasil (gráfico 2.2), o que é uma quantidade pequena em relação a outros materiais, como metais, vidros e plásticos. Apesar de essa porcentagem ser maior do que a do alumínio $(1 \%)$, considerando-se cada material individualmente, o alumínio tem a reciclagem de $96,5 \%$ de seu montante total, enquanto as embalagens longa vida têm apenas $25,5 \%$ de coleta de seu montante total (tabela 2.2).

Gráfico 2.2: Composição de materiais da coleta seletiva no Brasil, em peso.

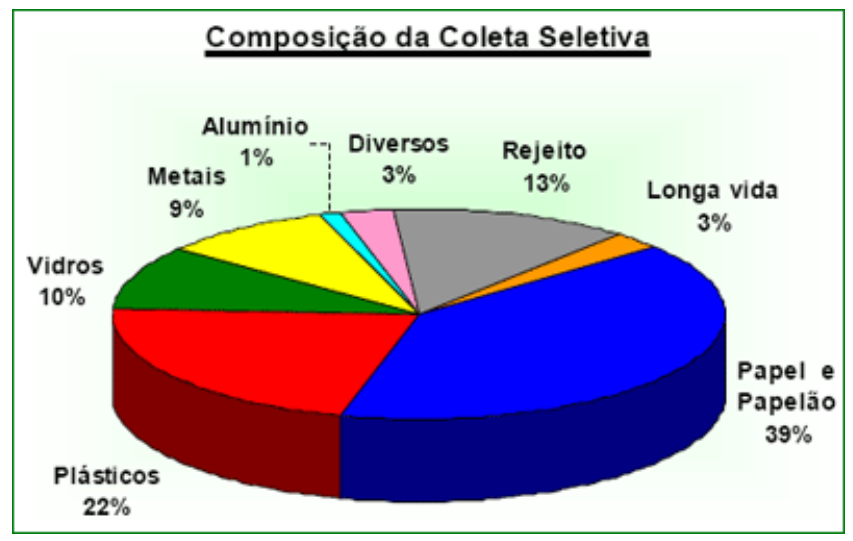

Fonte: CEMPRE (2008)

Tabela 2.2: Proporção de material reciclado em atividades industriais selecionadas

\begin{tabular}{|c|c|c|c|c|c|c|c|c|c|c|c|c|c|c|c|}
\hline \multicolumn{16}{|c|}{ Brasil } \\
\hline \multicolumn{16}{|c|}{ Variável = Proporção de material reciclado (Percentual) } \\
\hline \multirow{2}{*}{$\begin{array}{l}\text { Atividades } \\
\text { industriais }\end{array}$} & \multicolumn{15}{|c|}{ Ano } \\
\hline & 1993 & 1994 & 1995 & 1996 & 1997 & 1998 & 1999 & 2000 & 2001 & 2002 & 2003 & 2004 & 2005 & 2006 & 2007 \\
\hline $\begin{array}{ll}\text { Latas } & \text { de } \\
\text { alumínio } & \end{array}$ & 50,0 & 56,0 & 62,8 & 61,3 & 64,0 & 65,2 & 72,9 & 78,2 & 85,0 & 87,0 & 89,0 & 95,7 & 96,2 & 94,4 & 96,5 \\
\hline Papel & 38,8 & 37,5 & 34,6 & 37,1 & 36,3 & 36,6 & 37,9 & 38,3 & 41,4 & 43,9 & 44,7 & 45,8 & 46,9 & 45,4 & 45,0 \\
\hline Vidro & 25,0 & 33,0 & 35,0 & 37,0 & 39,0 & 40,0 & 40,0 & 41,0 & 42,0 & 44,0 & 45,0 & 45,0 & 45,0 & 46,0 & 47,0 \\
\hline $\begin{array}{l}\text { Embalagens } \\
\text { PET }\end{array}$ & - & 18,8 & 25,4 & 21,0 & 16,2 & 17,9 & 20,4 & 26,3 & 32,9 & 35,0 & 43,0 & 47,0 & 47,0 & 51,3 & 53,5 \\
\hline Latas de aço & 20,0 & 23,0 & 25,0 & 32,0 & 33,0 & 34,0 & 37,0 & 40,0 & 45,0 & 49,5 & 47,0 & 45,0 & 44,0 & 49,0 & 49,0 \\
\hline $\begin{array}{l}\text { Embalagens } \\
\text { longa vida }\end{array}$ & - & - & - & - & - & 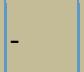 & 10,0 & 15,0 & 15,0 & 15,0 & 20,0 & 22,0 & 23,0 & 24,2 & 25,5 \\
\hline
\end{tabular}

Fonte: SIDRA IBGE (2010)

Associação Brasileira do Alumínio - ABAL; Associação Brasileira de Papel e Celulose - BRACELPA; Associação Técnica Brasileira de Indústrias Automáticas de Vidro - ABIVIDRO; Associação Brasileira da Indústria do PET ABIPET; Associação Brasileira de Embalagem de Aço - ABEAÇO; Associação Brasileira do Leite Longa Vida ABLV; Compromisso Empresarial para Reciclagem - CEMPRE.

Um dos motivos que explicam a baixa porcentagem de reciclagem das Embalagens Longa Vida é o baixo valor pago pela tonelada de material reciclado, como apresentado na tabela 2.3. Percebe-se que existe uma variedade muito grande de preços da tonelada dos recicláveis nas diversas regiões do país. O baixo preço pode ser atribuído a diversos 
fatores, como a quantidade de unidades recicladoras, a complexidade do processo de reciclagem das Embalagens Longa Vida, entre outros, porém foge do escopo desta pesquisa a identificação dessa problemática.

Tabela 2.3: Preço do material reciclável (preço da tonelada, em Real)

\begin{tabular}{|c|c|c|c|c|c|c|c|c|c|c|}
\hline & Papelão & $\begin{array}{c}\text { Papel } \\
\text { Branco }\end{array}$ & $\begin{array}{c}\text { Latas } \\
\text { deço }\end{array}$ & Alumínio & $\begin{array}{c}\text { Vidro } \\
\text { Incolor }\end{array}$ & $\begin{array}{c}\text { Vidro } \\
\text { Colorido }\end{array}$ & $\begin{array}{c}\text { Plástico } \\
\text { Rígido }\end{array}$ & PET & $\begin{array}{c}\text { Plástico Longa } \\
\text { Filme }\end{array}$ \\
Vida
\end{tabular}




\section{2 - Materialidade: conceituações técnicas}

A conceituação técnica é uma referência para a posterior caracterização de dados sobre as placas recicladas. A preocupação dos produtores de novos materiais reciclados em adequá-los aos padrões de qualidade técnica e em normas é constante. Muitos materiais têm desempenho satisfatório ou muito bom na prática, mas não possuem caracterização técnica sistematizada, o que compromete sua confiabilidade para especificação e uso. $\mathrm{O}$ processo de adequação pode ser lento, até que os novos materiais estejam completamente pesquisados em âmbito laboratorial e verificados para eficiência no uso.

Com os tópicos abaixo, buscou-se unir a classificação padrão dos materiais de construção às conceituações e classificações sobre sustentabilidade, para criar uma classificação atualizada. Esses tópicos serão referência para a posterior organização da classificação das Placas Recicladas de Embalagens Longa Vida.

\subsection{1 - Classificação dos materiais de construção}

\subsubsection{1 - Classificação quanto à procedência: biosfera, litosfera e tecnosfera}

Esta classificação é apresentada por Fuad-Luke (2002) e está relacionada à extração dos materiais, para uso de forma natural ou industrializada.

- Materiais da biosfera: são os materiais que tem procedência de plantas, animais e microorganismos. São renováveis. Fuad-Luke (2002) exemplifica um grupo especial entre os materiais da biosfera, como os biopolímeros biodegradáveis e os compostos biológicos derivados de plantas. Esses materiais reincorporam-se facilmente aos ciclos da natureza.

- Materiais da litosfera: são os materiais que têm procedência de estratos geológicos, como areia, cascalhos, pedras, argilas, e alguns mais limitados, como fósseis, minerais, pedras e metais preciosos.

- Materiais da tecnosfera: materiais naturais, da biosfera ou litosfera, que passam por um processo de sintetização ou concentração. Não são materiais renováveis pela natureza. 


\subsubsection{2 - Classificação quanto ao potencial de sustentabilidade e impacto} ambiental

A maioria dos materiais de construção precisa ser processada para serem transformados em componentes e incorporados a uma edificação, o que inevitavelmente exige extração de matéria-prima, uso de energia para sua produção e gera refugos. Assim, a escolha de um material de construção causa um impacto no meio ambiente devido à quantidade de energia gasta em todo o processo de extração, fabricação, transporte e aplicação. A classificação a seguir é definida ainda de acordo com o que Fuad-Luke (2002) apresenta sobre os materiais da biosfera e tecnosfera.

- Materiais que se reintegram na biosfera: são os biodegradáveis, que se decompõem sem prejudicar o solo.

- $\quad$ Materiais que se reintegram na tecnosfera: materiais cujos resíduos possuam condições de voltarem, no futuro, a um ciclo de produção de outro material ou produto, por meio da reciclagem.

Segundo Roaf, Fuentes e Thomas (2009), são improváveis que regras absolutas possam ser feitas para todas as situações de análise do impacto ambiental dos materiais de construção, já que as qualidades inerentes a um material e a maneira pela qual os materiais são incorporados a um projeto determinarão em conjunto o impacto ambiental.

As classificações a seguir são baseadas nos termos apresentados por Silva (1991), que classifica os materiais em cinco áreas principais: quanto à origem ou obtenção, função, composição, estrutura interna e composição química dos materiais. Adaptações e complementações foram feitas, objetivando a atualização dos termos relacionados aos materiais e que são utilizados até o momento de realização desta pesquisa.

\subsubsection{3 - Classificação quanto à composição da matéria-prima:}

o $\quad$ Simples: materiais cujos componentes são produzidos a partir de uma única matéria-prima, como tijolos e telhas cerâmicas, reciclados de borracha.

o Compostos: materiais cujos componentes são produzidos com mais de uma matéria-prima, como o concreto. 


\subsubsection{4 - Classificação quanto à estrutura interna:}
o Lamelar, como a argila.
o Fibrosa, como o amianto.
- Fibrosos com estrutura complexa, como a madeira.
o Vítrea, como o vidro.
o Cristalina, como o metal.
o $\quad$ Agregados complexos, como o concreto.

\subsubsection{5 - Classificação quanto à composição química.}

o Minerais

- Pétreos

- Metálicos

o Orgânicos

- Lenhosos

- Têxteis

- Betuminosos

- Mistos

\subsubsection{6 - Classificação quanto à origem e processo de obtenção:}

o Naturais: materiais encontrados na natureza

- Natural com baixo grau de processamento e visível aspecto natural, como areia, terra e madeira em sua forma rústica.

- Naturais com médio grau de processamento e visível aspecto natural, como madeira e pedra.

o Artificiais: materiais obtidos por processo industrial e que sofrem alto grau de transformação. O aspecto final torna-se muito diferente da matéria-prima original, como os metais, vidros, plásticos, cimento e componentes, como telhas e tijolos.

o Combinados: resultantes da combinação e/ou mistura de materiais naturais com artificiais, como concretos e argamassas.

Nessas três categorias pode-se encaixar como complemento ou subitens, ainda outras duas:

o Reconstituídos: materiais que foram fragmentados e constituem-se novamente em um novo e diferente componente, como as 
placas de MDF e OSB. Fragmentos de madeira são reconstituídos, formando uma categoria diferente de placa de madeira.

o Reciclados: materiais obtidos a partir do processamento industrial de materiais e objetos descartados - que agora se tornam matéria prima para a reciclagem - tornando-se um novo componente.

\subsubsection{7 - Classificação quanto à forma do componente}

$\begin{array}{ll}0 & \text { Perfis estruturais } \\ 0 & \text { Chapas } \\ 0 & \text { Painéis } \\ 0 & \text { Blocos e tijolos } \\ 0 & \text { Pulverulentos e granulares }\end{array}$

\subsubsection{8 - Classificação quanto à função do componente}

o Estruturais: materiais em forma de componentes estruturais que resistem aos esforços físicos e mecânicos que ocorrem no edifício, como Perfis de vigas e pilares metálicos, de madeira e de concreto.

o De vedação: materiais em forma de componentes que vedam e fecham externamente e/ou internamente uma edificação. Podem ter função estrutural ou não, como as placas cimentícias, blocos, tijolos, entre outros.

o De proteção: materiais que protegem outros materiais em forma de revestimento, podendo, também, ter a função estética.

o Estética: relativo às características visuais, decorativas e de design do material, como textura, tamanho, forma, cores, espessura, relevo, estampa, entre outras.

\subsection{2 - Propriedades dos materiais}

As propriedades dos materiais podem ser classificadas basicamente em mecânicas, térmicas, químicas, elétricas e óticas. A seguir, estão relacionadas algumas das principais propriedades dos materiais de construção que foram estabelecidas por Araujo, Rodrigues e Freitas (2000); Silva (1991) e Alves (1987) apud Arqtema (2005). As propriedades térmicas baseiam-se também na NBR 15220-1:2005 - Desempenho térmico de edificações: Definições, símbolos e unidades. 


\subsubsection{1 - Classificação quanto às propriedades Mecânicas}

\section{- $\quad$ Resistência mecânica}

De acordo com Silva (1991 apud Arqtema, 2005):

o Resistência à tração: expressa pela tensão que um material suporta quando submetido ao esforço mecânico de tração.

o Resistência à compressão: expressa pela tensão máxima que um material rígido suporta, sob compressão longitudinal, antes que o material colapse.

o Resistência à flexão: representa a tensão máxima desenvolvida na superfície de uma barra, quando sujeita a dobramento. Aplica-se a materiais rígidos, àqueles que não vergam excessivamente sob a ação de uma carga.

- Elasticidade e Módulo de deformação: todo material quando submetido a uma tensão, sofre uma deformação, ou suas dimensões e formas são alteradas. A tensão é definida como força por unidade de área e é expressa em Mpa (Mega Pascal) - $1 \mathrm{Mpa}=10 \mathrm{Kgf} / \mathrm{cm}^{2}$. (Arqtema, 2005, p.26).

- Ductilidade: é a deformação plástica total até o ponto de ruptura do material. Quanto mais dúctil é um material, maior é a redução de área ou alongamento antes da ruptura. (Arqtema, 2005, p.30).

- Resistência ao choque: é a resistência que o material oferece ao rompimento por choque, ou por carga de impacto. (Arqtema, 2005, p.30).

- Dureza: de acordo com Arqtema (2005, p.30), é a propriedade de resistir à penetração de um corpo estranho mais duro ou resistir ao risco. Não é proporcional à resistência mecânica, uma vez que há materiais que possuem cargas de ruptura bem diferentes e durezas semelhantes.

- Resistência à abrasão: de acordo com Arqtema (2005, p.30), é a capacidade que o material tem de resistir a cargas abrasivas, sem perda de massa e volume - sem se desgastar. 
- $\quad$ Resistência à fadiga: exprime a tensão máxima a que um material pode resistir quando a peça é exposta a dobramentos e desdobramentos consecutivos. (Arqtema, 2005, p.31).

\subsubsection{2 - Propriedades Térmicas}

- $\quad$ Resistência ao fogo: de acordo com Silva (1991 apud Arqtema 2005) é propriedade segundo a qual o material não é destruído pelo fogo. Os materiais podem ser incombustíveis, fracamente combustíveis e combustíveis.

o Incombustíveis: não inflamam sob a ação do fogo ou de altas temperaturas, podendo ou não se deformar.

o Fracamente combustíveis: dificilmente se inflamam, mas se consomem e calcinam sob a ação do fogo ou de alta temperatura.

o Combustíveis: inflamam e se consomem sob a ação do fogo ou de altas temperaturas.

- $\quad$ Resistência ao calor: é a capacidade de resistir à ação prolongada de altas temperaturas, sem se deformar. Alguns materiais também suportam mudanças bruscas de temperaturas. (Silva,1991 apud Arqtema ,2005)

o Refratários: suportam temperaturas maiores que $1.580^{\circ} \mathrm{C}$.

o Dificilmente fundidos: suportam temperaturas entre $1.300^{\circ} \mathrm{C} \mathrm{e}$ $1.580^{\circ} \mathrm{C}$.

o Facilmente fundidos: suportam temperaturas menores que $1.300^{\circ} \mathrm{C}$.

- Expansão térmica: avaliada pelo coeficiente de dilatação térmica linear, que é o alongamento relativo da peça por unidade de temperatura.

- $\quad$ Capacidade de transferir calor: Segundo Araújo, Rodrigues \& Freitas (2000 apud Arqtema, 2005) é a capacidade de conduzir o calor, medida pela condutividade térmica.

Rivero (1985) descreve que a condutividade térmica expressa a quantidade de calor transmitido através de um corpo. Sousa et al, (2009), descrevem que a condutividade ocorre por meio de vibração molecular, à qual a temperatura é uma proporcional, fazendo com que o calor flua das superfícies com temperatura mais alta para as de temperatura mais baixa, 
em virtude da vibração das moléculas transmitidas de uma a outra superfície. Com isso, as autoras ainda destacam que os metais transmitem calor com grande facilidade, sendo considerados condutores térmicos, enquanto os materiais fibrosos ou contendo espaços vazios têm grande dificuldade de transmitir calor, sendo considerados isolantes térmicos.

A condutividade térmica assume um papel crítico no desempenho de materiais em muitas aplicações. Baixos valores de condutividade térmica são exigidos, quando se pretende minimizar as perdas de calor. Por outro lado, a transferência de calor de uma parte para outra é obtida mais facilmente usando materiais de condutividade térmica mais alta. Essa característica é também desejável, se não crítica, para evitar falhas devido ao choque térmico. Assim sendo, dados confiáveis de condutividade térmica são essenciais na seleção de um material, para que o mesmo possa ter o melhor desempenho possível em uma dada aplicação. (SANTOS et al, 2004, p.355)

- $\quad$ Capacidade de armazenar calor: avaliada pelo calor específico, que se refere à quantidade de energia térmica exigida para elevar $1^{\circ} \mathrm{C}$ a unidade de massa do material.

Tabela 2.4 - Grandezas térmicas.

\begin{tabular}{|c|c|c|c|}
\hline Grandeza & Definição & Símbolo & Unidade \\
\hline $\begin{array}{c}\text { Densidade de massa } \\
\text { aparente }\end{array}$ & $\begin{array}{l}\text { Quociente da massa pelo volume } \\
\text { aparente de um corpo. Esses dados podem ser } \\
\text { obtidos através da pesagem do material e do } \\
\text { cálculo da metragem cúbica a partir das medidas } \\
\text { de largura, altura e comprimento do material. }\end{array}$ & $P$ & $\mathrm{Kg} / \mathrm{m}^{3}$ \\
\hline Refletância & $\begin{array}{l}\text { A refletância à radiação solar é definida como o } \\
\text { quociente da taxa de radiação solar refletida por } \\
\text { uma superfície pela taxa de radiação solar } \\
\text { incidente sobre essa mesma superfície. }\end{array}$ & $\rho$ & - \\
\hline Absortância & $\begin{array}{c}\text { A absortância à radiação solar é definida como o } \\
\text { quociente da taxa de radiação solar absorvida por } \\
\text { uma superfície pela taxa de radiação solar } \\
\text { incidente sobre essa superfície. }\end{array}$ & $\alpha$ & - \\
\hline Condutividade térmica & $\begin{array}{l}\text { Propriedade física de um material homogêneo e } \\
\text { isótropo, no qual se verifica um fluxo de calor } \\
\text { constante, com densidade de } 1 \mathrm{~W} / \mathrm{m}^{2} \text {, quando } \\
\text { submetido a um gradiente de temperatura } \\
\text { uniforme de } 1 \text { kelvin por metro. }\end{array}$ & $\lambda$ & $\mathrm{W} /(\mathrm{m} \cdot \mathrm{k})$ \\
\hline Calor específico & Quociente da capacidade térmica pela massa. & C & $\mathrm{J} /(\mathrm{kg} \cdot \mathrm{K})$ \\
\hline Capacidade térmica & $\begin{array}{l}\text { Quantidade de calor necessária para variar em } \\
\text { uma unidade a temperatura de um sistema. }\end{array}$ & CT & $\mathrm{kJ} /\left(\mathrm{m}^{2}.\right) \mathrm{k}$ \\
\hline Resistência Térmica de & Quociente da diferença de temperatura verificada & $\mathrm{R}$ & $\left(\mathrm{m}^{2} \cdot \mathrm{k}\right) / \mathrm{W}$ \\
\hline
\end{tabular}




\begin{tabular}{|c|c|c|c|}
\hline $\begin{array}{l}\text { elementos e } \\
\text { componentes }\end{array}$ & $\begin{array}{l}\text { entre as superfícies de um elemento ou } \\
\text { componente construtivo pela densidade de fluxo } \\
\text { de calor, em regime estacionário. }\end{array}$ & & \\
\hline Transmitância & $\begin{array}{l}\text { Também é chamada de coeficiente global de } \\
\text { transferência de calor. É o inverso da resistência } \\
\text { térmica total. }\end{array}$ & $U$ & $/\left(\mathrm{m}^{2} . \mathrm{K}\right)^{\mathrm{W}}$ \\
\hline Atraso térmico & $\begin{array}{l}\text { Tempo transcorrido entre uma variação térmica } \\
\text { em um meio e sua manifestação na superfície } \\
\text { oposta de um componente construtivo, submetido } \\
\text { a um regime periódico de transmissão de calor. }\end{array}$ & $\varphi$ & $\mathrm{h}$ \\
\hline Fator Solar & $\begin{array}{l}\text { O fator solar de elementos opacos (ou fator de } \\
\text { ganho de calor solar de elementos opacos) é } \\
\text { definido como o quociente da taxa de radiação } \\
\text { solar transmitida através de um componente } \\
\text { opaco pela taxa de radiação solar total incidente } \\
\text { sobre a sua superfície externa. }\end{array}$ & Fs & - \\
\hline
\end{tabular}

Fonte: NBR 15220-2 (2005)

Para a caracterização térmica de um material, os dados de Condutividade Térmica, de Calor Específico e absortância devem ser medidos por ensaios laboratoriais. Esses dados foram identificados para esta pesquisa e são apresentados no capítulo 4.

\subsubsection{3 - Propriedades Químicas}

É a propriedade de um material resistir à ação de agentes agressivos, como ácidos e bases. Além disso, também são considerados agressivos a água do mar, os ambientes industriais, os ambientes úmidos e os poluídos. A propriedade química também tem relação com a resistência à oxidação, à degradação térmica e às radiações ultravioleta (UV).

Os dados medidos em laboratório e calculados permitem identificar o quanto a característica técnica do material é propícia, ou não, para a aplicação nas superfícies que estão diretamente ligadas às situações que expõem o material mais intensamente ao calor, raios UV e umidade.

\section{3 - Materialidade: design como recurso}

O design revela a marca da tecnologia com que temos de trabalhar. É um tipo de linguagem, e é reflexo de valores emocionais e culturais. [...] O que torna essa visão do design realmente atraente é a noção de que há algo a entender sobre os objetos além das questões óbvias de função e finalidade. O design é a linguagem que uma sociedade usa para criar objetos que reflitam seus objetivos e seus valores. [...] é a linguagem que ajuda a definir, ou, talvez, a sinalizar valor. (SUDJIC, 2008, p. 49, grifo nosso) 
A abordagem sobre design objetiva estruturar conceitualmente e justificar teoricamente a hipótese apresentada para esta pesquisa. Pode-se dizer que design e projeto de arquitetura e seus resultados formais sejam complementares porque a arquitetura acumula e agrega em si diversos tipos de design: de interiores, de materiais, de superfícies, de produtos, além da própria forma arquitetônica e da qualidade de seus elementos visuais.

Gomes Filho (2006, p.41), observa que, na linguagem do design, é importante a "correspondência que se estabelece no diálogo entre homem e objeto", ou seja, da "interface entre usuário e produto". O autor destaca três funções básicas com as quais os objetos interagem com os usuários: "a função prática, a função estética e a função simbólica". A função prática é baseada nas "relações entre um produto e um usuário [...]" e está ligada à "facilidade de uso, [...] conforto, segurança e eficácia de utilização do objeto." Löbach (1981, apud GOMES FILHO, 2006, p.43) define: "A função estética é a relação entre um produto e um usuário, experimentada no processo de percepção. [...] É o aspecto psicológico da percepção sensorial durante o uso."

"A função estética é subordinada a diversos aspectos socioculturais no que diz respeito, principalmente, ao repertório de conhecimento do usuário, de sua vivência e de sua experimentação estética. É naturalmente agregada à função simbólica [...]". (GOMES FILHO, 2006, p.43)

A função simbólica, também de acordo com Löbach (1981, apud Id, p.44), está ligada à "[...] percepção de um objeto, estabelecendo relações com componentes de experiências e sensações anteriores. [...] Tem relação e também é determinada por todos os aspectos espirituais e psíquicos de uso do objeto, [...] a valores pessoais, sentimentais e emotivos."

Em relação a Gomes Filho e Löbach, pode-se observar que a aceitação estética de um material está ligada também ao quanto ele participou ou participa do meio em que se vive e qual representação exerce para o observador, podendo influenciar na opinião e formação ou alteração do gosto pessoal estético. Sendo assim, existe a possibilidade de aumento da empatia ao longo da permanência do contato visual e identificação simbólica com determinado objeto ou material.

Outro aspecto que tem influência na aceitação de um material é o fato de ser valorizado quando em contato com outros materiais que já estão consagrados no gosto estético comum, como as rochas ornamentais e vidros, por exemplo. A composição entre materiais nobres e novos materiais reciclados (sejam eles quais forem), podem criar, em um 
primeiro momento, a inserção e valorização desses novos materiais devido ao "suporte estético" que a materialidade conhecida oferece ao material novo.

\subsection{1 - Superfícies e organização dos materiais}

O tratamento de uma superfície construtiva é dado pela organização dos materiais sobre ela ou que a compõem. Essa organização evidencia-se com o corte dos materiais em módulos, que são dispostos ordenadamente, compondo o visual. Em arquitetura, essa disposição ordenada dos materiais é chamada de "paginação". Lupton e Phillips (2008, p.160) definem módulo como "um elemento fixo utilizado no interior de um sistema ou estrutura maior. [...] A variedade de possibilidades de composição com um módulo ocorre, no entanto, dentro dos parâmetros estritos do sistema, que permite apenas um tipo básico de conexão."

Peças cortadas, formando módulos de materiais, são também "unidades de forma", que se repetem na superfície.

"A repetição de 'unidades de forma' geralmente transmite uma sensação imediata de harmonia. Cada 'unidade de forma' repetida é como a batida de algum ritmo. Quando as unidades de forma são utilizadas em tamanho maior e número menor, o desenho pode parecer simples e evidente; quando são infinitamente pequenas e em grande número, o desenho pode parecer uma porção de textura uniforme, composto de elementos diminutos." (WONG, 2010, p.51)

A repetição de unidades de formas em uma padronagem ou composição é um elemento marcante para criação de novas texturas, provenientes de organizações compositivas de partes materiais.

Ching (2000, p.133) define superfície como "qualquer figura dotada de apenas duas dimensões, como um lugar geométrico bidimensional plano ou curvo dos pontos que definem o limite de um sólido." Complementando o que Ching definiu, a superfície arquitetônica possui também a tridimensionalidade, já que os materiais nela aplicados criarão um volume, a partir de sua espessura. Esse conjunto ainda gera percepções visuais e sensoriais que cada indivíduo terá em relação à superfície e ao todo arquitetônico. 
O termo "superfície arquitetônica" foi adotado nesta pesquisa, com base no conceito de design de superfícies, para nomear os planos horizontais e verticais internos e externos para valorizar o design.

No design de superfície, a geração de padrões desenvolve-se de maneira contínua sobre as superfícies e apresenta basicamente a repetição de padrões, sejam eles em formatos iguais e repetitivos (modulações) ou em combinações de vários formatos diferentes.

\subsection{2 - Design e expressão visual}

Segundo Wong (2010, p.13), o que se decide ser bonito e interessante em uma criação pode surgir de traços e formatos espontâneos, sem que se saiba, conscientemente, o por que. Essa seria, então, uma "abordagem intuitiva da criação visual". Por outro lado, em uma "abordagem intelectual", a criação pode ser feita, reconhecendo-se previamente os problemas específicos que precisam ser tratados. Essa abordagem "requer um raciocínio sistemático com alto grau de objetividade, ainda que a sensibilidade e o julgamento individual quanto à beleza, à harmonia devam estar presentes em todas as decisões visuais."

Relacionando-se o objeto desta pesquisa e o que Wong afirma sobre abordagens visuais sistemáticas, pode-se classificar como "problema específico" a identificação de potencialidades de uso das placas recicladas, de forma que possibilitem resultados visuais atraentes e coerentes tecnicamente com as superfícies arquitetônicas e as características técnicas do material.

Wong (2010, p.43) apresenta como principais elementos visuais o formato, o tamanho, a cor e a textura. Destes, a textura destaca-se como um forte elemento visual que caracteriza a superfície de um formato. A textura pode ser "simples ou decorada, lisa ou áspera" "visual ou tátil".

Assim como Wong, também Lupton e Phillips (2008, p. 53) definem a textura como "o grão tátil das superfícies e substâncias. [...] As texturas incluem tanto a superfície efetivamente empregada na feitura de uma peça impressa ou de um objeto palpável, quanto à aparência ótica desta superfície." 
"Os materiais, em geral em pequenos pedaços, lascas ou tiras, são organizados em um padrão que forma uma nova superfície. [...] os materiais podem às vezes ser identificáveis, mas a nova sensação criada pela superfície é muito mais importante." (WONG, 2010, p.122, grifo nosso)

Esse é um fenômeno que pode ser percebido com todos os materiais aplicados em superfícies e a percepção disso colabora com a especificação estética desses materiais. $O$ que era a textura de um granito, ou mármore, ou argamassa, vistos na proximidade, pode transformar-se em maciços planos, com textura indefinida, se observado a grandes distâncias. Entre um extremo e outro, restam resultados visuais variados.

No projeto a seguir, a textura manchada da superfície vista à distância revela-se, na proximidade, pontilhada por outro material. É um artifício criativo que proporciona surpresas quando alguém se aproxima ou se distancia do edifício (figuras 2.6, 2.7 e 2.8).

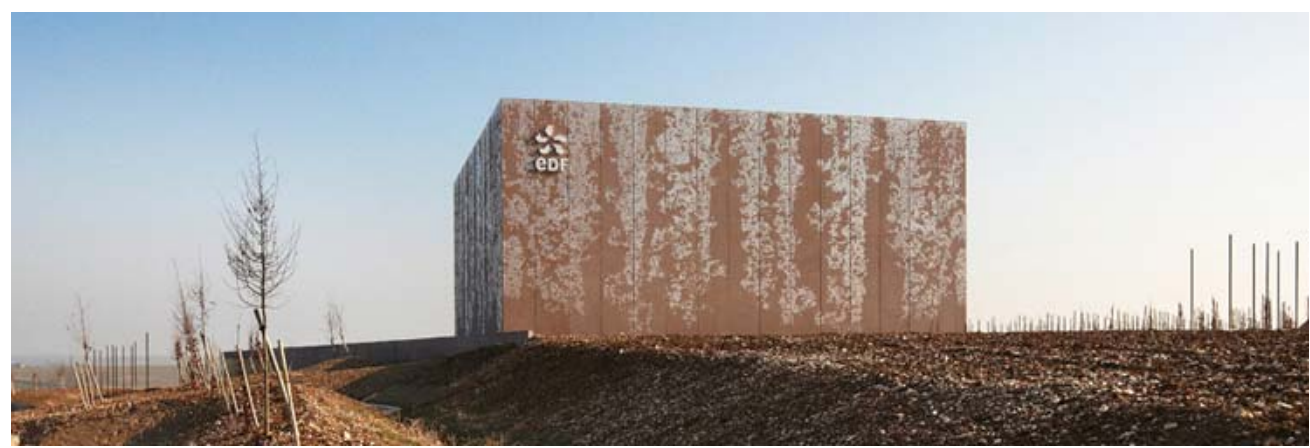

Figura 2.6: Edifício Arquivo nacional EDF - França - LAN Arquitetura Fonte: LANOO (2011) 


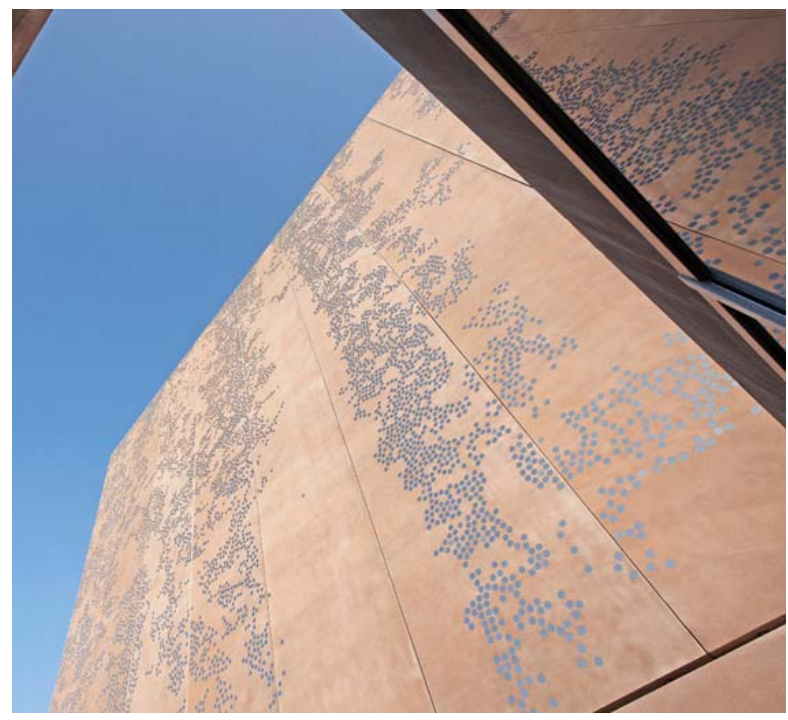

Figura 2.7: Edifício Arquivo nacional EDF - Detalhe da fachada Fonte: LANOO (2011)
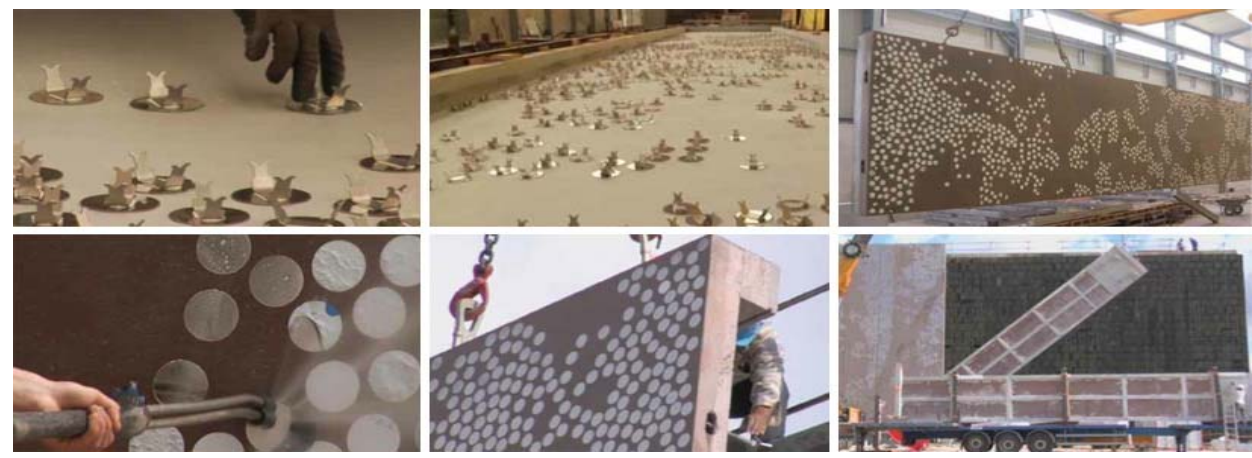

Figura 2.8: Edifício Arquivo nacional EDF - Processo de fabricação dos painéis texturizados Fonte: LANOO (2011)

A conscientização da ação que os elementos visuais exercem sobre o objeto projetado é, portanto, forte referência para definições materiais. Ainda que não sejam utilizados conscientemente pelo arquiteto, esses elementos certamente sempre estão presentes no resultado, colaborando de forma objetiva e subjetiva para a interpretação e atribuição de valor estético ao objeto arquitetônico.

Em complemento aos resultados formais estão os simbolismos e valores que são atribuídos aos objetos, pelas diferentes culturas ou mesmo por gosto momentâneo. Isso é observado por Sudjic (2008, p.34) da seguinte maneira: "Quando se compreende a linguagem do design, expressa por forma, cor, textura e imagem de um objeto, há constantes paradoxos entre função e simbolismo a ser considerados. Certas cores são mais associadas ao homem que à mulher. Alguns materiais sugerem luxo." E o autor deixa uma pergunta: "Essas propriedades são verdadeiramente intrínsecas ou seus significados são 
adquiridos pela repetição constante, pela familiaridade e pela convenção [...]"? Em outro momento afirma:

$O$ design cria as pistas táteis e visuais que simbolizam 'precioso' ou 'barato'- mesmo se, dada a infinita capacidade de ironia da mente humana, e a busca permanente por novidade, esses sinais forem regularmente subvertidos. Na moda, uma vez que um signo se torna muito óbvio, é inevitável que seu significado se inverta. Ruim equivale a bom. $\mathrm{O}$ que é buscado inescapavelmente se torna ubíquo. E vice-versa. [...] Às vezes a comunicação é mais emocional. Metais preciosos sugerem que objetos feitos com eles são em si mais importantes do que os feitos com materiais menos valiosos. (SUDJIC, 2008, p. 49-51, grifo nosso)

Assim, tem-se um embasamento teórico conceitual e algumas diretrizes para defender a ideia de que uma Placa Reciclada de Embalagem Longa Vida pode se estabelecer mais firmemente como material arquitetônico-construtivo, com a utilização de alguns recursos visuais de design do produto em composições projetuais. Essas alternativas serão apresentadas nos capítulos 5 e 6.

\section{4 - Materialidade: influências culturais}

No momento em que novas tipologias materiais começam a surgir (os materiais reciclados e reconstituídos), principalmente por necessidades ambientais, surge também uma certa estranheza na assimilação visual, estética e técnica dessa nova materialidade. 0 fato de um objeto voltar a ser matéria-prima de si mesmo (uma garrafa PET voltando a ser garrafa PET, ou uma garrafa de vidro que volta a ser garrafa, ou mesmo um copo) não causa um impacto ou incômodo visual, por ser praticamente imperceptível ao olhar. No entanto, a estranheza surge quando um objeto (como as Embalagens Longa Vida ou tubos de creme dental) se transforma em outro objeto (componentes construtivos, por exemplo), cuja materialidade original então difere da nova função, deixando visivelmente sua marca de uma mistura não muito bem conhecida. Assim, os objetos reciclados, apesar de uma mudança positiva e gradativa da sociedade, ainda carregam consigo o slogan de qualidade inferior, simplesmente pelo fato de serem "feitos de restos", do pós-consumo, ou partirem do que antes era lixo.

A estranheza é natural, quando se compara essa nova categoria de materiais da tecnosfera com os materiais naturais da biosfera e litosfera, como as rochas ornamentais; as madeiras maciças e "de lei", entre outros, considerados "materiais nobres", que são 
extraídos diretamente da natureza e, mesmo depois de processados, são usados em sua aparência mais íntegra e são muito duráveis; atravessam séculos e gerações, permanecendo na história de um povo, seja em forma de edifícios, objetos ou vestuário. Os slogans que os "materiais nobres" carregam são: pureza, beleza natural, resistência, integridade e originalidade. Têm um alto valor agregado e são os materiais mais imitados na criação de outros: revestimentos cerâmicos que imitam rochas, plásticos que imitam metálicos e pisos laminados melamínicos, que são confundidos com madeira.

Hoje, como jamais visto, a descoberta ou invenção de novos materiais, bem como o surgimento de novas tecnologias produtivas, acabam também por influenciar a concepção e a estética dos produtos industriais. A evolução da tecnologia e o surgimento de novas matériasprimas propiciam uma verdadeira revolução nos aspectos de uso e na forma dos artefatos. (MORAES, 2009, P.82)

A aceitação dos materiais reciclados acontece à medida do tempo que as pessoas necessitam para absorver e assimilar a imagem e funções simbólicas, estéticas e práticas desses materiais. Um exemplo disso é o processo de consolidação dos papéis reciclados no mercado. Folhas recicladas tem aspecto visual diferente das folhas brancas. As recicladas são folhas mais escuras e com texturas visuais próprias daquele material. Quando os primeiros produtos com papel reciclado apareceram no mercado, eram pouco apreciados pelo consumidor, pois o aspecto remetia a um papel "não limpo", ou simplesmente diferente daquele que era comumente visto, ainda que esse material fosse uniforme, limpo e bem acabado. Escrever em folhas de papel reciclado foi um costume que se estabeleceu aos poucos e, também, conforme o mercado aumentava as opções desses produtos. Isso demonstra que o costume cultural e o convívio com os materiais, influenciam na sua empatia e confiabilidade. Hoje, são encontrados pacotes de papéis reciclados de diversas marcas, não menos eficientes que os "papéis brancos", e as pessoas usam-nos sem mais se incomodar.

É importante, ainda, nesse processo, buscar a aceitação de que os materiais reciclados possuem uma identidade visual muito própria, assim como suas características técnicas que os destinam para usos específicos. Sendo assim, não devem ser consideradas comparações entre os materiais, que os classifiquem como melhores ou piores, já que um conjunto de situações às quais o material estará exposto que irá determinar a eficiência do uso, como o tipo de ambiente, tipo de superfície, função e uso específico a que estará sujeito. Desta forma, o granito não é melhor que a madeira, ou o alumínio não é melhor que 
o plástico, ou estes melhores ou piores que os materiais reciclados. Todos poderão satisfazer e se adequar a alguma necessidade.

O que também demonstra a gradativa aceitação dos materiais reciclados é o fato de as pessoas estarem se conscientizando para colaborar com o meio ambiente. $O$ aumento de variedade de opções de reciclados no mercado é um fator positivo. Ainda que o design para os reciclados possa ser melhorado, existe uma ação "proativa" que começa a se manifestar em oposição à estranheza e à resistência. Assim, Moraes descreve com bastante clareza:

O cenário atual do design, que não tem como seguir mais a "busca pela perfeição" da era moderna culmina também por "colocar em cheque o conceito de 'estilo' e 'estética', nos moldes até então empregados; para tanto, essas áreas do conhecimento passaram a ter mais afinidade com disciplinas de abrangência do âmbito comportamental, em detrimento daquelas que consideravam o estudo da coerência, da composição e do equilíbrio formal que predominaram no ensinamento estético da primeira modernidade.

A estética passa a ser mais diretamente atrelada à ética, aqui entendida no sentido de comportamento coletivo social. [...] Muitos chegam mesmo a pregoar a necessidade do surgimento de uma nova estética que deveria ser absorvida pelos consumidores na atualidade. Essa nova estética teria como base, por exemplo, a composição de diferentes plásticos reaproveitados e o colorido pontilhado dos papéis de embalagem em objetos reciclados. [...] Nesse novo modelo estético, que vai ao encontro da sustentabilidade ambiental, isto é, de uma estética em favor do meio ambiente, teriam lugar também as imperfeições de produtos feitos de novos e diferentes tipos de matérias-primas, produzidos com tecnologia de baixo impacto ambiental ou mesmo em processo semiartesanal. Ao aceitarmos de forma proativa os produtos desenvolvidos dentro desse modelo e, por consequência, a sua nova ordem plástica, nós, consumidores, acabaríamos por legitimar uma nova estética, possível em nome de um planeta sustentável [...].

(MORAES, 2010, p. 7-8, grifo nosso)

Concluindo o pensamento de Moraes, pode-se dizer que a atual realidade ambiental gera atitudes alternativas em relação à produção, design e utilização de materiais. $\mathrm{O}$ conceito de matéria-prima vem se alterando e a "nobreza" pode dar lugar à variedade de 
opções de soluções ambientalmente coerentes. A necessidade de resolver problemas ecológicos, em alguns casos, pode superar a exigência pela nobreza. Nobre passa ser aceitar o simples, aquele que, por uma "causa nobre", existe da maneira como pode existir acinzentado, mesclado, mais escuro, menos definido, mais opaco. E assim é sua personalidade e característica, assim como o tem um granito ou uma cerâmica.

As questões ambientais e técnicas são aspectos importantes para especificar um material. Com uma mentalidade proativa ao projeto sustentável, torna-se possível a criação de opções alternativas e, consequentemente, e uma maior demanda que aumente o volume de reciclagem.

\section{5 - Materialidade: diretrizes projetuais}

A metodologia clássica de projeto de produtos e projetos arquitetônicos encontra atualmente a necessidade de novos processos projetuais que contemplem não somente os aspectos técnicos, espaciais e estéticos, mas também os aspectos que causarão reflexos ambientais. Estes últimos devem, portanto, ser projetáveis, assim como são a estrutura, os espaços, entre outros. Para isto, algumas considerações seguintes são importantes.

\subsection{1 - Critérios para especificação de um material}

Os critérios para especificação dos materiais que Silva (1991) apresenta são os de ordem técnica, estética e econômica, relacionados, portanto, às funções primeiras e fundamentais dos materiais. No entanto, atualmente, com o desenvolvimento dos conceitos de sustentabilidade e a necessidade de preservação dos bens materiais naturais, outros critérios devem ser considerados para que um material possa ser utilizado, principalmente no que se refere à conservação ambiental, energética e das possibilidades de reciclagem e reuso. Os critérios a seguir são baseados em Silva (1991), mas complementados e adaptados para esta pesquisa.

- $\quad$ Critérios de ordem técnica: critérios gerais de conhecimento técnico do material, suas propriedades físicas, químicas e mecânicas, possibilidades de aplicação e construtibilidade.

o Pesquisa de novas tecnologias e materiais 
- Critérios de ordem estética: baseados no conceito e partido do projeto, na caracterização de identidade material, arquitetônica e de design que se pretende. Também incluem-se aqui as questões de ordem pessoal.

- Critérios de ordem econômica: conhecimento do correspondente financeiro e ponderação da viabilidade no que se refere ao transporte, execução, uso e manutenção de determinado material.

- $\quad$ Critérios de ordem ambiental: consideração dos gastos energéticos envolvidos para produção do material, proximidade de aquisição, transporte e o fato de serem recicláveis ou reciclados.

o Unir os fatores inerentes à prática projetual com a aplicação do Life Cycle Design - LCD - projeto do ciclo de vida dos produtos. (MORAES, 2009 , p. 63)

- $\quad$ Critérios de ordem socioculturais: comportamentos e costumes. E experiências de consumo.

Edwards (2005, p. 164-167) apresenta alguns outros critérios, denominados "ações para o projeto sustentável" e que são mais contemporâneos às necessidades atuais de projeto complementando os apresentados acima.

- $\quad$ Aplicar princípios ecológicos desde a fase inicial do projeto.

- $\quad$ Evitar espaços com especificidades funcionais: embora a função seja a base da forma e da identidade de uma edificação, sua duração é relativamente curta se comparada com a vida útil de sua estrutura. As edificações muito específicas são inerentemente muito inflexíveis.

- Priorizar iluminação e ventilação naturais.

- Projetar visando simplicidade operacional.

- Projetar visando durabilidade.

- Maximizar o uso de energia renovável.

- $\quad$ Possibilitar a substituição de partes, prevendo a deterioração total ou parcial de uma edificação

- Facilitar a renovação ou substituição de seus componentes ou sistemas.

- $\quad$ Priorizar os materiais construtivos que são facilmente substituídos. 
- Priorizar métodos construtivos flexíveis e desmontáveis que simplificam muito mais os processos de renovação necessários que as construções monolíticas.

\subsection{2 - Projetar para o sistema}

Os materiais abordados como sistema ou subsistemas construtivos são vistos de uma forma mais complexa do que apenas o material aparente em uma superfície. As camadas interagem entre si, garantindo a integridade do todo e bom funcionamento e durabilidade do material sobre a superfície. Nos sistemas de painéis de fechamento divisório ou forros, por exemplo, também contam os montantes, e peças estruturantes das placas que são utilizadas. Quando os materiais são especificados como um sistema, todos os componentes envolvidos passam a ter importâncias equivalentes na estabilidade e funcionamento do todo.

Especificar o material, considerando seu desempenho em conjunto com o sistema pode ser um facilitador ao uso quando se considera que alguns componentes do sistema podem compensar alguma característica técnica pouco eficiente de um material. Um exemplo típico é o uso de mantas para isolamento térmico como "recheio" em sistemas de steel frame que tenham placas de vedação pouco eficientes no desempenho de proteção térmica.

\subsection{3 - Metaprojeto}

O termo e conceito de metaprojeto são apresentados por Moraes (2010) e consideram o processo de projeto como um ciclo que analisa o todo e as variáveis, em que se especifica o material não somente para o fim dado no edifício, mas ao considerarem os seguintes aspectos: seu ciclo de vida; como e quanto tempo permanecerá no edifício; se poderá ser remanejado e, se não, qual será o seu destino. Moraes denomina esses procedimentos de "projetar o projeto" ou "o projeto do projeto", ou, ainda, "metaprojeto". Abaixo, as observações de Manzini e de Moraes revelam o conceito em que o metaprojeto está envolvido:

"A 'próxima economia' pede um 'próximo design'. Ao mesmo tempo considerando que a próxima economia é um novo tipo de economia social, o próximo design é também um novo tipo de design: o design da inovação social e sustentabilidade. Tudo isso, de igual forma, nos faz concluir que 
também será necessário o surgimento de novas abordagens projetuais, novos modelos e novas metodologias que sustentem e direcionem o projeto nesse cenário mutante e complexo que se delineia. Nesse caso, o metaprojeto surge como uma possível referência projetual para os cenários complexos e como linha guia para uma fase em transição, na qual não mais o produto é colocado em evidência, mas o contexto em que esse produto opera ou que deve operar. $O$ metaprojeto atua como uma plataforma de conhecimentos que considera as referências materiais e imateriais, tangíveis e intangíveis, objetivas e subjetivas e que promove redes e relações inéditas, bem como interfaces inovadoras para os produtos e serviços que comporão esse próximo design."

Ezio Manzini, in (MORAES, 2010, p. X e XI, grifo nosso)

[...]A nova realidade culminou também por colocar em cheque o conceito de 'estilo' e 'estética' nos moldes até então empregados; para tanto, essas áreas do conhecimento passaram a ter mais afinidade com disciplinas de abrangência do âmbito comportamental, em detrimento daquelas que consideravam o estudo da coerência, da composição e do equilíbrio formal que predominaram no ensinamento estético da primeira modernidade.

(MORAES, 2010, p.7, grifo nosso)

O autor apresenta esses termos, especialmente analisando o design do produto; porém, pode-se considerar como referência útil para o processo de projeto arquitetônico. 


\section{3 - PLACAS RECICLADAS: matéria-prima, produção e estado da arte.}

"Uma embalagem deve gerar mais economia do que ela custa" Dr. Ruben Rausing (fundador da Tetra Pak) - 1950

"As embalagens, decididamente, não são resíduos, mas uma matéria-prima que tem futuro." Fabrice Peltier e Henri Saporta ${ }^{1}$

O percurso das Embalagens Longa Vida, até o seu uso como placas recicladas (entre outros materiais), passa por um fluxo reverso, que não volta necessariamente para a mesma linha de fabricação das próprias Embalagens Longa Vida, mas desencadeia uma fabricação que gera diversos tipos de produtos reciclados. As etapas desse processo são listadas abaixo, seguidas do organograma de sua logística reversa. Essas etapas foram organizadas tomando-se como referência a conceituação teórica apresentada no capítulo anterior.

Etapas do ciclo de vida das Embalagens Longa Vida:

1. Extração e produção das matérias-primas

2. Transformação das matérias-primas

3. Concepção das embalagens

4. Fabricação das embalagens

5. Preenchimento das embalagens - envase

6. Venda dos produtos embalados

7. Consumo e descarte dos produtos embalados

8. Recuperação dos resíduos de embalagens - coleta seletiva

9. Triagem das embalagens e venda para as recicladoras

10. Nova matéria-prima para novo processo de produção.

\footnotetext{
${ }^{1}$ Fonte: Peltier e Saporta - Design Sustentável, caminhos virtuosos, p. 23.
} 


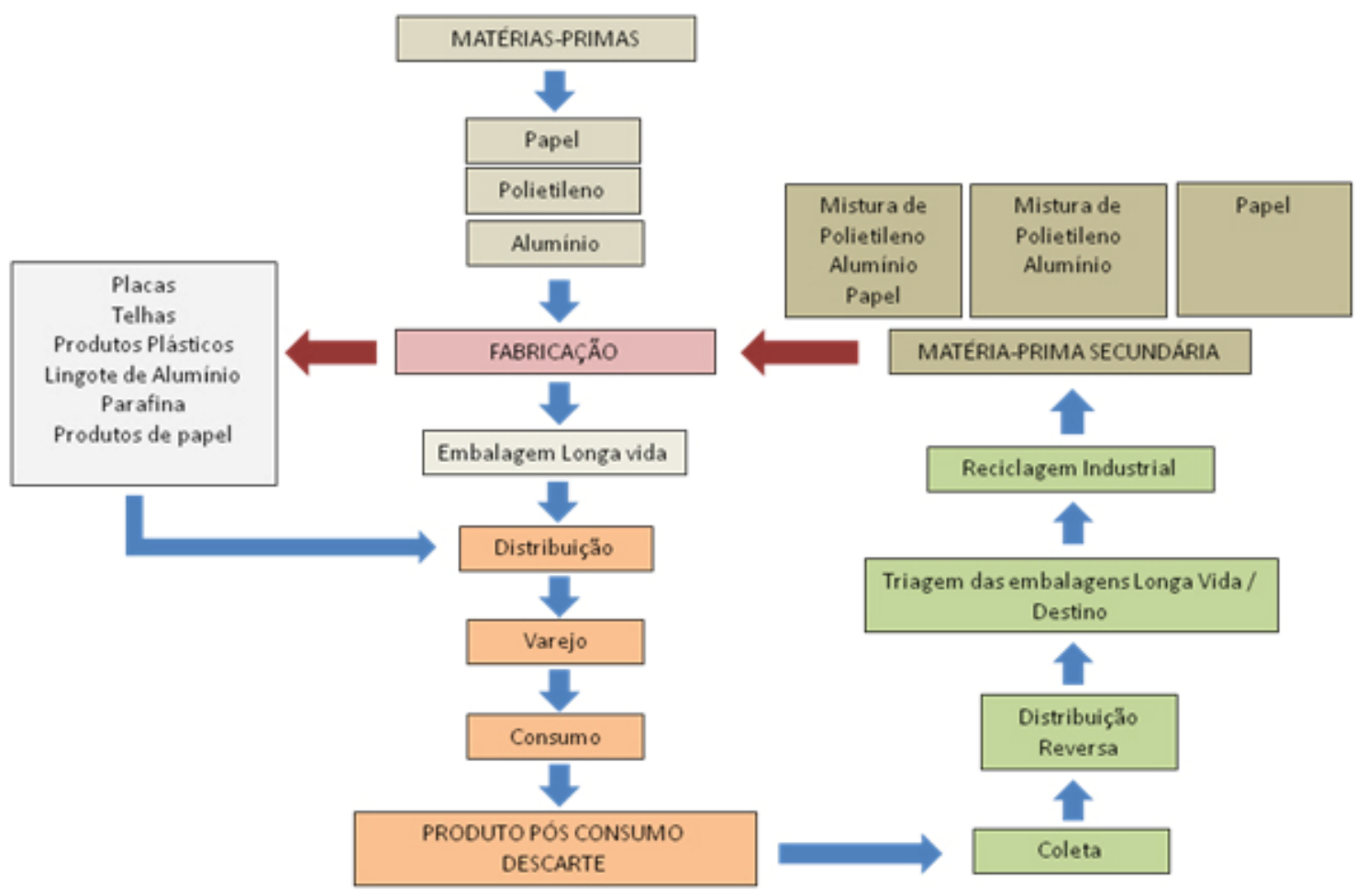

Figura 3.1: Logística Reversa para embalagens Longa Vida. Fonte: Organização da autora. Baseado no organograma apresentado por Leite (2003), apresentado no capítulo 2.

\section{1 - Matéria-prima: Embalagens Longa Vida}

A Embalagem Longa Vida foi projetada pela empresa multinacional sueca Tetra Pak. No processo de criação dessa embalagem, segundo Peltier e Saporta (2009) inicialmente, a empresa lançou, em 1951, uma embalagem de forma tetraédrica, feita de papelão parafinado, uma invenção de Ruben Rausing. Em 1963, a empresa lançou a Tetra Brik, já no formato das caixinhas de leite conhecidas atualmente, e, finalmente, em 1968, aperfeiçoou o projeto e lançou a Tetra Brik Aseptic, cuja tecnologia de acondicionamento permite uma longa conservação, à temperatura ambiente, de alimentos líquidos, sem conservantes. Isso foi possível também devido à tecnologia do envase asséptico.

$\mathrm{Na}$ época de sua criação, as Embalagens Longa Vida destacaram-se em comparação às tecnologias existentes: até então os alimentos eram acondicionados, principalmente, em embalagens metálicas, de madeira e papel. As embalagens plásticas 
começavam também a se estabelecer. Desde a época de sua criação, as Embalagens Longa Vida são destinadas principalmente aos líquidos, como leite e sucos de frutas.

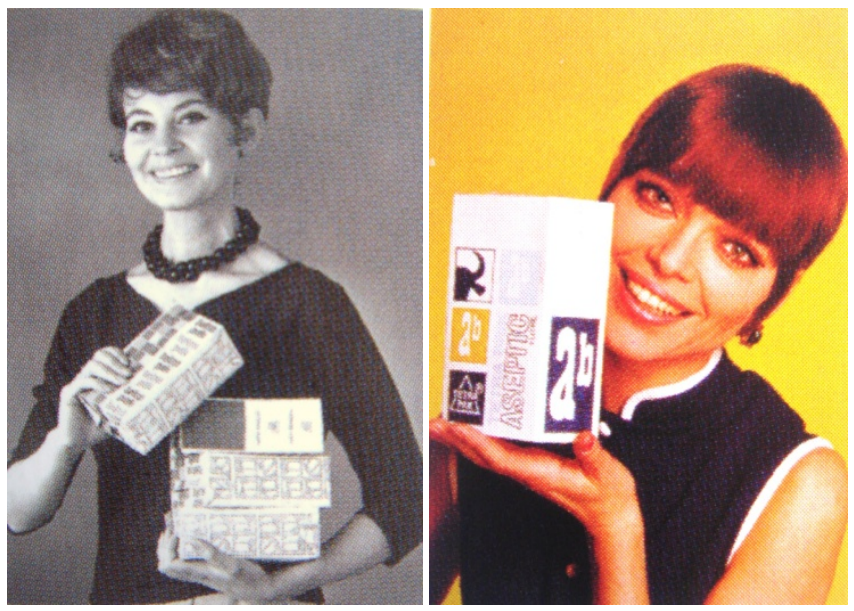

Figura 3.2: TetraBrik - 1963 (figura à esquerda) e Tetra Brik Aseptic - 1968 (figura à direita) Fonte: Peltier e Saporta (2009) - páginas 26 e 27

O leite Longa Vida é obtido por meio da ultra pasteurização do leite a elevadas temperaturas, $135^{\circ} \mathrm{C}$ a $150^{\circ} \mathrm{C}$, por 2 a 4 segundos. O resultado é a destruição de todos os microorganismos que podem se desenvolver no leite e a obtenção de um produto de alta qualidade. Assim, o leite embalado pode ser conservado fora da geladeira por até 180 dias, sem se estragar. Quando o leite é pasteurizado, ele é aquecido a temperaturas por volta de $70^{\circ} \mathrm{C}$, durante 15 a 20 segundos. Na pasteurização simples, apenas os microrganismos mais perigosos são destruídos, por isso o leite deve ser mantido na geladeira.

Juntos, eles impedem a penetração da luz, do ar, da água e dos microrganismos, protegendo o alimento para que não estrague.

A proteção contra a luz é importante, pois ela destrói vitaminas encontradas em alimentos, como leite e sucos. O oxigênio presente no ar produz uma reação nos alimentos, chamada oxidação, que pode causar neles alterações de cor e sabor. $\mathrm{O}$ ar pode levar microrganismos e odores estranhos para dentro da embalagem, se ela não for muito bem fechada.

(CULTURA AMBIENTAL, 2010) 
"Além do tratamento especial dado ao alimento, a embalagem necessita de camadas de proteção que impedem a penetração da luz, do oxigênio e de odores externos." (PINATTI, 1999, p. 109) O termo "Longa Vida" deve-se, portanto, ao fato de o alimento poder ser preservado em seu interior por um longo período - até 180 dias (6 meses aproximadamente) - sem precisar de refrigeração. Para essa proteção, as embalagens são, então, fabricadas com 3 materiais, distribuídos em várias camadas:

- $\quad 75 \%$ Papel: cartão duplex.

- 20\% Plástico: polietileno de baixa densidade.

- $5 \%$ Metal: lâmina de alumínio
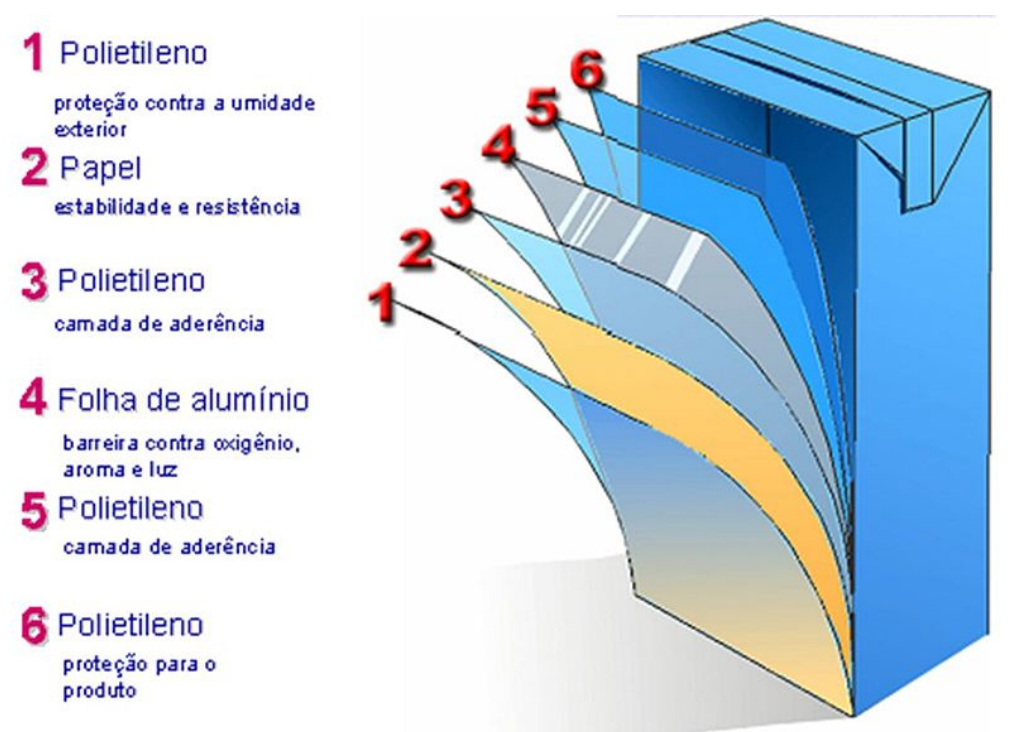

Figura 3.3: Multicamadas da embalagem longa vida. Fonte: Eco desenvolvimento (2009)

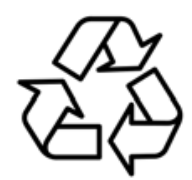

O papel, no que se refere à reciclagem, é renovável e muito fácil de ser identificado pelos consumidores e pelos agentes ambientais, no momento da coleta. Segundo Peltier e Saporta (2009), a coleta, no entanto, é inferior às necessidades industriais, apesar de os índices de reciclagem das embalagens de papel e papelão, por exemplo, chegarem recentemente a mais de $54 \%$. Os autores salientam, ainda, que as fibras papeleiras podem ser recicladas em torno de sete vezes, pois, no processo de reciclagem, suas fibras são quebradas, o que demanda a inserção de fibras novas no circuito para produção de novos produtos. Além disso, ainda informam que o fato de os papéis e papelões fazerem parte dos materiais que podem adaptar-se a várias etapas de 
tratamento, como a compostagem e a incineração, faz com que seu índice de valorização seja muito elevado.

"Ao lado da energia, o principal recurso da indústria papeleira é a água, que, ao mesmo tempo, serve para lavar as fibras papeleiras (a fim de eliminar as tintas e vernizes, por exemplo) e transportá-las para as máquinas de beneficiamento. Para administrar esse recurso crucial, as fábricas equipam-se de estações de purificação, funcionando em circuito fechado."

(PELTIER e SAPORTA, 2009, p.50)

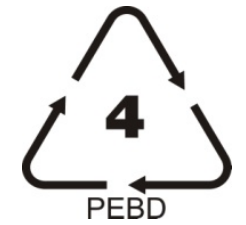

O plástico que compõe a Embalagem Longa Vida é o Polietileno de Baixa Densidade (PEBD). De acordo com ARQTEMA (2005), o plástico tem como componente principal o polímero orgânico sintético, cuja principal característica é o estado de fluidez que assume durante um determinado estágio de seu processamento, o que torna possível a moldagem por ação isolada ou conjunta do calor. o Polietileno de Baixa Densidade apresenta moléculas com alto grau de ramificação e é a versão mais leve e flexível do Polietileno (PE).

A riqueza dos plásticos é também sua fraqueza: todos esses materiais são, sem dúvida, incompatíveis entre si e, conseqüentemente, difícil de serem separados para a reciclagem. [...] Os plásticos, em geral, e em particular, os plásticos destinados à embalagem representam, todavia, apenas uma fração ínfima do consumo de petróleo, do qual são subprodutos. [...] No reverso da medalha, esses materiais oriundos da química, de qualidade inegáveis, rapidamente apareceram como os maus alunos do meio ambiente.

(PELTIER e SAPORTA,2009, p. 62)

O empecilho para a reciclagem dos plásticos é sua grande variedade de tipos, porque têm que ser separados, já que alguns objetos plásticos não podem ser reciclados. A reciclagem dos plásticos pode ser feita através de métodos químico, mecânico ou energético.

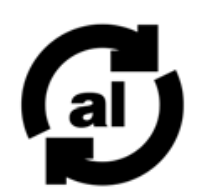

O aço e o alumínio são os principais metais utilizados na indústria das embalagens. Quanto à reciclagem, o alumínio tem um histórico de sucesso no Brasil, país que é conhecido mundialmente pelas suas ações sustentáveis em relação a este material. Ainda, segundo o site da Associação Brasileira de Alumínio, em 2008, o Brasil bateu novamente o recorde mundial de reciclagem de latas de alumínio para 
bebidas, com índice de $91,5 \%$. De acordo com essa mesma fonte, o processo de reciclagem utiliza apenas $5 \%$ da energia elétrica e, segundo dados do International Aluminium Institute - IAI, libera somente $5 \%$ das emissões de gás de efeito estufa, quando comparado com a produção de alumínio primário.

O alumínio, apesar de ser o terceiro elemento mais abundante na crosta terrestre, é o metal mais jovem usado em escala industrial. [...] Sua produção atual supera a soma de todos os outros metais não ferrosos. [...] Hoje, os Estados Unidos e o Canadá são os maiores produtores mundiais de alumínio. Entretanto, nenhum deles possui jazidas de bauxita em seu território, dependendo exclusivamente da importação. O Brasil tem a terceira maior reserva do minério no mundo, localizada na região amazônica, mas é o sexto produtor mundial. Além da Amazônia, o alumínio pode ser encontrado no sudeste do Brasil, na região de Poços de Caldas (MG) e Cataguases (MG). A bauxita é o minério mais importante para a produção de alumínio, contendo de $35 \%$ a $55 \%$ de óxido de alumínio.

(ABAL, 2010)

\subsection{1 - Reciclagem das embalagens Longa Vida}

Pinatti (1999), apresenta, em sua tese, a hipótese de que "todas as embalagens de papel são recicláveis, mesmo as de multicamadas", mas que estas podem dificultar o processo de reciclagem direta.

Ao longo do desenvolvimento tecnológico das embalagens e de seus materiais, também foram necessárias novas tecnologias que superassem as dificuldades de recuperação ambiental e material relativas às embalagens. Iniciativas de reciclagem tomadas pelas próprias empresas produtoras de embalagens vêm amenizando as críticas e criando um destino apropriado para as embalagens.

A própria Tetra Pak, juntamente com outras empresas envolvidas com a produção das embalagens, trabalha para minimizar os gastos energéticos envolvidos nos processos de reciclagem das Embalagens Longa Vida e recuperação dos materiais para novo processamento.

A produção cresceu ao longo dos anos, assim como a sua reciclagem. De acordo com Metaanálise (2010), o número de lançamentos de embalagens cresceu 10,5\%, em 2010. Esse crescimento também foi apresentado por Istoedinheiro (2010), que noticiou 
que a Tetra Pak tem capacidade de aumentar a produção de cinco milhões de embalagens por ano para oito milhões, a partir de 2013.

\section{Gráfico 3.1: Taxa de reciclagem de Embalagens Longa Vida no Brasil (em \%)}

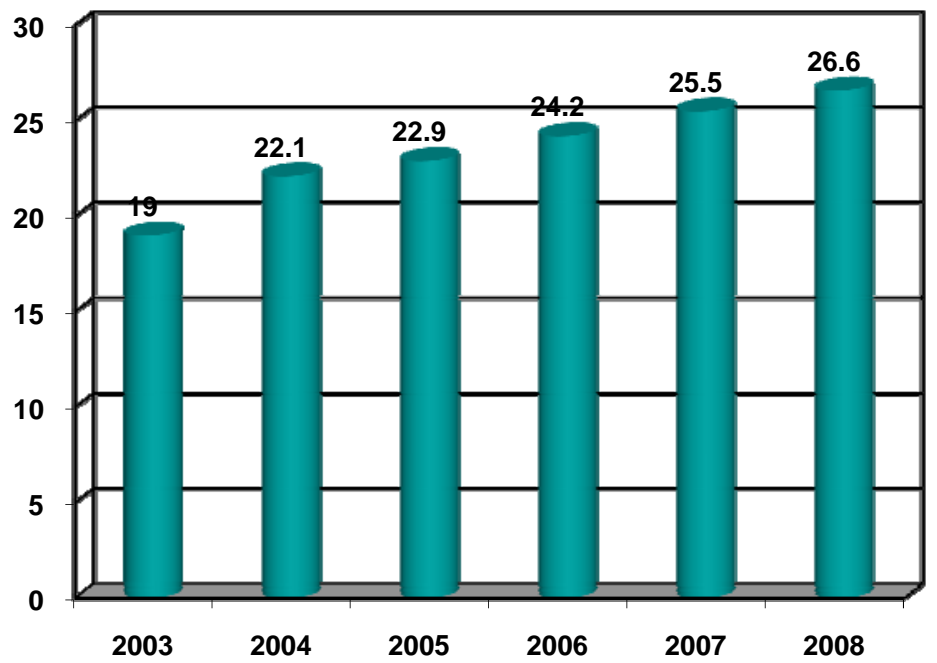

Fonte: Relatório anual Tetra Pak, com complementação dos dados de 2008, fornecidos pela empresa por e-mail (apêndice)

Até 2008, aproximadamente 5 milhões de embalagens eram produzidas por ano, no Brasil, segundo análise dos dados apresentados, considerando os $26,6 \%$ desse montante (gráfico acima), 1 milhão e 330 mil embalagens seriam recicladas, restando para o lixão ou aterro sanitário o montante de 3 milhões e 670 mil embalagens. Pouco ainda é reciclado, diante da produção anual e das perspectivas de aumento da produção.

Pinatti (1999), baseado na ficha técnica de 1998 da CEMPRE_TETRA PAK afirma que 1 tonelada de embalagem cartonada reciclada gera $650 \mathrm{~kg}$ de papel, o que gera também a economia no corte de 20 árvores de reflorestamento.

O processo de reciclagem das Embalagens Longa Vida acontece em várias etapas. Como as embalagens são compostas por 3 diferentes materiais, é necessária a separação do papel, do polietileno e do alumínio. Esse processo de separação acontece em diferentes indústrias, que retiram da Embalagem Longa Vida os materiais, conforme seu interesse e necessidade. De forma geral, primeiramente, os fardos de embalagens são vendidos pelo centro de triagem para as indústrias de papel que possuam "planta de instalação recicladora", onde, então, as embalagens são trituradas e batidas com água, para dissolver o papel que se separa dos outros materiais (polietileno e alumínio). 
Separar as camadas das Embalagens Longa Vida não é um processo tão complexo como pode parecer a princípio. Um simples teste caseiro demonstra que as camadas são facilmente separadas, após ficarem submersas por aproximadamente 12 horas em água. (figura 3.4). Obviamente, em escala de produção industrial, a situação é bem mais complexa.

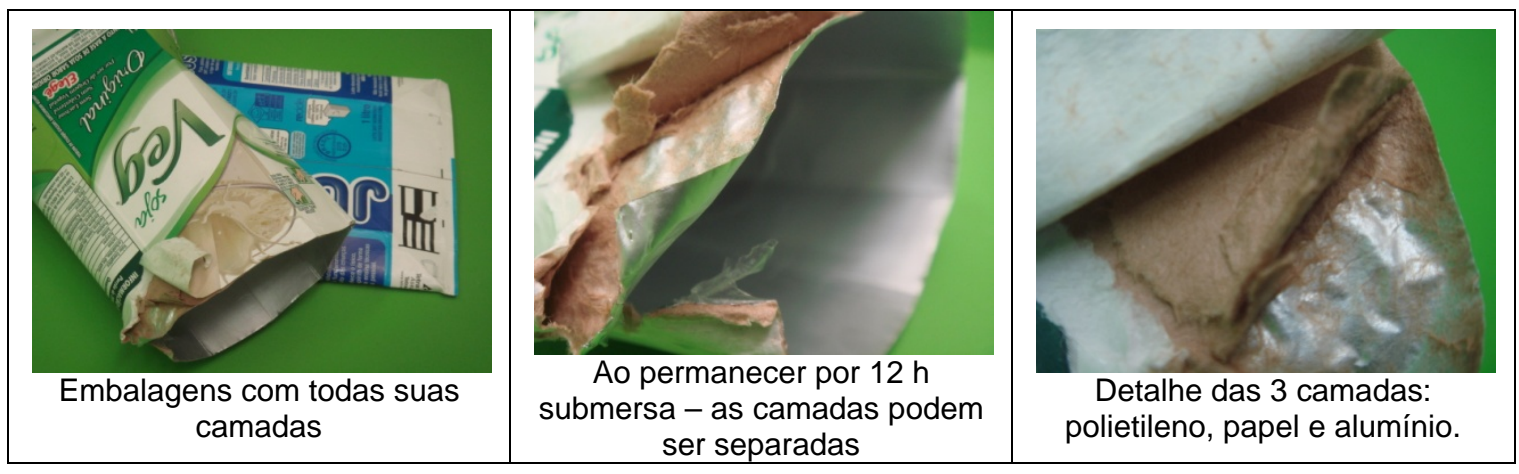

Figura 3.4: Teste caseiro para separação das camadas da Embalagem Longa Vida. Fonte: Fotos da autora, 2010.

Segundo Neves (2004), a maior parte das empresas brasileiras fabricantes de papel reciclado faz a desagregação dos materiais componentes da Embalagem Longa Vida, utilizando um equipamento chamado hidrapulper, equipamento que tem um sistema de funcionamento semelhante a uma grande batedeira.

As embalagens são colocadas no hidrapulper e são batidas com água. O hidrapulper hidrata as fibras celulósicas, em agitação com água (sem adição de produtos químicos), fazendo com que essas fibras transformem-se em uma massa, separando-se das camadas de plástico/alumínio, coladas umas às outras. Em seguida, essas fibras são lavadas e purificadas e podem ser usadas para a produção de papel, utilizado na confecção de caixas de papelão, tubetes ou na produção de material gráfico. Toda a água utilizada no processamento da celulose é reaproveitada e tratada. Há perda de $1,5 \mathrm{~m}^{3}$ de água por tonelada de celulose tratada (Agenda Sustentável, 2009).

A média de tempo para desagregação do papel nesse sistema é de $15 \mathrm{~min}$., segundo Neves (2004). Feita a desagregação, toda a polpa de papel está misturada à água. Essa pasta é escoada do hidrapulper pelos orifícios do equipamento e levada para as próximas etapas de reciclagem do papel.

Após a polpa de papel ser bombeada para tanques específicos, ocorre um processo de limpeza, com água, do polietileno e alumínio restantes no hidrapulper, para retirada do 
que possa ter sobrado de celulose no meio da batelada. Após essa etapa, o polietilenoalumínio é descarregado por uma saída lateral do hidrapulper, passa por uma peneira rotativa ou área de drenagem para retirada do excesso de água e, então, será armazenado, enfardado e vendido para outras indústrias recicladoras, que produzem materiais e componentes a partir do polietileno-alumínio.

Segundo Neves (2004), quanto menos agressiva é a limpeza na fábrica de papel, evitando-se a quebra e o arrancamento do filme de alumínio, maiores serão os rendimentos no processo de recuperação do alumínio posteriormente. Também afirma que a umidade do polietileno-alumínio, após o enfardamento, é em torno de $50 \%$ a $60 \%$. Isso irá influenciar nas etapas posteriores de reciclagem

Considerando-se que $75 \%$ da composição da Embalagem Longa Vida é de papel, a maior parte, portanto, é aproveitada para a indústria de reciclagem de papel. A mistura polietileno-alumínio corresponde aos $25 \%$ restantes.

"Cada tonelada de embalagem cartonada reciclada gera, aproximadamente, $650 \mathrm{~kg}$ de papel Kraft, economizando o corte de 20 árvores cultivadas em áreas de reflorestamento comercial." (REVIVERDE, 2009)

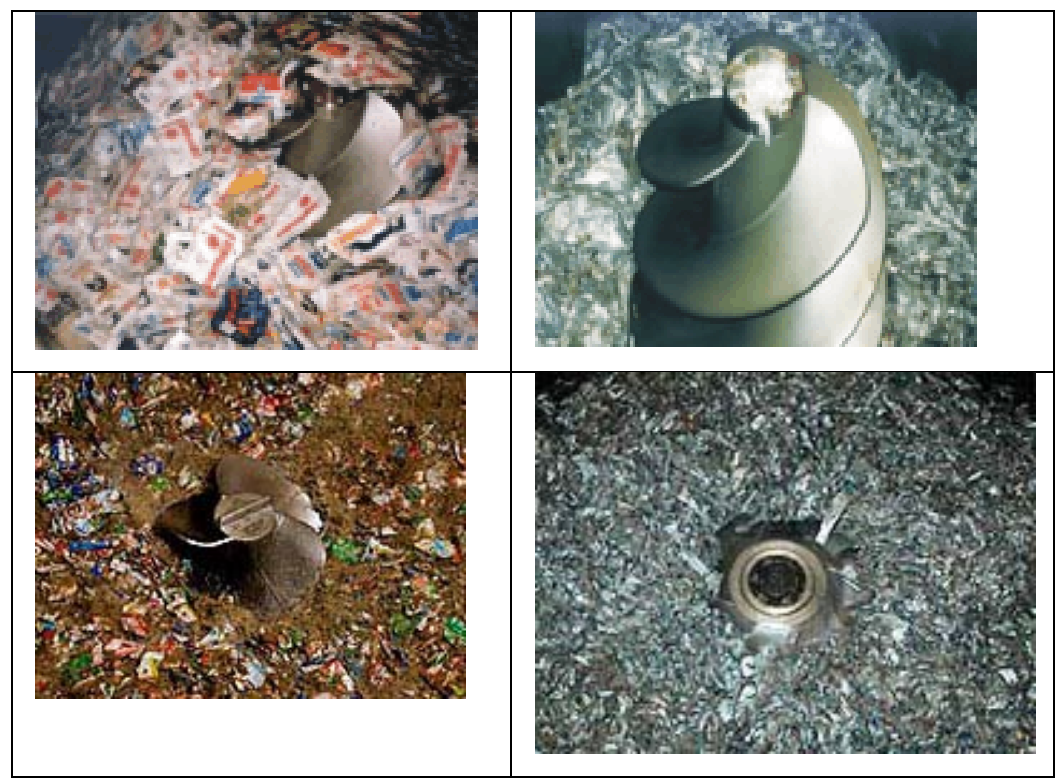

Figura 3.5: Início do processo de reciclagem - Hidrapulper Fonte: ABRE (2009) e TETRA PAK (2009)

Segundo Neves (2004), nesse processo também é necessário que exista uma planta de extração de fibras restantes na mistura de polietileno-alumínio antes do reator a plasma, 
para eliminar o residual que não foi extraído na fábrica de papel. O autor descreve que, no reator ocorre a fusão do alumínio que é retirado líquido e transformado em lingote e pode alcançar pureza (obtida em planta piloto) de 98,5\%. O polietileno sofre quebra das ligações químicas (carbono-carbono e carbono-hidrogênio) o que gera a degradação do polímero e forma uma mistura de hidrocarbonetos gasosos que passarão pelo processo de condensação, dando origem à parafina. A parafina pode ser destinada à fabricação de cosméticos e lubrificantes, entre outros produtos.

Após a retirada do papel, a mistura de polietileno e alumínio restante pode tomar três destinos diferentes. Primeiro a mistura é vendida, em fardos, para fábricas de componentes, onde é transformada, por exemplo, em placas e telhas para usos diversos (referente ao material estudado neste trabalho). Outro destino é a indústria de reciclagem, que transformará o polietileno e alumínio restantes em compósito peletizado, por processo de extrusão, que será matéria-prima para indústrias de transformação de plásticos, pelos diversos processos: injeção, rotomoldagem ou sopro, gerando produtos variados (figura 3.6). O terceiro destino do polietileno e alumínio é a indústria recicladora, que possui a tecnologia de transformação por reator de plasma térmico (o plasma térmico é um gás aquecido a elevadas temperaturas). Nesse sistema, a mistura é totalmente separada a partir de aquecimento a uma altíssima temperatura $\left(15.000^{\circ} \mathrm{C}\right.$, podendo atingir $\left.50.000^{\circ} \mathrm{C}\right)$. Após esse processo, o polietileno transforma-se em parafina, que é vendida e tem diversos usos, e o alumínio volta a seu estado íntegro e quase puro, transformado em lingotes e vendido para indústrias que utilizem este material (figura 3.7).

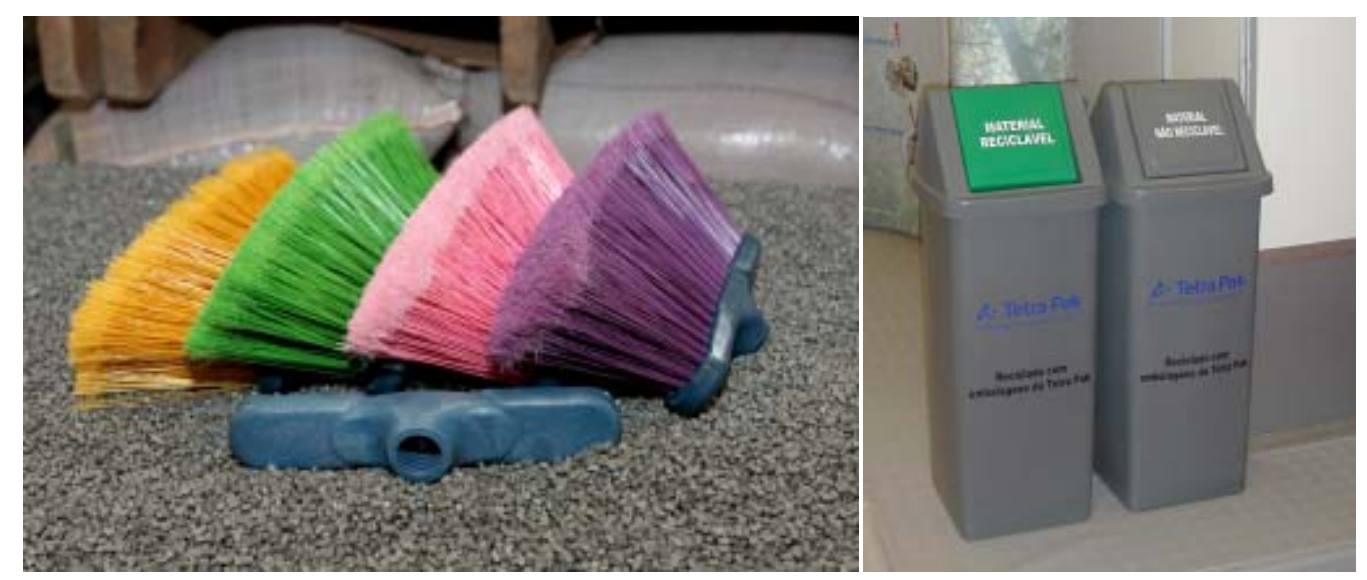

Figura 3.6: Vassoura e lixeira recicladas a partir de embalagens longa vida. Fonte: CULTURA AMBIENTAL (2010) 


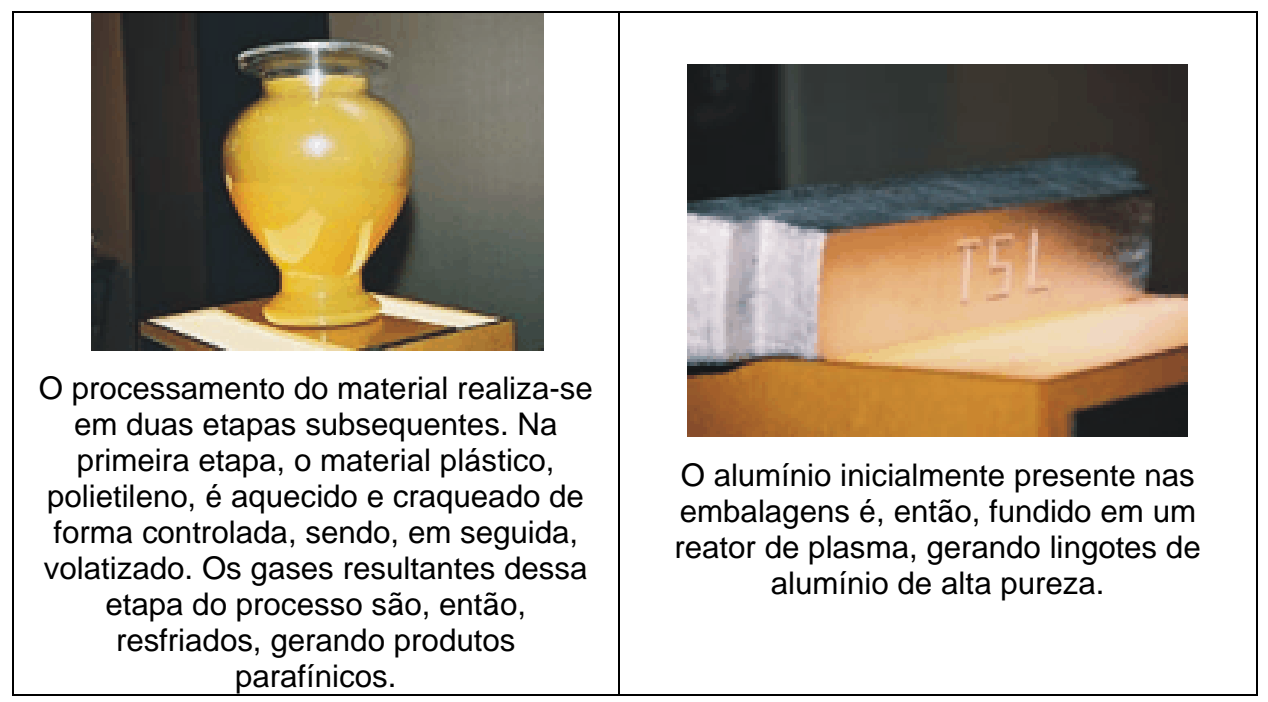

Figura 3.7: Parafina (esquerda) e lingote de alumínio (direita), resultados da reciclagem por plasma térmico. Fonte: TSL AMBIENTAL (2009)

\section{A tabela 3.1 apresenta as unidades recicladoras de Embalagens Longa Vida} existentes no Brasil, até o ano de 2009, e suas respectivas produções. São 36 unidades que, a partir da reciclagem das Embalagens Longa Vida, estão produzindo peças e objetos variados, papel, lingotes de alumínio, placas e telhas. As fábricas produtoras de placas e telhas somam 22 unidades.

Tabela 3.1: Unidades recicladoras de Embalagens Longa Vida no Brasil e produtos produzidos.

\begin{tabular}{|l|l|l|l|}
\hline Ramo & Reciclador & Cidade & Estado \\
\hline brindes de plástico/alumínio & Andu Brindes & Taboão da Serra & SP \\
\hline brindes de plástico/alumínio & Confetti & São Paulo & SP \\
\hline brindes de plástico/alumínio & Formatho Ideall & São Carlos & SP \\
\hline papel & Artivinco & Santa Rosa do Viterbo & SP \\
\hline papel & Klabin & Piracicaba & SP \\
\hline papel & Revita & Telêmaco Borba & PR \\
\hline papel & Nova Kraft & Potim & SP \\
\hline papel & Adami & Caçador & SC \\
\hline papel & Trombini & Canela & RS \\
\hline papel & Sonoco & Londrina & PR \\
\hline papel & Klabin Goiana & Goiana & PE \\
\hline papel e pellets & Mercoplás & Valinhos & SP \\
\hline parafina e alumínio & EET & Piracicaba & SP \\
\hline pellets & Maximoplas & Guarulhos & SP \\
\hline placas & Maxicomp & Campo Largo & PR \\
\hline placas & Ecopel & Mogi Guaçu & SP \\
\hline placas & Ecoway & Itupeva & SP \\
\hline placas e telhas & Ecológica & ES \\
\hline placas e telhas & Ecopak & Uberaba & MG \\
\hline placas e telhas & Ibiteca & Marialva & PR \\
\hline
\end{tabular}




\begin{tabular}{|l|l|l|l|} 
placas e telhas & Nova Telha & Ibiporã & $\mathrm{PR}$ \\
\hline placas e telhas & EcopaK - RJ & Queimados & $\mathrm{RJ}$ \\
\hline placas e telhas & Ecoplasth & Bocaína do Sul & $\mathrm{SC}$ \\
\hline placas e telhas & Brasilplac & Itapeva & $\mathrm{SP}$ \\
\hline placas e telhas & Ecofuturo & Campinas & $\mathrm{SP}$ \\
\hline placas e telhas & Ibaplac & Ibaté & $\mathrm{SP}$ \\
\hline placas e telhas & MR Comercio de Telhas & Piracicaba & $\mathrm{SP}$ \\
\hline placas e telhas & MR Comércio de Telhas & Rio Claro & $\mathrm{SP}$ \\
\hline placas e telhas & Recima & Iracemápolis & $\mathrm{SP}$ \\
\hline placas e telhas & Fênix Telhas Ecológicas & Aparecida & $\mathrm{SP}$ \\
\hline placas e telhas & Recipak & Araçatuba & $\mathrm{SP}$ \\
\hline telhas & Eco Industrial & Várzea Grande & $\mathrm{MT}$ \\
\hline telhas & Alluse & Olinda & $\mathrm{PE}$ \\
\hline telhas & Arteplás & Ponta Grossa & $\mathrm{PR}$ \\
\hline telhas & GLZ Telhas & Santa Cruz do Sul & $\mathrm{RS}$ \\
\hline telhas & Tecfort & São Domingos & SC \\
\hline
\end{tabular}

Fonte: Tetra Pak (2009) - tabela fornecida por e-mail pela Tetra Pak (Apêndice C)

\section{2 -Fabricação das placas.}

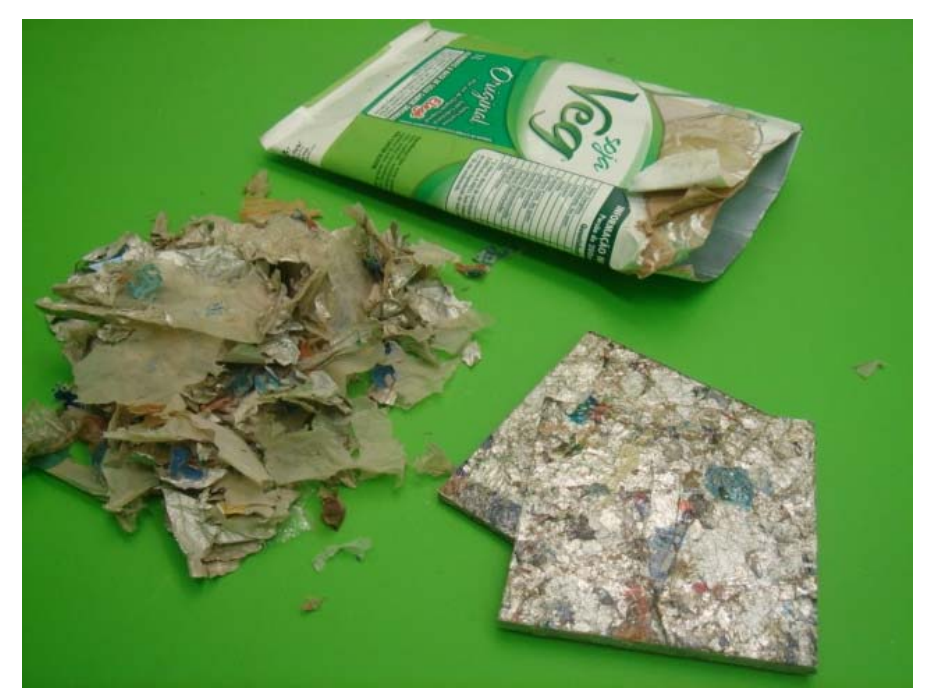

Figura 3.8: Embalagem, matéria-prima e placa Fonte: Foto da autora, 2010

O material chega à indústria recicladora em fardos úmidos, em função da primeira etapa da reciclagem, provenientes da indústria papeleira. A mistura também chega com resíduos de outros materiais, que deverão ser retirados a fim de não comprometer a qualidade dos componentes. Porém, alguns desses materiais permanecem, como pedaços de tampinhas, canudos, entre outros plásticos, que ao final da prensagem podem ser identificados em algumas placas. Um residual de papel também permanecerá na mistura até 
o final do processo de produção dos componentes reciclados e também fica visível em alguns pequenos pontos da placa acabada.

As etapas de fabricação são as seguintes:

1. Abertura dos fardos

2. Espalhamento da matéria-prima para secagem natural, ao ar livre.

3. Secagem mecânica (se necessário), na máquina secadora de plásticos.

4. Primeira trituração, com peneiramento dos resíduos indesejáveis.

5. Segunda trituração: ida ao tubo exaustor, que transporta para armazenamento perto da área de prensagem.

6. Pesagem do material $(18 \mathrm{~kg})$

7. Montagem do material nas formas: chapa metálicas + uma camada de filme poliéster (desmoldante) + camada de $18 \mathrm{~kg}$ de material reciclado + filme de polietileno (saco plástico preto, opcional, para melhorar a impermeabilidade da placa) + camada de $18 \mathrm{~kg}$ de material reciclado + filme de alumínio (opcional, usado principalmente em telhas) + filme de poliéster (desmoldante) + chapa metálica.

8. Colocação na prensa.

9. Prensagem em temperatura de $160^{\circ} \mathrm{C}$, aproximadamente.

10. Tempo de prensagem: 20 a 40 minutos, dependendo da espessura que será a placa e da umidade ainda presente na matéria-prima utilizada.

11. Retirada da prensa: a placa é retirada das chapas metálicas. Se for telha, ocorre a moldagem logo em seguida, ainda quente, e descanso. Se for placa, é colocada sobre um plano e deixada até esfriar e endurecer.

12. Retirada das arestas das placas e telhas para aparelhamento - uso de serra circular.

13. Controle de qualidade: inspeção e reparo (a quente ou frio) de falhas e acabamento em geral.

14. Armazenamento.

15. Transporte e Venda.

O quadro de figuras a seguir ilustra algumas dessas etapas: 
Quadro 3.1 -Processo de fabricação das Placas Recicladas de Embalagem Longa Vida.

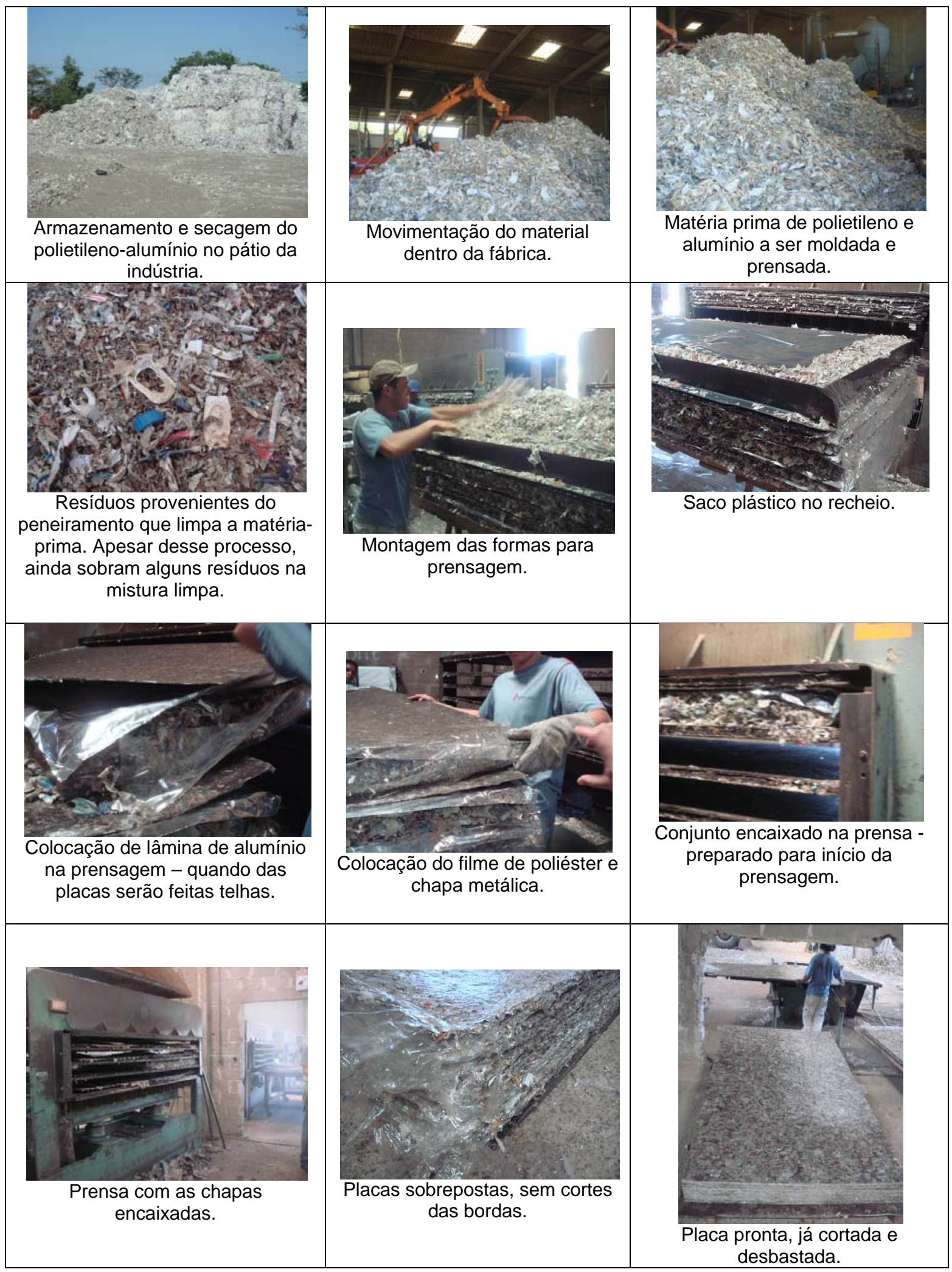

Fonte: Fotos da autora, 2009 


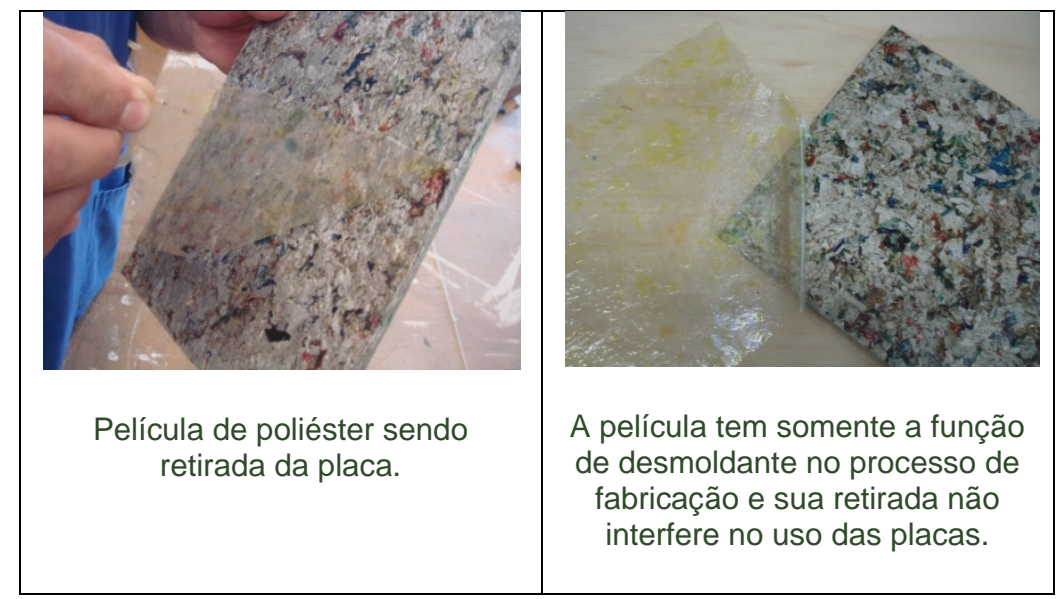

Figura 3.9: Película de poliéster sobre placa reciclada. Fonte: Foto da autora, 2010

As dimensões, tamanhos e formatos da peça irão influenciar na especificação e são importantes para o acabamento das superfícies. É necessário que sejam produzidas peças com estabilidade dimensional. Essa é uma característica das placas recicladas que manifesta-se como um problema. Aparentemente sutil ao se manusear uma única peça, pode tornar-se um inconveniente visível no momento de aplicação lado a lado, sobre as superfícies, formando ondulações que podem dificultar o alinhamento das espessuras entre uma placa e outra (figura 3.10).

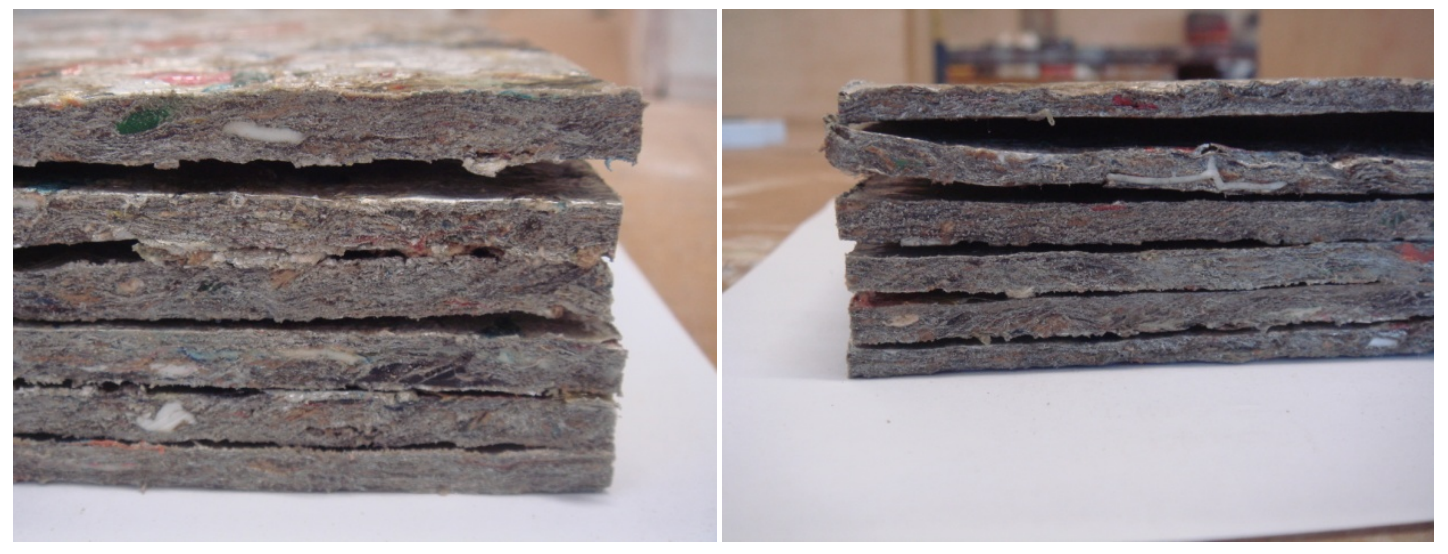

Figura 3.10: Placas empilhadas - Instabilidade dimensional. Fonte: Foto da autora, 2010. 


\section{3 - Estado da Arte do design com Placas Recicladas de Embalagens Longa Vida.}

Existe uma busca geral pela ampliação do design com materiais reciclados.Com as Placas Recicladas o design parece ser intuitivo e experimental, com certa timidez em ousar em desenhos e ampliar as suas funções. Enquanto novas opções se concretizam, conquistando o gosto comum das pessoas, e se estabilizam enquanto possibilidades de uso, vários produtos se apresentam como opções. A figura 3.11 mostra que as placas recicladas têm sido utilizadas para produção dos mais variados objetos, no entanto, para a construção civil, ainda se destacam o uso como telhas e tapumes. A forma ondulada das telhas propicia melhor estabilidade e rigidez da peça quando colocada na vertical, comparado com as placas lisas de madeirite, ou mesmo do próprio reciclado.

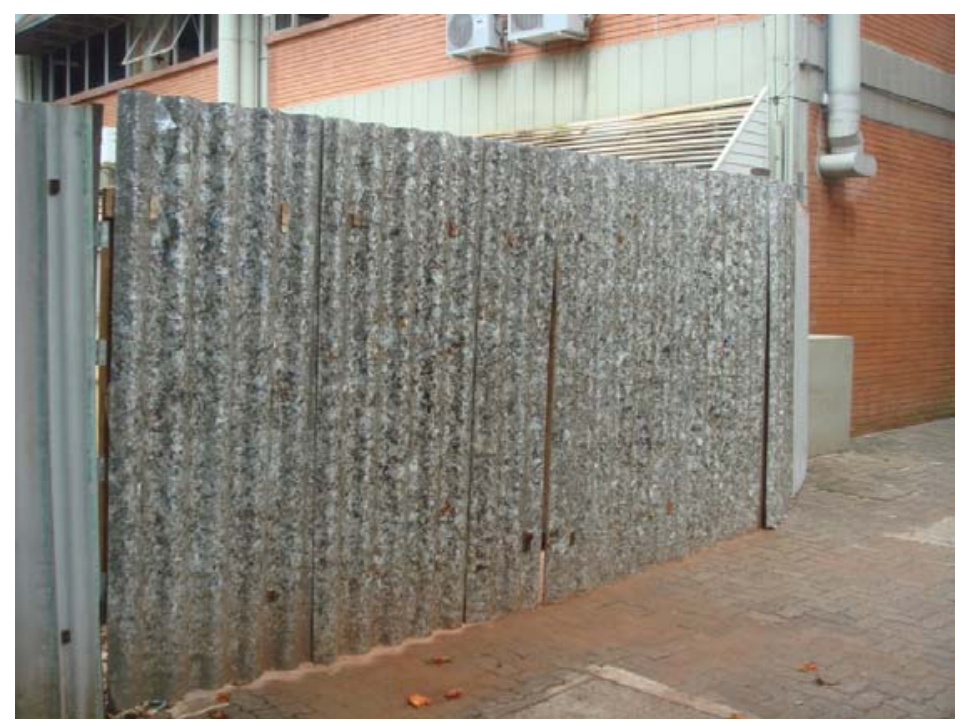

Figura 3.11: Telha reciclada usada como tapume nas dependências da EESC-USP Fonte: Foto da autora, 2010.

As figuras abaixo mostram dois exemplos de casinhas para animais (figura 3.12), que reproduzem o design existente da versão em madeira, mas também tirando partido de uma característica própria das Placas Recicladas de Polietileno-alumínio: a flexibilidade. Surge, então, o modelo de casinha em arco, que demanda menos cortes e fracionamento de peças do que o modelo tradicional. É um exemplo simples que demonstra claramente que cada material tem sua potencialidade e expressão. As Placas Recicladas produzem, com suas características, um design próprio, seja pela textura, seja pelas opções de trabalhabilidade com o material, por suas características técnicas, ou pelo conjunto de todos esses aspectos. 


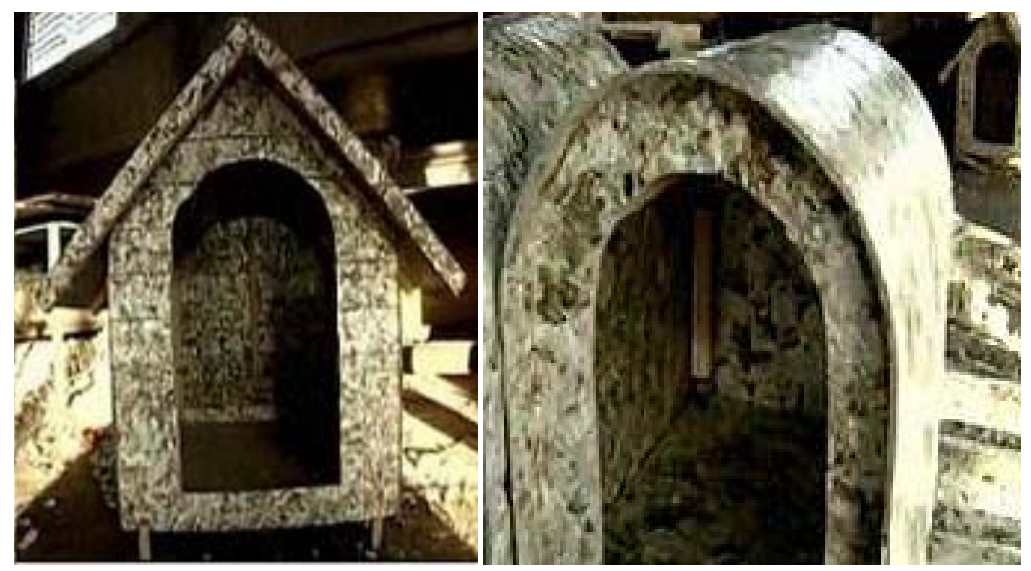

Figura 3.12: casinhas de cachorro feitas com placas recicladas de embalagem longa vida. Fonte: FELIZ PRA CACHORRO (2010)

A figura abaixo (figura 3.13). mostra a versão reciclada de uma lixeira em um dos padrões de design encontrados no mercado. Para a confecção desse objeto, assim como a do anterior, foram necessários cortes e conexões entre as partes. Isso também evidencia que a trabalhabilidade com as placas, para a produção desses padrões de objetos, é muito semelhante às placas de madeira.

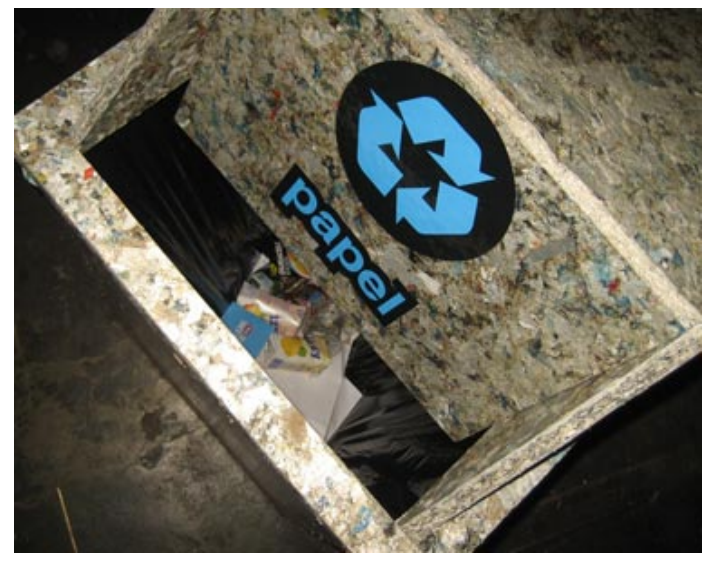

Figura 3.13: Lixeira de material reciclado de Embalagem Longa Vida. Fonte: FINÍSSIMO (2008)

Voltando o olhar para os componentes arquitetônicos, a figura abaixo apresenta uma variação de uso, além das telhas, como fechamentos verticais, do oitão da construção. A solução encontrada para a eficiência da vedação foi a sobreposição das placas. Completando a composição, o "beiral" acoplado é resultado da curvatura de várias placas inteiras organizadas lado a lado. Apesar da composição geral dessa obra parecer bastante rústica e simplificada construtivamente, demonstra que experimentos que tiram partido da característica, do potencial técnico e do estético do material, podem apresentar soluções 
interessantes. A impermeabilidade e flexibilidade da placa permitiram tal solução. (figura 3.14)

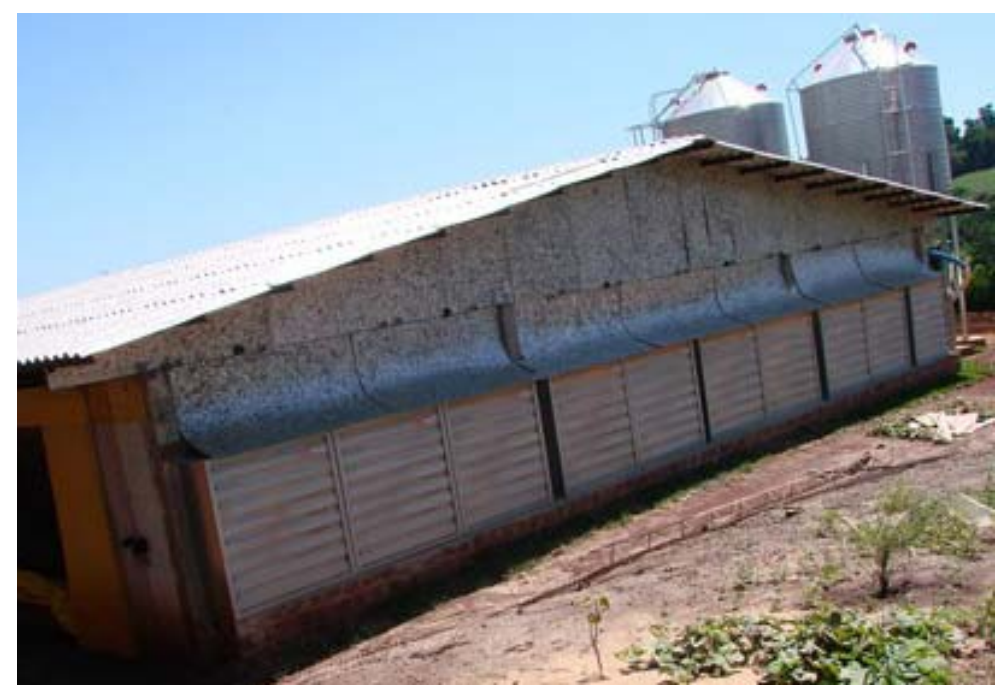

Figura 3.14: Galpão com acabamento externo com uso de placas curvadas, configurando um pequeno beiral. Fonte: REGIPLAC (2010)

O uso na forma de forro é outro exemplo de experimentos construtivos onde se procura adaptar as placas aos sistemas existentes. Na figura abaixo, perfis de madeira dão acabamento na junção entre uma placa e outra.

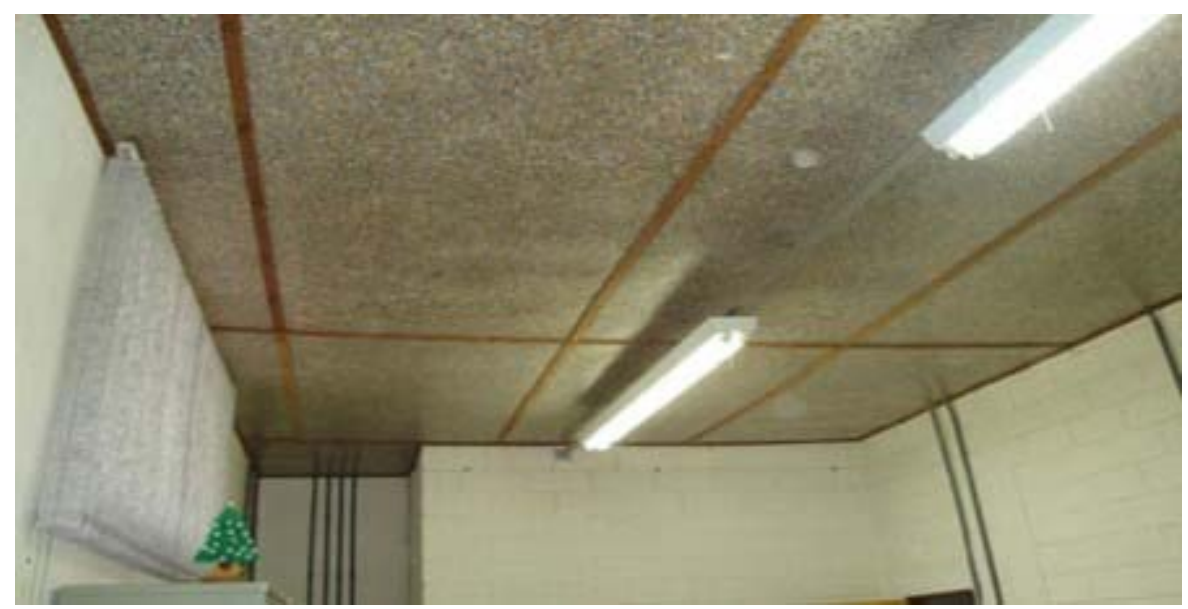

Figura 3.15: forro com placa reciclada Fonte: ECOWAY (2010)

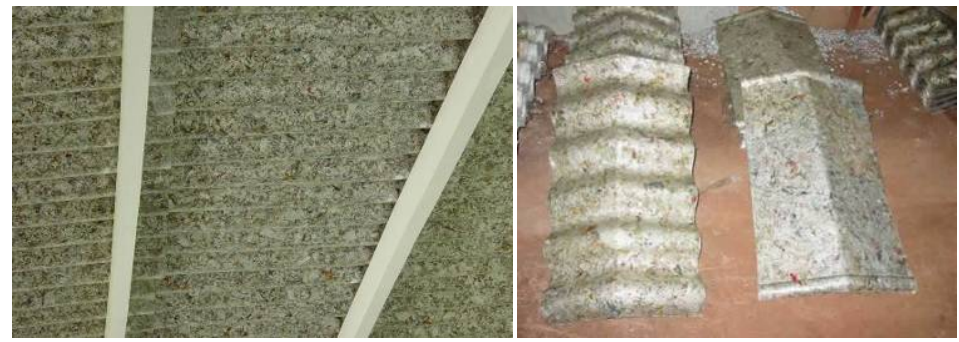


Figura 3.16 - Telhas e cumeeiras recicladas em Embalagens Longa Vida. Fonte: IBAPLAC (2009)

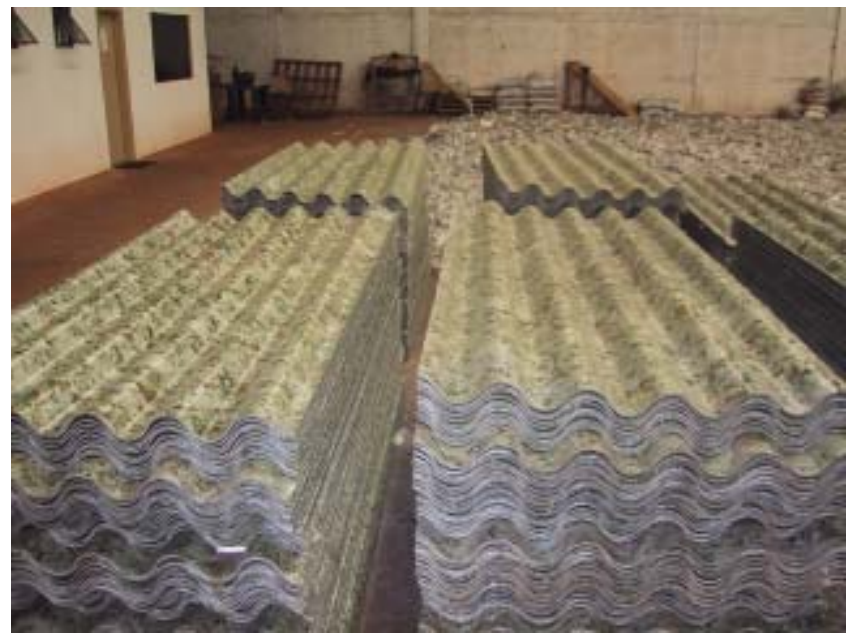

Figura 3.17:Telhas Recicladas de Embalagem Longa Vida. Fonte: CULTURA AMBIENTAL (2009)

\subsection{1 - Projetos arquitetônicos}

Algumas soluções construtivas mais ousadas, com o uso das Placas Recicladas de Embalagens Longa Vida, foram testadas e projetadas e são analisadas a seguir. Esses projetos demonstram a busca por soluções que integram o design dos materiais reciclados.

\subsubsection{1 - Step House}

A história da Stephouse começou em 2008, quando a Escola Politécnica da Universidade Federal do Rio de Janeiro (UFRJ) recebeu um convite para participar do SDEurope - Solar Decathlon Europe 2010, evento sediado em Madrid, na Espanha. Na época, Glória Brandão era aluna do curso de especialização em Engenharia Urbana da Escola Politécnica e foi convidada por um de seus professores para montar uma equipe de arquitetos e fazer o projeto de uma casa eco eficiente para representar a POLI-UFRJ no evento. O projeto foi elaborado em um mês por Glória e seu sócio, Othon de Castro, com a participação dos arquitetos Leonardo Lopes, Lígia Tammela e Daniel Gomes.

A Stephouse, foi projeto finalista do International Design Excellence Awards (IDEA/Brasil), a partir do conceito de casa eco eficiente. 
O projeto de residência uni familiar inclui quarto, sala e banheiro, em um total de $72 \mathrm{~m}^{2}$ de área. O material da construção pode ser transportado num container e a obra pode ser toda feita em apenas três dias, contando com uma equipe de 10 pessoas. A montagem é fácil e não requer nenhum nível técnico.

Segundo a projetista Glória Brandão, a casa ecoeficiente pode ter uma vida útil de 30 a 40 anos e exige uma equipe especializada para sua execução. De acordo com o clima da região em que for construída a casa, pode ser necessária a mudança de inclinação da cobertura que apóia painéis fotovoltáicos para captação adequada de energia solar. (ECOLOUCA, 2009)

O conjunto construtivo é composto por materiais reciclados, sistemas de ventilação natural, captação de água da chuva e equipamentos de reuso de água, energia e aquecimento solar. Foram especificados os materiais que possibilitassem rápida montagem e transporte e que pudessem ser reciclados. Os materiais especificados foram "madeira plástica", um material proveniente de resíduos industriais (borracha, EVA, silicone, tecidos e outros), cargas minerais (calcitas, gesso, carbonato de cálcio e outros), fibras animais (resíduos de couro e pelos) e fibras vegetais de qualquer natureza, além de placas e telhas recicladas.

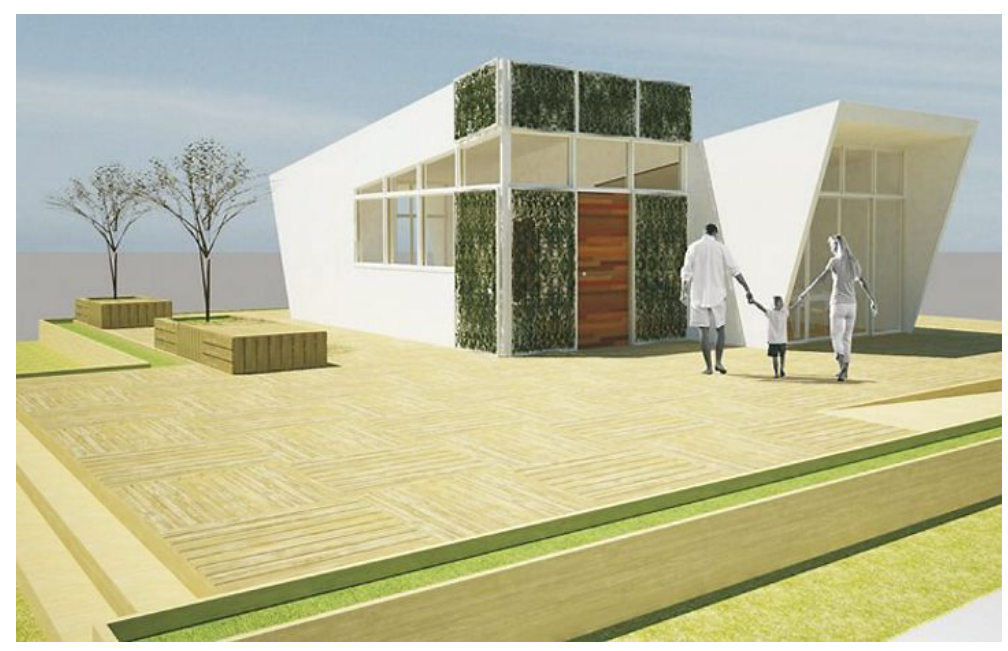

Figura 3.18: StepHouse Fonte: ECOLOUCA (2010) 


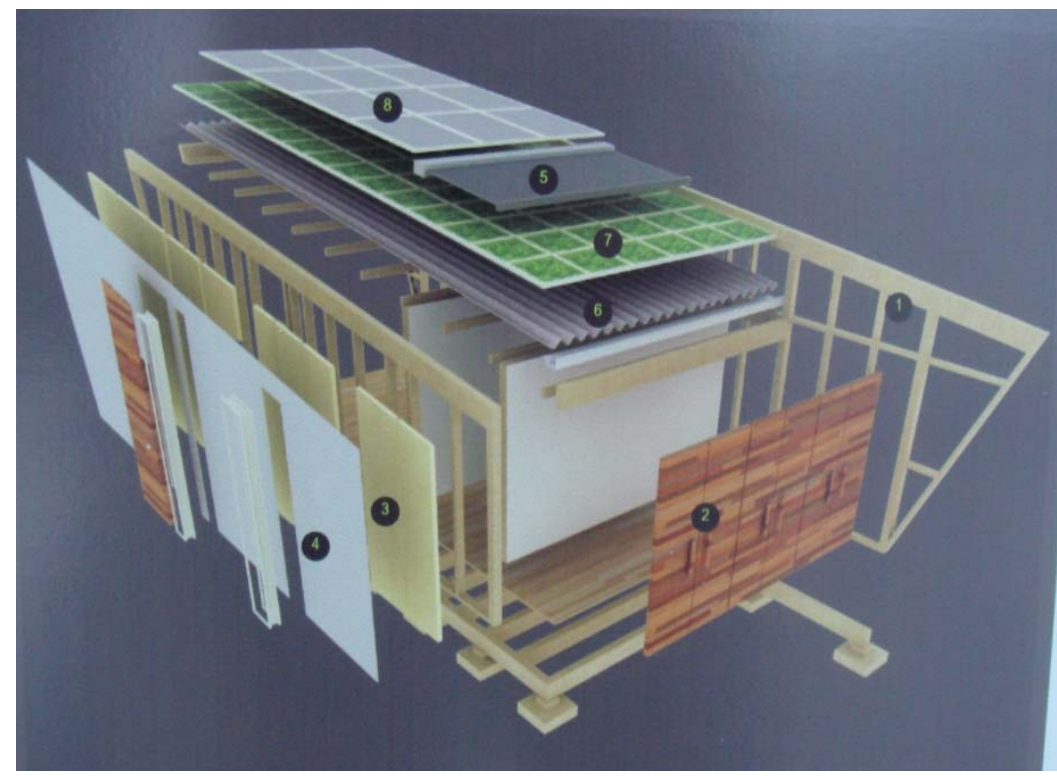

Figura 3.19: StepHouse fragmentada - etapas (steps)

Fonte: foto da autora (retirada do painel apresentado na Bienal de Arquitetura de 2009.

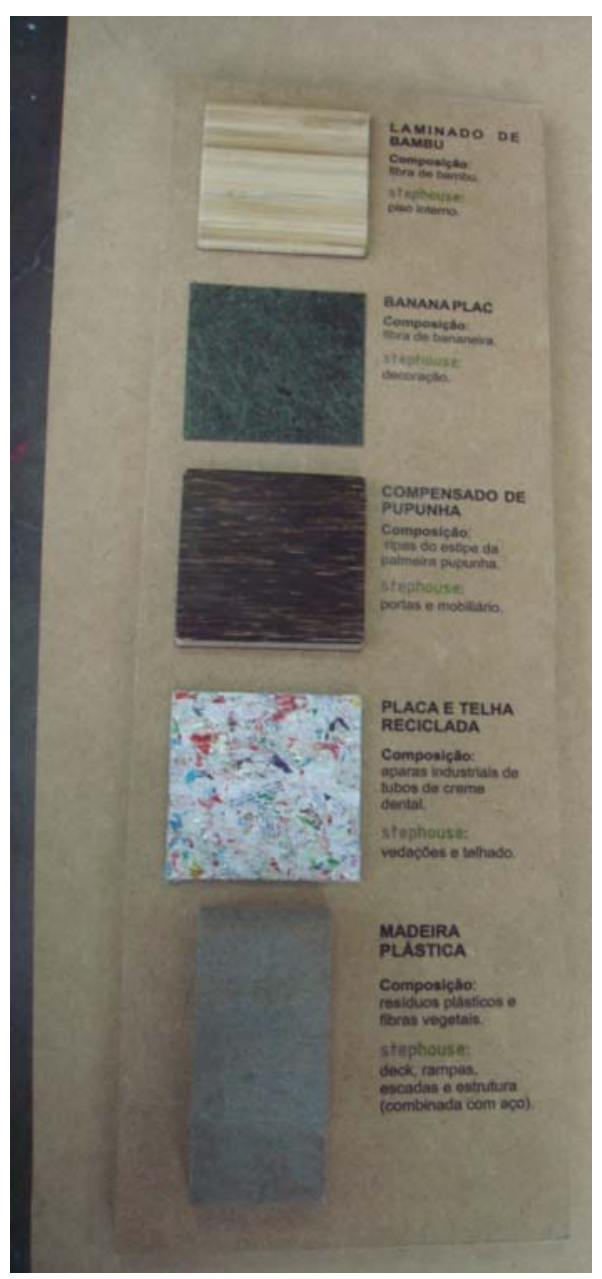

Os Steps:

Step 1 - madeira plástica

Step 2 - Portas e janelas em compensado de pupunha

Step 3 - Proteção térmica e acústica com poliestireno expandido.

Step 4 - Placas recicladas.

Step 5 - Aquecedor solar.

Step 6 - Telhas Recicladas.

Step 7 - Telhado verde.

Step 8 - Painéis fotovoltaicos.

As placas especificadas para a StepHouse foram as recicladas do refugo industrial da fabricação de tubos de creme dental (e não do pós-uso); porém, da mesma forma, poderiam ser utilizadas as Placas Recicladas de Embalagem Longa Vida.

Figura 3.20: Paleta de materiais propostos para a Step House Fonte: foto da autora (exposição do projeto e maquete na Bienal de Arquitetura de 2009). 


\subsubsection{2 - Casa AQUA}

A Casa Aqua é uma proposta de casa modelo de referência de construção sustentável que apresenta soluções construtivas de baixo impacto ambiental. Foi concebida para atender aos critérios do Referencial Técnico de Certificação da Construção Sustentável - Processo AQUA (Alta Qualidade Ambiental). A ideia surgiu de relações da Fundação Vanzolini com a Missão Econômica da França no Brasil.

Até o momento desta pesquisa, foram projetadas duas versões da Casa AQUA, pelo arquiteto Rodrigo Mindlin Loeb, e apresentadas na forma de Show Room. A primeira versão, exposta na Feicon 2009 (Feira Internacional da Construção), foi um sobrado de $100 \mathrm{~m}^{2}$ (figura 3.21). Na segunda versão, em 2010, na $2^{\mathrm{a}}$ Ambiental Expo (Feira Internacional de Equipamentos e Soluções para o Meio Ambiente) a proposta foi para uma residência térrea de $40 \mathrm{~m}^{2}$. (figura 3.22)

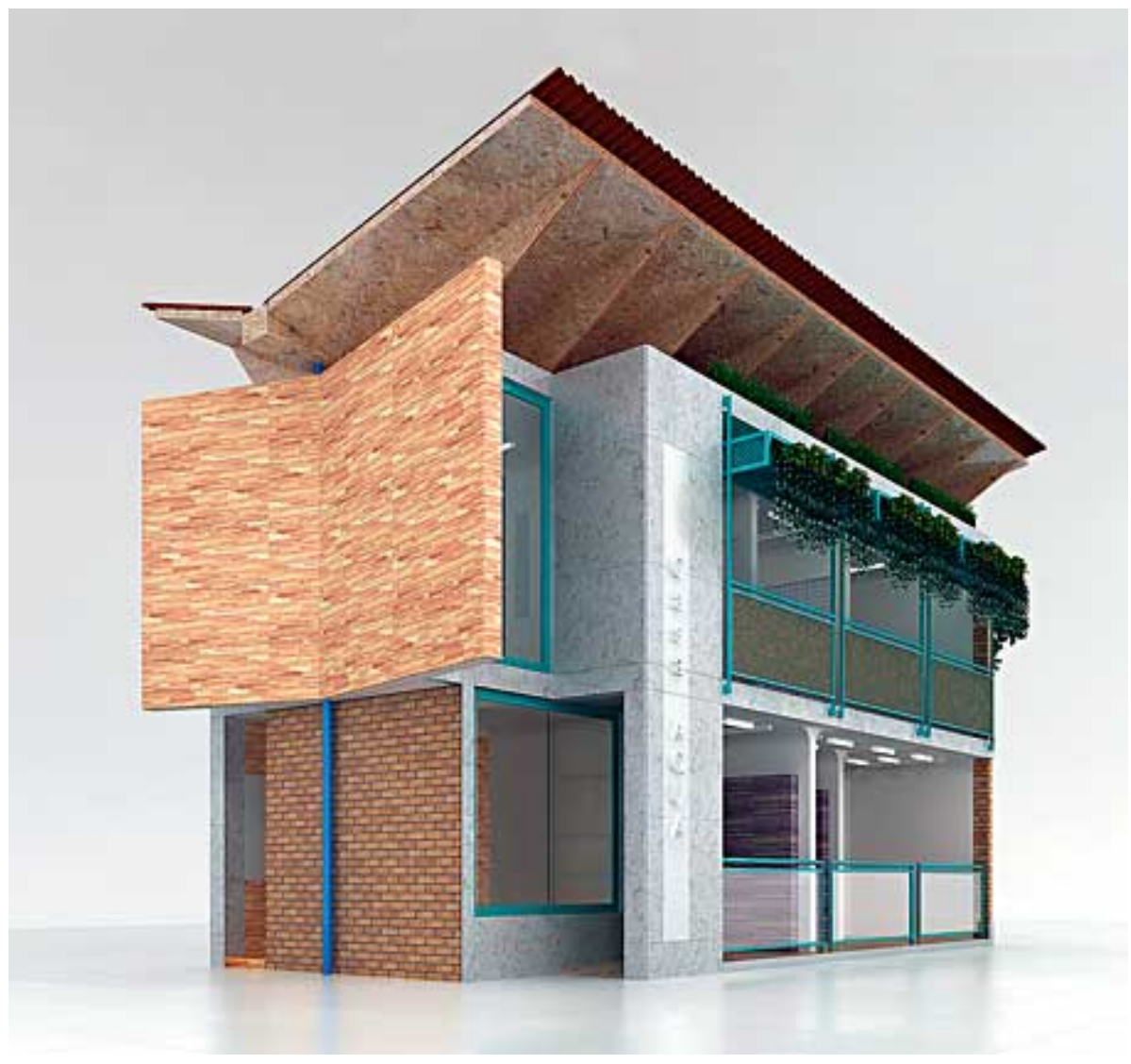

Figura 3.21: Maquete Eletrônica da Casa AQUA - sobrado versão 2009. Fonte:FINESTRA (2010) 


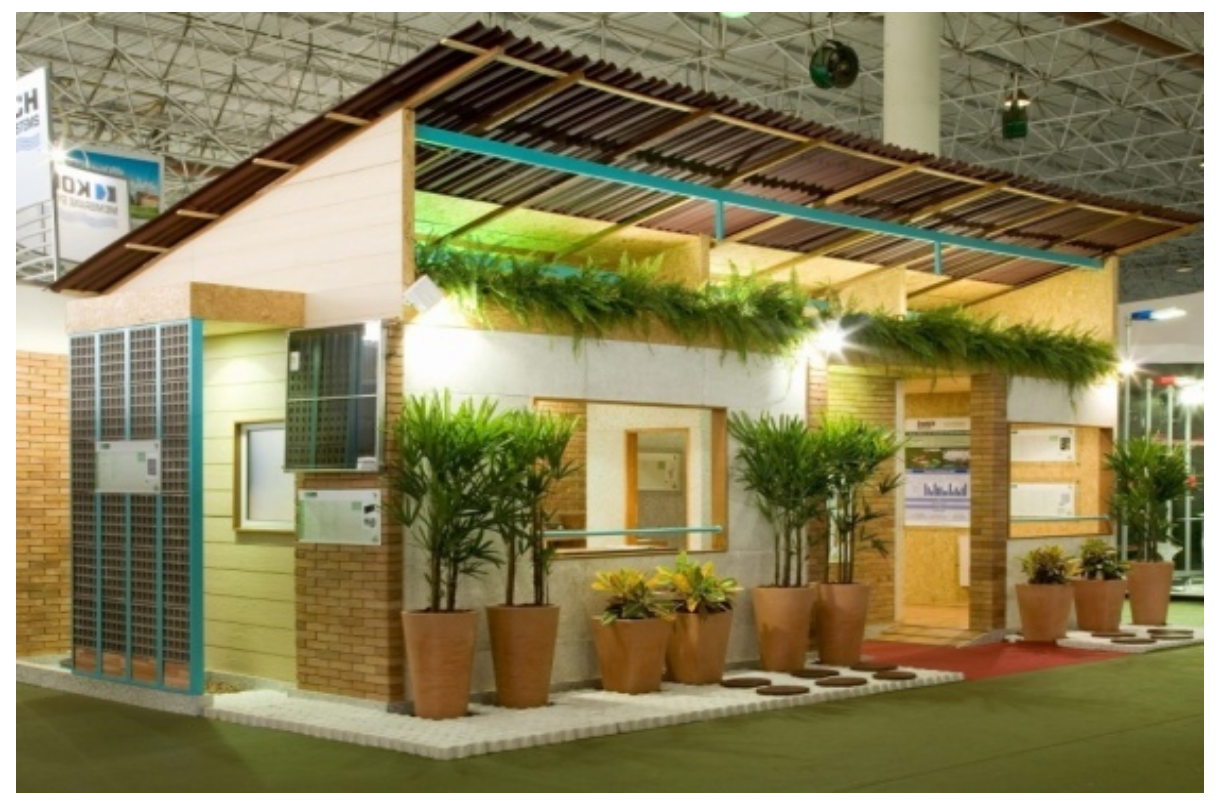

Figura 3.22: Protótipo da construção da Casa Aqua - Térrea - versão 2010 Fonte:CONSTRUARTE (2009)

Os materiais utilizados foram principalmente os reciclados, os reconstituídos e os recicláveis. Foram projetados de forma a terem o sistema construtivo racionalizado. As madeiras são certificadas:

- OSB.

- Tijolo de solo cimento.

- Placas recicladas de embalagens longa vida.

- Dry-wall.

- Gradil metálico.

- Argila expandida. 


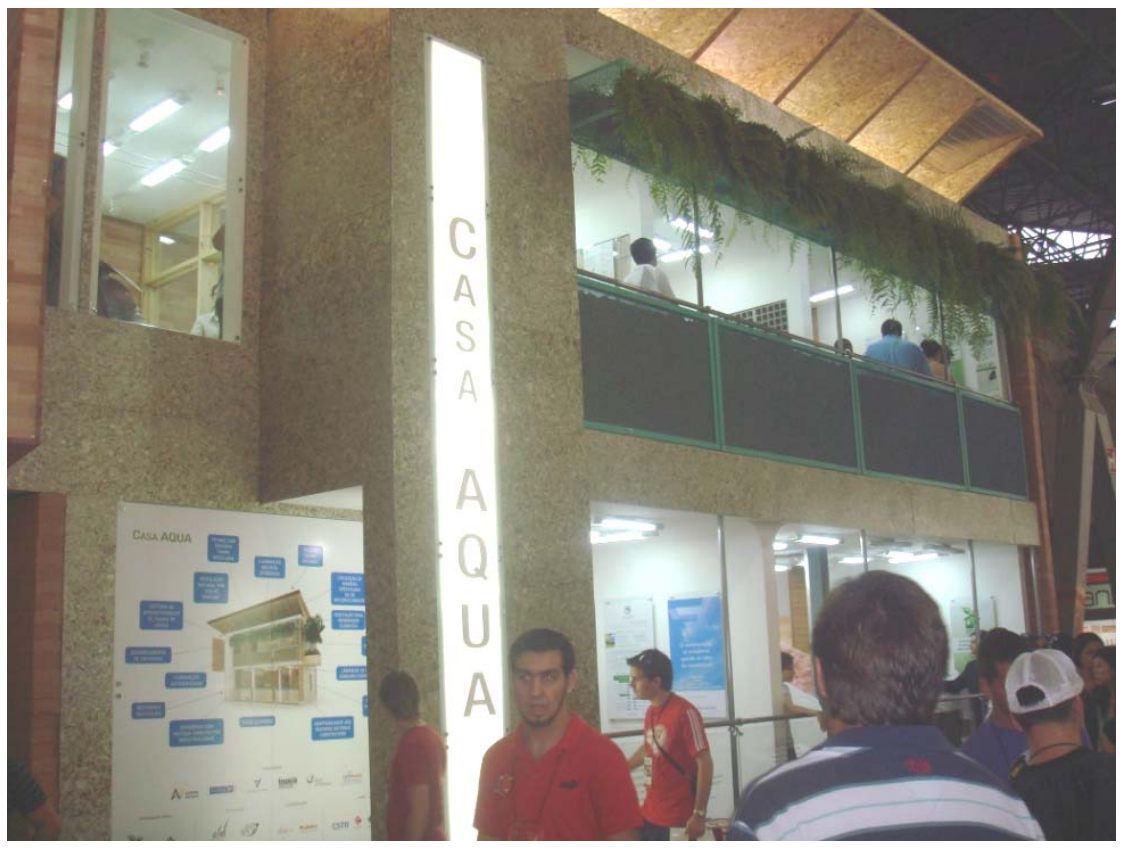

Figura 3.23: Casa AQUA, 2009 - fachada frontal Fonte: Foto da autora, 2009.

Tecnicamente, o uso das placas parece ter sido especificado para a área externa devido sua impermeabilidade aos líquidos e boa resistência ao calor. Construtivamente, percebe-se a boa adaptação ao corte para modulação das placas à fachada.

Como ponto negativo, ficou visível o efeito abaulado de algumas placas em relação às outras, causando algumas sutis "barrigas" ao longo da superfície. O uso das placas em cortes menores do que seu tamanho padrão de fábrica foi uma solução que ajudou a diminuir o problema. As placas foram fixadas por parafusos nos quatro cantos. Os parafusos, por serem metálicos, camuflam-se na superfície do material. Percebe-se que o uso de mais parafusos, ao longo das laterais de cada placa, talvez pudesse amenizar o efeito "barriga". Assim, provavelmente seria necessário um número maior de montantes internos para a estruturação dos painéis.

A junção entre as placas recicladas e outros materiais foi feita com mástiques ou deixados sem preenchimento (devido ao fato de o protótipo se encontrar dentro do pavilhão de exposição). No caso de uma construção em condições reais de ambientação, todas as juntas teriam que ser muito bem tratadas, inclusive aquelas de faceamento entre uma placa reciclada e outra, ou, no caso de as juntas entre placas permanecerem sem rejuntamento, seria necessário um sistema de impermeabilização por trás dos painéis, ou a colocação de outra placa, para que a umidade não caminhe até o espaço interno da edificação. 
Esteticamente o efeito resultante parece homogêneo à distância, com uma superfície cinza, salpicada por cores. O fato de ser um material plástico misturado com alumínio proporciona uma superfície lisa que reflete a iluminação, criando efeitos variados ao longo da fachada, mas que também evidenciou o efeito abaulado. As juntas parecem imperceptíveis à distância, devido à proximidade entre uma placa e outra.

A composição de cor e textura parece agradável, em conjunto com os outros materiais e soluções volumétricas. Apesar da tonalidade cinza predominante das placas e da materialidade muito diferente dos outros materiais em contato, a madeira (OSB) e do marrom avermelhado do solo-cimento, o conjunto apresenta um aspecto dinâmico visualmente.

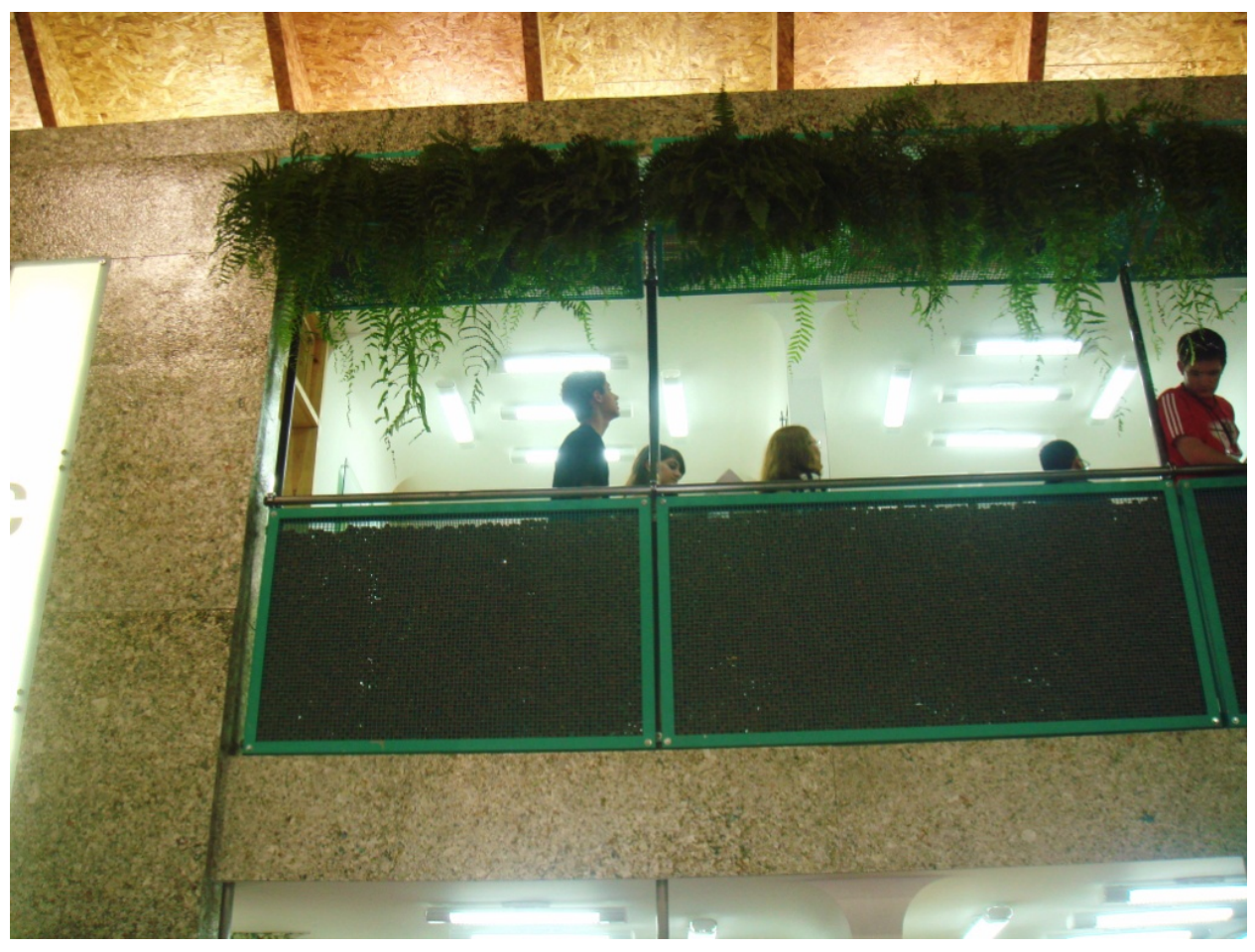

Figura 3.24: Casa AQUA, 2009: placas recicladas e peitoril metálico com preenchimento de argila expandida. Fonte: Foto da autora, 2009. 


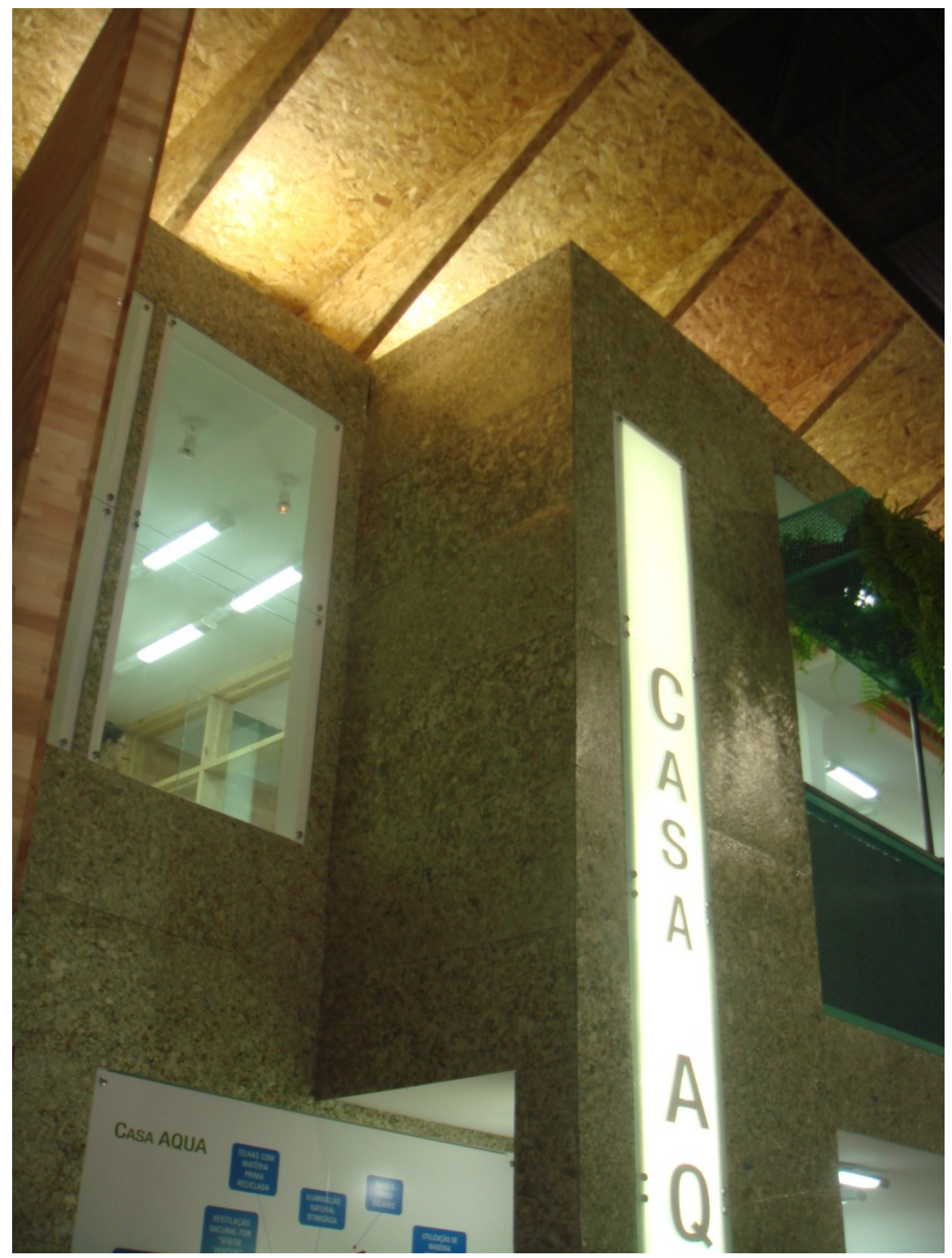

Figura 3.25 : Casa AQUA, 2009 - fachada frontal destaque para Placas Recicladas de Embalagens Longa Vida.

Fonte: Foto da autora, 2009. 


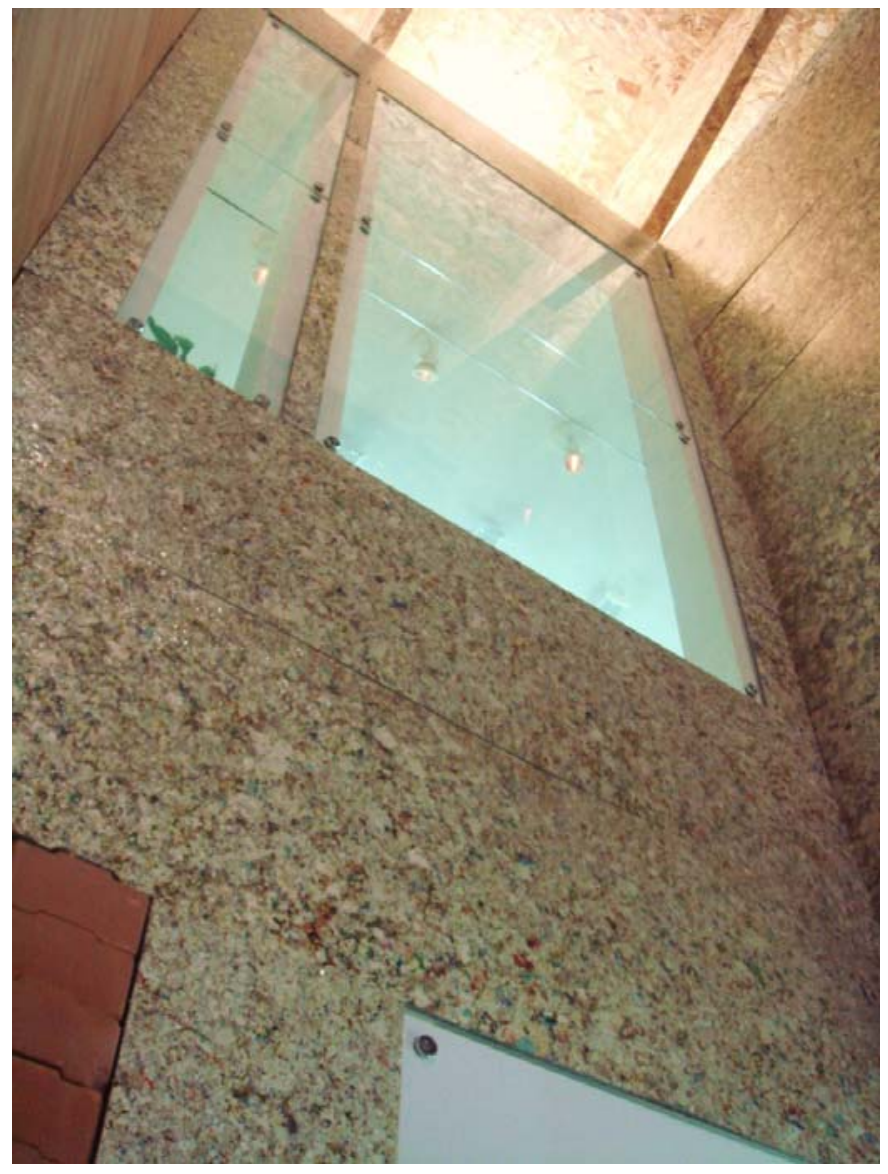

Figura 3.26 : Casa AQUA, 2009 - detalhe dos painéis de fechamento externo. Fonte: Foto da autora, 2009

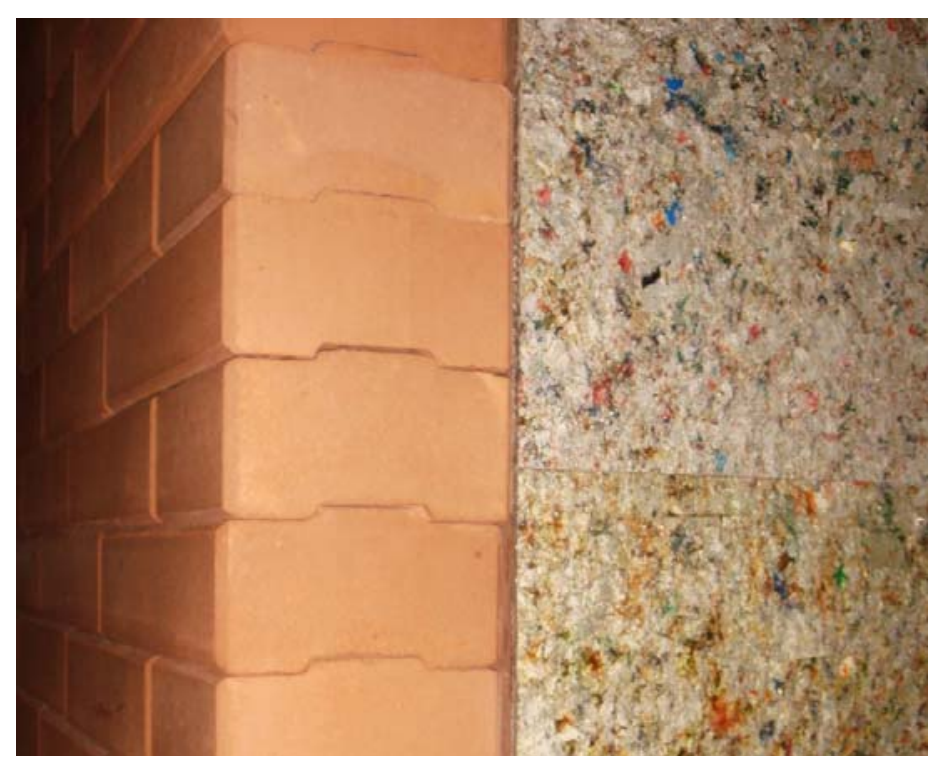

Figura 3.27 : Casa AQUA, 2009 - Detalhe de encontro das Placas Recicladas com tijolo de solo-cimento. Fonte: Foto da autora, 2009. 
Placas recicladas: matéria-prima, produção e estado da arte. 


\section{4 - CARACTERIZAÇÃO TÉCNICA}

Para caracterização técnica, primeiramente foram identificados os dados técnicos existentes sobre o material. Para complementação desses dados, foram realizados quatro ensaios técnicos e, em seguida,. o que se propõe como caracterização técnica das Placas Recicladas de Embalagens Longa Vida é a sistematização conjunta de todos os dados analisados e ensaiados, na forma de tabelas organizadas, baseadas na organização padrão para os materiais de construção, apresentadas no capítulo 2. Desta forma pôde-se criar um panorama mais estruturado para referência projetual.

Os dados existentes sobre as Placas Recicladas de Embalagens Longa Vida, foram encontrados em relatórios do Instituto de Pesquisas Tecnológicas (IPT) e dos Laboratórios de Construção Civil (LCC) e de Madeira (LaMEM) da Escola de Engenharia de São Carlos. De todos os relatórios analisados, foram selecionados os que apresentaram resultados mais claros e objetivos (relatórios em anexo). Esses dados foram compilados e são apresentados na tabela a seguir. 
Tabela 4.1: Compilação de dados técnicos: Placas Recicladas de Embalagens Longa Vida.

\begin{tabular}{|c|c|}
\hline Características técnicas & Dados existentes \\
\hline & $\begin{array}{l}\text { De acordo com IPT (2002a): } \\
\text { Resistência à tração: } 7,62 \mathrm{Mpa} \\
\text { Alongamento na ruptura 4,2 \% }\end{array}$ \\
\hline $\begin{array}{l}\text { Resistência Mecânica } \\
\text { Tração e flexão }\end{array}$ & $\begin{array}{c}\text { De acordo com IPT (2002a): } \\
\text { Resistência à flexão: tensão de } \\
\text { ruptura 15,1 Mpa } \\
\text { De acordo com LaMEM (2001): } \\
\text { Resistência a flexão (placa com } \\
\text { 12mm de espessura): } \mathbf{9 , 0 6 M p a} \\
\text { (média) } \\
\text { Módulo de elasticidade: } \mathbf{4 2 9 , 4 M p a} \\
\text { (média) }\end{array}$ \\
\hline Absorção de água & $\begin{array}{c}\text { De acordo com IPT (2002a) - 5,3\% } \\
\text { De acordo com LaMEM - 15,22\% } \\
\text { Média: } 10,26 \%\end{array}$ \\
\hline Propagação de chamas & $\begin{array}{l}\text { De acordo com IPT (2002b): } \\
\text { Índice de propagação de chamas } \\
\text { (IP): } \\
\text { Médio, classe D } \\
\text { "A propagação superficial de chama } \\
\text { avançou, em média, 393mm ( } 85 \% \text { do } \\
\text { comprimento total do corpo-de- } \\
\text { prova). } \\
\text { "A carbonização superficial alcançou, } \\
\text { em média, } 448 m m \text { ( } 97 \% \text { do } \\
\text { comprimento total do corpo de } \\
\text { prova)." } \\
\text { "Desenvolvimento de fumaça cinza." }\end{array}$ \\
\hline
\end{tabular}

Fonte: IPT (2002a); IPT (2002 b); e LAMEM (2001).

Para complementação das características técnicas, foram realizados os ensaios de Condutividade Térmica e Calor específico, que são importantes para calcular várias outras características térmicas dos materiais, como a Resistência térmica e Transmitância térmica. Foi também realizado o ensaio de Refletância, que, em consequência, possibilita determinar a Absortância do material, dado importante para identificar o quanto o material reflete e absorve de energia solar. A fim de verificar o comportamento das placas perante as intempéries, foi realizado ensaio que simulou a exposição do material aos raios Ultravioleta 
e nebulização de água, complementado com ensaio de Análise Dinâmico-Mecânica ${ }^{1}$ para identificar os efeitos causados por essa exposição na integridade das placas.

Por esta pesquisa buscar caracterizar tanto os dados técnicos, quanto os estéticos e de possibilidades projetuais de forma equivalente, traçando um panorama equilibrado sobre as placas, houve um limite na definição da quantidade de ensaios técnicos e, ainda, para realização desses ensaios, buscou-se o auxílio de pesquisadores e técnicos especializados, sem os quais não seria possível que se cumprisse esta etapa do trabalho.

Optou-se, também, por não estender a caracterização térmica além da descrição e tabulação dos dados ensaiados, portanto, não foram realizados cálculos de transmitância, capacidade térmica, entre outros. Por ser um tópico muito extenso e complexo, apresentar os cálculos demandaria uma abordagem muito ampla de discussões, o que se estenderia muito além dos objetivos desta pesquisa.

\section{1 - Ensaio para determinação de Refletância e Absortância à radiação solar}

Este ensaio foi realizado de acordo com a Norma ASHRAE 74-1988: method of measuring solar-optical properties of materials, com ajuste das absortâncias ao Espectro Solar Padrão (Apêndice B), de acordo com dados da Norma ASTM G173-03: standard tables for reference solar spectral irradiances - direct normal and hemispherical on $37^{\circ}$ tilted surface.

O ensaio foi realizado no Laboratório Interdisciplinar de Eletroquímica e Cerâmica do Instituto de Química da Universidade Federal de São Carlos, com acompanhamento de Dornelles ${ }^{2}$.

\footnotetext{
1 “A análise dínamo-mecânica é um método termoanalítico desenvolvido para a caracterização do comportamento mecânico de um material, quando este é submetido a forças dinâmicas (freqüência - carga oscilante) a um programa controlado de temperatura." (WENDHAUSEN,20--, p.35)

${ }^{2}$ Engenheira Civil Kelen Almeida Dornelles, Doutora em engenharia civil com a tese : Absortância Solar de Superfícies opacas: método de determinação e base de dados para tintas látex acrílica e PVA.
} 


\section{Objetivo do ensaio}

Identificar a porcentagem de Refletância e Absortância à radiação solar das Placas Recicladas de Embalagens Longa Vida.

\section{Corpo de prova}

O ensaio foi realizado em uma placa de $10 \times 10 \mathrm{~cm}$ e $0,5 \mathrm{~cm}$ de espessura. Devido à variedade de cores, brilho e de materiais da superfície, foram marcados três pontos diferentes na placa, conforme figura 4.1. Comparando-se, por exemplo, o ponto dois com o ponto três, percebe-se que o ponto três marca uma área composta praticamente por alumínio, enquanto o dois possui quantidade maior de pedaços coloridos (plásticos).

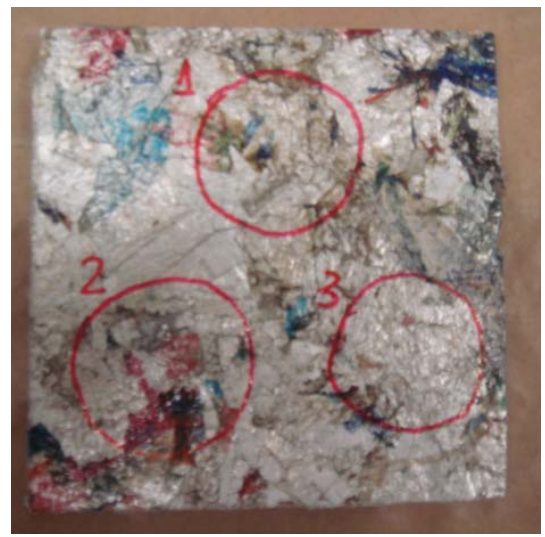

Figura 4.1: Corpo de prova marcado em três pontos, para ensaio de Refletância. Fonte: Foto da autora, 2010.

\section{Materiais e equipamentos}

O equipamento utilizado foi o Espectrofotômetro Varian CARY 5G.

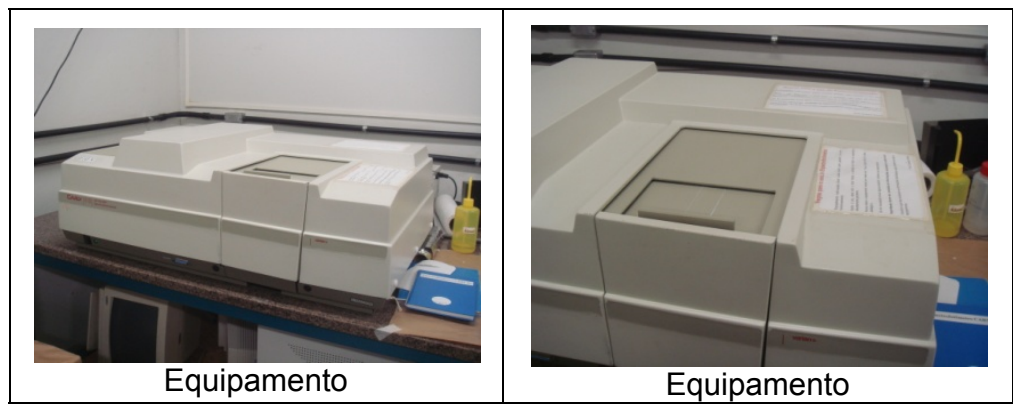

Figura 4.2: Espectrofotômetro: Equipamento para ensaio de Refletância. Fonte: Foto da autora, 2010. 


\section{Procedimentos}

No procedimento, a placa é encaixada no ponto de saída da fonte de radiação. Segundo Andrade; Custódio (2005 apud DORNELLES, 2008, p. 72), essas fontes emissoras de radiação são lâmpadas de deutério e de tungstênio-halogênio e, normalmente, a troca de uma lâmpada por outra ocorre durante a varredura do espectro de modo automático.

Enquanto a leitura no ponto de radiação é feita, o gráfico é traçado, apresentando a variação de porcentagem de refletância entre os pontos de comprimento de onda.

O intervalo medido foi entre os comprimentos de onda de $300 \mathrm{~nm}$ a $2500 \mathrm{~nm}$

Quadro 4.1: Etapas ensaio de Refletância / Absortância

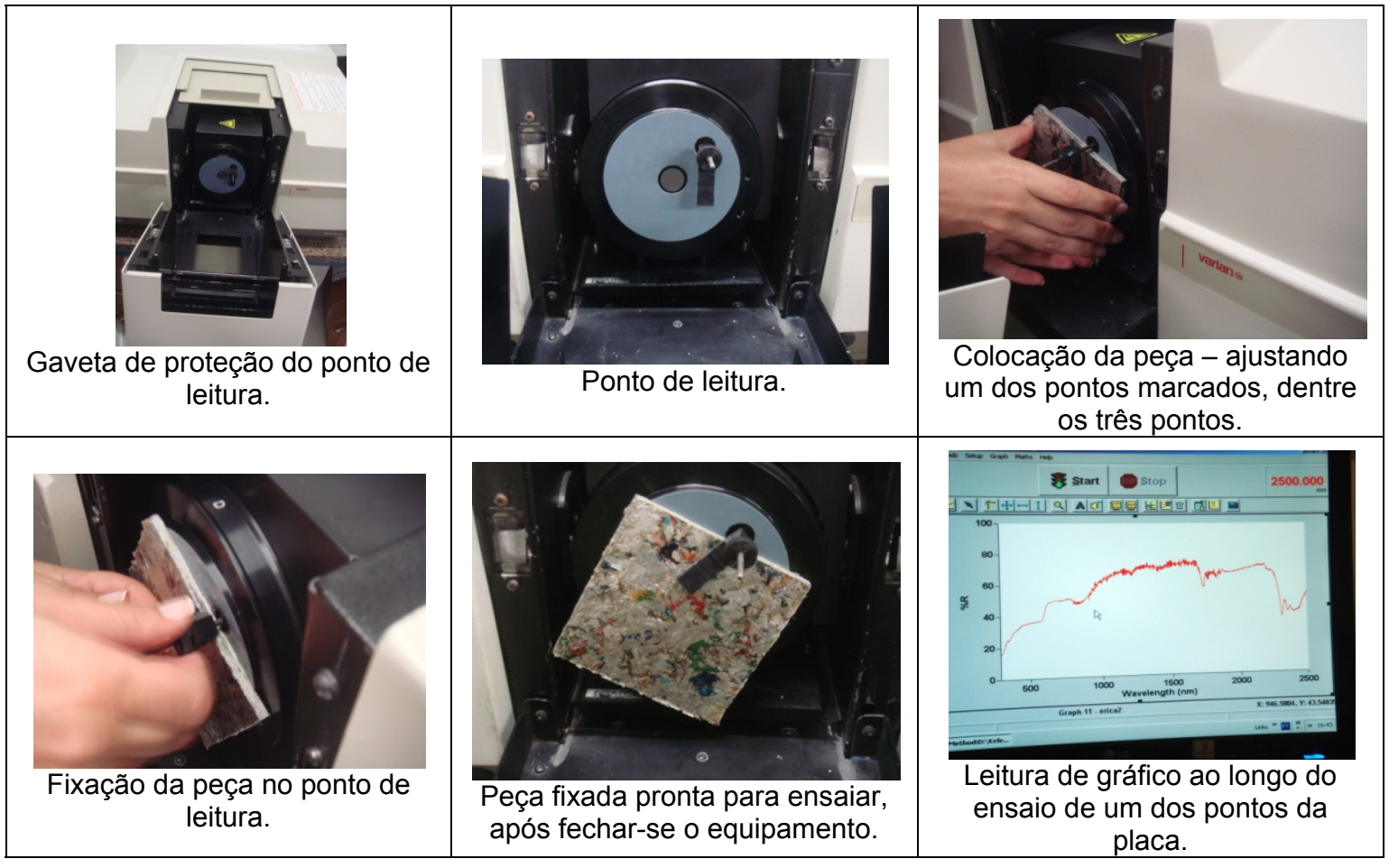

Fonte: Fotos da autora, 2010. 


\section{Resultados obtidos}

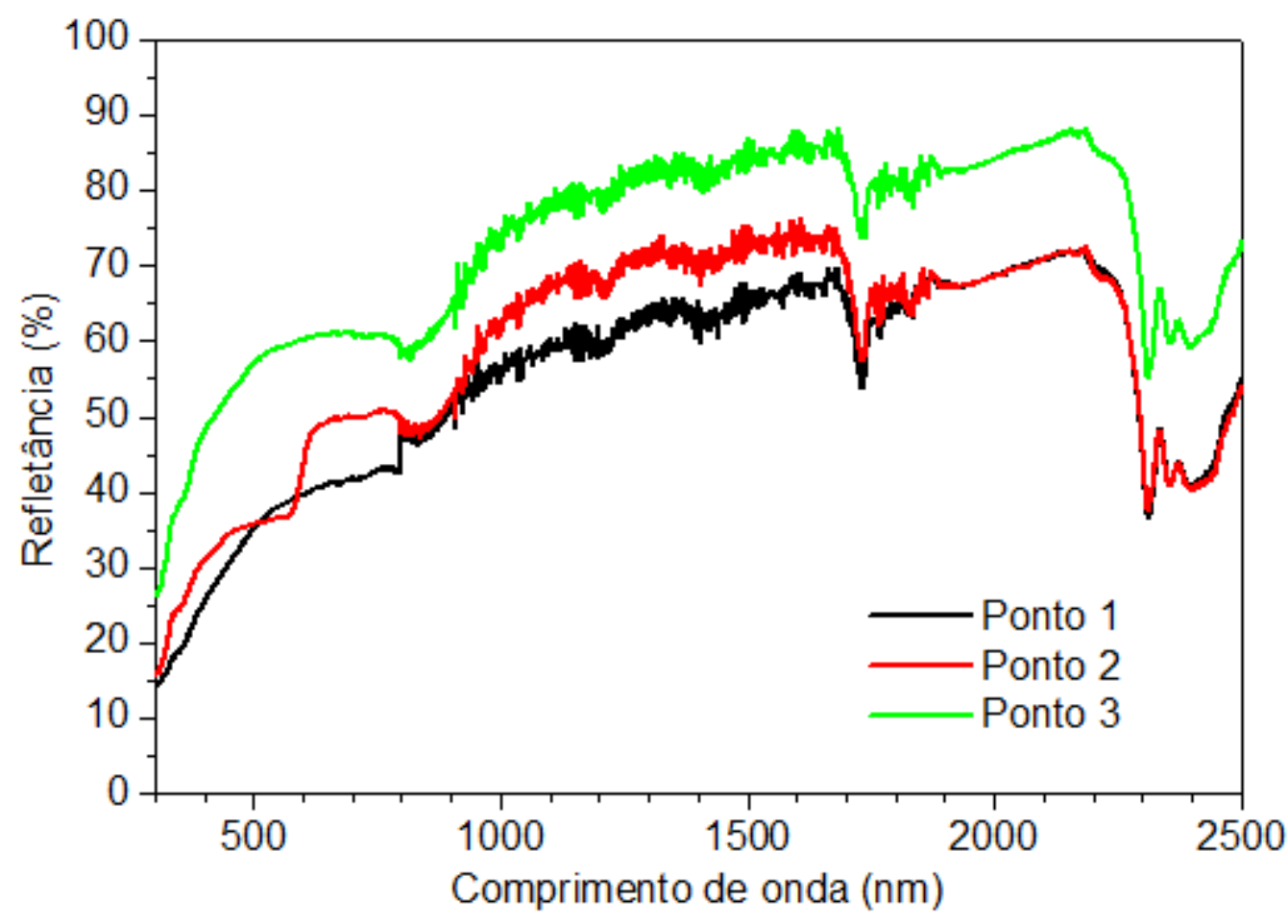

Gráfico 4.1 - Refletância em três pontos da Placa Reciclada de Embalagem Longa Vida Fonte: Dornelles (2010)

O gráfico acima representa o traçado dos resultados de refletância para os três pontos marcados na placa: Ponto 1 - traçado em preto; Ponto 2, traçado em vermelho, e Ponto 3, traçado em verde.

$\mathrm{Na}$ marcação da placa, o ponto 3 é o ponto que tem maior área de alumínio e, no gráfico, percebe-se que foi o ponto que apresentou maior porcentagem de refletância, o que indica claramente que a presença do alumínio colabora para refletir os raios solares.

Tabela 4.2 : Resultados de Refletância e Absortância nos três pontos marcados na placa (\%).

\begin{tabular}{|c|c|c|c|}
\hline & Ponto 1 & Ponto 2 & Ponto 3 \\
\hline Refletância & 45,8 & 50,3 & 64,6 \\
\hline Absortância & 54,2 & 49,7 & 35,4 \\
\hline
\end{tabular}

Fonte: organização da autora baseada nos dados do relatório de ensaio (Apêndice B) 
Tabela 4.3: Refletância e Absortância total das Placas Recicladas de Embalagem Longa Vida.

\begin{tabular}{|c|c|}
\hline & Média dos pontos ensaiados \\
\hline Refletância & $53,6 \%$ \\
\hline Absortância & $46,4 \%$ \\
\hline
\end{tabular}

Fonte: organização da autora

Esta tabela com resultados finais indica que, da quantidade de energia radiante total que atingiu a superfície da placa, $46,4 \%$ foi absorvida e $53,6 \%$ foi refletida. No entanto, esse percentual não demonstra a energia incidente ajustada, a cada comprimento de onda, os raios UV (ultravioleta), VIS (visíveis) e IV (Infravermelho). Os raios UV são os responsáveis, de forma geral, pela degradação dos materiais e, os IV, pelo calor. A tabela 4.4 apresenta os resultados de Refletância e Absortância para cada faixa de comprimento de onda, proporcionando a identificação, principalmente, do quanto de calor (IV), e de raios de degradação (UV), foram absorvidos e refletidos pela Placa Reciclada de Embalagens Longa Vida.

Tabela 4.4: Porcentagem de Refletância e Absortância das Placas Recicladas de Embalagens Longa Vida, por comprimento de onda (UV, VIS e IV).

\begin{tabular}{|c|c|c|}
\hline & $\begin{array}{c}\text { Media dos } \\
3 \text { pontos } \\
\text { (\%) }\end{array}$ & \\
\hline & Absortância & Refletância \\
\hline UV ajustada & 72 & 28 \\
\hline VIS ajust & 54 & 46 \\
\hline IV ajust & 36 & 64 \\
\hline
\end{tabular}

Fonte: relatório de ensaio de Refletância e Absortância - DORNELLES (2011) (anexo)

O fato da absortância aos raios UV ser bem maior (72\%) do que a refletância (28\%), pode, a princípio, indicar fragilidade da placa reciclada à exposição em áreas externas. Porém, esse dado deve ser avaliado em conjunto com outros aspectos relacionados ao UV, e será analisado ao final desse capítulo.

Com relação ao IV, percebe-se, pela tabela, que a porcentagem de refletância é bem maior $(64 \%)$ do que a porcentagem de absortância (36\%). Isso indica que as Placas 


\section{Recicladas de Embalagens Longa Vida podem funcionar bem como barreiras contra 0 calor.}

\section{2 - Condutividade térmica e calor específico}

Segundo Santos (2002), a condutividade térmica é uma das propriedades físicas mais importantes de um material; ela estabelece os níveis de temperatura de trabalho desse material, sendo um parâmetro importante em problemas que envolvem transferência de calor em regime estacionário. Esses dados são essenciais na seleção de materiais que possam ter o melhor desempenho possível em uma dada aplicação. [...] Baixos valores de condutividade térmica são exigidos, quando se pretende minimizar as perdas de calor.

O ensaio de condutividade térmica adotado para esta pesquisa foi pelo método do fio quente paralelo. Esse método foi testado e descrito por Santos et al (2004), que utilizaram a técnica de fio quente paralelo normalizada para materiais cerâmicos, para a determinação da condutividade térmica de polímeros. O ensaio foi realizado na Universidade Federal de São Carlos, no Departamento de Engenharia de Materiais - Laboratório de Propriedades Térmicas, com acompanhamento de Santos ${ }^{3}$.

\section{Objetivo do ensaio}

Identificar a condutividade térmica e o calor específico das Placas Recicladas de Embalagem Longa Vida para complemento dos dados técnicos existentes sobre o material.

\section{Corpo de Prova}

Para realização do ensaio são necessários dois corpos de prova, em forma de paralelepípedos retangulares, de $23 \times 11,5 \times 3 \mathrm{~cm}$ cada. Como não havia disponíveis placas com essa espessura, cada corpo de prova foi formado por um conjunto de 4 placas de $8 \mathrm{~mm}$ cada, totalizando portanto $3,2 \mathrm{~cm}$. Assim, foi utilizado um total de 8 placas de $8 \mathrm{~mm}$ (4 por baixo dos fios paralelos e 4 por cima) (ver quadro 4.2).

\footnotetext{
${ }^{3}$ Professor Dr. Wilson Nunes dos Santos,é físico, pesquisador do DEMa - Departamento de Engenharia de Materiais - Laboratório de Propriedades Térmicas da UFSCar - Universidade Federal de São Carlos, onde atua principalmente com os temas de condutividade térmica, difusividade térmica, fio quente e propriedades térmicas.
} 


\section{Materiais e equipamentos}

O equipamento utilizado é totalmente automatizado (figura 4.3). De acordo com Santos (2002), o transiente de temperatura que é detectado pelo termopar é processado em um microcomputador, via um conversor analógico-digital. É feito um duplo ajuste por regressão não linear, obtendo-se, simultaneamente, a partir do mesmo transiente térmico experimental, a condutividade térmica e o calor específico.

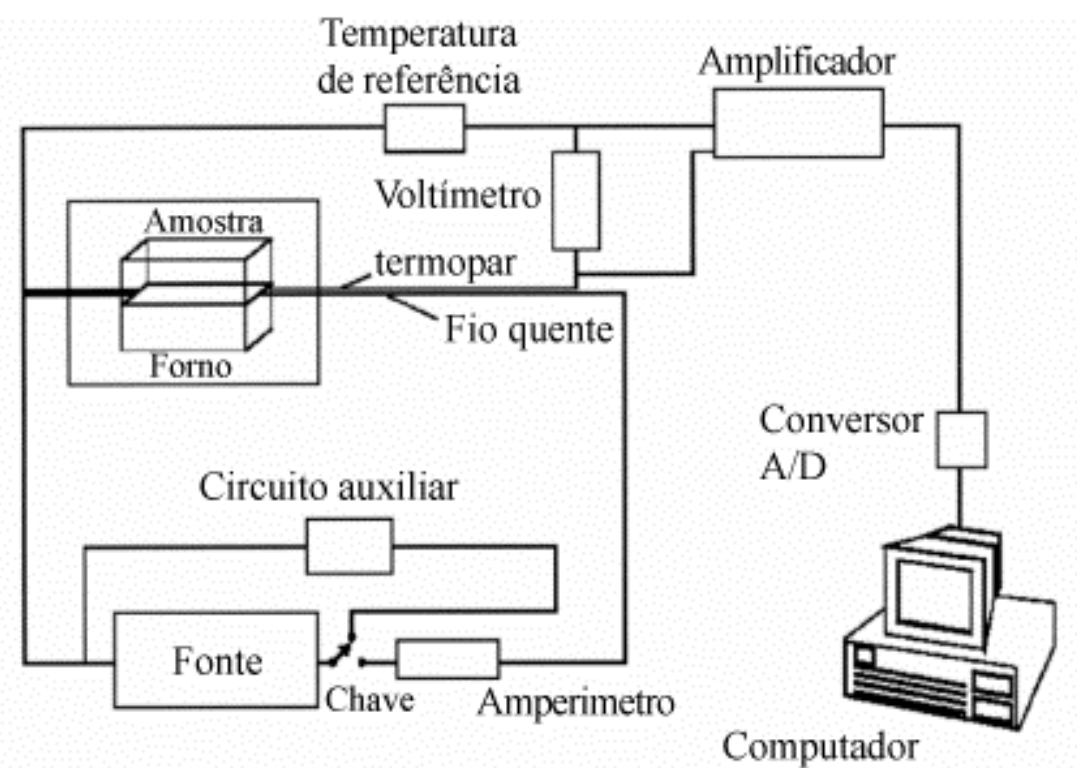

Figura 4.3: diagrama esquemático dos equipamentos e técnica do fio quente Fonte: SANTOS, 2002.

\section{Procedimento}

As amostras são colocadas entre os dois fios paralelos: um fio quente e um termopar $^{4}$ (figura 4.4). No centro da amostra que vai por baixo, foram feitas duas ranhuras paralelas, com distância de $16 \mathrm{~mm}$ entre elas. Por uma ranhura, passou o fio quente e, por outra, o termopar. Segundo Santos (2004), a profundidade desses sulcos deve corresponder aproximadamente ao diâmetro dos fios a serem neles inseridos, e a distância recomendada entre eles é de 15 a $17 \mathrm{~mm}$. Sobre esse arranjo foi, então, colocado o segundo conjunto de placas. Como as placas têm ondulações na superfície, foi necessária a colocação de pesos

\footnotetext{
${ }^{4}$ Os termopares são dispositivos elétricos para medição da temperatura.
} 
sobre elas, para garantir compressão entre as placas e melhor contato térmico com os fios (ver quadro 4.2).

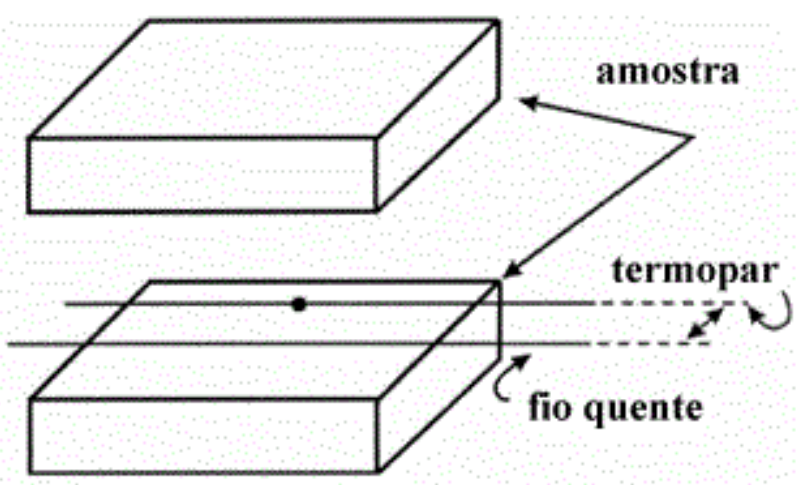

Figura 4.4: Diagrama esquemático do arranjo experimental dos corpos de prova. Fonte: SANTOS (2002).

A junção de referência do termopar é mantida a uma temperatura constante (referência). No processo de medida da condutividade térmica, faz-se passar uma corrente elétrica constante através do fio, e registra-se o aumento de temperatura no material a uma distância $r$ desse fio, a partir da temperatura inicial de equilíbrio.

No caso de medida em temperaturas superiores à ambiente, os corpos de prova e o dispositivo de medida são colocados no interior de um forno. (SANTOS, 2004, p.357)

As placas recicladas foram ensaiadas em temperatura ambiente e, portanto, não foram colocadas dentro do forno.

Os dados abaixo foram gerados pelo equipamento no relatório de ensaio.

Dados da Amostra:

- Nome da Amostra: TETRA PAK

- Material: Isolante $(0,05 \sim 0,25)$

Dados Preliminares de Ensaio:

- Tempo de Ensaio: $15.00 \mathrm{~min}$.

- Temperatura da Amostra: $23.0^{\circ} \mathrm{C}$

- Tipo de Termopar: $\mathrm{K}$

- Resistência do Fio: 6.4900 ohms/m

- Tipo de Resistência: KANTHAL

- Montagem: PARALELA 
- Densidade da Amostra: $934.0 \mathrm{~kg} / \mathrm{m}^{3}$

- Distância Fio-Termopar: 0.0150 m

Dados Finais de Ensaio:

- Corrente no Fio: $1.9992 \mathrm{~A}$

- Estimativa inicial: 0.1500

- Intervalo de Tempo: $299.2 \mathrm{~s}$ a $601.7 \mathrm{~s}$

- Difusividade Térmica: $9.3100 \mathrm{E}-7 \mathrm{~m}^{2} / \mathrm{s}$

- Coeficiente de Correlação: 0.99109

Quadro 4.2: Etapas de ensaio de condutividade térmica pelo método do fio quente.

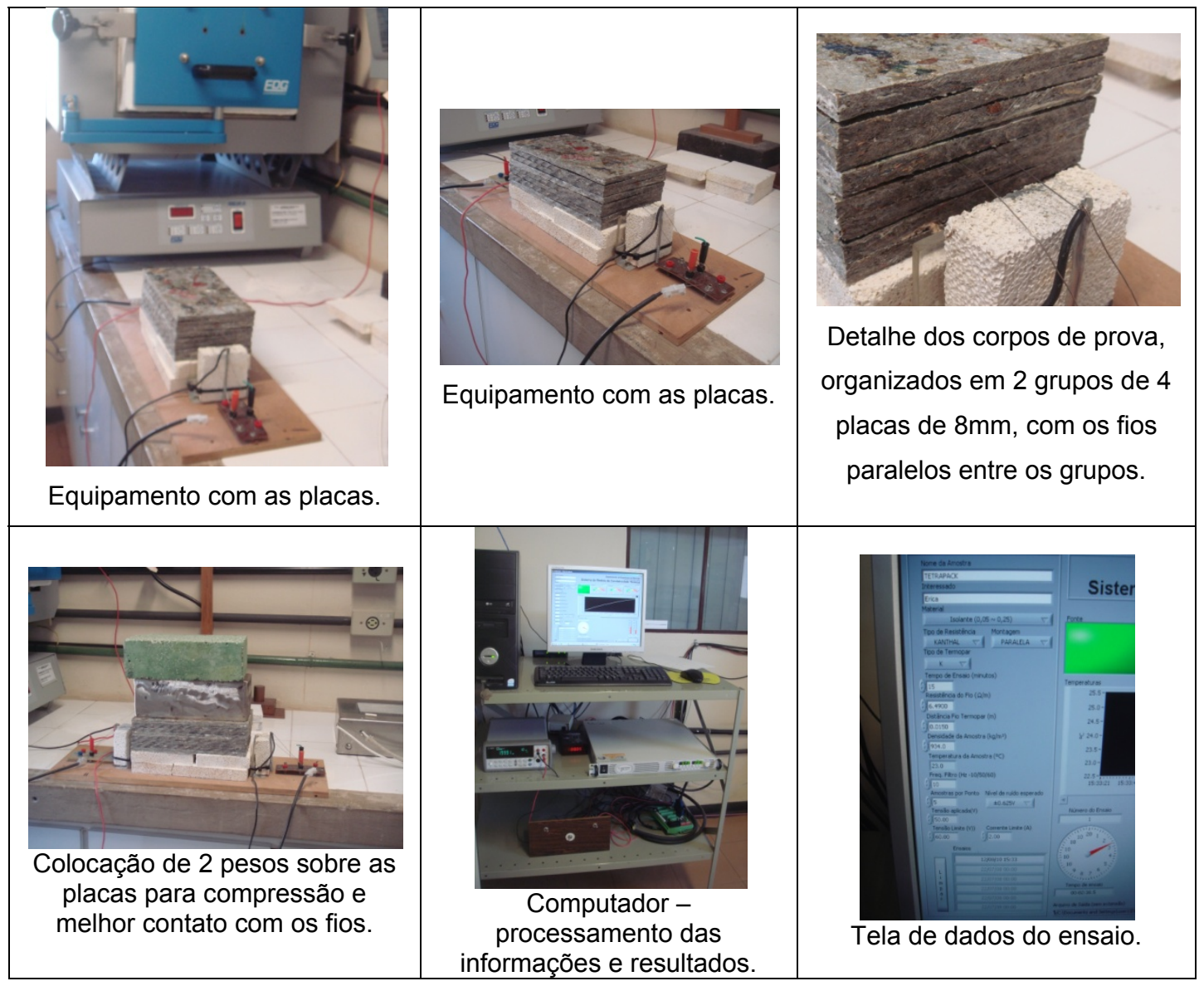

Fonte: Fotos da autora - 2010

\section{Resultados obtidos}

- Condutividade Térmica: $0.8099 \mathrm{~W} /(\mathrm{m} . \mathrm{K})$

- Calor Específico: 931.3583 J/kg.K 
Os dados obtidos serão úteis para o cálculo de outras características térmicas, de acordo com o projeto em que o material for utilizado (tipos de sistemas e envoltórios), devendo-se, para tanto, utilizar a ABNT NBR 15220-2: 2005 (Desempenho térmico de edificações - Parte 2: Método de cálculo da transmitância térmica, da capacidade térmica, do atraso térmico e do fator solar de elementos e componentes de edificações).

Na tabela 4.5, estão relacionados os dados de densidade, condutividade térmica e calor específico de alguns materiais selecionados a partir da tabela apresentada na norma ABNT NBR 15220-2: 2005 e complementada com os dados ensaiados para as Placas Recicladas de Embalagens Longa Vida.

Tabela 4.5: Condutividade térmica $(\mathrm{k})$ de alguns materiais de construção.

\begin{tabular}{|c|c|c|c|}
\hline Material & $\begin{array}{l}\text { Densidade } \\
\left(\mathrm{kg} / \mathrm{m}^{3}\right)\end{array}$ & $\begin{array}{c}\text { Condutividade } \\
\text { térmica } \\
(\mathrm{W} /(\mathrm{m} . \mathrm{k}))\end{array}$ & $\begin{array}{l}\text { Calor específico } \\
(\mathrm{kj} /(\mathrm{kg} . \mathrm{k}))\end{array}$ \\
\hline Argamassa comum & $1800-2100$ & 1,15 & 1,0 \\
\hline $\begin{array}{c}\text { Tijolos e telhas de } \\
\text { barro }\end{array}$ & $1000-1300$ & 0,70 & 0,92 \\
\hline $\begin{array}{c}\text { Placas de } \\
\text { fibrocimento }\end{array}$ & $1800-2200$ & 0,95 & 0,84 \\
\hline Concreto normal & $2200-2400$ & 1,75 & 1,0 \\
\hline $\begin{array}{c}\text { Placa de gesso; } \\
\text { Gesso acartonado }\end{array}$ & $750-1000$ & 0,35 & 0,84 \\
\hline Isolante: Lã de rocha & $20-200$ & 0,045 & 0,75 \\
\hline Isolante: lã de vidro & $10-100$ & 0,045 & 0,70 \\
\hline $\begin{array}{c}\text { Poliestireno } \\
\text { expandido moldado }\end{array}$ & $15-35$ & 0,040 & 1,42 \\
\hline $\begin{array}{l}\text { Aglomerado de fibras } \\
\text { de madeira (denso) }\end{array}$ & $850-1000$ & 0,20 & 2,30 \\
\hline $\begin{array}{l}\text { Aglomerado de fibras } \\
\text { de madeira (leve) }\end{array}$ & $200-500$ & 0,058 & 2,30 \\
\hline Compensado & $450-550$ & 0,15 & 2,3 \\
\hline Aço, ferro fundido & 7800 & 55 & 0,46 \\
\hline Alumínio & 2700 & 230 & 0,88 \\
\hline Granito & $2300-2900$ & 3,00 & 0,84 \\
\hline Mármore & $>2600$ & 2,90 & 0,84 \\
\hline Polietilenos (e outros) & $900-1700$ & 0,40 & - \\
\hline Vidro & 2500 & 1,0 & 0,84 \\
\hline $\begin{array}{c}\text { Placa Reciclada de } \\
\text { Embalagem Longa } \\
\text { Vida } \\
\text { (Polietileno-alumínio) }\end{array}$ & 934 & 0.80 & 0,93 \\
\hline
\end{tabular}

Fonte: ABNT NBR 15220-2: 2005. A última linha contém os dados calculados e ensaiados para a Placa Reciclada de Embalagens Longa Vida. 
Comparando-se a condutividade térmica ensaiada, com a condutividade térmica de placas usadas para ambientes internos, como as placas de gesso acartonado $[0,35$ $\mathrm{W} /(\mathrm{m} . \mathrm{k})]$, as placas de aglomerados densos $[0,20 \mathrm{~W} /(\mathrm{m} . \mathrm{k})]$ e compensados $[0,15 \mathrm{~W} /(\mathrm{m} . \mathrm{k})]$; percebe-se que a condutividade térmica da placa reciclada é maior; porém, comparando-se com placas usadas para fechamentos externos, como as de fibrocimento $[0,95 \mathrm{~W} /(\mathrm{m} . \mathrm{k})]$, percebe-se que a placa reciclada tem condutividade térmica menor $[0,80 \mathrm{~W} /(\mathrm{m} . \mathrm{k})]$. Esses dados indicam que as Placas Recicladas de Embalagens Longa Vida podem ser favoráveis no desempenho de proteção da condução do calor. Este é um indicativo preliminar, que analisa o material individualmente; porém, o desempenho irá variar de acordo com o conjunto de materiais que estiverem compondo a envolvente do edifício.

Os resultados obtidos no ensaio de condutividade térmica e calor específico diferenciaram-se dos resultados apresentados por Barata (2008), que apresenta, em sua tese, os seguintes dados de condutividade térmica e calor específico para a Placa Reciclada de Embalagem Longa Vida: Condutividade Térmica: 0,54 W/(m.K). Calor Específico: 6,53 $\mathrm{Kj} /(\mathrm{Kg} . \mathrm{K}$ ) (o autor apresenta os dados em Kj). Isso indica que os dados podem variar de um ensaio para o outro, considerando que os equipamentos utilizados nestes ensaios são próprios para outros tipos de materiais e, portanto, adaptados para ensaiar as placas recicladas.

\section{3 - Envelhecimento acelerado: exposição das placas aos raios UV e intemperismo artificial}

O ensaio de envelhecimento acelerado reproduz os efeitos naturais do tempo que ocorrem quando os materiais estão expostos à luz do sol (raios Ultra-Violeta) e umidade, como chuva ou orvalho. O ensaio tem como referência a norma ASTM G 154 - 06Standand Practice for Operating Fluorescent Light Apparatus for UV Exposure of Nonmetallic Materials e foi realizado no Departamento de Arquitetura e Urbanismo da Escola de Engenharia de São Carlos - USP - Laboratório de Construção Civil, com acompanhamento de Trevelin ${ }^{5}$.

\footnotetext{
${ }^{5}$ Sérgio Trevelin é técnico do Laboratório de Construção Civil do Departamento de Arquitetura e Urbanismo da Escola de Engenharia de São Carlos, da Universidade de São Paulo.
} 


\section{Objetivo do ensaio}

Simular o envelhecimento da Placa Reciclada de Embalagens Longa Vida para:

- Verificar se ocorrem mudanças no aspecto visual e na integridade da placa.

- Preparar as placas para o ensaio de Transição Vítrea.

\section{Corpo de prova}

Foram necessárias 9 placas retangulares de $6 \mathrm{~cm} \times 29 \mathrm{~cm}$. A espessura utilizada foi de $4 \mathrm{~mm}$.

\section{Materiais e Equipamentos}

- O aparelho para ensaio foi construído pelo próprio laboratório.

- As lâmpadas utilizadas foram Lâmpadas Fluorescentes UV - L40W/79K.

- Gerador de vapor - Compact Line - Sodramar com quadro de comando analógico O quadro de comando tem a função de automatizar o funcionamento do gerador, ligando e desligando o gerador sempre que a temperatura desejada for atingida.

Quadro 4.3: Equipamento para ensaio de envelhecimento acelerado UV e Umidade.

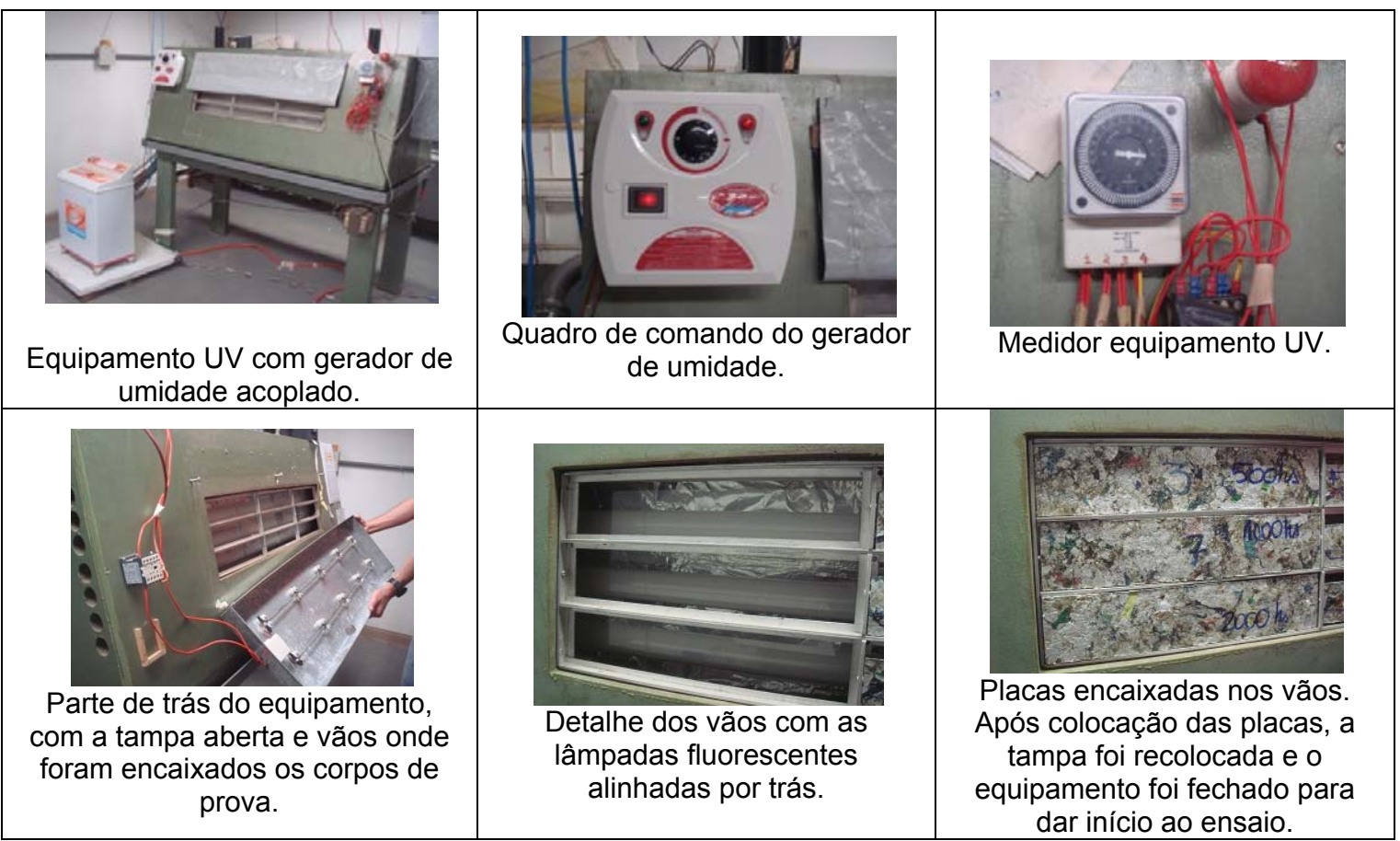

Fonte: Fotos da autora, 2010. 


\section{Procedimento}

As 9 amostras foram encaixadas nos 9 vãos do aparelho, como visto na figura anterior.

Após fechado e ligado o aparelho, as amostras começaram a ser expostas a ciclos repetitivos de luz e umidade, sob condições controladas de meio ambiente. A umidade foi produzida por condensação do vapor emitido pelo aparelho gerador de vapor.

A exposição das placas aos raios UV e à umidade foram dividas em 6 ciclos alternados de 4 horas, que totalizam as 24 horas do dia, conforme descrito abaixo:

- $\quad 1^{\circ}$ Ciclo - ligar vapor, resistência para manter calor de $60^{\circ} \mathrm{C}$ e exaustor.

- $2^{\circ}$ Ciclo - Ligar lâmpada UV, cooler de refrigeração da lâmpada UV e resistência de $60^{\circ} \mathrm{C}$ para manter calor.

- $\quad 3^{\circ}$ Ciclo - Igual $1^{\circ}$ ciclo

- $\quad 4^{\circ}$ Ciclo - Igual $2^{\circ}$ ciclo

- $5^{\circ}$ Ciclo - Igual $1^{\circ}$ ciclo

- $6^{\circ}$ Ciclo - Igual $2^{\circ}$ ciclo

Além dos 6 ciclos diários, os corpos de prova também foram reposicionados diariamente no aparelho, conforme figura 4.5, para garantir uniformidade na exposição sobre as placas.

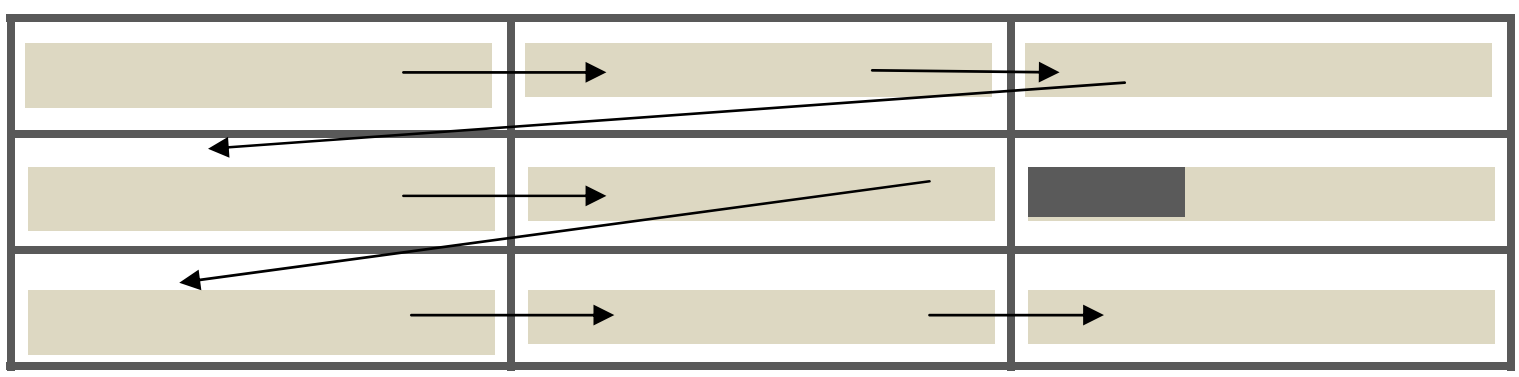

Figura 4.5: Organização e movimentação das placas diariamente dentro do aparelho. Fonte: desenho da autora

O tempo de duração do ensaio foi de 500, 1000 e 2000hs. Ao final de cada um desses períodos, foram retiradas 3 placas. Assim, foram, então, retiradas 3 placas que foram expostas à UV e umidade durante 500 horas, 3 placas que foram expostas por 1000 horas e 3 placas que foram expostas por 2000 horas.

A figura 4.6 mostra o registro de retirada dos corpos de prova ao longo das horas. 


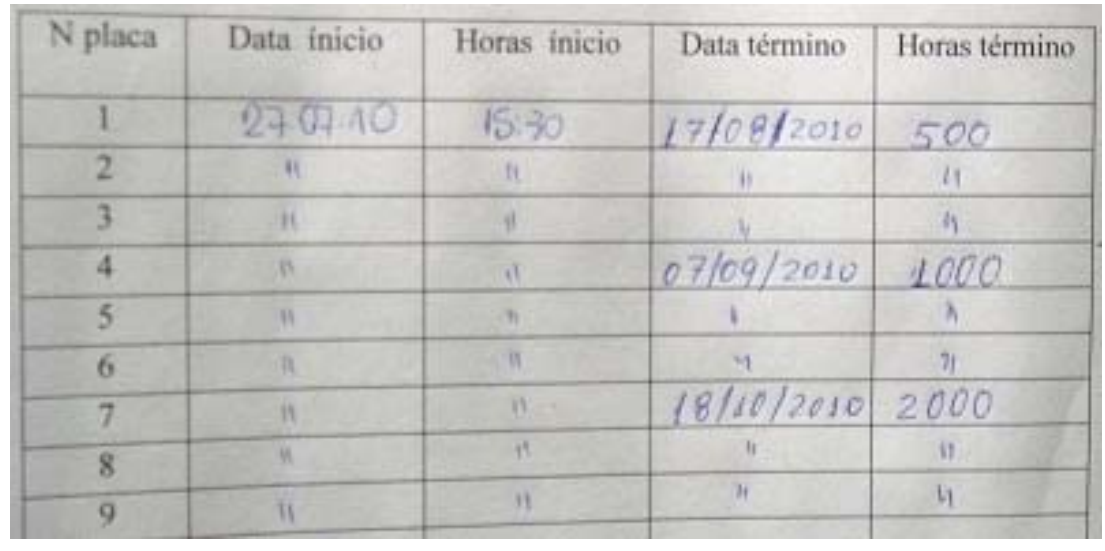

Figura 4.6: Registro de retirada das placas ao longo do ensaio de Intemperismo. Fonte: Foto da autora, 2010.

- 500 horas - aproximadamente 21 dias - retirada de 3 corpos de prova - 17-8-2010

- 1000 horas - aproximadamente 42 dias - retirada de mais 3 corpos de prova - 7-92010

- 2000 horas - aproximadamente 84 dias - retirada dos últimos 3 corpos de prova 18-10-2010

\section{Resultados obtidos}

Após quase 3 meses de exposição das placas, o que se pôde notar foram alterações nos aspectos visuais e de flexibilidade. Visualmente, as placas que ficaram expostas por 2000 horas ficaram um pouco mais opacas em sua superfície, em comparação com as placas que não foram ensaiadas. Esse resultado não ficou tão evidente quando se observaram e compararam as placas que ficaram 500 e 1000 horas. Concluiu-se que a exposição à UV e à umidade alternada deixa as Placas Recicladas de Embalagens Longa Vida com a superfície mais opaca do que antes da exposição.

Dados pesquisados indicam que a radiação UV feita sob medida (com as lâmpadas fluorescentes) é uma tecnologia que tem diversas finalidades, como esterilizar a água e as superfícies, endurecer tintas, adesivos e plásticos, além de várias outras funções. O efeito de endurecimento foi percebido ao manusearem-se as placas ensaiadas. Notou-se o endurecimento, ou perda de flexibilidade em relação às placas que não foram ensaiadas. Concluiu-se também que a exposição à UV e à umidade alternada endureceu um pouco as placas, diminuindo, portanto, sua flexibilidade. 
Esses dados foram comprovados no ensaio de DMA e podem ser visualizados nos gráficos apresentados a seguir.

\section{4 - Análise Dinâmico-mecânica - Transição vítrea (DMA Tg)}

O ensaio foi realizado no Laboratório de Química Analítica e Tecnologia de Polímeros, do Instituto de Química da Escola de Engenharia de São Carlos - IQSC, da Universidade de São Paulo - USP, com acompanhamento de Claro Neto ${ }^{6}$.

A Norma referente a este ensaio é a ASTM D7028 - 07e1 Standard Test Method for Glass Transition Temperature (DMA Tg) of Polymer Matrix Composites by Dynamic Mechanical Analysis (DMA).

"A temperatura de transição vítrea permite prever o comportamento de um determinado material numa temperatura, assim como designa indiretamente certas propriedades do material, como propriedades mecânicas e resistência à temperatura." (SÃO FRANCISCO, 2011) A transição vítrea é uma transição termodinâmica.

Cassu e Felisberti (2005) destacam que os materiais poliméricos apresentam comportamento mecânico intermediário ao elástico e ao viscoso, sendo denominados viscoelásticos. A análise dinâmico-mecânica permite a separação da contribuição elástica e viscosa em materiais viscoelásticos, em função tanto da temperatura como do tempo. Relaciona as propriedades macroscópicas dos materiais, tais como as propriedades mecânicas, às relaxações moleculares associadas a mudanças conformacionais e a deformações microscópicas geradas a partir de rearranjos moleculares. $\mathrm{Na}$ região de transição vítrea, o comportamento mecânico do polímero varia de um comportamento de material rígido para o de um material elastomérico. Na prática esse procedimento permite identificar se as partículas do material se desagregam e fragilizam sua resistência ou não.

\footnotetext{
${ }^{6}$ Salvador Claro Neto é Químico, Pesquisador Doutor do Laboratório de Química Analítica e Tecnologia de Polímeros, do Instituto de Química da Escola de Engenharia de São Carlos, da Universidade de São Paulo. Desenvolve pesquisas com poliuretano, compósitos poliméricos, óleo de mamona, estudo do comportamento mecânico de polímeros, entre outras.
} 


\section{Objetivo do ensaio}

- Identificar quais níveis de influência têm a ação do UV e Umidade constante nas Placas Recicladas de Embalagens Longa Vida e se isso, consequentemente, compromete seu uso em algum aspecto.

\section{Corpos de prova}

O corpo de prova para este ensaio deve ter $60 \mathrm{~mm} \times 13 \mathrm{~mm} \times 3 \mathrm{~mm}$. Para tanto foi necessário o fatiamento longitudinal, que retirou espessura da placa, que tem espessura mínima de $4 \mathrm{~mm}$. Os corpos de prova foram preparados a partir dos corpos de prova do ensaio de Intemperismo anterior. Foram utilizados 4 corpos de prova: um sem ensaio de UV; um com 500 horas, outro com 1000 horas e, o último, com 2000 horas de exposição à UV e umidade. A figura abaixo apresenta cada uma dessas amostras.

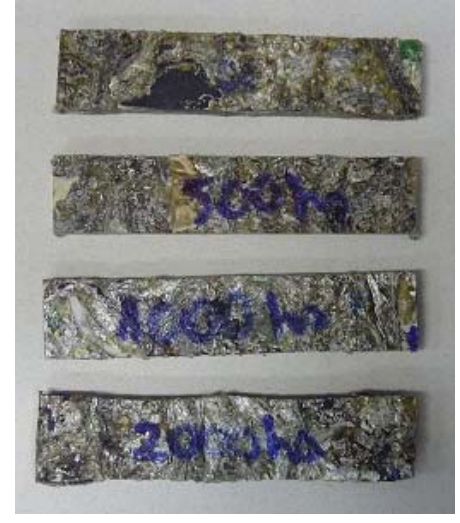

Figura 4.7: Corpos de prova para ensaio de Análise Dinâmico Mecânica - Transição Vítrea. Fonte: Foto da autora, 2011.

\section{Materiais e Equipamentos}

Equipamento: DMA TA Instruments - Modelo DMA Q800

Condições de análise:

- Frequência fixa de $1 \mathrm{~Hz}$

- Amplitude: $20 \mu \mathrm{m}$

- Temperatura Inicial: $-70^{\circ} \mathrm{C}$

- Temperatura Final: $110^{\circ} \mathrm{C}$

- Razão de aquecimento: $3^{\circ} \mathrm{C} / \mathrm{min}$. 
Quadro 4.4: Equipamento para ensaio de DMA Tg.

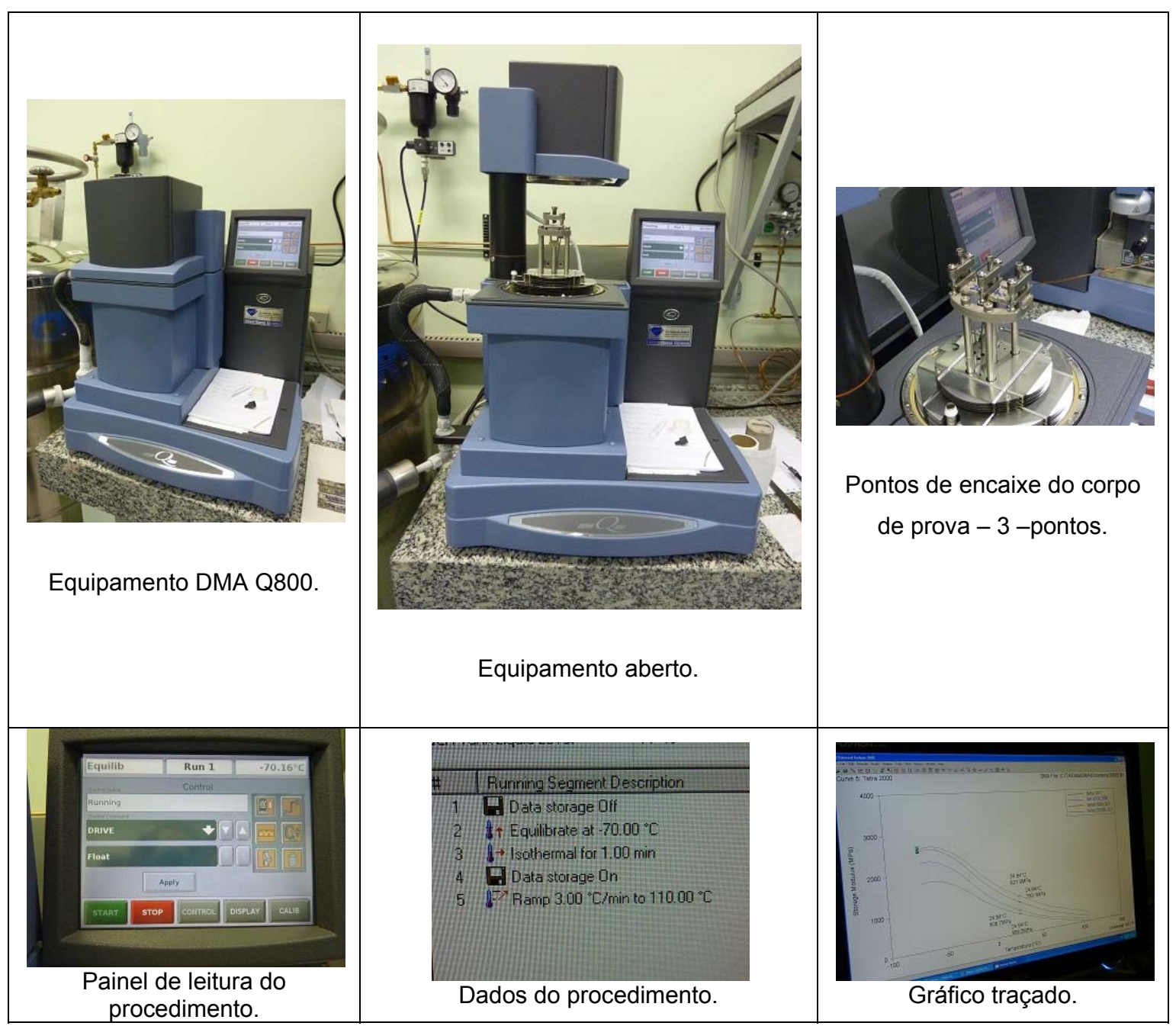

Fonte: Foto da autora, 2011.

\section{Procedimento}

O corpo de prova é colocado no equipamento e apoiado em três pontos: os pontos das extremidades fixam o corpo de prova, enquanto o ponto central é flexível na parte de baixo e proporciona as medições, (figura 4.8). Após a colocação do corpo de prova, o equipamento é fechado e a temperatura começa a baixar.

A faixa de temperatura aplicada a esse tipo de ensaio é ampla. A variação de temperatura foi de $-70{ }^{\circ} \mathrm{C}$ a $110^{\circ} \mathrm{C}$, em uma frequência fixa de $1 \mathrm{~Hz}$, com aquecimento (a partir de $-70^{\circ} \mathrm{C}$ até $110^{\circ} \mathrm{C}$ ) de $3^{\circ} \mathrm{C}$ por minuto. 


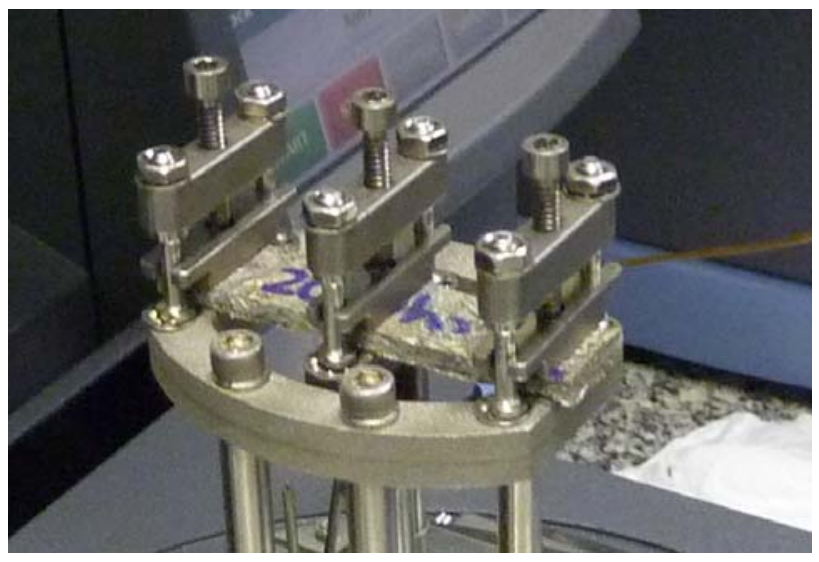

Figura 4.8: Detalhe de Corpo de prova, encaixado e pronto para ensaio de DMA Fonte: Foto da autora, 2011.

\section{Resultados obtidos}

O gráfico abaixo demonstra que, fixando-se em uma temperatura ambiente de $24,94^{\circ} \mathrm{C}$, houve o aumento da propriedade mecânica conforme o aumento do tempo de exposição à UV. O módulo de armazenamento passou de 566,2 Mpa, das placas sem exposição à UV e umidade, para 821,9 Mpa, das placas com 2000 horas de exposição.

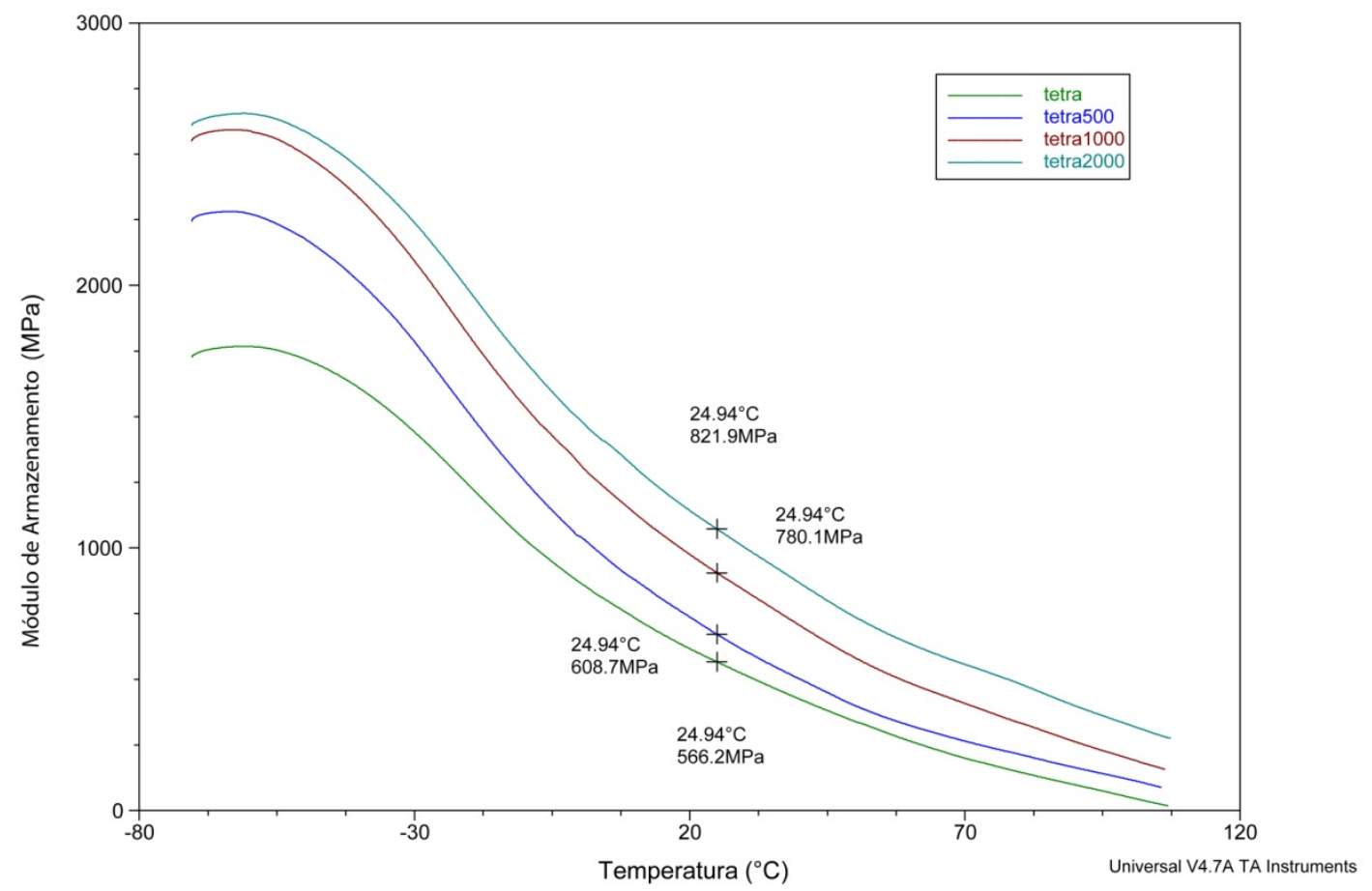

Gráfico 4.2 - Módulo de armazenamento por Temperatura Fonte: Relatório de ensaio DMA, 2011. 


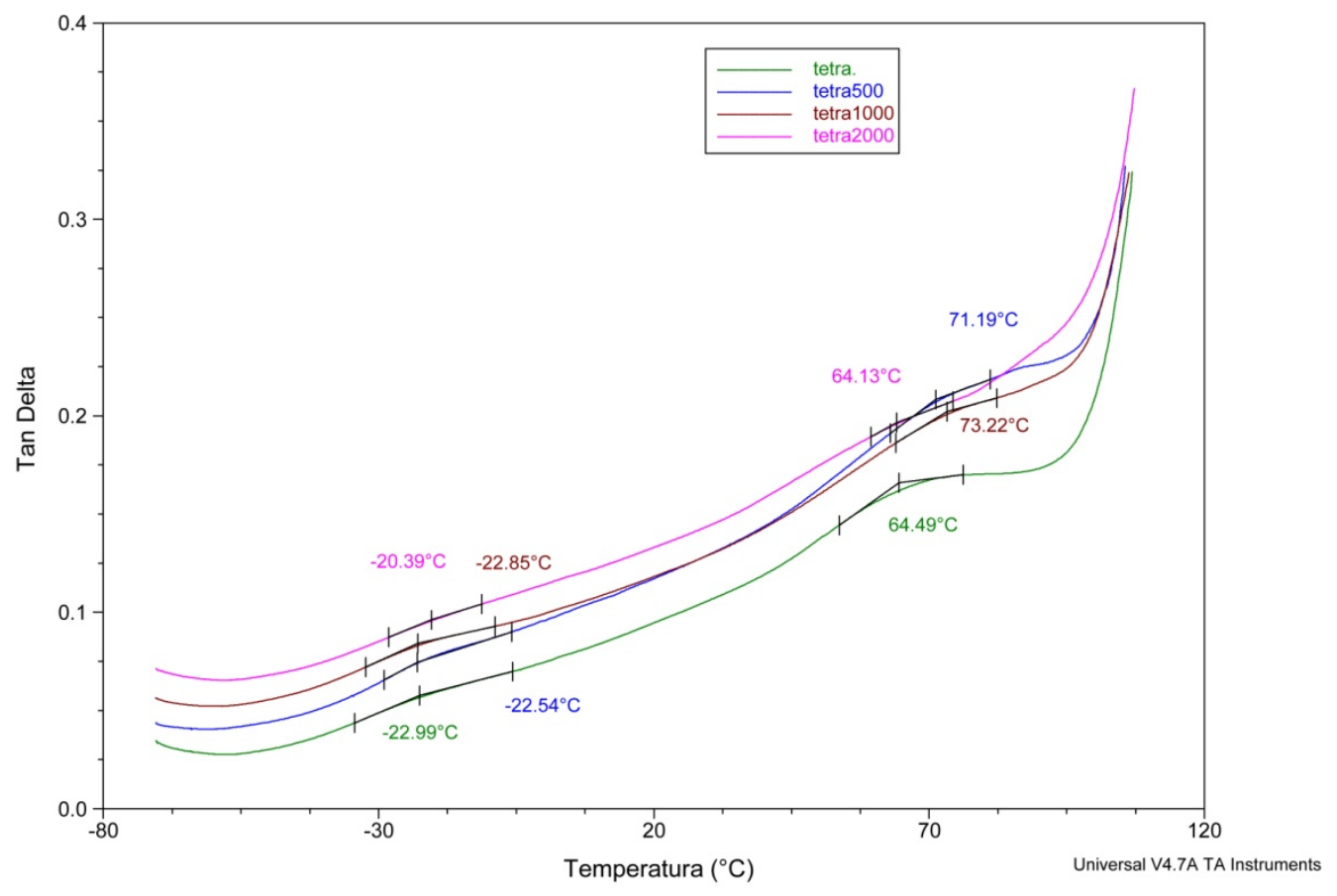

Gráfico 4.3 - Tan Delta por Temperatura

Fonte: Relatório de ensaio DMA, 2011

O gráfico demonstra que a temperatura de transição vítrea não se alterou muito de uma placa para outra, ficando entre $-22,99^{\circ} \mathrm{C}$ e $-20,39^{\circ} \mathrm{C}$. O gráfico também apresenta um aumento de Tan Delta entre 64 e $73^{\circ} \mathrm{C}$ o que, segundo Claro Neto, pode indicar uma segunda transição vítrea e, assim, a possível presença de mais um tipo de polímero na composição das placas. Isso faz sentido, pois, quando se observa a placa, pode-se notar visualmente a presença de pedaços de tampinhas, canudos e outras peças plásticas prensadas. Esses dados também foram interpretados como um possível início de processo de fusão, devido à alta temperatura.

Percebe-se que o material continuou íntegro e sem alterações significativas em sua estrutura interna (figura 4.9). Ocorre que, no uso do material aplicado em superfícies arquitetônicas, sujeito às variações de temperatura ambiente no Brasil, os pontos de transição vítrea, ou seja, sua estrutura interna que podem sofrer rearranjos, são praticamente inatingíveis. Desta forma os resultados indicam a possibilidade do material permanecer íntegro em sua estrutura, mesmo com a ação dos raios Ultravioleta. 


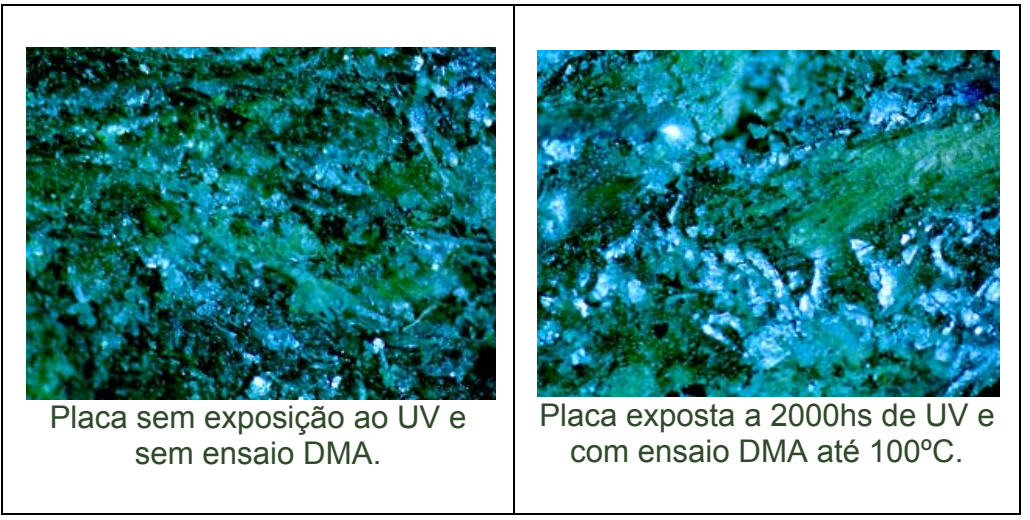

Figura 4.9: Vista microscópica comparativa de estrutura interna das placas recicladas. Fonte: Imagem gerada pelo microscópio, 2011.

O ensaio também confirmou que as Placas Recicladas de Embalagens Longa Vida tornaram-se mais compactas e rígidas com a exposição à UV e umidade. O que, também, por consequência do rearranjo das lâminas internas do material, ficou com menos espaços entre elas, porém isso não ficou muito evidente na imagem microscópica.

\section{5 - Resultados e discussões: Caracterização técnica}

Baseando-se em todos os dados apresentados neste capítulo e, como descrito anteriormente, na organização padrão para os materiais de construção apresentados no capítulo 2, é apresentada a seguir, a caracterização técnica proposta por esta pesquisa para a Placa Reciclada de Embalagens Longa Vida. 


\section{Classificação geral}

Tabela 4.6: Classificação das placas recicladas de embalagem longa vida.

\begin{tabular}{|c|c|c|}
\hline Categoria & \multicolumn{2}{|c|}{ Classificação } \\
\hline Quanto à procedência & Material da tecnosfera & $\begin{array}{c}\text { Não são renováveis pela } \\
\text { natureza. }\end{array}$ \\
\hline $\begin{array}{l}\text { Quanto à origem e processo } \\
\text { de obtenção }\end{array}$ & Artificiais & Materiais reciclados \\
\hline $\begin{array}{c}\text { Quanto ao potencial de } \\
\text { sustentabilidade e impacto } \\
\text { ambiental }\end{array}$ & Sustentável & 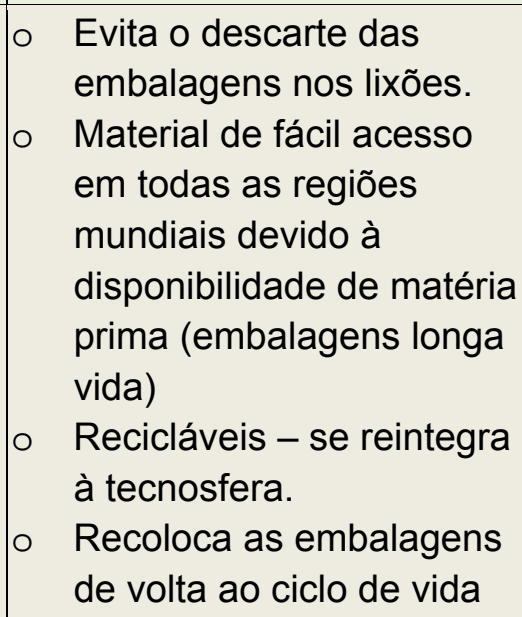 \\
\hline $\begin{array}{l}\text { Quanto à composição da } \\
\text { matéria-prima }\end{array}$ & Compostos & \begin{tabular}{|ll}
0 & Polietileno - aprox.70\% \\
0 & Alumínio - aprox. $25 \%$ \\
0 & Resíduos de papel e de \\
& plásticos 5\% (variável) \\
\end{tabular} \\
\hline Quanto à estrutura interna & Mista & Cristalina \\
\hline Quanto à composição química & Mista & Minerais e Orgânicos \\
\hline $\begin{array}{l}\text { Quanto à função do } \\
\text { componente }\end{array}$ & Não estrutural & $\begin{array}{c}\text { Vedação e proteção } \\
\text { (revestimentos) de superfícies } \\
\text { Fabricação de objetos } \\
\text { variados. }\end{array}$ \\
\hline
\end{tabular}

Fonte: Organização de dados da autora com referência nas categorias de propriedades apresentadas em Arqtema (2005) 


\section{Caracterização dimensional}

Tabela 4.7: Características dimensionais das placas recicladas de polietileno-alumínio.

\begin{tabular}{|c|c|c|}
\hline \multirow{2}{*}{ Tamanho $(\mathrm{m})$} & $\begin{array}{c}\text { Espessura }(\mathrm{mm}) \\
\text { A espessura pode variar em até } \\
\text { 10\%, de acordo com fabricante. }\end{array}$ & $\begin{array}{c}\text { Peso }(\mathrm{kg}) \\
\text { Dados aproximados }\end{array}$ \\
\hline \multirow{3}{*}{$1,10 \times 2,20$} & 4 & 8,5 \\
\cline { 2 - 4 } & 6 & 14,0 \\
\cline { 2 - 4 } & 8 & 18,0 \\
\cline { 2 - 4 } & 10 & 19,0 \\
\hline Densidade média & 15 & 28,0 \\
\hline
\end{tabular}

Fonte: Organização da autora

\section{Propriedades gerais}

Tabela 4.8: Propriedades gerais das placas recicladas de polietileno-alumínio.

\begin{tabular}{|c|c|c|}
\hline \multicolumn{2}{|r|}{ Propriedades } & Resultados \\
\hline \multirow{3}{*}{$\begin{array}{l}\text { Propriedades } \\
\text { Mecânicas }\end{array}$} & Resistência à tração & 7,62 Мpa* \\
\hline & Alongamento na ruptura & $4,2 \%$ * \\
\hline & Resistência à flexão & $15,1 \mathrm{Mpa}^{*}$ \\
\hline \multirow{5}{*}{$\begin{array}{l}\text { Propriedades } \\
\text { Térmicas }\end{array}$} & Índice de propagação de chamas & Médio - Classe D* \\
\hline & $\begin{array}{l}\text { Capacidade de conduzir o calor } \\
\text { Condutividade térmica }\end{array}$ & $0.8099 \mathrm{~W} / \mathrm{mK}^{* *}$ \\
\hline & $\begin{array}{l}\text { Capacidade de armazenar calor. } \\
\text { Calor específico }\end{array}$ & $931.3583 \mathrm{~J} / \mathrm{kg} \cdot \mathrm{K}^{* *}$ \\
\hline & Refletância & $53,6 \% * *$ \\
\hline & Absortância & $46,4 \%$ ** \\
\hline $\begin{array}{l}\text { Propriedades } \\
\text { Químicas }\end{array}$ & Resistência à UV & $\begin{array}{l}\text { A ação dos raios ultravioleta } \\
\text { deixa as placas mais } \\
\text { opacas, com perda de brilho } \\
\text { superficial. } \\
\text { A ação do UV enrijece as } \\
\text { fibras poliméricas das } \\
\text { placas, deixando-as menos } \\
\text { flexíveis e aumentando sua } \\
\text { resistência mecânica. } \\
\text { A ação do UV não degrada } \\
\text { as placas. }\end{array}$ \\
\hline Absorção de água & $\begin{array}{c}\text { Este dado pode variar muito, de } \\
\text { acordo com a quantidade de papel } \\
\text { restante na matéria-prima e qualidade } \\
\text { da prensagem. }\end{array}$ & $10,3 \% * * *$ \\
\hline
\end{tabular}

Fonte:, ${ }^{*}$ Relatórios do Laboratório de Construção civil da EESC-USP e relatórios coletados no site da empresa IBAPLAC (2009). ${ }^{* *}$ Dados de ensaios. ${ }^{* * *}$ Média dos resultados dos ensaios do IPT e LaMEM 
Tabela 4.9: Resumo dos Resultados térmicos com símbolos e unidades

\begin{tabular}{|c|c|c|c|}
\hline Característica & Símbolo & Unidade & Resultados \\
\hline Refletância & $\rho$ & - & $0,536(53,6 \%)$ \\
\hline Absortância & $\alpha$ & - & $0,464(46,4 \%)$ \\
\hline $\begin{array}{c}\text { Condutividade } \\
\text { Térmica }\end{array}$ & $\lambda$ & $\mathrm{W} /(\mathrm{m} . \mathrm{K})$ & $0.8099 \mathrm{~W} / \mathrm{mK}$ \\
\hline Calor específico & $\mathrm{c}$ & $\mathrm{J} /(\mathrm{kg} . \mathrm{K})$ & $931.3583 \mathrm{~J} / \mathrm{kg} . \mathrm{K}$ \\
\hline
\end{tabular}

Fonte: Organização da autora.

\section{Sobre os dados térmicos}

Os resultados dos ensaios térmicos permitirão o cálculo de várias outras características térmicas e comparativo referencial para especificação das placas. As seguintes normas são referências :

o ABNT NBR 15220-1: 2005 - Desempenho térmico de edificações - Parte 1: Definições, símbolos e unidades.

o A ABNT NBR 15220-2: 2005 - Desempenho térmico de edificações - Parte 2: Método de cálculo da transmitância térmica, da capacidade térmica, do atraso térmico e do fator solar de elementos e componentes de edificações.

o ABNT NBR15575-4: 05/2008: Edifícios Habitacionais de até cinco pavimentos Desempenho - Parte 4: Sistemas de vedações verticais externas e internas.

Especialmente em relação aos dados de transmitância térmica (U), pode-se identificar a adequação das características térmicas das placas recicladas às exigências da tabela de transmitância térmica (tabela 4.10), apresentada na NBR 15575-4: 2008 - Edifícios habitacionais de até 5 pavimentos: sistemas de vedações verticais externas e internas. 
Tabela 4.10: Transmitância térmica de paredes externas - Valores máximos admissíveis

\begin{tabular}{|c|c|c|}
\hline \multicolumn{3}{|c|}{$\begin{array}{c}\text { Transmitância Térmica U } \\
W / \mathrm{m}^{2} . \mathrm{K}\end{array}$} \\
\hline Zonas 1 e 2 & \multicolumn{2}{|c|}{ Zonas 3,4,5,6,7 e 8 } \\
\hline $\mathrm{U} \leq 2,5$ & $\mathrm{\alpha} \leq 0,6$ & $\mathrm{a}>0,6$ \\
\hline \multicolumn{2}{|c|}{$\mathrm{U} \leq 3,7$} & $\mathrm{U} \leq 2,5$ \\
\hline \multicolumn{2}{|c|}{$\alpha$ - é a absortância à radiação solar da superfície externa da parede. } \\
\cline { 2 - 3 }
\end{tabular}

Fonte: ABNT - NBR 15575-4:2008, p.20.

Para identificação da Transmitância térmica $(U)$ de referência na tabela acima, é necessário identificar a zona bioclimática da cidade em que a placa estiver sendo aplicada. Essa identificação pode ser feita com a NBR 15220-3: 2005 - Desempenho térmico de edificações - Parte 3: Zoneamento bioclimático brasileiro e diretrizes construtivas para habitações unifamiliares de interesse social. São Carlos, por exemplo, (local de desenvolvimento desta pesquisa), encontra-se na Zona Bioclimática 4. A absortância da placa reciclada, de acordo com resultados apresentados na tabela 4.9, é $\alpha=0,464$ e, portanto, menor que o 0,6 apresentado na tabela 4.10. Desta forma, conclui-se que, para a Zona Bioclimática 4 (exemplo dado), usando-se a placa reciclada que tem absortância $\alpha \leq$ 0,6, a Transmitância Térmica $(U)$ deve ser menor ou igual a $3,7 \mathrm{~W} /\left(\mathrm{m}^{2} . \mathrm{K}\right)$. (dados sombreados na tabela 4.10). O valor de transmitância apresentado pela norma é maior, por exemplo, do que a transmitância térmica de uma parede de $13 \mathrm{~cm}$ de espessura, de tijolos maciços rebocados, em ambas as faces, cuja transmitância, de acordo com exemplo apresentado na NBR 15220-2: 2005 , é de $U=3,34 \mathrm{~W} /\left(\mathrm{m}^{2} . \mathrm{K}\right)$.

A análise que pode ser feita é que no, projeto com uso das placas recicladas, é importante o cuidado com as espessuras (tanto das placas, quanto do sistema), com as camadas de isolamento térmico e camadas de ar que possam compor o sistema de vedações.

A grande refletância de IV (64\%) é um excelente indicativo de sustentabilidade para a maioria das regiões climáticas brasileiras. A refletância contribui para retardar o aquecimento dos ambientes e pode minimizar o uso de ar condicionado.

Optou-se por não apresentar o demonstrativo dos vários cálculos térmicos a fim de não estender a análise muito além dos objetivos gerais e específicos desta pesquisa, para manter o equilíbrio entre as abordagens técnicas, estéticas e projetuais propostas. Assim, 
limitou-se à organização dos dados técnicos pesquisados e ensaiados, sistematizando-os em um panorama técnico, que poderá ser um referencial para novas pesquisa na área de eficiência energética com uso das placas recicladas estudadas, assim como para projetos.

\section{Sobre a ação do UV}

Pela tabela de refletância e absortância por comprimento de onda (UV, VIS e IV), observou-se que a porcentagem de absortância de UV (72\%) é bem maior do que os $28 \%$ refletidos; a princípio, isto poderia indicar que a placa é facilmente degradável. No entanto, após a exposição das placas ao ensaio de envelhecimento acelerado, com exposição à UV e umidade, complementado com os resultados obtidos no ensaio de DMA, verificou-se que o material não sofreu degradação significativa, apresentando evidências somente em seus aspectos visuais, que se tornaram mais opacos e enrijecidos (perda de flexibilidade). A integridade material da placa não foi alterada, como demonstrado na figura de comparativo microscópico. Com essa análise conclui-se que as Placas Recicladas de Embalagens Longa Vida podem ser utilizadas em áreas externas sem sofrer degradação significativa dos raios UV.

Influência do enrijecimento das placas na execução dos sistemas construtivos.

O aumento da rigidez da placa pode ser um aspecto positivo ou negativo, dependendo da forma como ela estará aplicada na superfície. Se o enrijecimento ao longo do tempo se der com a placa abaulada (formando barrigas na superfície), será difícil o manuseio, caso a peça tenha que ser colocada de forma plana novamente, corrigindo possíveis imperfeições construtivas. Por outro lado, se a placa estiver bem colocada na superfície, o enrijecimento, com o tempo, irá garantir sua estabilidade naquela posição. Desta forma, é muito importante que os sistemas construtivos das áreas externas estejam integralmente bem executados, evitando-se abaulamento das placas, para que não enrijeçam em posições indesejadas.

\section{Relação dos resultados de DMA Tg com a produção das placas}

Se, durante a prensagem das placas, a aderência entre as matérias-primas não fica perfeita, com o tempo isso pode comprometer a estrutura interna entre as fibras. 
Os resultados de DMA Tg poderiam ser melhores se o processo de produção de prensagem das placas fosse mais criterioso, proporcionando melhor união das fibras e melhoramento das propriedades gerais das placas.

\section{Influência do processo de produção e da matéria-prima nas características técnicas}

As características técnicas evidenciam que a qualidade das placas está diretamente ligada ao controle da "pureza" da matéria-prima e ao desenvolvimento tecnológico e controle do processo de fabricação, Isso envolve problemas como variações de espessura ao longo da placa, devido a possíveis irregularidades na distribuição da matéria-prima entre as chapas que serão prensadas, variações de quantidade de papel que resta do hidrapulper e a instabilidade dimensional das espessuras e acabamento das arestas devido a todo o processo manual.

Melhorar a tecnologia instalada na primeira etapa da reciclagem, ainda no Hidrapulper, poderá melhorar a qualidade da retirada do papel e, desta forma, a quantidade de papel nas placas poderá diminuir, colaborando com a estabilidade dimensional das peças, principalmente nas arestas, o que, consequentemente, melhorará a impermeabilidade. Da mesma forma, a melhoria do processo de fabricação das placas, com temperatura e força de prensagem mais controlada e produção de formas mais bem dimensionadas podem produzir um material mais bem acabado, com características técnicas melhores.

\section{Possibilidades de nova reciclagem das placas}

Se sofrer uma mudança estrutural ao longo dos anos, o polietileno pode perder a propriedade de aderência entre suas próprias fibras, o que dificultaria a reciclagem das placas para produção de outras novas placas, especialmente na etapa de prensagem. Uma opção poderia ser a reciclagem das placas, adicionando-se, à mistura triturada, uma porcentagem de polietileno novo, ou mesmo de polietileno que esteja sendo reciclado pela primeira vez, para ajudar na aderência interna do material. 


\section{5 - DESIGN E CARACTERIZAÇÃO ESTÉTICA}

Como visto anteriormente, no capítulo 3 desse trabalho, a produção do design com uso das Placas Recicladas de Embalagens Longa Vida está em processo de evolução. Existe ainda certa cautela, por parte de designers e arquitetos, ao buscar novas soluções construtivas com uso dos materiais reciclados, devido as características visuais e falta de conhecimento das propriedades técnicas. Uma reação natural diante de um material que se conhece pouco.

Para um breve olhar sobre esta condição, foi elaborado um questionário com cinco perguntas (Apêndice D) e enviado por e-mail para 50 profissionais (arquitetos e engenheiros) juntamente com um link para acesso ao site de uma empresa fabricante de placas recicladas de polietileno-alumínio. Somente 21 profissionais responderam 0 questionário; um número bastante pequeno, porém, ainda assim, optou-se por apresentar seus resultados, no sentido de poder configurar uma pequena amostragem sobre as opiniões relacionadas às placas recicladas. Os resultados do questionário demonstraram o seguinte: dos 21 profissionais que responderam, 17 já conheciam as placas recicladas e 4 não conheciam. Dos que conheciam as placas, 15 já viram aplicadas e 2 não. As aplicações descritas foram principalmente em telhas e tapumes, confirmando o que está sendo descrito nessa pesquisa. Dos 17, ainda, 13 conheciam alguma característica técnica das placas e 4 não. Estes últimos 4, somados aos 4 que não conhecem o material, totalizaram 8 que não conheciam nenhuma característica técnica das placas. Dos dados técnicos conhecidos pelos 13 profissionais, a impermeabilização e proteção térmica foram as mais citadas, mas também destacaram: longevidade e maior durabilidade em relação a outras placas recicladas.

Sobre as questão estética, dos 21 profissionais, 12 gostam do aspecto visual e 9 não gostam. Este dado causou certa surpresa e levou à interpretação de que o gosto pelo material vem sendo modificado positivamente. Por outro lado, os motivos para os 9 que não gostam do material são variados e valem ser listados como elemento de reflexão. Descreveram: 
- "A placa tem aspecto sujo e irregular."

- "A colocação parece desleixada, embora o aspecto do material não seja desagradável."

- "Dependendo do tipo de empreendimento não dá para usar"

- "É necessário a aplicação de algum tipo de revestimento sobre a placa."

- "Aparenta ser rústico e grosseiro."

- "Este material não foi criado para ser um material de acabamento final."

- "A mescla de cores não dá muita segurança, precisa ser um acabamento liso."

- "Lembra algo improvisado, habitação cortiço, parece estar sujo, mas tem potencial estético e formal se for trabalhado."

De todos os 21 profissionais, somente 3 já utilizaram as placas recicladas, especialmente para tapumes e telhados. Os 18 restantes não utilizaram, mas responderam, (inclusive os que não gostaram da placa esteticamente), que utilizariam, se conhecessem o desempenho técnico do material, catálogos, e se já tivessem visto o material aplicado em alguma obra. As principais indicações para aplicação foram, principalmente, em forros e vedações (internas e externas).

Complementando o questionário, alguns comentários, em relação às placas, foram feitos pelos profissionais:

- Pelas informações parece ser um bom produto, mas o visual dificulta a aplicação. Se puder receber pintura ajudaria.

- Essas placas de embalagens longa vida recicladas parecem não ser feitas para agradar visualmente o consumidor. As próprias indústrias fabricantes atribuem subusos ao material, subestimando o seu potencial para usos mais nobres.

- Deveriam ser desenvolvidos produtos estética e tecnicamente adequados para cada uso.

- Gosto e acho que a textura poderia ser explorada como parte do desenho final.

Com o questionário percebeu-se que os pontos negativos declarados pelos profissionais não foram muito diferentes das problemáticas apresentadas para esse trabalho. No entanto, o número de pessoas que conhecem ligeiramente as placas e, das que gostam de seu aspecto visual, foi maior do que o esperado, ainda que pouquíssimos já tenham usado de fato. Os usos conhecidos nas versões "tapume e telha" também vieram de encontro ao previsto, mas a predisposição ao uso como vedações e forros surpreendeu, o que sinaliza um aspecto muito positivo para possibilidades de especificações futuras.

O questionário representou um exemplar de discussão sobre o quanto algumas questões estéticas, e de acabamento, são importantes para a especificação de um material. 
A fim de visualizar esta problemática com mais proximidade, foram realizadas algumas análises das placas recicladas nos aspectos que mais caracterizam esteticamente um material: sua cor, textura, forma e tamanho. Também foram analisados seus desdobramentos enquanto possibilidades de composição com outros materiais e algumas possibilidades de cortes e modulações. Com este repertório foi possível sistematizar a caracterização estética para as Placas Recicladas de Embalagens Longa Vida e, em seqüência, traçar um referencial para as decisões projetuais apresentadas no capítulo seguinte.

\section{1 - Texturas, cores e brilho}

Visualmente, as Placas Recicladas de Embalagens Longa Vida aparentam, como resultado estético, um aglomerado manchado dos materiais que a compõem. Entre tons de cinza e prata, com reflexos, provenientes do alumínio e nuances coloridas e transparentes, provenientes do plástico, também surgem manchas e pontilhados opacos marrons (figuras 5.1 e 5.2). Existe uma variedade de cores e tonalidades que aparecem nas placas, em decorrência dos diversos tipos de impressos na superfície das caixinhas Longa Vida, mas observou-se que, entre todo o colorido (com exceção da cor prata do alumínio), as que são mais comuns são vermelho, azul e verde. Amarelo, laranja e outras cores são menos freqüentes. O conjunto resulta em um aspecto estético triturado e fundido, rústico e peculiar, com característica e identidade própria. Uma textura tanto visual quanto tátil, resultado da prensagem.

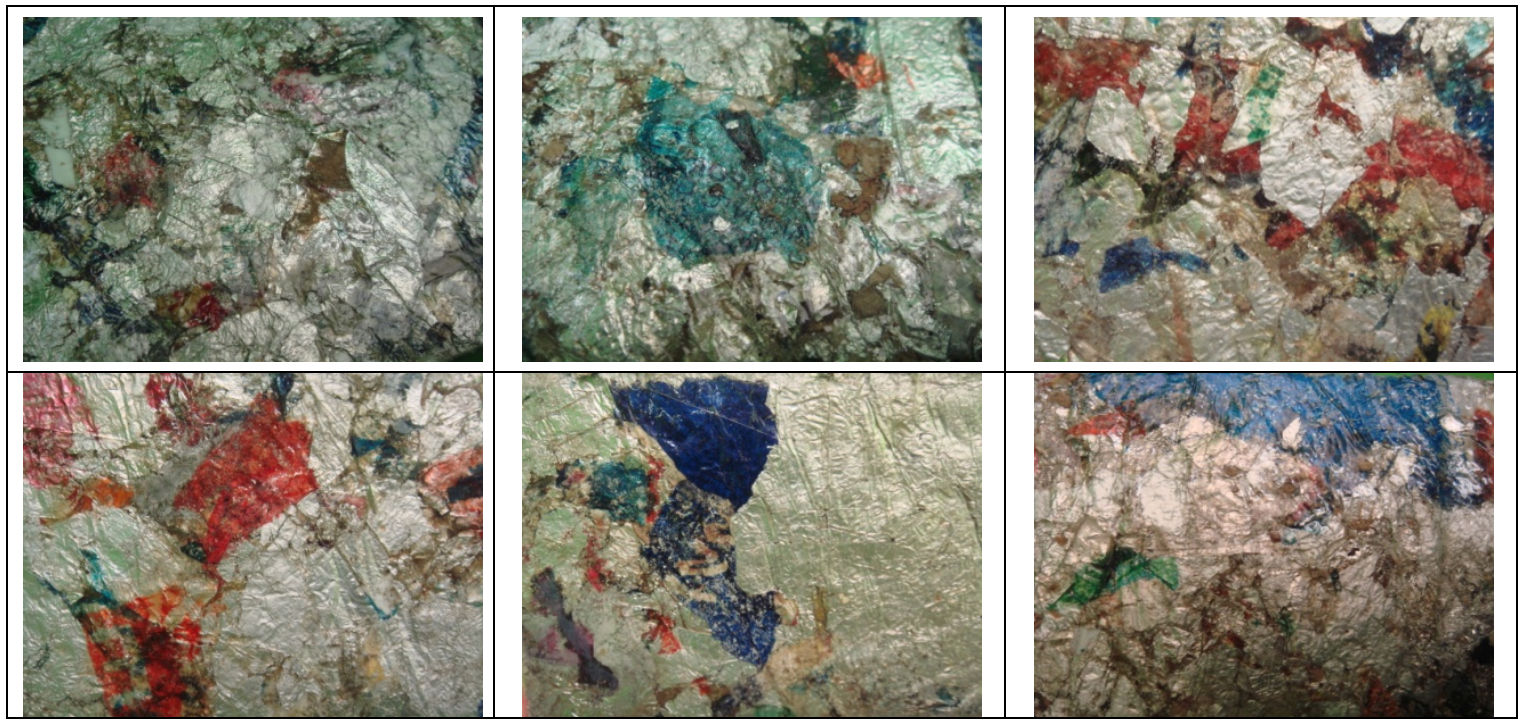

Figura 5.1: Texturas e cores das placas recicladas de embalagem longa vida Fonte: Fotos da autora, 2010. 


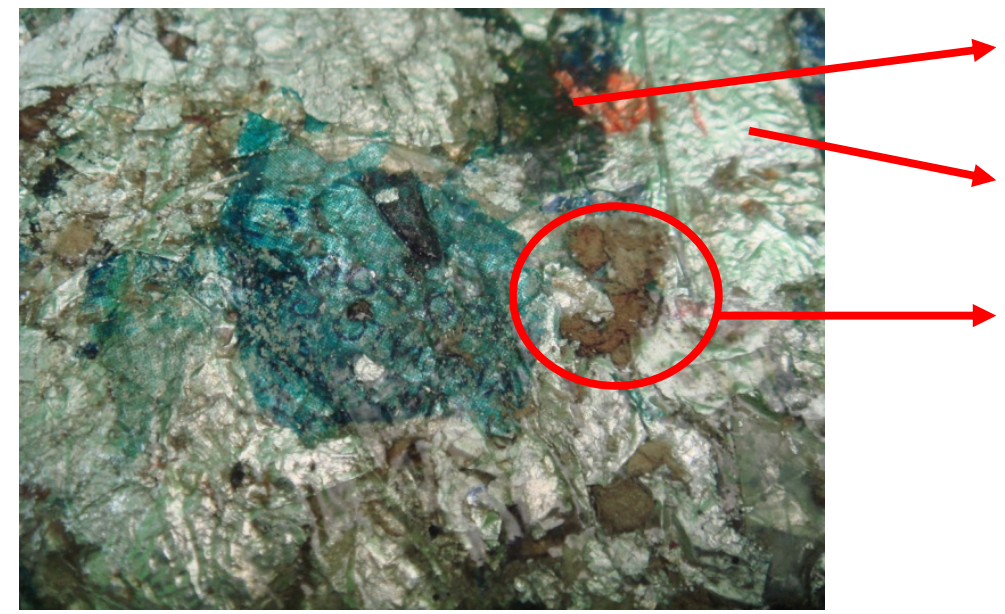

Polietileno - Colorido,

brilho e transparência.

Alumínio - Cinza e brilho

Papel restante -

Marrom e opaco

Figura 5.2: Detalhes da mescla de materiais Fonte: Foto da autora (2010).

Algumas placas podem receber um filme plástico colorido em sua superfície. Em alguns casos isso pode ser um partido para projeto. Assim como nesta figura.

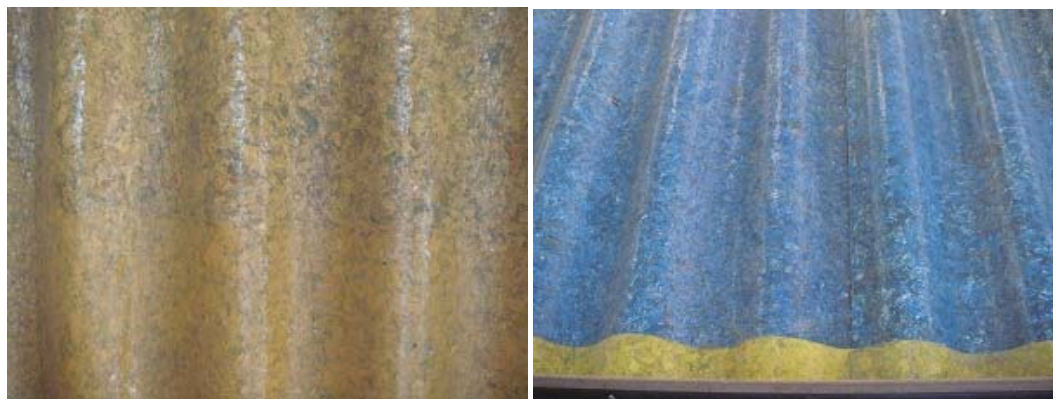

Figura 5.3: Placa reciclada revestida com filme plástico colorido. Fonte: Foto da autora (2009)

A sensação visual de "um material sujo" descrita por algumas pessoas pode ser atribuída principalmente ao restante de papel na mistura, A quantidade de papel nas placas irá depender da quantidade de papel que sobra do hidrapulper e irá influenciar em sua tonalidade; com tons mais escuros puxando para o marrom, quanto mais papel restar na mistura. As nuances marrons por toda a placa causam a impressão de sujeira. Porém é fato que esta sensação não se dê somente pelo papel. Considerando que esta placa é proveniente de uma embalagem pós-consumo, antes da reciclagem, estavam no lixo, em contato com vários outros materiais e tipos de sujeira. Depois, passou pelas esteiras dos centros de triagem e, então, foi para a primeira trituração com água no hidrapulper, como descrito no capítulo 3. A água do equipamento não limpa totalmente o material e, também, ao saírem do equipamento, são enfardadas e transportadas para a recicladora, onde ficam 
abertas no chão, ao ar livre, ou dentro dos galpões. Durante todo esse processo, a matériaprima acumula diversos tipos de sujeira, como também restos de terra. Mesmo após o processo de trituração, a matéria-prima chega à etapa de prensagem ainda muito suja. (figura 5.4)

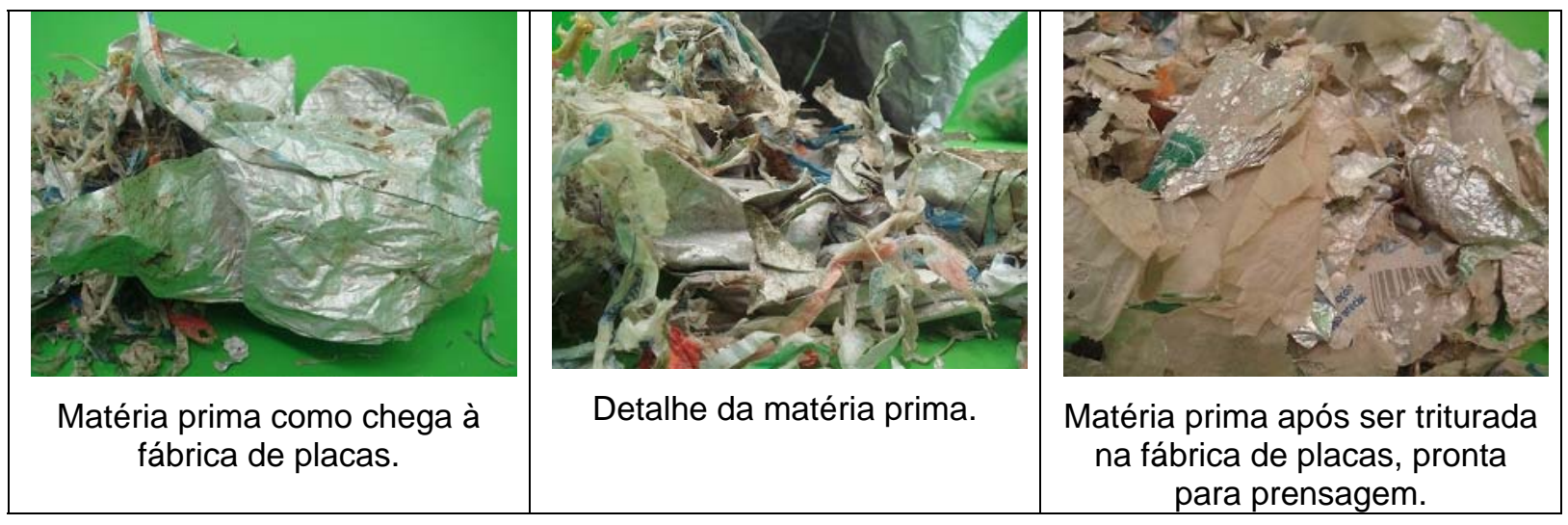

Figura 5.4: Detalhe da Matéria-prima com sujeira. Fonte: Foto da autora, 2010.

Com relação ao brilho, ocorre um contraste do alumínio e do polietileno com a opacidade dos resíduos de papel. Por grande parte da superfície das placas ser de alumínio e polietileno, o contato com a luz pode sempre causar efeitos de reflexão. Em uma superfície que reflete, o trabalho com jogos de luz pode ser bastante interessante. Também pode ser inconveniente em outras. A intensidade da incidência de luz artificial, ou solar, sobre a placa influencia, também, no reconhecimento visual de sua textura, podendo alterá-la de acordo com o ponto de vista e da distância observada.

As distâncias a serem observadas são fortes influências no gosto pela textura do edifício.

A textura e a cor das placas recicladas são fortes indicativos de sua estética e o que, a princípio mais influenciam no gosto estético em relação a este material. Porém, usando as afirmações de Wong (2010) apresentadas no capítulo 2, pode-se deduzir que a textura identificada individualmente, e em proximidade, em uma placa, não será, necessariamente, a que será identificada quando da aplicação desse material em uma padronagem organizada sobre uma superfície. O fato da textura original das placas poder se perder no conjunto de uma determinada padronagem, pode propiciar a empatia ao uso do material reciclado, para aquelas pessoas que não identifiquem a textura de maneira positiva. Para os que se identificam positivamente com o aspecto visual das placas, terão à sua vista uma composição alternativa, podendo, inclusive, decepcionar-se, à distância, com a perda dos 
aspectos visuais originais. O visual original é recuperado, aos poucos, a medida que se reaproximarem do conjunto.

As imagens a seguir foram registradas em estúdio de fotografia e mostram um estudo de pontos de vista, a distâncias específicas, de no máximo $5 \mathrm{~m}$ (comprimento máximo do estúdio), aproximando até $0,5 \mathrm{~m}$ (distância referente a uma placa vista na mão). A iluminação do estúdio foi mantida constante, porém, por motivos de posicionamento do tripé da câmera para atingir as distâncias desejadas, ocorreram algumas variações de tons nas imagens.

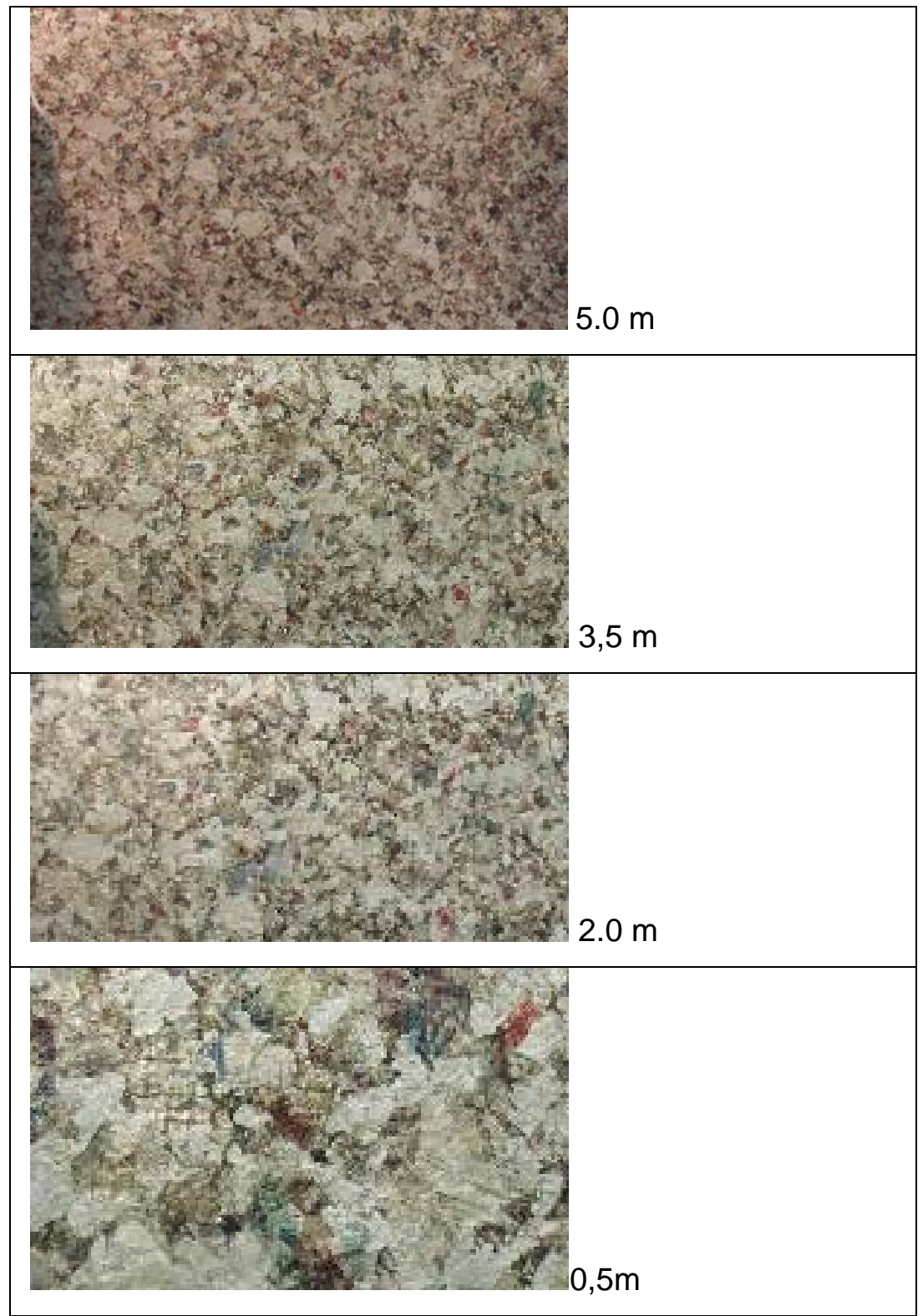

Figura 5.5: Estudos de vista das placas a diferentes distâncias Fonte: Fotos da autora, 2011. 
Com 5 metros de distância já começa-se a perceber a homogeneização da textura da placa reciclada, apesar de ainda ser possível reconhecê-la (mesmo porque neste estudo já se sabe de qual material se trata, o que facilita o reconhecimento). O que pretendeu-se com esta exposição foi reforçar o fato de que o material aplicado em superfícies arquitetônicas pode causar diferentes efeitos, de acordo com as variáveis envolvidas, assim como o exemplo mostrado, no segundo capítulo desse trabalho, com a obra do Edifício Arquivo Nacional EDF.

Escolher os materiais prezando, primeiramente, pelo meio ambiente, em detrimento do gosto estético, é uma atitude sustentável, e reafirmada por Moraes (2010). Esta consciência pode deixar o aspecto estético em segundo plano.

Apesar das possibilidades de usos de artifícios e técnicas construtivas para compensar estéticas indesejáveis dos materiais, ainda é defendido por esta tese o fato dos materiais novos (reciclados e reconstituídos), ou diferentes do padrão visto pelo senso comum, poderem conquistar o senso estético das pessoas, ao longo de sua exposição. Uma forma encontrada para isso é a identificação de composições que criem harmonia com as texturas das Placas Recicladas de Embalagens Longa Vida. Para tanto, a seguir propõe-se algumas análises comparativas e analogias com outros materiais.

\section{2 - Composições: relações materiais.}

A composição entre os materiais, em uma superfície, é o que confere a padronagem, ou estampa, que o edifício irá exprimir esteticamente. Nas superfícies arquitetônicas, a padronagem será conferida pela composição de várias outras padronagens, provenientes de cada um dos materiais de fechamento, ou revestimento, que irão compor as paredes, tetos e pisos. Uma somatória de formas, texturas, cores e tamanhos, que, juntas, conferem o conjunto das superfícies.. Decidir esta composição é, em primeira ação, um trabalho de observação de composições.

Nos tópicos seguintes foram selecionados alguns exemplares de diversos materiais para fazer composição com a textura da Placa Reciclada de Embalagem Longa Vida, para visualizar tons, texturas e contrastes que possam harmonizar. A partir dessa visualização foi possível ter um referencial visual, mais claro, de quais materiais podem valorizar os padrões estéticos das placas recicladas e quais foram os menos compositivos. 


\subsection{1 - Composição com Concreto}

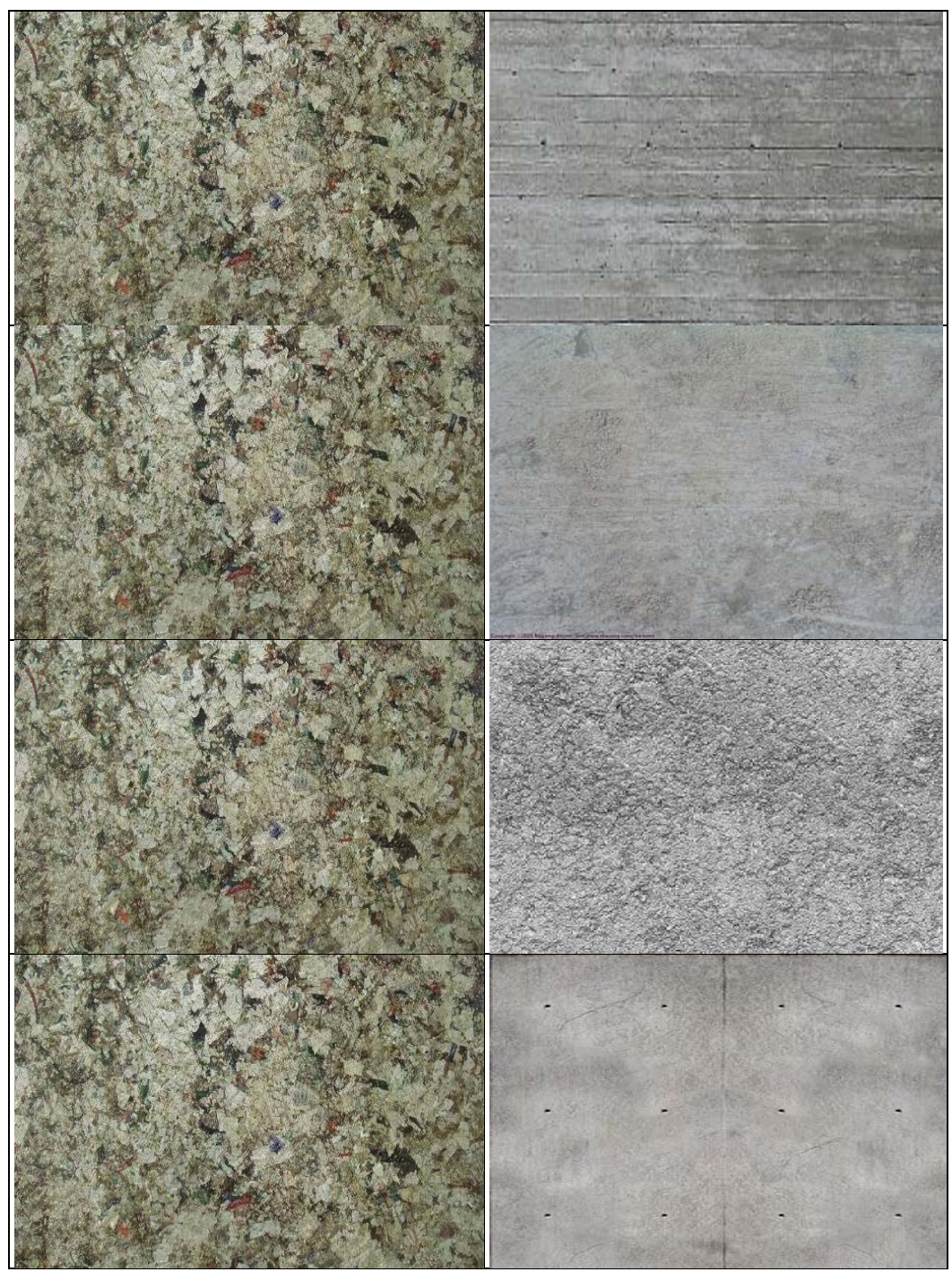

Figura 5.6: Texturas argamassadas e concreto em composição com placa reciclada. Fonte: Foto da autora, 2011 (placa reciclada) e Cg Textures (2011).

Os materiais cimentícios, argamassados e os concretos em suas diversas versões: lisos, rústicos, aparentes, marcados por formas, envernizados, entre outras, são naturalmente acinzentados, o que confere proximidade visual com a coloração das placas. 


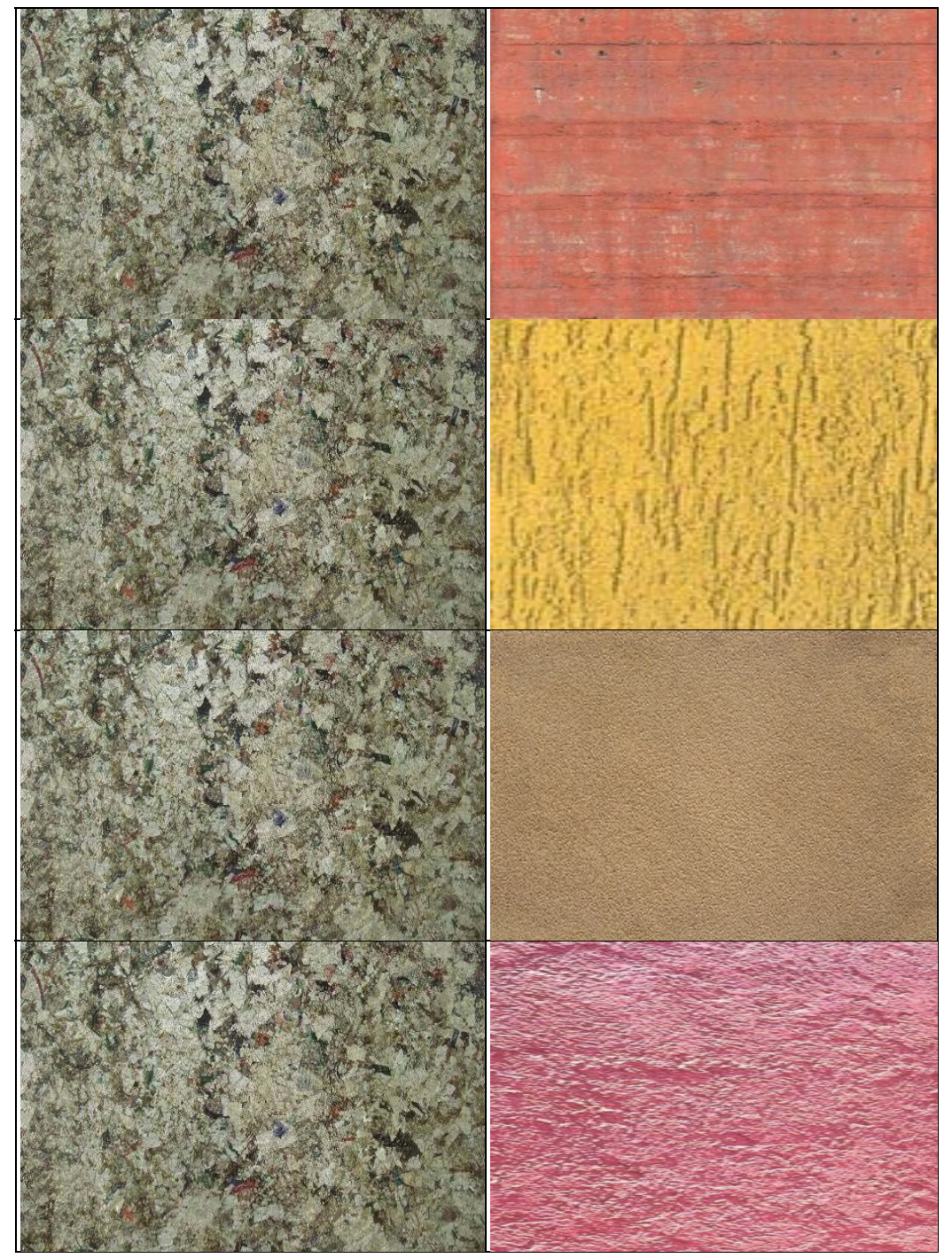

Figura 5.7: Texturas argamassadas coloridas em composição com placa reciclada. Fonte: Foto da autora, 2011 (placa reciclada) e Cg Textures (2011)..

As superfícies coloridas contrastam com a predominância acinzentada e aluminizada das placas recicladas. São composições interessantes que podem destacar os pontilhados coloridos das placas. Texturas rústicas e muito marcadas podem criar aspectos carregados visualmente. As texturas mais suaves e as colorações neutras criam maior proximidade visual com o pontilhado de papel. 


\subsection{3 - Composição com madeiras}

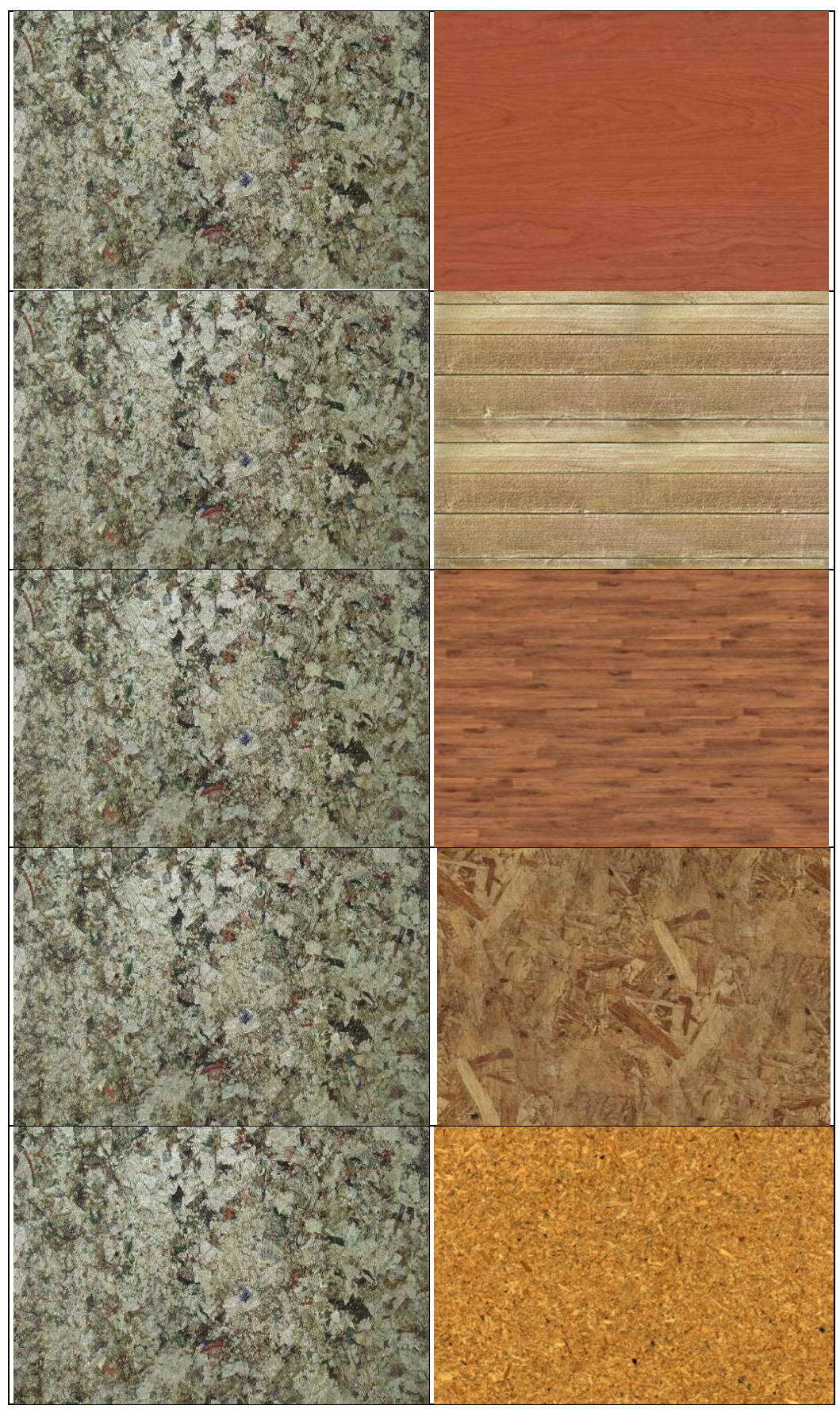

Figura 5.8: Texturas de madeiras em composição com placa reciclada. Fonte: Foto da autora, 2011 (placa reciclada) e Cg Textures (2011).

As texturas naturais da madeira, sejam maciças, sejam reconstituídas, contrastam com a composição processada da placa reciclada, e com sua coloração. A característica "pontilhada" ou de "pedaços unidos" das placas se aproxima da textura de algumas madeiras trituradas, ou em lascas, como os aglomerados e o OSB (Oriented Strand Board). 


\subsection{4 - Composição com metais}

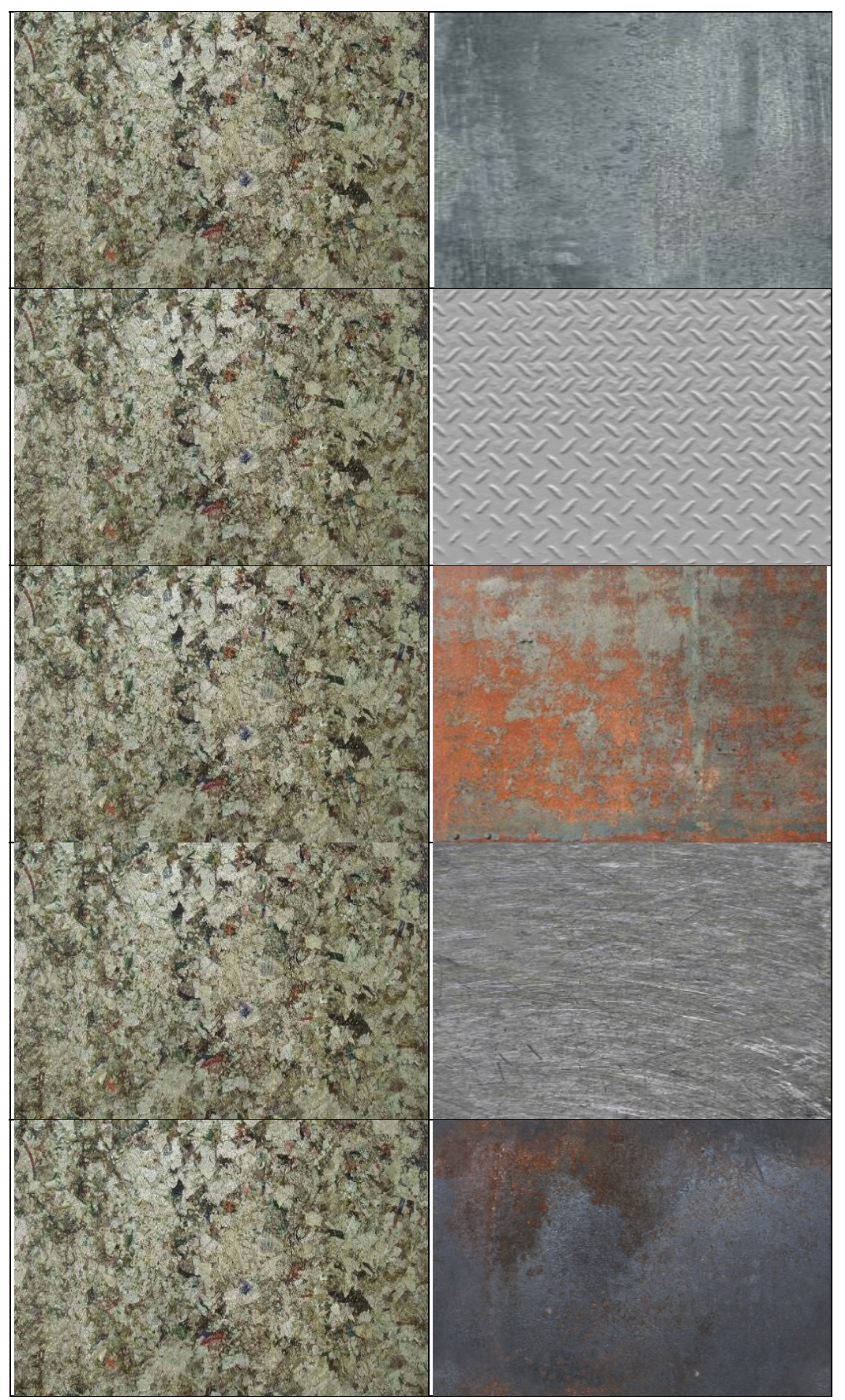

Figura 5.9: Texturas de metais em composição com placa reciclada. Fonte: Foto da autora, 2011 (placa reciclada) e Cg Textures (2011).

A composição com os metais é favorecida pela própria natureza do alumínio, presente na placa reciclada. A cor prata acinzentada e o brilho similar entre os materiais proporciona, visualmente, uma boa composição estética. 


\subsection{5 - Composição com pedras}

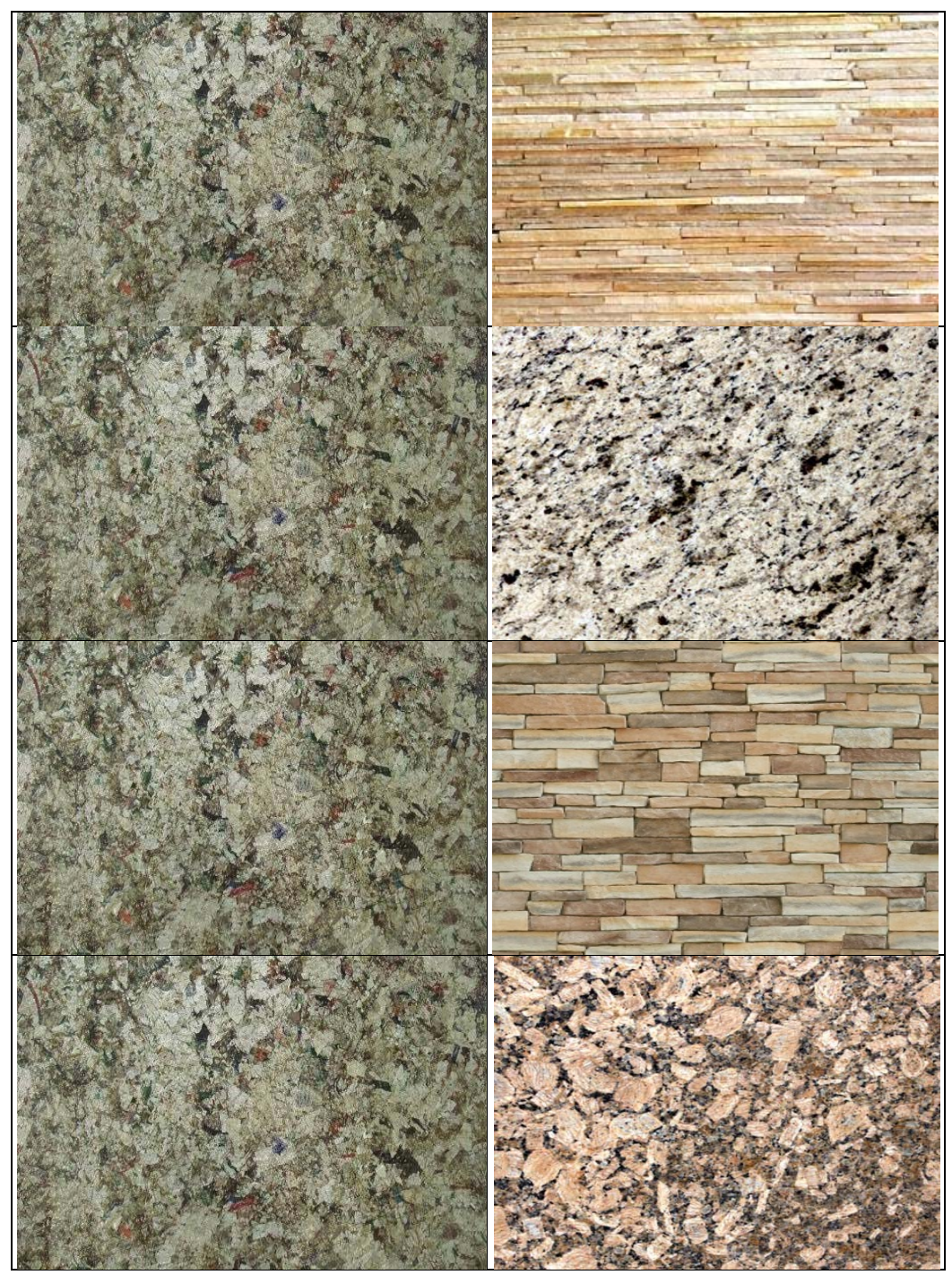

Figura 5.10: Texturas de pedras em composição com placa reciclada. Fonte: Foto da autora, 2011 (placa reciclada) e Cg Textures (2011).

Plástico e alumínio (materiais da tecnosfera) são de naturezas e propriedades muito diferentes das pedras (materiais da litosfera). Isto, por si, parece causar certa incompatibilidade. O tom de cinza/prata parece muito "técnico" em comparação com a naturalidade das pedras. Uma combinação que parece não ser muito harmônica. No entanto, interessante perceber que o salpicado do reciclado tem muita semelhança visual com o salpicado natural dos granitos (o que será discutido mais adiante neste capítulo). 


\subsection{6 - Composição com vidros}

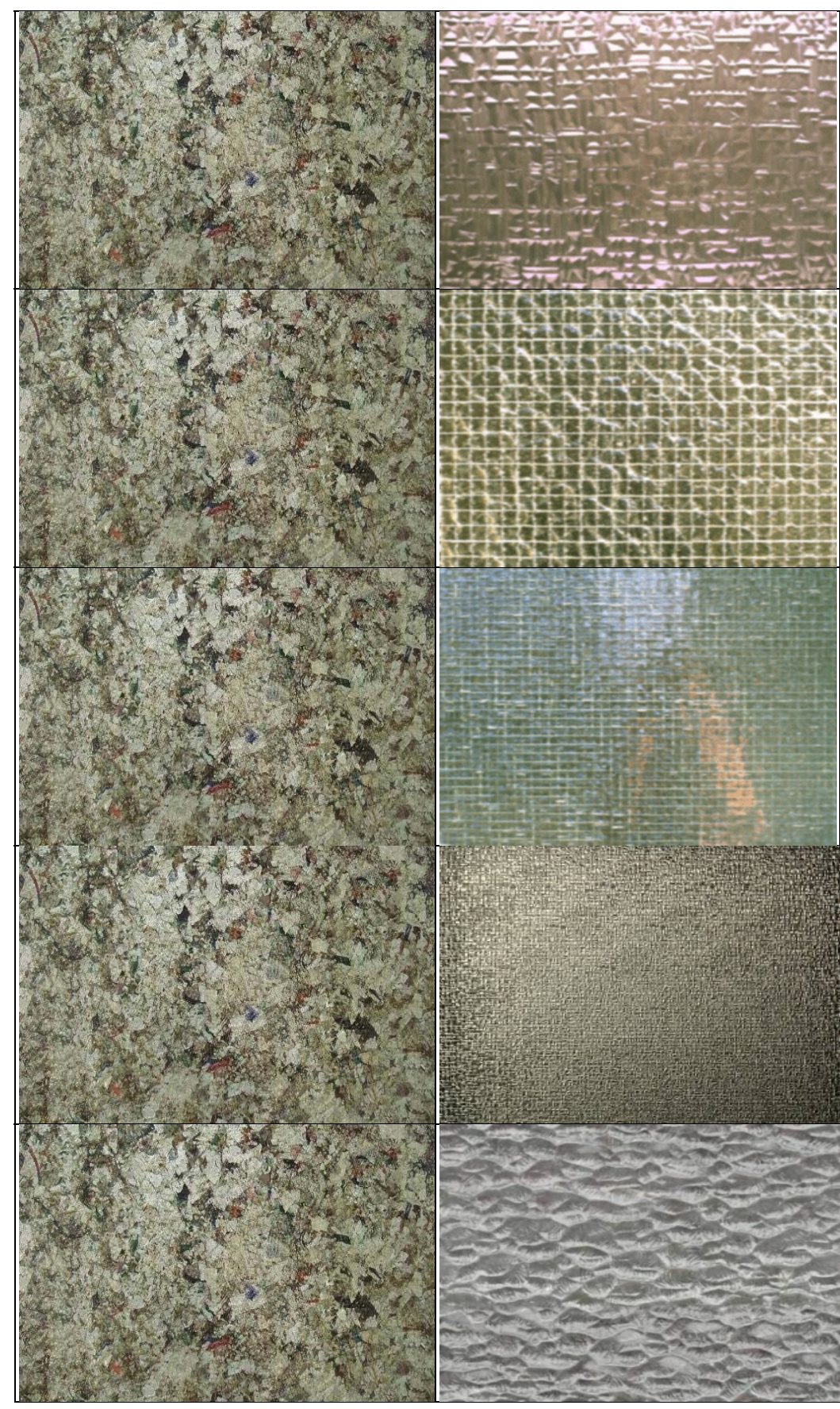

Figura 5.11: Texturas de vidros em composição com placa reciclada.

Fonte: Foto da autora, 2011 (placa reciclada) e Cg Textures (2011).

Os tons acinzentados, esverdeados ou azulados dos vidros, lisos ou "fantasia", fazem uma composição harmônica com a textura e coloração da placa reciclada. Além disso, o vidro liso pode proporcionar um ótimo acabamento se colocados sobre as placas recicladas, deixando à mostra a sua textura. 
5.2.7 - Composição com plásticos e borrachas

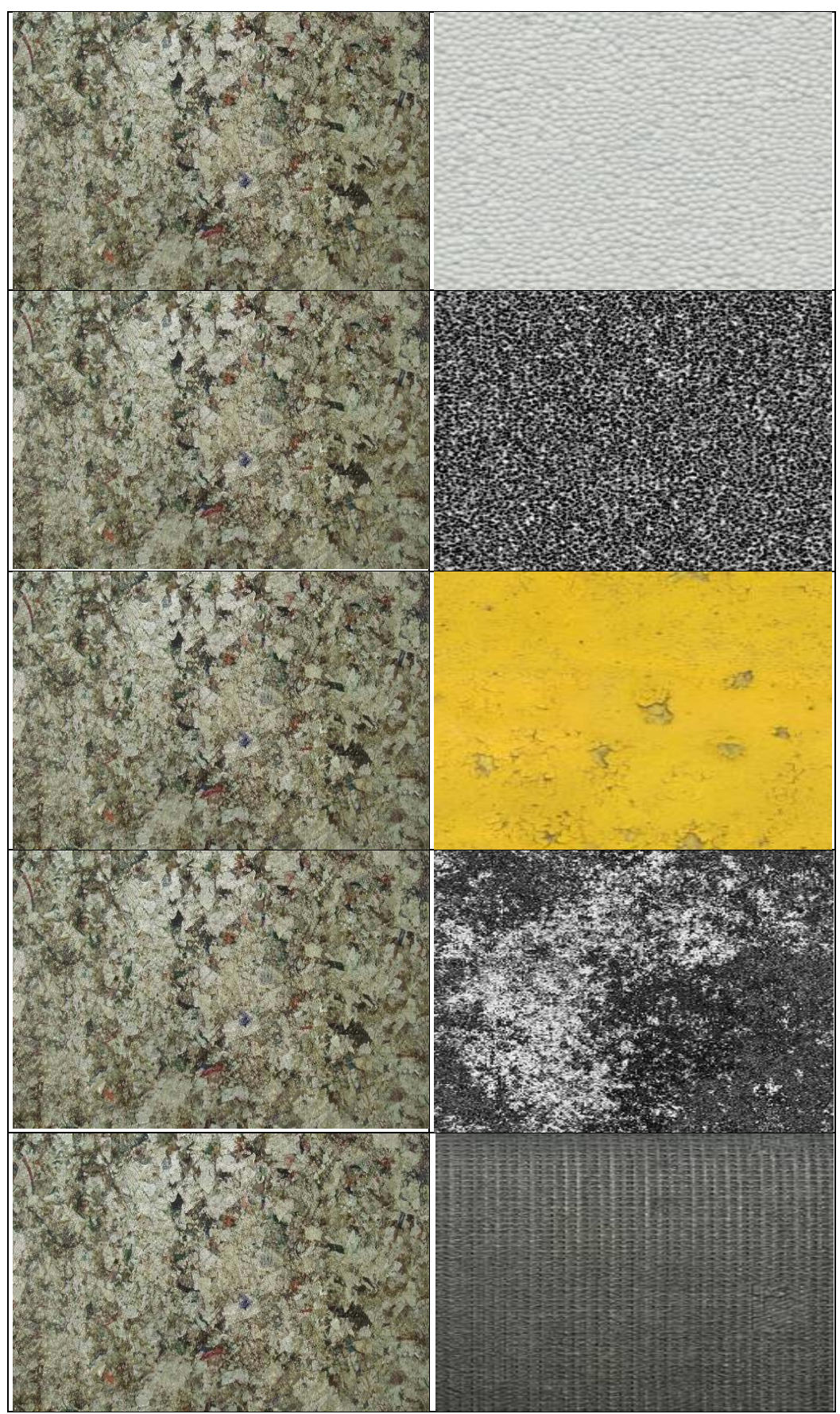

Figura 5.12: Texturas de plásticos e borrachas em composição com placa reciclada. Fonte: Foto da autora, 2011 (placa reciclada) e Cg Textures (2011).

Plásticos e borrachas são materiais da tecnosfera e, por esta natureza já estabelecem certa familiaridade entre si. A similaridade de sensação visual e tátil, além da coloração, favorece a composição entre os materiais. As borrachas, menos manchadas, com texturas mais homogêneas, parecem compor melhor com a textura da placa reciclada. 
Através deste comparativo foi possível perceber alguns materiais de mesma natureza (tecnosfera, litosfera ou biosfera - abordados no capítulo 2 dessa tese), tem possibilidades maiores de harmonizarem-se visualmente, o que não exclui, necessariamente, as outras combinações. Pode ser observado que a predominância acinzentada, com certo brilho, proporcionada pelo alumínio, e os salpicados coloridos com marrom pardo, se harmonizam mais aos materiais com tonalidades e texturas semelhantes. O tom do alumínio fez melhor composição com os metais, os concretos e os vidros. Os salpicados coloridos proporcionam combinações com os outros exemplares coloridos, sejam argamassados, pinturas os de texturas menos rústicas, com dimensões da textura semelhantes às do pontilhado das placas recicladas. O marrom/ocre, ou tom de "craft", cria certa harmonia com os materiais de mesma tonalidade, como as pedras naturais ou as madeiras. No entanto, por ter o contraste do alumínio, em grande quantidade, nessa análise não são identificadas como as melhores opções.

Por esta análise ter sido feita a partir de uma simples observação, naturalmente não é determinante ou definitiva, pois vários outros elementos estão em composição em um projeto arquitetônico, além da importância da percepção do especificador, que pode criar soluções surpreendentes. Buscou-se um ponto de partida estético, com olhar mais cuidadoso para as placas, dando referência para especificações e também para futuras discussões.

\subsection{8 - Semelhanças visuais}

Entre todos os materiais apresentados anteriormente, as texturas das Placas Recicladas de Embalagem Longa Vida assemelham-se às texturas das amostras de granito, chegando a camuflar-se entre elas (figura 5.13). Comparar granito com peças plásticas recicladas pode parecer extremo, considerando a originalidade natural de uma peça de granito e a origem reciclada das placas de polietileno-alumínio. No entanto, este comparativo está sendo destacado como forma de exemplificar o que foi apresentado sobre a materialidade e suas relações culturais, no capítulo 2 dessa tese. O objetivo é essencialmente conceitual. A maioria das pessoas tem afinidade pela textura e cores dos granitos. Por dedução, pode-se entender que a textura da placa reciclada possa, cada vez mais, agradar esteticamente. Para isto é preciso que o material esteja em contato com o observador. Perceber desta maneira pode elevar o uso das placas a um novo patamar de possibilidades projetuais. 


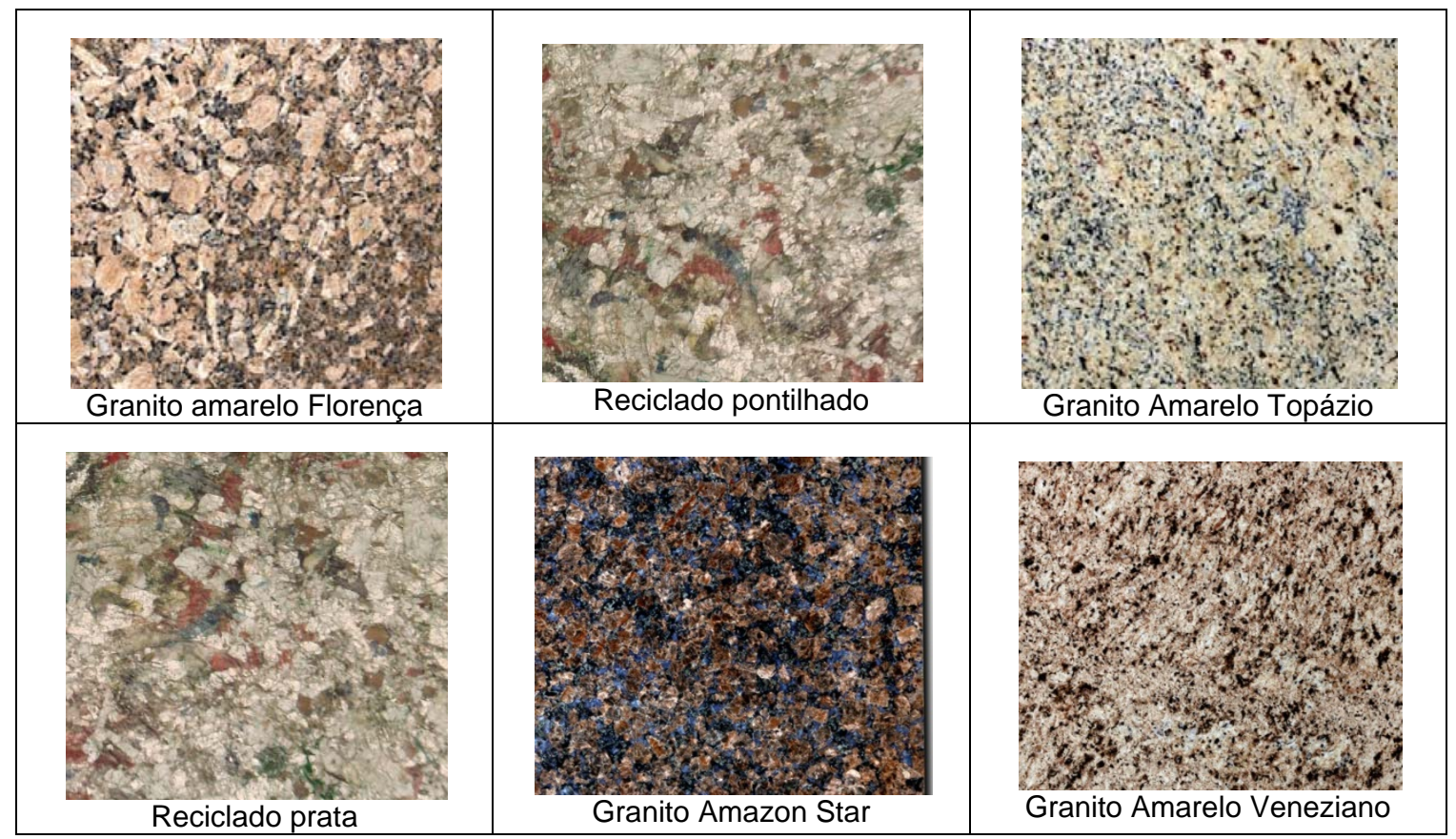

Figura 5.13: Texturas comparadas - granitos e Placas Recicladas de Polietileno Alumínio. Fonte: Pedras (2009)

Muitas outras placas recicladas são produzidas com os mesmos princípios de reciclagem das Embalagens Longa Vida. Encontra-se no mercado uma variedade de painéis que utilizam sobras e aparas de embalagens, ou mesmo com as caixinhas Longa Vida, em diferentes composições e acabamentos e qualidade.

As placas recicladas de aparas de produção de tubos de creme dental, tem a vantagem de não necessitar do processo de retirada de papel (pois não possuem) e ser uma matéria-prima mais limpa para a reciclagem. Esteticamente também são mais homogêneas e em cores mais claras, o que pode agradar mais visualmente do que as outras placas.

Algumas outras placas recicladas são feitas com a prensagem da matéria-prima reciclada, sem a total separação do papel, o que influencia em suas características técnicas. São menos resistentes às chuvas e favorecem o amolecimento e apodrecimento das placas, comprometendo sua vida útil e resistência. São materiais praticamente descartáveis. Outras placas ainda recebem a mistura de outros plásticos em sua composição. Assim, pode-se encontrar uma variedade de tipologias de placas semelhantes. (Quadro 5.1). 
Quadro 5.1: Comparativo placas recicladas semelhantes.

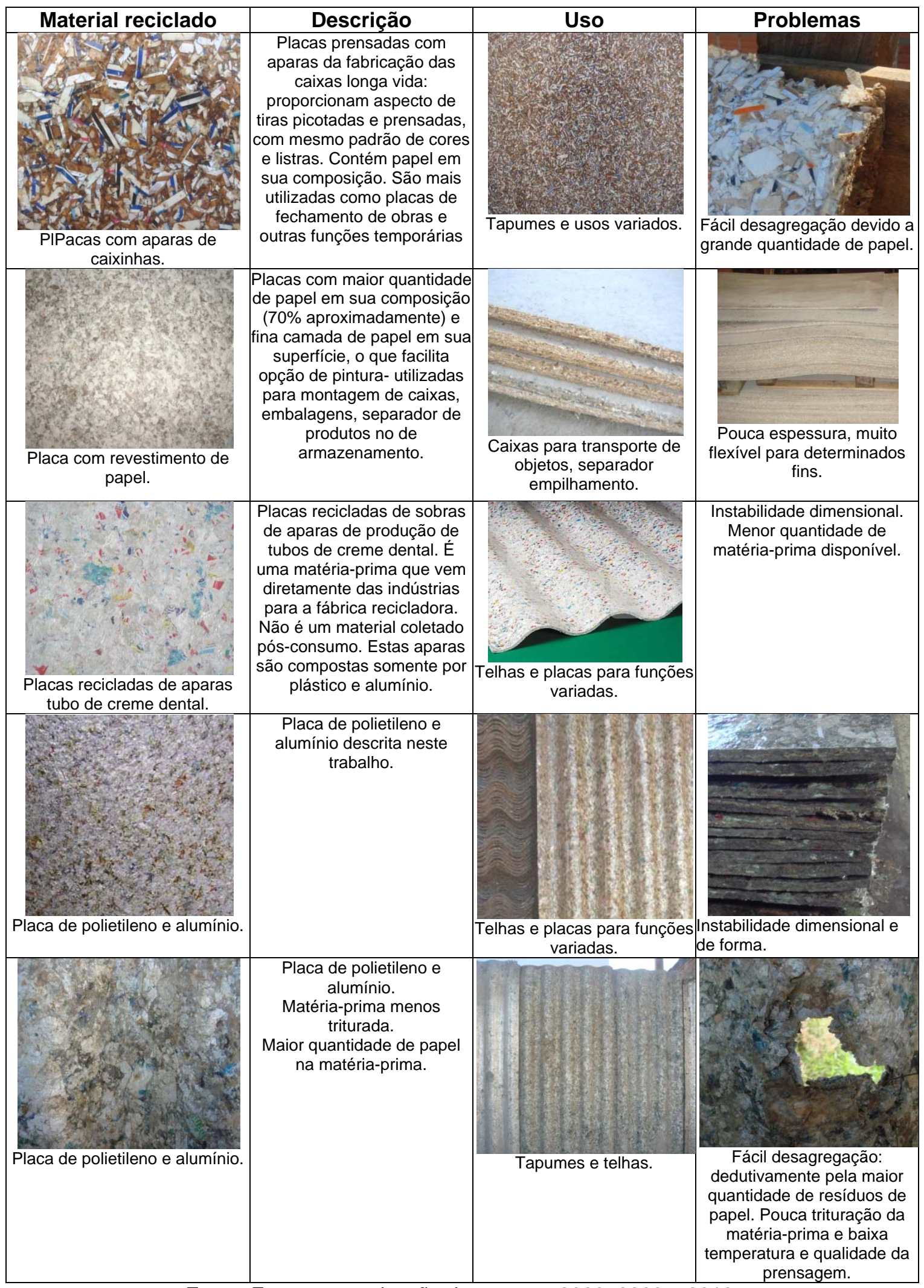

Fonte: Fotos e organização da autora - 2008, 2009 e 2010. 


\section{3 - Design da peça - Formas, cortes e modulação}

As Placas Recicladas de Embalagem Longa Vida propiciam trabalho com cortes, curvas, flexibilidade, perfurações, entre outras, que criem soluções alternativas para valorizar seu uso em cada tipo de superfície. Projetar as modulações e organizações sobre as superfícies arquitetônicas pode ser um recurso para tornar o aspecto do material mais atraente.

\subsection{1 - Flexibilidade}

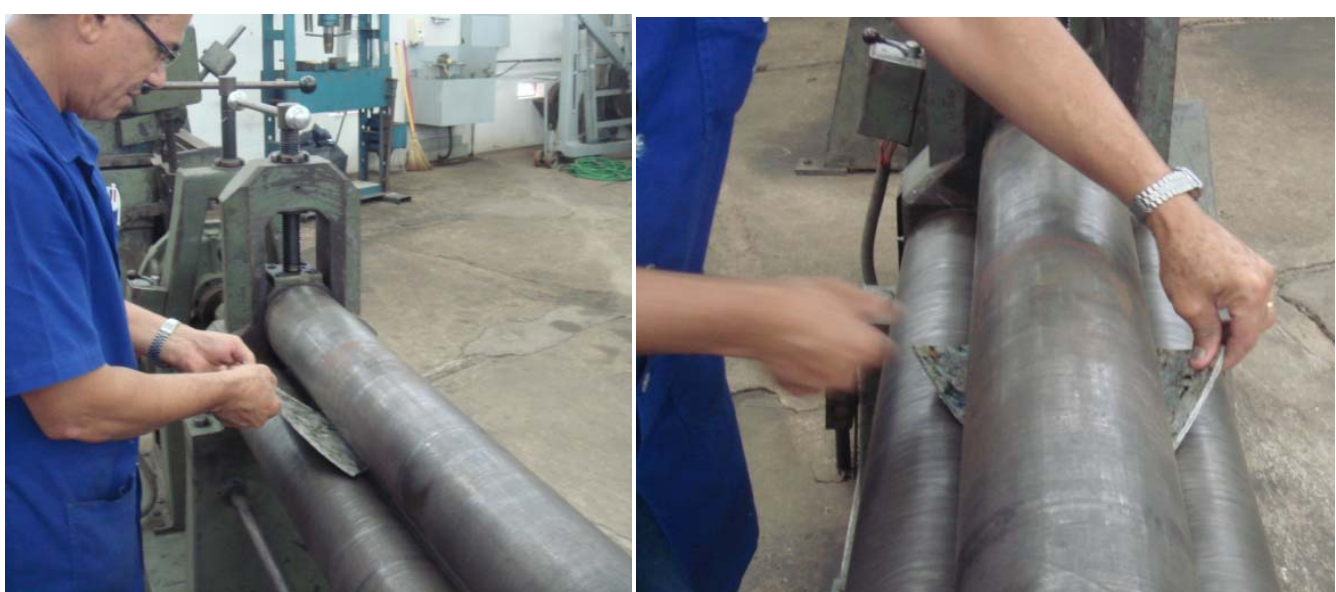

Figura 5.14 : Placa reciclada sendo curvada em Calandra Departamento de Engenharia Mecânica da EESC - USP Fonte: Foto da autora, 2010.

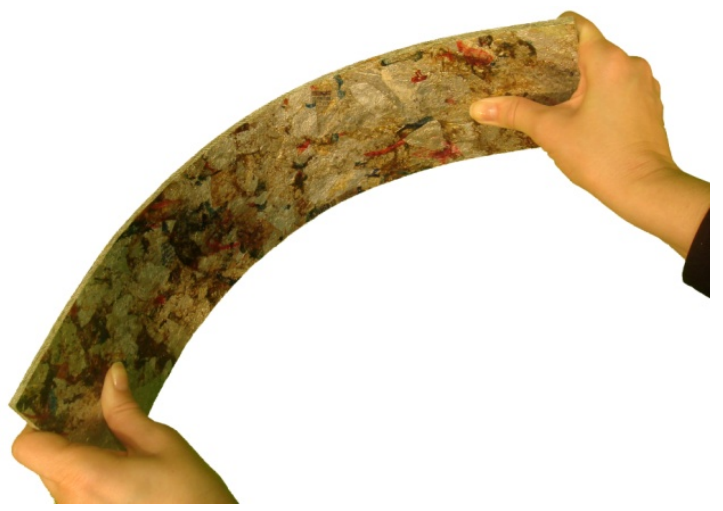

Figura 5.15: Placa reciclada sendo curvada manualmente. Fonte: Foto da autora, 2011. 


\subsection{2 - Cortes e perfurações.}

Assim como as madeiras reconstituídas, como o compensado, aglomerado, MDF e OSB, as placas recicladas de materiais plásticos e as de plástico e alumínio são trabalhadas com os mesmos equipamentos de cortes e perfurações. Tanto nas marcenarias como na construção civil, em muitos casos já substitui a madeira, um exemplo bastante evidente é o uso como tapume. A seguir algumas possibilidades de trabalho com as placas.

Quadro 5.2: Trabalhabilidade das Placas Recicladas de Embalagens Longa Vida.

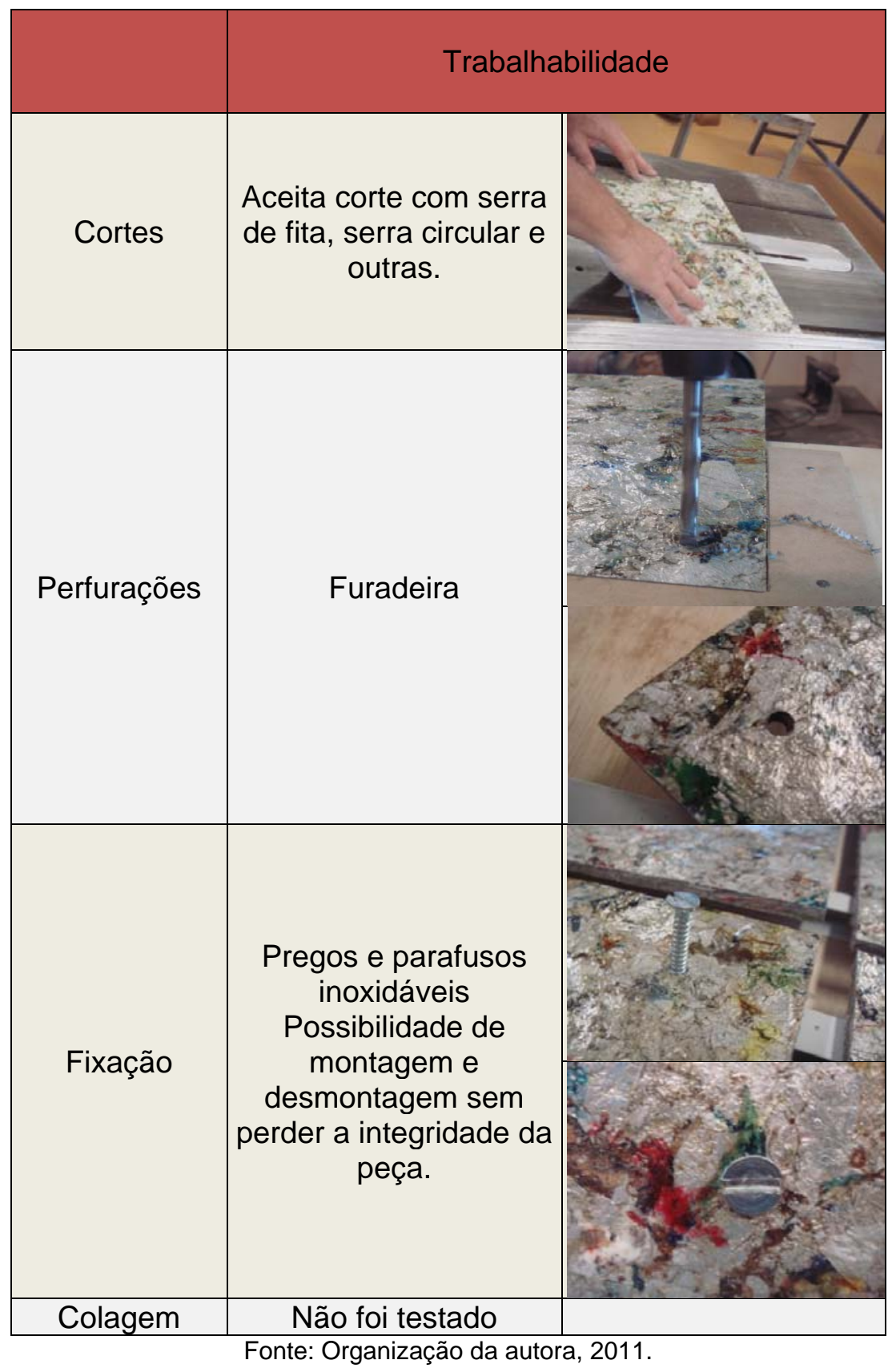




\subsection{3 - Estudos de modulações e formas.}

A variedade possível de cortes é imensa, não sendo conveniente demonstrar todas nesse trabalho, porém, como referência pode-se ver no quadro 5.3, onde as placas são moduladas em diversas medidas, de $60 \mathrm{~cm}$ a $10 \mathrm{~cm}$. A partir dessas modulações, incluindo também o próprio tamanho integral da placa, é possível imaginar soluções para tamanhos quadrados e retangulares variados.

O estudo das possibilidades de corte da placa, tendo como referência os cortes padrão dos materiais encontrados no mercado (como os quadrados e retangulares das cerâmicas, o "tabuado" das madeiras, ou as grandes placas dos cimentícios), é uma busca por sua potencialidade para composições em superfícies, ou mesmo em objetos. A característica de flexibilidade das placas é um forte diferencial em relação à outras várias placas recicladas. Propicia trabalhos curvos em diversas direções. Assim, foram feitos alguns estudos em curvas (quadro 5.4), o que pode ser referencial para placas como revestimento ou na função vedação. Este potencial também pode ser aproveitado para coberturas curvas, assim também como para o design de objetos. 
Quadro 5.3: Módulos - aproveitamento de corte das placas recicladas $(110 \times 220 \mathrm{~cm})$

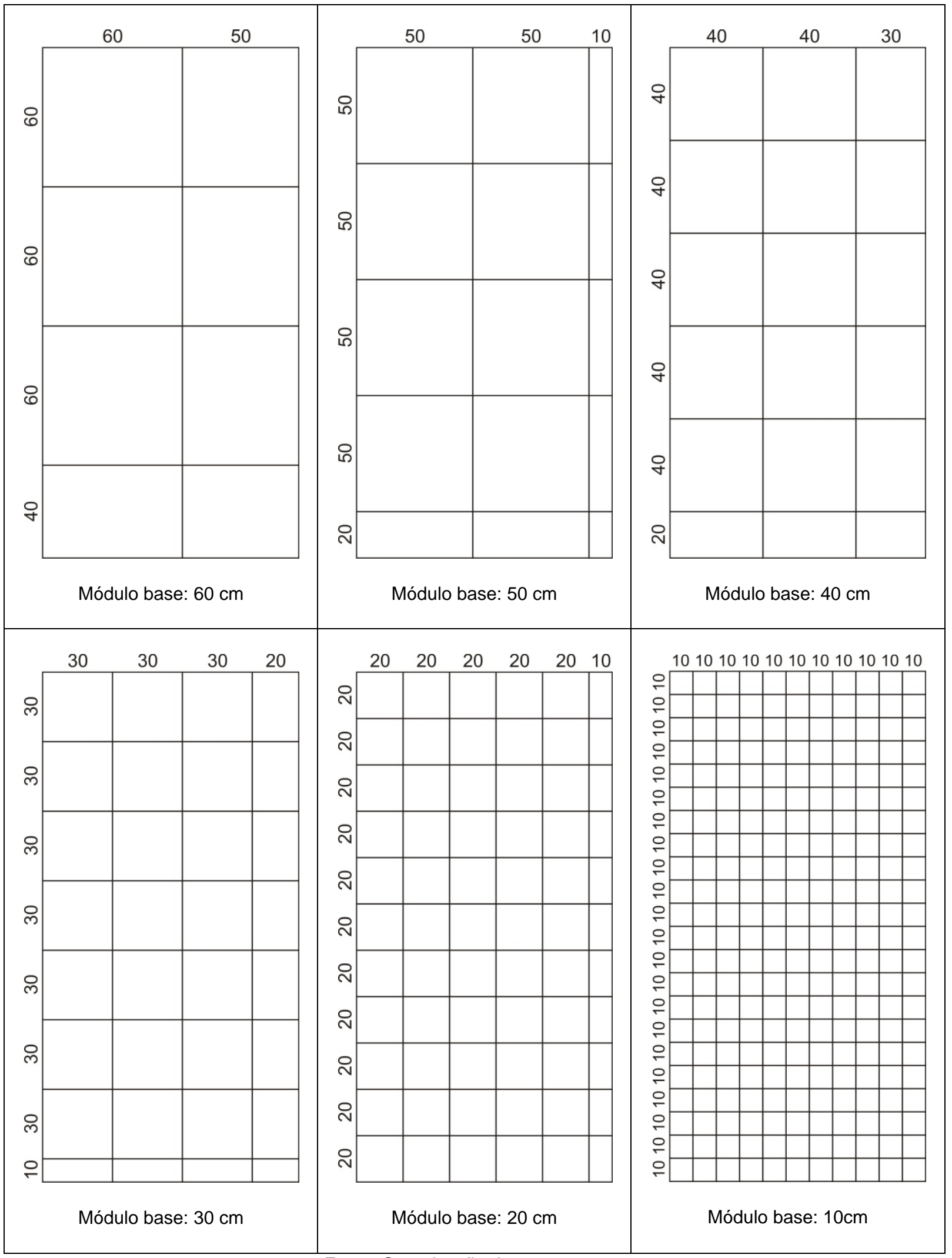

Fonte: Organização da autora, 2011. 
Quadro 5.4: Estudos de composição com placas quadradas curvadas.

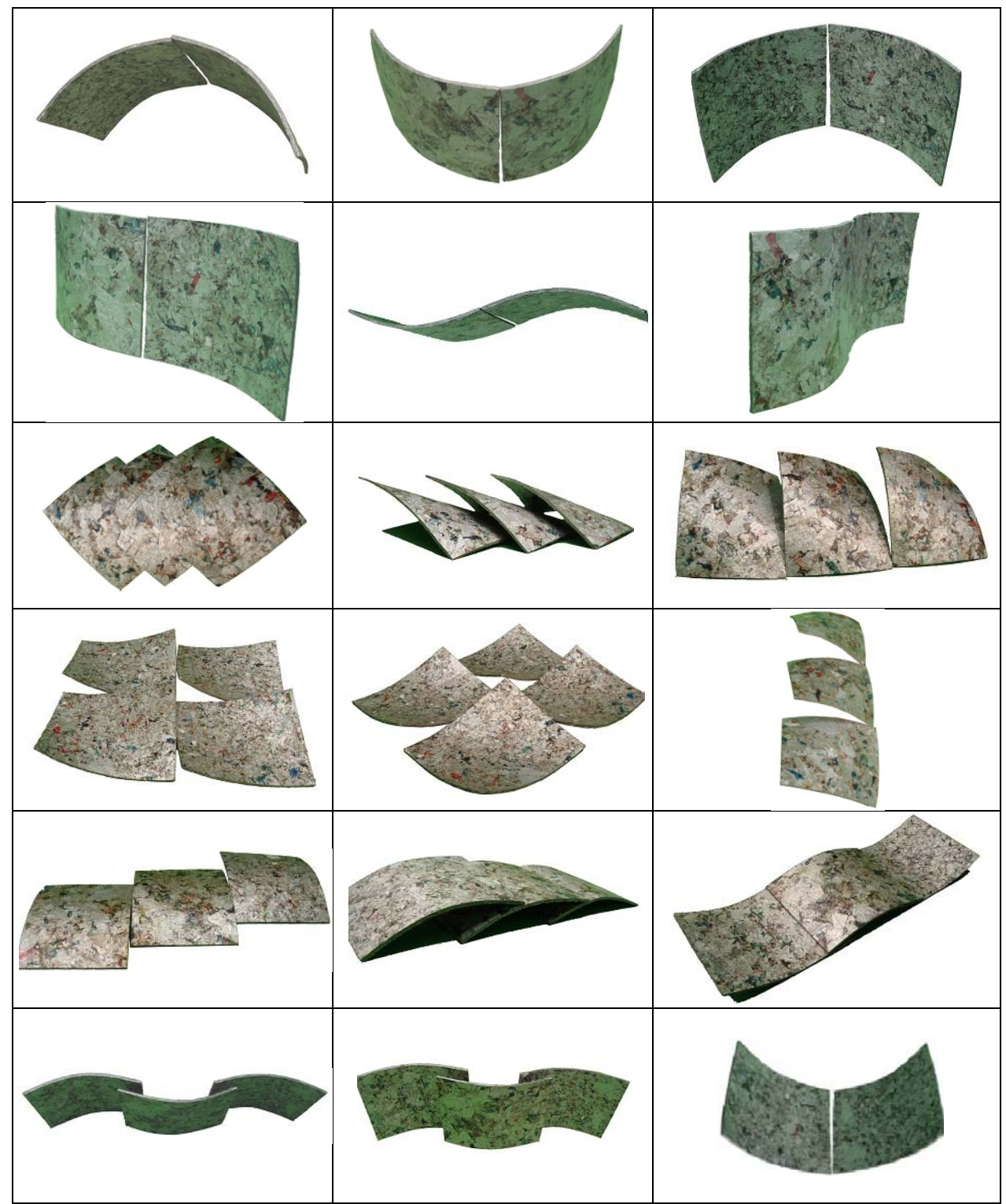

Fonte: Montagens e fotos da autora, 2010.

\subsection{4 - Estudo de placas sobre superfície.}

O estudo com placa sobre a superfície foi iniciado com a intenção de verificar uma solução construtiva das placas sobre perfil metálico comercial (perfil $U$ ), uma versão muito simplificada dos perfis utilizados para dar suporte aos revestimentos em fachadas ventiladas (imagens no capítulo seguinte). A idéia foi identificar se o uso destes perfis seriam resistentes para manter as placas recicladas em superfícies externas. Para isto seria realizado um ensaio em túnel de vento. Essa idéia foi abandonada quando o caminho da pesquisa foi redirecionado para a abordagem do design e de possibilidades projetuais. 
Para aproveitar o estudo, enquanto análises de composição e construtiva, abaixo são organizadas algumas figuras que demonstram o processo de execução do protótipo.

As placas foram aplicadas na superfície na forma quadrada e através de fixação em perfil metálico (quadro 5.5). A organização das placas na superfície mantém um espaço de aproximadamente $0,5 \mathrm{~cm}$ entre uma placa e outra. Isso não seria um problema, em uma fachada, onde a superfície fosse impermeabilizada antes da aplicação das placas como revestimento. Em fachadas ventiladas, muitos materiais são colocados mecanicamente dessa maneira.

Quadro 5.5 : Estudos de possibilidade construtiva com uso das placas recicladas

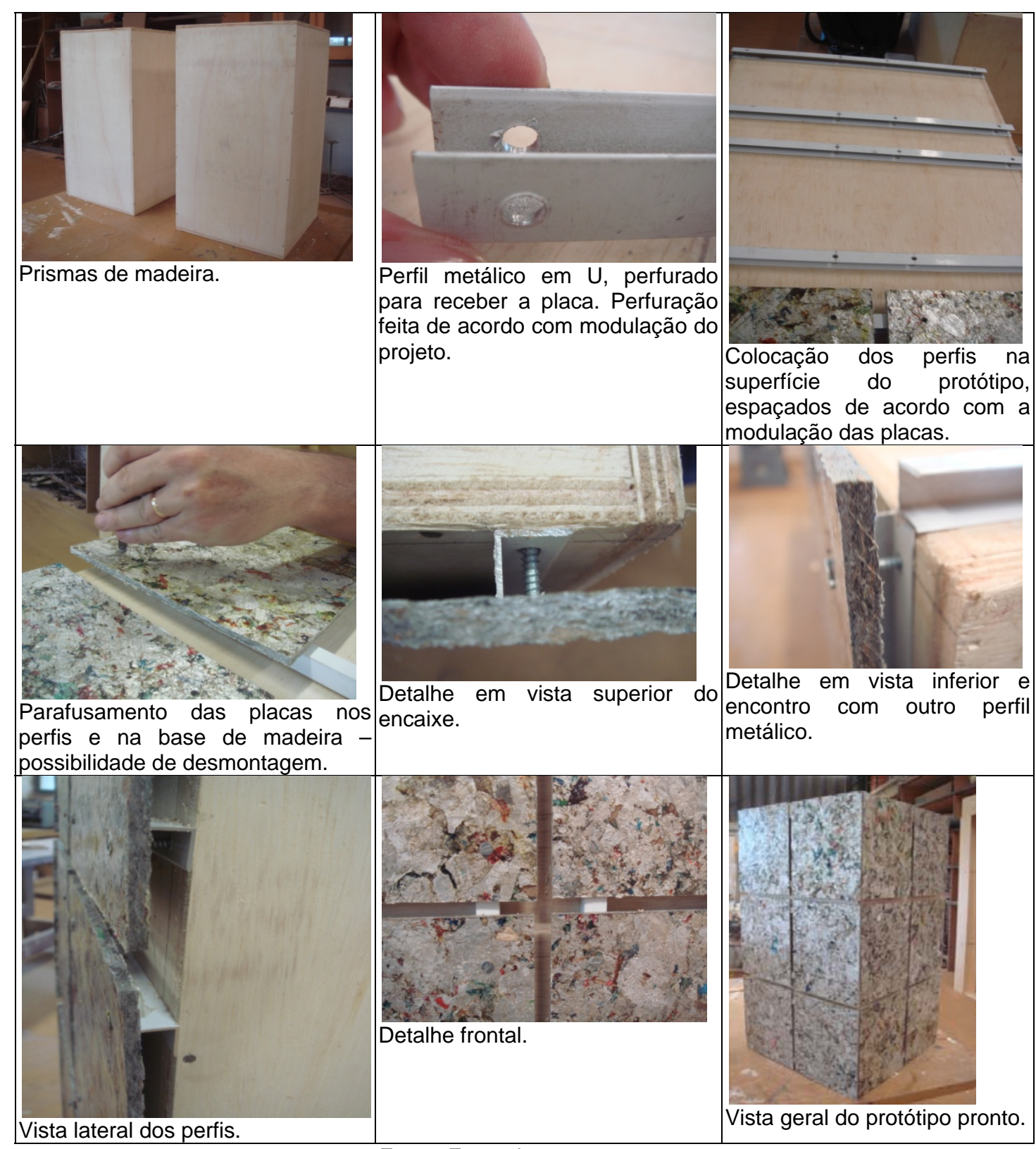

Fonte: Fotos da autora, 2010. 

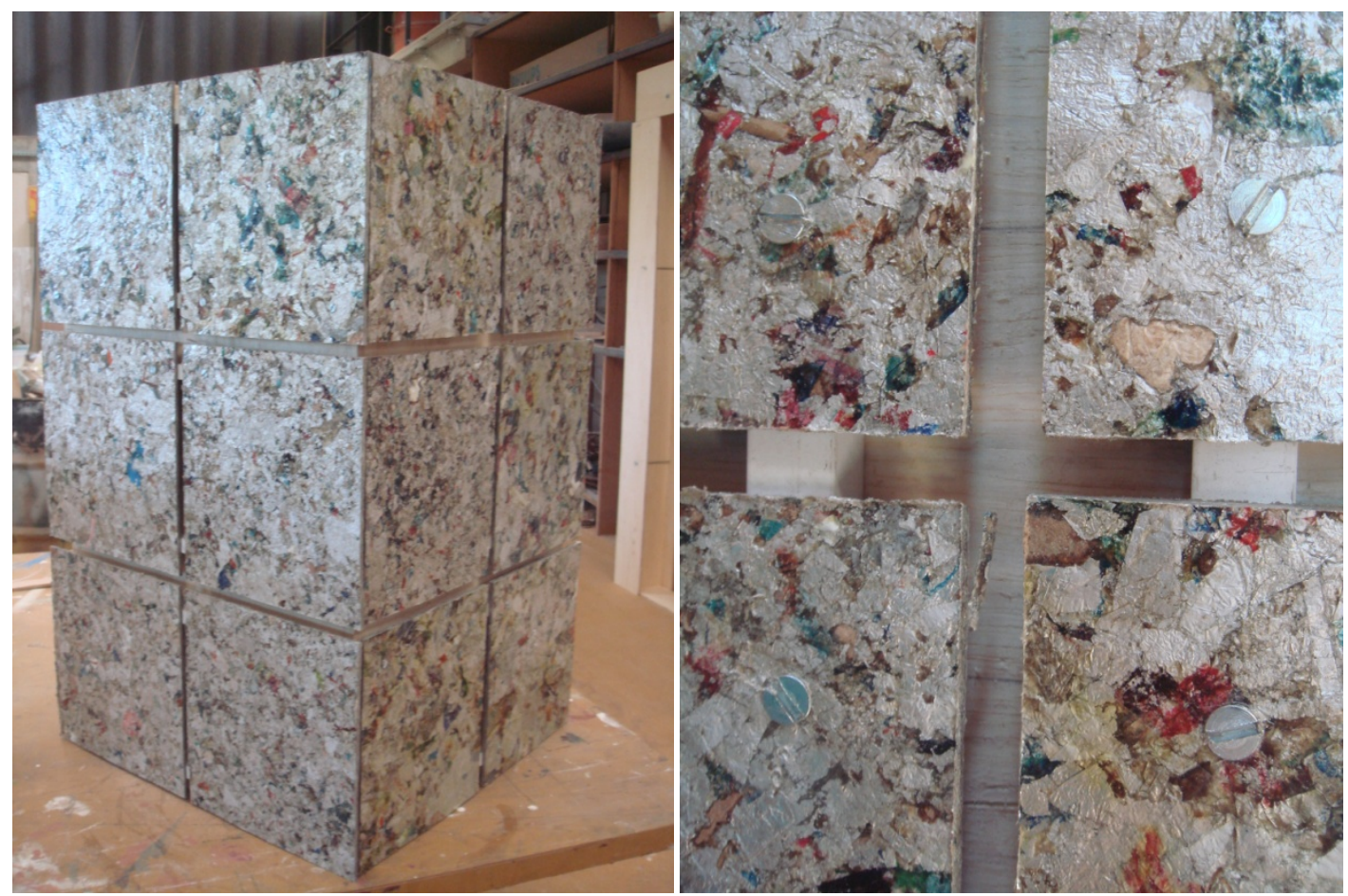

Figura 5.16 : Protótipo final e detalhe da fixação com parafusos inoxidáveis. Fonte: Foto da autora, 2010.

Percebe-se no protótipo, observado a uma certa distância, que os elementos de fixação (parafusos inoxidáveis) se camuflam na estampa das placas. Obviamente, por ter a mesma tonalidade de cor do alumínio, presente na placa. Isso pode ser um ponto positivo, já que um elemento de fixação aparente normalmente incomoda o observador.

\section{4 - Design enquanto possibilidades}

Algumas peças feitas com plástico reciclado são semelhante às Placas Recicladas de Embalagens Longa Vida. Podem ser referenciais para design, já que assemelham-se em características, como espessura, textura, flexibilidade (que possibilita desenhos em curvas), dimensões e possibilidades de cortes e fixação. Construtivamente são referências alternativas para composição em ambientes e acabamento entre as placas. As imagens abaixo são design de Bär+Knell, um estúdio de design alemão que produz peças com reciclados de plásticos. 


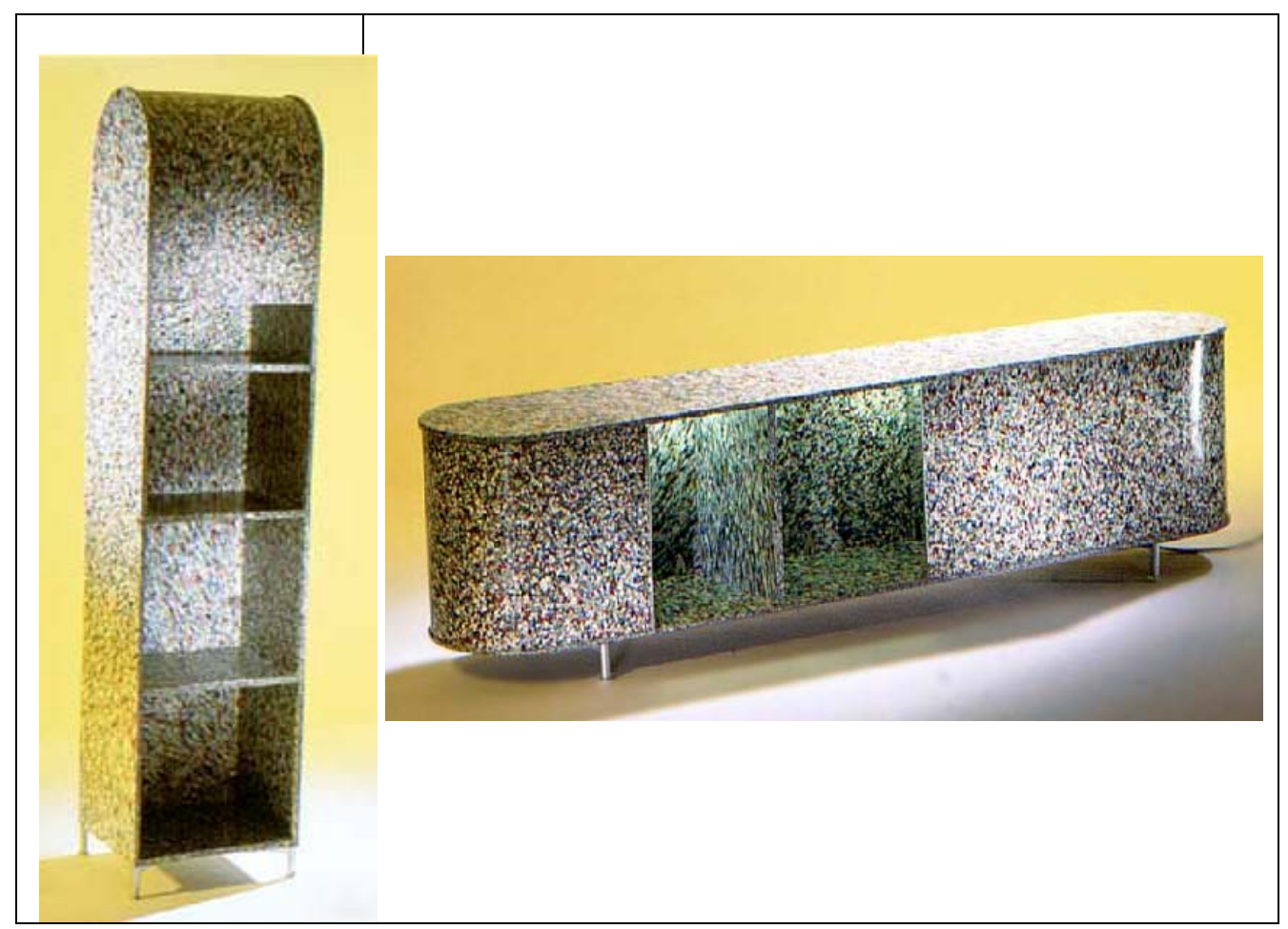

Figura 5.17: Possibilidades de design: Prateleira e Cômoda de plástico reciclado. Fonte: Fonte: Baer-Knell (2010)

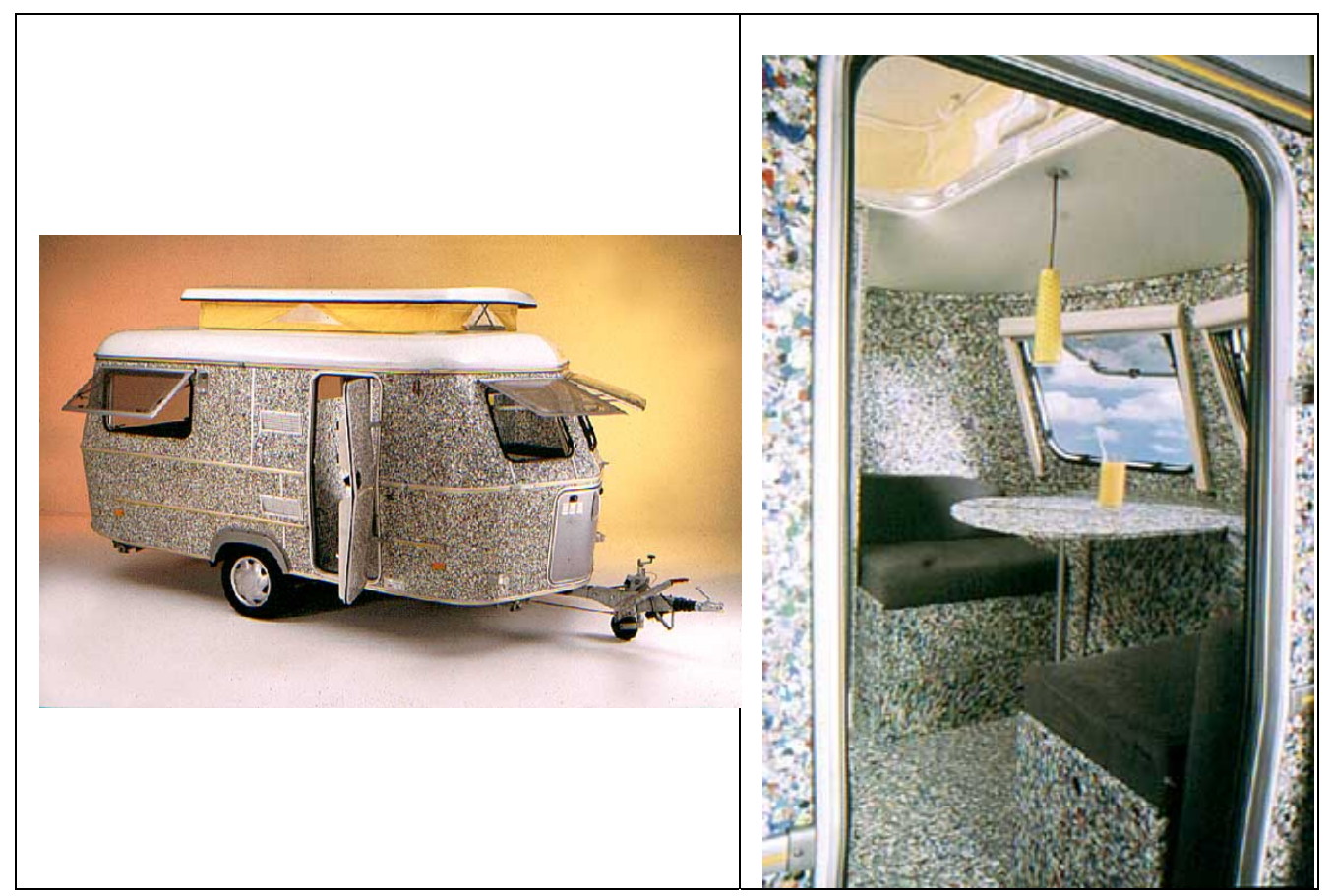

Figura 5.18: Wohnwagen - veículo com material reciclado. Fonte: Baer-Knell (2010) 


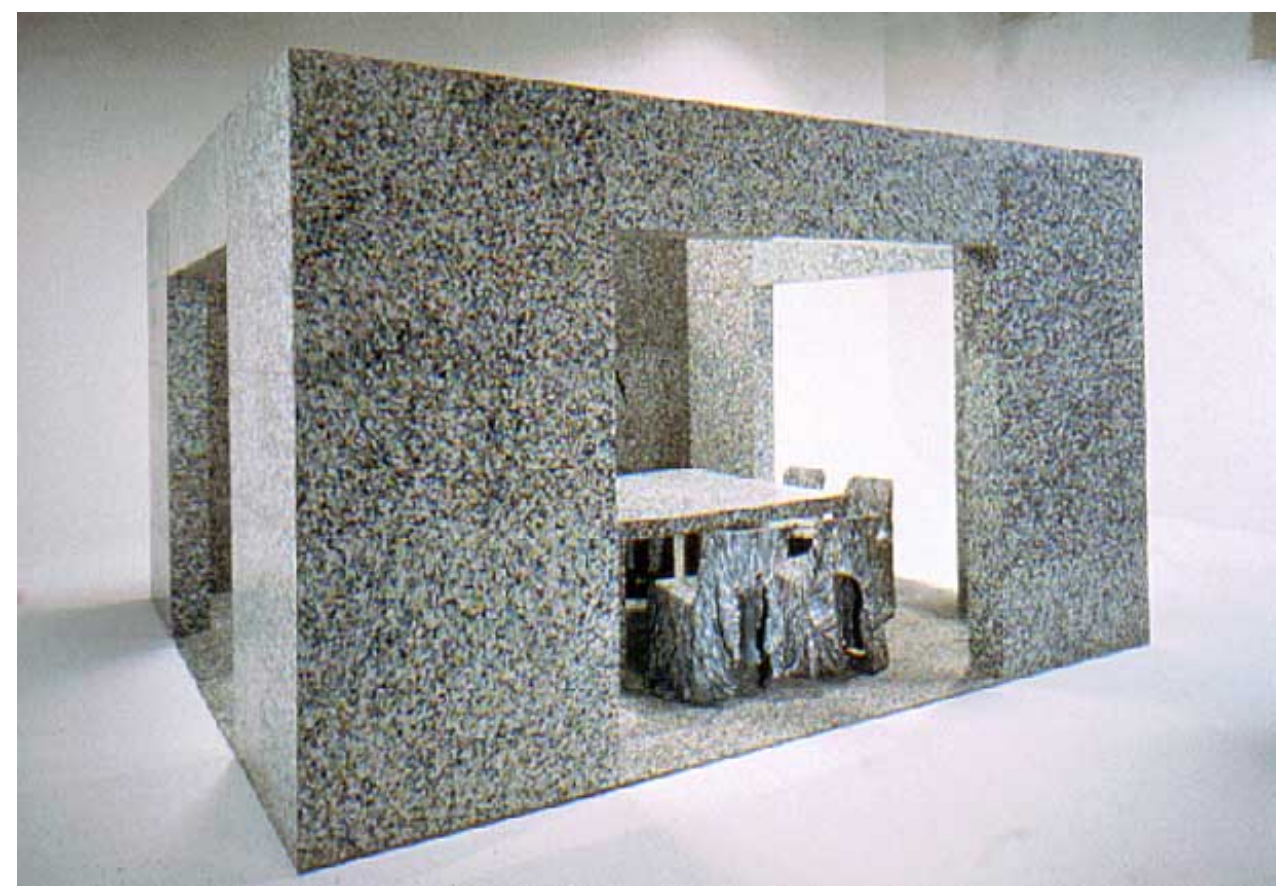

Figura 5.19: Kubus - Instalação com painéis de placas recicladas de embalagens plásticas - Design Baer-Knell. Exposição "Re(f)uso" de 1997

Fonte: Baer-Knell (2011)

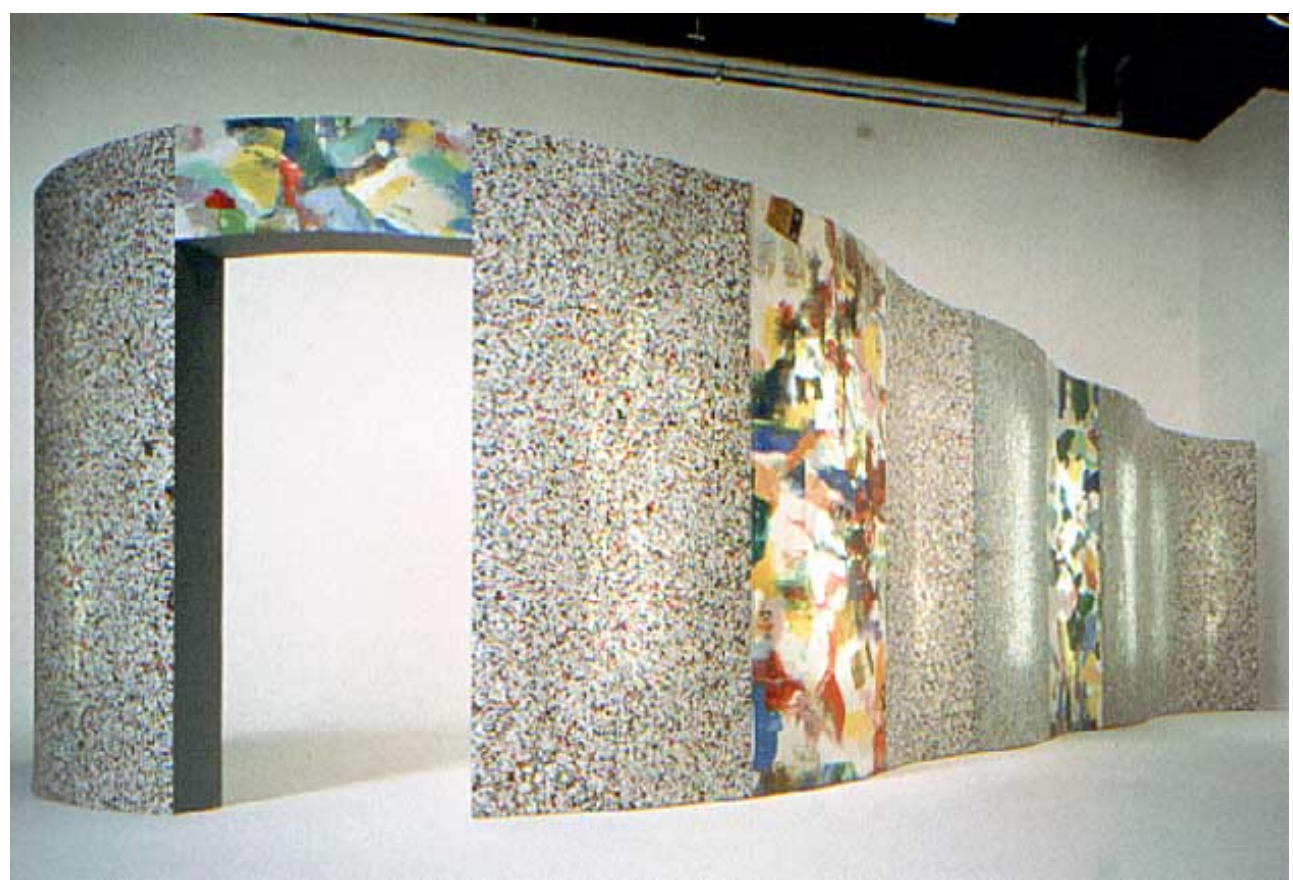

Figura 5.20: Rotunde - Instalação com painéis de placas recicladas de embalagens plásticas - Design BaerKnell. Exposição de 1996

Fonte: Baer-Knell (2011) 


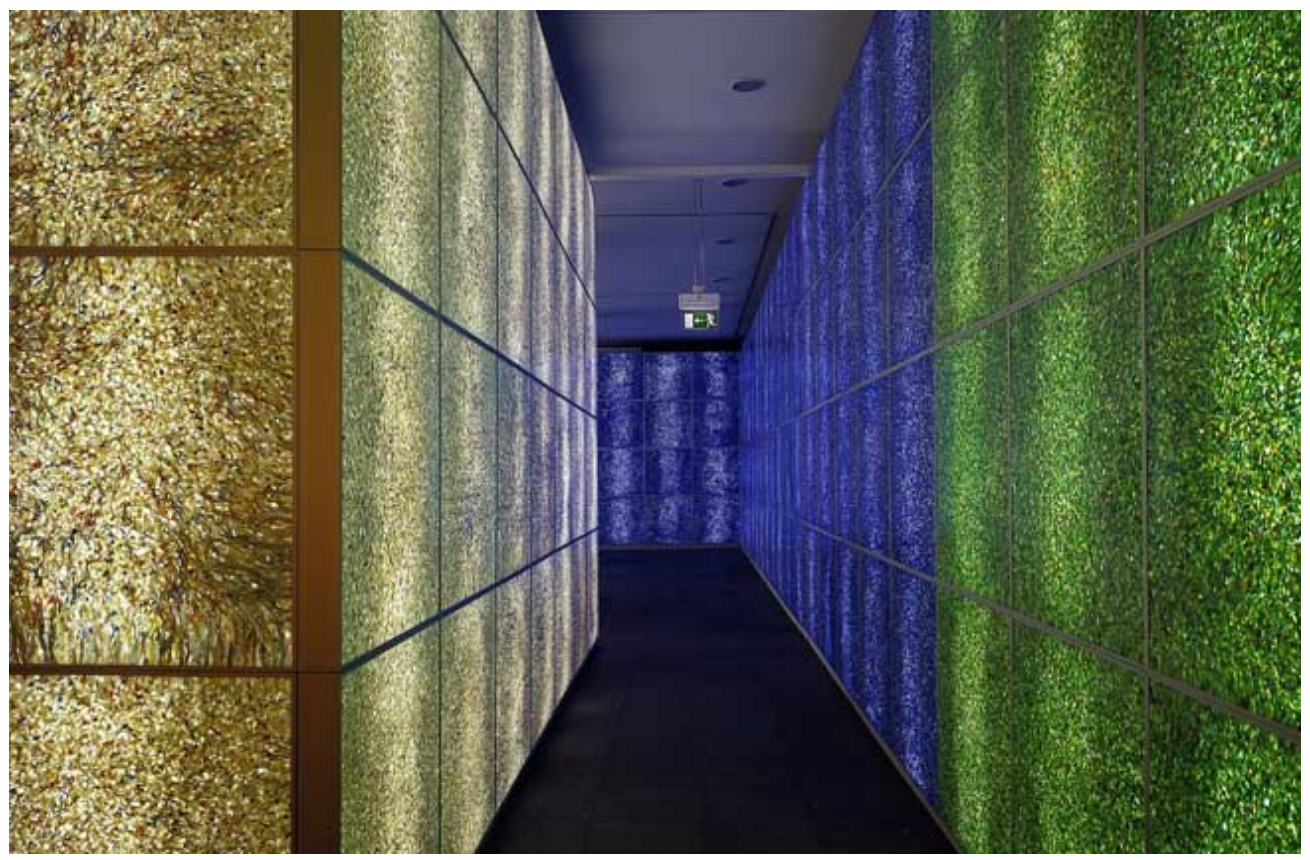

Figura 5.21: Ambiente com painéis de placas recicladas proveniente de embalagens plásticas - Design BaerKnell. Instalação "Cores do Consumo" - Düsseldorf. Fonte: Baer-Knell (2011)

\section{5 - Resultados e discussões - caracterização estética}

A partir das análises feitas anteriormente, é proposta a seguinte classificação estética para as Placas Recicladas de Embalagens Longa Vida: quanto aos elementos visuais (tabela 5.1) e indicativos para composições com outros materiais (tabela 5.2). 
Tabela 5.1: Classificação quanto aos elementos visuais

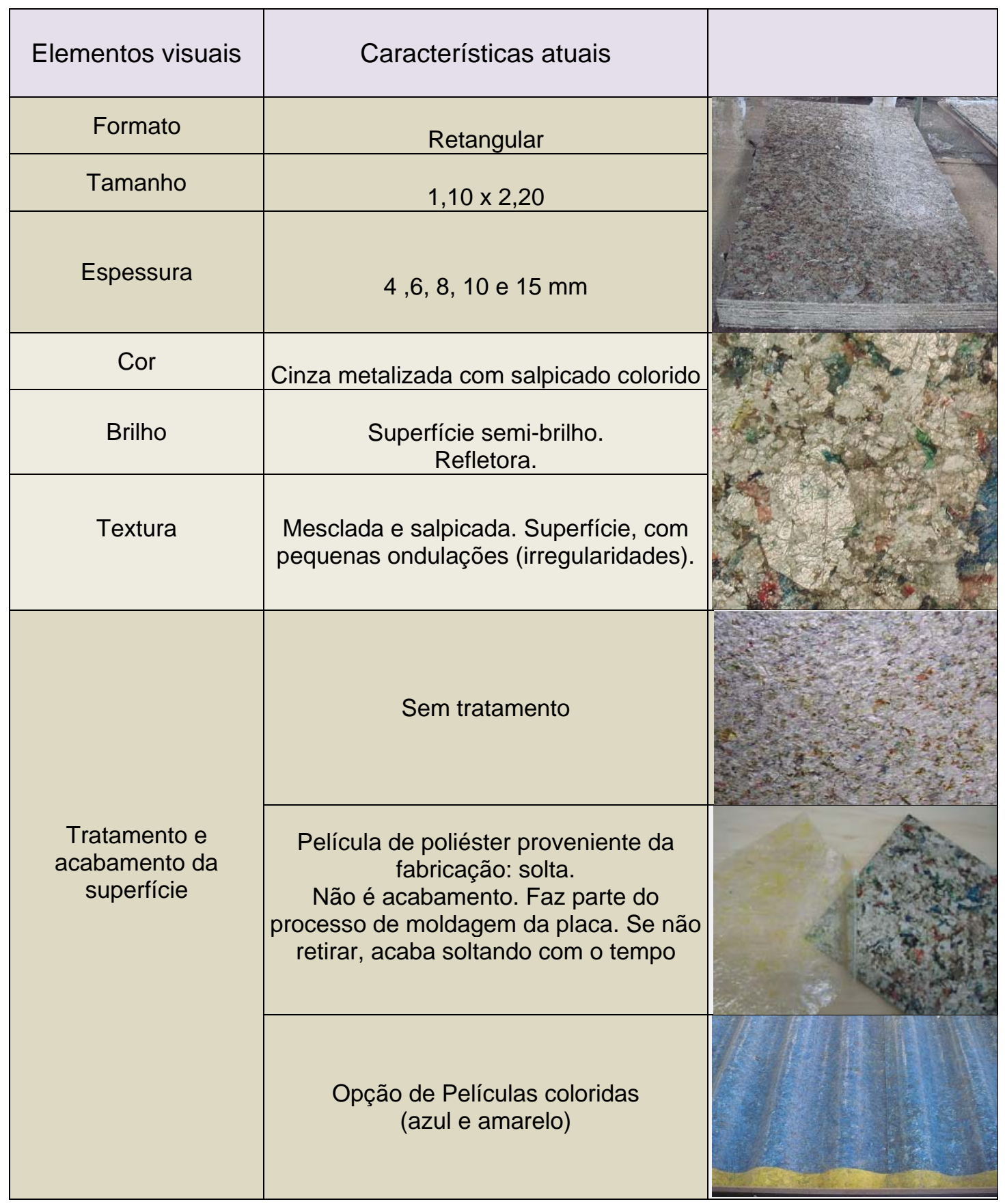

Fonte: Organização da autora, 2011. 
Tabela 5.2: Indicativo de relações estéticas.

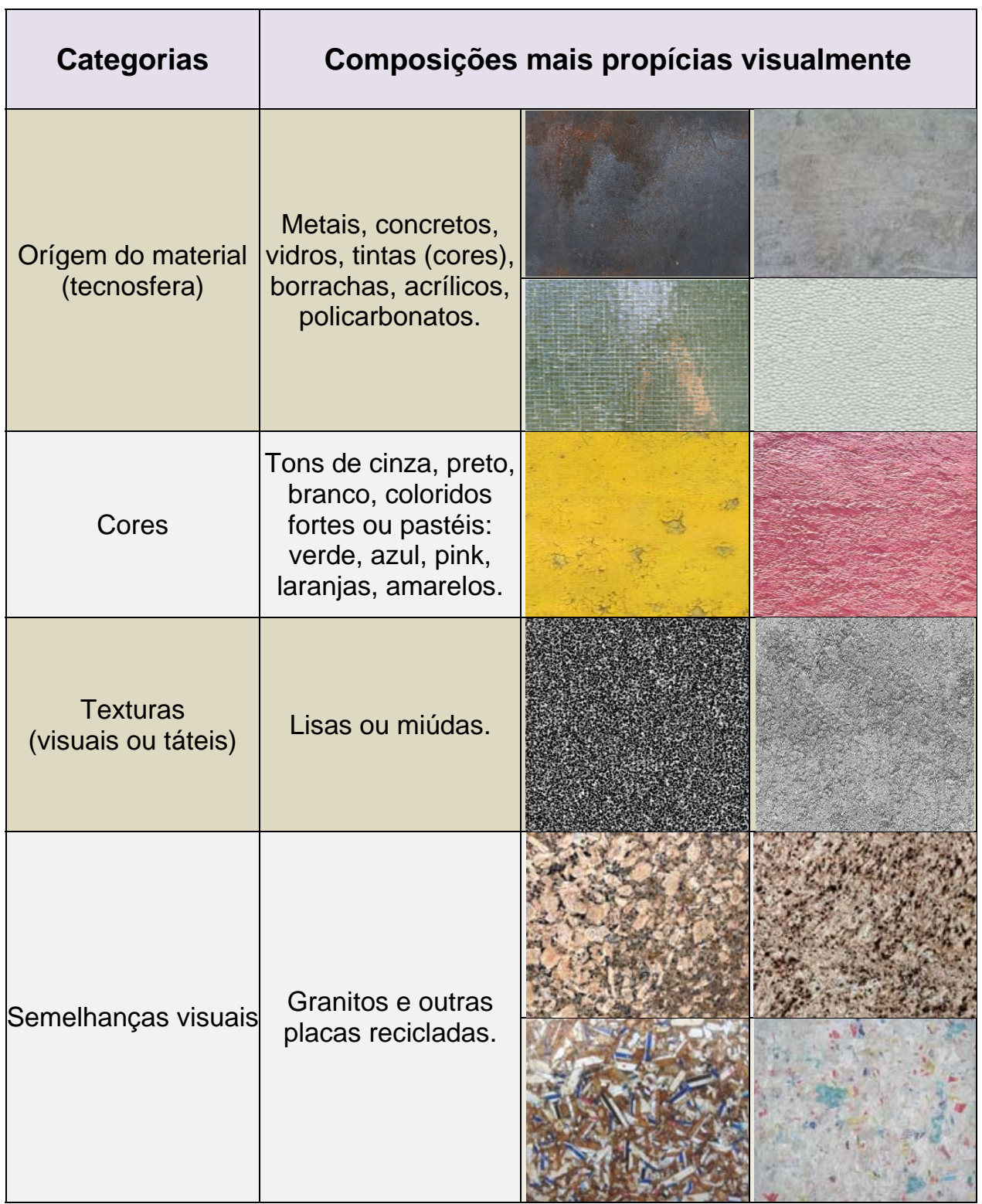

Fonte: Organização da autora, 2011.

Esse "mostruário" de características e opções de composições permite observar as placas através de um panorama estético, mais criterioso do que simplesmente olhar para o material individualmente. Com esses resultados foi possível criar um processo de identificação dos pontos fortes e fracos das placas. Foi essencial para as decisões dos projetos apresentadas no capítulo seguinte. Escolher com referenciais visuais enriquece o processo e gera caminhos projetuais mais assertivos. 


\section{6 -PROPOSTAS PROJETUAIS}

As análises estéticas e os estudos compositivos entre materiais proporcionaram o desenvolvimento de um "raciocínio projetual" que facilitou a visualização das possibilidades de composição. Da mesma forma, as características técnicas direcionaram as possibilidades de uso nas variadas superfícies. Esse capítulo apresenta algumas maneiras de articular essas composições materiais, através de três soluções de projeto.

\section{1 - Metodologia de projeto}

As diretrizes tomadas para definição do projeto têm como referência as análises feitas nos capítulos anteriores e nas "ações para um projeto sustentável" propostas por Edwards (2008). Também importante referência as "coordenadas para aplicação prática do metaprojeto" apresentada por Moraes (2010). São elas:

- Projetar visando a durabilidade.

- Possibilitar a substituição das partes.

- Emprego de materiais reciclados/reutilizados/reutilizáveis/recicláveis.

- Facilmente substituídos.

- Uso de materiais locais.

- Sistema flexível - desmontável e remontável.

- Simplicidade operacional.

- Utilização de poucas matérias-primas no mesmo produto: maior economia de uso dos materiais utilizados e maior facilidade para o processo de reciclagem.

- Uso de materiais compatíveis entre si - evitar adesivagens, laminações, entre outros, que dificultem o desmembramento para reciclagem.

- Facilidade no desmembramento e na substituição dos componentes. 
Para atender esses requisitos foi definido exclusivamente que as melhores opções seriam as composições com fixação mecânica, descartando as possibilidades de sistemas com fixação com colas ou argamassas. O uso de sistemas de fixação com adesivos e argamassas dificultaria o processo de recuperação das placas para reuso.

As diretrizes técnicas e estéticas foram:

- Design da forma das placas.

- Valorização da textura compondo superfícies com outros materiais de forma harmônica.

- Valorização da textura através da iluminação.

- Uso de acabamento nas peças: perfis metálicos por exemplo.

- Uso dos sistemas construtivos existentes como partidos para criação de componentes com as placas. São exemplos:

o Sistemas de vedações internas tipo Drywall

o Sistemas de vedações externas tipo Steel Frame.

o Sistemas de cobertura metálica com camadas isolantes - Foil, mantas termo acústicas, sanduíches com polipropileno.

$\mathrm{Na}$ elaboração de projetos, a materialidade representa uma pequena, porém importante, fração das decisões projetuais. Por esta pesquisa tratar especificamente de um único material reciclado, a metodologia adotada toma como referência projetual esta materialidade. É proposta uma sequência de análises e projetos que partem do design do "micro" (peças e componentes) para o design do "macro" (o edifício). A relação entre o material (placas) e o edifício foi fracionada em diversas fases; desde a placa enquanto objeto fornecido pela fábrica, assim como os cortes dessa placa, que podem gerar novos componentes. As placas, ou cortes das placas, aplicadas formam o design das superfícies e essas, em conjunto, irão compor o design do todo arquitetônico. Essas etapas de evolução do design são, paralelamente, respaldadas pelos referenciais técnicos e estéticos, como apresentados nos capítulos anteriores. A demanda projetual de cada uma dessas etapas é apresentada na tabela 6.1. Os croquis dos projetos encontram-se no Apêndice E. 
Tabela 6.1: Aspectos técnicos e estéticos.do design: material, componente, superfície e edifício.

\begin{tabular}{|c|c|c|}
\hline Design & Estético & Técnico \\
\hline $\begin{array}{c}\text { Design do Material } \\
\text { (Objeto Placa) }\end{array}$ & $\begin{array}{c}\text { Textura, cores, dimensões } \\
\text { (largura, comprimento e } \\
\text { espessura.), formato e função. }\end{array}$ & $\begin{array}{c}\text { Propriedades e } \\
\text { Características técnicas. }\end{array}$ \\
\hline $\begin{array}{c}\text { Design do Componente } \\
\text { (Objeto construtivo) }\end{array}$ & $\begin{array}{c}\text { Textura, cores, dimensões } \\
\text { (largura, comprimento e } \\
\text { espessura.), formato e função. }\end{array}$ & $\begin{array}{c}\text { Propriedades e } \\
\text { Características técnicas. }\end{array}$ \\
\hline $\begin{array}{c}\text { Design da Superfície } \\
\text { (Paredes, forros, } \\
\text { coberturas e pisos) }\end{array}$ & $\begin{array}{c}\text { Modulação e paginação: } \\
\text { padronagem } \\
\text { Proporções: módulo x superfície. } \\
\text { Composições materiais: efeito e } \\
\text { comunicação visual. }\end{array}$ & $\begin{array}{c}\text { Adequação aos sistemas } \\
\text { construtivos existentes. } \\
\text { Possibilidade de criação de } \\
\text { sistemas específicos. } \\
\text { Encaixes, acabamento e } \\
\text { vedações. }\end{array}$ \\
\hline $\begin{array}{c}\text { Design do Edifício } \\
\text { (Objeto arquitetônico) }\end{array}$ & $\begin{array}{c}\text { Material enquanto e identidade. } \\
\text { Percepção sensorial } \\
\text { Partido, estilo, época. }\end{array}$ & $\begin{array}{c}\text { Proteção. } \\
\text { Funcionamento dos } \\
\text { sistemas. }\end{array}$ \\
\hline
\end{tabular}

Fonte: Organização da autora, 2011.

Definido este princípio, foram gerados alguns resultados projetuais:

1. Identificação de materiais: compatibilidades estéticas entre a placa reciclada e outros materiais. (identificadas no capítulo anterior)

2. Design da peça / design de componentes: identificação das possibilidades de trabalhabilidade com as placas. (analisadas no capítulo anterior)

3. Especificação de sistemas possíveis: Identificação de sistemas construtivos que possam servir construtivamente para aplicação das placas recicladas.

4. Design de superfícies: algumas possibilidades de design de superfícies com uso das placas.

5. Design de objetos: objetos complementares

6. Propostas projetuais - Possibilidades arquitetônicas com o uso das placas recicladas. 


\section{2 - Sistemas construtivos possíveis}

As etapas 1 e 2 foram abordadas no capítulo anterior. Segue então um elenco de sistemas construtivos que podem receber as Placas Recicladas de Embalagens Longa Vida. Os desenhos da figura 6.1 e os protótipos do quadro 6.1 são referências construtivas que indicam possibilidades de uso com as placas recicladas, tanto na forma plana como curva.

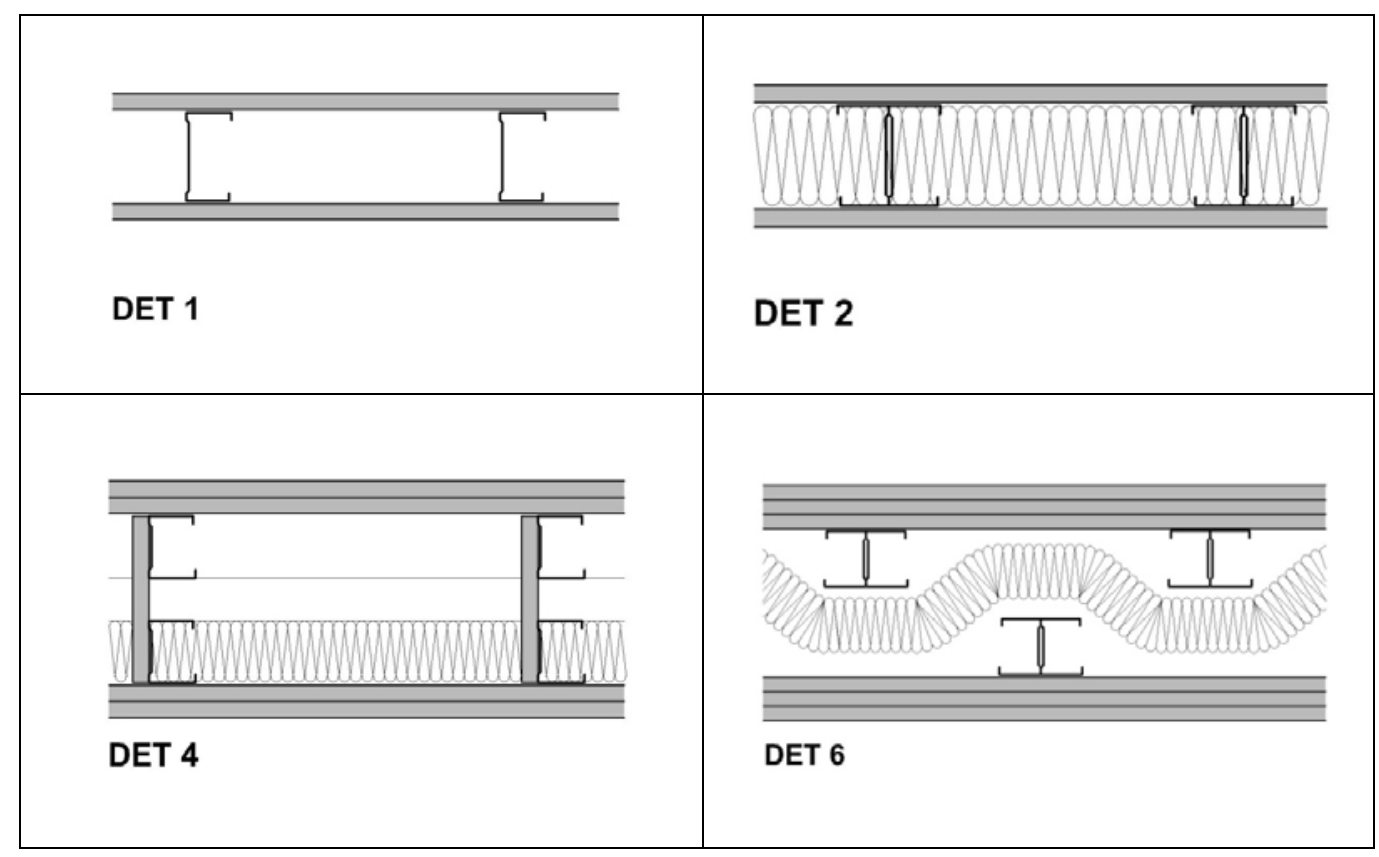

Figura 6.1: Detalhes em planta de sistemas Drywall. Fonte: DRYWALL (2011). 
Quadro 6.1: Sistemas construtivos de referência para projeto.

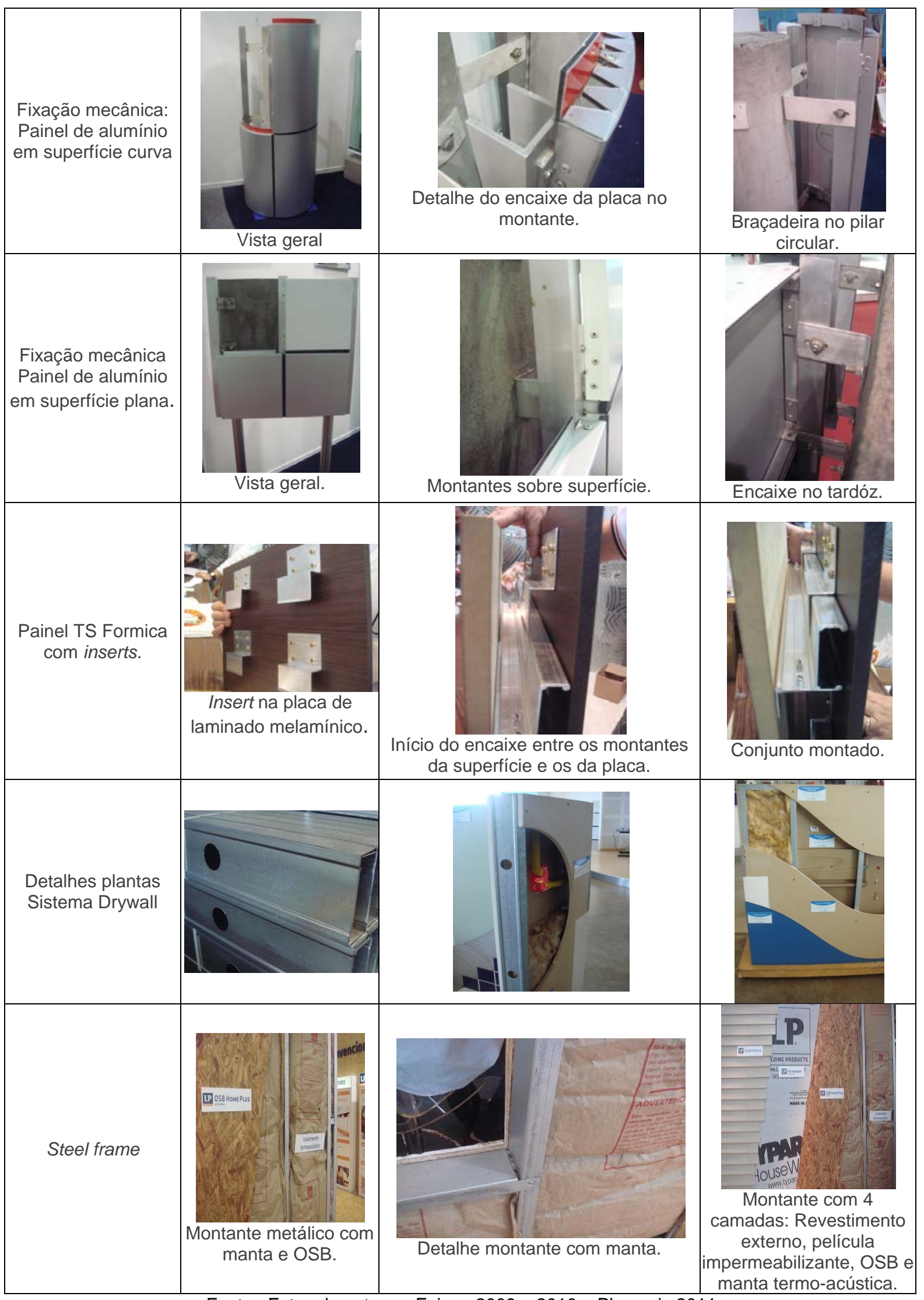

Fonte: Fotos da autora - Feicon 2009 e 2010 e Placomix 2011. 
Quadro 6.2 - Possibilidades projetuais com Placas Recicladas de Embalagens Longa Vida.

\begin{tabular}{|c|c|c|c|}
\hline & & Sistema Existente & Proposta \\
\hline \multirow[t]{3}{*}{ Interno } & \multirow[t]{2}{*}{ Parede } & $\begin{array}{l}\text { Fechamento Drywall. } \\
\text { Montantes metálicos. } \\
\text { Montantes de madeira. }\end{array}$ & $\begin{array}{c}\text { Uso das placas recicladas em } \\
\text { substituição ao gesso acartonado. } \\
\text { Opções: uso de placas inteiras, no } \\
\text { mesmo padrão do sistema drywall. } \\
\text { Ou uso de placas cortadas em } \\
\text { paginação variada, com diferentes } \\
\text { tamanhos, com parafusos visíveis. } \\
\text { Possibilidade de trabalho em } \\
\text { relevo, através da sobreposição das } \\
\text { placas. }\end{array}$ \\
\hline & & $\begin{array}{l}\text { Revestimento com placas } \\
\text { de gesso acartonado } \\
\text { diretamente sobre a } \\
\text { alvenaria. }\end{array}$ & $\begin{array}{l}\text { Substituição com as placas } \\
\text { recicladas, no modo padrão ou } \\
\text { criando paginações, como descrito } \\
\text { acima, porém aplicadas } \\
\text { diretamente sobre a alvenaria. }\end{array}$ \\
\hline & Teto & $\begin{array}{c}\text { Forro de gesso } \\
\text { acartonado, com } \\
\text { montantes metálicos. } \\
\text { Os forros são variados - } \\
\text { podem ser encontrados } \\
\text { com perfurações variadas } \\
\text { e de diversas dimensões }\end{array}$ & $\begin{array}{l}\text { Possibilidade de uso de placas } \\
\text { recicladas. Possibilidade de } \\
\text { tratamento da placa com } \\
\text { perfurações, sobreposições. }\end{array}$ \\
\hline \multirow[t]{4}{*}{ Externo } & \multirow[t]{4}{*}{ Paredes } & Steel frame & Substituição com placas recicladas \\
\hline & & $\begin{array}{l}\text { Revestimento com } \\
\text { fixação mecânica. }\end{array}$ & $\begin{array}{l}\text { Referência no "TS fórmica", no } \\
\text { alumínio e na cerâmica. }\end{array}$ \\
\hline & & Siding. & $\begin{array}{l}\text { Organização de paginação em } \\
\text { forma de siding. }\end{array}$ \\
\hline & & $\begin{array}{l}\text { Brises horizontais e } \\
\text { verticais. }\end{array}$ & Uso de peças com cantoneiras. \\
\hline
\end{tabular}

Fonte: organização da autora, 2011. 


\section{3 - Estudos de aplicação em Superfícies}

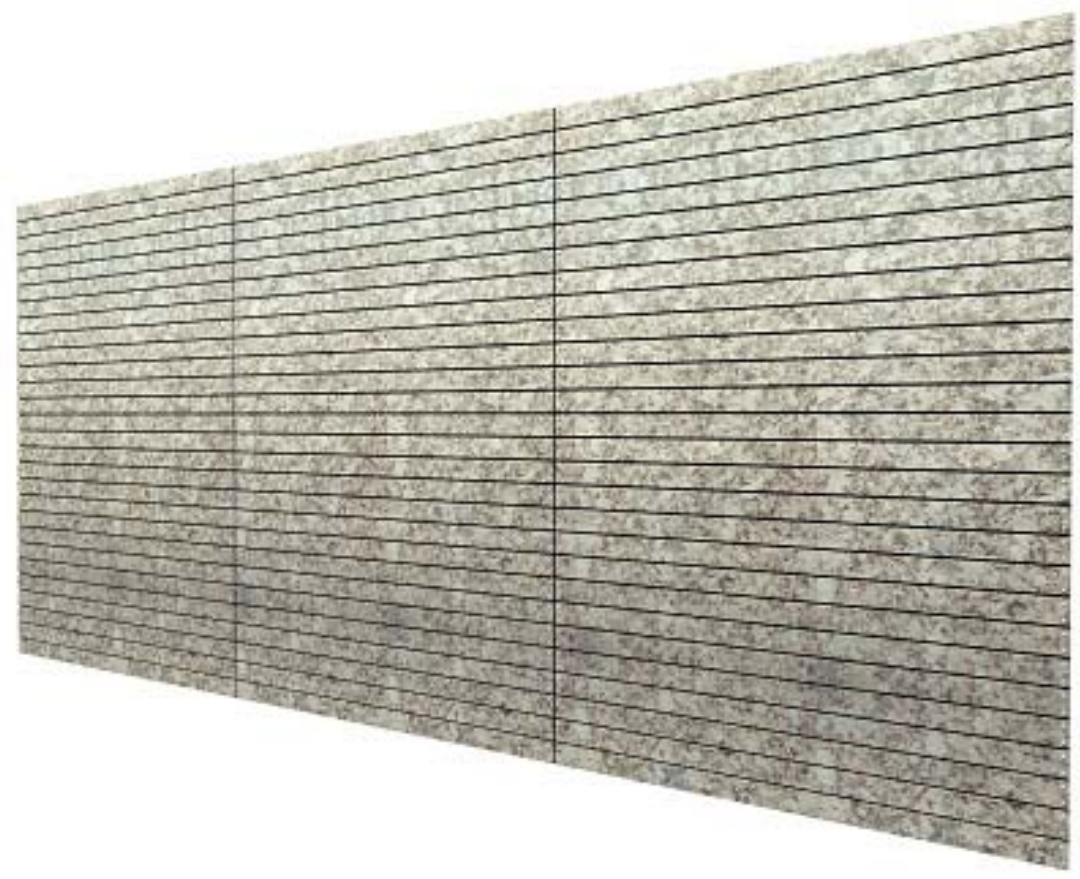

Desenho 6.1 : Painel com tabuado de Reciclado Longa Vida - Paginação Horizontal. Fonte: Criação da autora. Desenho de Albano ${ }^{1}$.

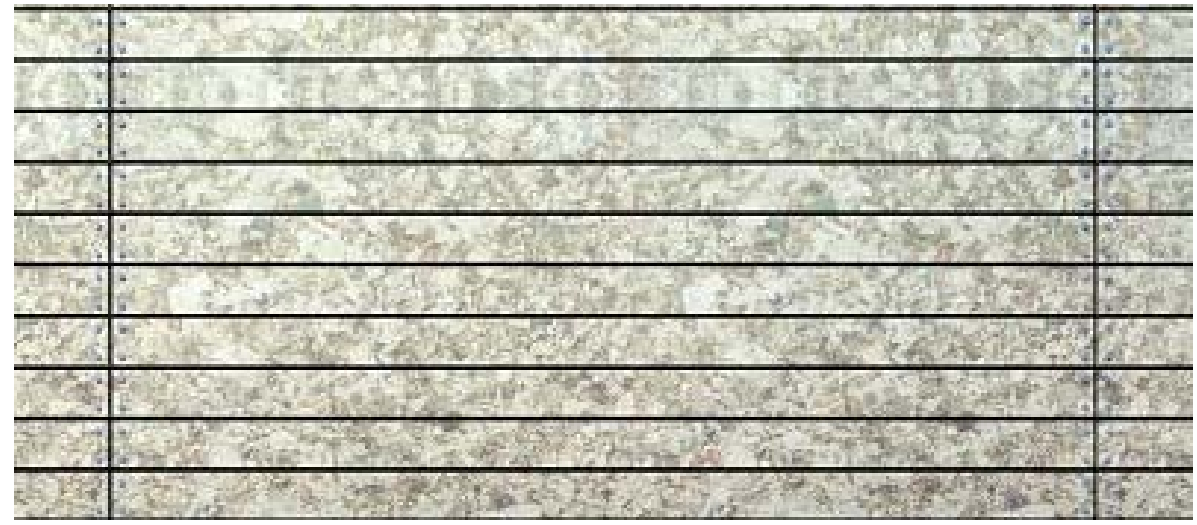

Desenho 6.2: Detalhe de Painel com tabuado de Reciclado Longa Vida Fonte: Criação da autora. Desenho de Albano.

\footnotetext{
${ }^{1}$ Matheus Albano - Desenhista de projetos em 3D.
} 


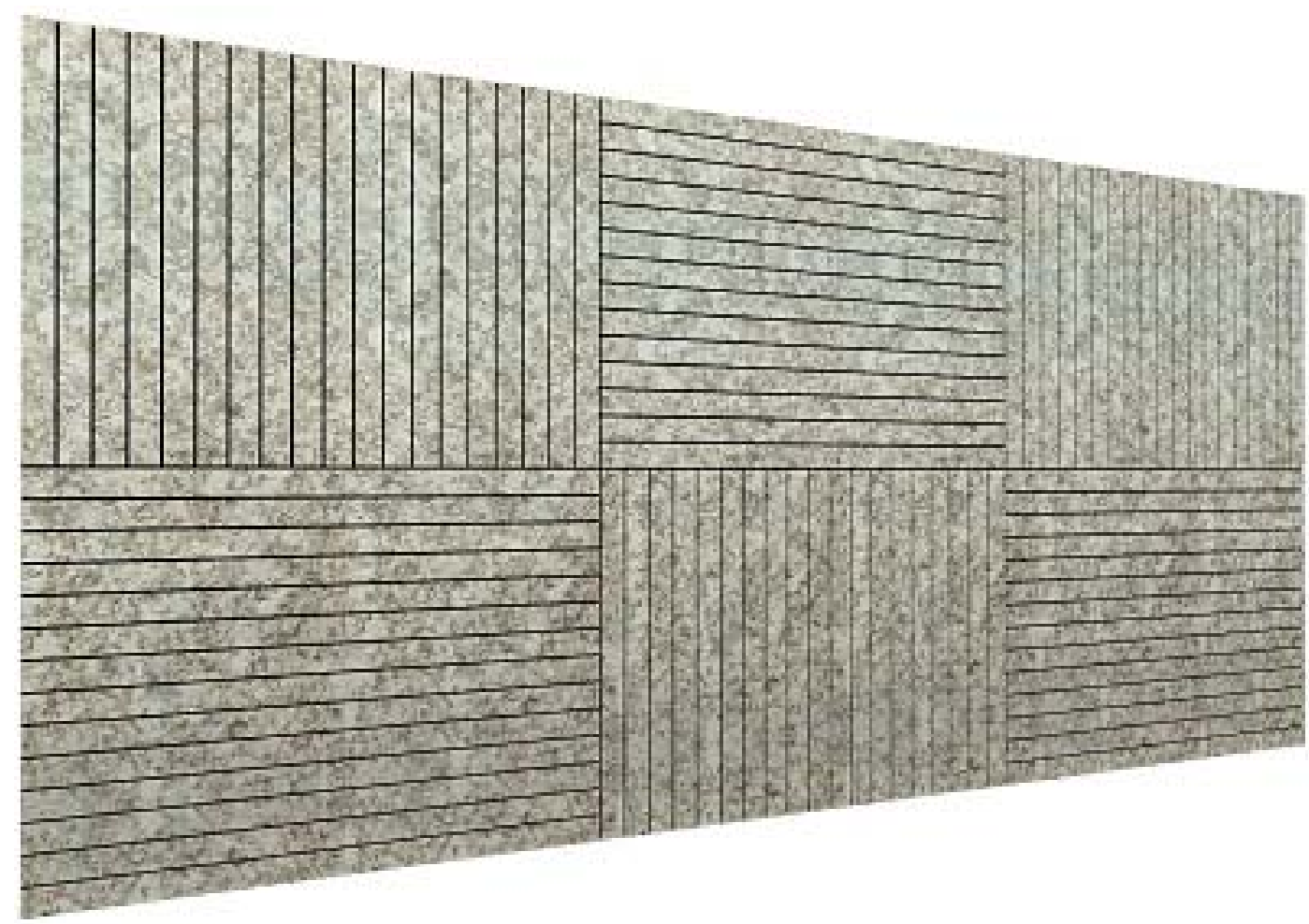

Desenho 6.3: Painel com tabuado de Reciclado Longa Vida - Paginação alternada.

Fonte: Criação da autora. Desenho de Albano.

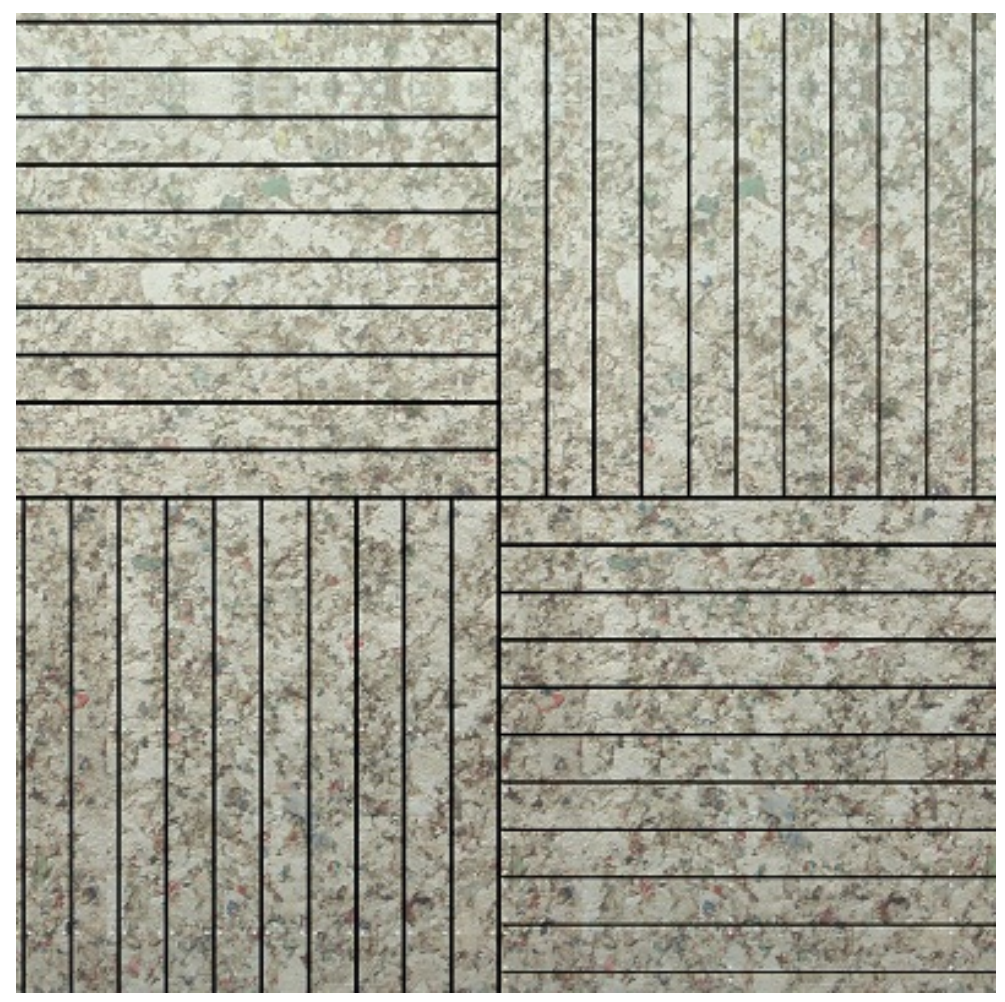

Desenho 6.4 : Detalhe da paginação tabuada alternada.

Fonte: Criação da autora. Desenho de Albano. 


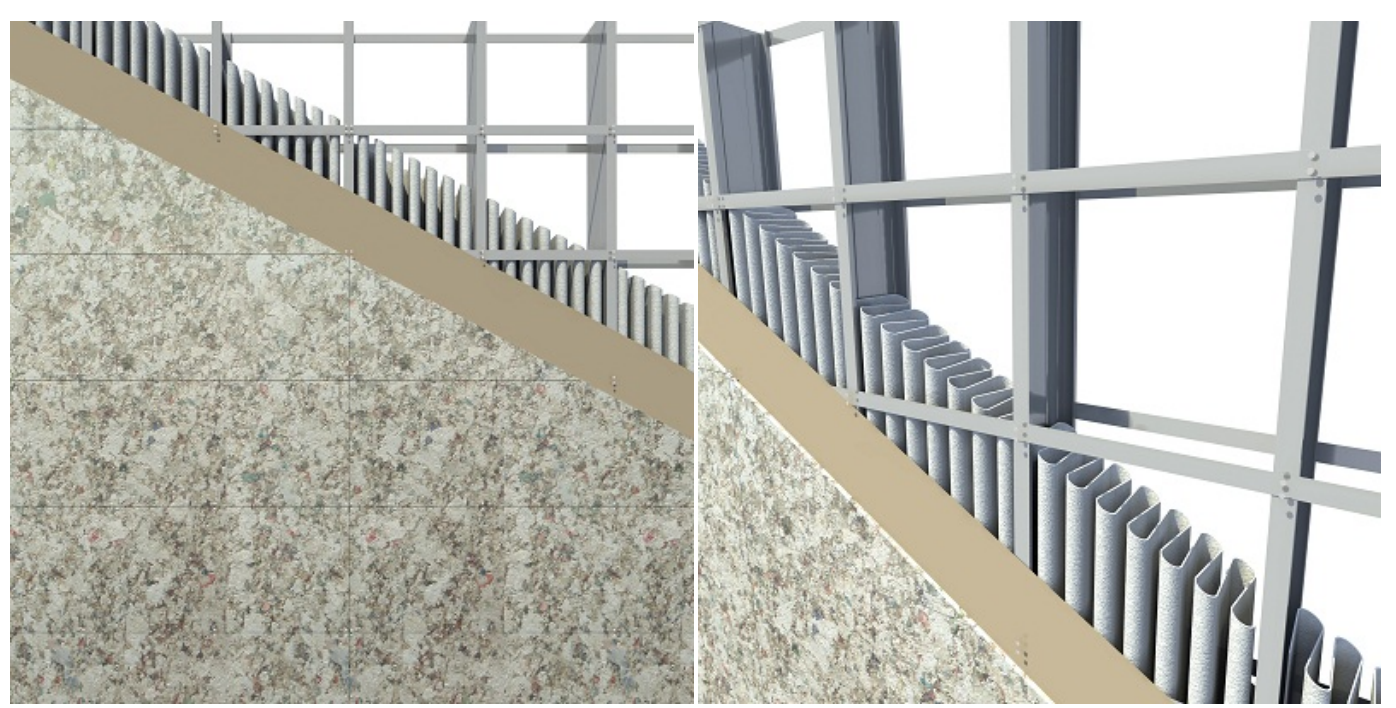

Desenho 6.5: Estudo de aplicação da peça em sistema Steel Frame.

Fonte: Criação da autora. Desenho de Albano.

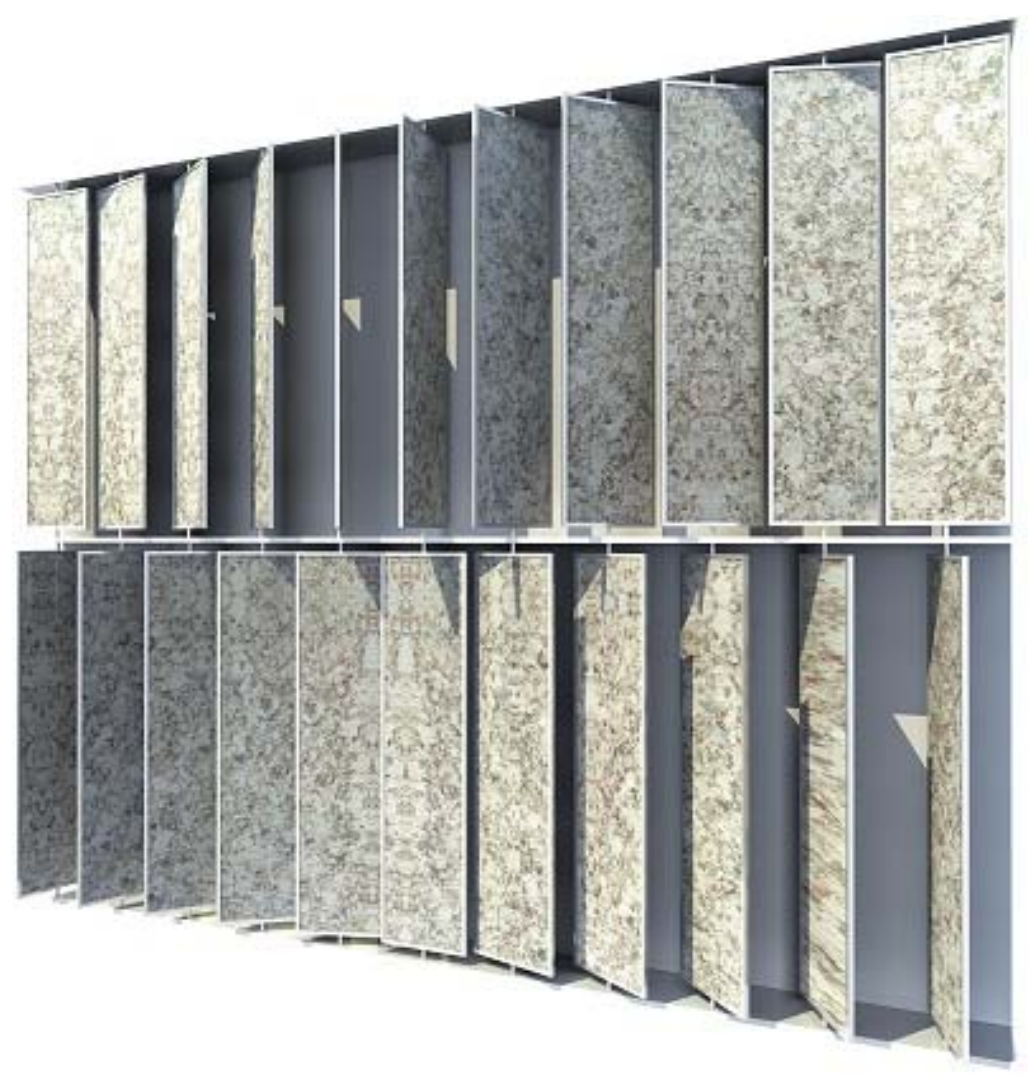

Desenho 6.6: Brise com aletas verticais, baseado em modelos existentes. Fonte: Criação da autora. Desenho de Albano. 


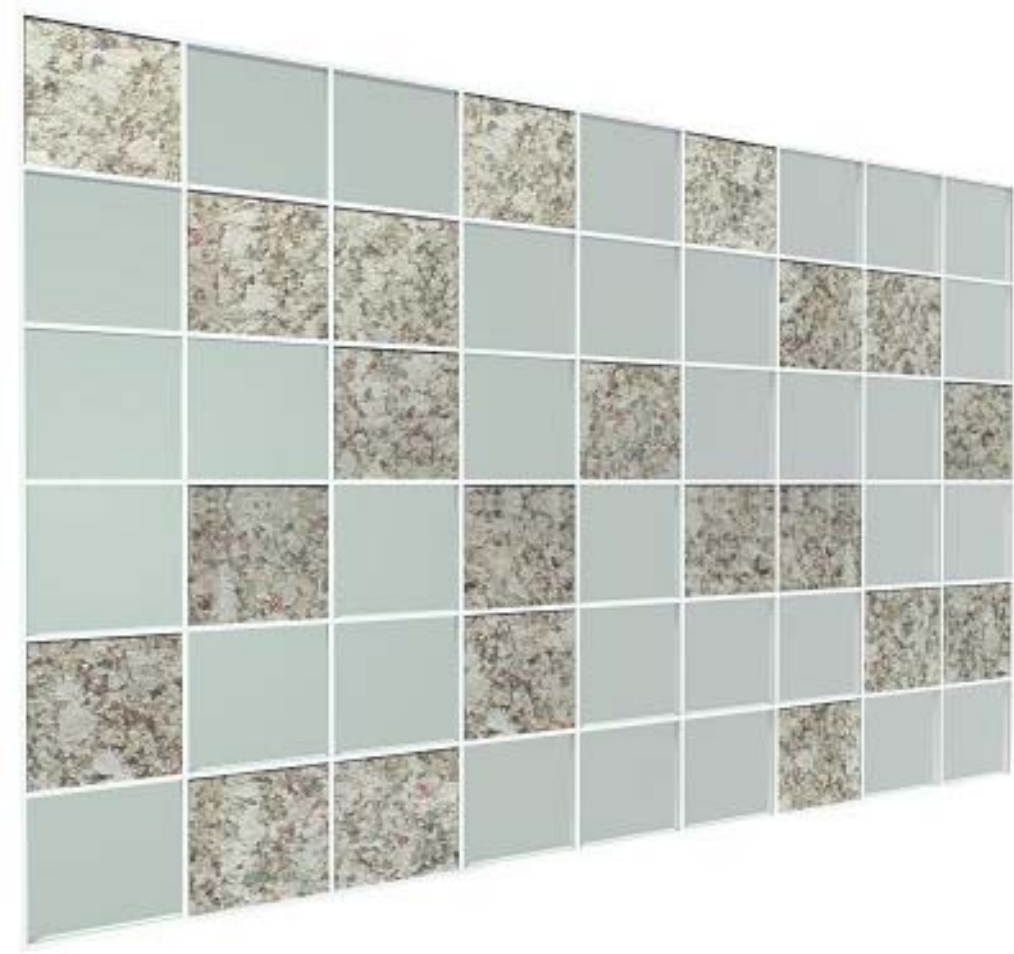

Desenho 6.7: Painel interno ou externo com quadriculado de reciclado Longa Vida e vidro Fonte: Criação da autora. Desenho de Albano.

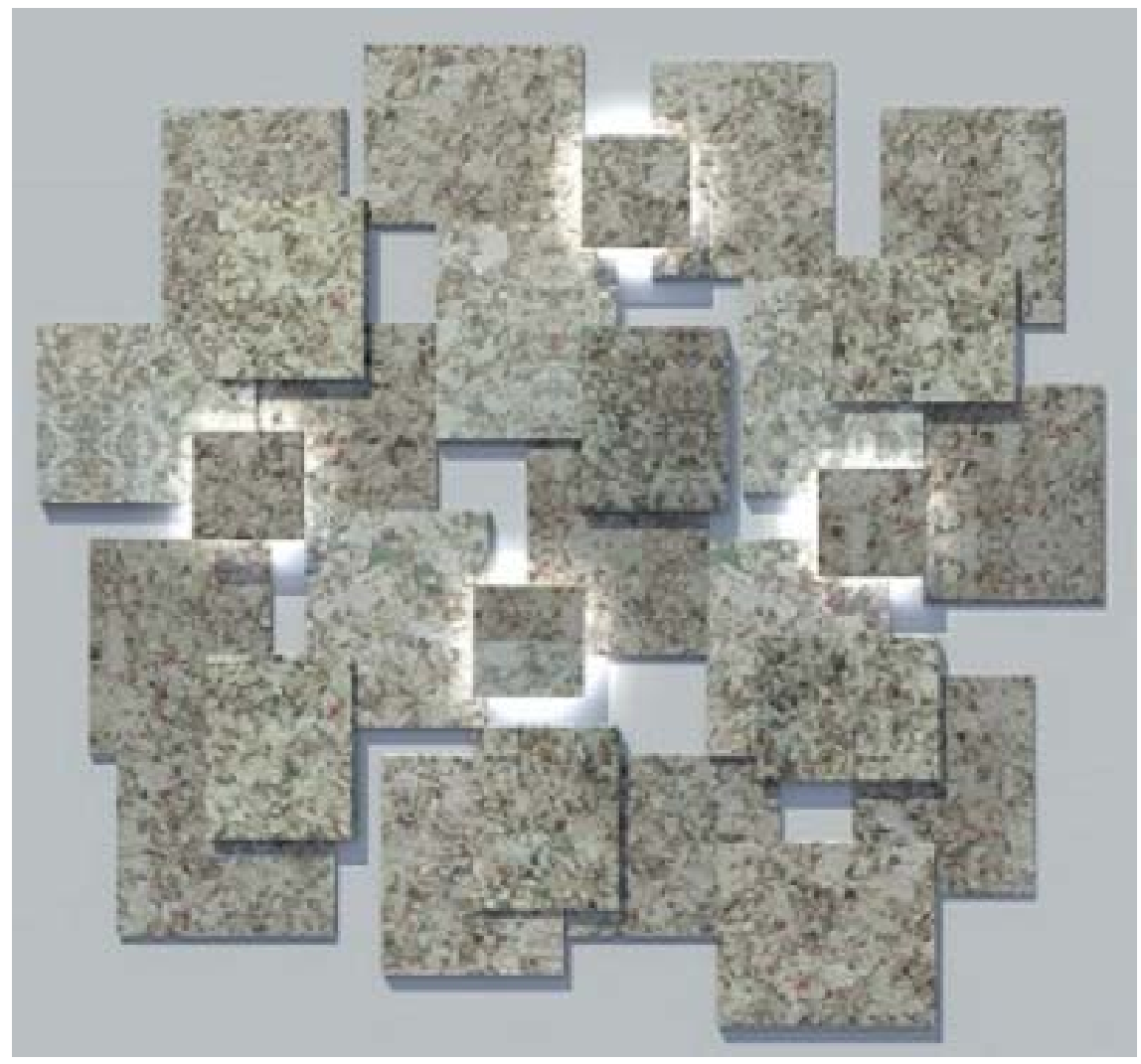

Desenho 6.8: Painel interno: mosaico iluminado

Fonte: Criação da autora. Desenho de Albano. 


\section{4 - Estudos de objetos}

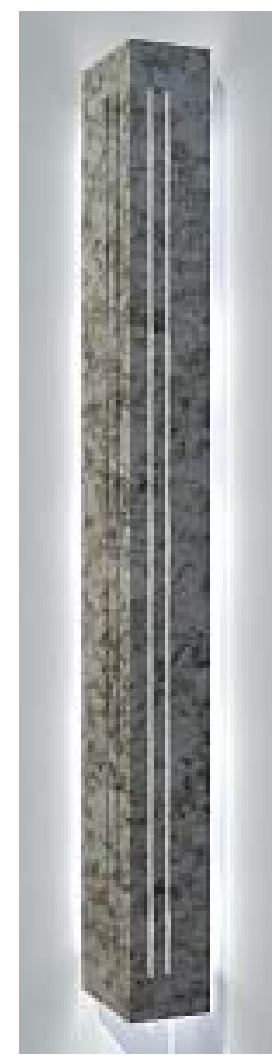

Desenho 6.9: Objeto luminoso para parede - arandela

Fonte: Criação da autora. Desenho de Albano.

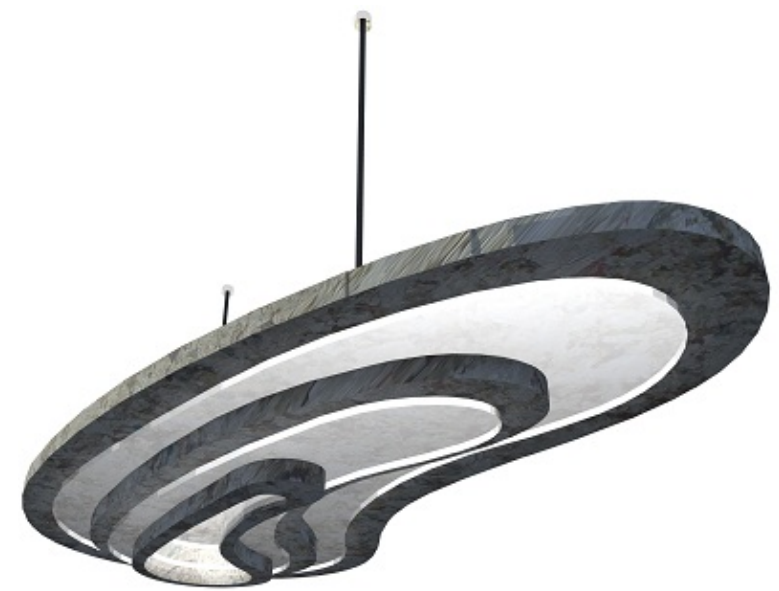

Desenho 6.10: Objeto luminoso para teto - Luminária orgânica de reciclado e vidro Fonte: Criação da autora. Desenho de Albano. 

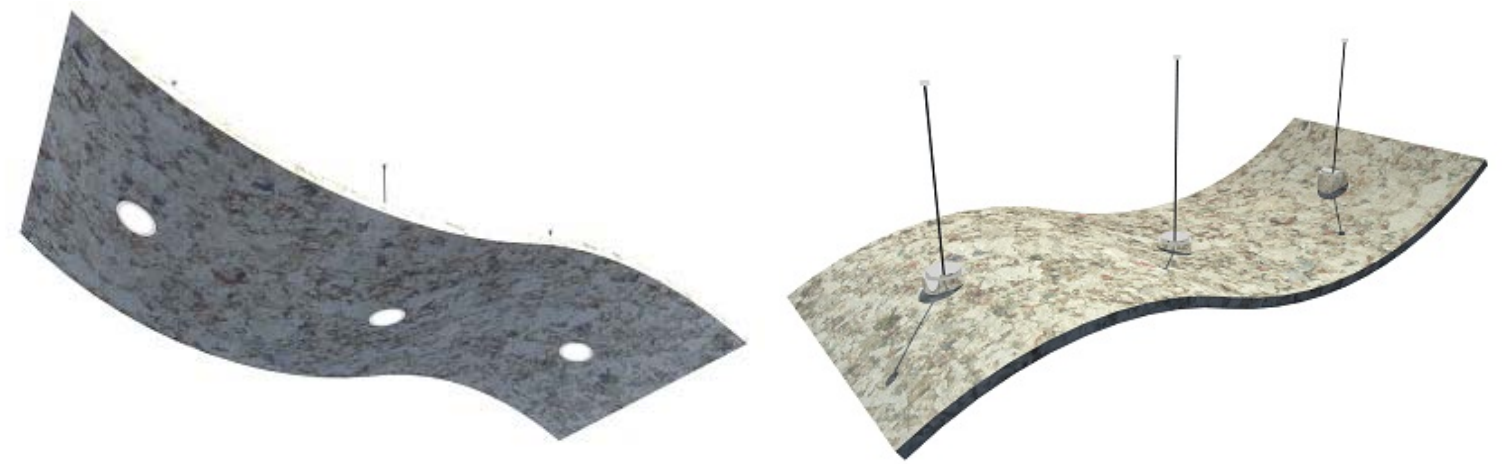

Desenho 6.11: Objeto luminoso para teto - Luminária ondulada com "sanduíche" de placas recicladas. Fonte: Criação da autora. Desenho de Albano.

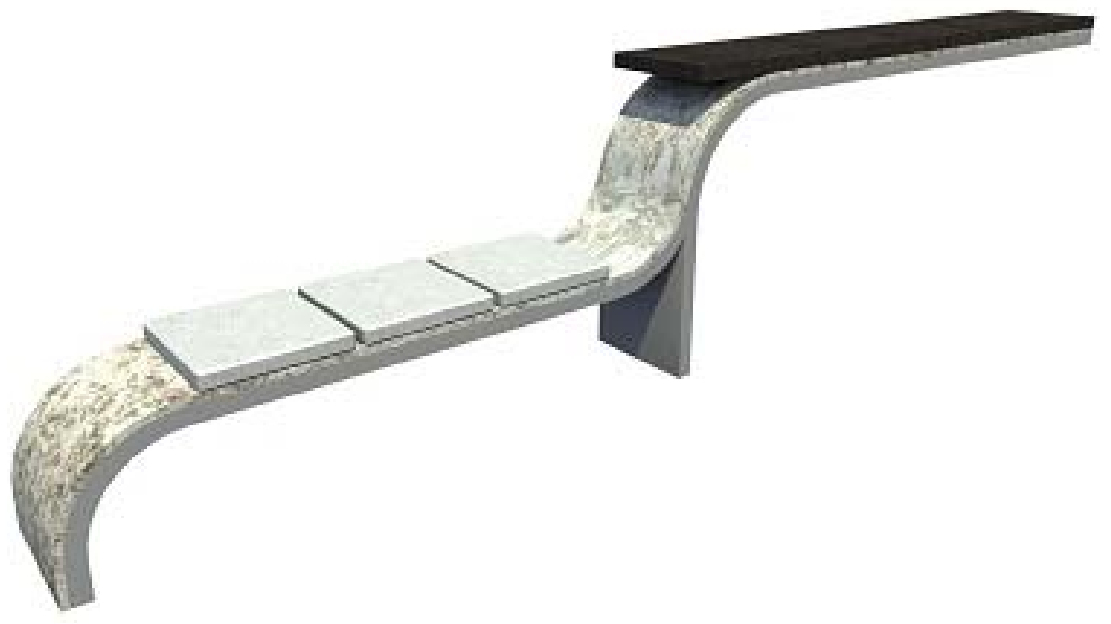

Desenho 6.12: Banco curvo com reciclado Longa Vida em suporte metálico Fonte: Criação da autora. Desenho de Albano.

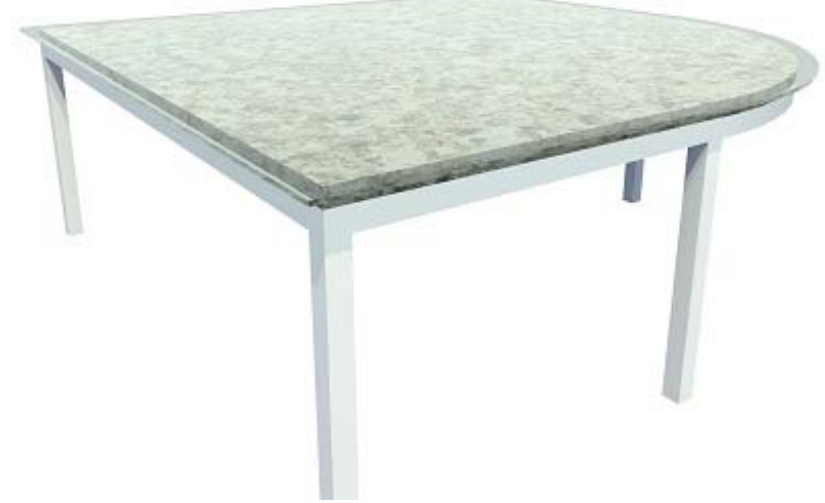

Desenho 6.13 :Mesa de reciclado Longa Vida com cobertura/acabamento de vidro. Fonte: Criação da autora. Desenho de Albano. 

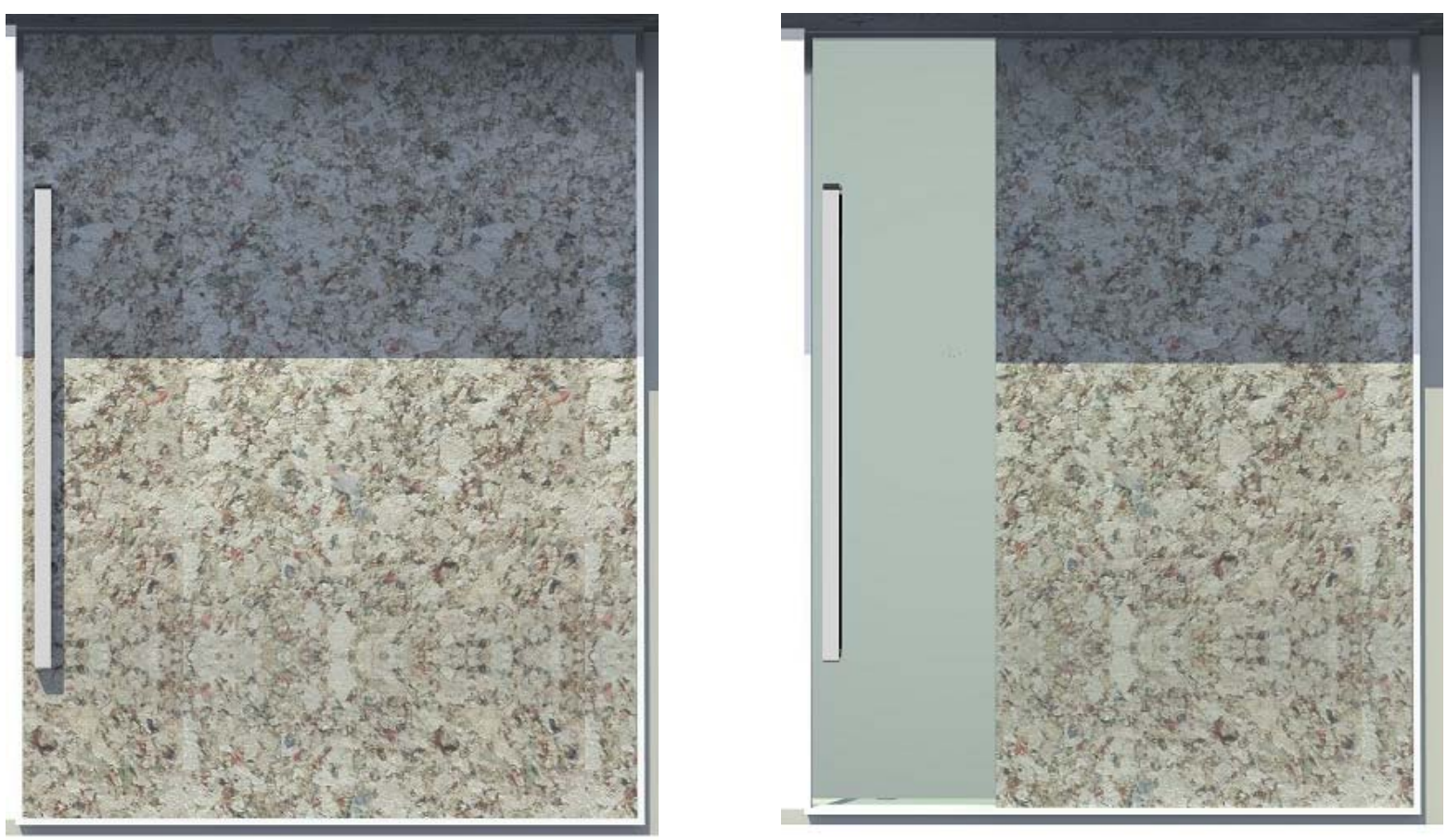

Desenho 6.14: Portas com reciclado Longa Vida e vidro (direita)

Fonte: Criação da autora. Desenho de Albano.

\section{5 - Projetos}

Foram, por fim, elaboradas 3 propostas projetuais que, além da metodologia citada anteriormente, preza pelos seguintes partidos:

- Elaborar um espaço neutro, sem lugar definido e sem função específica, mas com suporte para o "estar"/permanecer.

- $\quad$ Tirar partido das possibilidades construtivas disponíveis no mercado.

- Sugerir (visualmente) novas possibilidades construtivas.

- Usar as placas nos espaços externos e internos.

- Elaborar mais de uma opção de projeto para ampliar a visualização do uso.

- Compor as placas com materiais que valorizem sua estética.

- Usar curvas para explorar o potencial de flexibilidade do material. 
Propostas Projetuais 


\subsection{1 - Projeto 1}

No Projeto 1 foi evidenciado o trabalho com curvas. O painel frontal é estruturado no sistema Steel Frame e pode ter diversas larguras ou compor várias camadas, de acordo com as necessidades de proteção térmica. Uma ou duas camadas de placa podem compor cada lado do painel (interno e externo). As juntas estão preenchidas com mástique cinza. Para fixação das placas na malha metálica estruturante é necessário o uso de parafusos inoxidáveis. Estes se camuflam nas placas, por serem da mesma coloração. A cobertura utiliza a telha reciclada da maneira padrão. Internamente o mesmo painel pode ser visto, em conjunto com outros objetos com uso das placas recicladas: a luminária e o banco ondulado, também tirando partido do potencial de curvatura das placas. A materialidade escolhida para compor este projeto foi: externamente, placas de concreto, porta metálica e janelas de vidro. Internamente, o uso de piso em porcelanato e pastilhas de vidro, fizeram boa composição com as placas recicladas. O vermelho das pastilhas realça os pontos vermelhos do painel curvo interno.

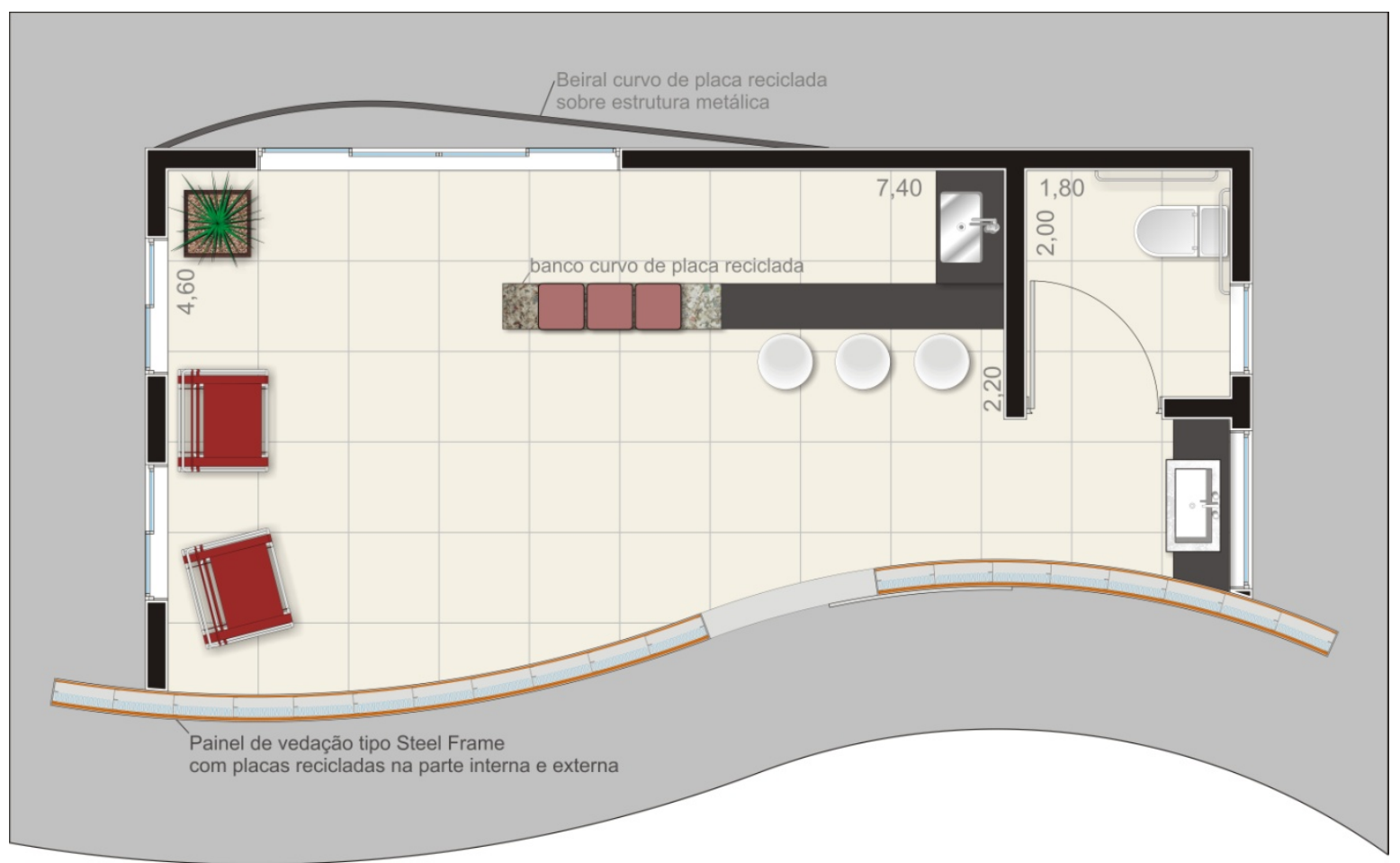

Planta Projeto 1

sem escala - área $43,65 m^{2}$

Projeto 1 - Planta

Fonte: Projeto da autora. Desenho: Albano. 


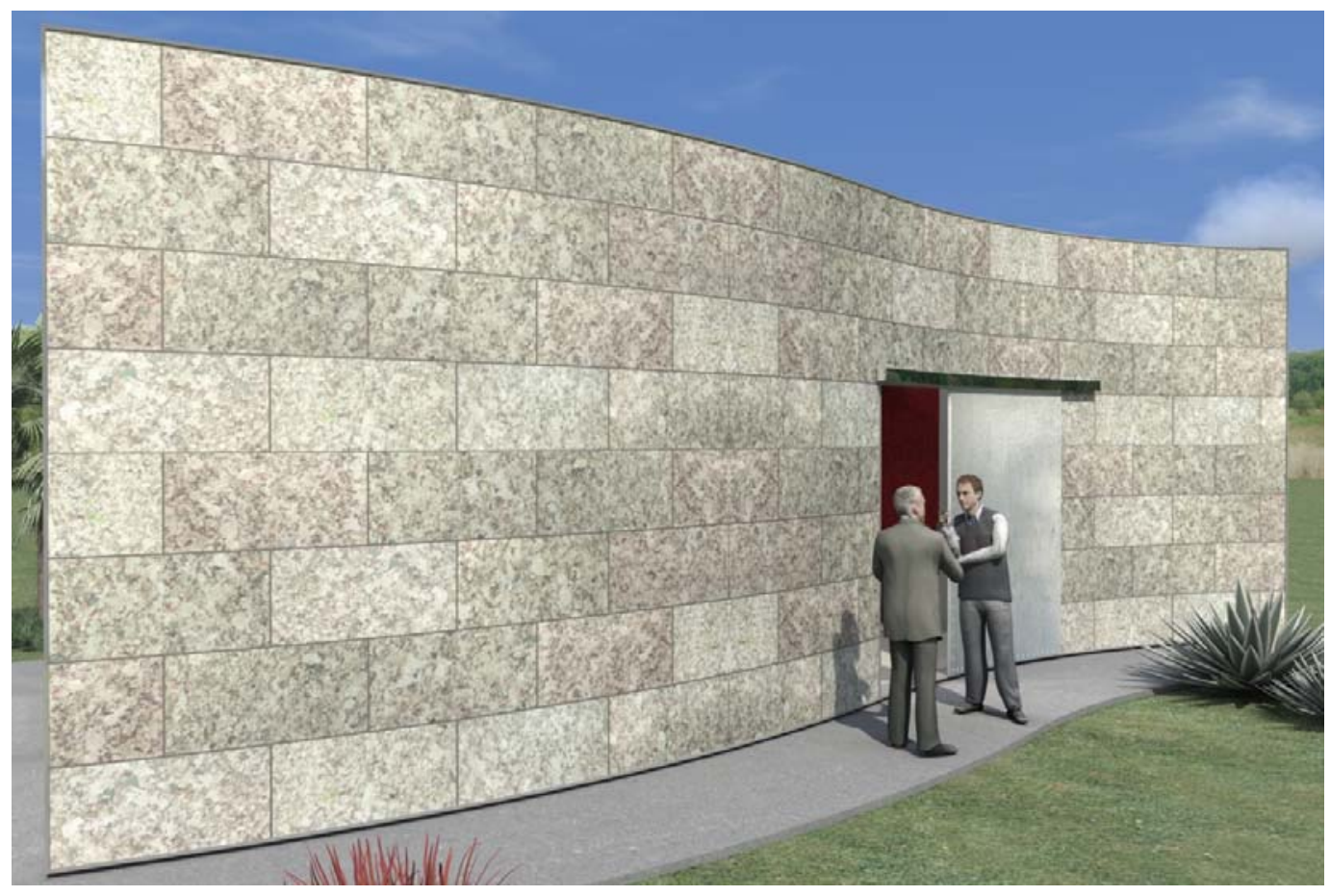

Projeto 1 - Vista externa 1

Fonte: Projeto da autora. Desenho: Albano.

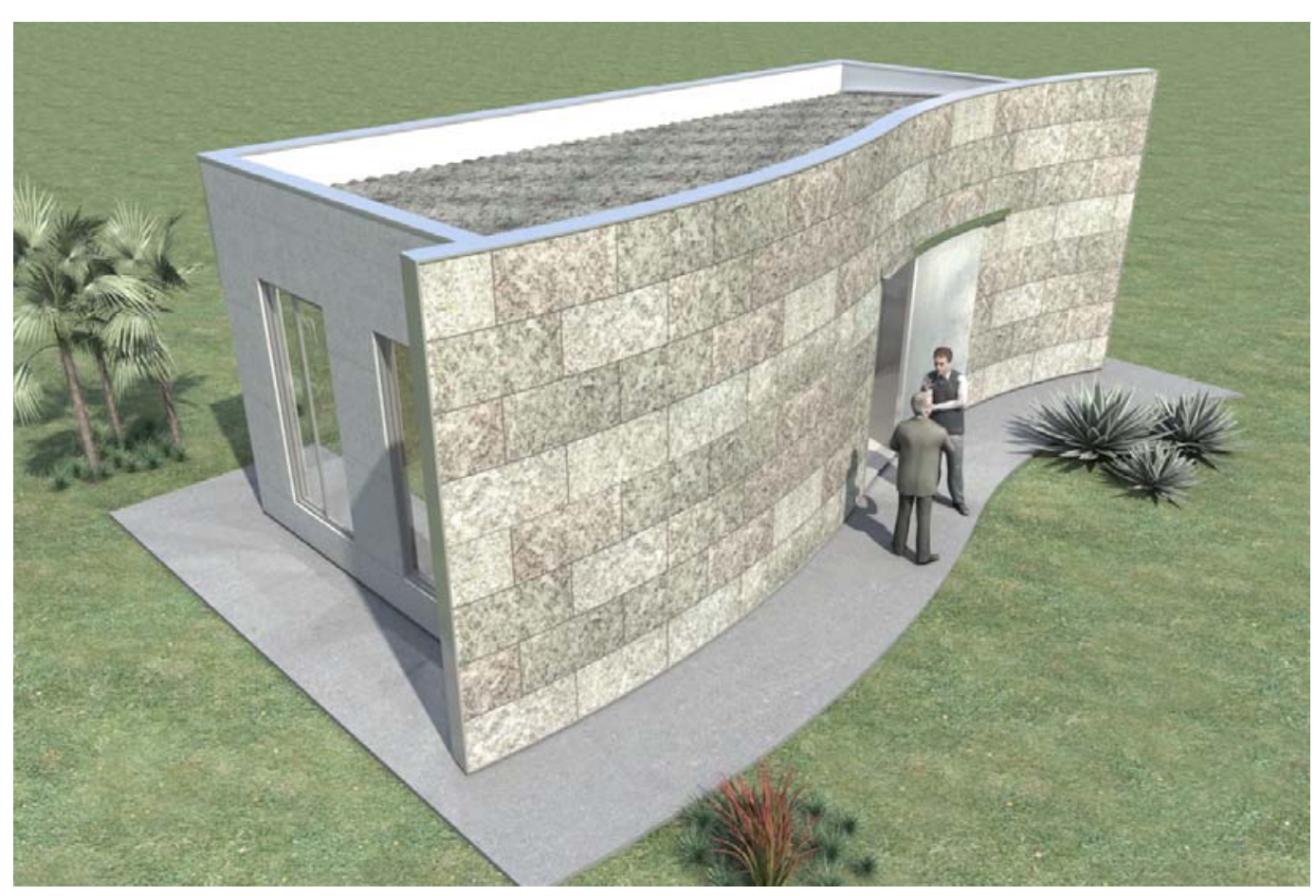

Projeto 1 - Vista externa 2

Fonte: Projeto da autora. Desenho: Albano. 


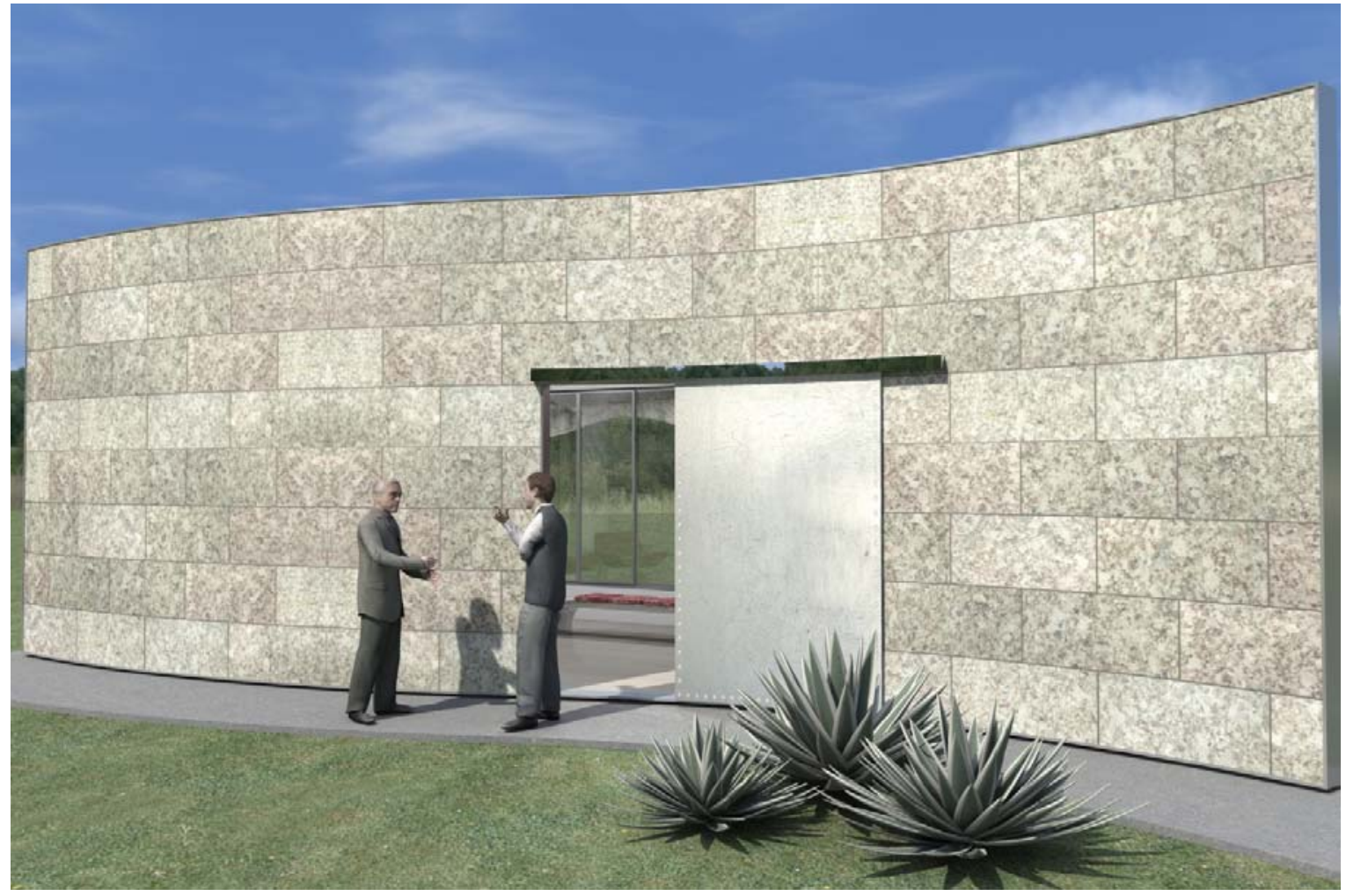

Projeto 1 - Vista externa 3

Fonte: Projeto da autora. Desenho: Albano.

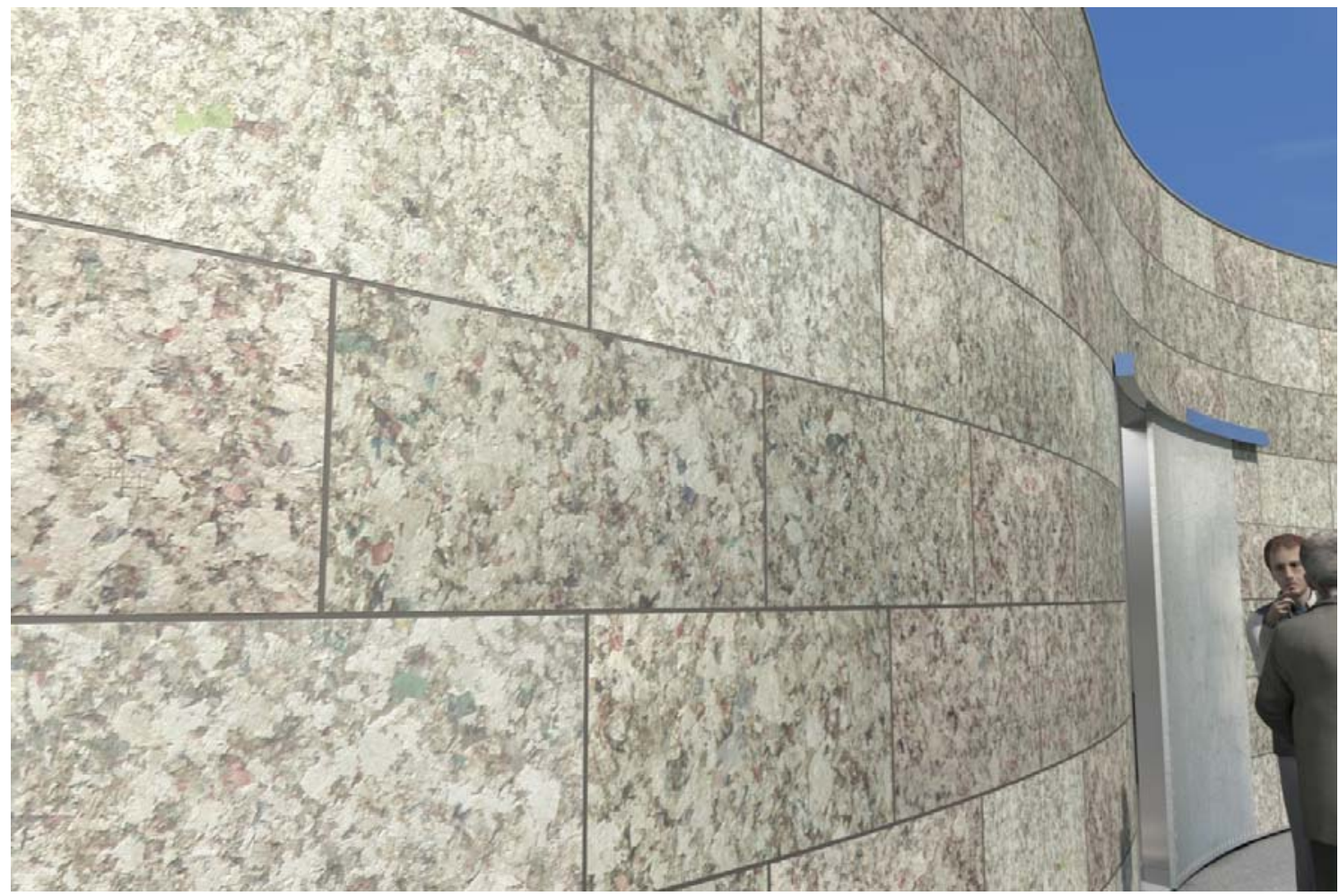

Projeto 1 - Vista externa 4

Fonte: Projeto da autora. Desenho: Albano. 


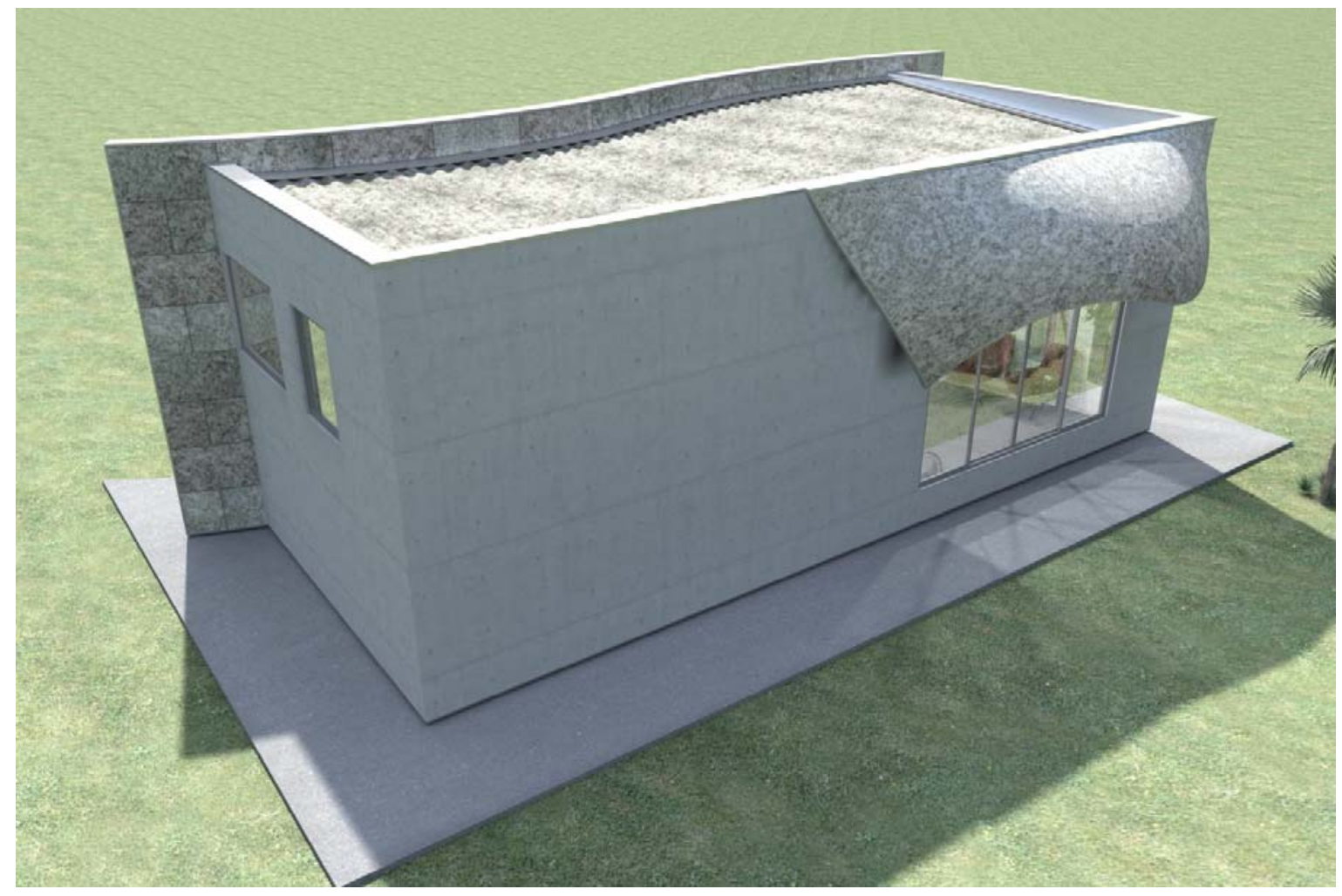

Projeto 1 - Vista externa 5

Fonte: Projeto da autora. Desenho: Albano.

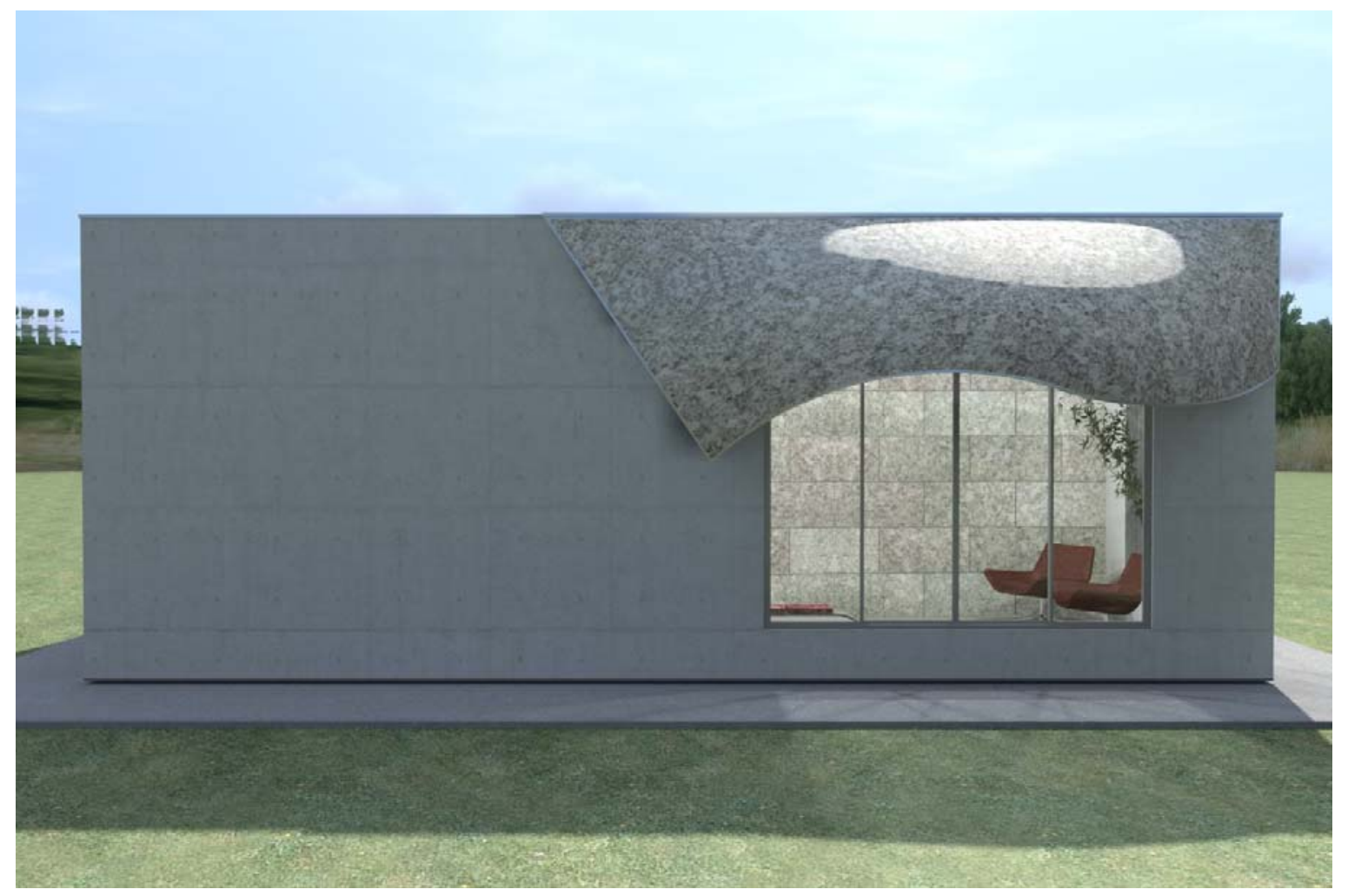

Projeto 1 - Vista externa 6

Fonte: Projeto da autora. Desenho: Albano. 


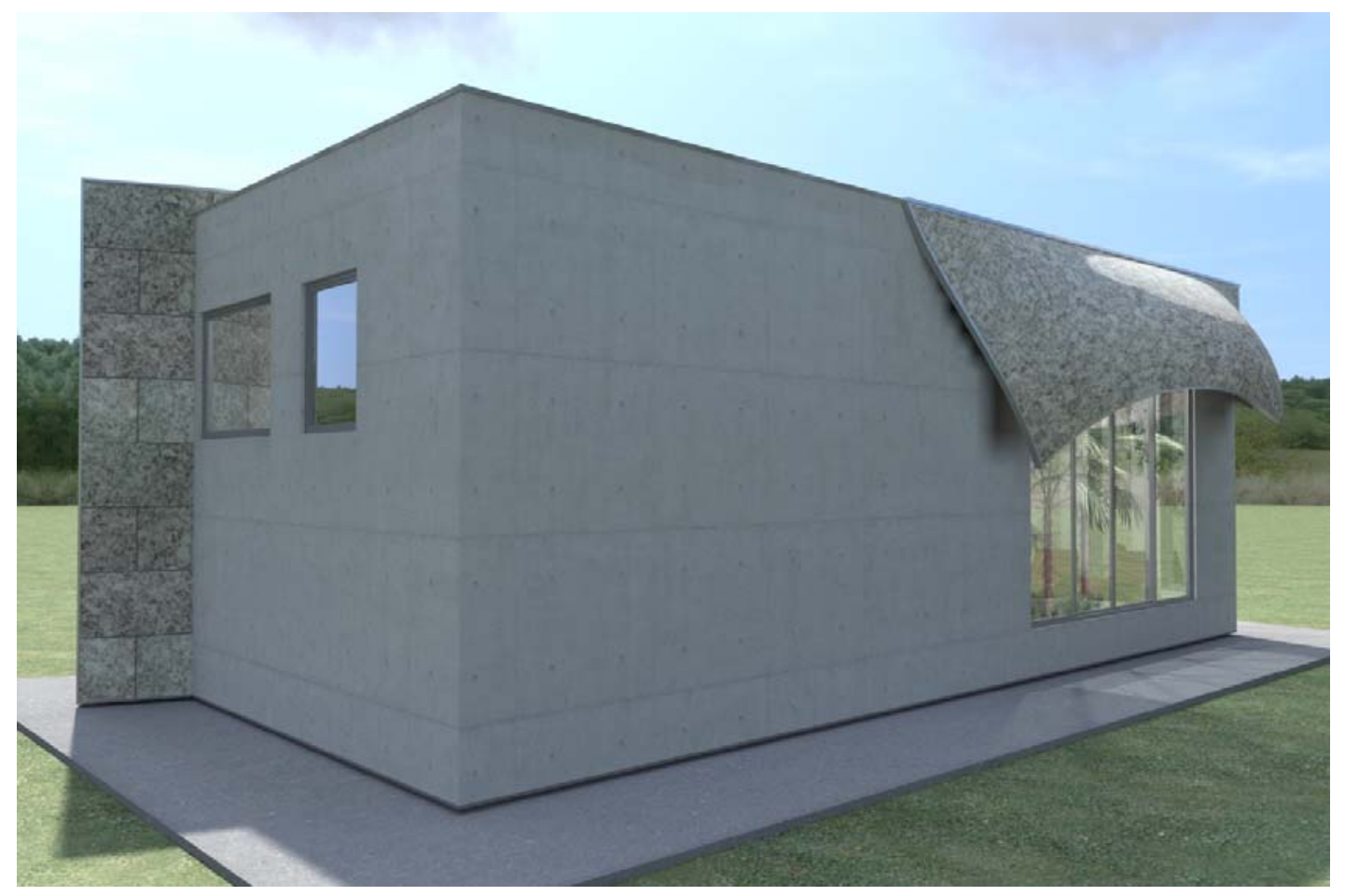

Projeto 1 - Vista externa 7

Fonte: Projeto da autora. Desenho: Albano.

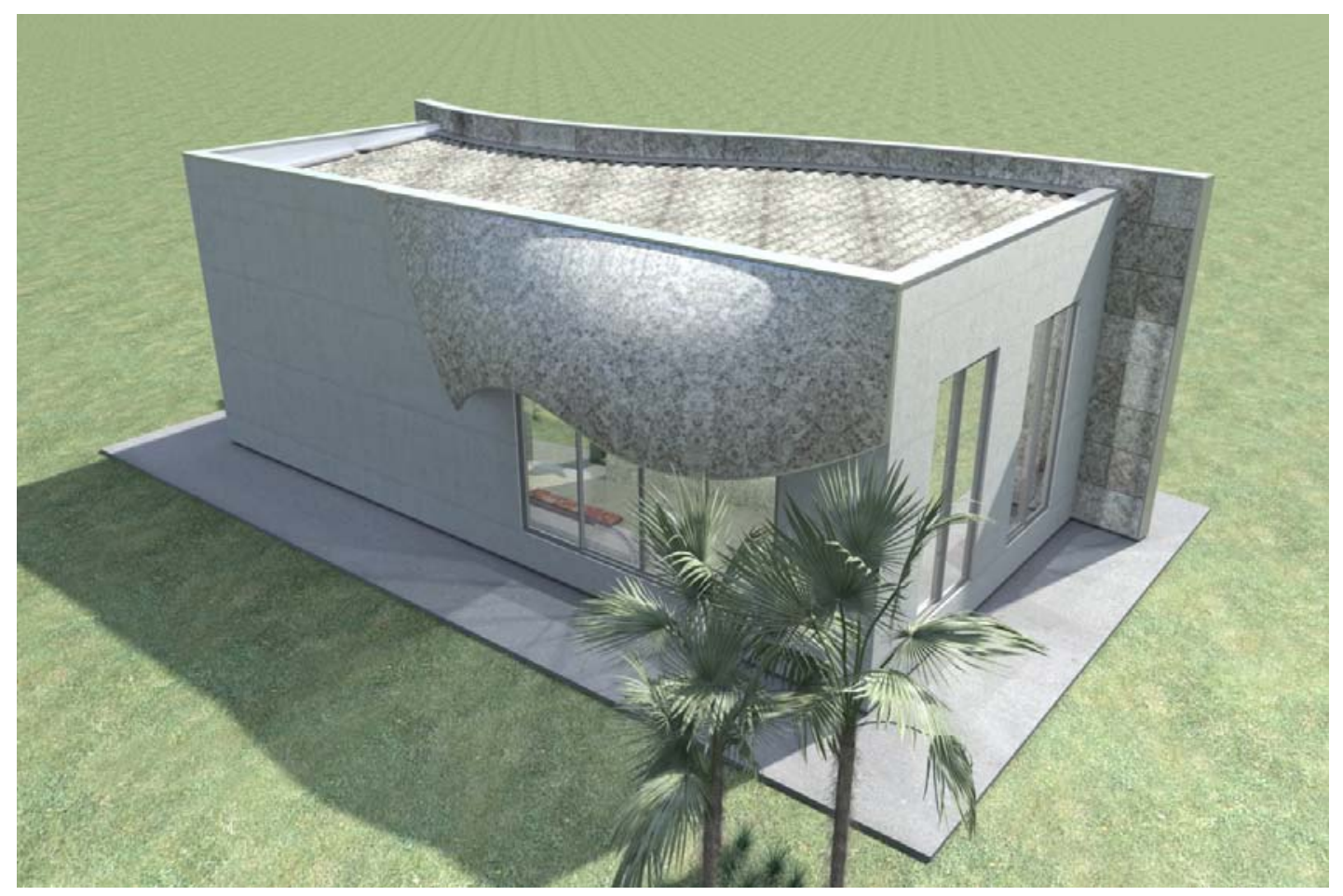

Projeto 1 - Vista externa 8

Fonte: Projeto da autora. Desenho: Albano. 


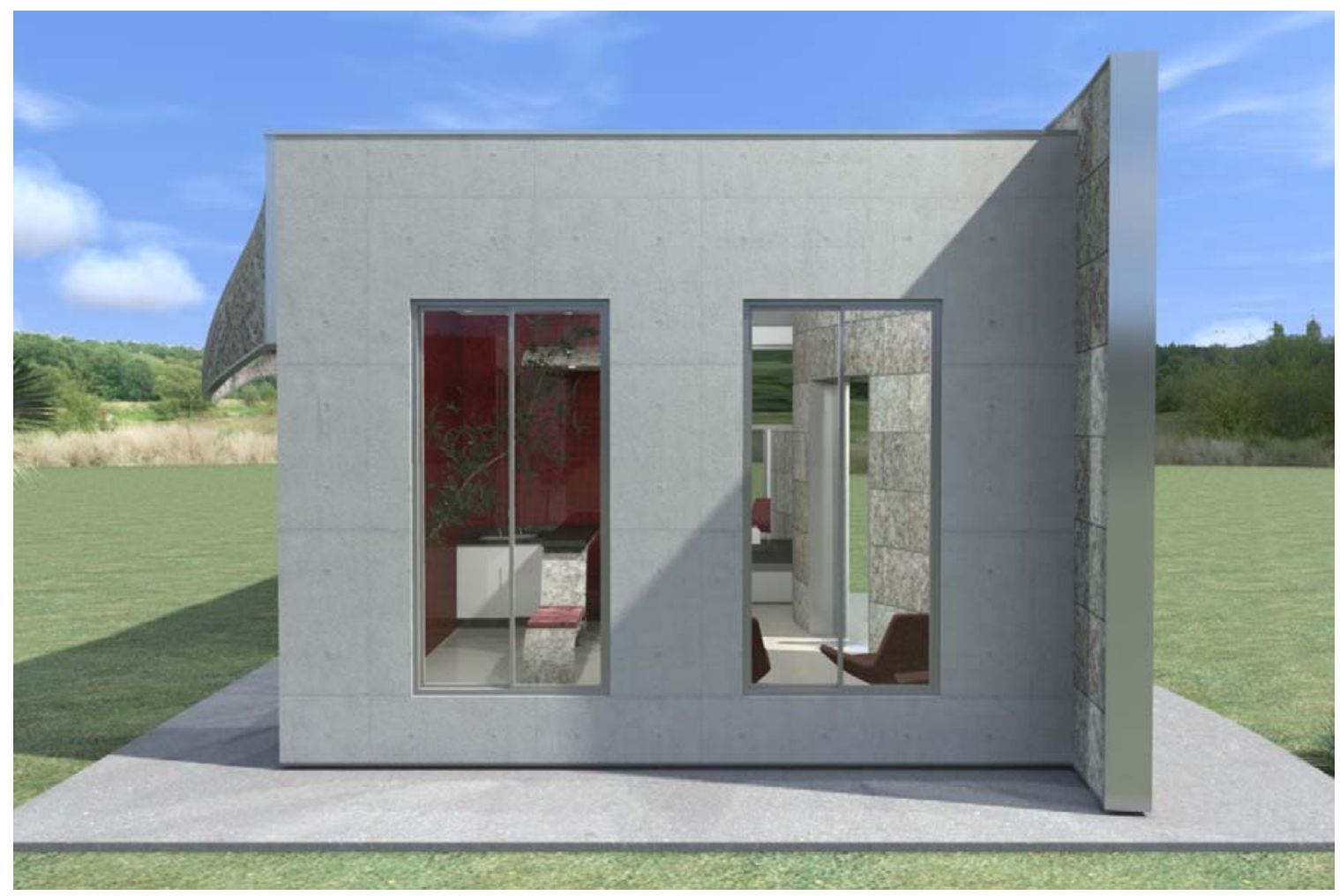

Projeto 1 - Vista externa 9

Fonte: Projeto da autora. Desenho: Albano.

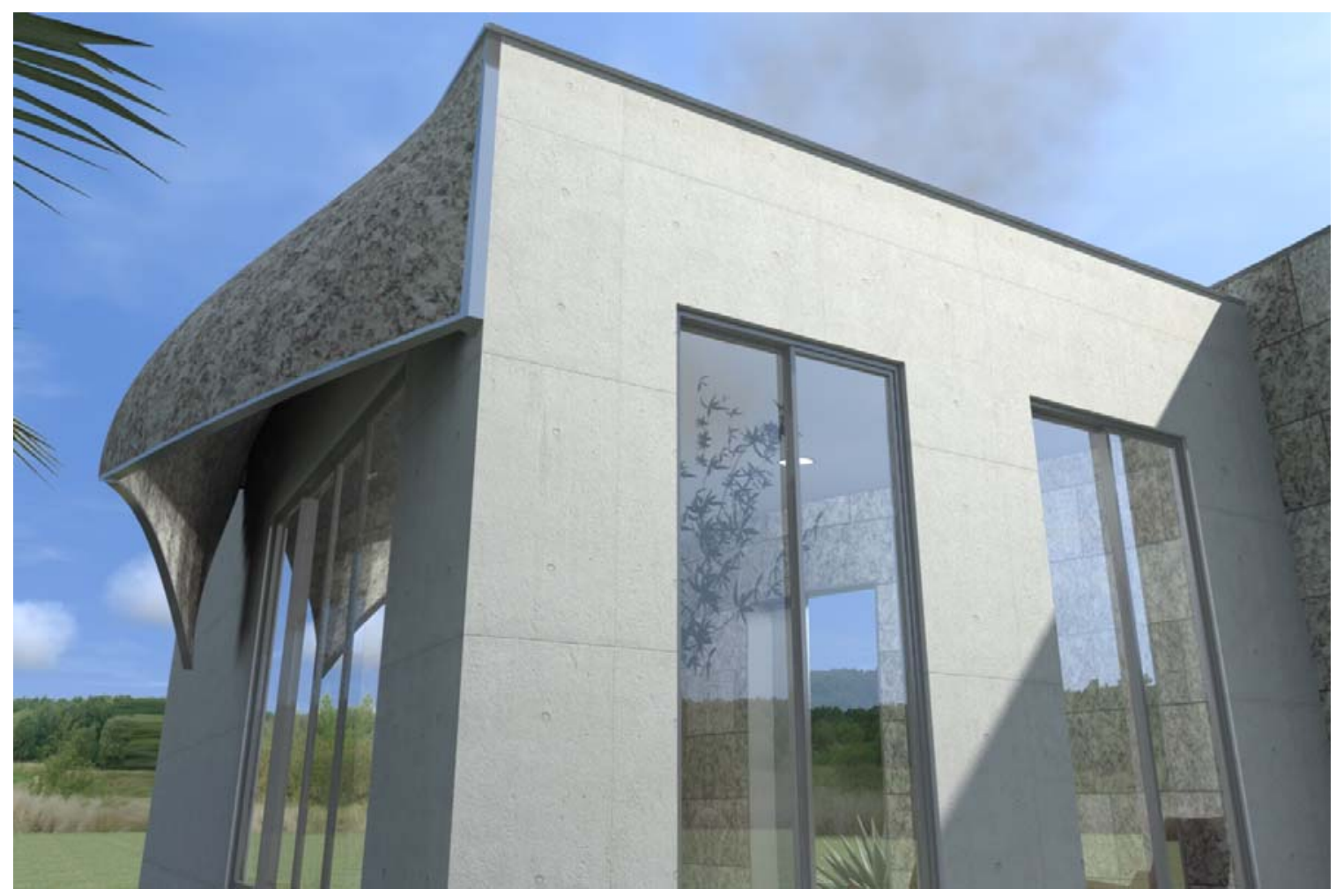

Projeto 1 - Vista externa 10

Fonte: Projeto da autora. Desenho: Albano. 


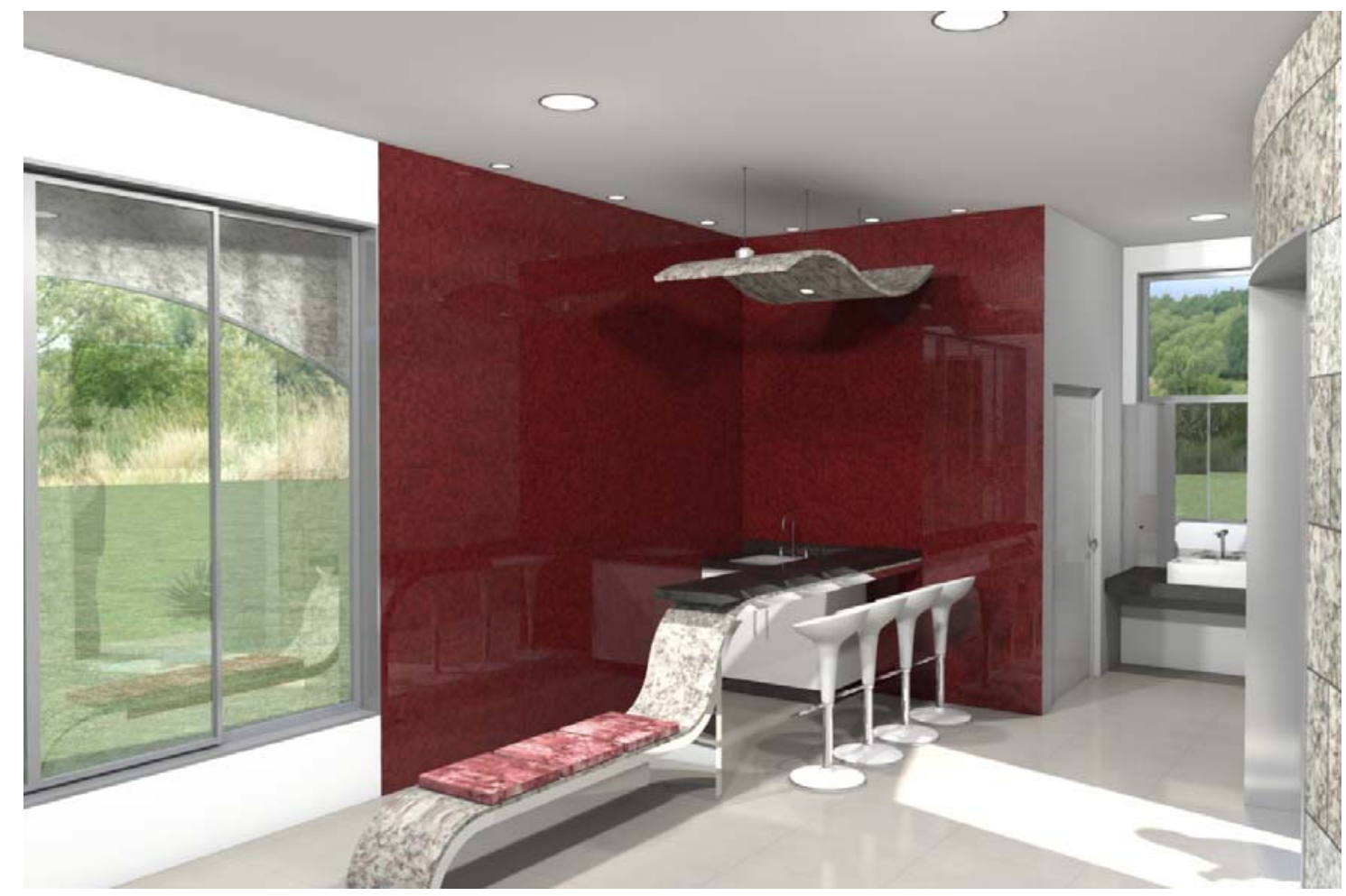

Projeto 1 - Vista interna 1

Fonte: Projeto da autora. Desenho: Albano.

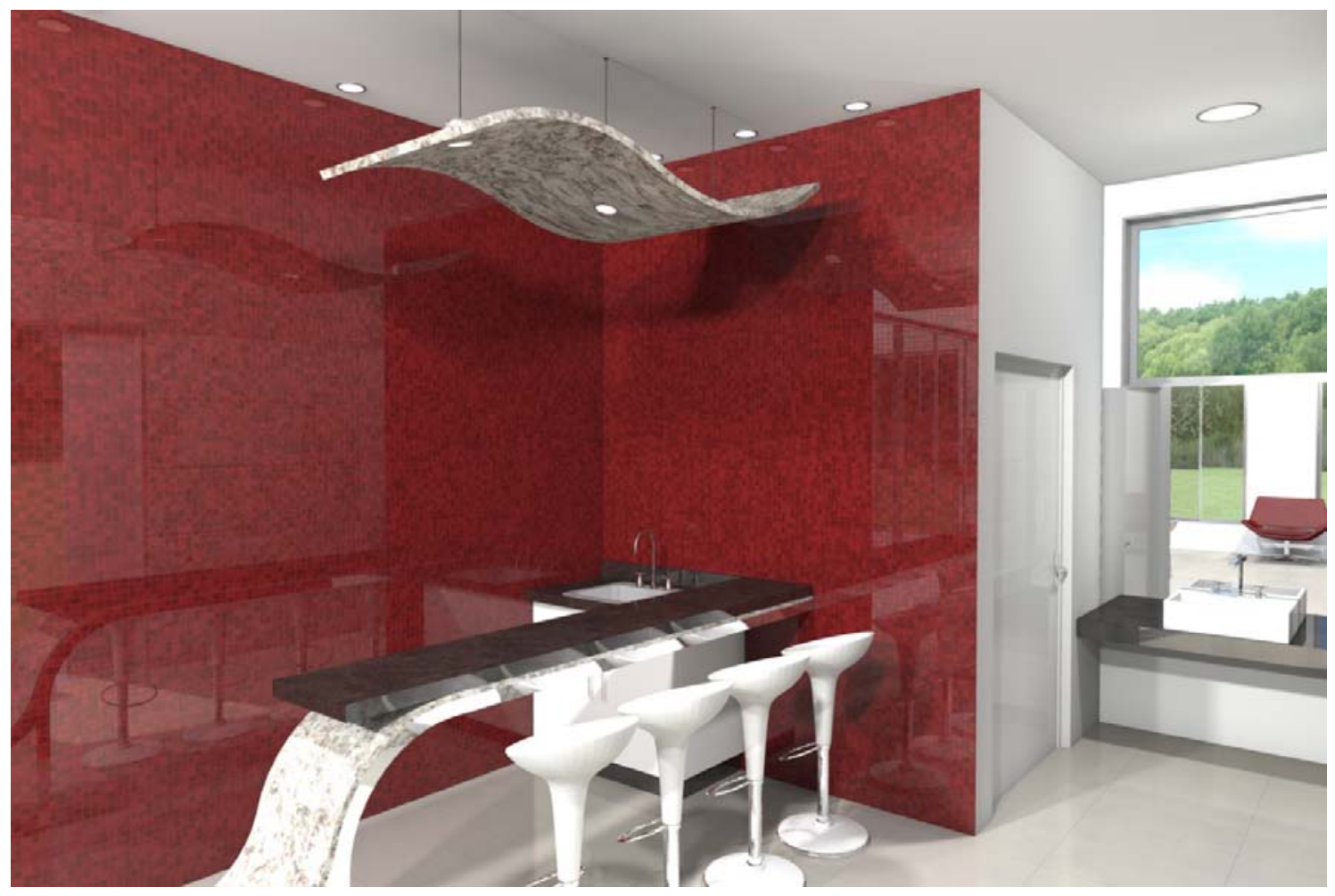

Projeto 1 - Vista interna 2

Fonte: Projeto da autora. Desenho: Albano. 


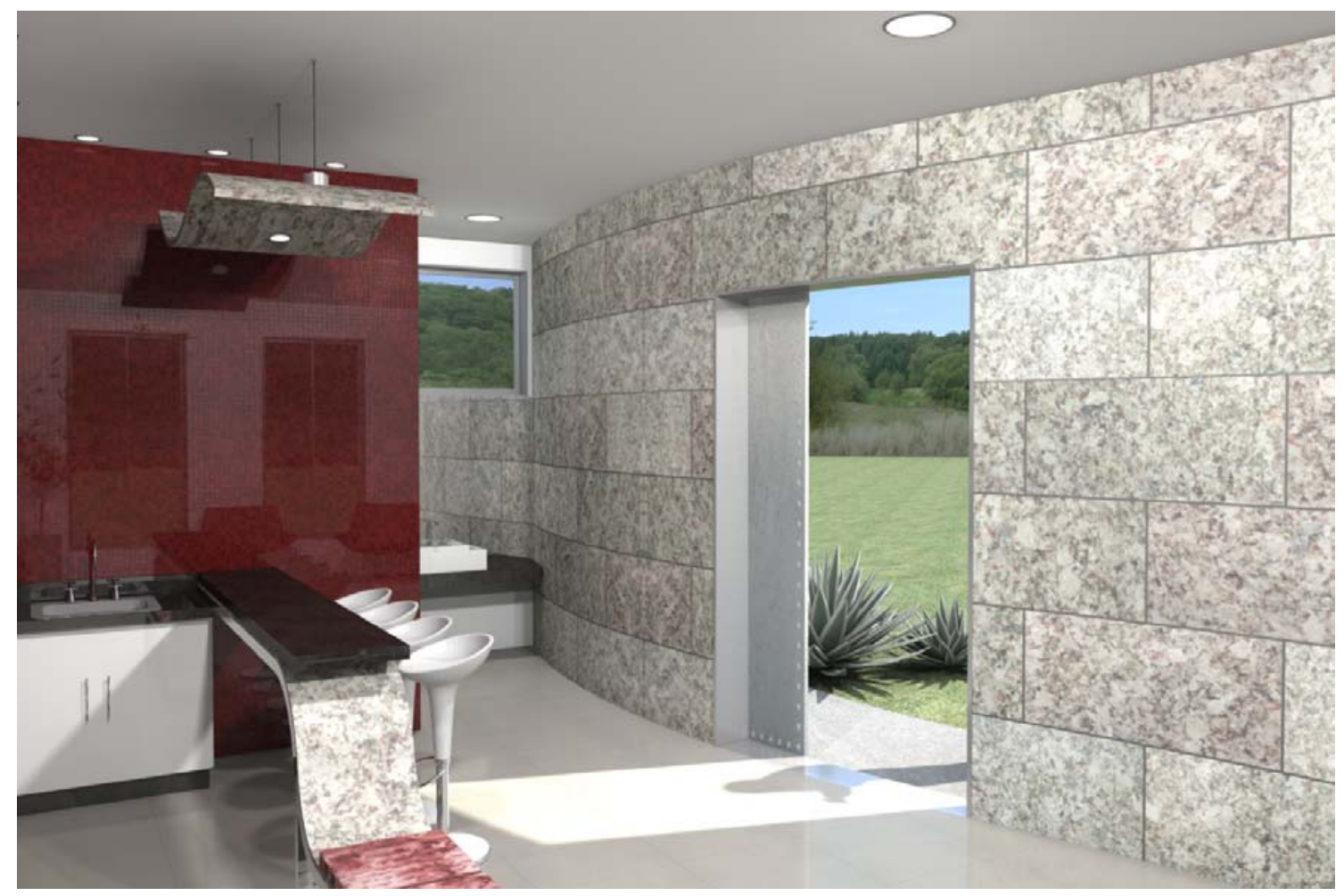

Projeto 1 - Vista interna 3

Fonte: Projeto da autora. Desenho: Albano.

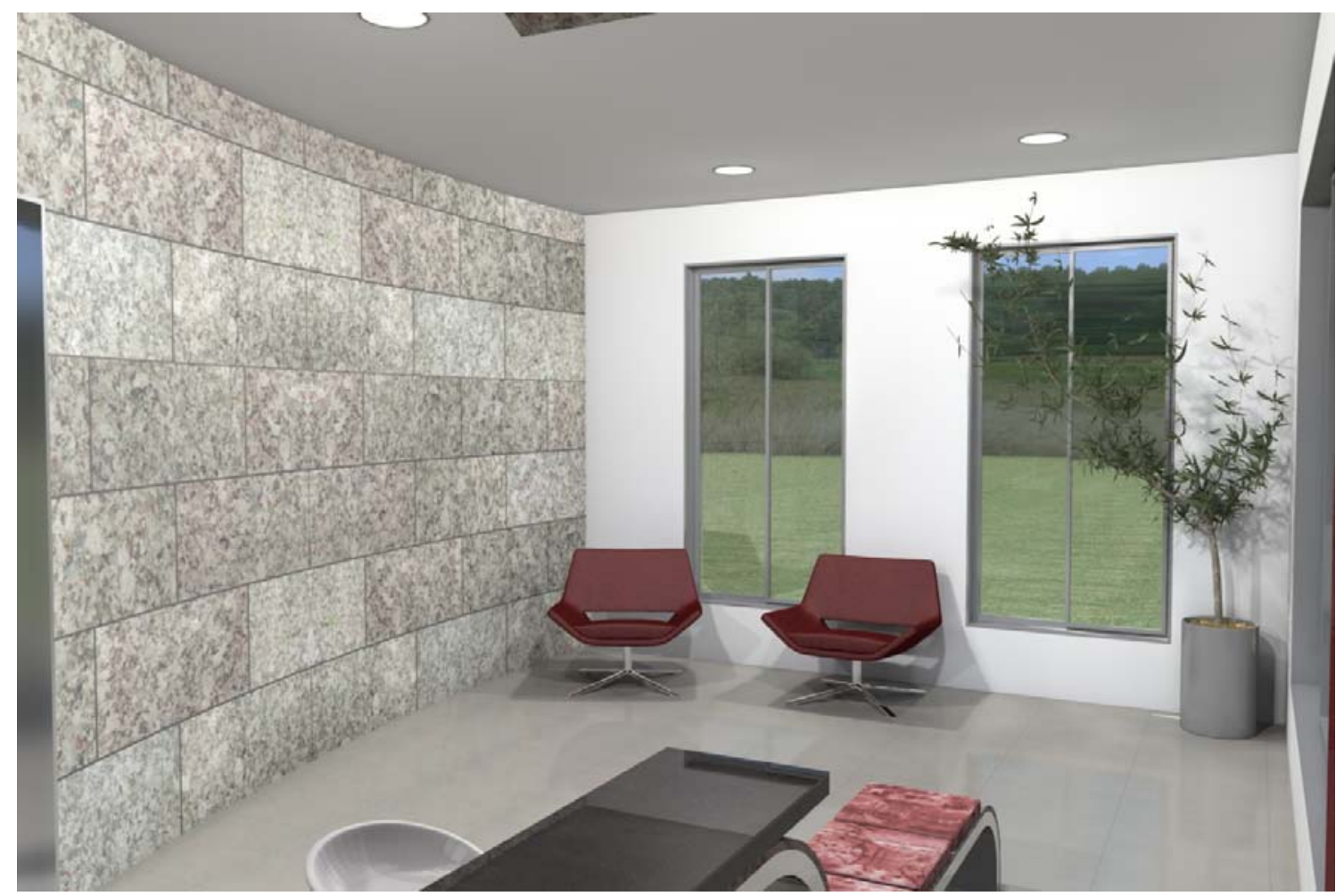

Projeto 1 - Vista interna 4

Fonte: Projeto da autora. Desenho: Albano. 


\subsection{2 - Projeto 2}

Neste segundo projeto, as curvas também foram realçadas, desta vez, na cobertura de estrutura metálica e fechamento com placas compridas de $0,20 \times 2,20 \mathrm{~m}$, encaixadas em perfis metálicos que dão acabamento entre uma placa e outra. A porta de entrada foi projetada também com as placas recicladas em conjunto com vidro. Na parte interna, o uso das placas aparece também em um painel/porta divisória entre a mesa de reuniões e o estar. O forro reciclado também pode ser visto internamente, compondo com luminárias também com uso das placas recicladas. Neste projeto, os tons coloridos foram especificados para realçar o salpicado colorido das placas, deixando o conjunto com um aspecto leve e alegre.

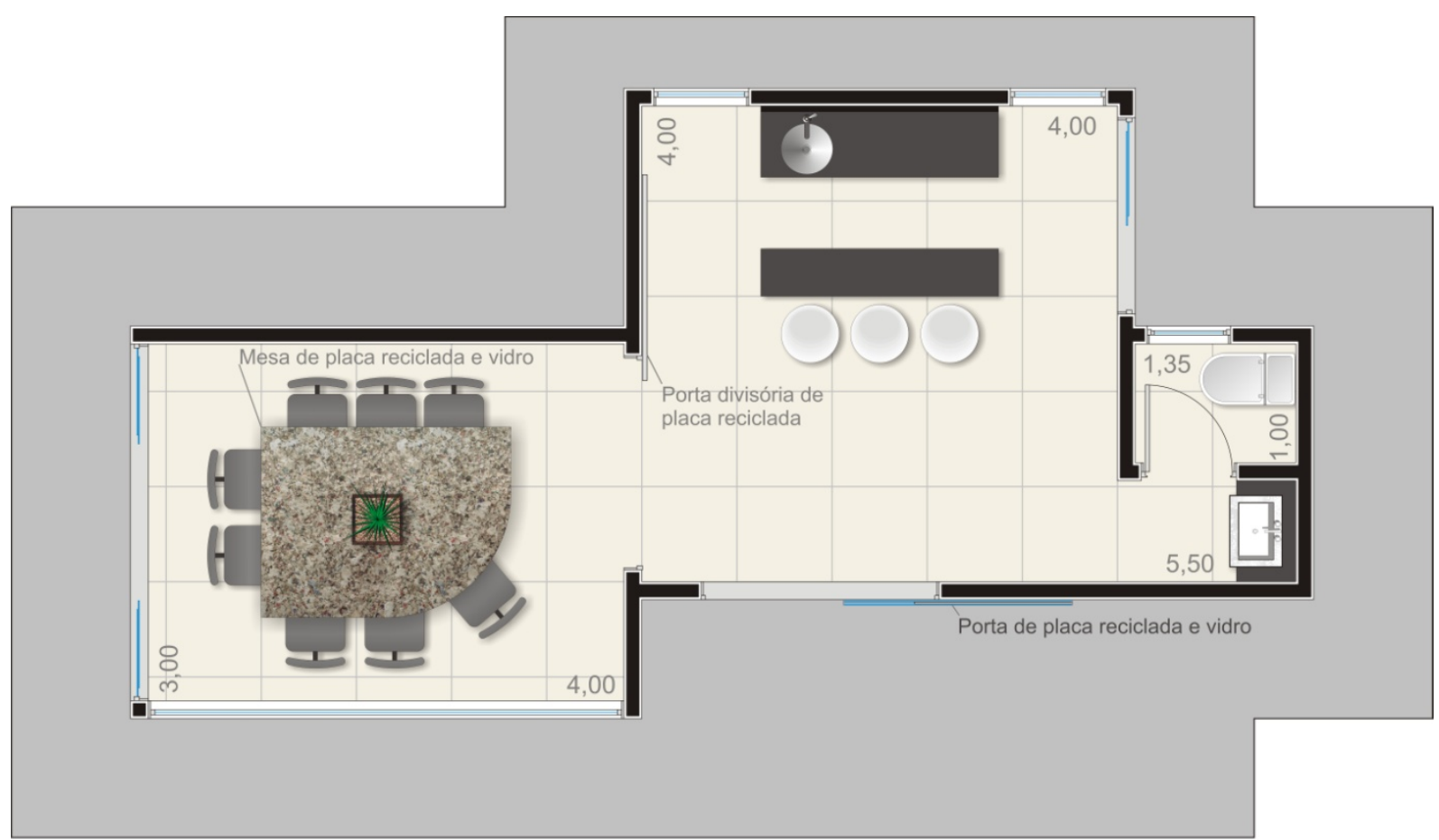

Planta Projeto 2

sem escala - área $35,78 \mathrm{~m}^{2}$

Projeto 2 - Planta

Fonte: Projeto da autora. Desenho: Matheus Albano. 


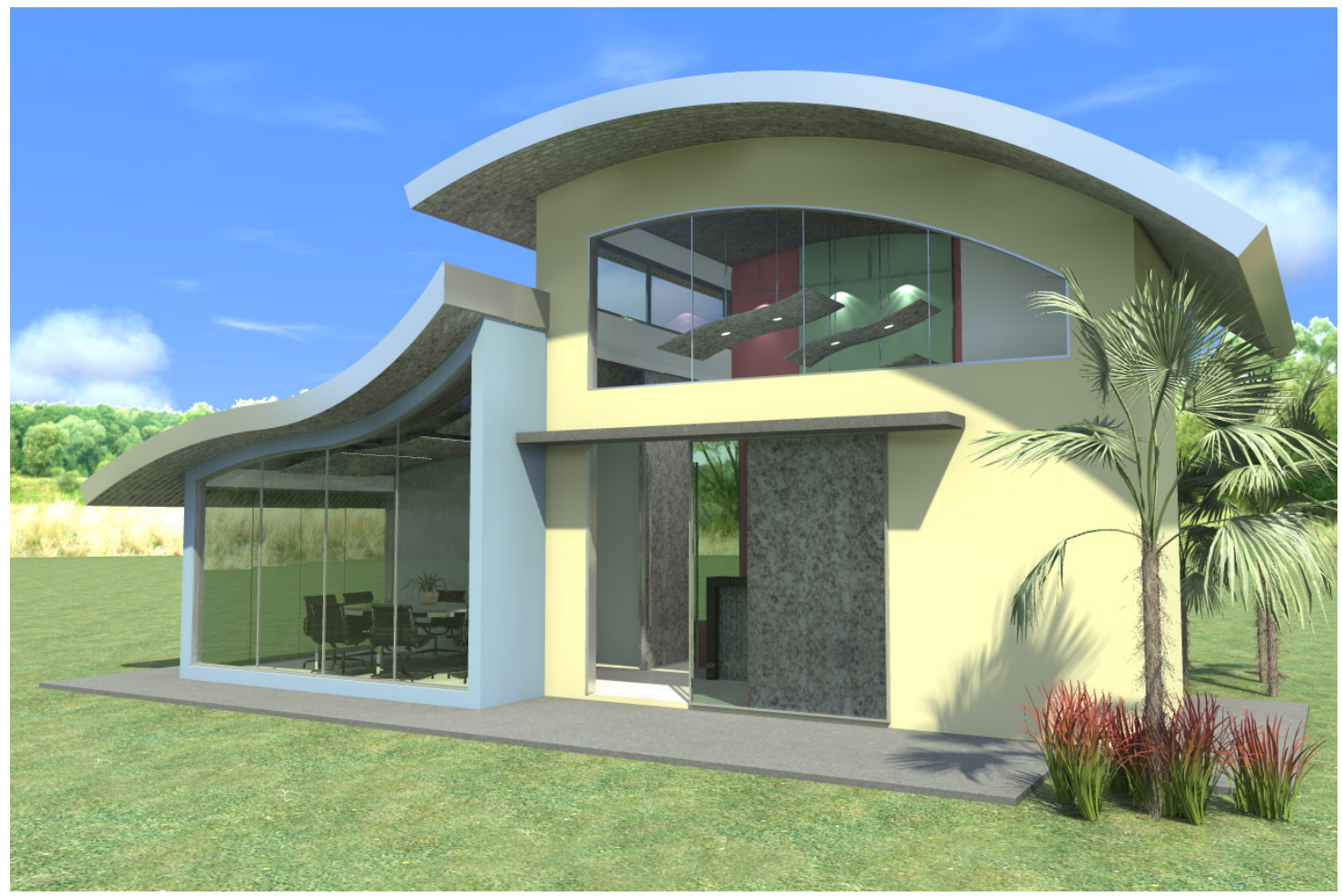

Projeto 2 - Vista externa 1

Fonte: Projeto da autora. Desenho: Albano.

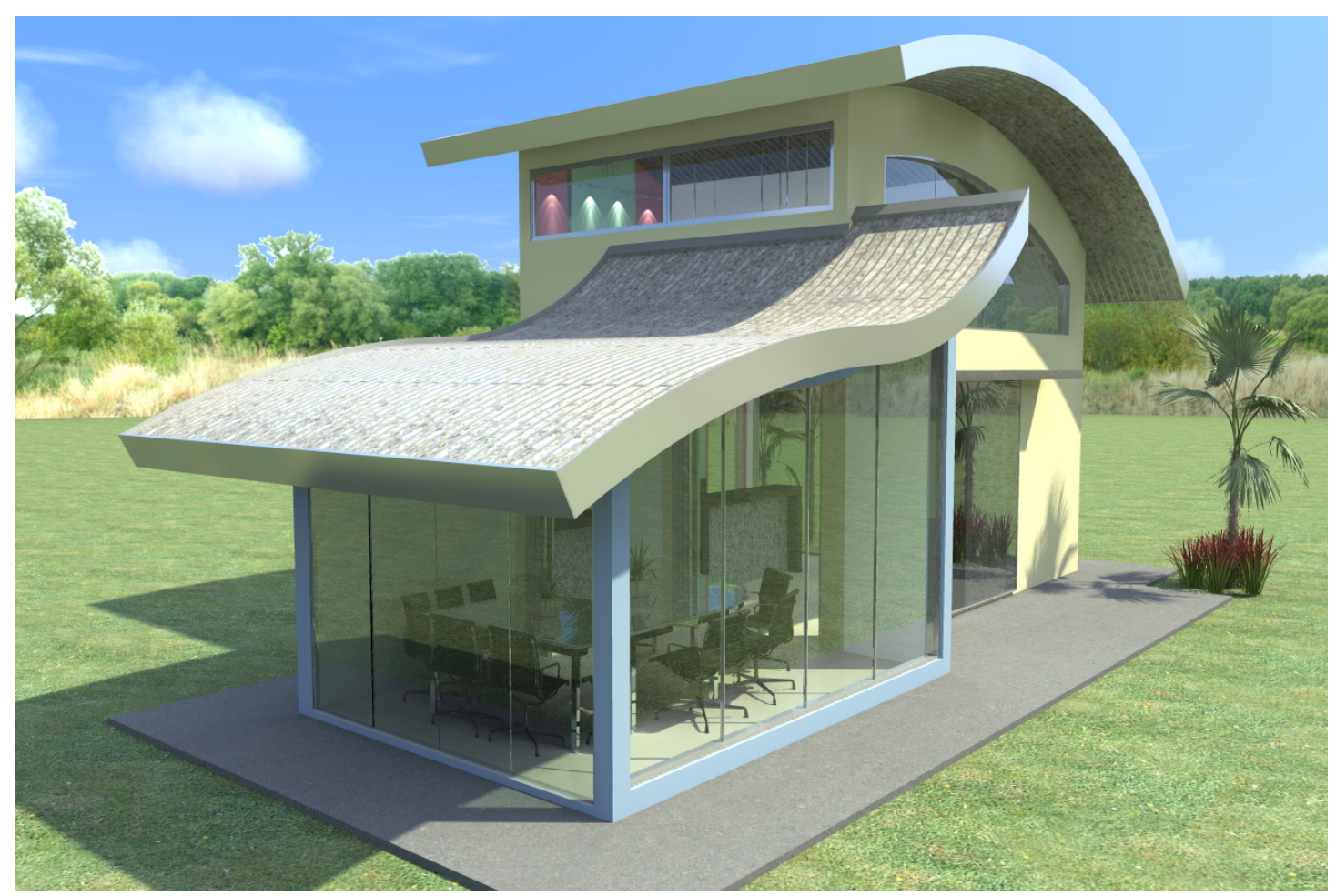

Projeto 2 - Vista externa 2

Fonte: Projeto da autora. Desenho: Albano. 


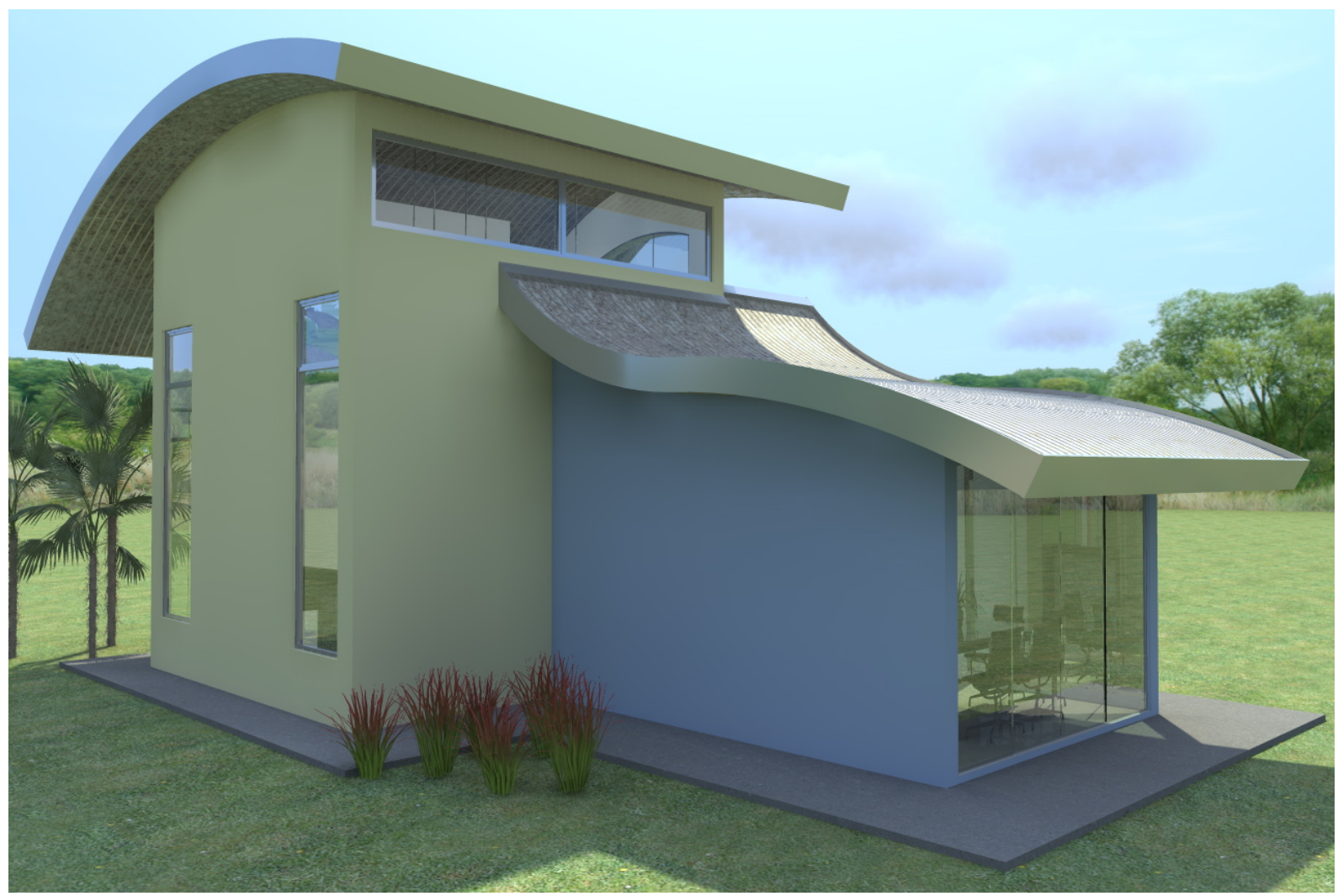

Projeto 2 - Vista externa 3

Fonte: Projeto da autora. Desenho: Albano.

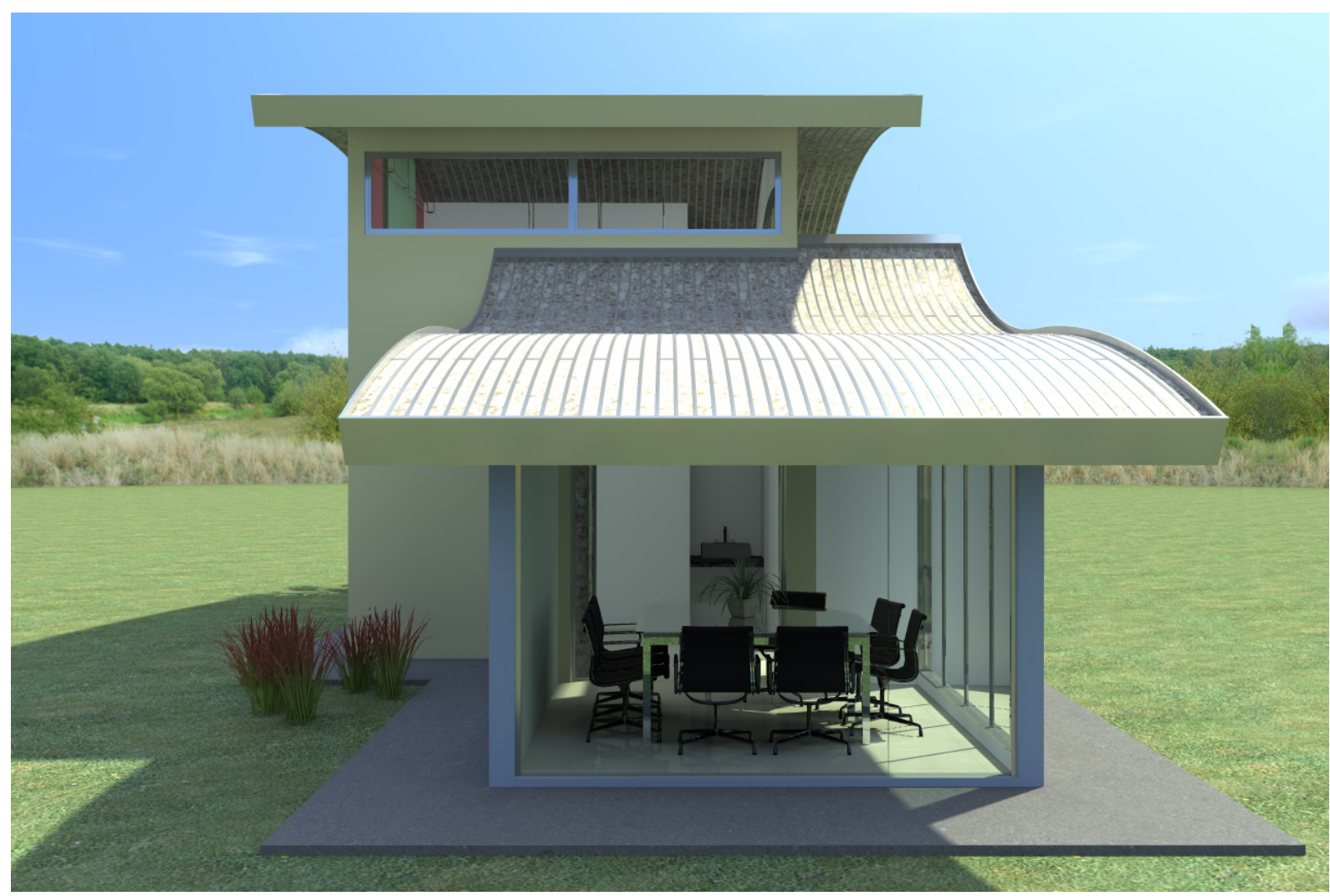

Projeto 2 - Vista externa 4

Fonte: Projeto da autora. Desenho: Albano. 


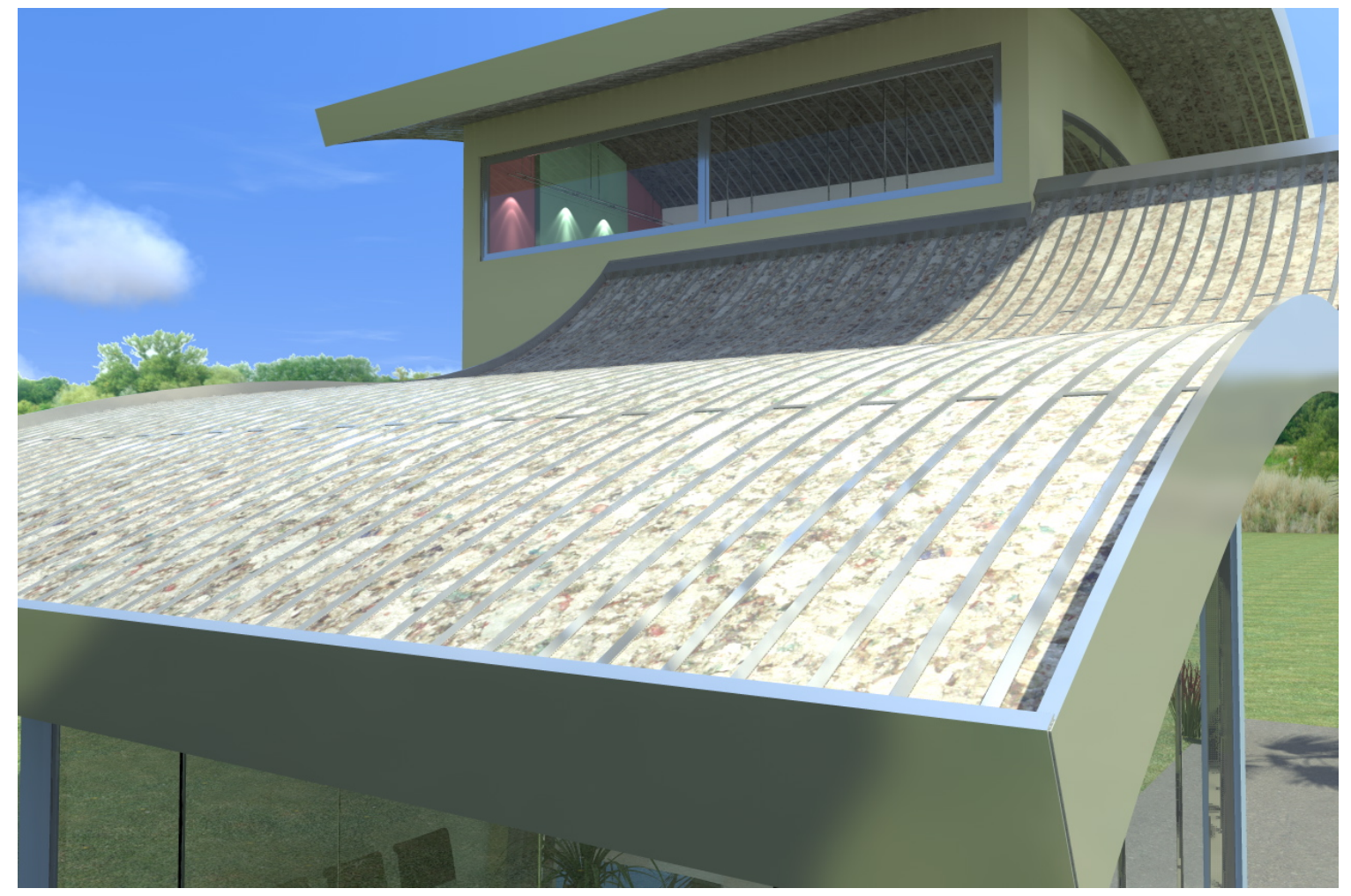

Projeto 2 - Vista externa 5

Fonte: Projeto da autora. Desenho: Albano.

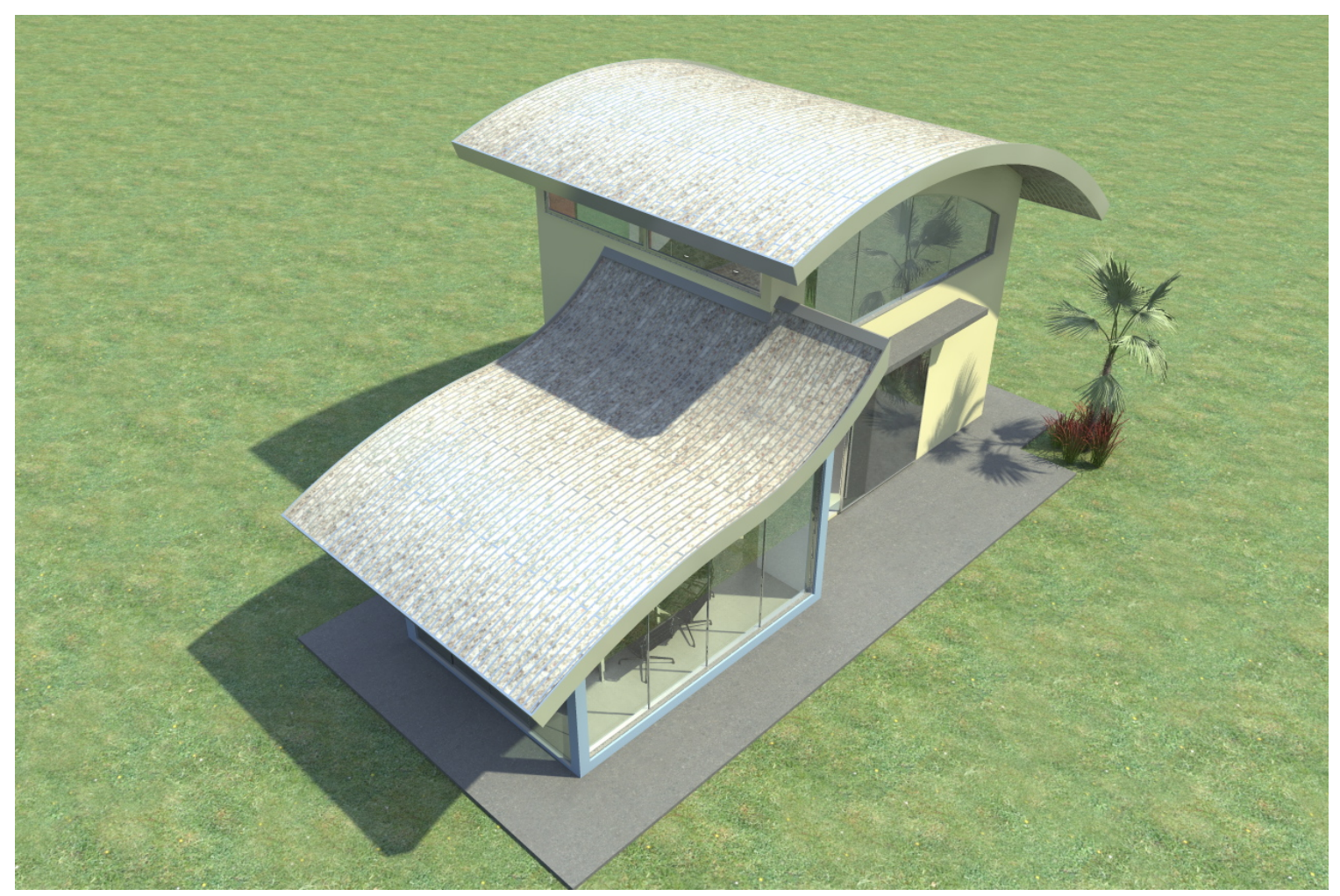

Projeto 2 - Vista externa 6

Fonte: Projeto da autora. Desenho: Albano. 


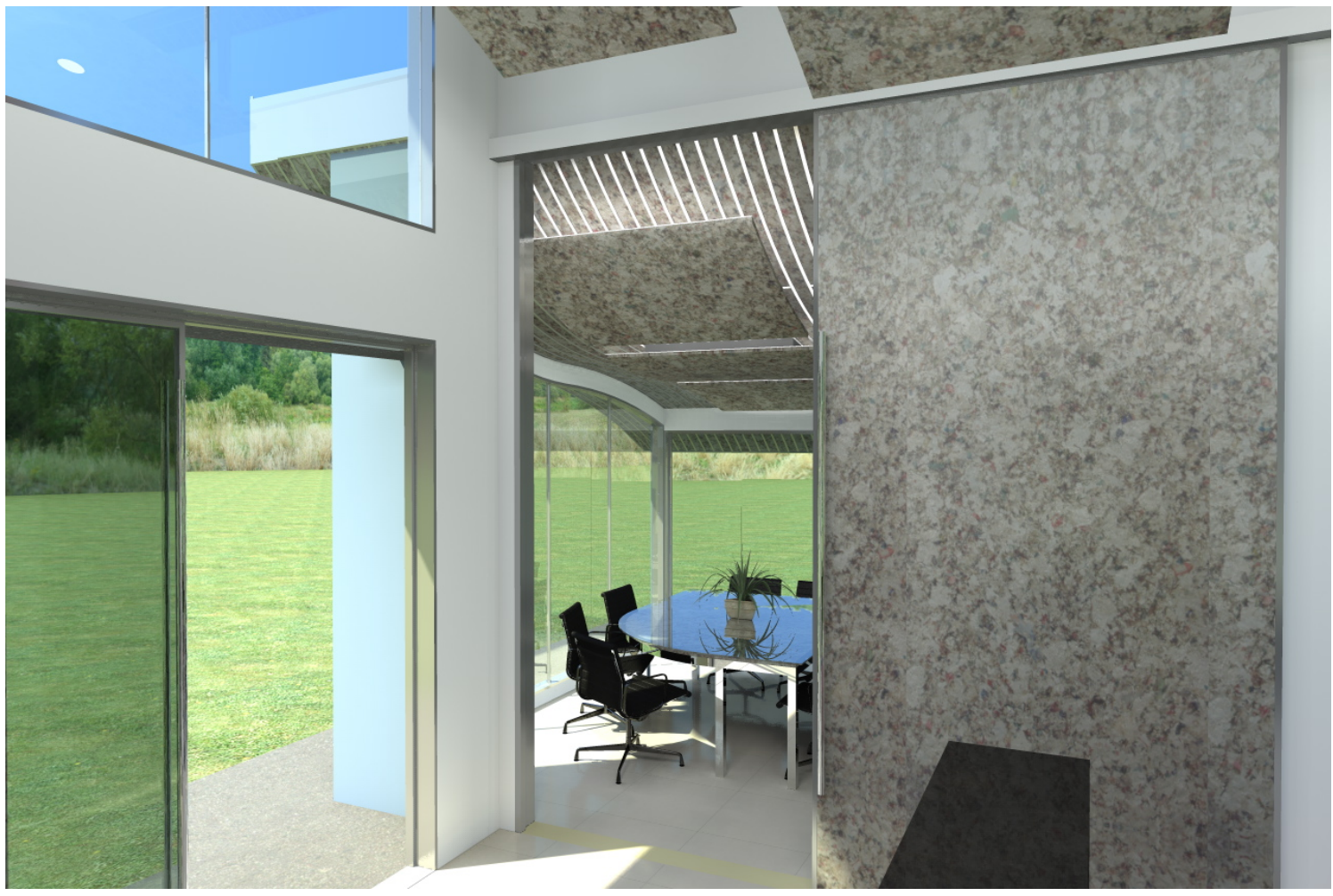

Projeto 2 - Vista interna 1

Fonte: Projeto da autora. Desenho: Albano.

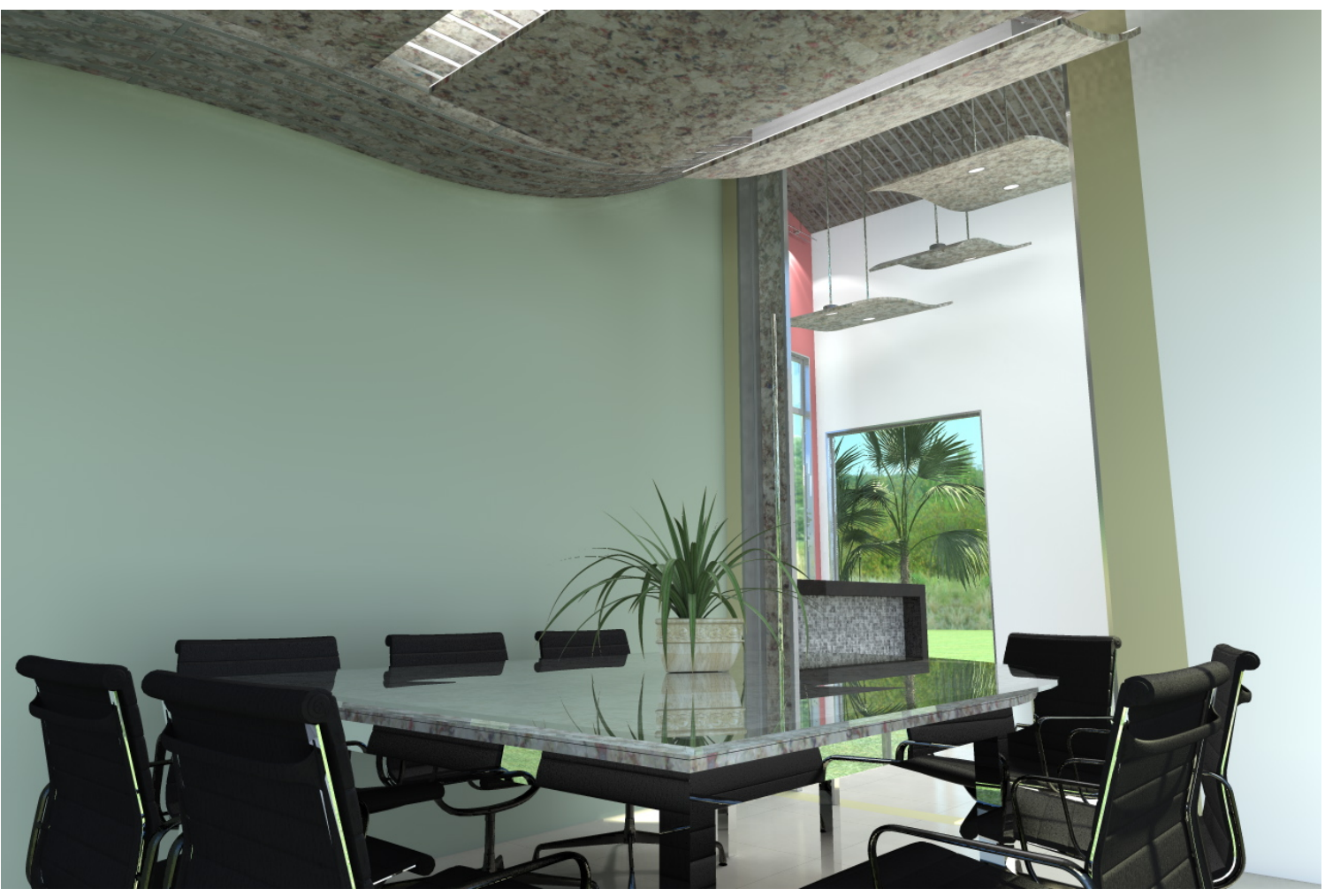

Projeto 2 - Vista interna 2

Fonte: Projeto da autora. Desenho: Albano. 


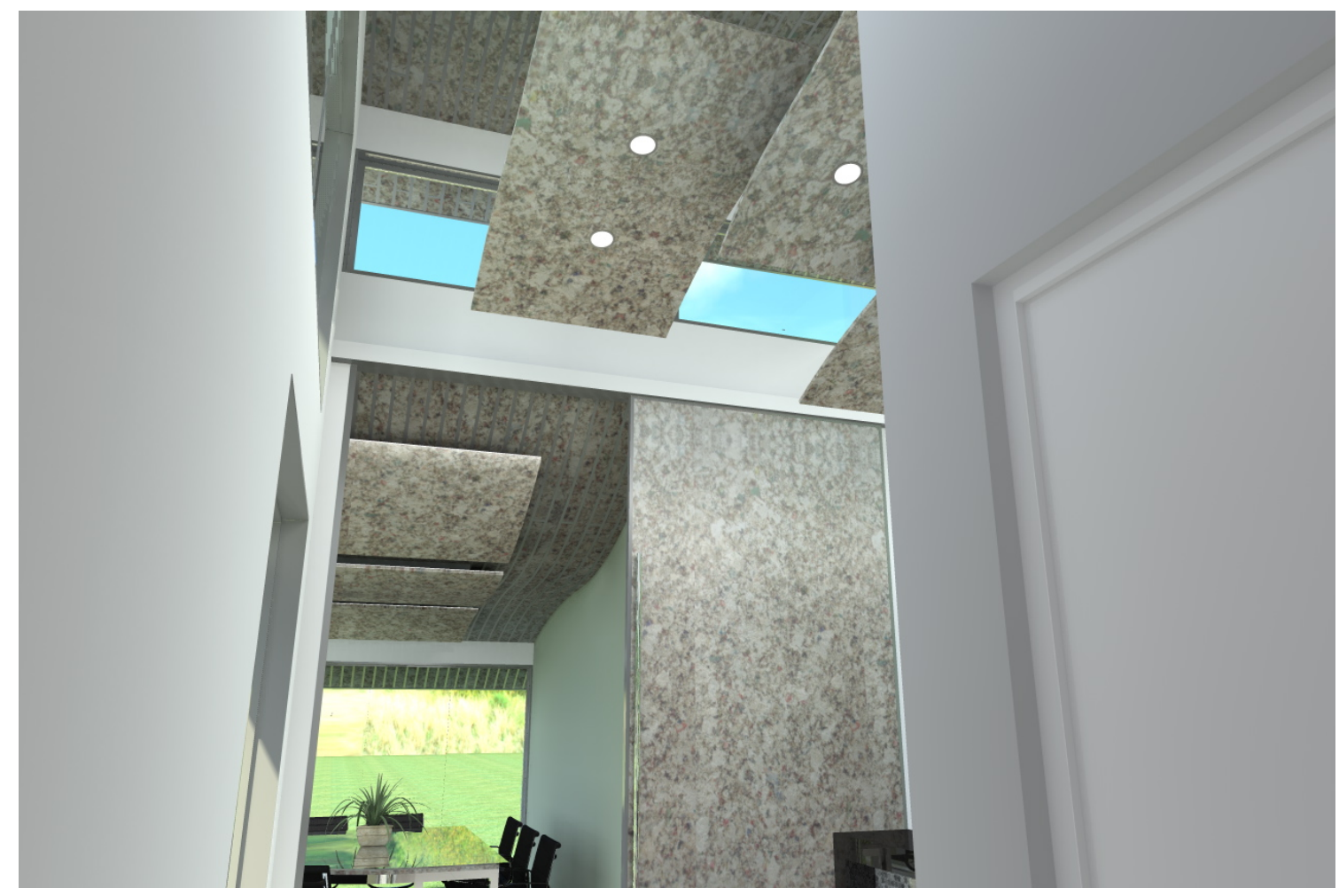

Projeto 2 - Vista interna 3

Fonte: Projeto da autora. Desenho: Albano.

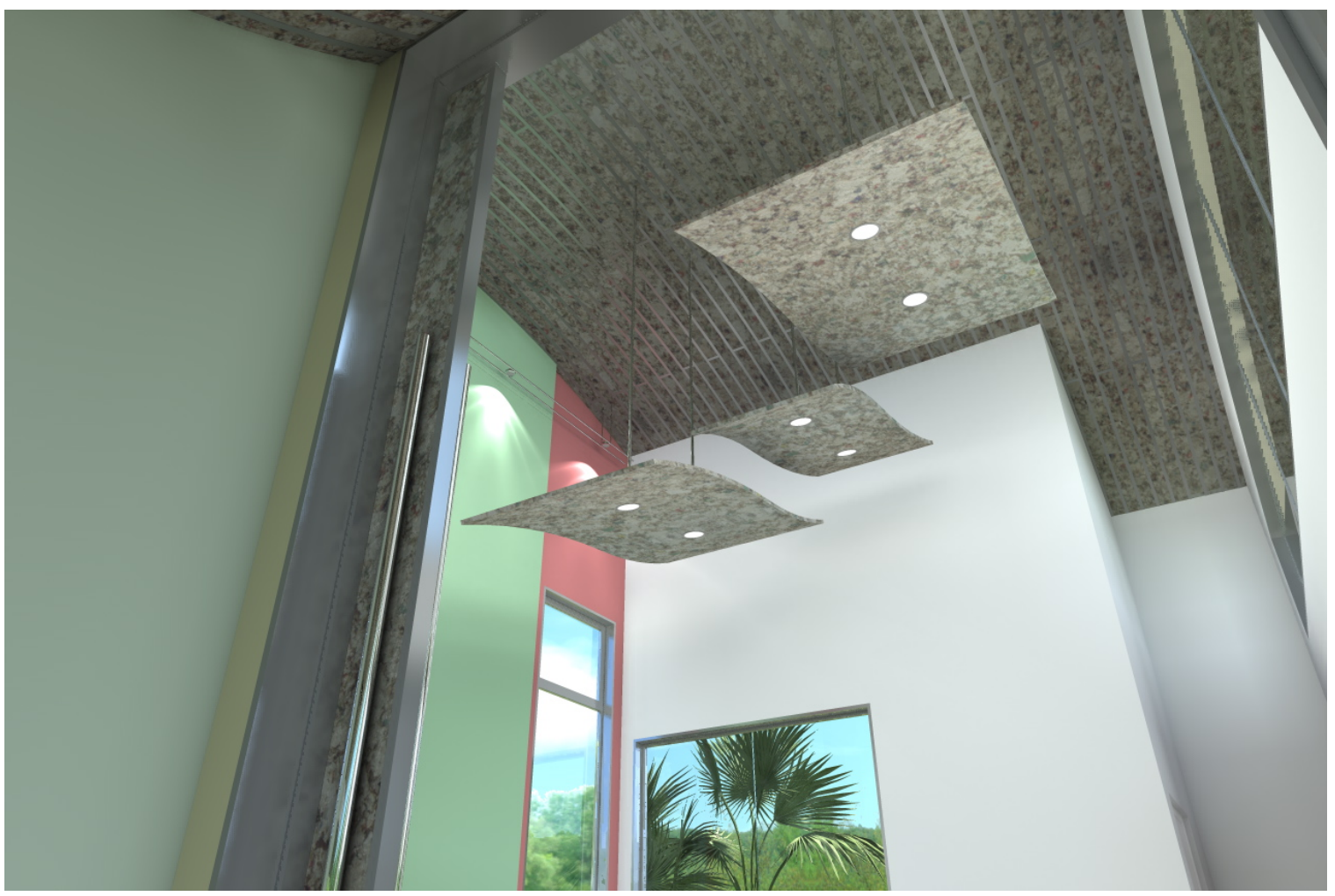

Projeto 2 - Vista interna 4

Fonte: Projeto da autora. Desenho: Albano. 


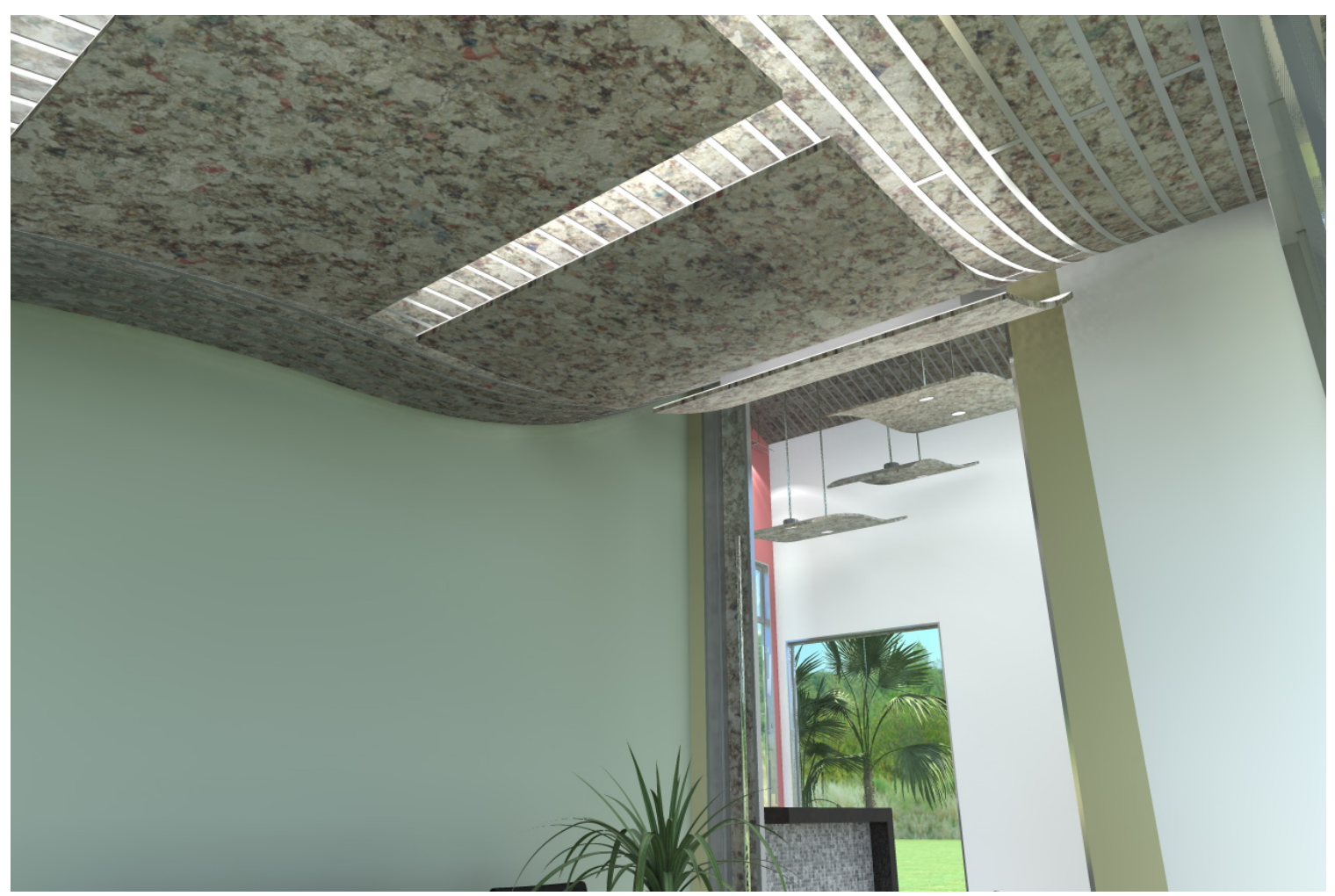

Projeto 2 - Vista interna 5

Fonte: Projeto da autora. Desenho: Albano.

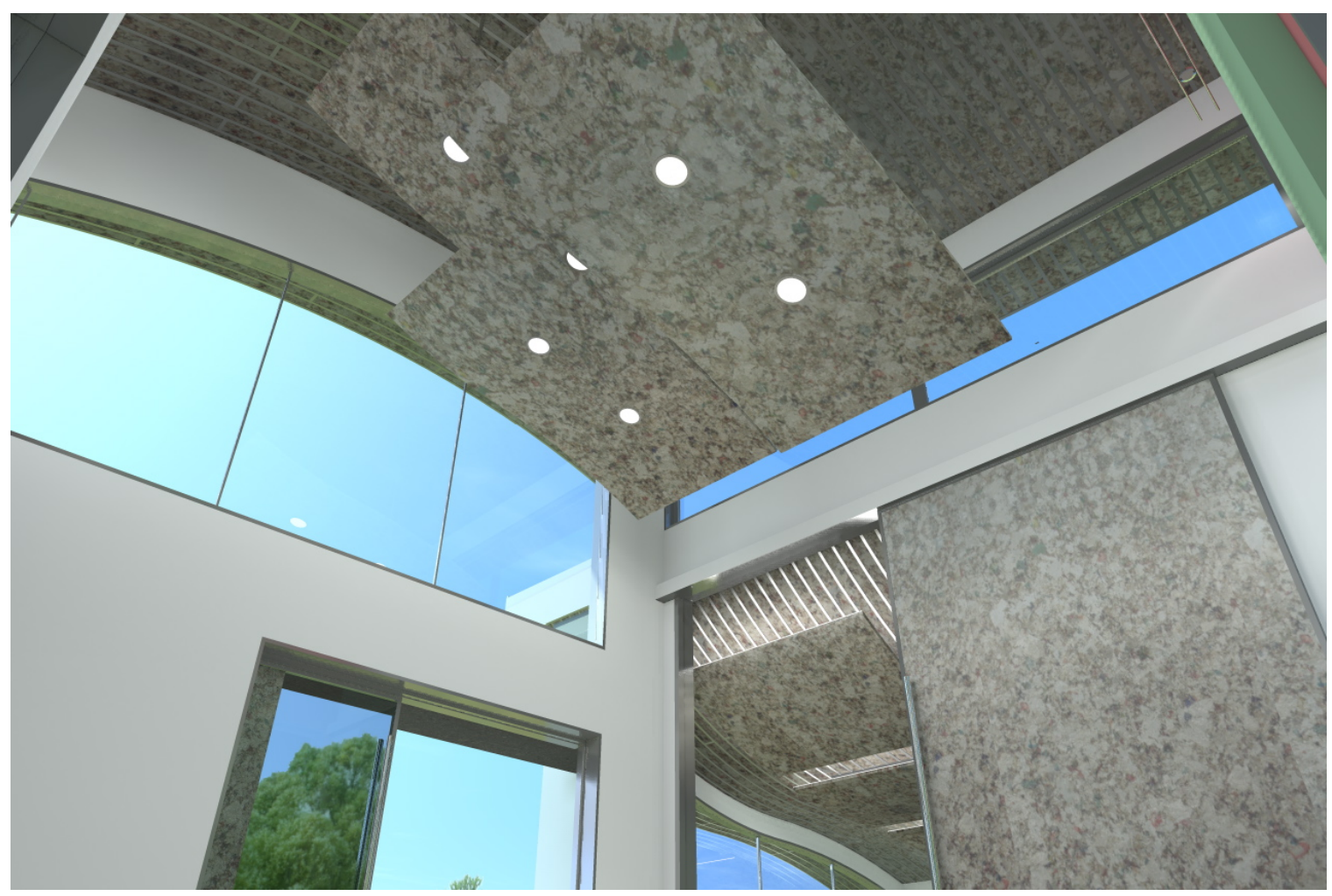

Projeto 2 - Vista interna 6

Fonte: Projeto da autora. Desenho: Albano. 
Propostas Projetuais 


\subsection{3 - Projeto 3}

Neste terceiro projeto, novamente foram utilizados os tons de cinza na materialidade para compor com a tonalidade da placa. O que se destaca externamente é o painel de brise com quadriculado parcialmente preenchido com as placas recicladas. A parede externa é de concreto moldado em formas horizontais, deixando aspecto rústico marcado. Uma outra opção boa para esta composição seriam os blocos de concreto. A porta de entrada também, como no projeto 1 é metálica. Na cobertura também são utilizadas as telhas onduladas recicladas, de maneira tradicional. Internamente, as composições materiais para harmonizar com a textura das placas foram: piso metálico recalcado (tipo "piso de ônibus"), na parede também chapas metálicas lisas. Os objetos desenhados com uso das placas recicladas foram: luminária curva, arandela e painel mosaico iluminado.

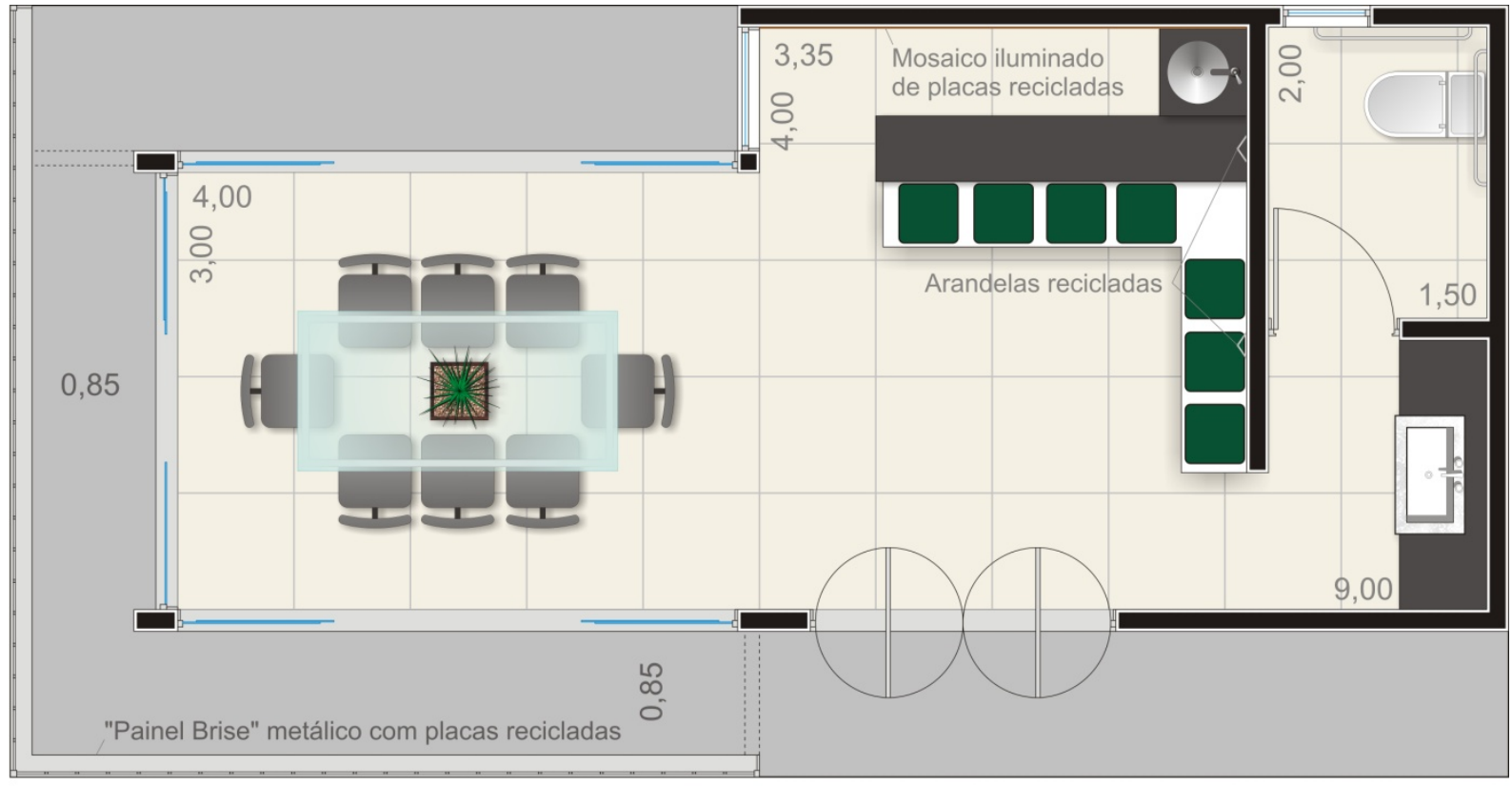

Planta Projeto 3

sem escala - área $36 \mathrm{~m}^{2}$

Projeto 3 - Planta

Fonte: Projeto da autora. Desenho: Matheus Albano. 


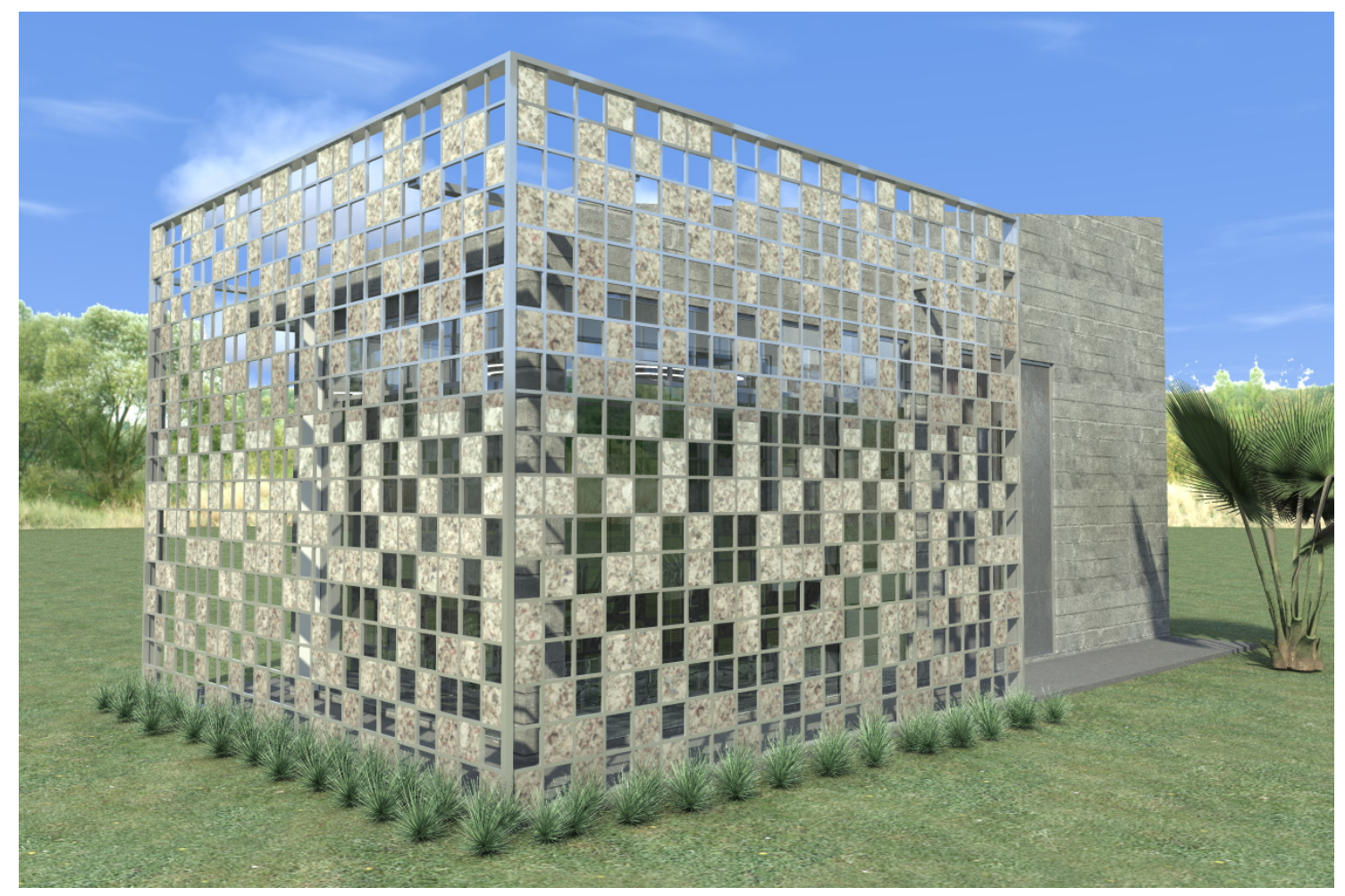

Projeto 3 - Vista externa 1

Fonte: Projeto da autora. Desenho: Albano.

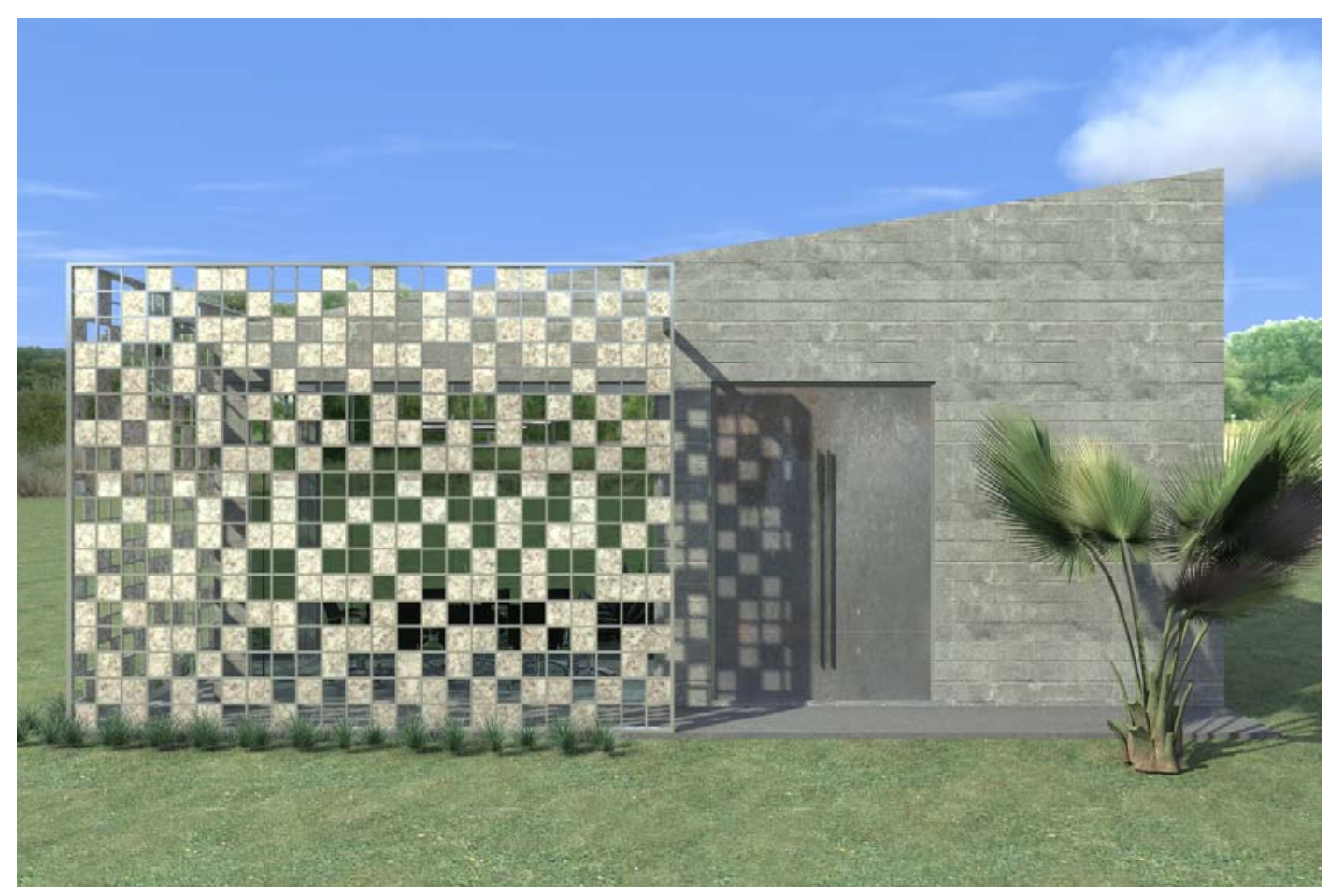

Projeto 3 - Vista externa 2

Fonte: Projeto da autora. Desenho: Albano. 


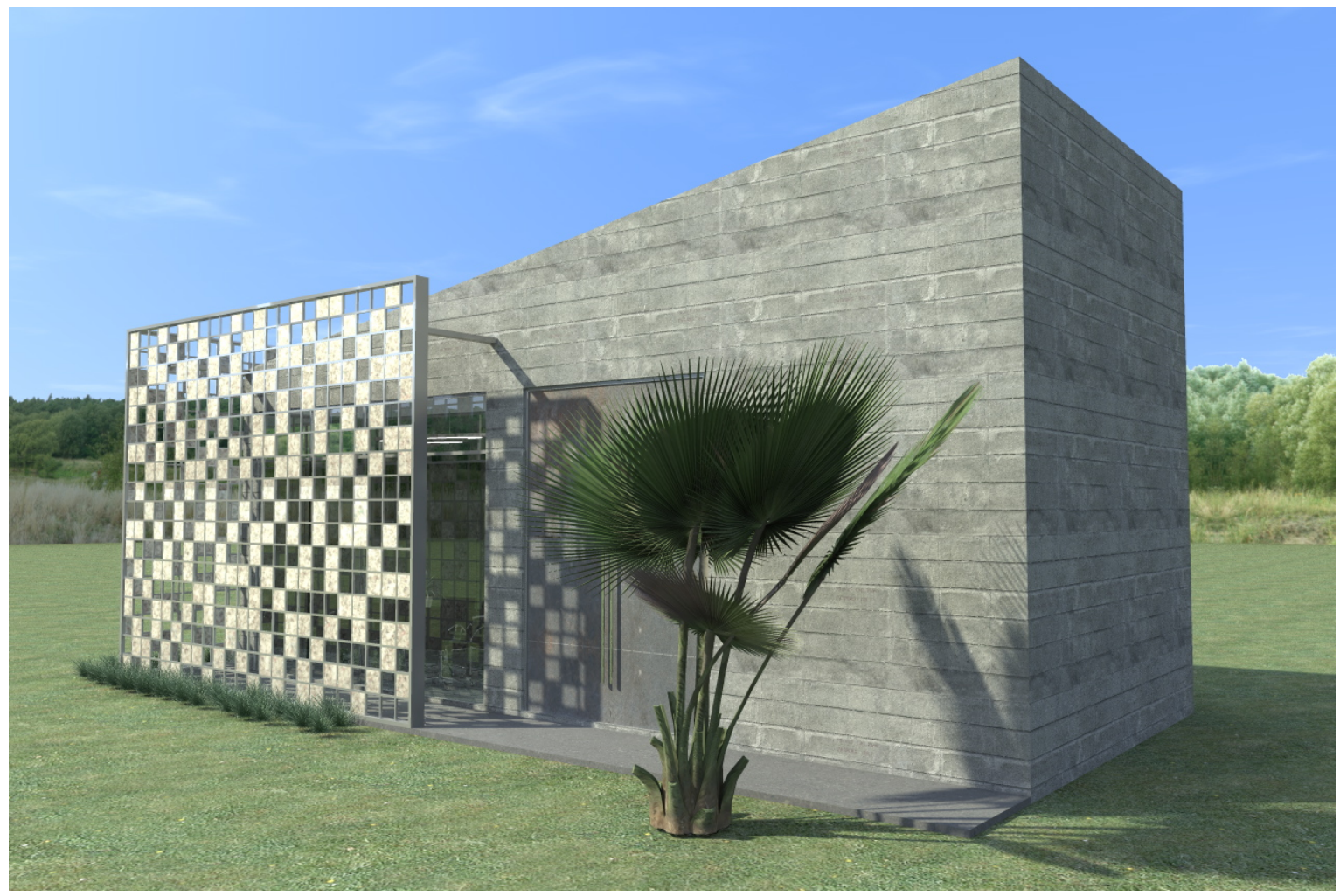

Projeto 3 - Vista externa 3

Fonte: Projeto da autora. Desenho: Albano.

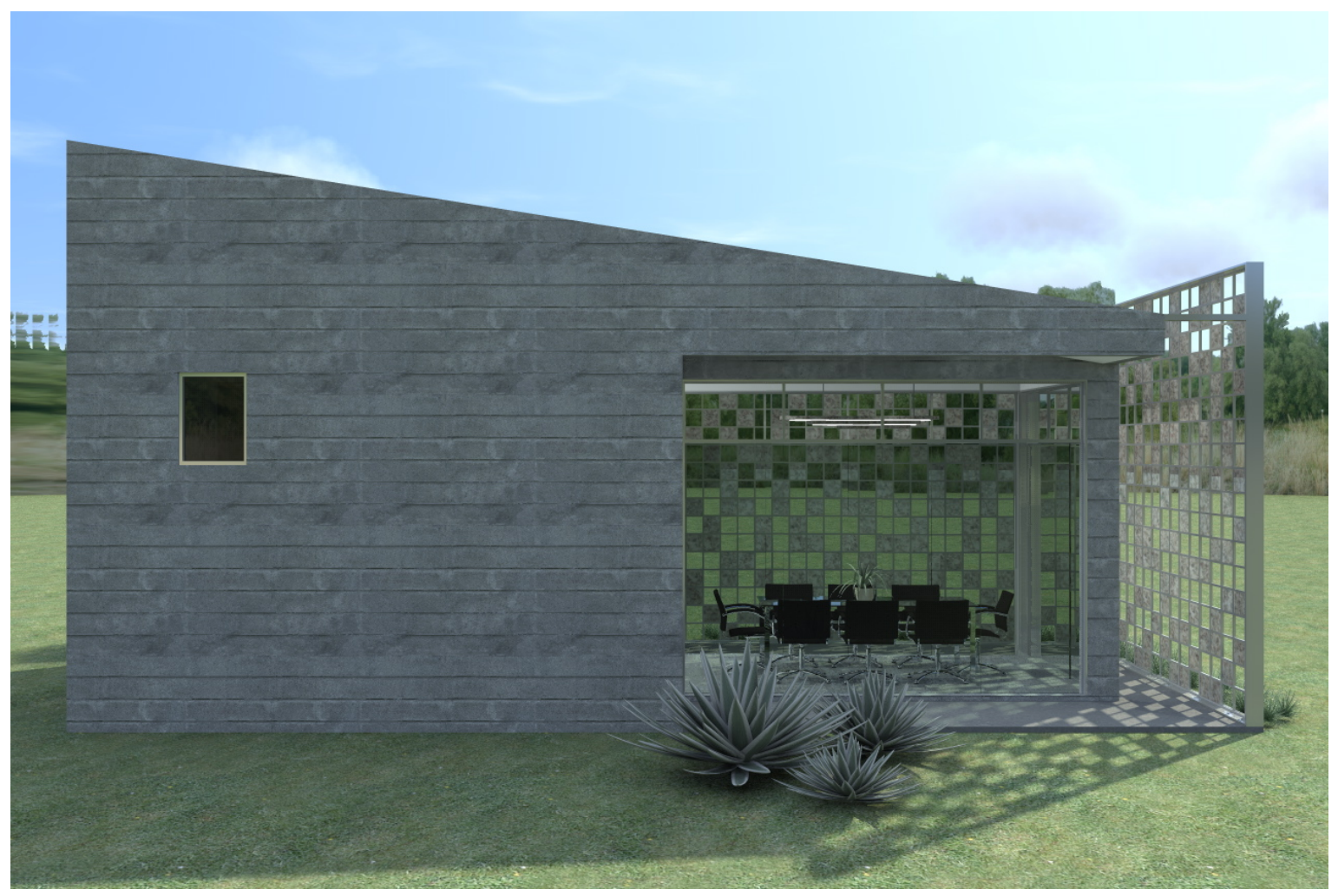

Projeto 3 - Vista externa 4

Fonte: Projeto da autora. Desenho: Albano. 


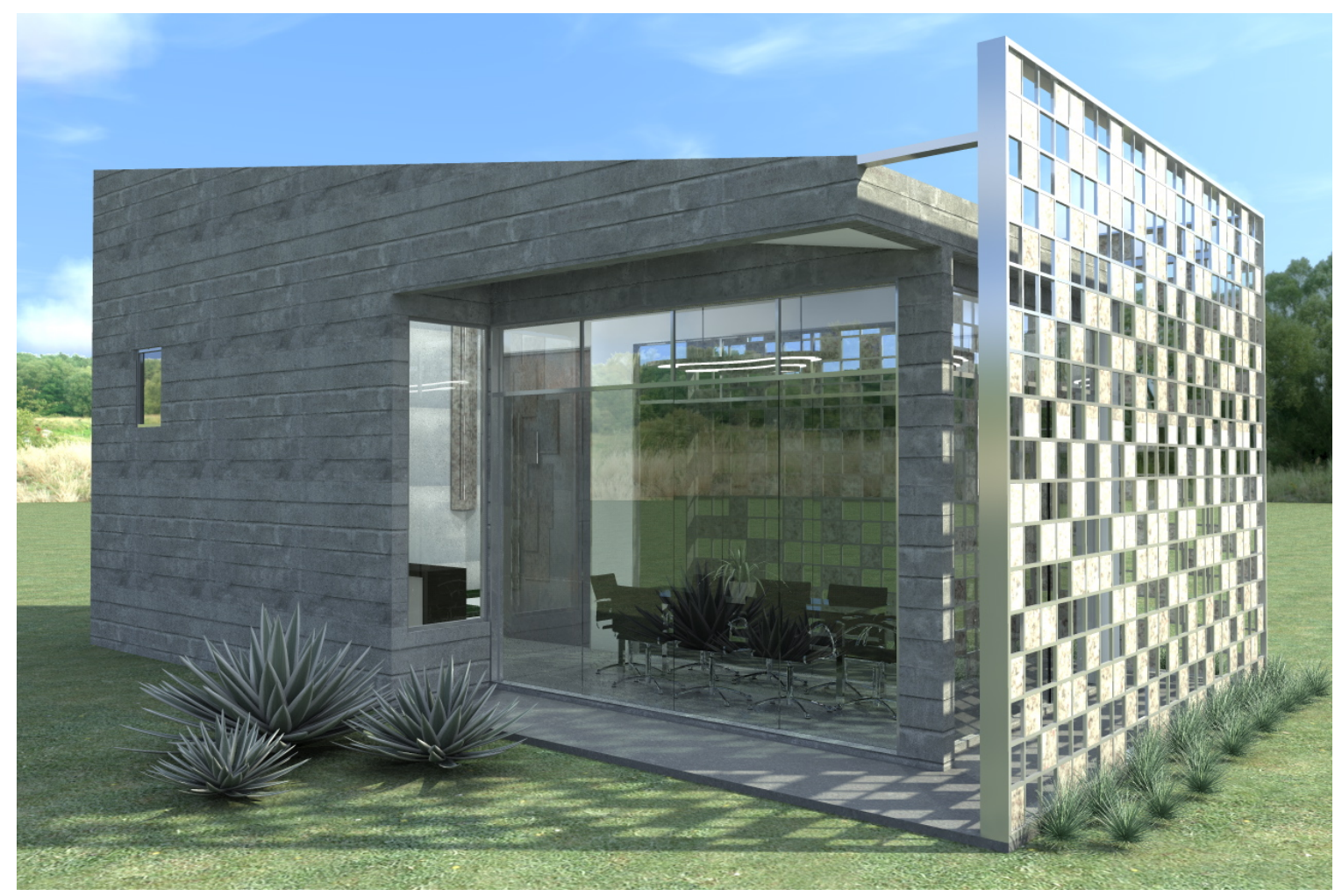

Projeto 3 - Vista externa 5

Fonte: Projeto da autora. Desenho: Albano.

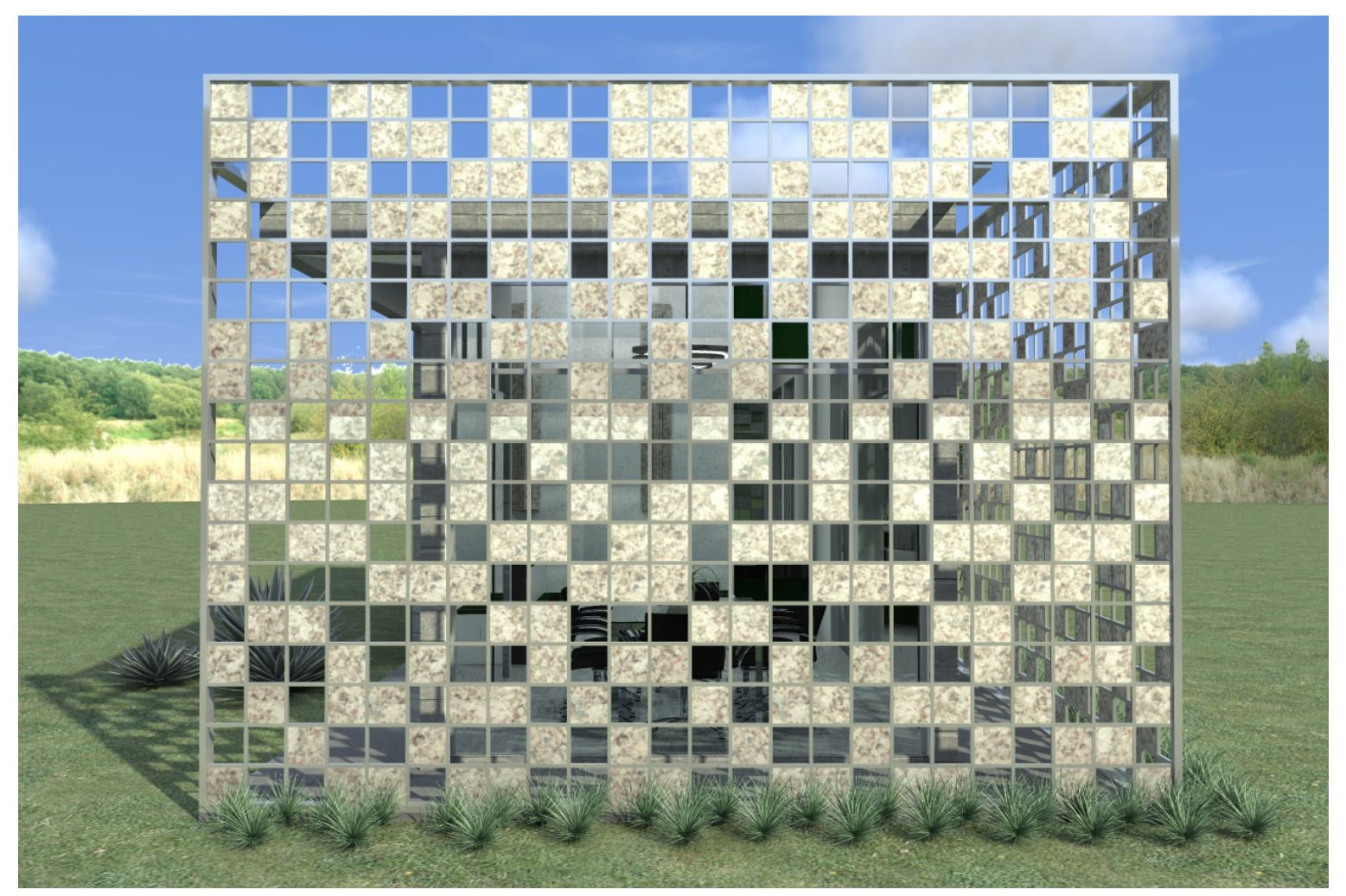

Projeto 3 - Vista externa 6

Fonte: Projeto da autora. Desenho: Albano. 


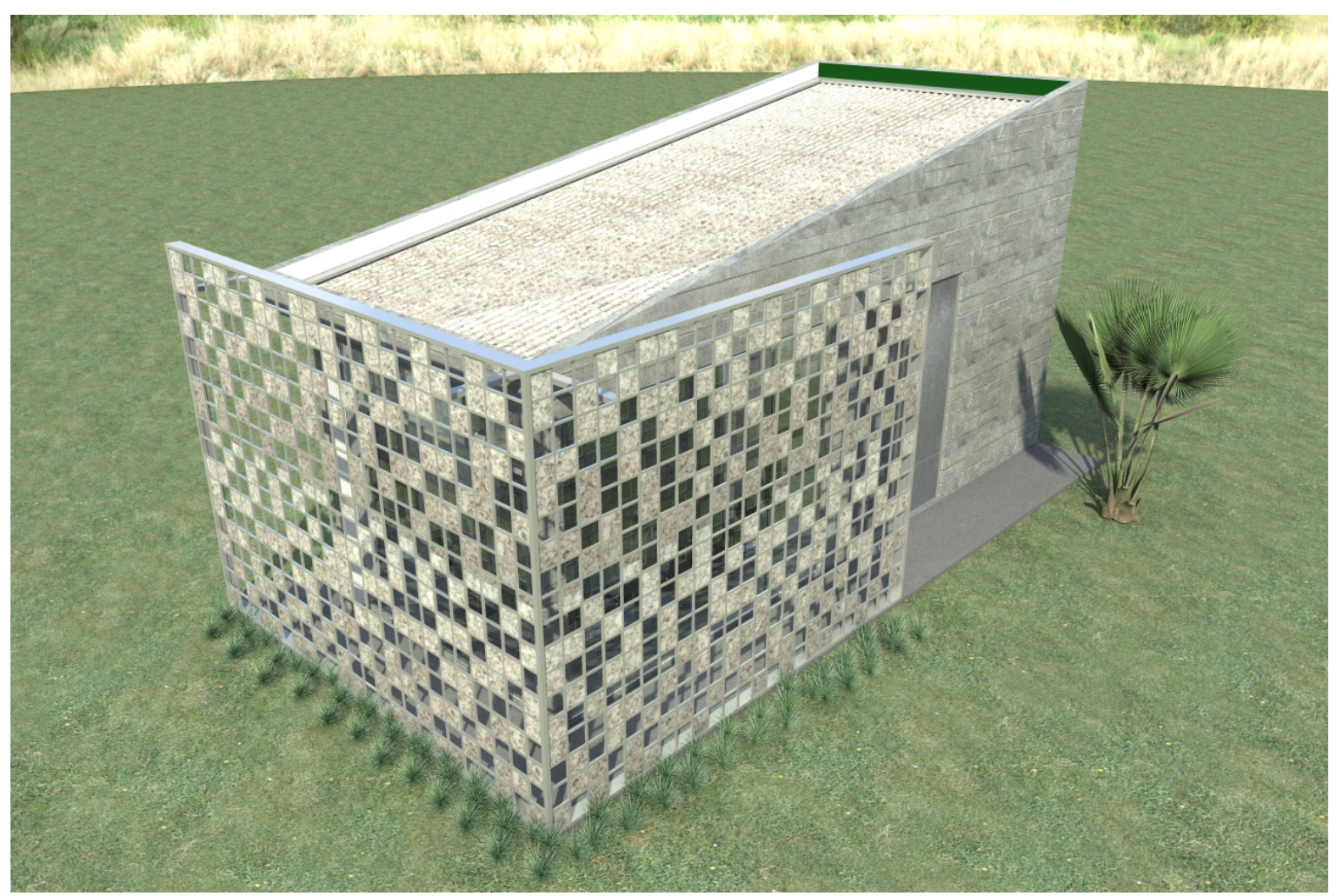

Projeto 3 - Vista externa 7

Fonte: Projeto da autora. Desenho: Albano.

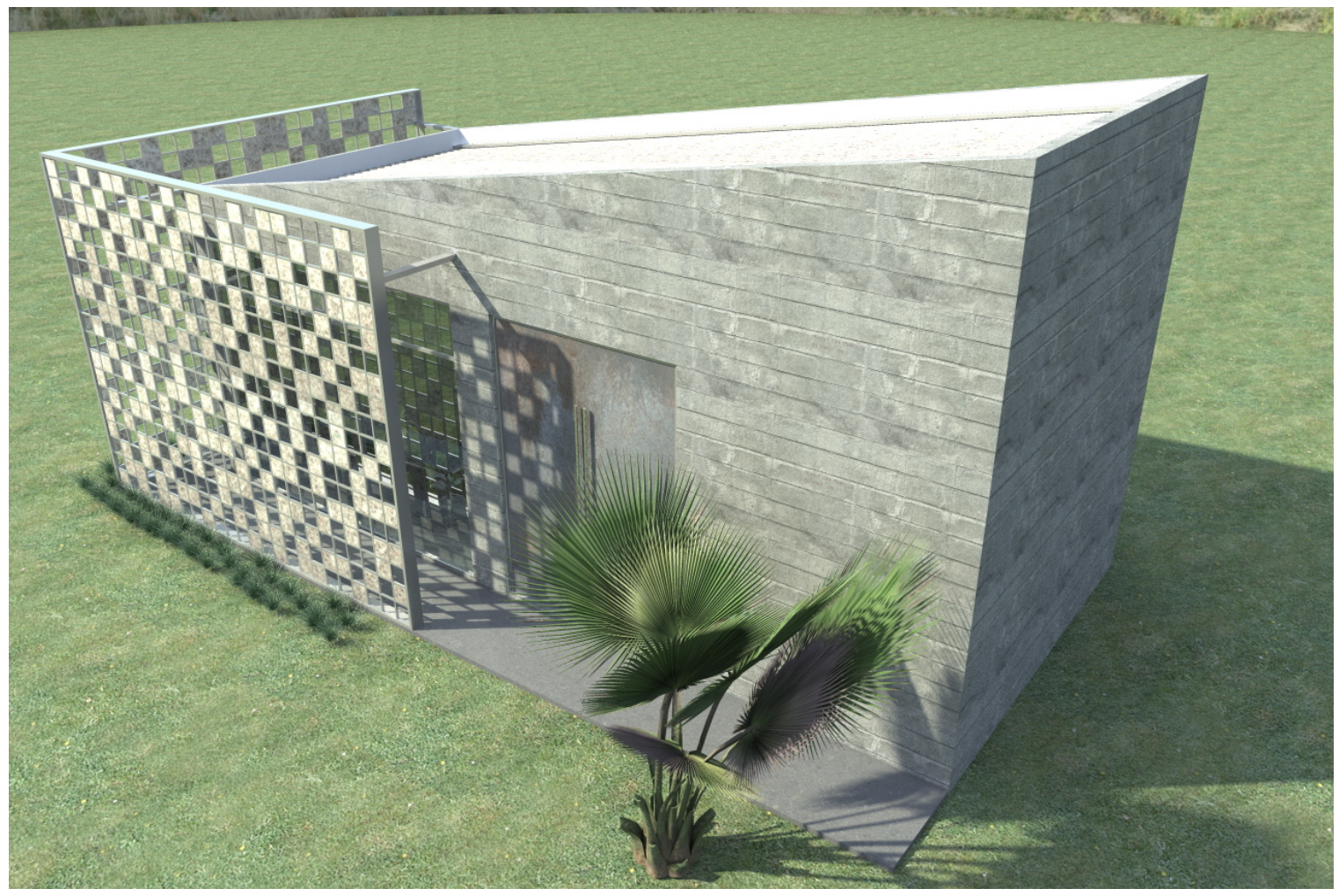

Projeto 3 - Vista externa 8

Fonte: Projeto da autora. Desenho: Albano. 


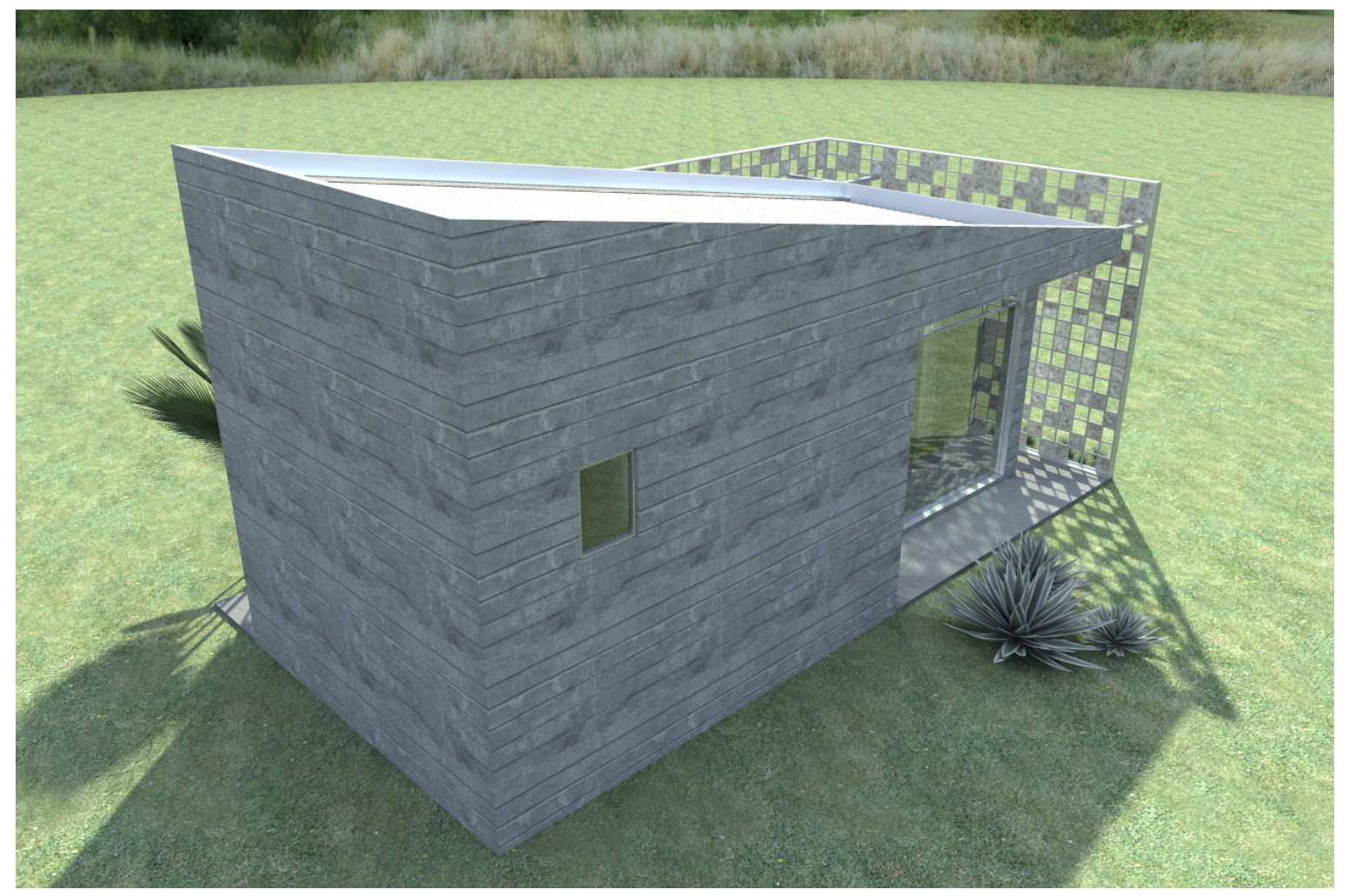

Projeto 3 - Vista externa 9

Fonte: Projeto da autora. Desenho: Albano.

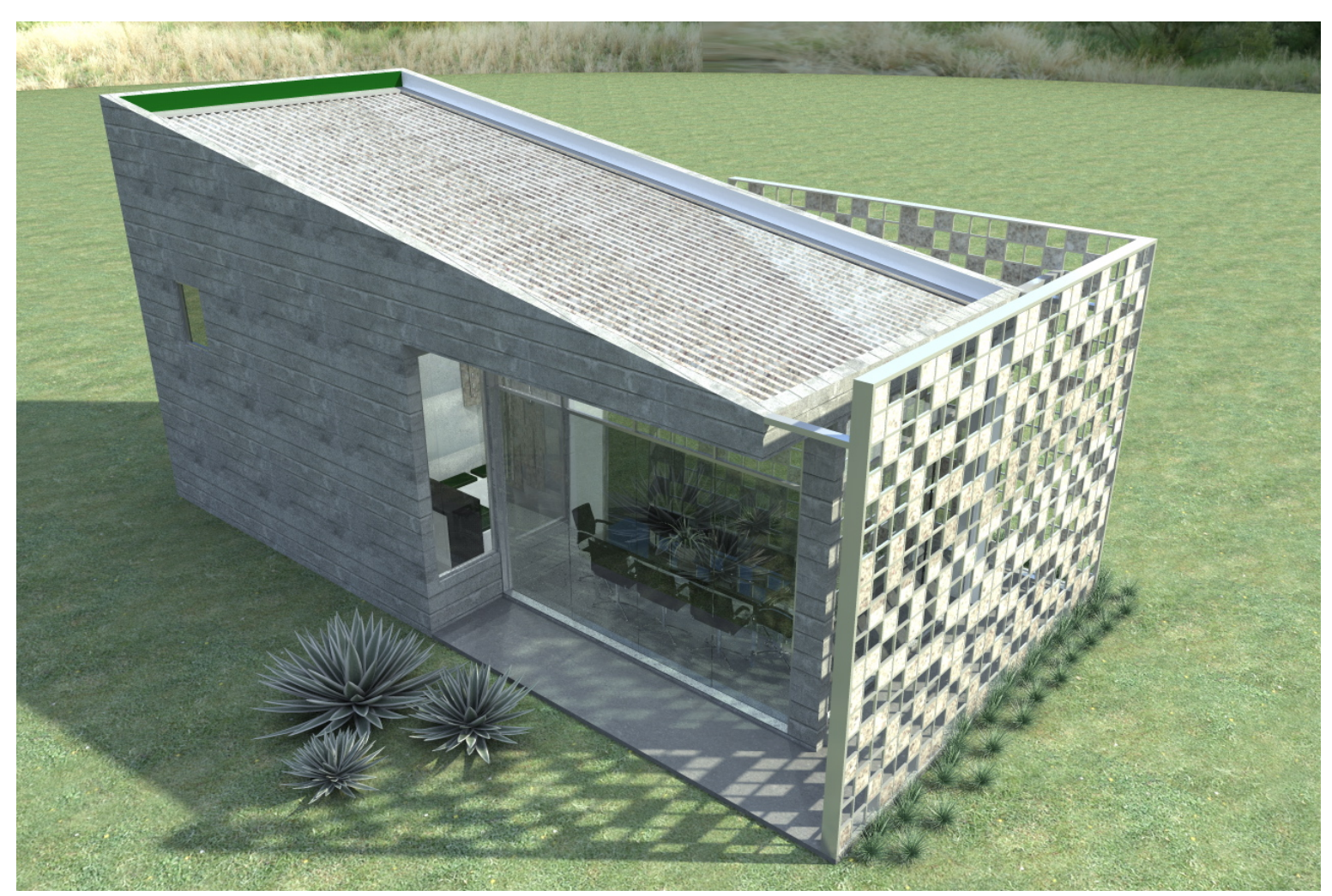

Projeto 3 - Vista externa 10

Fonte: Projeto da autora. Desenho: Albano. 


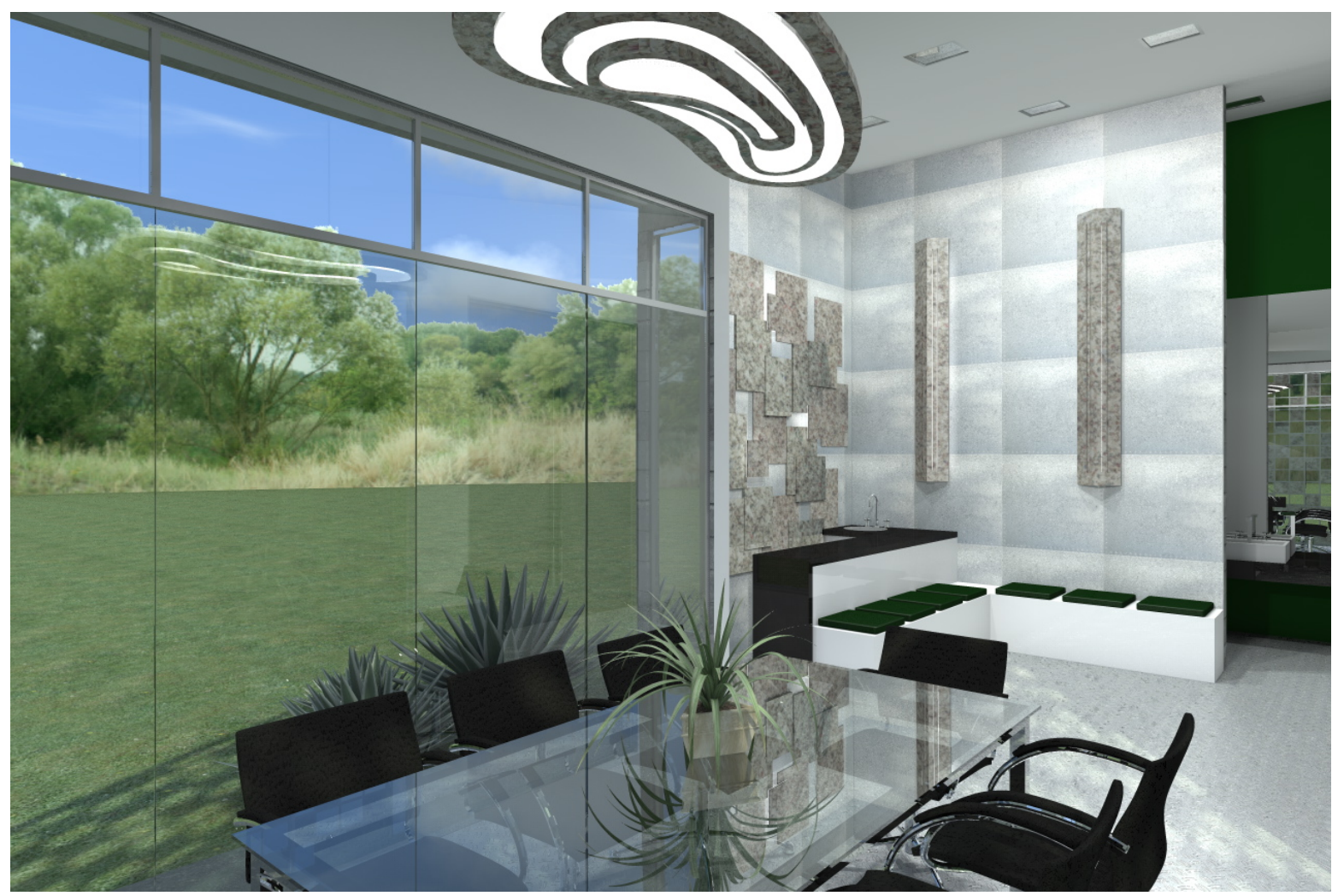

Projeto 3 - Vista interna 1

Fonte: Projeto da autora. Desenho: Albano.

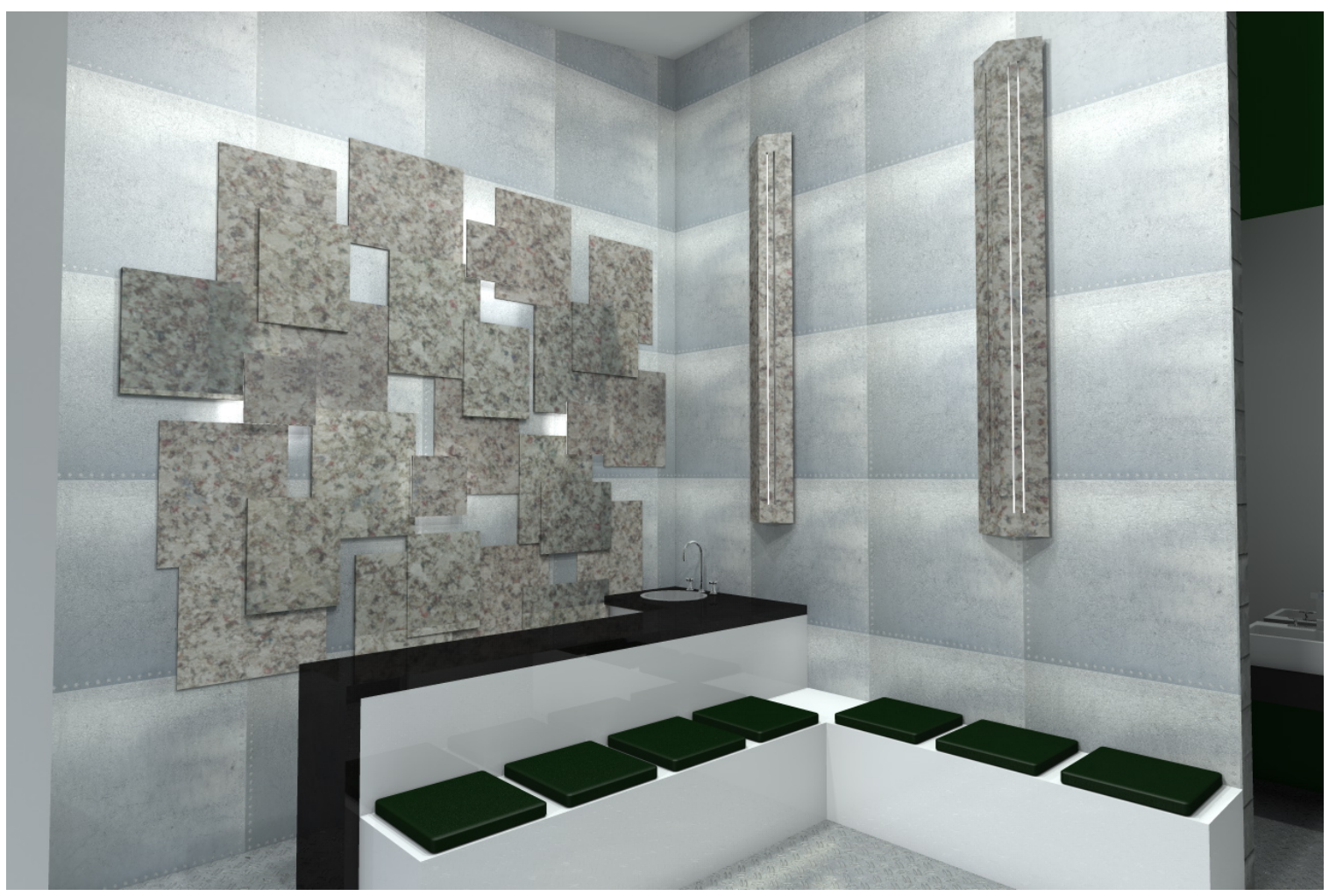

Projeto 3 - Vista interna 2

Fonte: Projeto da autora. Desenho: Albano. 


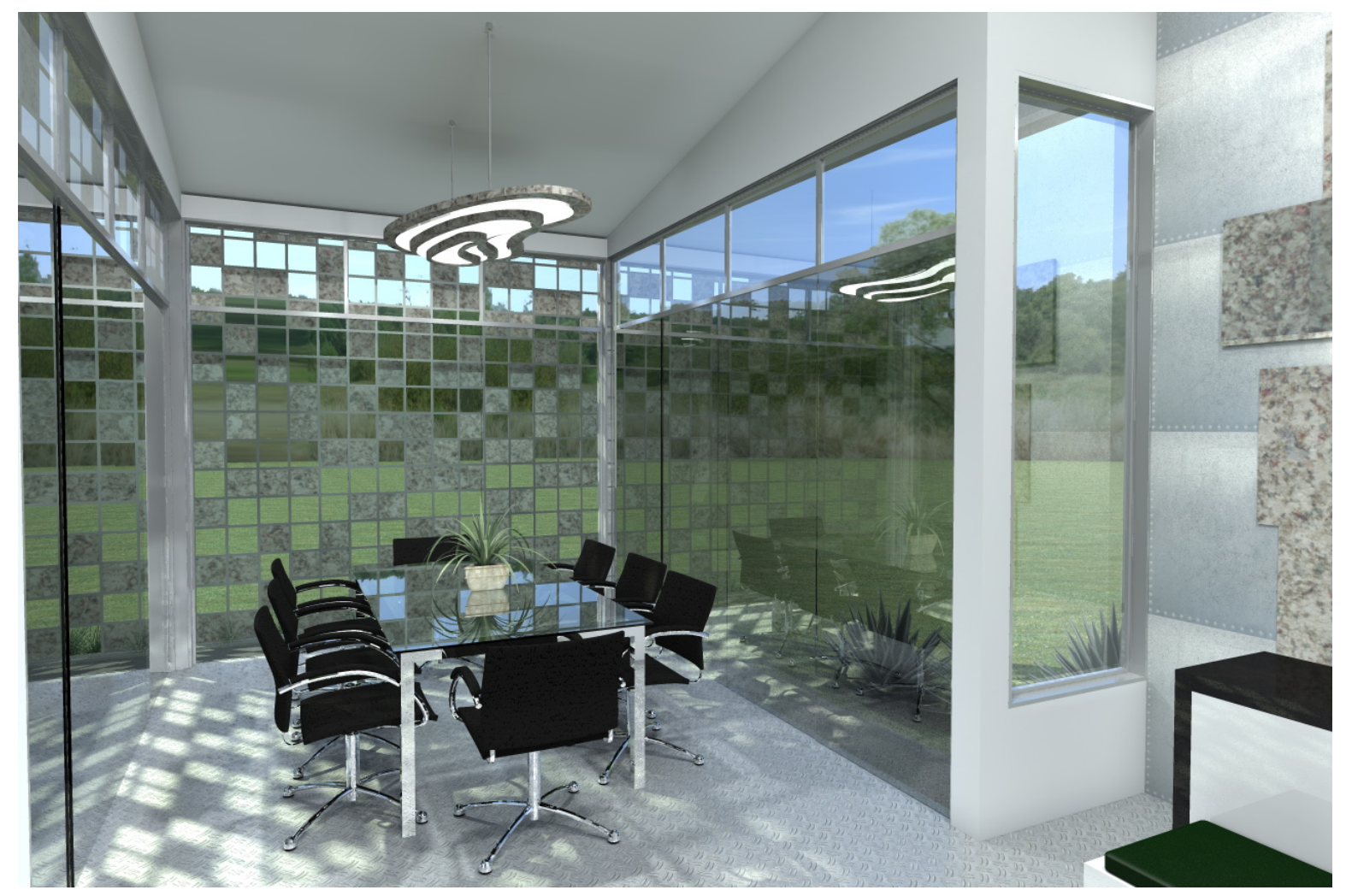

Projeto 3 - Vista interna 3

Fonte: Projeto da autora. Desenho: Albano.

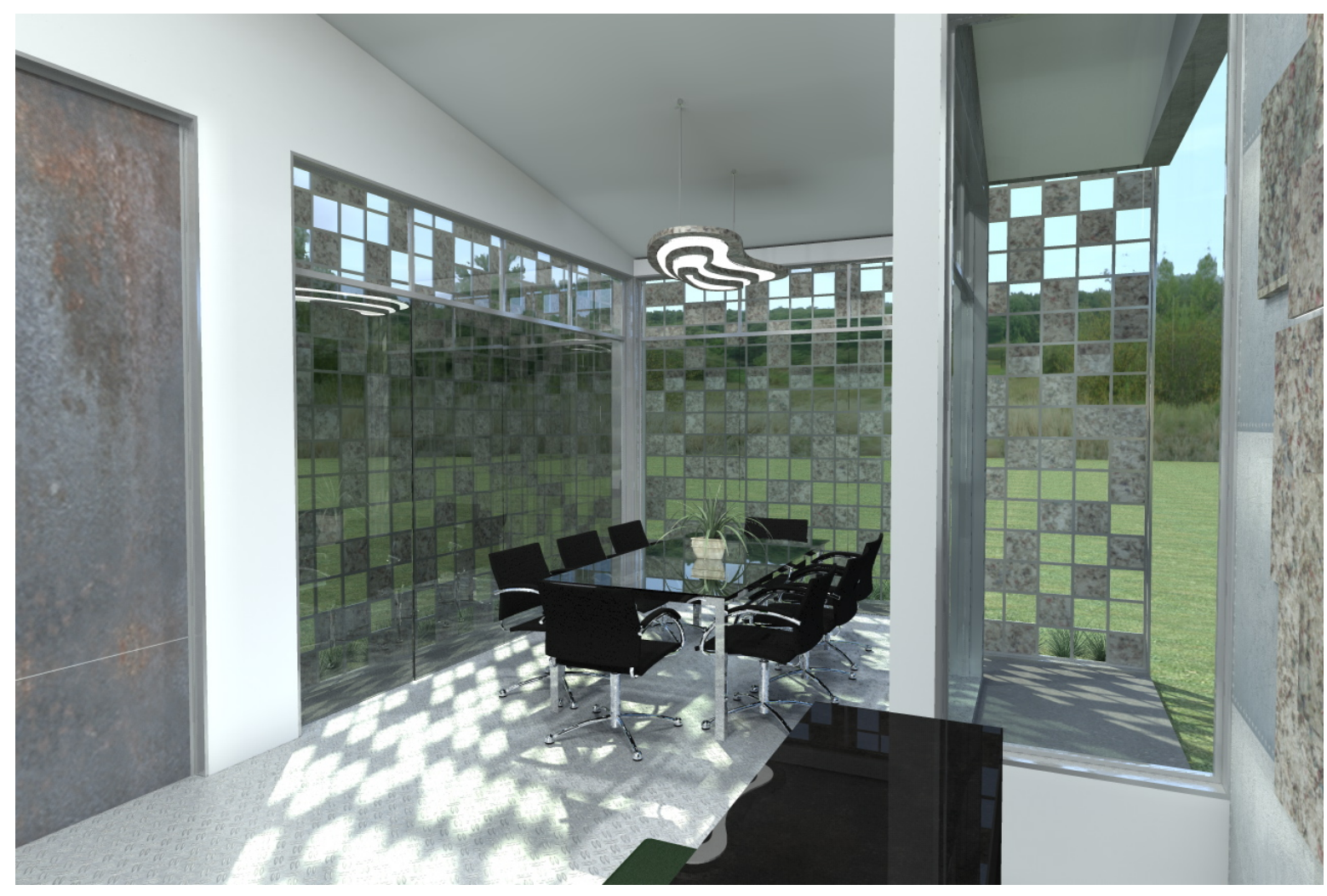

Projeto 3 - Vista interna 4

Fonte: Projeto da autora. Desenho: Albano. 


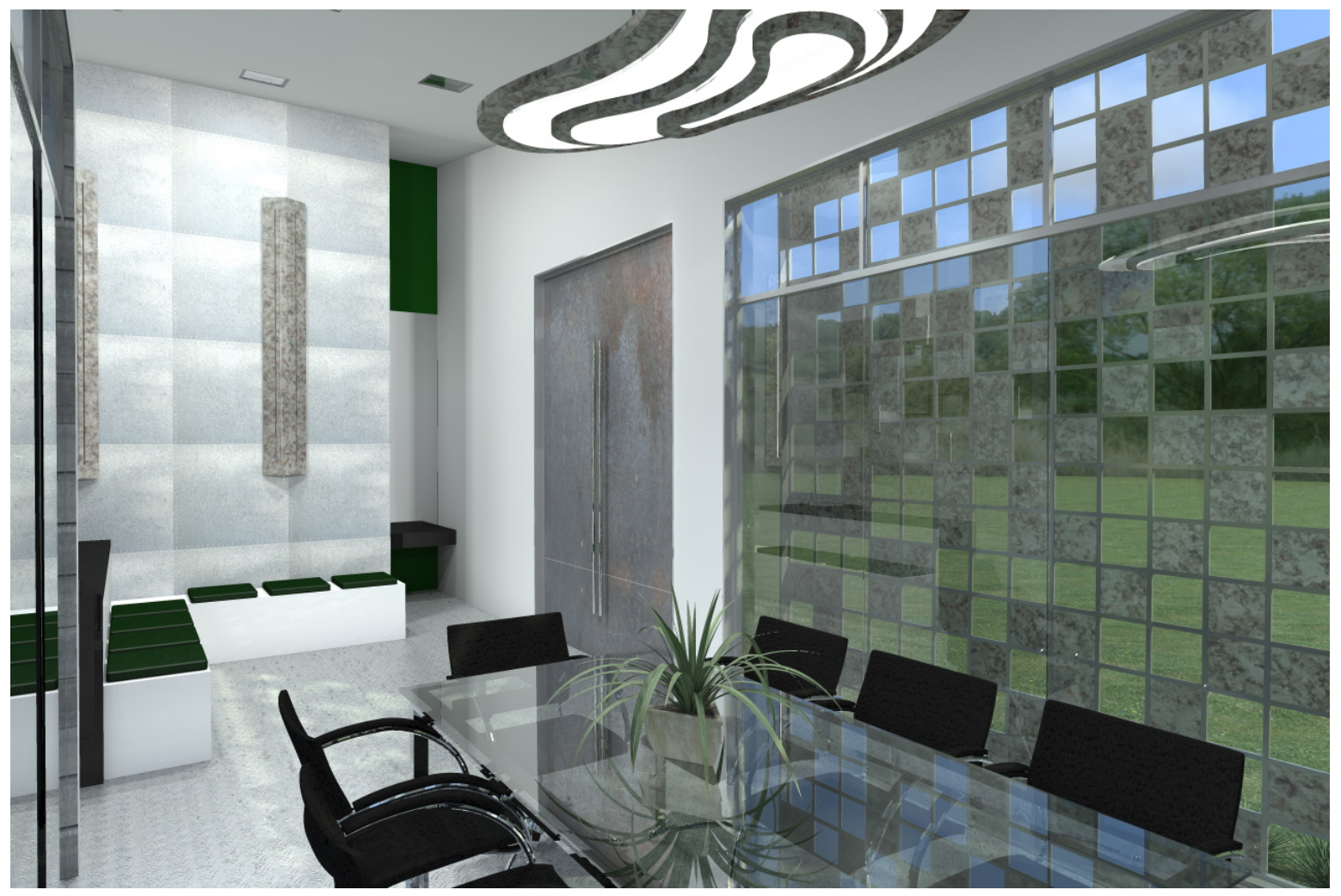

Projeto 3 - Vista interna 5

Fonte: Projeto da autora. Desenho: Albano.

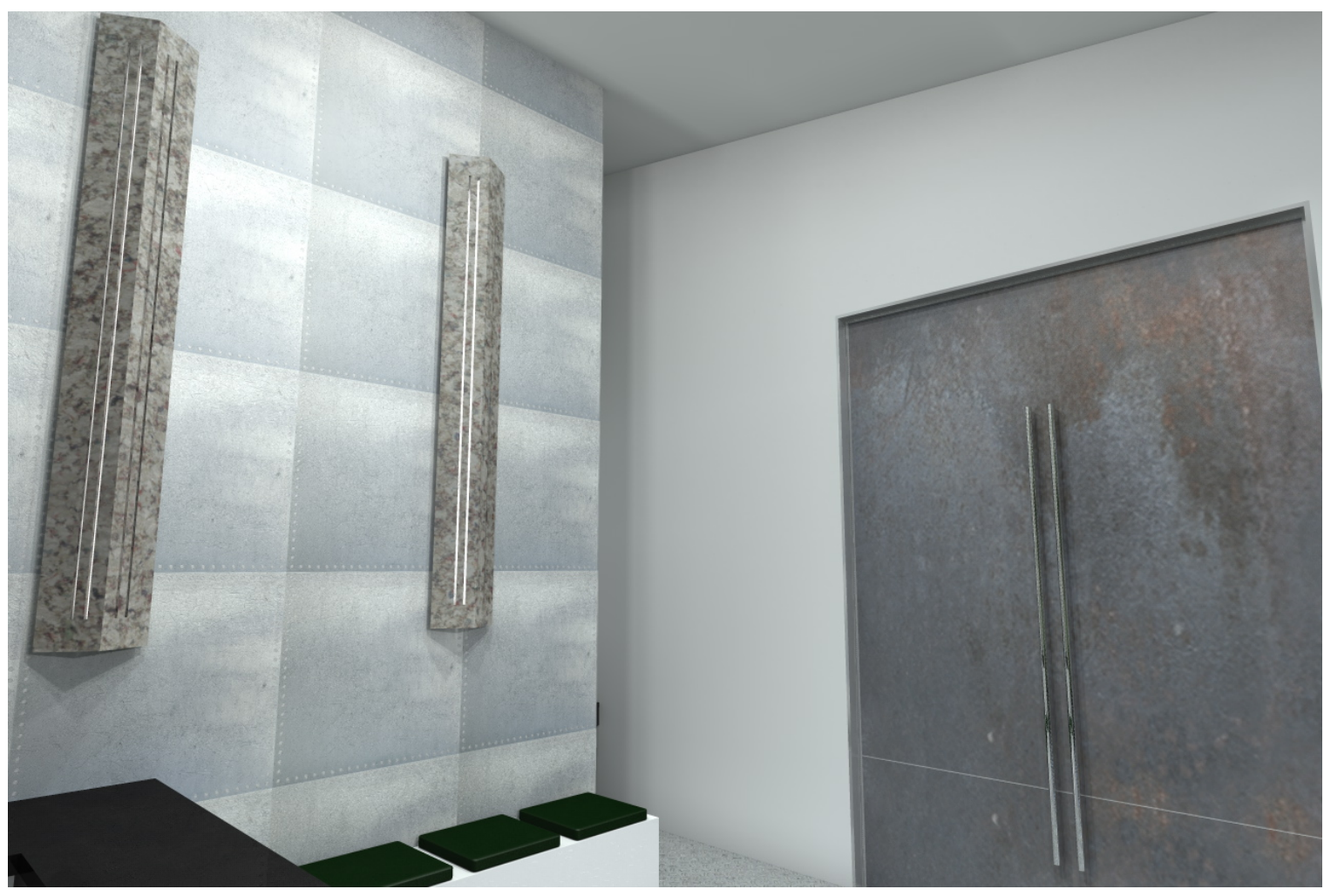

Projeto 3 - Vista interna 6

Fonte: Projeto da autora. Desenho: Albano. 


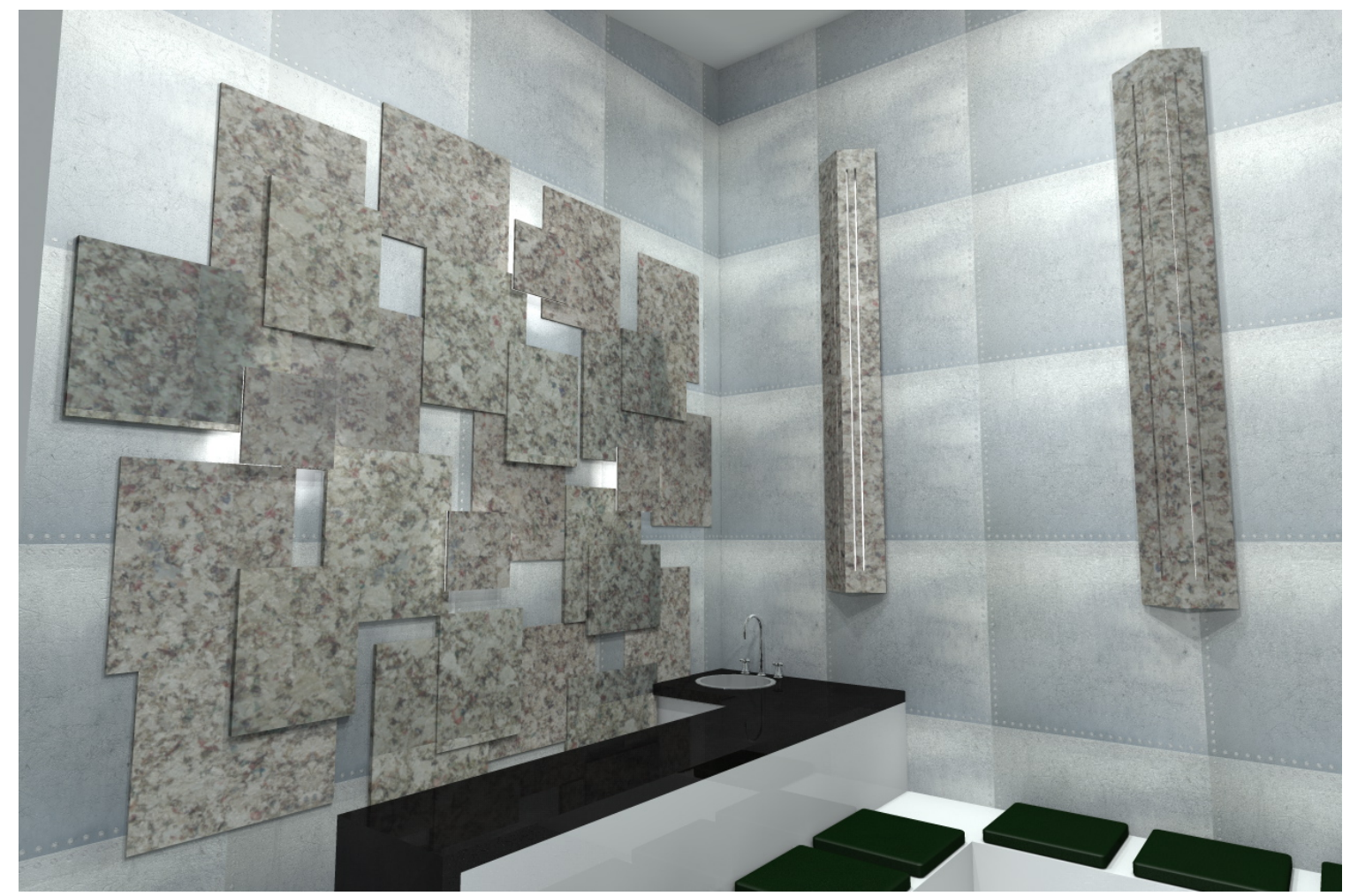

Projeto 3 - Vista interna 7

Fonte: Projeto da autora. Desenho: Albano.

\section{6 - Resultados e discussões}

Projetar utilizando como referência um único material foi uma experiência que gerou muitas possibilidades, inclusive, muitas delas não apresentadas nesta pesquisa. As opções são imensas e o potencial do material se apresentou cada vez maior a medida que se buscavam novas composições. Foi surpreendente perceber que, no processo de projetar as vedações e coberturas, acabaram por surgir soluções para mobiliário, objetos luminosos e painéis.

Com o embasamento e estrutura conceitual, somado às análises estéticas de materiais que compõem com as placas, culminando com os desenhos dos projetos o que se identificou foi que as hipóteses desta pesquisa, no que se refere ao design, se comprovaram. O uso das Placas Recicladas de Embalagens Longa Vida é muito mais atraente quando associado de maneira cuidadosa com materiais e desenhos que integrem a placa de maneira equivalente aos outros materiais, ou seja, que não sejam simplesmente utilizadas em subprodutos. 


\section{7 - DISCUSSÕES}

Embalagens são um problema muito grande, porque demandam muito material para sua fabricação e porque se transformam em um descarte gigante no meio ambiente. Com problemas instalados, o caminho parece pedir soluções mais enfáticas, ainda que não sejam perfeitas, de acordo com as definições de sustentabilidade. Se assim fossem (soluções perfeitas para o meio ambiente), a rotina das pessoas seria tão modificada que a vida cotidiana perderia muito de suas facilidades. Sucos e leites não seriam mais embalados e as pessoas viveriam, novamente, de somente espremer as frutas (o que para a saúde seria ideal) e tomar o leite acessível. Mas a situação é instalada e a produção das embalagens, como Longa Vida, estão funcionando muito bem, mas gerando grande quantidade de resíduos. A iniciativa que se toma com as embalagens Longa Vida é surpreendente, pois, do artesanato à reciclagem de absolutamente todo o conteúdo da embalagem já demonstram possibilidades de um retorno quase que total para o reuso dos materiais componentes - 0 papel, o polietileno e o alumínio. Mas ainda é muito pouco. Poucas embalagens são recicladas em comparação com o montante produzido e descartado.

Obviamente as ações de reciclagem, geram muito gasto de energia. Mas, o que é melhor, ou pior, a extração incessante de matéria-prima com um lixão cheio de embalagens, ou o gasto de energia e água, e o retorno do "lixo" ao ciclo de vida em forma de novos objetos? Esse é um problema a ser estudado e cabe, como tema, para várias outras pesquisas. Até o momento entende-se que, ou por falta de alternativa, ou por necessidade de se "fazer alguma coisa", ainda a reciclagem, mesmo com grandes gastos de energia, seja a melhor solução.

O que percebe-se é que a reciclagem das embalagens poderá ser ainda mais valorizada como mais uma matéria-prima, não da biosfera e litosfera, mas como um "original" da tecnosfera, na era da reciclagem. Assim como o mármore, granito e madeira, cada qual com sua originalidade própria, a "verdade do material reciclado" poderá se exprimir de maneira autêntica e única de acordo com o aumento de opções e usos na arquitetura e design. 
Acredita-se que os materiais reciclados possam ser então os representantes da arquitetura e design de "nosso tempo" e talvez sejam reconhecidos e valorizados, mais fielmente como tal, em um momento futuro, quando estiverem mais estabelecidos enquanto identidade e funcionalidade.

Felizmente o desconhecimento dos materiais reciclados vem se quebrando aos poucos, de forma gradativa, conforme estes materiais são expostos ao olhar comum e oferecendo respostas de eficiência no uso em termos técnicos. Um ciclo de tentativa, acertos, erros, aceitação/não aceitação e verificação da resposta (técnica e visual).

A teoria que se prega para um design sustentável/ecológico encontra muitos entraves na prática real. O valor estético que se dá a um objeto tem influência na cultura onde se vive. Os olhos foram educados, ao longo do tempo, para determinados gostos estéticos. Um conjunto de fatores estéticos ainda compromete o processo de consolidação das placas recicladas enquanto componente arquitetônico. Porém, o aspecto visual próprio da placa parece estar sendo absorvido pelo gosto do observador, assim como no exemplo dado sobre papéis reciclados, no capítulo 2 .

O caminho está traçado, atitudes estão sendo tomadas e a cara do design mundial está mudando, através de novos produtos, novos comportamentos, mas também muita resistência, afinal muitos materiais já foram criados, já estão estabelecidos e funcionando eficientemente há muito tempo, mas a um alto custo ambiental. Então, o que deve ser feito com o que funciona muito bem, que proporciona conforto, mas que produz uma enorme quantidade de resíduos? A busca do equilíbrio pode ser a resposta. Consumir menos do capital material natural e mais dos novos produtos. Esse é também um caminho dado por Moraes (2010), quando ressalta que, para que os novos produtos sejam mais aceitos, as pessoas, de uma maneira consciente, devem legitimar sua estética em nome principalmente da sustentabilidade.

Esse trabalho pode ser visto como um exemplar da busca de valorização dos materiais reciclados. Nas diversas abordagens das Placas Recicladas de Embalagens Longa Vida pode-se tirar um referencial para identificar o valor de vários outros materiais reciclados, cada um com suas características e potenciais, assim como também a verificação da necessidade de melhoria dos processos de produção e acabamento desses materiais. 
Ao longo da pesquisa vários caminhos foram experimentados, e reformulados. Em um primeiro momento, a abordagem técnica foi tomada como essencial, porém, no processo foi percebido que o intuito de abordagem estava mais voltado para o lado do design. Por fim, considerou-se positivo, pois foi possível traçar um panorama sobre as Placas Recicladas de Embalagens Longa Vida com enfoque que até então não se tinha traçado em outras pesquisas. Foi importante que se deixasse o tema com certa abertura pois, assim, foi possível propor alguns parâmetros equilibrados sobre o material, tanto nas qualidades técnicas quanto estéticas.

Como profissional, a autora pode perceber que "estudar" o material através de vários enfoques, colaborou para a requalificação da percepção estética e técnica que se tinha das placas e, dessa forma, ampliou a identificação e empatia com as mesmas.

Ao longo da pesquisa, com a busca de exemplares representativos da aplicabilidade das placas recicladas, foram vistas algumas criações com o design indo além do uso em objetos improvisados ou de uso secundário, e sim incorporando estes materiais ao processo de criação e produção de objetos e edificações como na Step House e Casa AQUA.

Os projetos elaborados nessa pesquisa puderam complementar essas possibilidades. Ainda que não tenham sido elaborados protótipos ou modelos construtivos, os projetos representaram visualmente muitas possibilidades de uso das Placas Recicladas de Embalagens Longa Vida. Os referenciais visuais são muito importantes para a assimilação de um produto ou de uma idéia.

Com dados técnicos e estéticos compilados, as referências visuais, construtivas e os resultados estéticos, em composições arquitetônicas, evidenciaram as potencialidades do material estudado.

Ao visar a ampliação de uso das placas recicladas, pode-se identificar a necessidade de produção de placas com cortes propícios para usos em fachadas, outros modelos de coberturas, em revestimentos, retangulares e quadradas. Assim as placas poderiam, então, ser apresentadas em catálogos, divulgando novos usos. Isso implicaria na mudança da planta de fabricação nas recicladoras. As recicladoras se focam na fabricação de placas e telhas. Com o desenvolvimento do design, as mesmas fábricas, ou outras, deveriam trabalhar com os cortes e acabamentos das peças. Isso demanda novo equipamento, espaço, mão de obra e marketing. 
Para colaborar com a divulgação das placas recicladas e, conseqüentemente, com sua especificação seria importante um material de divulgação que apresentasse os dados, técnicos e estéticos, inclusive com imagens, propício para consulta de arquitetos, designers e engenheiros. Os dados poderiam ser inseridos de maneira que facilitasse a consulta, assim como nos catálogos técnicos, onde se identifica as propriedades do material e também suas opções de tamanhos, cores e texturas. Muito importante também, para esta divulgação seria a execução de um "ambiente modelo", ou um protótipo, com variadas aplicações das placas.

Ficou evidente que existem muitas variações estéticas possíveis que podem ser utilizadas para valorizar o uso das placas nas superfícies. Tecnicamente não existem problemas significativos que impeçam este uso proposto. O principal inconveniente está na secção das placas: para comercialização em formatos menores, estas teriam que receber melhor acabamento, apesar de não ser necessariamente relevante em termos técnicos.

Considerando todos os pontos analisados, cabe dizer que o uso das Placas Recicladas de Embalagens Longa Vida é instigante e desafiador como material construtivo, por serem placas recicladas e recicláveis, por terem respondido tecnicamente ao longo do tempo às intempéries, à impermeabilização e proteção térmica, assim como por estarem conquistando interesse de pesquisa, na área do design e da arquitetura, favoráveis e promissoras no sentido de conquistar um público usuário e especificador cada vez maior. 


\section{8 - CONCLUSÕES}

Para responder às questões da problemática dessa pesquisa, esse trabalho buscou abordar o material de forma holística, tratando de cada um dos vários aspectos relacionados às Placas Recicladas de Embalagem Longa Vida, a fim de propiciar um panorama sobre as características e potencialidades deste material e, desta forma, também incentivar a continuidade de várias outras pesquisas. Com o desenvolvimento da pesquisa pode-se comprovar as hipóteses apresentadas assim como outras conclusões:

- Os dados apresentados na pesquisa complementam a caracterização técnica das Placas Recicladas de Embalagem Longa-vida, mas, naturalmente, pela extensão de pontos a serem identificados, não encerram esta caracterização, sendo necessários vários outros ensaios e estudos que deverão ser realizados por novas pesquisas.

- A Placa Reciclada de Embalagem Longa Vida pode se estabelecer mais firmemente enquanto material para design de produto e arquitetônico-construtivo, pois tem perfil técnico e estético para tais funções.

- Assim como no sistema de reciclagem por peletização e plasma térmico, onde a matéria-prima com polietileno-alumínio são limpas para retirada do restante de papel, no sistema de prensagem poderia ser inserida esta etapa, para que a matéria-prima a ser prensada para produção das placas pudesse gerar produtos mais impermeáveis. Controle tecnológico da produção e qualidade do produto.

- Com o ensaio de DMA, pode-se comprovar que as placas recicladas podem voltar ao ciclo de reciclagem por várias vezes, no entanto é recomendado a adição de porcentagens de plástico novo ou de primeira reciclagem para ajudar na união das fibras do material. 
- As Placas Recicladas de Embalagens Longa Vida podem ser utilizadas, de forma eficiente, como componentes para variados usos arquitetônicos e de design além do sub-uso na construção civil.

- Verificou-se que o design de componentes e sistemas construtivos pode realmente agregar valor estético às placas, o que, conseqüentemente irá aumentar o interesse pela sua especificação.

- Nas relações de composição com outros materiais de construção, as melhores composições indicadas foram aquelas em que as Placas Recicladas de Embalagens Longa Vida tenham similaridade de procedência do material, coloração e textura. Como indicativo foram selecionados os seguintes materiais: concreto, metálicos, plásticos, vidros e borrachas.

- A similaridade da textura das placas com as texturas do granito é um bom indicativo de que possam agradar e consquistar visualmente, já que o granito é um material que faz parte do gosto comum da maioria das pessoas.

- Ficou comprovada a característica de reflexão como um ponto positivo para as condições de proteção térmica, já que, assim como reflete quase $50 \%$ dos raios visíveis (VIS), também reflete ainda mais o calor (reflexão dos raios IV =64\%). Desta forma, a superfície ficar exposta é um ponto favorável ao uso do material.

- A exposição aos raios UV enrijecem as fibras da placa e tornam sua superfície um pouco mais opaca, mas não compromete sua eficiência enquanto impermeabilidade e proteção térmica.

- Os ensaios de condutividade térmica pelo método do fio quente paralelo podem sofrer algumas diferenças de resultados, devido a técnica ser adaptada para as placas. Portanto, é indicado o desenvolvimento de procedimentos de ensaio (deste e de outros ensaios) melhor adaptados aos novos materiais reciclados.

- Para produção de placas com melhor acabamento há necessidade de melhoria da produção em fábrica, o que demanda desenvolvimento tecnológico das mesmas. 
- Se o processo de produção das placas recicladas fosse com tecnologia instalada especificamente para este produto, provavelmente as peças teriam sua constituição material, acabamento e dimensionamento mais estáveis

\section{1 - Sugestões para pesquisas complementares}

Por ser um material ainda pouco estudado cientificamente, muitas outras pesquisas podem complementar este estudo, algumas delas são sugeridas a seguir:

- Pesquisa sobre as propriedades mecânicas das placas recicladas de embalagens longa vida para aplicação na arquitetura.

- Pesquisa de métodos de ensaios e adaptação de equipamentos para materiais reciclados,

- Eficiência energética de envoltória com uso de placas recicladas de embalagens longa vida. Variação de opções e comparativo com sistemas existentes.

- Identificação de Processos de produção mais eficientes para as placas recicladas.

- Estudos de detalhes construtivos para painéis de fechamento externo com placas recicladas de embalagens longa vida.

- Construção de modelos físicos para testes variados.

- Detalhamento construtivo para uso de placas recicladas em vedações. 
Conclusões e sugestões para pesquisas complementares. 


\section{REFERÊNCIAS BIBLIOGRÁFICAS}

ABAL (2010) O alumínio. Associação Brasileira de Alumínio. Disponível em $<$ www.abal.org.br/aluminio/introducao.asp $>$ Acessado em: 06-11-2010.

ABRE (2009). Imagem: Hidrapulper. Associação brasileira de embalagens. Disponível em: http://www.abre.org.br/tetra.php. Acessado em: 20-07-2009.

ABNT NBR 15220-1:2005 - Desempenho térmico de edificações -Parte 1: Definições, símbolos e unidades

ABNT NBR 15220-2:2005 - Desempenho térmico de edificações - Parte 2: Método de cálculo da transmitância térmica, da capacidade térmica, do atraso térmico e do fator solar de elementos e componentes de edificações

ABNT - NBR 15575-1:2008 - Edifícios Habitacionais de até cinco pavimentos Desempenho - Parte 1: Requisitos gerais.

ABNT - NBR 15575-4:2008 - Edifícios Habitacionais de até cinco pavimentos Desempenho - Parte 4: Sistemas de vedações verticais externas e internas.

ABNT NBR 10004:2004. Resíduos Sólidos - Classificação.

AGENDA SUSTENTAVEL (2009) . Hidrapulper-Klabin. Disponível em: $<$ http://www.agendasustentavel.com.br/artigo.aspx?id=1232\&area > Acessado em: 26-082009.

AKATU (2010). Anel Möbius. Disponível em: < $\underline{w w w . a k a t u . o r g . b r}>$ acessado em 12-092010.

ALVES, Salete M.; GOMES, João F. (2007). Adequação ambiental dos processos de usinagem utilizando Produção mais Limpa como estratégia de gestão ambiental, Numa-USP, São Paulo. Disponível em 
<http://www.scielo.br/scielo.php?pid=S010365132007000100009\&script=sci arttex t> Acesso em 23-09-2010.

ARQTEMA (2005) - Grupo de Pesquisa em Arquitetura, Tecnologia e Materiais, Materiais de construção I: Aglomerantes minerais, agregados, argamassas, concreto e dosagem, São Carlos: EESC - USP. 271p.

ARQTEMA (2005) - Grupo de Pesquisa em Arquitetura, Tecnologia e Materiais, Materiais de Construção III: Polímeros na Arquitetura e na Construção Civil, São Carlos: EESC USP. 247p.

ASTM G 154 - 06- Standand Practice for Operating Fluorescent Light Apparatus for UV Exposure of Nonmetallic Materials.

ASHRAE 74-1988: Method of measuring solar-optical properties of materials.

ASTM G173-03: standard tables for reference solar spectral irradiances - direct normal and hemispherical on $37^{\circ}$ tilted surface.

ASTM G 154 - 06- Standand Practice for Operating Fluorescent Light Apparatus for UV Exposure of Nonmetallic Materials.

ASHRAE 74-1988: Method of measuring solar-optical properties of materials.

ASTM G173-03: standard tables for reference solar spectral irradiances - direct normal and hemispherical on $37^{\circ}$ tilted surface.

BAER-KNELL (1996). Imagem: Rotunde - Ambiente de Instalação. Disponível em: <http://www.baer-knell.de/HTML/altauss_6.htm> Acessado em:15-07-2011.

BAER-KNELL (1997). Imagem: Kubus - Ambiente de Instalação. Disponível em: <http://www.baer-knell.de/HTML/altauss 5.htm> Acessado em:15-07-2011.

BAER-KNELL (2010). Imagem: Prateleira e Cômoda de plástico reciclado. Disponível em: <http://www.baer-knell.de/HTML/divers_3.htm> Acessado em:20-07-2010.

BAER-KNELL (2010). Imagem: Wohnwagen - veículo com material reciclado. Disponível em: <http://www.baer-knell.de/HTML/divers_3.htm> Acessado em:20-07-2010.

BAER-KNELL.(2010) Luminárias de plástico reciclado. Disponível em < http://www.baerknell.de/HTML/sofas 7.htm> Acessado em -20-07-2010. 
BAER-KNELL. (2010) Espreguiçadeira de plástico reciclado. Disponível em <http://www.baer-knell.de/HTML/sofas 7.htm>- acessado em -20-07-2010.

BAER-KNELL (2011). Imagem: Ambiente da Instalação Cores do Consumo. Disponível em: < http://www.baer-knell.de/HTML/NRWfo_1.htm> Acessado em:15-07-2011.

BAHAMÓN, A.e SANJINÉS, M. C.(2008), Rematerial: Del Desecho a La Arquitectura, Barcelona: Parramóm Arquitectura y Diseño.

BARATA, T. Q. F. (2008). Propostas de painéis leves de madeira para vedação externa. Tese de doutorado, Faculdade de Engenharia Civil da Universidade Estadual de Campinas, FEC-UNICAMP, Campinas.

BARBOSA, J. C. L. (2002) - o projeto de nosso lixo de todo dia - I congresso Internacional de pesquisa em Design / V Congresso Brasileiro de Pesquisa e Desenvolvimento em Design - anais, Volume 5: Eco design.

BATTAGLINI, A. (2007). A Fronteira como território - in Disegno.Desenho.Desígnio, São Paulo: Editora Senac, p. 111.

BLUME, H. (1988) - La construcción de la architectura - técnica, diseño y estilo, Editor Michael Foster.

BRUNDTLAND (1987). Relatório de Brundtland. p.9-10. Disponível em: $<$ http://www.scribd.com/doc/12906958/Relatorio-Brundtland-Nosso-Futuro-Comum-Em-

Portugues $>$ Acessado em 20-05-2010.

CAPELINI, M. (2007). Potencialidade e aplicação da prevenção de resíduos de embalagens: abordagem sobre o projeto do produto e o consumo. Tese de doutorado, Escola de Engenharia de São Carlos, Universidade de São Paulo, São Carlos.

CASA CERTIFICADA (2010). Casa Certificada. Disponível em:

$<$ http://www.casacertificada.pt/empresas/solucao/materiais-a-reintegrar-na-biosfera> Acessado em 03-09-2010.

CASSU, S. N. e FELISBERTI, M. I. (2005) Comportamento dinâmico-mecânico e relaxações em polímeros e blendas poliméricas. Química. Nova, Vol. 28, No. 2, 255-263. Disponível em <www.scielo.br/pdf/qn/v28n2/23648.pdf> Acessado em 07 de julho de 2011. 
CEMPRE. (2008) Distribuição dos municípios com coleta seletiva no Brasil. Compromisso empresarial para a reciclagem. Disponível em:<http://www.cempre.org.br/ciclosoft 2008.php> Acessado em: 21-07-2010.

CEMPRE. (2008) Composição de materiais da coleta seletiva no Brasil, em peso. Compromisso empresarial para a reciclagem. Disponível em:<http://www.cempre.org.br/ciclosoft 2008.php> Acessado em: 21-07-2010.

CEMPRE. (2008). Preço do material reciclável. Compromisso empresarial para a reciclagem. Disponível em:<www.cempre.org.br/serv mercado.php $>$ Acessado em: 21-072010.

CG TEXTURES (2011). Imagens: texturas de materiais. Disponível em: $<$ http://www.cgtextures.com/>. Acessado em: 6-06-2011.

CHING, F. D. K (2000). Dicionário Visual de Arquitetura. São Paulo, Martins Fontes.

CLRB (2009). Conselho de Logística Reversa do Brasil. Disponível em: www.clrb.com.br/livro.php Acessado em, 7-9-2009.

CONSELHO (2010) Logística Reversa. Conselho de Logística Reversa do Brasil. Disponível em: <http://www.clrb.com.br/livro.php> Acessado em: 23-09-2010.

CONSTRUARTE (2009). Imagem: Protótipo da constução da Casa Aqua:Térrea - versão 2010. Disponível em: <http://revistaconstruarte4.blogspot.com/2009 0301 archive.html> Acessado em: 09-06-2010.

CULTURA AMBIENTAL (2010) O leite Longa Vida. Cultura ambiental nas escolas. Disponível em: <http://www.culturaambientalnasescolas.com.br/aluno/a-embalagem-e-oambiente/embalagens-longa-vida>. Acessado em 05-09-2010.

CULTURA AMBIENTAL (2010), Imagem: vassouras recicladas. Cultura ambiental nas escolas. Disponível em: <http://www.culturaambientalnasescolas.com.br/aluno/aembalagem-e-o-ambiente/embalagens-longa-vida>. Acessado em 05-09-2010.

CULTURA AMBIENTAL (2010). Imagem: lixeira reciclada. Cultura ambiental nas escolas. Disponível em: <http://www.culturaambientalnasescolas.com.br/aluno/a-embalagem-e-oambiente/embalagens-longa-vida>. Acessado em 05-09-2010. 
CULTURA AMBIENTAL (2010). Imagem: telhas recicladas. Cultura ambiental nas escolas. Disponível em: <http://www.culturaambientalnasescolas.com.br/aluno/a-embalagem-e-oambiente/embalagens-longa-vida>. Acessado em 05-09-2010.

DIRECTIVA 75-442/CEE (Comunidade Econômica Européia) de 15 de julho de 1975. Conselho das comunidades européias relativa aos resíduos.

DIRECTIVA 94/62/CE DO PARLAMENTO EUROPEU E DO CONSELHO de 20 de Dezembro de 1994 relativa a embalagens e resíduos de embalagens

DORNELLES, K. A. (2008). Absortância solar de superfícies opacas: métodos de determinação e base de dados para tintas látex acrílica e PVA. 160p. Tese (Doutorado) Faculdade de Engenharia Civil, Arquitetura e Urbanismo, Universidade Estadual de Campinas, Campinas.

DORNELLES, K. A.(2010) Relatório de ensaio de absortância à radiação solar. São Carlos.

DRYWALL (2011). Imagem: Detalhes construtivos de sistemas drywall. Disponível em: <http://www.drywall.org.br/index1.php/7/parede>Acessado em: 08-3-2011.

ECODESENVOLVIMENTO. (2009) Multicamadas da embalagem longa vida. Disponível em < www.ecodesenvolvimento.org.br $>$ Acessado em 29-12-2009.

ECOLOUCA (2010). Step House. Disponível em:

$<$ http://ecolouca.wordpress.com/2009/08/18/stephouse-o-projeto-de-residencia-ecoeficientefeita-com-material-reciclado

ECOPRÁTICO (2009). Imagem: Passo a passo manta térmica Tetra Pak. Disponível em: <http://images.google.com.br/imgres?imgurl=http://ecopratico.com.br> Acessado em: 29-122009

ECOWAY (2010) Imagem: forro com placa reciclada. Disponível em: $<$ http://www.ecoway.com.br/produtos.html>. Acessado em: 15-08-2010.

EDWARDS, B. (2008), O guia básico para a sustentabilidade, Barcelona: Editorial Gustavo Gili, 226p. 
FELIZ PRA CACHORRO (2010). Imagens: Casinhas de cachorro recicladas. Disponível em: $\quad$ http://www.felizpracachorro.com.br/index.php/2010/02/casinha-de-cachorro-feita-detetra-pak> Acessado em:11-10-2010.

FIGUEIREDO, L.(2010). O conceito de Produção Mais Limpa como uma evolução do tratamento de final de tubo. disponível em $<$ http://www.revistasustentabilidade.com.br/blogs/pensando-a-sustentabilidade/o-conceitode-producao-mais-limpa-como-uma-evolucao-do-tratamento-de-final-de-tubo > Acesso em 23-09-2010.

FINISSIMO (2011). Imagem: Lixeira de material reciclado de embalagem Longa Vida. Disponível em: <http://finissimo.com.br/spfw2008verao/page/2>. Acessado em 11-10-2011.

FINESTRA. (2010) Maquete Eletrônica da Casa AQUA: sobrado versão 2009. Disponível em: $\quad<$ http://www.revistafinestra.com.br/ecoeficiencia/92-casa-aqua-fundacao-vanzolini-10-

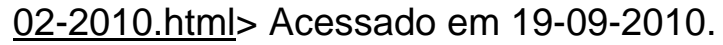

FROTA, A. B. e SCHIFFER, R.(2001), Manual de Conforto Térmico. 5ed.,São Paulo: Studio Nobel.

FUAD-LUKE, A. (2002), Manual de diseño ecológico: um detallado libro de consulta de gran utilidad para el entorno doméstico o la oficina, Palma de Mallorca, Cartago.

GESTÃO AMBIENTAL, Portal (2010). Disponível em: $<$ www.portalga.ea.ufrgs.br/ecodesign.htm> Acessado em 20/07/2010.

GOMES FILHO, J. (2006), Design do Objeto: Bases conceituais, São Paulo: Escrituras Editora, 255p..

HAWKEN, P.; LOVINS, A. e LOVINS, L. (2007), Capitalismo Natural: Criando a próxima revolução industrial, São Paulo: Cultrix.

IBAPLAC. (2009) Imagem: Telhas e Cumeeiras recicladas. Disponível em: <http://www.ibaplac.com.br/prod_cumeeiras.html> Acessado em: 15-02-2009.

ISTOEDINHEIRO. (2010), Tetra Pak. Disponível em: $<$ www.istoedinheiro.com.br/.../?month=7\&year=2010> Acessado em 08-10-2010. 
IPT (2002 a). Relatório de Ensaio Nº 890 824: Determinação de propriedades físicas em amostras de plástico. Instituto de Pesquisas Tecnológicas. Disponível em: <http://www.ibaplac.com.br/824/cert 1 824.html> Acessado em: 20-07-2011.

IPT (2002 b). Relatório de Ensaio № 890 868: Determinação do índice de propagação de chamas em amostras de plástico. Instituto de Pesquisas Tecnológicas. Disponível em: <http://www.ibaplac.com.br/868/cert 2 868.html> Acessado em: 07-08-2009.

LAMEM (2001). Relatório técnico: Ensaios em chapas e telhas de material reciclado. Laboratório de Madeiras e de Estruturas de Madeira. Disponível em: <http://www.ibaplac.com.br/fipai/cert_2_fipai.html> Acessado em: 20-07-2011.

LANOO, J. (2011) Imagem: edifício Arquivo Nacional EDF - LAN Arquitetura. Disponível em: <http://www.designboom.com/weblog/cat/9/view/14390/lan-architecture-edf-nationalarchives-now-complete.html; > Acessado em 15-05-2011.

LEITE, P. (2003). Organograma de Logística reversa. Associação Brasileira de $\begin{array}{lllll}\text { Metalurgia, } & \text { Materiais } & \text { e } & \text { Mineração. } & \text { Disponível }\end{array}$ <www.abmbrasil.com.br/cim/download/Paulo-Leite-Logistica2003.pps > Acessado em 23-092010.

LUPTON, E e PHILLIPS, J C. (2008), Novos fundamentos do Design, São Paulo: Cosac Naify, 248p..

LUPTON, E. e PHILLIPS, J. C.(2008), Novos fundamentos do Design, São Paulo: Cosac Naify, 248p.

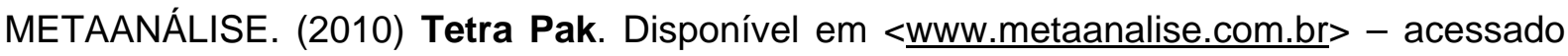
em 15-10-2010

MIDIAMAIS (2009). Imagem: Parede de caixinhas Tetra Pak. Disponível em: <http://images.google.com.br/imgres?imgurl=http://www.midiamais.jor.br/> Acessado em: 29-12-2009

MONOLITO (2010). Imagem: Maquete eletrônica Casa AQUA. Disponível em: <http://monolitho.labin.pro.br/?cat=267 - acessado em 09-06-2010. 
MORAES, D. D. (2010). Metaprojeto: o design do design. São Paulo: Blucher.

MUHRINGER, S. M. e SHAYER, Michelle M.(2007), Lixo e Sustentabilidade, São Paulo: Ática.

MUNDO EDUCAÇÃO (2010). Disponível em:

$<$ http://www.mundoeducacao.com.br/geografia/politica-dos-3rs.htm> Acessado em 22-092010.

NEVES, F.L. (2004). Novos Desenvolvimentos para Reciclagem de embalagens longa vida. In: $37^{\circ}$ Congresso Anual de Celulose e Papel - Anais - Mídia CD, 2004. São Paulo.

NOSSO AMBIENTE (2010). Programa nosso Ambiente do Tribunal Regional Eleitoral de Sergipe. Disponível em:

$<$ http://www.trese.gov.br/conheca trese/programas institucionais/programa nosso ambient e/leiamais 3rs residuos.htm> Acessado em 12-09-2010.

PEDRAS (2009). Imagem: granitos. Disponível em:

<http://www.pedrasanaliafranco.com.br/imagens/pedras/granito_amarelo_florenca.jpg>. Acessado em:16-10-2009.

PEGADA ECOLÓGICA (2010) Disponível em: $<$ http://wwf.org.br/wwf brasil/pegada ecologica/o que e pegada ecologica/> Acessado em 25-09-2010.

PELTIER, F. e SAPORTA, H. (2009), Design sustentável: caminhos virtuosos, São Paulo: Editora Senac.

PINATTI, A. E. (1999) O design de embalagem de consumo e o meio ambiente - O sistema ecológico-ambiental: ecodesign. Tese de doutorado, Universidade de São Paulo, Faculdade de Arquitetura e Urbanismo-FAU, São Paulo.

PORTALGA (2009) Portal Gestão Ambiental. Disponível em: $<$ www.portalga.ea.ufrgs.br/ecodesign.htm> Acessado em: 5-8-2009.

PROGRAMAERA (2010). Imagem: casas com embalagens longa vida. Disponível em: < http://www.programaera.blogspot.com/> Acessado em 08-10-2010. 
PROTOLAB (2010). Tabela de condutividade térmca de materiais. Laboratório de Propriedades Termofísicas e Prototipação. Disponível em: <http://www.protolab.com.br/Tabela-Condutividade-Material-Construcao.htm>. Acessado em: 15/08/2010.

RECICLAGEM DO ALUMíNIO (1999), Anais. São Paulo: ABAL.

RECYCLEDVENUES (2011). Imagem: Cabana com cobertura de embalagens Longa Vida. Disponível em: <http://recycledvenues.org.uk/projects/tetrapak-tunnels/> Acessado em: 15-07-2011.

REGIPLAC (2010). Galpão com acabamento externo com uso de placas recicladas curvadas. Disponível em: <www.regiplac.com.br> Acessado em: 19-09-2010.

RIVERO (1985). Arquitetura e Clima: Condicionamento térmico natural. Porto Alegre: Luzzato.

ROAF, S.; FUENTES, M. e THOMAS, S. (2009), Ecohouse: A casa ambientalmente sustentável, 3 ed., Porto Alegre: Bookman.

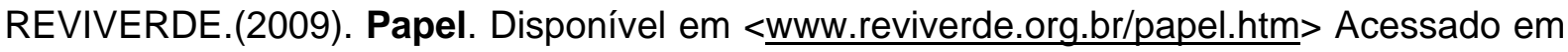
19-08-2009.

SANTOS, W. N.(2002) O método do fio quente: técnica em paralelo e técnica de superfície, Cerâmica vol.48 no.306 São Paulo Abr./Jun. Disponível em: $<$ http://www.scielo.br/scielo.php?pid=S0366-69132002000200007\&script=sci arttext >acessado em 7 de julho de 2011.

SANTOS, W. N. et al. (2004) Método de fio quente na determinação das propriedades térmicas de polímeros. Polímeros: Ciência e Tecnologia, vol.14, n5, p.354-359, 2004. Disponível em: < http://www.scielo.br/pdf/po/v14n5/23070.pdf>. Acesso em: 15 ago, 2010.

SÃO FRANCISCO (2011). Polímeros. Disponível em:

<http://www.portalsaofrancisco.com.br/alfa/polimeros/polimeros-10.php> Acessado em 0707-2011.

SECRETARIA (2010). Tabela de tempo de decomposição de resíduos. Secretaria do meio ambiente do estado de São Paulo. Disponível em:<http://www.ambiente.sp.gov.br/> Acessado em 05-02-2010. 
SIDRA IBGE (2010), Proporção de material reciclado em atividades industriais selecionadas. Sistema Integrado de Recuperação Automática - Instituto Brasileiro de Geografia e Estatística. Disponível em $<$ http://www.sidra.ibge.gov.br/bda/tabela/protabl.asp?c=1202\&z=p\&o=10\&i=P> Acessado em 01-02-2010

SILVA, M.R.(1991). Materiais de Construção. São Paulo: PINI.

SIMBOLOGY (2010) Anel de Möbius. Disponível em: <http://simbology.blogspot.com> Acessado em 12-09-2010.

SOUSA et al. (2009). Análise comparativa das propriedades térmicas de materiais aplicados em revestimentos de paredes internas: um estudo de caso em subestações elétricas. IV SEPRONe, Fortaleza.

SUDJIC, D. (2010). A linguagem das coisas. Rio de Janeiro: Intrínseca.

SUSTENTABILIDADE (2010). Sustentabilidade. Disponível em: $<$ www.sustentabilidade.org.br> Acessado em 20/05/2010.

TETRA PAK (2009). Imagem: Hidrapulper. Disponível em: $<$ http://www.tetrapak.com/br/reciclagem/ciclo de vida da embalagem/pages/reciclagem.as px> Acessado em: 4-07-2009.

TRESE (2010). Tribunal Regional Eleitoral de Sergipe. Disponível em: <http://www.trese.gov.br> Acessado em 12-09-2010

TRINDADE, S. C.(2002). O design sustentável. in: Um olhar sobre o Design Brasileiro, organização: Joice Joppert Leal, São Paulo: Objeto Brasil; Instituto UNIMEP; Imprensa Oficial do Estado (p.184-187).

TSL AMBIENTAL.(2009) Sistema Plasma de reciclagem. Disponível em: < www.tslambiental.com.br> Acessado em: 25-07-2009.

TSL AMBIENTAL.(2009) Figuras: Parafina e Lingote de alumínio. Disponível em: < www.tslambiental.com.br> Acessado em: 25-07-2009.

VALT, Renata B. G.(2007) Ciclo de vida de embalagens para bebidas no Brasil, Brasília: Editora Thesaurus. 
VICTORIA \& ALBERT MUSEUM. (2010) Imagem: Cadeira reciclada de Bär \& Knell. Disponível em <www.vam.ac.uk/images/image/11224-large.jpg> Acessado em 20-07-2010.

WENDHAUSEN, Paulo A. P. [20--]. Apostila de Análises Térmicas. Elaboração de Guilherme V. Rodrigues e Otávio Marchetto. Universidade Federal de Santa Catarina: Departamento de engenharia mecânica,. Disponível em:< http://www.materiais.ufsc.br/Disciplinas/EMC5733/Apostila.pdf>. Acesso em: 24 jun. 2011.

WWF (2009). Pegada Ecológica. Disponível em:

$<$ http://wwf.org.br/wwf brasil/pegada ecologica/o que e pegada ecologica/> Acessado em: 23-9-2009.

WONG,W (2010). Princípios de forma e desenho. 2 ed., São Paulo: Editora WMF Martins Fontes.

ZUBEN, F. v.(2009) Entrevista sobre reciclagem de embalagens longa vida ao programa Ressoar. Disponível em:

$<$ http://www.youtube.com/watch?v=xpGr Y5G2C4\&feature=related) > Acessado em: 07/02/2009.

ZUBEN, F.V. \& NEVES, F.L. [ 20--] Reciclagem do alumínio e do polietileno presentes nas embalagens cartonadas Tetra Pak. Disponível em: <http://www.afcal.pt/destinoFinal/Reciclagem_Poli_Alu.pdf> Acessado em 18/03/2008. 
Referências Bibliográficas 


\section{APÊNDICE A}

\section{TERMOS RELACIONADOS À SUSTENTABILIDADE}

\section{Desenvolvimento sustentável}

Apesar das questões ambientais mundiais terem começado a ser discutidas mais formalmente e intensamente no começo da década de 70, o conceito de desenvolvimento sustentável surgiu formalizado em um dos eventos mundiais. Foi em 1987, no Retalório de Brundtland, intitulado "Our Common Future" (Nosso futuro comum), que, pela primeira vez, foi formalizado o conceito de desenvolvimento sustentável, definido da seguinte maneira:

"O desenvolvimento que procura satisfazer as necessidades da geração atual, sem comprometer a capacidade das gerações futuras de satisfazerem as suas próprias necessidades. Significa possibilitar que as pessoas, agora e no futuro, atinjam um nível satisfatório de desenvolvimento social e econômico e de realização humana e cultural, fazendo, ao mesmo tempo, um uso razoável dos recursos da terra e preservando as espécies e os habitats naturais."

(BRUNDTLAND, 1987, p.9-10)

Principais eventos e acordos ambientais mundiais:

\begin{tabular}{|c|c|}
\hline \multicolumn{2}{|r|}{ PRINCIPAIS ACORDOS AMBIENTAIS INTERNACIONAIS } \\
\hline 1972 & Conferência de Estocolmo para o Meio Ambiente Humano (ONU) \\
\hline 1979 & Convenção de Genebra sobre a Poluição do Ar (ONU) \\
\hline 1980 & $\begin{array}{c}\text { Estratégia Mundial para a Conservação (UICN - União internacional para a } \\
\text { conservação da natureza e dos recursos naturais.) }\end{array}$ \\
\hline 1983 & Protocolo de Helsinque sobre a Qualidade do $\mathrm{Ar}(\mathrm{ONU})$ \\
\hline 1983 & Comissão Mundial sobre o Meio Ambiente e Desenvolvimento (ONU) \\
\hline 1987 & Protocolo de Montreal sobre a Camada de Ozônio (ONU) \\
\hline 1987 & Nosso Futuro Comum - Relatório Brundtland (ONU) \\
\hline 1990 & Livro Verde sobre o Meio Ambiente Urbano (União Européia) \\
\hline 1992 & Cúpula da Terra (Rio 92) - Rio de Janeiro (ONU) \\
\hline 1996 & Conferência Habitat (ONU) \\
\hline 1997 & Conferência de Kyoto sobre o Aquecimento Global (ONU) \\
\hline 2000 & Conferência de Haia sobre as Mudanças Climáticas (ONU) \\
\hline 2002 & Cúpula de Joanesburgo $\left(\right.$ Rio + 10) ${ }^{\star}$ sobre o Desenvolvim. Sustentável (ONU) \\
\hline $2009^{*}$ & Conferência de Copenhague sobre Mudanças Climáticas - Cop 15 (NU)* \\
\hline
\end{tabular}

Fonte: (EDWARDS, 2008, p. 9) - *complementação da autora. 


\section{Sustentabilidade}

"Sustentabilidade é um conceito sistêmico, relacionado com a continuidade dos aspectos econômicos, sociais, culturais e ambientais da sociedade humana. Propõe-se a ser um meio de configurar a civilização e atividade humanas, de tal forma que a sociedade, os seus membros e as suas economias possam preencher as suas necessidades e expressar o seu maior potencial no presente, e ao mesmo tempo preservar a biodiversidade e os ecossistemas naturais, planejando e agindo de forma a atingir pró-eficiência na manutenção indefinida desses ideais. A sustentabilidade abrange vários níveis de organização, desde a vizinhança local até o planeta inteiro." (SUSTENTABILIDADE, 2010)

"A sustentabilidade tem sido base para tecnologias inovadoras e abordagens de design, representando um novo paradigma para a equidade social, proporcionando nova forma estética e cultural à paisagem, além de uma nova perspectiva por meio da qual as empresas poderão projetar seus futuros." (EDWARDS, 2008, p.11).

As definições abaixo foram elaboradas com base em várias definições existentes (de Foster + Partners, Brian Edwards, BSRIA - Building Services Research and Information Association). Foram eliminados e complementados alguns termos com o objetivo de apresentar as informações de maneira mais clara.

Arquitetura sustentável: criação de ambientes cujos espaços, funcionamento e materialidade utilizem energias e recursos renováveis, para sua produção, manutenção e uso.

Arquitetura ecológica é elaborada considerando o uso de materiais naturais, que se integrem à natureza e não agrida o meio ambiente, valorizando os sistemas naturais de conforto térmico e luminoso.

\section{Projeto Sustentável:}

Projeto que tem como partido a preservação, conservação e reutilização dos recursos naturais e energéticos, visando um produto com vida longa, confortável, flexível, reciclável e/ou reutilizável. 


\section{Design sustentável:}

"O design sustentável permite responder às necessidades socioeconômicas e ambientais dos consumidores, propondo formas, inovações, materiais, tecnologias e procedimentos que gerem impacto ambiental mínimo em cada etapa do ciclo de vida do produto." (PELTIER e SAPORTA, 2009, p.96)

\section{Ecodesign:}

"O Ecodesign, ou projeto para o meio ambiente, avalia o efeito que um produto tem sobre o meio ambiente em todos os estágios do seu ciclo de vida, ou seja, desde a escolha da matéria prima, produção e distribuição até o seu uso e pós-uso." (PORTALGA, 2009)

\section{Design Ecológico:}

"O design ecológico tem raízes na natureza tanto em sua concepção quanto na utilização de materiais, e seus resultados contribuem para o ajuste entre grupos humanos e seu ambiente." (TRINDADE, 2002, p.185)

\section{Materiais Sustentáveis:}

Materiais produzidos ou processados de forma a minimizar o impacto ambiental e que sejam duráveis, reciclados, recicláveis, ou facilmente repostos ao meio ambiente.

\section{Lixo}

Tecnicamente, o lixo é definido como Resíduo Sólido. A NBR 10004:2004 define resíduos sólidos da seguinte maneira:

Resíduos nos estados sólido e semi-sólido, que resultam de atividades de origem industrial, doméstica, hospitalar, comercial, agrícola, de serviços e de varrição. Ficam incluídos nesta definição os lodos provenientes de sistemas de tratamento de água, aqueles gerados em equipamentos e instalações de controle de poluição, bem como determinados líquidos cujas particularidades tornem inviável o seu lançamento na rede pública de esgotos ou corpos de água, ou exijam para isso soluções técnica e economicamente inviáveis em face à melhor tecnologia disponível. (ABNT NBR 10004:2004 p.1) 
A diretiva 75-442-CEE (Comunidade Econômica Européia) de 1975 e que trata dos resíduos sólidos, definiu resíduo e eliminação, no artigo $1^{\circ}$, da seguinte maneira:

\section{Resíduo:}

"qualquer substância ou objecto que o detentor se desfaz ou tem a obrigação de se desfazer."

\section{Eliminação:}

"A recolha, a triagem, o transporte e o tratamento de resíduos, assim como o seu armazenamento e o seu depósito à superfície ou enterrado."

"As operações de transformação necessárias a sua reutilização, recuperação ou reciclagem."

Os R's.

A política dos 3R's é um conjunto de ações sugeridas durante a Conferência da Terra, realizada no Rio de Janeiro em 1992, e o $5^{\circ}$ Programa Europeu para o Ambiente e Desenvolvimento, realizado em 1993. Os 3R's consistem nos atos de Reduzir, Reutilizar e Reciclar o lixo produzido. (MUNDOEDUCAÇÃO, 2010)

A metodologia 3 R's constitui práticas simples de combate ao desperdício, mas que fazem a diferença no volume de lixo descartado. Abrange os seguintes gestos: Reduzir, Reutilizar e Reciclar. É importante observar a seqüência lógica da filosofia dos 3 R's: primeiro, reduzir, para depois pensar em reutilizar e reciclar, pois não há benefícios para o meio ambiente e para a sociedade em geral se houver o aumento do consumo só para se obter um volume maior de material a ser reutilizado ou reciclado. (TRESE, 2010)

As atitudes diante de um resíduo começa a ser olhada com mais critério a partir da RIO 92. O conceito dos 3R's colaboram com a sistematização de ações perante os resíduos e passa a ser gradativamente adotado em empresas, nas escolas e na vida cotidiana.

Passados quase 20 anos, aos 3R's foram se juntando vários outros R's: Refletir, Recusar, Reaproveitar, Redesenhar, entre outros, assim como também os Ecos e os sustentáveis. Abaixo, uma seqüência que analisa cada um destes R's. 
- Refletir: Considerar a importância real em se consumir determinado objeto/bem.

- Recusar: Recusar embalagens excessivas, sacolas, papéis dispensáveis que venham junto aos produtos.

\section{- Reduzir}

o Reduzir o consumo de energia para produção dos objetos

o Reduzir o uso de materiais naturais/virgens para produção destes objetos

o Reduzir o consumo evitando a aquisição de produtos desnecessários

o Reduzir a quantidade de lixo que produzimos (relacionada diretamente à redução de consumo)

- Reutilizar: Reutilizar o que possa ser novamente utilizado, ainda que com finalidade diferente da original, evitando o descarte, ou seja, evitando-se que vá para o lixo aquilo que ainda pode ser aproveitado e que sugira, em alguns casos a possibilidade de aplicar criatividade e inovação.

- Reaproveitar: Aproveitar um objeto para outros usos, sozinho ou em conjunto com outros objetos, podenso surgir até um terceiro desenho de objeto, estando então associado ao conceito de design

- Redesenhar (Redesign): Renovar ou dar novas funções e aspecto estético a um determinado objeto

- Reciclar: Transformar em matéria-prima para reciclagem, através de um novo processamento industrial, o que não se pode mais utilizar ou reutilizar.

\section{Análise do ciclo de vida - ACV}

A análise do ciclo de vida (ACV) estuda a complexa interação entre um produto e o ambiente, utilizando para tanto a avaliação dos aspectos ambientais e dos impactos potenciais associados ao ciclo de vida do produto. (...) compreende as etapas que vão desde a retirada da natureza das matérias primas no sistema produtivo, passando por todas as operações industriais e de consumo até a disposição do produto final quando de encerra sua vida útil. 
A Logística Reversa é o estudo dos Canais de Distribuição Reversos, uma nova área da Logística Empresarial, tem o seu foco principal no exame dos fluxos reversos, ou seja, naqueles que fluem no sentido inverso da cadeia direta, a partir dos produtos descartados como pós - consumo ou dos produtos de pós - venda, visando agregar-Ihes valor de diversas naturezas, através da reintegração de seus produtos, componentes ou materiais constituintes ao ciclo produtivo e de negócios. (CLRB, 2009)

Fluir no sentido reverso busca o resgate dos materiais descartados, seja na reutilização, seja na reciclagem, administrando de forma organizada e eficiente estes materiais pósconsumo, sua reciclagem e redirecionamento para o mercado.

\section{Pegada ecológica}

Pegada ecológica é uma expressão que vem do inglês "ecological footprint", uma ferramenta usada para designar de forma estimada a área e quantidade de impacto humano no meio ambiente ao se apropriarem dos recursos materiais e energéticos do ecossistema (terras e águas) para sustentar os gastos energéticos de uma determinada população.

O termo foi criado pelo Professor William Rees, na década de 90 do século XX. Em 1995 publicou, junto com Mathis Wackernagel o livro "Our Ecological Footprint: Reducing Human Impact on the Earth".

Lovins e Hawken (2000, p. 47) dizem que todo produto que consumimos tem uma história oculta, um inventário não escrito de material, recursos e impactos e essa história oculta é chamada "pegada ecológica, que avalia a capacidade ecológica necessária para sustentar o consumo de produtos e até mesmo os estilos de vida. Calcula-se uma pegada ecológica somando os fluxos de material e energia requeridos para sustentar qualquer economia ou segmento da economia. Tais fluxos são então convertidos em medidas padrão da produção que se exige das regiões de terra e água. Pegada é a superfície total de terra necessária para sustentar uma determinada atividade ou produto." 
Assim é também a 'Pegada Ecológica': quanto mais se acelera nossa exploração do meio ambiente, maior se torna a marca que deixamos na Terra. O uso excessivo de recursos naturais, o consumismo exagerado, a degradação ambiental e a grande quantidade de resíduos gerados são rastros deixados por uma humanidade que ainda se vê fora e distante da Natureza. A Pegada Ecológica não é uma medida exata e sim uma estimativa. Ela nos mostra até que ponto a nossa forma de viver está de acordo com a capacidade do planeta de oferecer, renovar seus recursos naturais e absorver os resíduos que geramos por muitos e muitos anos. (WWF, 2009)

As sociedades mais desenvolvidas, que são as mais consumistas, deixam uma pegada muito maior no meio ambiente do que as sociedades menos desenvolvidas e, portanto, menos consumistas destes recursos.

\section{Impacto ambiental e energia incorporada}

Roaf, Fuentes e Thomas (2009) salientam que talvez a medida mais importante do impacto ambiental de um objeto seja fornecida pelo conceito de "energia incorporada", que descreve a quantidade de energia usada para produzir um objeto.

Como os dados para energia incorporada de alguns materiais ainda não estão amplamente disponíveis, espera-se uma escolha e especificação do material que seja coerente nas condições mínimas de impacto ambiental, considerando dados percebidos na prática, como por exemplo a localidade da produção do material - e portanto a distância de sua fabricação até o local de uso e a fonte de retirada da matéria-prima.

\section{Produção mais limpa $-\mathrm{P}+\mathrm{L}$}

A produção mais limpa é uma importante estratégia a ser adotada pelas empresas que pretendem melhorar seu desempenho de produção de forma a minimizar os impactos ambientais e gastos energéticos.

De acordo com Figueiredo (2010), este conceito foi lançado em 1989, pela United Nations Environment Programme - Division of Technology, Industry and Economics - UNEP-DTIE, que define o termo da seguinte maneira: "Produção Mais Limpa é a aplicação contínua de 
uma estratégia integrada de prevenção ambiental a processos, produtos e serviços, para aumentar a eficiência de produção e reduzir riscos para o ser humano e o ambiente"

Figueiredo (2010) complementa dizendo que a visão proporcionada pela análise do ciclo de vida ( $A C V$ ) também pode auxiliar em iniciativas de $P+L$, uma vez que cada etapa de vida do produto ou serviço é passível de otimizações ambientais.

Alves e Oliveira (2007) observam que a necessidade da indústria de se adequar ambientalmente tem feito com que muitas empresas revejam seus processos. Considerando as legislações vigentes e a demanda por produtos e processos considerados "verdes", tem motivado a busca por metodologias de gestão ambiental. Destacam a produção mais limpa $(\mathrm{P}+\mathrm{L})$ como uma metodologia que auxilia as indústrias a obter uma boa gestão ambiental.

\section{Retrofit}

Retrofit é um termo utilizado, em sua forma original, para denominar reforma, com objetivo de melhoria da eficiência de sistemas de funcionamento de objetos e edifícios. Na área da arquitetura e construção civil tem caráter de modernização de sistemas e instalações com o objetivo de melhorar a eficiência da edificação.

\section{Redesign}

"Genericamente, denomina o processo de aperfeiçoamento, a reforma ou reformulação de qualquer tipo de produto já existente - preservando sua essência inalterada." (GOMES FILHO, 2006, p.21)

Em 1970, época em que as questões ambientais começaram a ganhar força na mídia, a fabricante de papelão reciclado Conteiner Corporation of America patrocinou um concurso nacional para estudantes de arte e design com 0 objetivo de encontrar o símbolo definitivo para o movimento.

Quem levou a melhor foi Gary Anderson, que na época tinha apenas 23 anos e estudava design na Universidade do Sul da Califórnia.

A grande sacada das três flechas, ou do anel que nunca termina, é que ele foi criado sobre a faixa Möbius, um signo conceitual matemático que revela duas faces e sugere eterna continuidade. [...] o Anel Möbius - como é chamado o símbolo universal da reciclagem - é um elemento de domínio público e não 
uma marca registrada, o que permite que ele seja reproduzido nas mais diversas circunstâncias. (AKATU, 2010)

O ano de 1970 será o ponto de partida de uma nova era para a reciclagem. Os partidários da defesa do meio ambiente lançam um logotipo universal - o anel de Moebius - para marcar os produtos recicláveis e os produtos oriundos de materiais reciclados. Os consumidores despertam pouco a pouco para a noção de produto reciclável e o reconhecem graças ao símbolo gráfico que as mercadorias trazem." (PELTIER e SAPORTA, 2009, p. 18.)

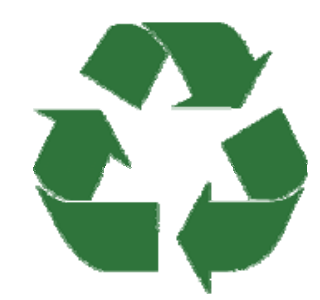

Figura 5: Anel de Möbius para a reciclagem - logotipo universal.

Fonte: SIMBOLOGY (2010) 


\section{APÊNDICE B}

\section{RELATÓRIO DE ENSAIO - ABSORTÂNCIA À RADIAÇÃO SOLAR}

1) NATUREZA DOTRABALHO: determinação de absortância à radiação solar.

\section{2) MÉTODOUTUZADO:}

4.1 Medição de absortância à radiação solar de acordo com a Norma "ASHRAE 74-1988: method of measuring solar-optical properties of materials".

- Equipamento: espectrofotômetro Varian CARY 5G;

- Intervalo de medição: 300 a 2500 nm.

4.2 Ajuste das absortâncias ao Espectro Solar Padrão, de acordo com dados da Norma "ASTM G173-03: standard tables for reference solar spectral irradiances - direct normal and hemispherical on $37^{\circ}$ tilted surface".

\section{Ajuste das absortâncias ao espectro solar padrão:}

Os dados de refletância solar obtidos pelo espectrofotômetro caracterizam o comportamento ótico das diferentes amostras quando expostas a uma energia constante ao longo de todo o espectro solar. No entanto, este cálculo não considera o percentual de energia incidente em cada comprimento de onda, pois o espectrofotômetro não faz essa distinção. Para se chegar à quantidade de energia relativa que é absorvida pelas amostras, os valores de refletância devem ser corrigidos de acordo com a intensidade da radiação solar para cada comprimento de onda, a partir de um espectro solar padrão (ASTM G173-03), apresentado na figura abaixo:

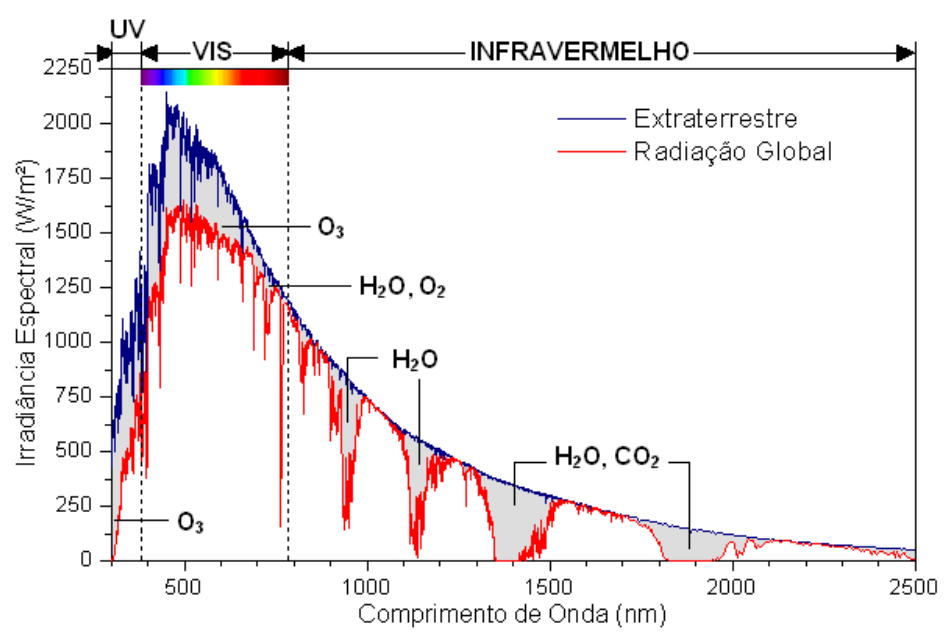

Fonte: DORNELLES (2008)

DORNELLES, Kelen Almeida. Absortância solar de superfícies opacas: métodos de determinação e base de dados para tintas látex acrílica e PVA. 2008. 160p. Tese (Doutorado) Faculdade de Engenharia Civil, Arquitetura e Urbanismo, Universidade Estadual de Campinas, Campinas, 2008. 
APÊNDICE C

\section{Questionário enviado por e-mail à TETRA PAK e e-mail com respostas da empresa}

http://br.mg4.mail.yahoo.com/dc/launch?.gx=1\&.rand=cee3a4jqlv1ri

Quinta-feira, 13 de Agosto de 2009 14:23:11

questionário Tetra Pak

De: Pinheiro Luana <Luana.Pinheiro@tetrapak.com>

Exibir contato

Para: Erica <ericacris@yahoo.com>

2 arquivos Fazer o download de tudo

Questionário TETRA PAK 30-07-2009.doc (132KB); Copy of Environment2009.zip (3640KB)

Érica,

Estou encaminhando as respostas do seu questionário e o relatório sócio ambiental mundial de 2009. Espero que ajude.

Qualquer dúvida, entre em contato.

Até mais,

Luana

Questionário respondido (anexado ao e-mail)

FORMALIZAÇÃO DE QUESTIONÁRIO PARA PESQUISA DE DOUTORADO

Observação: caso não seja possível uma resposta direta, se possível, favor indicar uma fonte para busca da resposta.

1 - Qual a produção anual de embalagens longa vida pela Tetra Pak? 8,5 bilhões de embalagens foram produzidas no Brasil em 2008

2 - Qual a porcentagem de produção em relação às outras embalagens mais comuns no mercado? Você pode procurar essa informação na ABRE, Associação Brasileira de Embalagens (www.abre.org.br)

3 - Da produção, quantos por cento são recicladas no Brasil? Em 2008, 26,6\% das embalagens produzidas no Brasil foram recicladas.

4 - Do montante que vai para reciclagem, qual porcentagem de produção de cada um dos materiais abaixo?

Separação do papel

- Produção de papel:

Polietileno/Alumínio

- Produção de placas: 
- Produção de telhas:

Polietileno/Alumínio reprocessado

- Produção de pellets:

Tecnologia Plasma

- Produção de lingote de alumínio:

- Produção de parafina:

Resposta: Hoje 100\% das embalagens a serem recicladas passam pela separação do papel necessariamente. Só dessa forma os recicladores de plástico/alumínio têm acesso à sua matériaprima. Para os processos subsequêntes à separação do papel, o maior volume do plástico/alumínio é utilizada para a produção de placas e telhas, seguidas pela tecnologia à plasma e por fim a pelletização. A Tetra Pak não tem o controle sobre essas porcentagens pois o mercado é o responsável por absorver o material e ditar as variações.

5 - Quantas e quais são as empresas recicladoras de embalagens longa vida no Brasil e o que cada uma destas estão produzindo (placas, telhas, pellets, etc)?

\begin{tabular}{|l|l|l|l|}
\hline Ramo & Reciclador & Cidade & Estado \\
\hline $\begin{array}{l}\text { brindes } \\
\text { plástico/alumínio }\end{array}$ & Andu Brindes & Taboão da Serra & SP \\
\hline $\begin{array}{l}\text { brindes } \\
\text { plástico/alumínio } \\
\text { brindes } \\
\text { plástico/alumínio }\end{array}$ & Confetti & Sẽo Paulo & SP \\
\hline papel & Formatho Ideall & São Carlos & SP \\
\hline papel & Artivinco & $\begin{array}{l}\text { Santa Rosa do } \\
\text { Viterbo }\end{array}$ & SP \\
\hline papel & Klabin & Piracicaba & SP \\
\hline papel & Revita & Telêmaco Borba & PR \\
\hline papel & Nova Kraft & Potim & SP \\
\hline papel & Adami & Caçador & SC \\
\hline papel & Trombini & Canela & RS \\
\hline papel & Sonoco & Londrina & PR \\
\hline papel e pellets & Klabin Goiana & Goiana & PE \\
\hline parafina e alumínio & Mercoplás & Valinhos & SP \\
\hline pellets & EET & Piracicaba & SP \\
\hline placas & Maximoplas & Guarulhos & SP \\
\hline placas & Maxicomp & Campo Largo & PR \\
\hline placas & Ecopel & Mogi Guaçu & SP \\
\hline placas e telhas & Ecoway & Itupeva & SP \\
\hline placas e telhas & Ecológica & Cariacica & ES \\
\hline placas e telhas & Ecopak & Uberaba & MG \\
\hline placas e telhas & Ibiteca & Marialva & PR \\
\hline placas e telhas & Nova Telha & Ibiporã & PR \\
\hline placas e telhas & EcopaK - RJ & Queimados & RJ \\
\hline placas e telhas & Ecoplasth & Bocaína do Sul & SC \\
\hline placas e telhas & Brasilplac & Itapeva & SP \\
\hline & Ecofuturo & Campinas & SP \\
\hline
\end{tabular}




\begin{tabular}{|l|l|l|l|} 
placas e telhas & Ibaplac & Ibaté & SP \\
\hline placas e telhas & $\begin{array}{l}\text { MR Comercio de } \\
\text { Telhas Comércio de }\end{array}$ & Piracicaba & RP Claro \\
\hline placas e telhas & $\begin{array}{l}\text { MR Celhas } \\
\text { Tero }\end{array}$ & SP \\
\hline placas e telhas & Recima & $\begin{array}{l}\text { Iracemápolis } \\
\text { Ecolix }\end{array}$ & SP \\
\hline placas e telhas & Recipak & Araçatuba & SP \\
\hline placas e telhas & Eco Industrial & Várzea Grande & SP \\
\hline telhas & Alluse & Olinda & PE \\
\hline telhas & Arteplás & Ponta Grossa & PR \\
\hline telhas & GLZ Telhas & Santa Cruz do Sul & RS \\
\hline telhas & Tecfort & São Domingos & SC \\
\hline telhas & & & \\
\hline
\end{tabular}

6 - Existem dados de produção, coleta e reciclagem em outros países (Europa, EUA, outros)? Quais são os montantes? Em que ranking o Brasil se encontra? A taxa mundial média de reciclagem das embalagens longa vida é 18\%. O Brasil, em toneladas recicladas, está em $3^{\circ}$ lugar no ranking, atrás da Alemanha $\left(1^{\circ}\right)$ e Espanha $\left(2^{\circ}\right)$. Para os dados mais específicos da coleta e reciclagem dos outros países, você pode procurar no relatório mundial divulgado pela Tetra Pak ou nos próprios sites da Tetra Pak desses países. Outra possibilidade, para obtenção de dados da Europa, é o site da ACE, The Alliance for Beverage Cartons and the Environment (www.ace.be).

7 - Em relação ao design de objetos utilizando as embalagens recicladas, existem inovações com o uso do "polietileno-alumínio? Ou seja, além dos produtos "telhas e placas", existem outras moldagens de objetos que já foram feitas com a mistura "polietileno-alumínio"? Quais seriam estes objetos? Quais empresas/designers estão produzindo isto? (observação: a partir destes dados poderemos fazer novas pesquisas de campo). Hoje existem empresas que fazem brindes com o plástico/alumínio pelletizado (Andu Brindes) ou apenas moldado (Formatho Ideall), outras conseguem fazer laminados a partir desse material (Confetti). Mais possibilidades onde já vem sendo aplicado são tijolos (Recima), casinhas de cachorro (Ecofuturo) e móveis (sob demanda). 


\section{APÊNDICE D}

\section{Questionário aplicado por e-mail para arquitetos e engenheiros}

1 - Você já conhece este material reciclado?

( ) sim

2 - Já viu este material aplicado em alguma obra?

( ) sim, aplicado como/em:

( ) não

3 - Qual sua opinião técnica sobre este material ?

( ) Conheço alguns dados sobre:

( ) Não conheço dados técnicos sobre este material.

4 - Qual sua opinião estética/visual sobre este material?

( ) Gosto do aspecto visual.

( ) Não gosto do aspecto visual, porque:

\section{5 - Você especificaria/usaria em algum de seus projetos?}

( ) sim, especificaria como (responda quantas alternativas desejar):
( ) vedação externa.
( ) revestimento externo.
( ) forro.
( ) vedação ou revestimento interno.
( ) Outro

( ) Não. Não usaria principalmente porque

( ) Não gosto do aspecto visual deste material

( ) Não conheço seu desempenho técnico.

( ) Não sei onde encontrar / comprar.

\section{( ) Usaria se:}

( ) conhecesse seu desempenho técnico.

( ) já conhecesse a aplicação em alguma obra.

( ) conhecesse catálogos e/ou outras referências técnicas construtivas de como aplicar.

( ) Outro:

( ) Já usei para e

( ) gostei do resultado/

( ) não gostei do resultado porque

( ) Outro 
APÊNDICE E

Desenhos do processo de criação dos projetos. 
Estudos para paginação de superfícies S6PEPFICAES
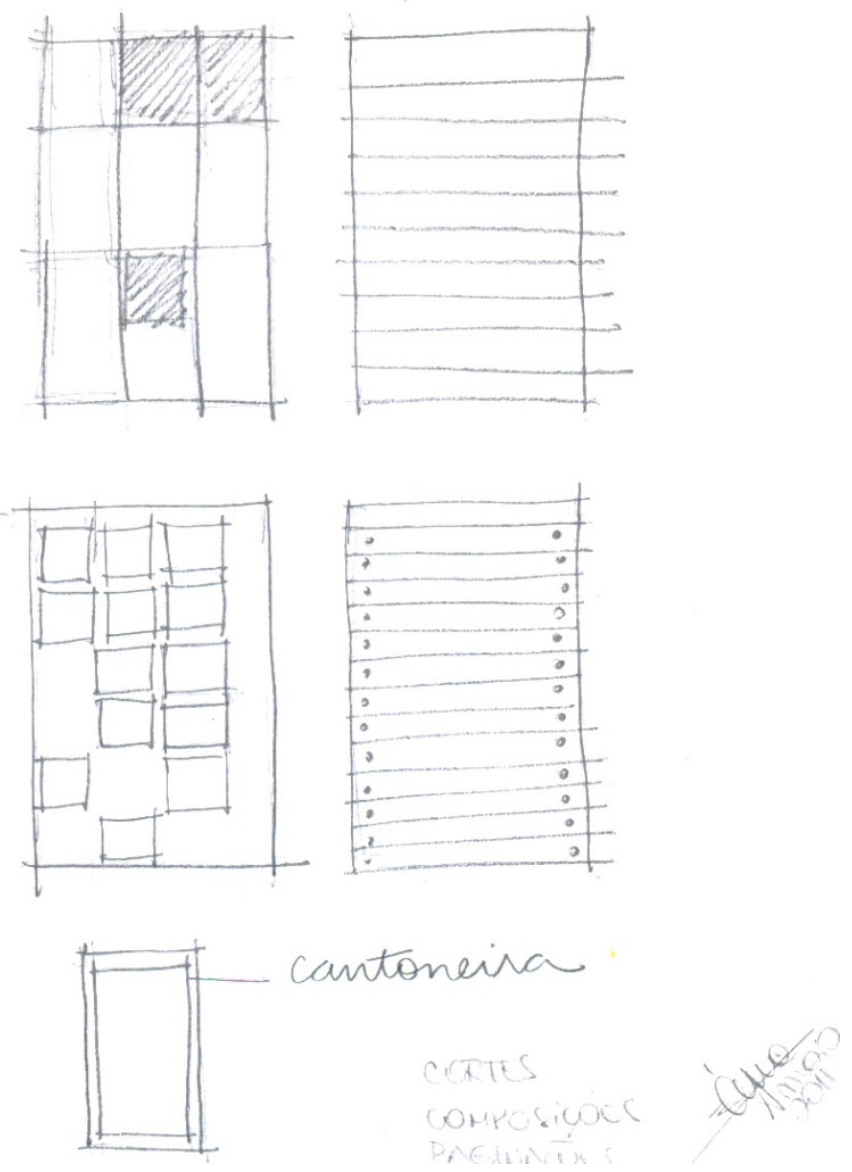

Normas editicacos supertíais - corts.
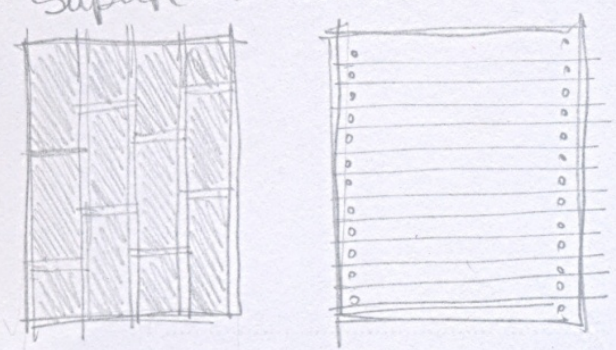

Potencialidode propterais.

Modelos

Deserinos isolodos I dos modelos Desentro en conlexto $\rightarrow$ mopto Hodelo.
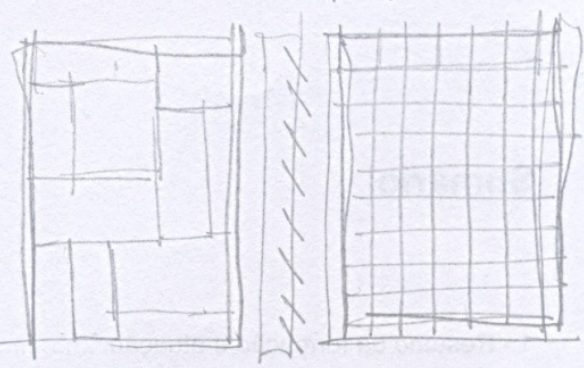


\section{BRISES}

Estudos para brises horizontais e verticais - eixo pivotante.

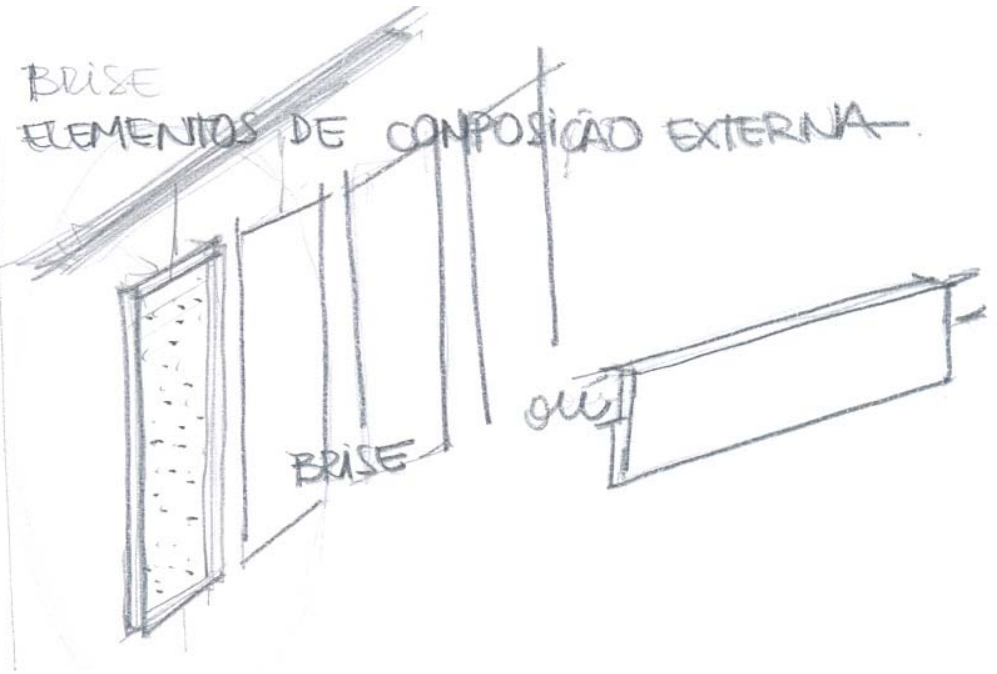

Uso das placas recicladas fixas na fachada - brise na parte superior das aberturas.

Detalhe de acabamento metálico nas extremidades.

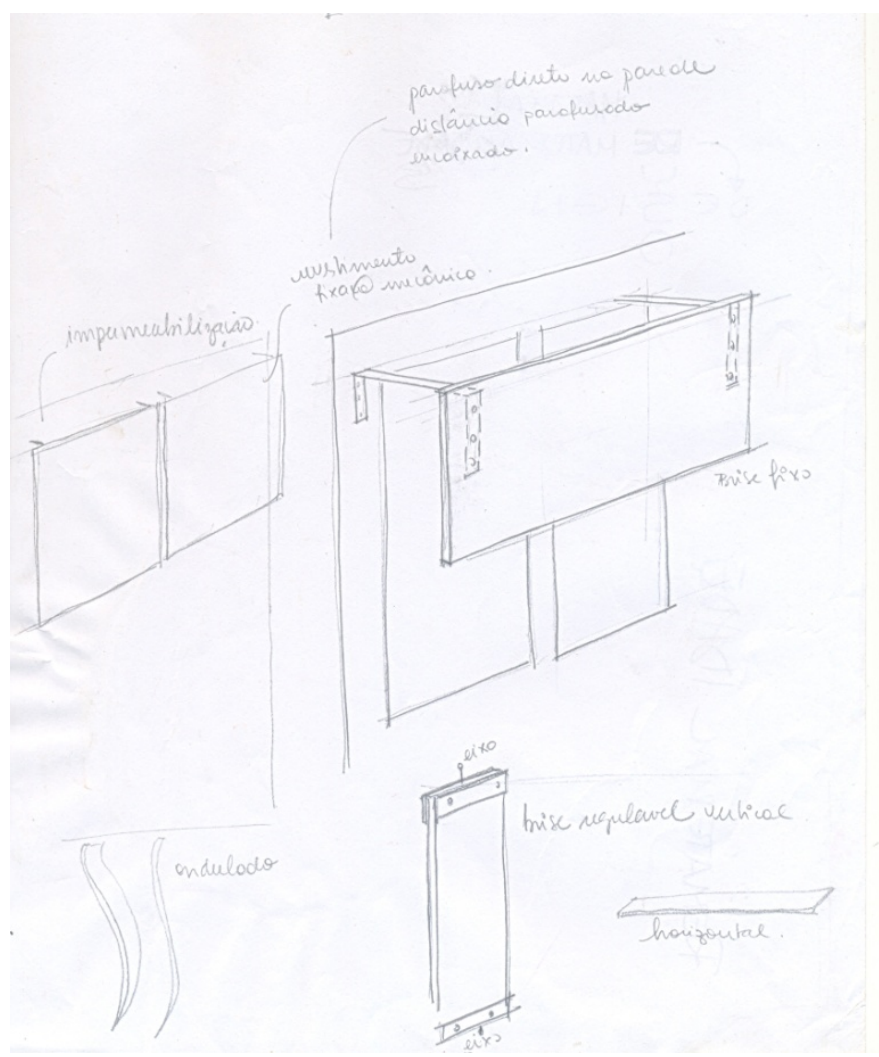


VARIADOS

Estudos construtivos variados

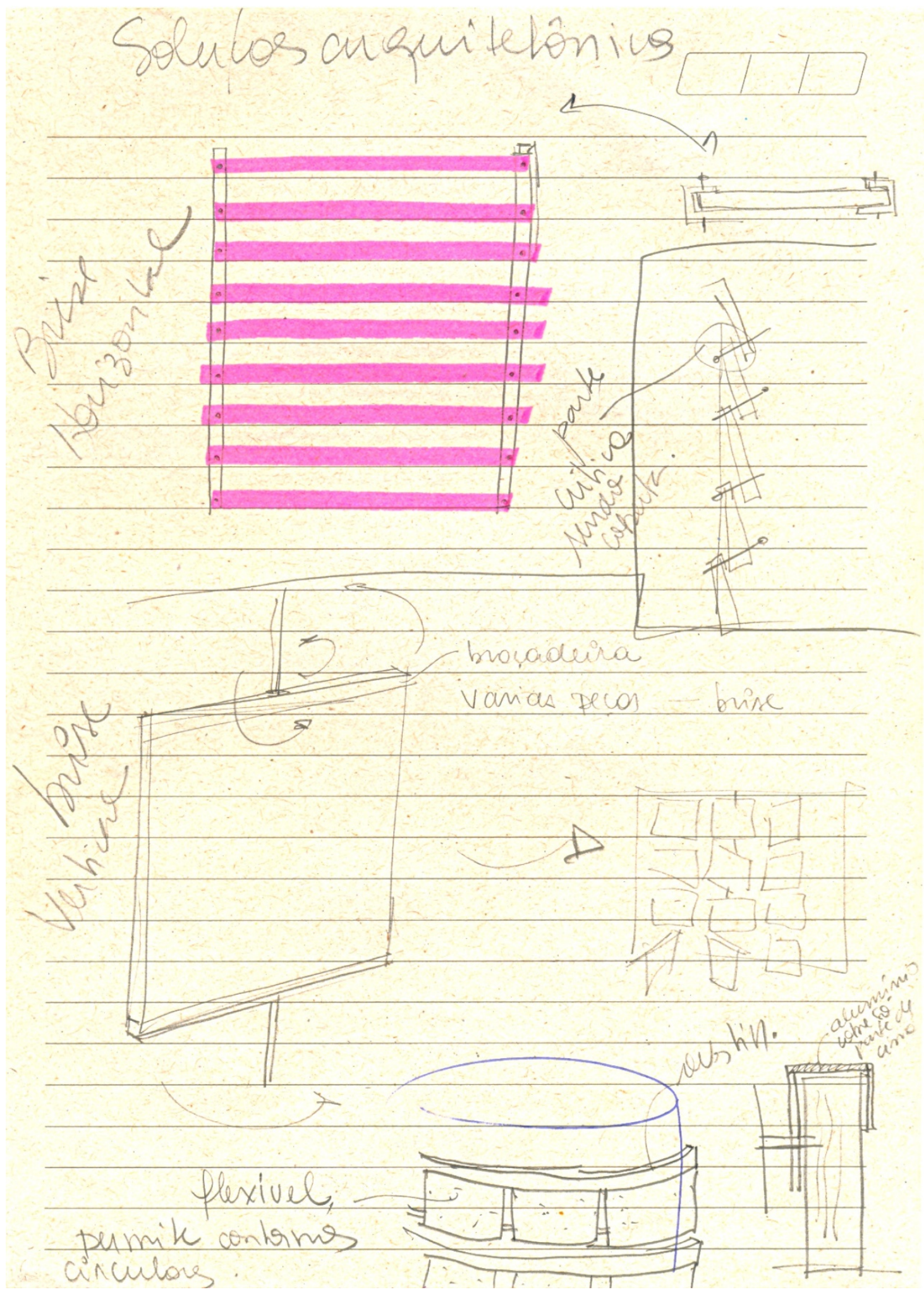


União de peças curvas.

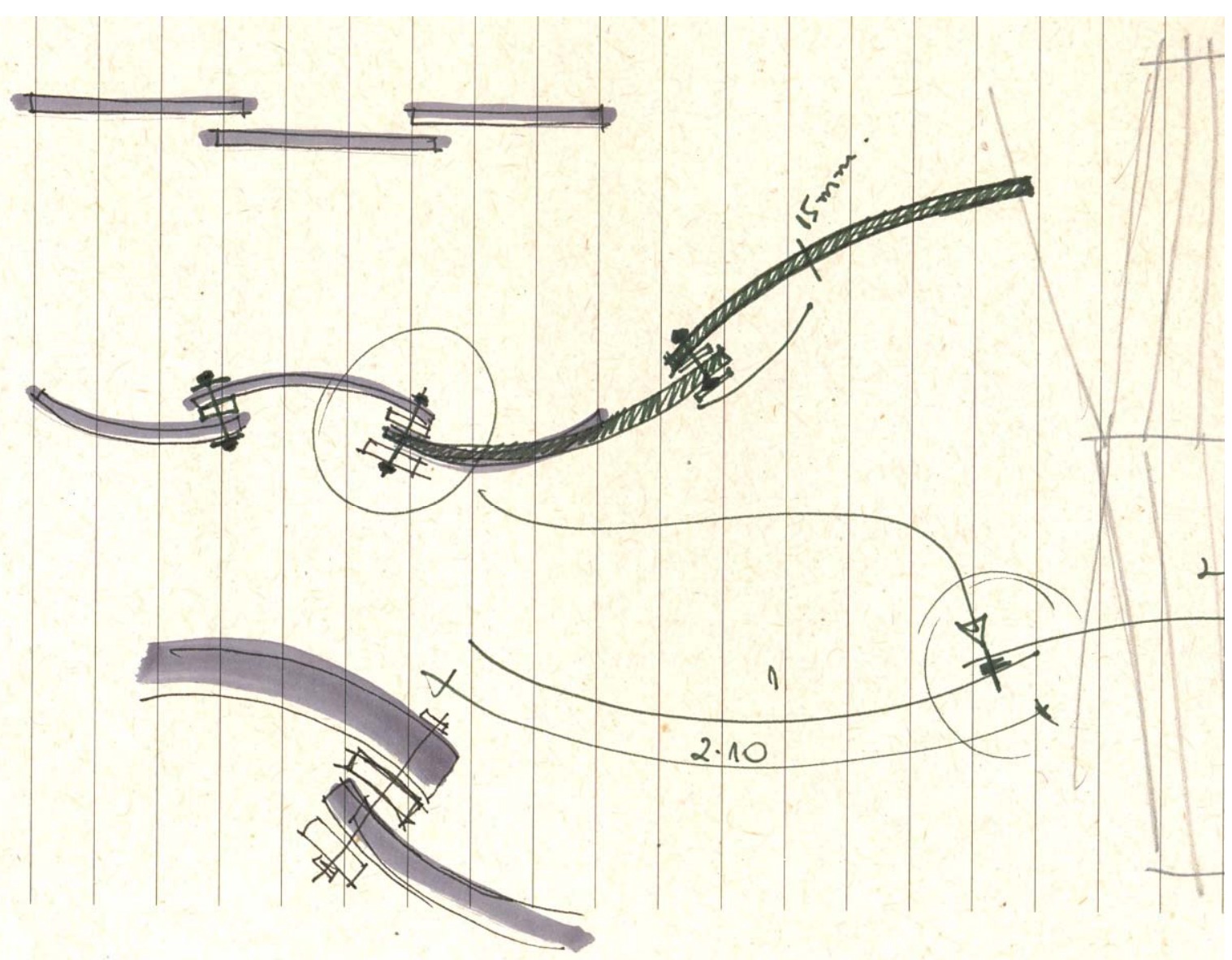

Encaixe de placas (cor preta) em montantes metálicos (cor vermelha)

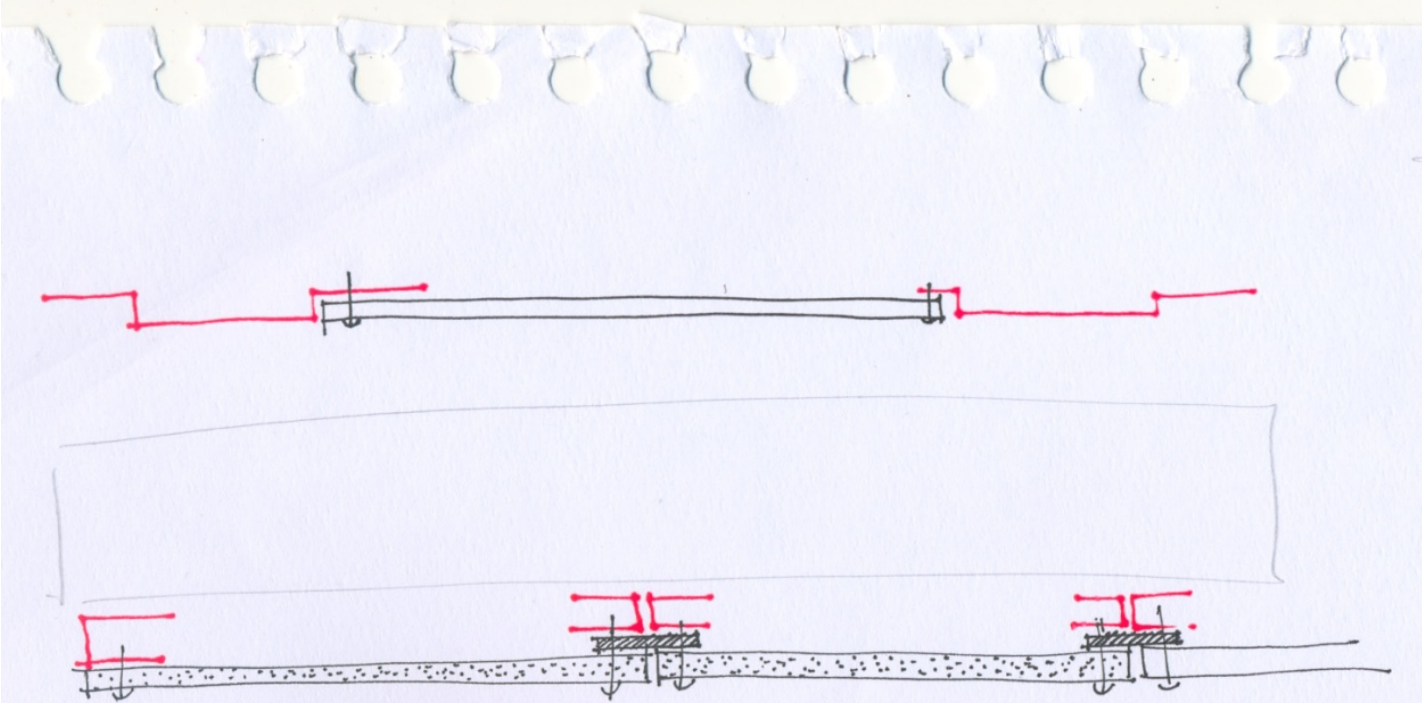


FORROS

Placas curvas, formando conjunto ondulado.
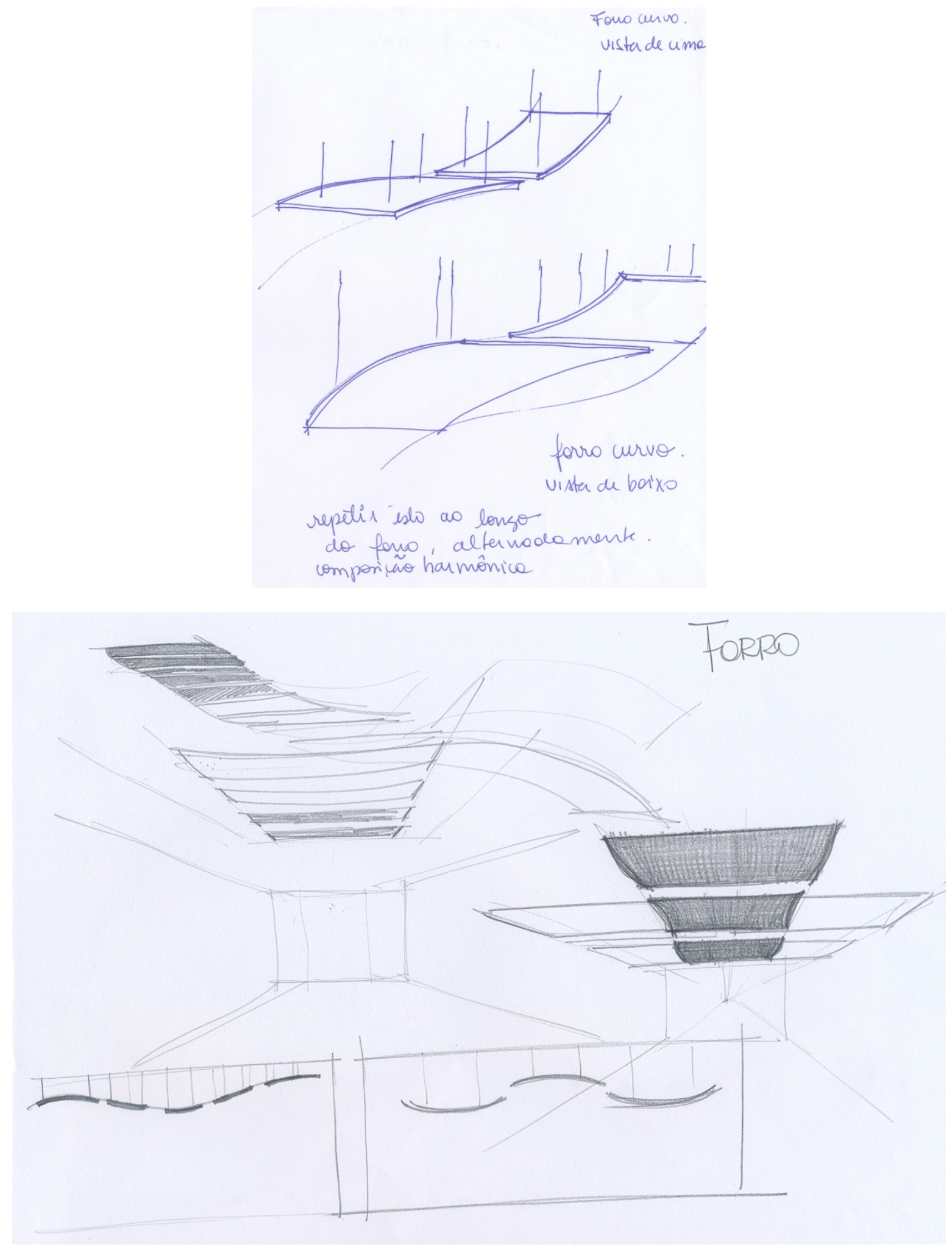


\section{OBJETOS}

Estudo para "porta sanduíche" (placa reciclada + placa de vidro + metálica)

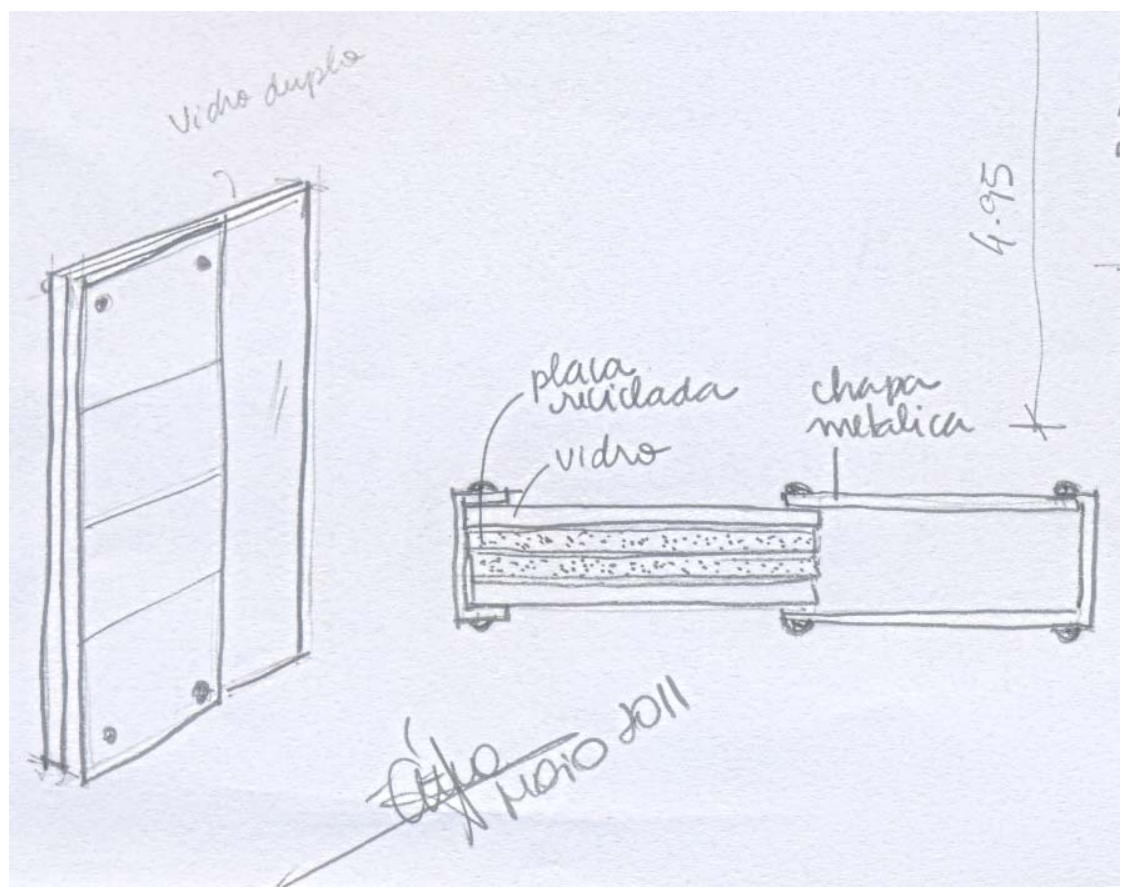

Estudo para mesa em camadas de placa e vidro
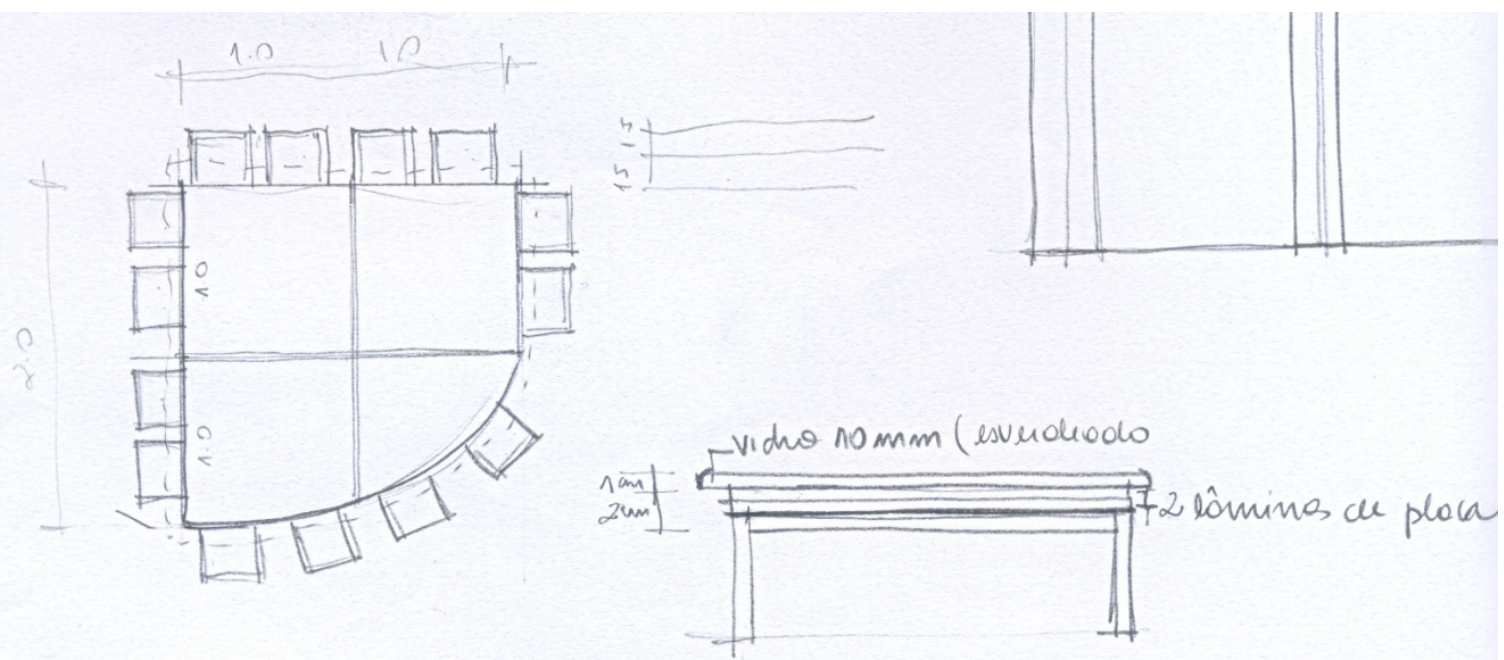
Estudo para objeto com dupla função: banco e bancada de apoio.

Base rígida e curva metálica, com placa reciclada dando acabamento.

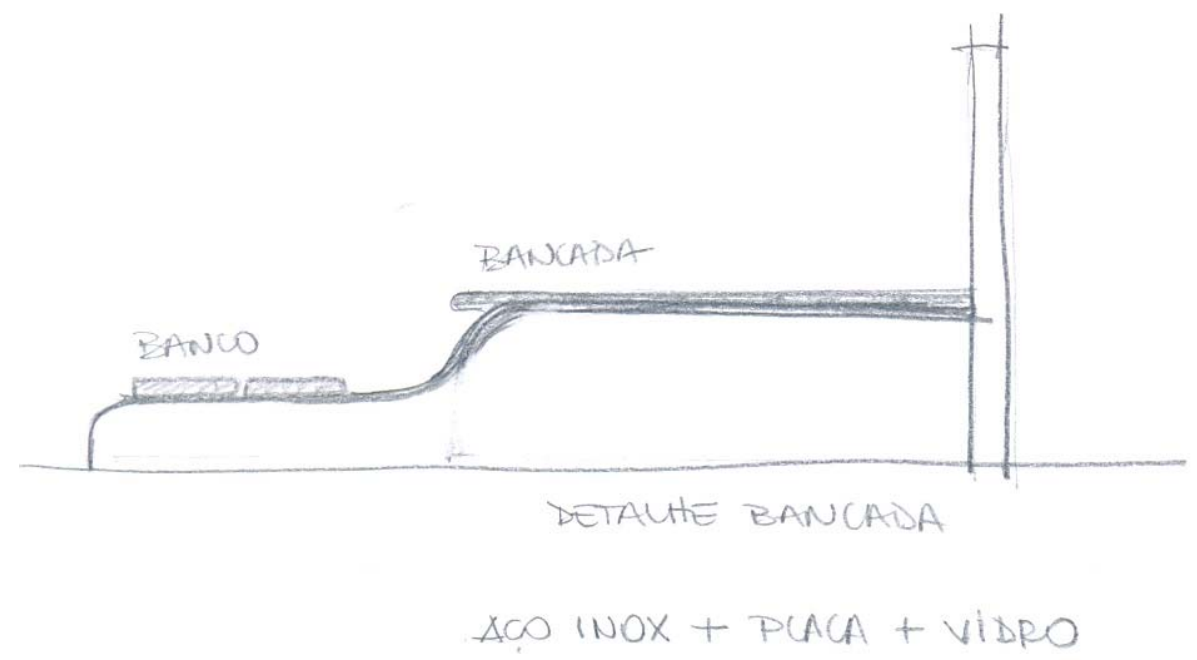

PAINEIS

Estudo de organização das placas para uso em painel com iluminação

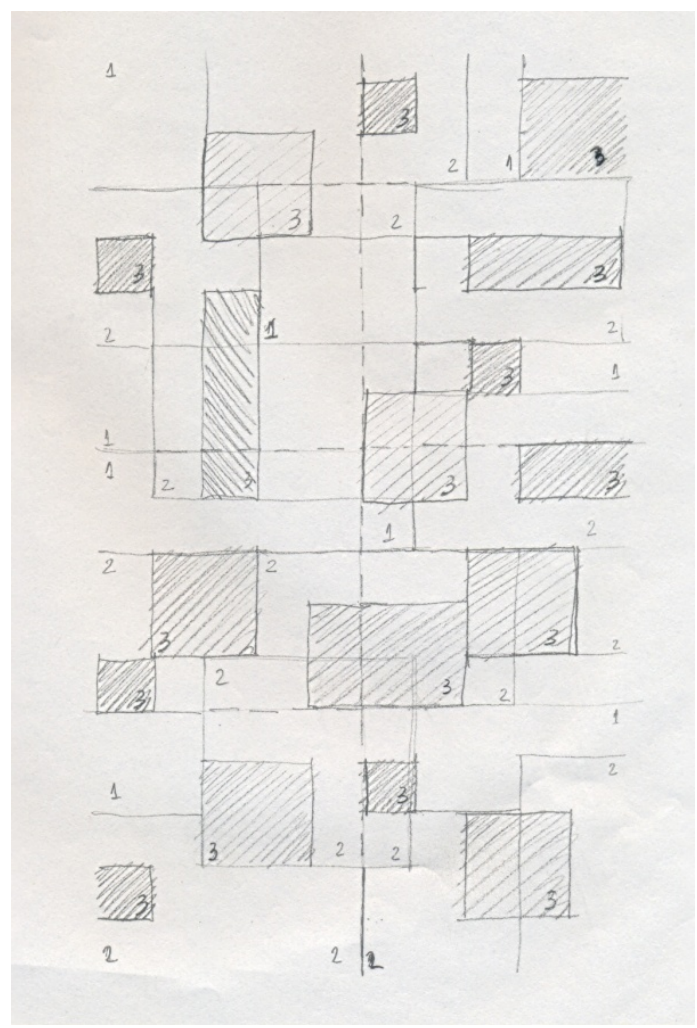


Estudo de painel com placas recicladas em "tiras", com referência nos painéis de madeira.

Estudo com placas compridas retangulares fixadas com parafusos inoxidáveis no contorno.

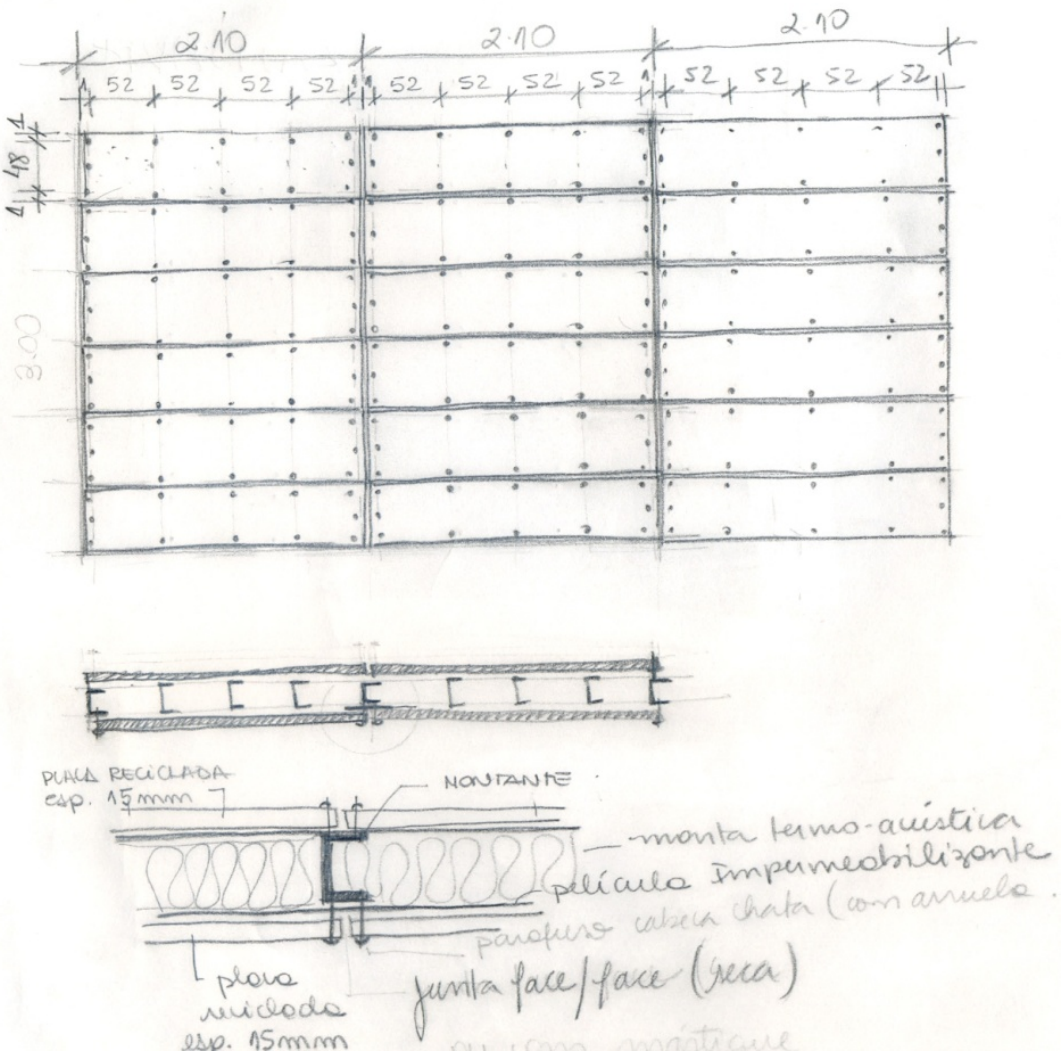




\section{PROJETOS}

Projeto 1 - estudo de planta.

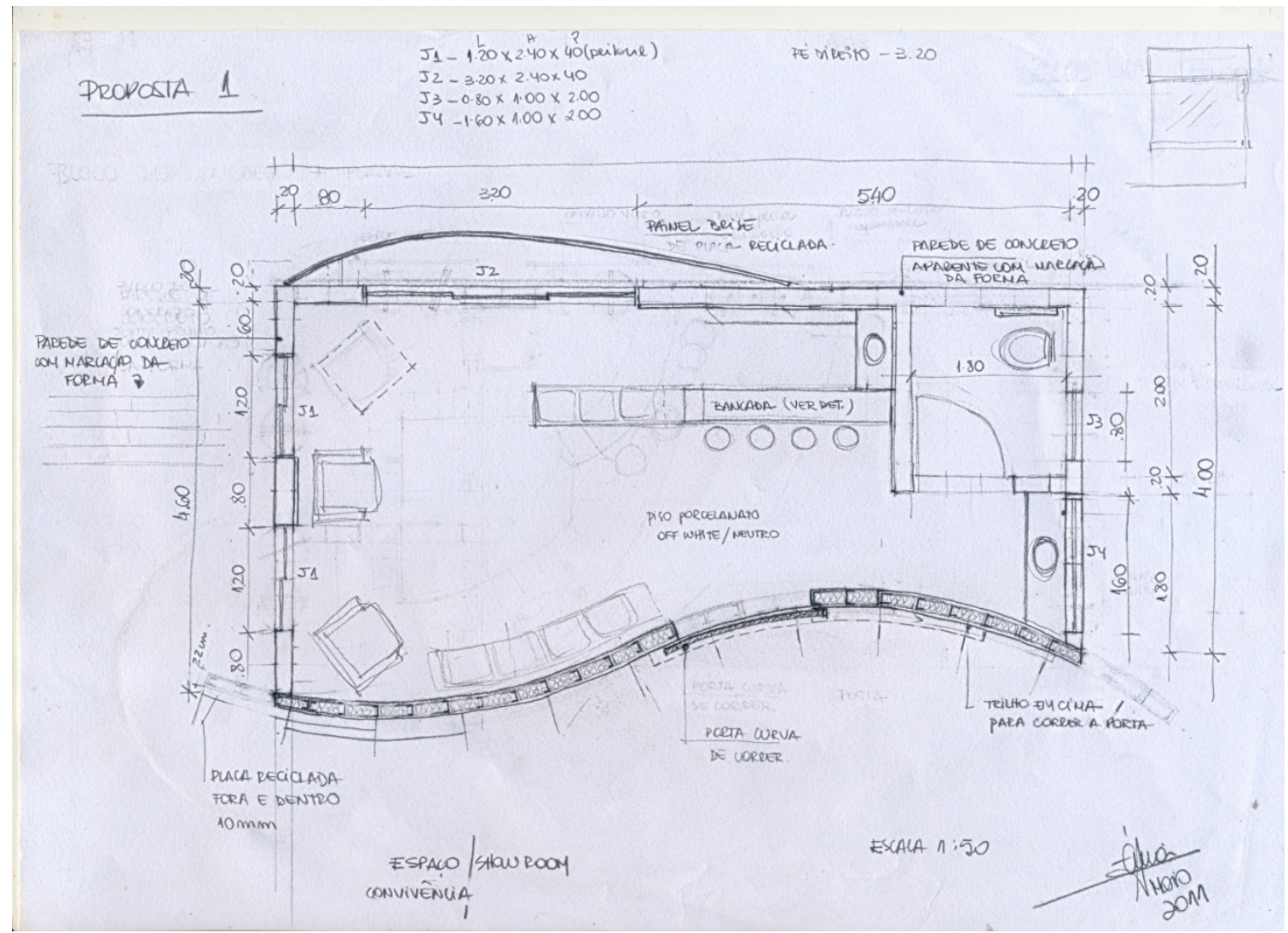

Desenvolvimento da planta - opção com painel curvo de correr (fechamento interno).

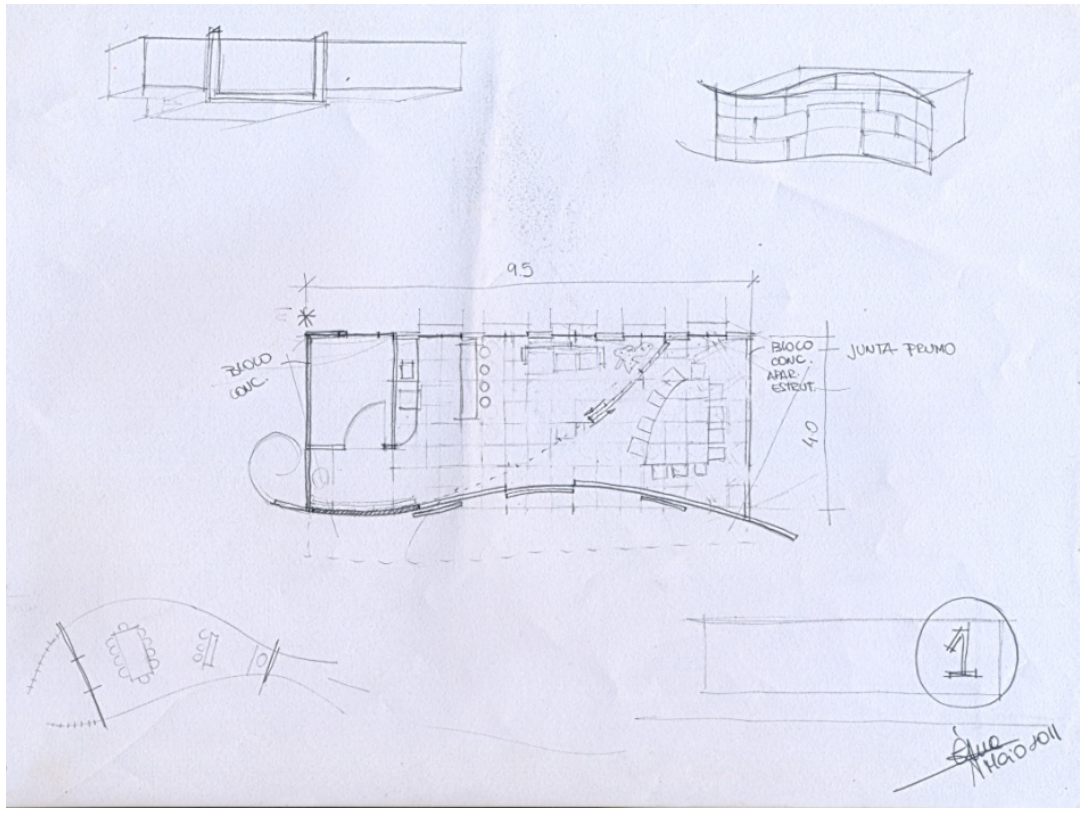


Volumetria e detalhe para sistema de vedação externa.

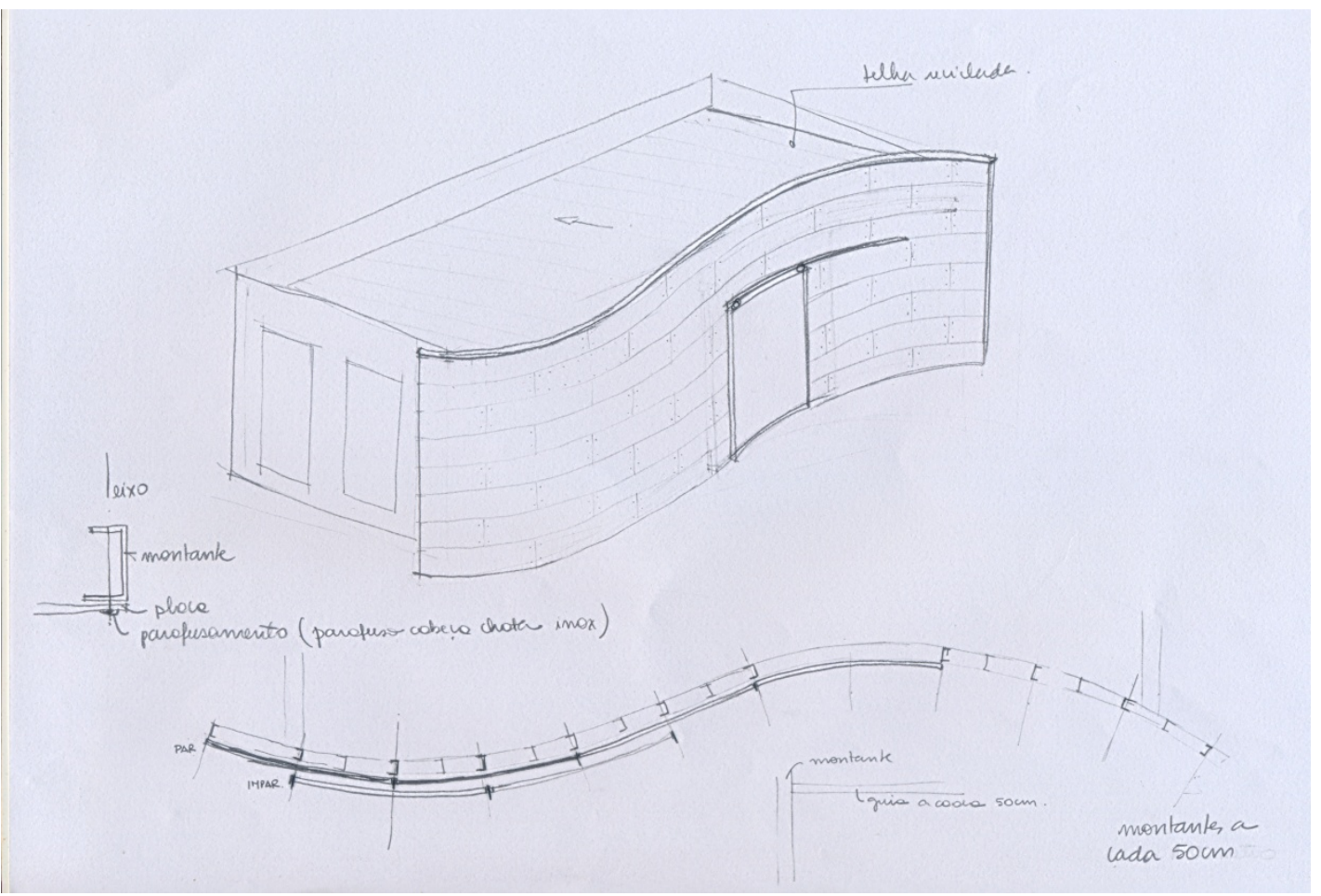

Vista lateral e corte do brise com placas recicladas

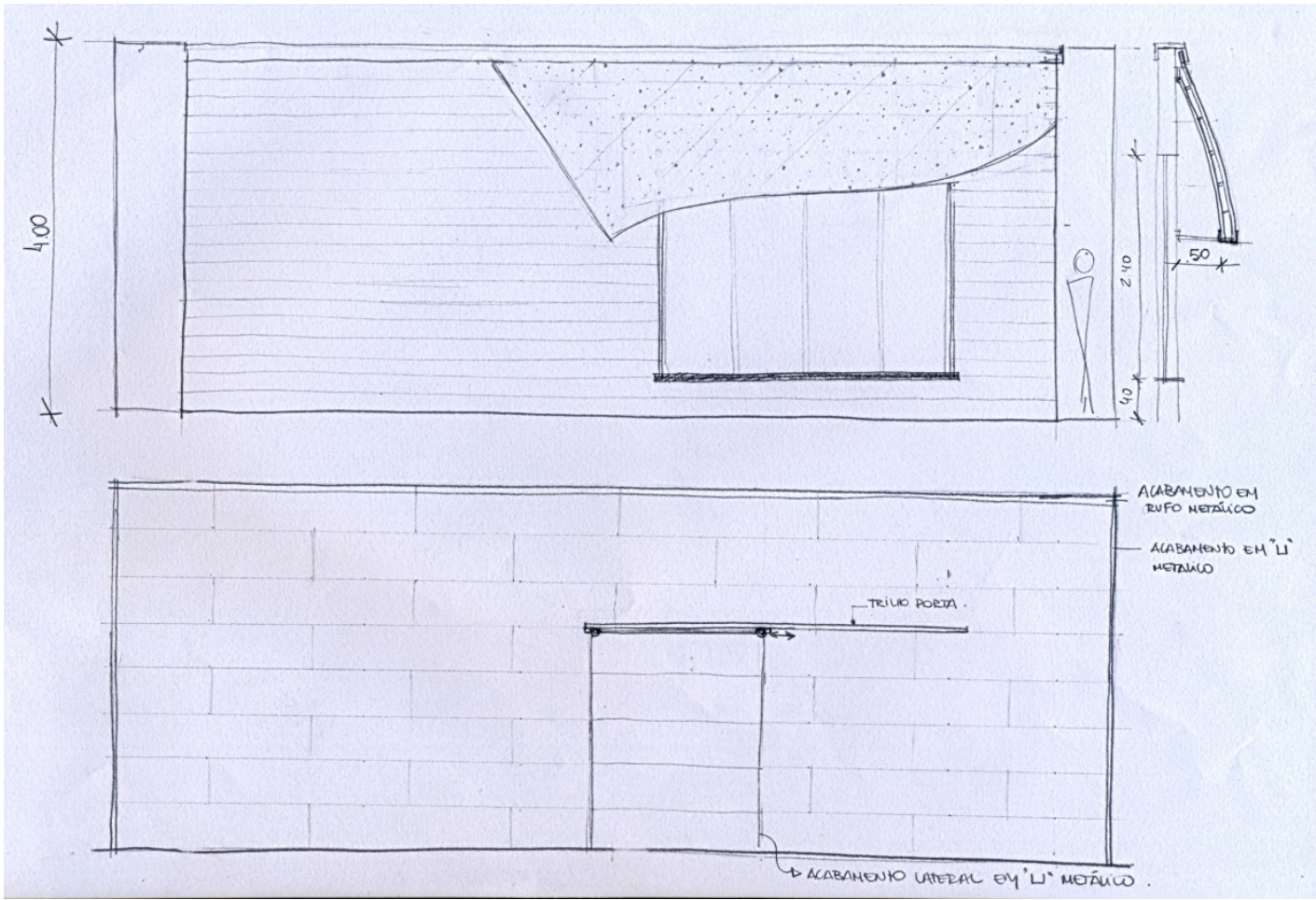


Projeto 2 - estudo de planta

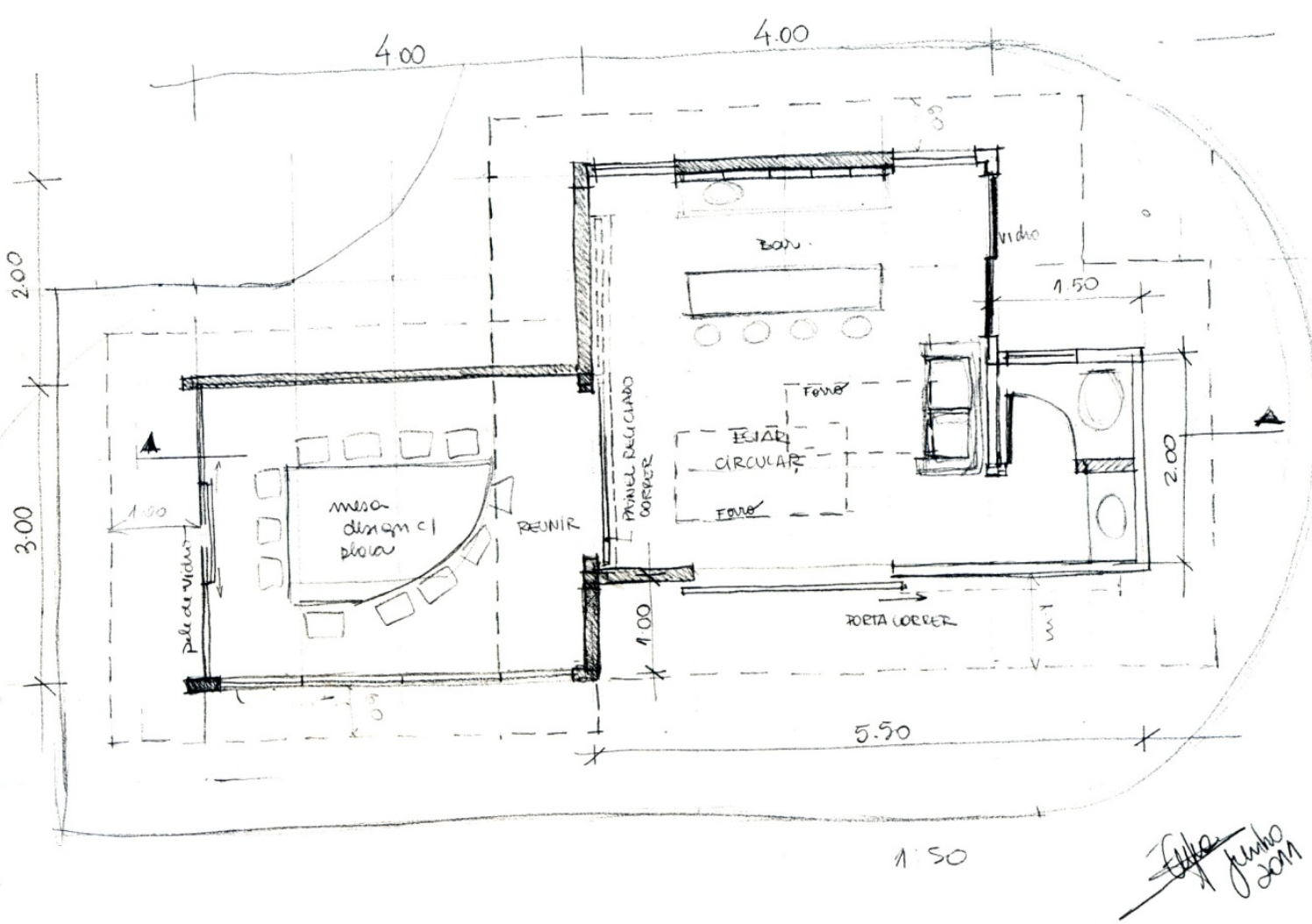

Relação com a cobertura

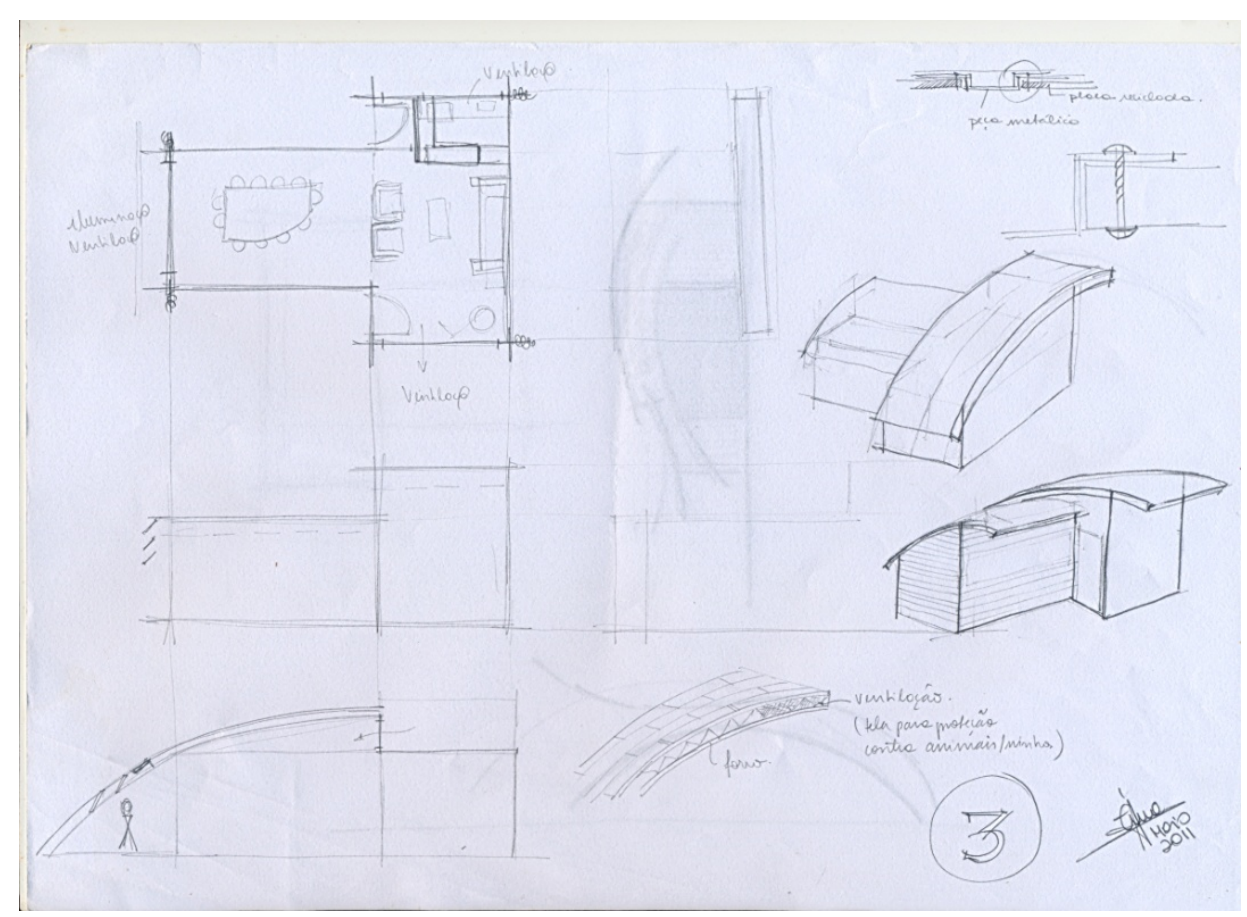


Estudo para solução de cobertura

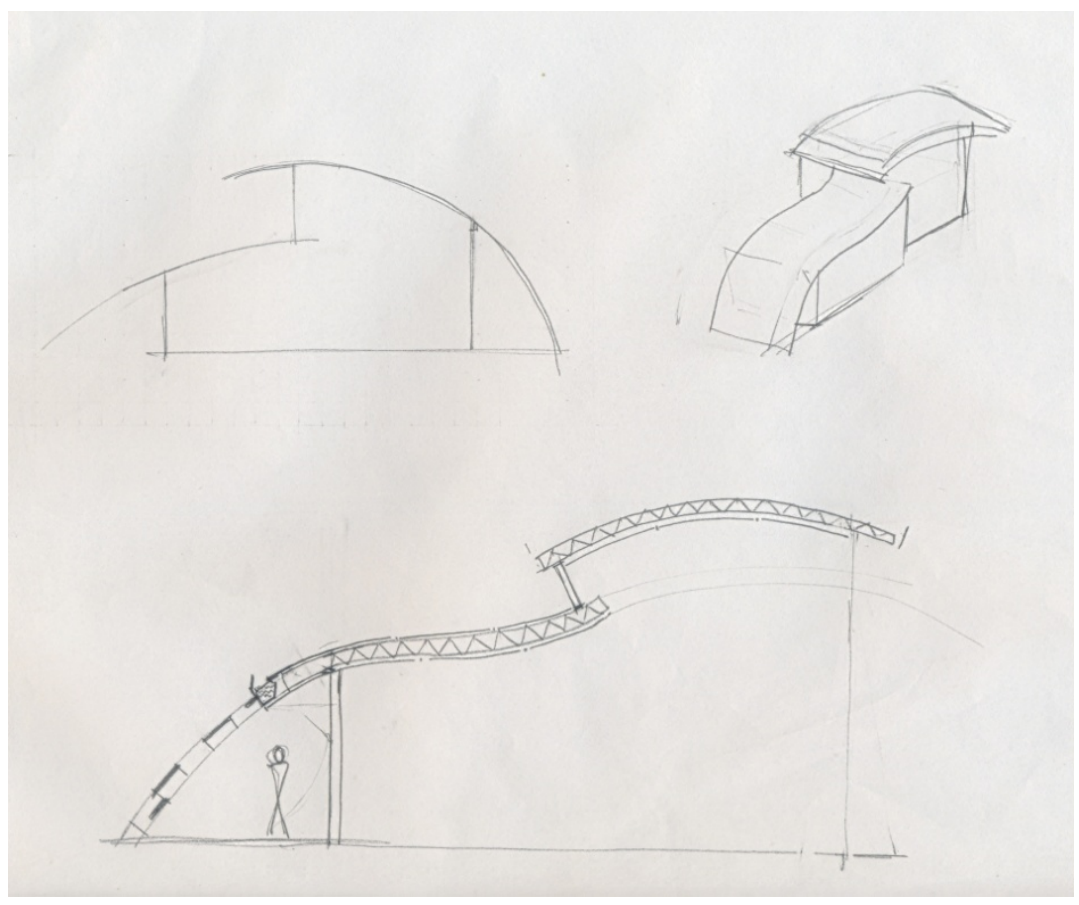

Estudo de fachada

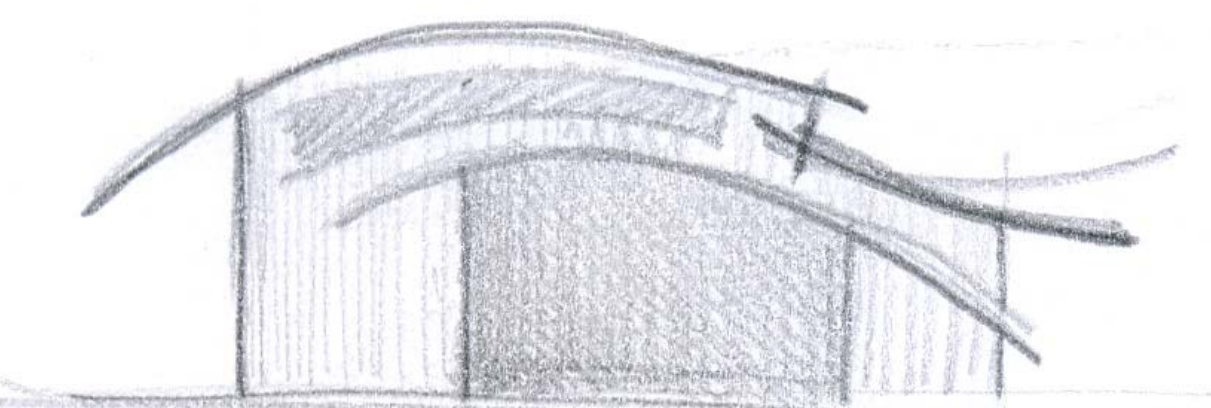




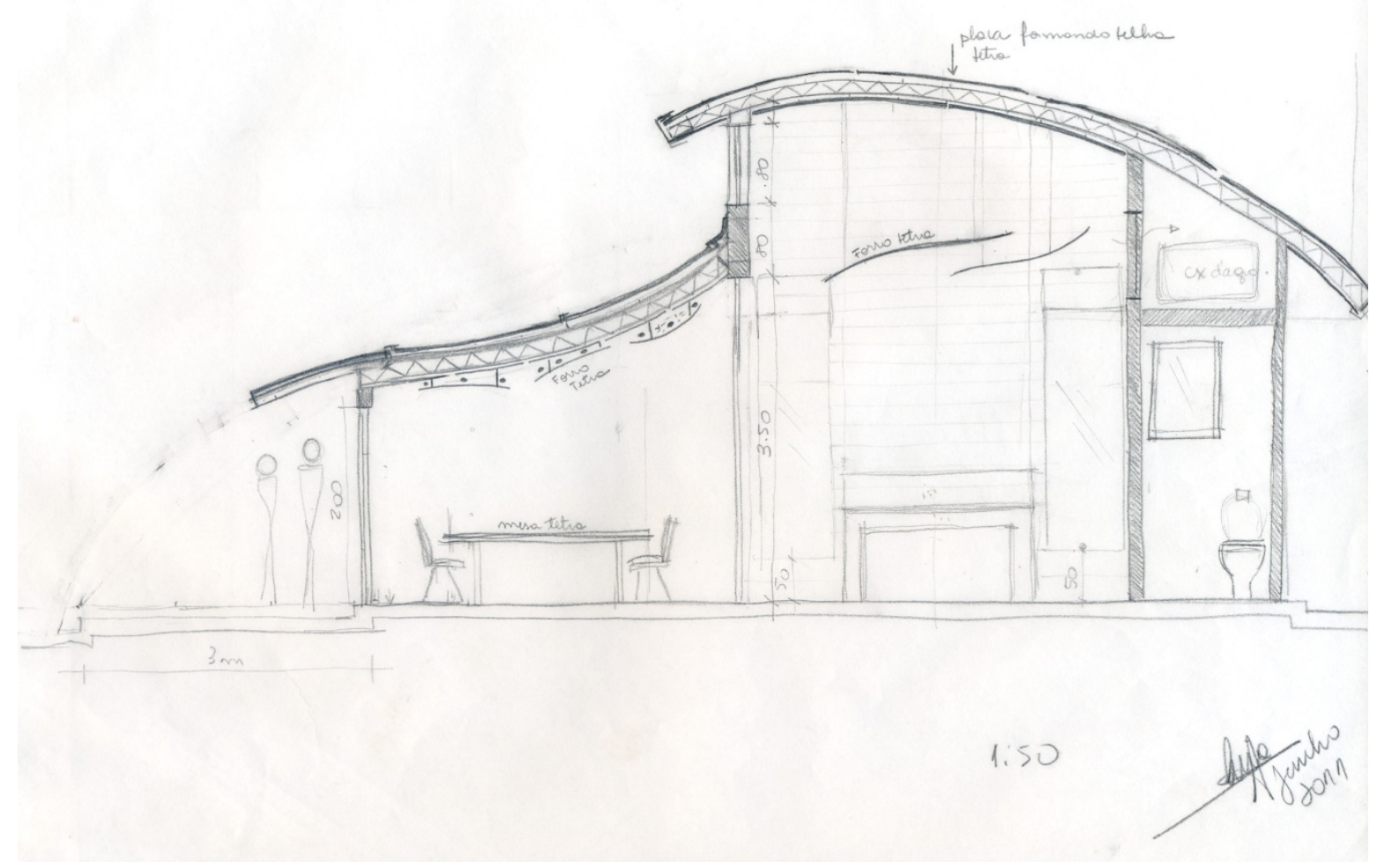

Vista lateral

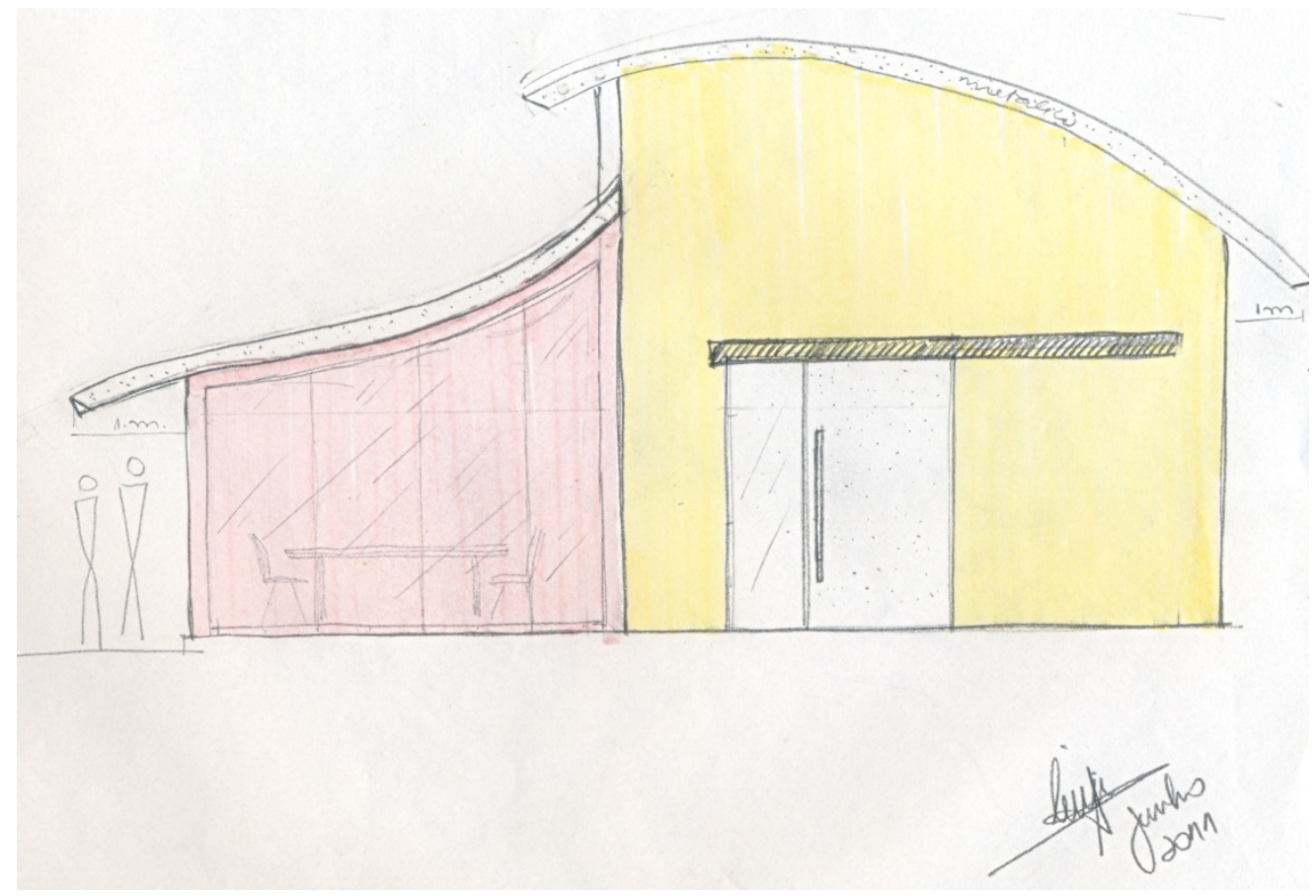


Projeto 3 - Estudos de planta e painel-brise externo.
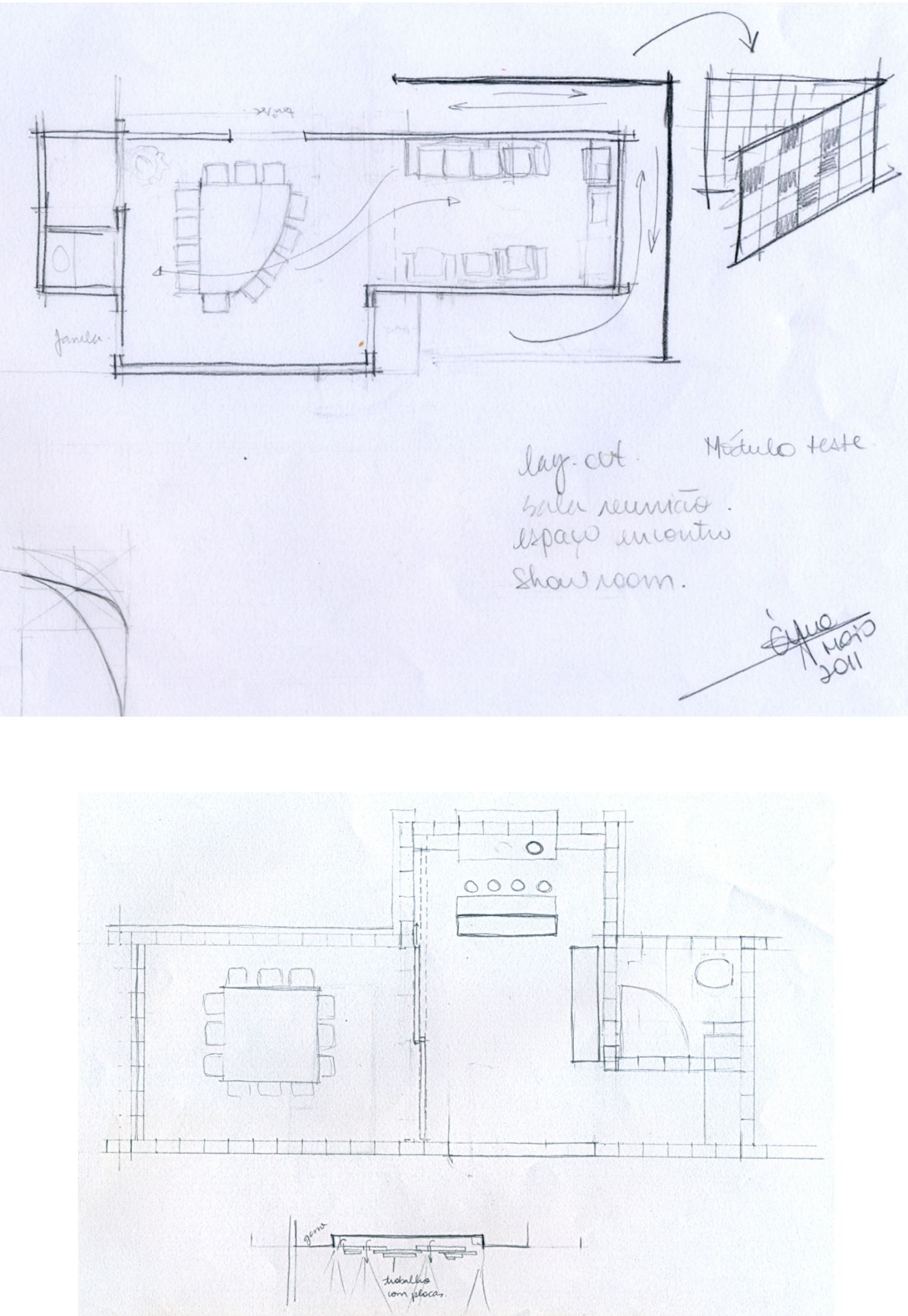
Estudo de fachada com o painel/brise

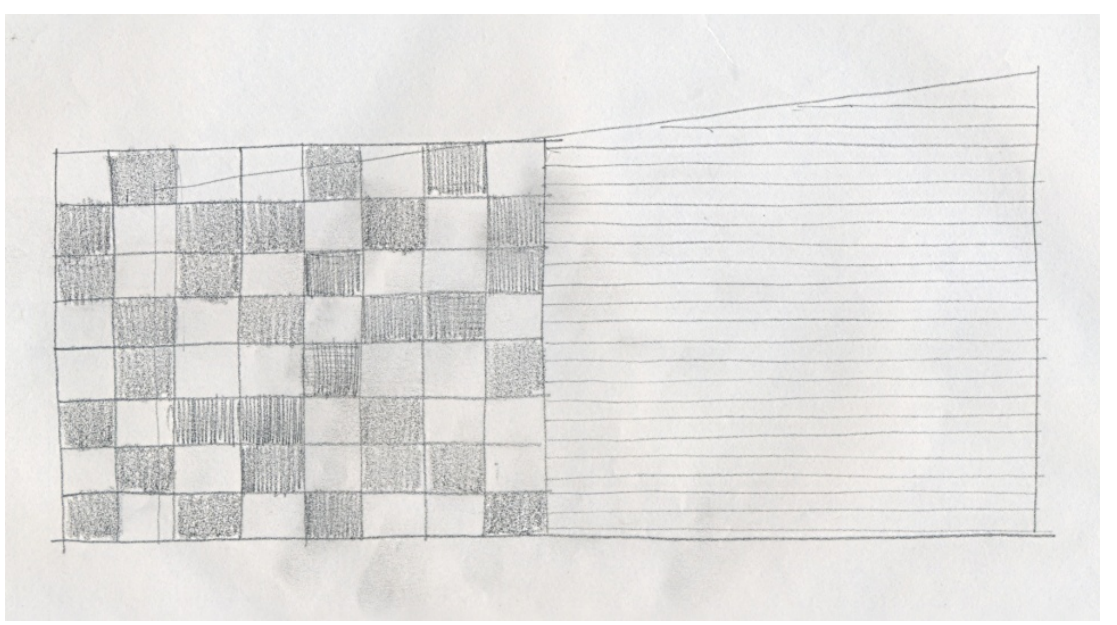

Estudos de fachada - volumetrias e texturas.

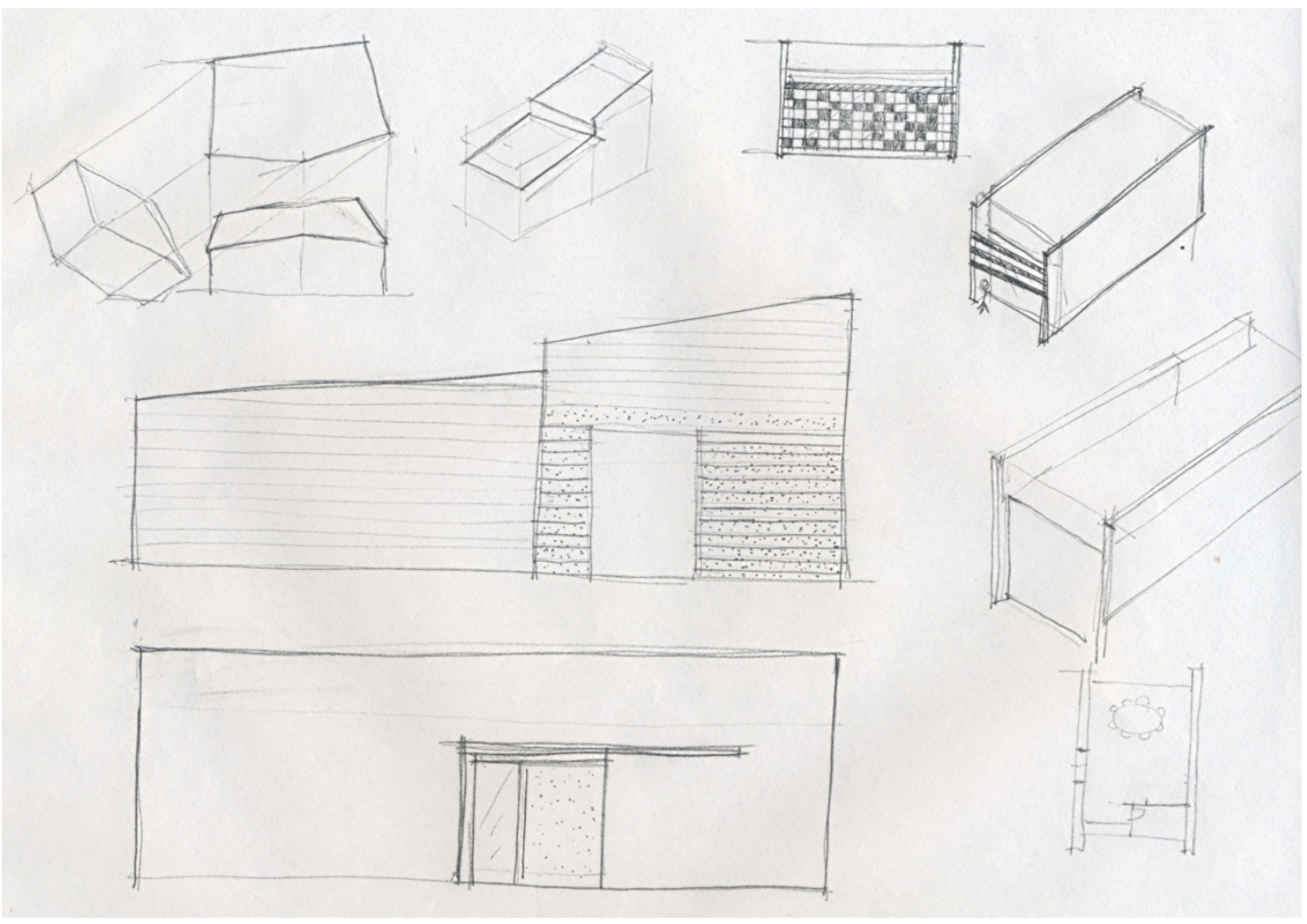


Estudo volumétrico e de paginação externa - painel com placa reciclada.

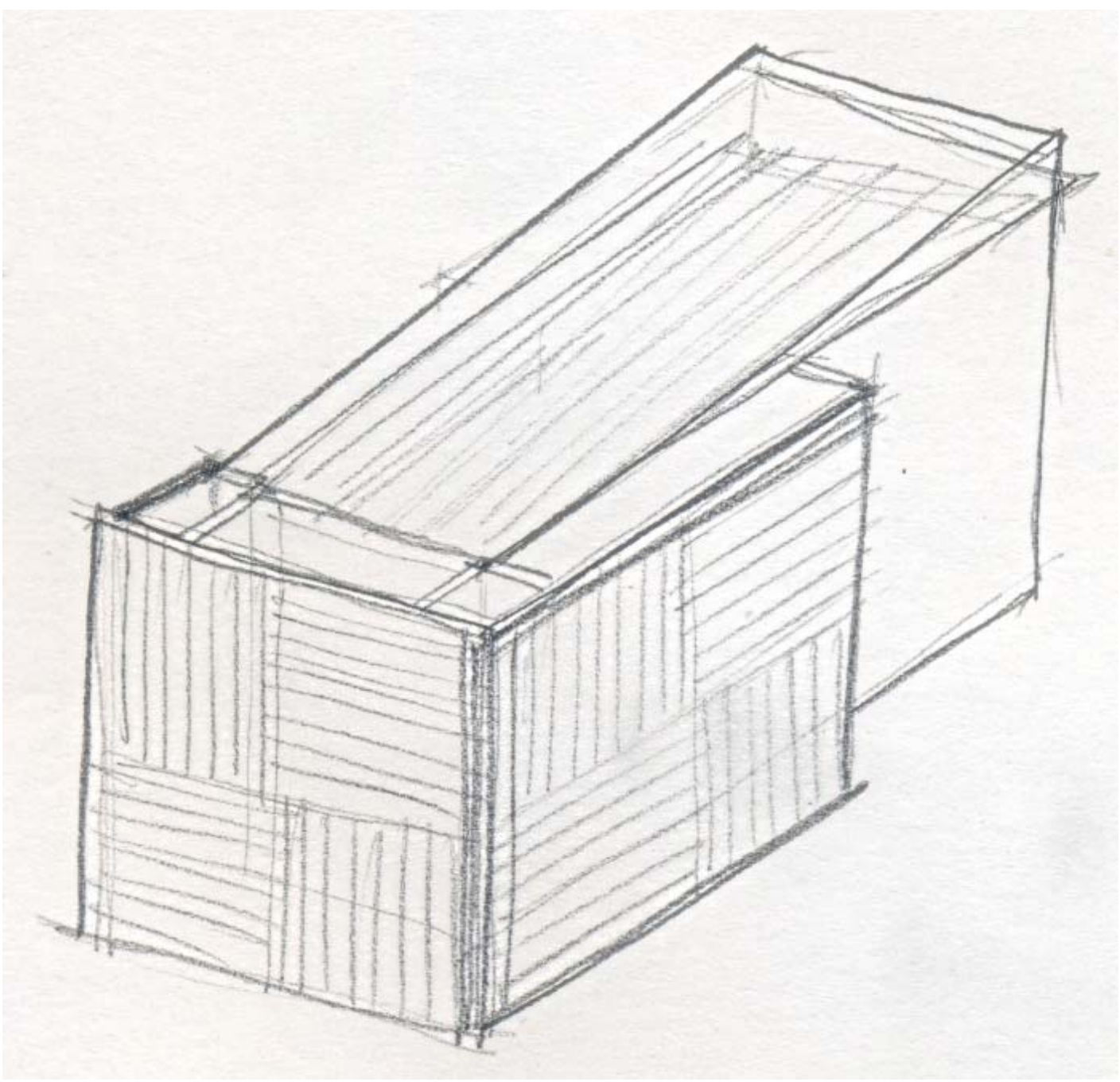




\section{Perspectiva interna}

Detalhes de porta, luminária e painel iluminado.

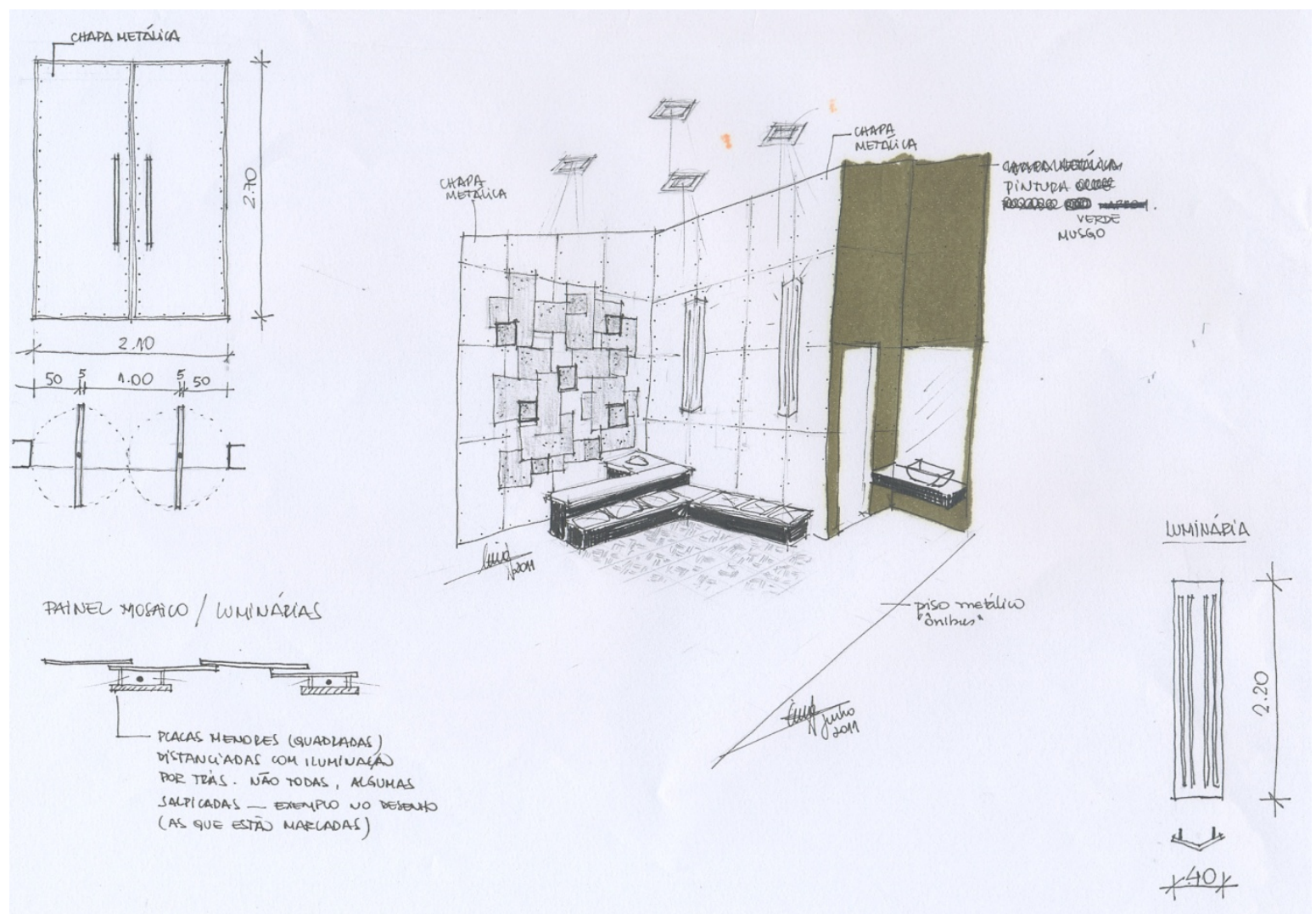


ANEXO A

Tabela de condutividade térmica de materiais de construção

Células marcadas: materiais com condutividade térmica semelhante à placa reciclada de embalagem longa vida $(0.8 \mathrm{~W} / \mathrm{m} . \mathrm{K})$

\begin{tabular}{|c|c|c|c|c|}
\hline \multirow[t]{2}{*}{ GRUPR } & \multirow[t]{2}{*}{ MATERIAL } & \multirow{2}{*}{$\begin{array}{c}\text { MASSA } \\
\text { ESPECÍFICA } \\
\text { (KG/M3) }\end{array}$} & \multicolumn{2}{|c|}{$\begin{array}{l}\text { CLNDUTIVIDADE } \\
\text { TÉRMICA (W/MK) }\end{array}$} \\
\hline & & & SEC口 & MロLHADQ \\
\hline \multirow[t]{5}{*}{ METAL } & ALUMÍNII & 2800 & $2 \square 4$ & $2 \square 4$ \\
\hline & CロBRE & 900 & 372 & 372 \\
\hline & LIGAS & 12250 & 35 & 35 \\
\hline & AÇ口, FERR口 & 78ロ & 52 & 52 \\
\hline & ZINCD & $720 \square$ & $11 \square$ & $11 \square$ \\
\hline \multirow[t]{3}{*}{ PEDRA NATURAL } & $\begin{array}{l}\text { BASALTD, } \\
\text { GRANITI }\end{array}$ & 3ロᄆ口 & 3.5 & 3.5 \\
\hline & $\begin{array}{l}\text { CALCÁRID, } \\
\text { MÁRMORE }\end{array}$ & 2700 & 2.5 & 2.5 \\
\hline & ARENITD & 2600 & 1.6 & 1.6 \\
\hline \multirow[t]{3}{*}{ ALVENARIA } & TI」ロடロ & $16 \square \square-19 \square \square$ & $\square .6-\square .7$ & 0.9-1.2 \\
\hline & $\begin{array}{l}\text { TIJ口Lם DE AREIA- } \\
\text { CAL }\end{array}$ & 1900 & $\square .9$ & 1.4 \\
\hline & & 1 ロロロ- 1 4ロ & $\square .5-\square .7$ & \\
\hline \multirow[t]{11}{*}{ CINCRETD } & $\begin{array}{l}\text { CDNCRETI DE } \\
\text { CASCALHD }\end{array}$ & 230口-25ㅁ & 2. & 2.0 \\
\hline & CDNCRETI LEVE & $1600-1900$ & $\square .7-\square .9$ & 1.2-1.4 \\
\hline & & 1 ロロロ- 1 Зロロ & ㅁ.35-口.5 & ‥5-口.8 \\
\hline & & 3ロ०-7ロ & ㅁ. $12-0.23$ & \\
\hline & $\begin{array}{l}\text { CDNCRETI DE PÚ } \\
\text { DE PLLIMENTI }\end{array}$ & 1 ㅁ- 14 प & ㅁ. 35-口. 5 & ㅁ.5-口.95 \\
\hline & & 7ロロ- 1 ロロ & $\square .23-\square .35$ & \\
\hline & $\begin{array}{l}\text { CロNCRETD DE } \\
\text { ISロLAÇÃA }\end{array}$ & 3ロロ-7ロロ & ㅁ. $12-\square .23$ & \\
\hline & $\begin{array}{l}\text { CDNCRETD } \\
\text { CELULAR } \\
\end{array}$ & 1 ロロロ- 1 3ロ & ㅁ.35-口.5 & ㅁ.7-1.2 \\
\hline & & 4ロロ-7ロロ & ㅁ. $17-\square .23$ & \\
\hline & $\begin{array}{l}\text { CDNCRETI DE } \\
\text { ESCǴRIA }\end{array}$ & 1 6ロᄆ-19ロ0 & ㅁ. 45-口.7ロ & 口.7-1. $1 . \square$ \\
\hline & & 1 ロロロ- 1 3ロロ & $\square .23-\square .3 \square$ & $\square .35-\square .5$ \\
\hline
\end{tabular}




\begin{tabular}{|c|c|c|c|c|}
\hline \multirow[t]{7}{*}{ INARGÂNICL } & $\begin{array}{l}\text { CIMENTI DE } \\
\text { ASBESTI }\end{array}$ & $1600-1900$ & | & $0.9-1.2$ \\
\hline & PLACA GIPSITA & 8पव-1 40口 & $0.23-0.45$ & \\
\hline & CARTÃI GIPSITA & 9ロ० & $0.2 \square$ & \\
\hline & VIDRD & 2500 & 0.8 & 0.8 \\
\hline & LÃ DE VIDRI & $15 \square$ & $\square .04$ & \\
\hline & LÃ DE RDCHA & 35-2ם0 & 0.04 & \\
\hline & TELHAS & 2पि口 & 1.2 & 1.2 \\
\hline \multirow[t]{3}{*}{ EMPLASTRIS } & CIMENTI & 1900 & 0.9 & 1.5 \\
\hline & CAL & 1600 & 0.7 & 0.8 \\
\hline & GIPSITA & 1300 & 0.5 & 0.8 \\
\hline \multirow[t]{4}{*}{ DRGÂNICL } & $\begin{array}{l}\text { EDRTIÇA } \\
\text { (EXPANDIDA) }\end{array}$ & 1 ロロ-2ロロ & $\begin{array}{l}.04- \\
0.0045\end{array}$ & \\
\hline & LINǴLED & 1200 & 0.17 & \\
\hline & BIRRACHA & 1 2व口-15口व & $\square .17-\square .3$ & \\
\hline & PLACA DE FIBRA & 200-40० & ㅁ.๑8-ロ. 12 & \begin{tabular}{|l|}
$.09-$ \\
$\square .17$
\end{tabular} \\
\hline \multirow[t]{7}{*}{ MADEIRA } & FロLHロSA & 8वि & 0.17 & 0.23 \\
\hline & MADEIRA LEVE & 550 & 0.14 & $\square .17$ \\
\hline & CDMPENSADA & 7ロव & 0.17 & 0.23 \\
\hline & EARTÃa DURI & 10प् & 0.3 & \\
\hline & SRFT-BIARD & $3 \square 0$ & प.व8 & \\
\hline & CARTÃa & 5ロロ- 1 ロव口 & $0.1-\square .3$ & \\
\hline & \begin{tabular}{|l|} 
CARTÃם DE \\
MADEIRA \\
\end{tabular} & 350-700 & ㅁ. 1 - - . 2 & \\
\hline \multirow[t]{3}{*}{ SINTÉTICDS } & PaLIÉSTER (GPV) & 1200 & 0.17 & \\
\hline & \begin{tabular}{|l} 
PロLIETILEN口, \\
PロLIPRAPILEND \\
\end{tabular} & 930 & (0.17 & \\
\hline & \begin{tabular}{|l} 
ELIRETO DE \\
PLLYVINYL \\
\end{tabular} & 1400 & 0.17 & \\
\hline \multirow[t]{5}{*}{ ESPUMA SINTÉTICA } & $\begin{array}{l}\text { ESPUMA DE } \\
\text { POLIESTIREND, } \\
\text { EXP. } \\
\text { (PICDSEGUNDQ) }\end{array}$ & $1 \square-4 \square$ & 0.035 & \\
\hline & DITTO, EXPULS口 & 3ロ-4口 & प.口3 & \\
\hline & \begin{tabular}{|l} 
ESPUMA DE \\
PQLIURETAN口 \\
(PUR) \\
\end{tabular} & 3ㅁ-150 & |ㅁ. & \\
\hline & \begin{tabular}{|l} 
ESPUMA DURA \\
ÁCIDA DI FENDL
\end{tabular} & 25-200 & 0.035 & \\
\hline & PVC-ESPUMA & 20-5口 & 0.035 & \\
\hline ISLLAÇÃ̃ DE & ISLLAÇÃロ DA & 2ם-1口ם & $\square .05$ & \\
\hline
\end{tabular}




\begin{tabular}{|c|c|c|c|c|}
\hline CAVIDADE & $\begin{array}{l}\text { CAVIDADE DA } \\
\text { PAREDE }\end{array}$ & & & \\
\hline \multirow{2}{*}{$\begin{array}{l}\text { MATERIAIS } \\
\text { BETUMINGSLS }\end{array}$} & AsFALTD & 2100 & $\square .7$ & \\
\hline & BETUME & 1 प5口 & 0.2 & \\
\hline \multirow[t]{4}{*}{ ÁGபA } & ÁgபA & 1 पव口 & 0.58 & \\
\hline & GELD & 9प0 & 2.2 & \\
\hline & NEVE, FRESCA & 8ロ-200 & $\square .1-\square .2$ & \\
\hline & NEVE, VELHA & 2००-৪०० & $0.5-1.8$ & \\
\hline$A R$ & AR & 1.2 & 0.023 & \\
\hline \multirow[t]{4}{*}{ Sロட口 } & SロL口 FLURESTAL & 1450 & 0.8 & \\
\hline & ARGILA ARENOSA & 1780 & 0.9 & \\
\hline & $\begin{array}{l}\text { SRLI ARENDSD } \\
\text { ÚMIDI }\end{array}$ & 1700 & 2.0 & \\
\hline & SRLロ (SECa) & 1600 & 0.3 & \\
\hline \multirow[t]{6}{*}{$\begin{array}{l}\text { REVESTIMENTI DE } \\
\text { ASSDALHI }\end{array}$} & \begin{tabular}{|l} 
TELHAS DE \\
ASSIALHI
\end{tabular} & 2000 & 1.5 & \\
\hline & PARQUET & 8पव & 口.17-ם.27 & \\
\hline & $\begin{array}{l}\text { TAPETE DE } \\
\text { FELTRD DE NYLIN }\end{array}$ & $\square .05$ & & \\
\hline & $\begin{array}{l}\text { TAPETE (CDM } \\
\text { BDRRACHA DE } \\
\text { ESPUMA) }\end{array}$ & (ם.ロ9 & & \\
\hline & CDRTIÇA & 200 & ㅁ. & \\
\hline & LÃs & $40 \square$ & 口. . & \\
\hline
\end{tabular}

Fonte: PROTOLAB (2010) 


\section{Casas com blocos feitos de embalagens tetra pak}

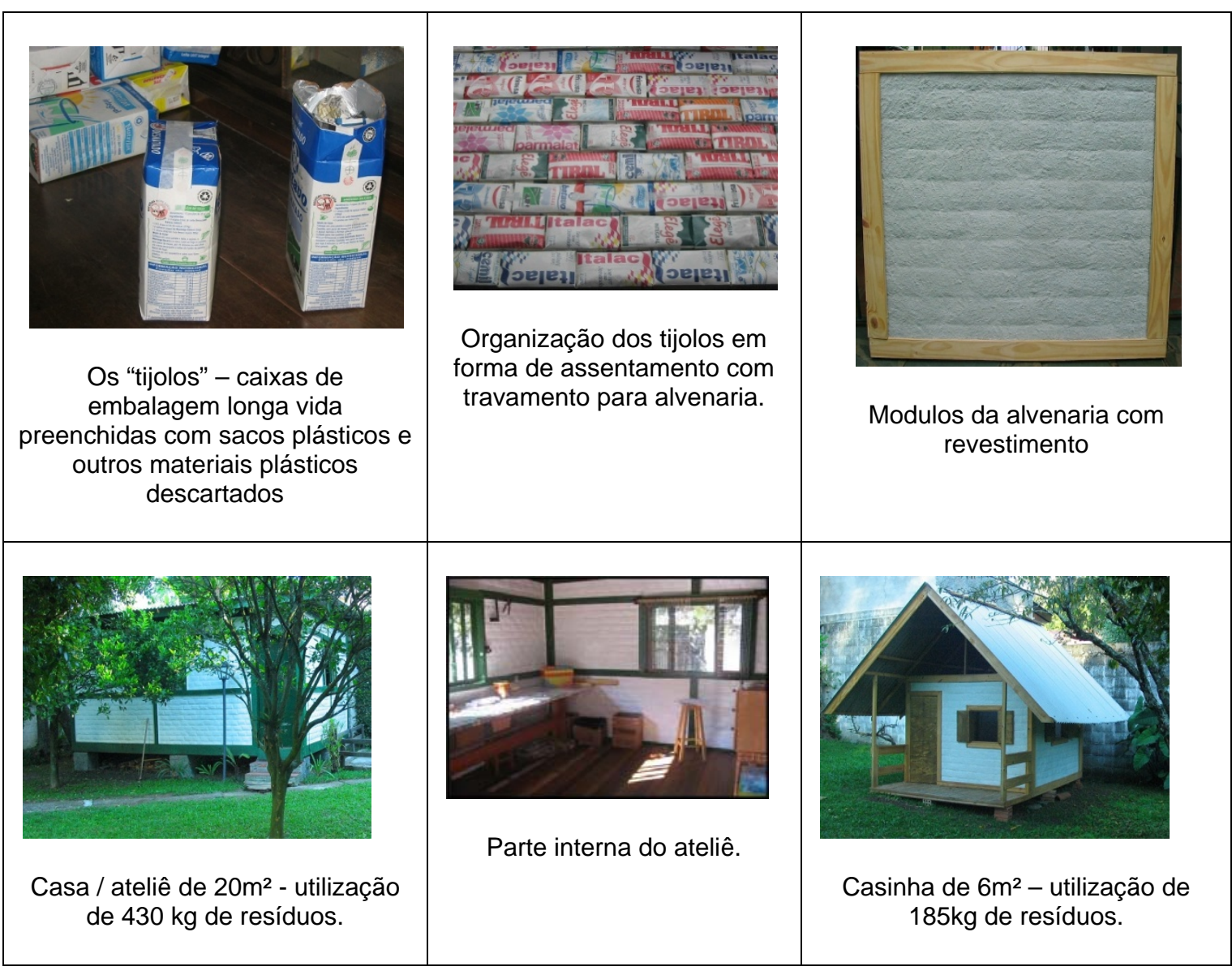

Figura:Casas executadas com embalagens longa vida na função de tijolos. Fonte:PROGRAMAERA (2010) 


\section{ANEXO C}

\section{Manta térmica de tetra pak}

Por se tratar de uma área do conhecimento relativamente nova, a sustentabilidade tem como tendência se popularizar cada vez mais. Somente há poucos anos, os mais diversos setores da sociedade começaram a se preocupar com essa questão. A construção civil, por exemplo, é um deles. Justamente por essa novidade do tema, a grande maioria dos prédios e casas no Brasil não foram projetados de acordo com critérios sustentáveis.

A solução, portanto, é que nós adotemos medidas no nosso dia a dia, que tornem nossa casa e nosso estilo de vida um pouco mais sustentáveis. Uma dessas soluções, dentre várias que o ECOPRÁTICO já mostrou, é a manta térmica feita de caixinhas tetra pak! Ela ajuda não apenas a manter a temperatura da casa mais amena, refletindo a luz solar (e o calor) para o espaço, como também ajuda na eliminação de resíduos, pois é feita com material reaproveitado.

Caixinhas tetra pak são usadas como embalagem para produtos tipo longa vida, como leites e sucos. A quantidade necessária para a produção da manta vai depender do tamanho da área que você pretende cobrir. Uma vez que elas esteja separadas e lavadas, mãos às obras.

\section{Passo-a-passo:}
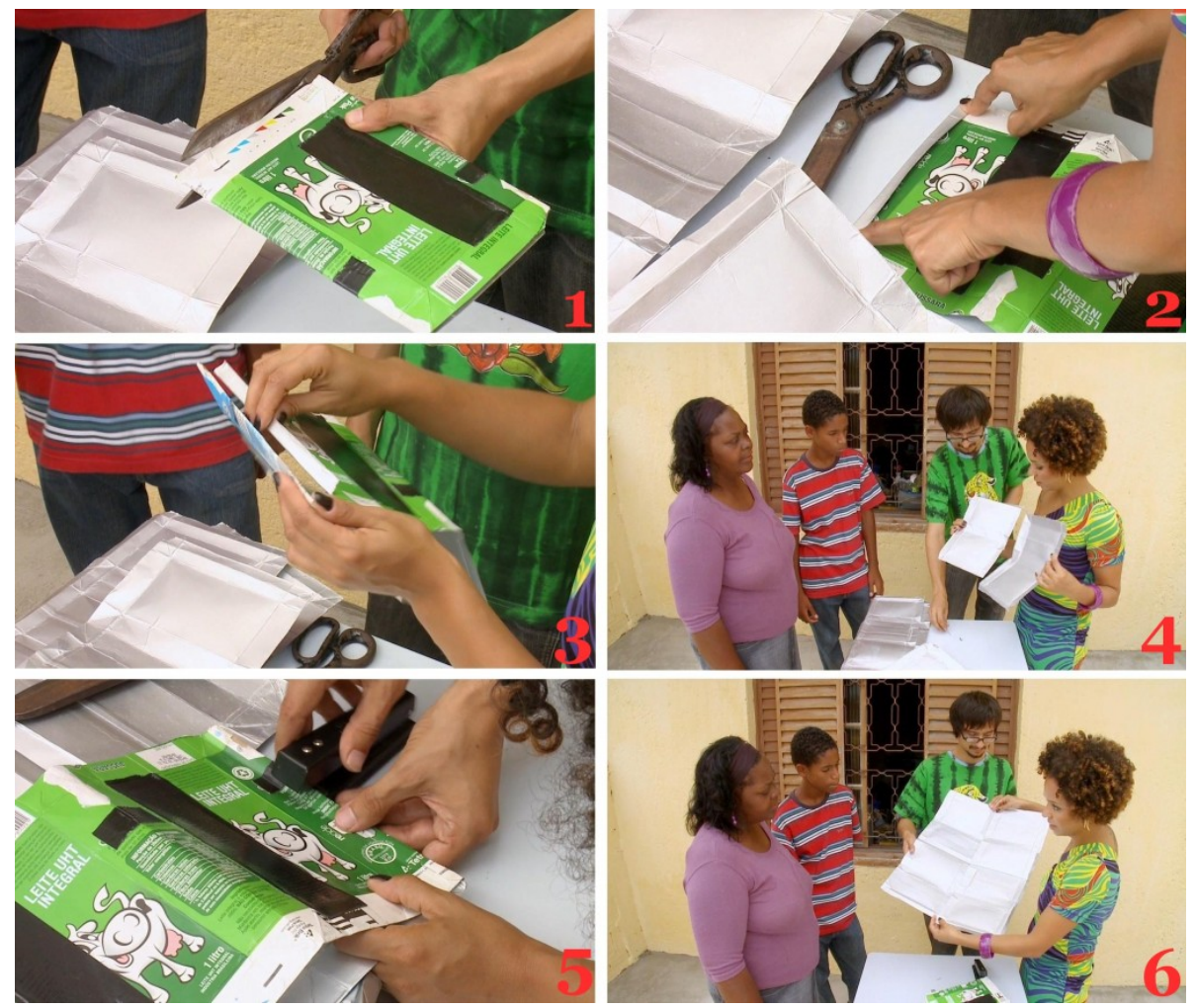

Figura: Passo a passo manta térmica Tetra Pak Fonte: ECOPRÁTICO (2009) 
ANEXO D

\section{Alunos da EMC Tiradentes fazem casa com caixas de leite}

\section{Eles recolhem o material da merenda escolar e o transformam em tijolos}

Ainda é uma casa muito engraçada. Por enquanto não tem teto, nem chão. Faltam paredes, janelas, porta. Mas tem, e bastante, consciência ambiental. Parece contraditório juntar caixinhas de leite Tetra Pak no interior, já que a maioria dos moradores tira o leite fresquinho, direto da vaca. Mas na Escola Municipal do Campo Tiradentes, os alunos estão construindo uma casinha com esse material. Vindo da merenda escolar, ao invés das caixas serem jogadas na lixeira, são lavadas, pintadas e se transformam em tijolos.

Darlan Carlos Zanella, 10 anos, da quarta série, lembra que a primeira parede foi construída com a ajuda do Consórcio Lambari. Cerca de 240 caixinhas foram utilizadas. Para dar consistência, a turma de "pedreiros" - composta pelo $1^{\circ}$ e $2^{\circ}$ anos e $3^{a}$ e $4^{a}$ séries - preenche as caixas com jornal e, a cada três, passa fita para ficar firme. Depois de pronta, a construção mais esperada do ano vai receber verniz, para ficar impermeável. "E a gente decidiu que as paredes vão ser coloridas", acrescenta.

\section{Consciência}

João Ernesto Magro, 10 anos, explica que as caixinhas que poderiam poluir o meio ambiente ganharam uma utilidade. João e os colegas também construíram brinquedos, como o bate-e-volta, flores com garrafas pet, que enfeitarão a casinha, sacolas, fantoches, cestas de páscoa, carrinhos com madeira e papelão, entre

outros.

A professora Maria Luiza Alves Favaretto comenta que esta é uma maneira de criar consciência. "A escola faz o seu papel de contribuir para isso, mas as famílias também devem ajudar". Os alunos já foram visitar o
Aterro
Sanitário
para
entenderem
a importância
da separação
do lixo.

Projeto

Criado em 2004 pelo Consórcio Lambari, o projeto "Conhecer e fazer para preservar" foi levado aos alunos para incrementar as brincadeiras com consciência ambiental.Segundo a bióloga do Consórcio Lambari Simone Marció, quando trabalhado em escolas, o projeto mostra que lixo é o rejeito de tudo o que não pode mais ser reutilizado. Nos Clubes de Mães, são oferecidas as técnicas para decoração natalina, entre outras.

\section{Patrícia Galelli}

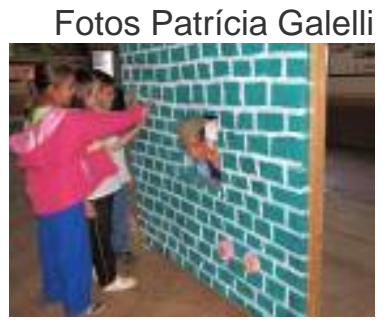

Alunos constroem casinha com caixas de leite Tetra Pak, em Tiradentes

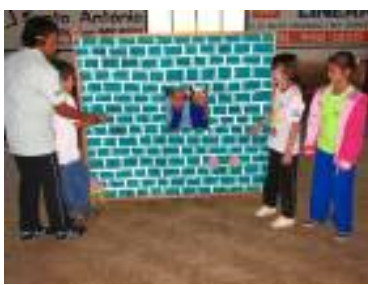

Maria Luiza constribui na formação da consciência dos estudantes

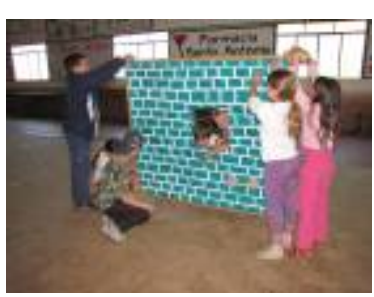

Um jeito de aprender se divertindo

Figura: Parede de caixinhas Tetra Pak Fonte: MIDIAMAIS (2009) 


\section{Caixas de leite podem proteger telhado Embalagens 'longa vida' funcionam como isolantes térmicos}

As caixas de leite tipo 'longa vida' podem ser reaproveitadas para a confecção de material de construção como isolante térmico de telhados. Quem garante é o engenheiro civil industrial Luis Otto Faber Schmutzler, também pesquisador da Universidade Estadual de Campinas (Unicamp). Além de reaproveitar um material poluente (uma embalagem de leite pode levar até cem anos para se decompor), a proposta de Schmutzler soluciona de forma econômica o problema das altas temperaturas em construções que usam telhas de cimento-amianto, como casas populares, oficinas e escolas públicas.

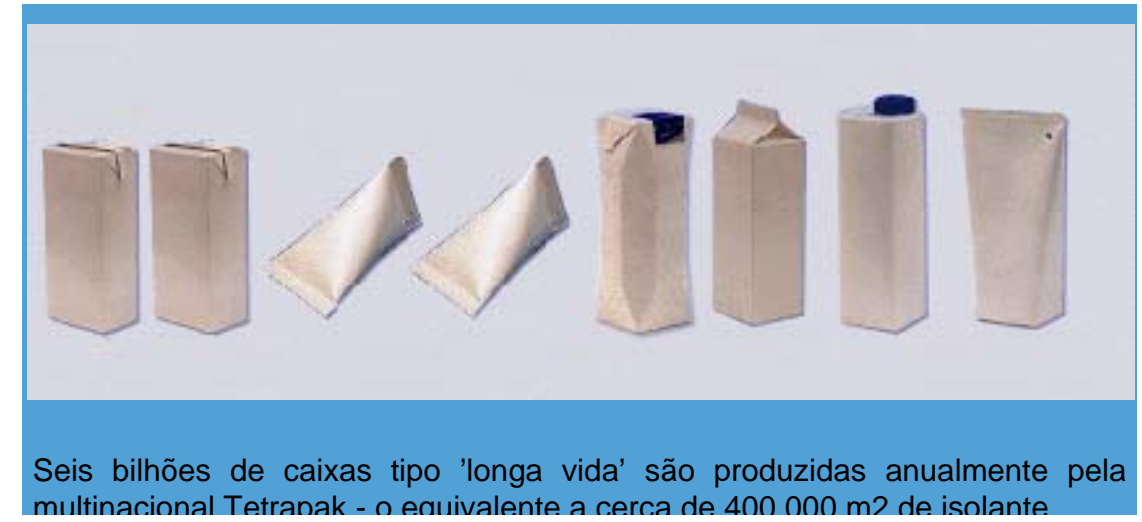

A partir de caixas de leite previamente abertas e unidas umas às outras, o engenheiro desenvolveu uma manta que é colocada sob as telhas a uma distância média de dois centímetros destas. O alumínio das caixas reflete até $95 \%$ da radiação infravermelha do Sol. A face de alumínio das caixas fica voltada para baixo, por motivos estéticos, mas o mesmo resultado é obtido se ela estiver voltada para cima. Com a técnica, é possível diminuir em até $100 \mathrm{C}$ a temperatura do interior das casas - o que representa um conforto razoável.

Geralmente, casas populares de famílias de baixa renda são construídas com telhas de cimento-amianto que, além de mais baratas que as telhas cerâmicas, requerem uma estrutura de madeira reduzida, o que também barateia a construção. No entanto, essas telhas absorvem muito calor e, expostas ao sol, podem atingir até $70 \mathrm{oC}$, superaquecendo o interior das casas. "A população economiza na construção, mas não imagina os transtornos do calor e a péssima qualidade de vida que ele gera", diz Schmutzler. Segundo ele, o problema pode se tornar ainda mais crônico com a presença das lajes. "O calor que vem das telhas é absorvido pelo concreto das lajes e mantém o ambiente interior abafado durante toda a noite."

A curiosidade foi a principal arma do pesquisador para idealizar o novo isolante. Ao abrir uma embalagem, Schmutzler percebeu que o material da caixa lembrava outro, caro e importado, que ele havia utilizado para proteger do calor sua casa de praia. Uma caixa de leite é composta por quatro camadas de polietileno (tipo de plástico), uma de papelão e uma de alumínio, e foi este último que se tranformou no grande trunfo do engenheiro, já que o material importado é composto por $95 \%$ de alumínio. "O custo de uma manta, que desempenha função semelhante à do material importado, é muito inferior, pois ela é feita a partir de embalagens destinadas

Além de desenvolver conceitualmente seu experimento, Luis Schmutzler pretende agora divulgá-lo junto a prefeituras. A idéia é estabelecer um sistema de coleta seletiva e ensinar a população a construir por si só as mantas isolantes.

Pablo Pires Ferreira

Ciência Hoje On-line

10/01/01 http://cienciahoje.uol.com.br/3778 - acessado em 29-06-2009 
ANEXO F

\section{Architectural Magpies}

\section{Tetrapak Tunnels}

In the summer of 2008 , recycled venues experimented with tetrapaks as a building material. Because they are designed to retain water, drinks cartons are wonderfully water proof. They are also lightweight and flexible, making them a fun material to make shelter with.

We built a tetrapak dome ('the blamange') at Glastonbury Festival, and a tunnel at Shoreditch Festival.
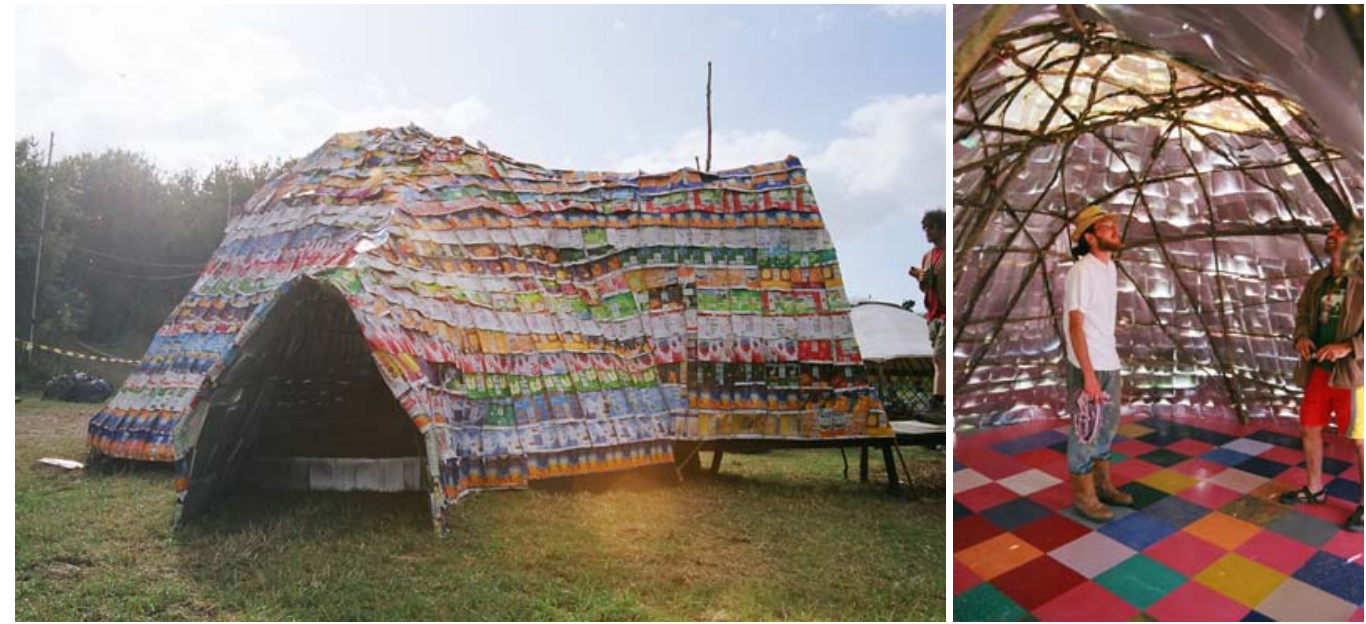

Figura: Cabana com cobertura de embalagens Longa Vida. Fonte: RECYCLEDVENUES (2011)

At the time, tetrapaks were not widely recyclable, but since then the company has put a lot of work into saving tetrapaks from landfill, and in many boroughs in the UK they now collect them from your home. However, what they do with them after that is a bit of a mystery...pulped and reprocessed into building boards - but where can we buy these boards and at what cost? 
ANEXO G

\section{Relatórios ensaios}


Escola de Engenharia de Slo Carlos - EESC

Departamento de Engenharia de Estruturas - SET

Laboratório de Madeiras e de Estruturas de Madeira - LaMEM

Fones.: (016) 273.9448/9454 - Fone/Fax.: (016) 273.9483

Lamem Av. Dr. Carlos Botelho, 1465 - Vila Pureza - Cx. P. 359 - 13560-970 - São Carlos - SP

\section{PROCEDIMENTOS:}

Os ensaios foram conduzidos de acordo com os procedimentos das seguintes normas:

3.1. Ensaio de flexão estática em chapas: Norma NBR 9533 / 1986, da ABNT "Compensado - Determinação da Resistencia à Flexão Estática".

3.2. Ensaio para determinaçå̃o da absorçảo de água: Norma NBR 9486/1986, da ABNT "Compensado - Determinação da absorção de água".

3.3. Ensaio de fexão estática em telha ondulada: Norma NBR 6468/1993, da ABNT -

"Telha de fibrocimento - Determinação da resistência à flexão".

\section{RESULTADOS OBTIDOS}

\subsection{Ensaio de nexão estática em chapas:}

As tabclas 1 e 2 apresentam os resultados obtidos nos ensaios de flexão estática, paras os corpos-de-prova de chapas com $12 \mathrm{~mm}$ e $15 \mathrm{~mm}$, respectivamente:

Tabela 1 - Resistência à flexão e módulo e elasticidade (chapa PT-120)

\begin{tabular}{|c|c|c|c|c|c|c|}
\hline $\begin{array}{c}\text { Corpo-de- } \\
\text { prova n. }\end{array}$ & $\begin{array}{c}\text { Largura } \\
(\mathbf{b}) \\
(\mathbf{m m})\end{array}$ & $\begin{array}{c}\text { Espessura } \\
(\mathbf{e}) \\
(\mathbf{m m})\end{array}$ & $\begin{array}{c}\text { Vão Livre } \\
(\mathbf{L}) \\
(\mathbf{m m})\end{array}$ & $\begin{array}{c}\text { Força } \\
\mathbf{m a ́ x i m a} \\
(\mathbf{N})\end{array}$ & $\begin{array}{c}\text { Resistência } \\
\text { à fexão } \\
(\mathbf{M P a})\end{array}$ & $\begin{array}{c}\text { Módulo de } \\
\text { Elasticidade } \\
(\mathbf{M P a})\end{array}$ \\
\hline 1 & 76,2 & 12,2 & 300 & 222 & 8,8 & 408 \\
\hline 2 & 76,3 & 11,8 & 300 & 185 & 7,8 & 268 \\
\hline 3 & 76,3 & 12,7 & 300 & 212 & 7,8 & 357 \\
\hline 4 & 75,8 & 12,3 & 300 & 268 & 10,5 & 520 \\
\hline 5 & 76,3 & 12,0 & 300 & 254 & 10,4 & 594 \\
\hline
\end{tabular}
Tabela 2 - resistência à flexão e módulo e elasticidade (chapa PT-150)

\begin{tabular}{|c|c|c|c|c|c|c|}
\hline $\begin{array}{c}\text { Corpo-de- } \\
\text { prova n. }\end{array}$ & $\begin{array}{c}\text { Largura } \\
(\mathbf{b}) \\
(\mathbf{m m})\end{array}$ & $\begin{array}{c}\text { Espessura } \\
(\mathbf{e}) \\
(\mathbf{m m})\end{array}$ & $\begin{array}{c}\text { Vão Livre } \\
\mathbf{( \mathbf { L } )} \\
(\mathbf{m m})\end{array}$ & $\begin{array}{c}\text { Força } \\
\text { máxima } \\
(\mathbf{N})\end{array}$ & $\begin{array}{c}\text { Resistência } \\
\text { à flexão } \\
(\mathbf{M P a})\end{array}$ & $\begin{array}{c}\text { Módulo de } \\
\text { Elasticidade } \\
(\mathbf{M P a})\end{array}$ \\
\hline 1 & 75,3 & 13,7 & 375 & 245 & 9,8 & 530 \\
\hline 2 & 75,8 & 14,7 & 375 & 353 & 12,1 & 589 \\
\hline 3 & 75,9 & 14,5 & 375 & 317 & 11,2 & 546 \\
\hline 4 & 75,5 & 16,2 & 375 & 353 & 10,0 & 468 \\
\hline 5 & 75,7 & 15,0 & 375 & 345 & 11,4 & 581 \\
\hline
\end{tabular}


Escola de Engenharia de S30 Carlos - EESC

Departamento de Engenharia de Estruturas - SET

Laboratório de Madeiras e de Estruturas de Madeira - LaMEM

LAMEM

Av. Dr. Carlos Botelho, 1465 - Vila Pureza - Cx. P. 359 - 13560-970 - São Carlos - SP

4.2. Ensaio para determinação da absorção de água:

A tabela 3 apresenta os resultados obtidos no ensaio para determinação de água. A absorção é expressa em porcentagem de água absorvida, em relaçāo à massa inicial.

Tabela 3 - Absorção de água (chapa PT-120)

\begin{tabular}{|c|c|c|c|}
\hline $\begin{array}{c}\text { Corpo-de- } \\
\text { prova n. }\end{array}$ & $\begin{array}{c}\text { Massa } \\
\text { inicial (g) }\end{array}$ & $\begin{array}{c}\text { Massa } \\
\text { final (g) }\end{array}$ & $\begin{array}{c}\text { Absorção de } \\
\text { água (\%) }\end{array}$ \\
\hline 1 & 16,1 & 18,3 & 13,6 \\
\hline 2 & 14,7 & 18,1 & 23,2 \\
\hline 3 & 17,0 & 18,9 & 11,2 \\
\hline 4 & 17,1 & 19,4 & 13,5 \\
\hline 5 & 15,8 & 18,1 & 14,6 \\
\hline \multicolumn{4}{|r}{} \\
\hline
\end{tabular}

4.3. Ensaio de flexảo estática em telba ondulada

A tabela 4 apresenta os resultados obtidos nos ensaios de flexão estática das telhas onduladas.

Como a telha não apresenta ruptura frágil, também é apresentado o valor do deslocamento vertical no meio do vão para a força máxima obtida no ensaio.

Tabela 4 - Força máxima aplicada e deslocamento - Telha ondulada IBLAPAC

\begin{tabular}{|c|c|c|}
\hline $\begin{array}{c}\text { Corpo-de- } \\
\text { prova n. }\end{array}$ & $\begin{array}{c}\text { Força máxima } \\
\text { aplicada }(\mathbf{N})\end{array}$ & $\begin{array}{c}\text { Deslocamento } \\
\text { vertical (cm) }\end{array}$ \\
\hline 1 & 1553 & 12 \\
\hline 2 & 1279 & 10 \\
\hline 3 & 1828 & 9 \\
\hline 4 & 1791 & 10 \\
\hline 5 & 1828 & 11 \\
\hline
\end{tabular}

\section{DIVULGAÇÃo dos RESULTADOS}

A divulgação de resultados destes serviços realizados, em que haja referência explícita à Escola de Engenharia de São Carlos e/ou à Universidade de São Paulo, deverá ter a anuência prévia do Departamento de Engenharia de Estruturas da EESC/USP.

São Carlos, 14 de novembro de 2001.

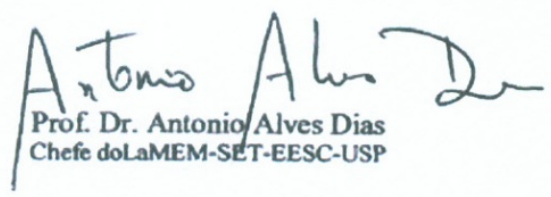

k página anterior 
Certificados

Instituto de. Pesquisas Tecnol6glcas

Loboratbeio de Pilsticos o Borrachan/APODOO

RELATORIO DE ENSAIO Nº 890824

CLIENTE: Tetra Pak Ltda.

Rodovla Campinas-Capivari, km 23,6

13190-000 - Monte Mor - SP

MATERIAL: PIástico

NATUREZA DO TRABALHO: Determinaçăo de propriedades fisicas em amostras de plástico

REFERENCLA: Fax $s / n^{\circ}$ de 23.04.2002

Orçamento DQ/APO/LAPB n` 193/02

\section{AMOSTRAS}

Duas amostras, fornecidas pelo cliente, designadas, descritas e identificadas no Laboratório de Plásticos e Borrachas (LAPB) do IPT conforme tabela 1, a seguir.

Tabela 1: Descriçå das amostras

\begin{tabular}{|c|c|c|}
\hline $\begin{array}{l}\text { Designaçâo da amostra } \\
\text { pelo cliente }\end{array}$ & Oescriçao das amostras no LAPB & 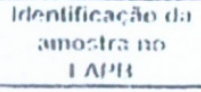 \\
\hline "placas recicladas" & 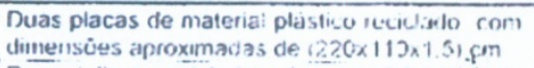 & $0310 \% ?$ \\
\hline twihas recicladas & 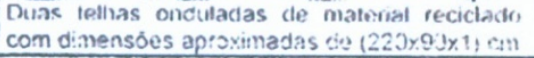 & $031 \mathrm{i} 4)_{2}^{2}$ \\
\hline
\end{tabular}

\section{MÉTODOS UTILIZADOS}

2.1 Resistência à tracalo - ASTM D 638 - 98 "Tensile Properties of Plastics" (DQLAPB-PE-011)

Equipamentos:

- Máquine Universal de Ensaios (Emic) -MUE- 001. Certificado de Calibraçấ nீ 42 032, do Laboratório de Metrologia/AMAEVDME do IPT. Data da Calibraçăo: 28.01.2002. Validade: 28.01.2003.

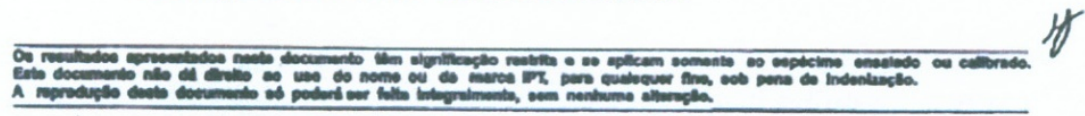

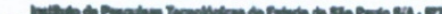
Anto on 
- Paquimetro Pequeno Digital (Faixa Nominal $150 \mathrm{~mm}$ ) - PA- 004. Certificado de Calibraçăo $n^{\circ} 43036$ do Laboratório de Metrologia/AMAEI/DME do IPT. Data da Calibraçăo: 26.03.2002. Validade: 26.03.2003.

- Termohigrómetro - Homis - TH - 003 - Certificado de calibração n 38494 do Laboratório de Vazăo/LVIDME do IPT. Data da calibraçăo: 18.04.2001. Validade 18.06.2002.

Condiçăo do ensaio:

- Corpos-de-prova: 06, do tipo I

- Velocidade de separaçăo de garras: $5 \mathrm{~mm} / \mathrm{min}$

2.2 Reslstencia à flex/o - ASTM D 790-98 - "Flexural Properties of Unreinforced and Reinforced Plastics and Electrical Insulating Materials" - Motodo 1 Procedimento A (DQ-LAPB-PE-042)

Equipamentos:

- Máquina Universal de Ensaios (Emic) -MUE- 001. Certificado de Calibraçăo $n^{\circ} 42$ 032, do Laboratório de Metrologia/AMAEI/DME do IPT. Data da Calibraçấo: 28.01.2002. Validade: 28.01.2003.

- Paquimetro Pequeno Digital (Faixa Nominal $150 \mathrm{~mm}$ ) - PA- 004. Certíficado de Calibraçăo $n^{\circ} \mathbf{4 3} 036$ do Laboratório de Metrologia/AMAEI/DME do IPT. Data da Calibraçăo: 26.03.2002. Validade: 26.03.2003.

- Termohigrómetro - Homis - TH - 003 - Certificado de calibraçăo n ${ }^{\circ} 38494$ do Laboratório de Vazåo/LVIDME do IPT. Data da calibraçăo: 18.04.2001. Validade 18.06.2002.

Condiçấo de ensaio:

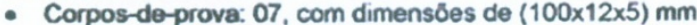

- Distancia entre apoios: $80 \mathrm{~mm}$

- Velocidade de aplicaçăo de carga: $5,0 \mathrm{~mm} / \mathrm{min}$

2.3 Absorçăo de água - ASTM D 570-98 "Water Absorption of Plastics" (DQLAPB-PE-014).

Equipamentos:

- Balança Analitica Eletrónica-Mettler - BL-001 - Certificado de Calibraçăo nº 42016 do Laboratório de Metrologia/AMAEUDME do IPT. Data da Calibraçăo: 07.01.2002. Validade: 07.01.2003.

- Estufa Fabbe - ES-002. Mapeamento de temperatura na cámara interna da estufa consta do Relatório Técnico n 49 058, do Laboratório de Medidas Térmicas/AET/DME do IPT. Data da Calibraçăo: 01.12.2000. Validade: 01.12 .2002 .

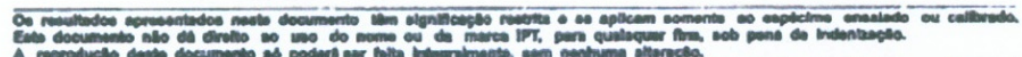


Termometro de liquido em vidro - TE-004. Certificado de Calibraçăo no 39330 do Laboratório de Metrologia/AMAEI/DME do IPT. Data da Calibraçâo: 30.05.2001. Validade: 30.05.2003.

- Termohigrometro - Homis - TH - 003 - Certificado de calibraçáo n 38494 do Laboralório de Vazào/LVIDME do IPT. Data da calibraçăo: 18.04.2001. Validade 18.06.2002.

Condiç̋̄es de ensaio:

- Corpos-de-prova: 05 com dimensőes de $(75 \times 25 \times 5) \mathrm{mm}$

- Imersåo em água deionizada: $168 \mathrm{~h} / 21^{\circ} \mathrm{C}$

\section{RESULTADOS}

Os resultados dos ensaios de resistência à traçăo, resistència à flexâo e absorçăo de água, constam das tabelas 2 a 7, a seguir.

Tabela 2: Resistência à traç̆o da amostra "placas recicladas"

\begin{tabular}{|c|c|cc|}
\hline Amostra & $\begin{array}{c}\text { Determinaçāo } \\
\mathbf{N}^{\circ}\end{array}$ & $\begin{array}{c}\text { Tensão de Ruptura } \\
\text { (MPa) }\end{array}$ & $\begin{array}{c}\text { Alongamento na } \\
\text { Ruptura (\%) }\end{array}$ \\
\hline \multirow{5}{*}{ placas } & 1 & 6.84 & 4.4 \\
recicladas & 2 & 7.70 & 3.5 \\
& 3 & 7.65 & 45 \\
& 4 & $i .29$ & 5.2 \\
& 5 & 8.10 & 48 \\
& 6 & 8.11 & 2.9 \\
& Média & 7.62 & 4.2 \\
& Desvio Padrăo & $\mathbf{0 . 4 9}$ & $\mathbf{0 . 8 4}$ \\
\hline
\end{tabular}

Tabela 3: Resistência à traçâo da amostra "telhas recicladas"

\begin{tabular}{|c|c|cc|}
\hline Amostra & $\begin{array}{c}\text { Determinação } \\
\mathbf{N}^{\circ}\end{array}$ & $\begin{array}{c}\text { Tensão de Ruptura } \\
\text { (MPa) }\end{array}$ & $\begin{array}{c}\text { Alongamento na } \\
\text { Ruplura (\%) }\end{array}$ \\
\hline & 1 & 7.94 & 50 \\
& 2 & 9.20 & 5.1 \\
-telhas & 3 & 9.18 & 3.2 \\
recicladas & 4 & 671 & 4.4 \\
& 5 & 7.70 & 4.5 \\
& 6 & 4.72 & 2.7 \\
& Dédia & $\mathbf{7 , 5 8}$ & 4.2 \\
& Desvio Padrão & $\mathbf{1 , 6 9}$ & $\mathbf{0 . 9 8}$ \\
\hline
\end{tabular}




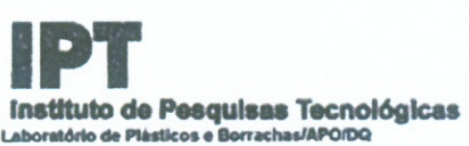

Tabela 4: Resistência à flexảo da amostra "placas recicladas"

\begin{tabular}{|c|c|c|}
\hline Amostra & Determinaçäo No & Tensăo de Ruptura (MPa) \\
\hline \multirow{4}{*}{ "placas } & 1 & 13,7 \\
recicladas" & 2 & 15,0 \\
& 3 & 14,8 \\
& 4 & 14,4 \\
& 5 & 14,8 \\
& 6 & 17,9 \\
\cline { 2 - 3 } & Média & 15,1 \\
& Desvio Padrăo & 1,4 \\
\hline
\end{tabular}

Tabela 5: Resistência à flexăo da amostra "telhas recicladas"

\begin{tabular}{|c|c|c|}
\hline Amostra & Determinaçăo N $^{\circ}$ & Tensăo de Ruptura (MPa) \\
\hline & 1 & 15,0 \\
& 2 & 13,5 \\
telhas recicladas & 3 & 16,8 \\
& 4 & 12,8 \\
& 5 & 14,4 \\
& 6 & 18,1 \\
\cline { 2 - 3 } & Média & 15,1 \\
& Desvio Padrăo & 2,0 \\
\hline
\end{tabular}

Tabela 6: Absorçăo de água da amostra "placas recicladas"

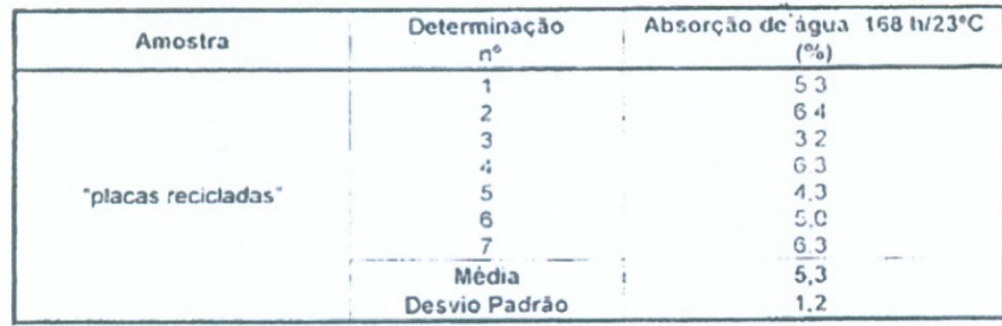

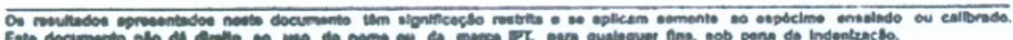

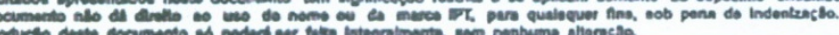

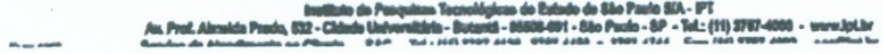


Certificados

Página 1 de 1

PT

Instituto de Pesquilsas Tecnolbgicas

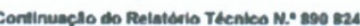
Labotatorio de Plasticos e Borrachas/MPODDO

Tabela 7: Absorçăo de água da amostras "telhas recicladas"

\begin{tabular}{|c|c|c|c|c|}
\hline Amostra & $\begin{array}{c}\text { Determinaçao } \\
n^{\circ}\end{array}$ & 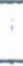 & $\begin{array}{c}\text { Absorça de água } \\
(\%) \\
\end{array}$ & $168 \mathrm{~h} / 23^{\circ} \mathrm{C}$ \\
\hline \multirow{9}{*}{ "telhas recicladas" } & 1 & ! & 45 & \\
\hline & 2 & & 5.3 & \\
\hline & 3 & ! & 4.6 & \\
\hline & 4 & & $7 B$ & \\
\hline & 5 & i & 4.4 & \\
\hline & 6 & & $i 7$ & \\
\hline & 7 & ! & 11 & - \\
\hline & Média & , & 6.5 & 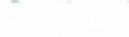 \\
\hline & Desvio Padrāo & T & 2,5 & \\
\hline
\end{tabular}

São Paulo, 05 de junho de 2002

OMnSAO DE OUIMica Agrupamento de Prodichos Orginicos blum Bablesa ba

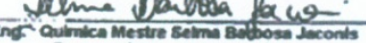
Rosponatwot peto Laboratorio
DIVISAO De Qulmica

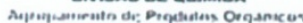

$$
\text { if }
$$$$
(\mid, \ldots)
$$

Eng." Ovimic Meatre Aminto Comes Pirto

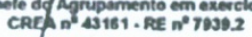

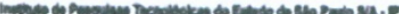

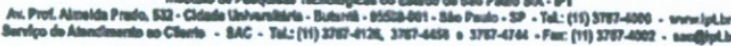




\section{RELATÓRIO DE ENSAIO N 890869}

CLIENTE: Tetra Pak Ltda

Rodovia Campinas-Capivari, km 23.5

13190-000 - Monte Mor/SP

MATERIAL: Placas planas de material reciclado.

NATUREZA DO TRABALHO: Determinaçao da densidade ótica especifica de fumaça

Referéncia: Carta datada de 08032002

Amostra: AISF/LSF $211 / 02$

\section{AMOSTRA}

Foi entregue o material denominado "Placas aglomeradas de material reciclado" com as seguintes caracteristicas determinadas por este Laboratorio

massa especifica aparente: $930 \mathrm{~kg} / \mathrm{m}^{3}$

espessura média $13 \mathrm{~mm}$.

coloraçāo indefinida

as placas apresentavam-se acabadas superficiaimente com um filme polimérico

Segundo informaçóes do Cliente o materiai e composto por embaiagens Tetra Pak (polietileno/aluminio). picadas e aglomeradas As porcentagens de polietileno e de aluminio sao de $75 \%$ e $25 \%$. respectivamente

\section{MÉTODO UTILIZADO}

ASTM E 662-92 - "Specific Optical Density of Smoke Generated by Solid Materials" Procedımento de Ensaio DEC-LSF.PE 002 - "Determinaçào da densidade ótıca especifica de fumaça'.

\section{EQUIPAMENTOS UTILIZADOS}

Camara de mediçăo de densidade ótica de fumaça (identificaçâo EQ-003, última calıbraçáo: 15.06 1999. orgăo calibrador: IPT/DEC/AISF/LSF).

Balança digital Mettler modelo PB-3000 (identificaçăo: BL-001. última calibraçao. 14.03.2001. certificado de calibraçào $n^{\circ} 38347$. órgáo calibrador: IPT/DME/LME. próxima calibraçào: 03.2003):

Paquimetro Digimess (identificaçào: PQ-002. ultima calibraçâo: 14.112001 certificado de calibraçăo $n^{\circ}$ 41423. órgáo calıbrador. IPT/DME/LME. próxima clibraça: 11.2002):

Régua metálica $300 \mathrm{~mm}$ marca Hope (identificaçăo RG-007. última calibraçăo 2311.1999 . certificado de calibraçào n 32847. órgáo calibrador IPT/DMEILME).

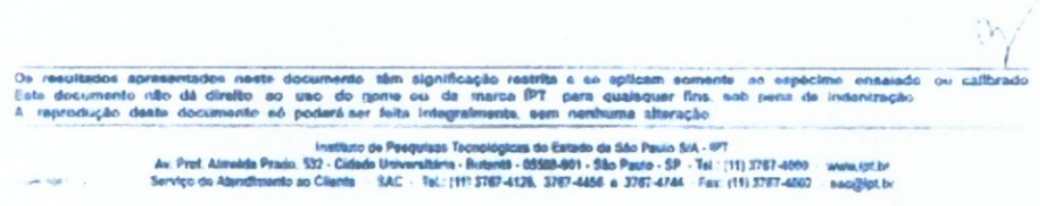


Certificados

Página 1 de 1

instituto de Pesquisas Tecnolbgicas

Continuacio do Retatorio de Ensaio No $8908692 / 2$

Laboratorio de Seguranca ao FogolAISFIDEC

$\triangle$ RESULTADO

Ensaio realızado em 28.05.2002

4.1 Densidade ótica especifica (Ds) em funçảo do tempo para a queima sem chama

\begin{tabular}{|c|c|c|c|c|c|c|c|c|c|c|c|c|c|c|}
\hline \multirow{2}{*}{$\begin{array}{l}\text { Corpe. } \\
\text { do-prova }\end{array}$} & \multicolumn{14}{|c|}{ Tempo (minutos) } \\
\hline & 15 & 40 & 8.0 & 12.0 & 16.0 & 20.0 & 24.0 & 28.0 & 29.5 & 30.9 & 320 & 34.5 & 36.0 & 40.0 \\
\hline $\mathrm{Cr}_{1}$ & 0 & 13 & 69 & 168 & 323 & 581 & 755 & 805 & $812^{\circ}$ & - & 812 & . & 812 & \\
\hline C.P2 & 0 & 11 & 53 & 132 & 314 & 595 & 731 & 805 & $\therefore$ & . & 845 & $861^{\circ}$ & 861 & 861 \\
\hline $\mathrm{CP}_{3}$ & 0 & 8 & 23 & 92 & 245 & 528 & 755 & 832 & $\therefore$ & 845. & 845 & & 845 & \\
\hline
\end{tabular}

4.2 Densidade ótica especifica (Ds) em funçăo do tempo para a queima com chama

\begin{tabular}{|c|c|c|c|c|c|c|c|c|c|c|c|c|c|c|}
\hline \multirow{2}{*}{$\begin{array}{l}\text { Corpo- } \\
\text { de-prova }\end{array}$} & \multicolumn{14}{|c|}{ Tempo (minutos) } \\
\hline & 1.5 & 4.0 & 8.0 & 12.0 & 16.0 & 20,0 & 240 & 26,5 & 280 & 29.3 & 32.0 & 35.6 & 36.0 & 40,0 \\
\hline$C P$, & 0 & 48 & 82 & 132 & 405 & 599 & 713 & $\therefore$ & 765 & $769^{\circ}$ & 769 & . & & 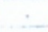 \\
\hline $\mathrm{CP} 2$ & 0 & 33 & 82 & 69 & 177 & 343 & 450 & $\cdot$ & 518 & & 563 & $569^{\circ}$ & 568 & 564 \\
\hline $\mathrm{CP} 3$ & 0 & 9 & $\Delta ;$ & 105 & 381 & 600 & 731 & $769^{\circ}$ & 769 & & 752 & . & & \\
\hline
\end{tabular}

Nota 1: CP corpo-de-prova

- densidade otica especifica máxıma (Dm)

4.3 Resultado Geral do Ensaio

\begin{tabular}{|c|c|c|}
\hline Tipo de Ensaio & sem chama & com chama \\
\hline Número de corpos-de-prova ensaiados & 3 & 3 \\
\hline Tempo, em minutos, para atingir Dm & 32 & 30 \\
\hline Densidade otica especifica aos $90 \mathrm{~s}$ & 0 & 0 \\
\hline Densidade otica especifica aos 4 min & 11 & 30 \\
\hline Densidade otica especifica aos $20 \mathrm{~min}$ & 568 & 515 \\
\hline Densidade btica especifica maxima corrigida (Om) & 825 & 659 \\
\hline Tempo, em minulos, para atingir $D s=16$ & 48 & 4 \\
\hline Razâo máxima de desenvolvimento de fumaca (Ds/min) & 89 & 70 \\
\hline Cor da fumaca & cinza & $\operatorname{cinza}$ \\
\hline
\end{tabular}

Cor da fumaca

Nota 2: Os valores da tabela supra referem-se à media de 03 corpos-de-prova (ver tens 31 e 3.2)

Sào Paulo. 06 de junho de 2002
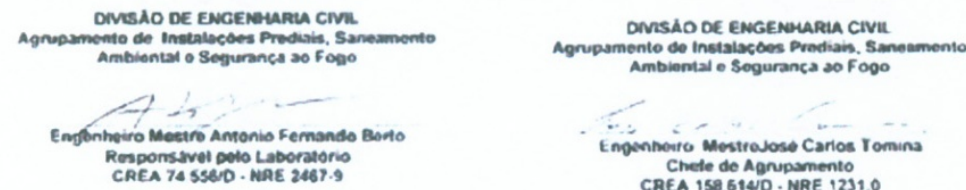

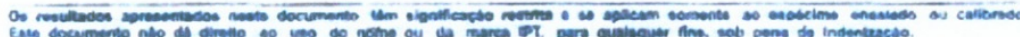

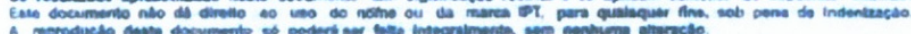

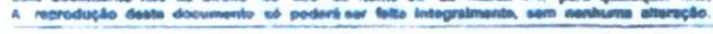

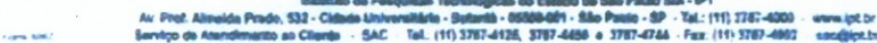


Certificados

Página 1 de 1

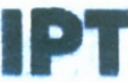

Instituto de Pesquisas Tecnológicas

Continuaça do Relatorio de Ensaio No 890868 2/2 Laboratório de Segurança ao FogolAISFiOEC

4 RESULTADOS

Ensaio realizado em 29.04 .2002

\begin{tabular}{|c|c|c|c|}
\hline & \multicolumn{3}{|c|}{ Valores } \\
\hline & Médio & Minimo & Máximo \\
\hline Indice de propagação de chama (lp) & 160 & 138 & 195 \\
\hline Fator de evoluçâo de calor (Q) & 44,8 & 38.3 & 55.9 \\
\hline Fator de propagação de chama (PC) & 3.6 & 3.5 & 3.6 \\
\hline Classificaçāo & & :lasse D & 1 \\
\hline
\end{tabular}

\subsection{Observaçōes de ensaio}

A propagaçăo superficial de chama avançou, em média. $393 \mathrm{~mm}(85 \%$ do comprimento total do corpo-de-prova):

A carbonizaçâo superficial alcançou. em média. $448 \mathrm{~mm}(97 \%$ do comprimento total do corpo-de-prova):

Desenvolvimento de fumaça cinza.

\section{LIMITES ESPECIFICADOS EM NORMA}

O método de ensaio NBR 9442/1986 propőe o enquadramento dos materiais em cinco classes distintas. de acordo com o Índice Médio de Propagaçăo de Chamas, sendo as Classes $\mathrm{A}$ e E com melhor e pior desempenho, respectivamente, conforme abaixo descrito:

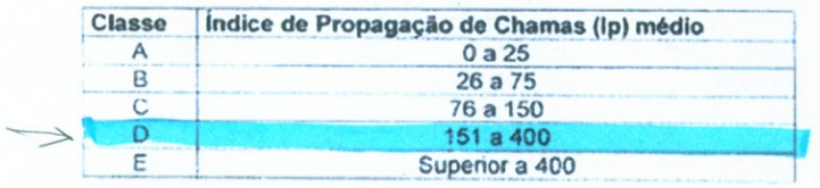

Săo Paulo, 06 de junho de 2002

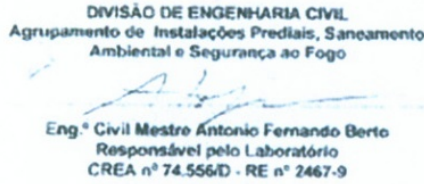

ONISAOO DE ENGENHARIA CNVI

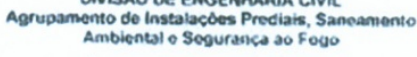

Ambenta seguranca so foog

Eng Civil Mestre dose Carios Tomina

CREA n' 158.6140 . RE $n^{\circ} 1231$.

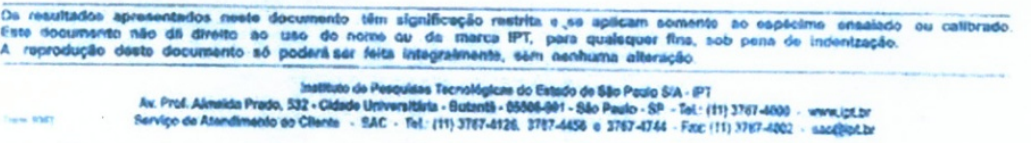

